\title{
Brønsted-Lowry Acid Strength of Metal Hydride and Dihydrogen Complexes
}

\author{
Robert H. Morris
}

\author{
Version Post-print/accepted manuscript \\ Citation Morris, R. H. Chemical Reviews 2016, 116, 8588-8654. \\ (published version) \\ http:/doi.org//10.1021/acs.chemrev.5b00695
}

Copyright / License

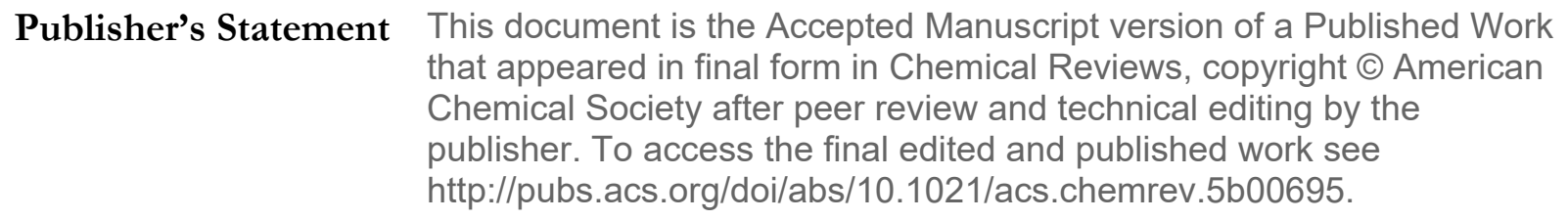

How to cite TSpace items

Always cite the published version, so the author(s) will receive recognition through services that track citation counts, e.g. Scopus. If you need to cite the page number of the author manuscript from TSpace because you cannot access the published version, then cite the TSpace version in addition to the published version using the permanent URI (handle) found on the record page.

This article was made openly accessible by $U$ of $T$ Faculty. Please tell us how this access benefits you. Your story matters. 


\title{
Brønsted-Lowry Acid Strength of Metal Hydride and Dihydrogen Complexes
}

\author{
Robert H. Morris*
}

Department of Chemistry, University of Toronto, 80 Saint George St. Toronto, Ontario, M5S3H6, Canada

Transition metal hydride complexes are usually amphoteric, not only acting as hydride donors, but also as Brønsted-Lowry acids. A simple additive ligand acidity constant equation (LAC for short) allows the estimation of the acid dissociation constant $\mathrm{K}_{\mathrm{a}}{ }^{\mathrm{LAC}}$ of diamagnetic transition metal hydride and dihydrogen complexes. It is remarkably successful in systematizing diverse reports of over 450 reactions of acids with metal complexes and bases with metal hydrides and dihydrogen complexes, including catalytic cycles where these reactions are proposed or observed. There are links between $\mathrm{pK}_{a}{ }^{\mathrm{LAC}}$ and $\mathrm{pK}_{\mathrm{a}}{ }^{\mathrm{THF}}, \mathrm{pK}_{\mathrm{a}}{ }^{\mathrm{DCM}}, \mathrm{pK}_{\mathrm{a}}{ }^{\mathrm{MeCN}}$ for neutral and cationic acids. For the groups from chromium to nickel, tables are provided that order the acidity of metal hydride and dihydrogen complexes from most acidic $\left(\mathrm{pK}_{\mathrm{a}}{ }^{\mathrm{LAC}}-18\right)$ to least acidic ( $\mathrm{pK}_{\mathrm{a}}^{\mathrm{LAC}} 50$ ). Figures are constructed showing metal acids above the solvent $\mathrm{pK}_{\mathrm{a}}$ scales and organic acids below in order to summarize a large amount of information. Acid-base features are analyzed for catalysts from chromium to gold for ionic hydrogenations, bifunctional catalysts for hydrogen oxidation and evolution electrocatalysis, $\mathrm{H} / \mathrm{D}$ exchange, olefin hydrogenation and isomerization, hydrogenation of ketones, aldehydes, imines, and carbon dioxide, hydrogenases and their model complexes, and palladium catalysts with hydride intermediates.

\section{CONTENTS}

1 Introduction 3

2 Experimental and theoretical methods for determining acid strengths of transition metal hydrides 4

2.1 Measurement of $\mathrm{p} K_{\mathrm{a}}$ for acids in solvents with medium to high dielectric constants ................5

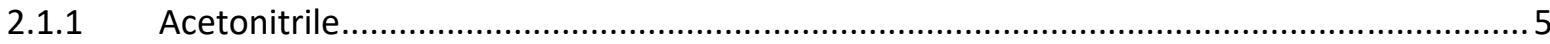

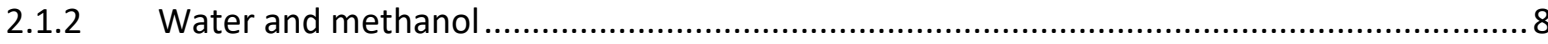

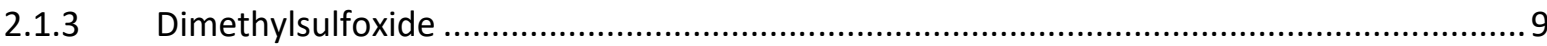

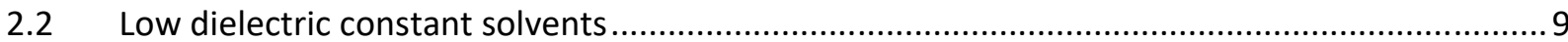

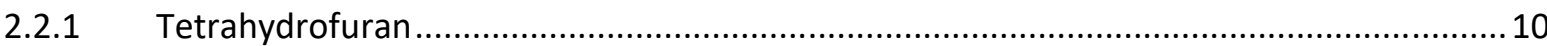

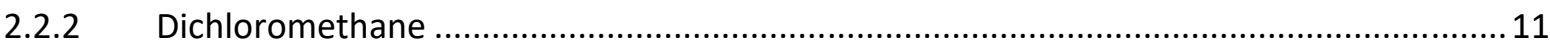

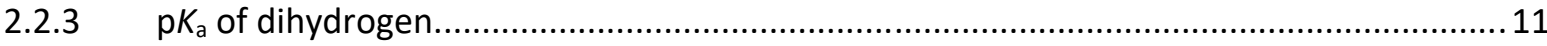

$2.3 \quad$ Comparing $\mathrm{p} K_{\mathrm{a}}$ values of acids in different solvents ......................................................... 11

3 Additive ligand acidity constant (LAC) method used for ordering acid strengths .......................... 12

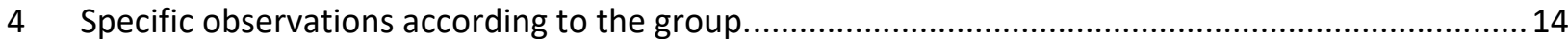

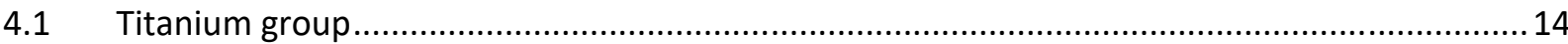

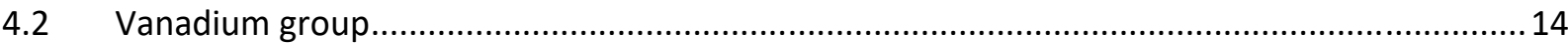

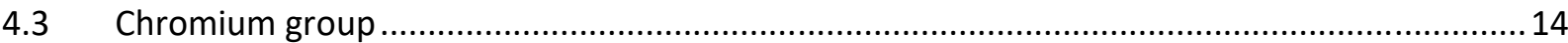

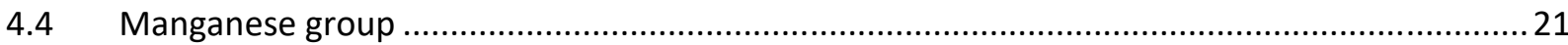




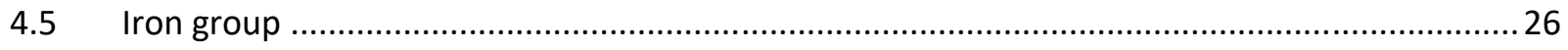

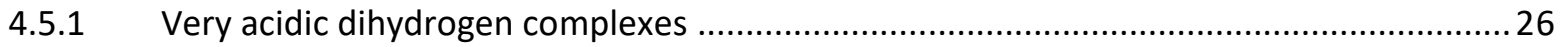

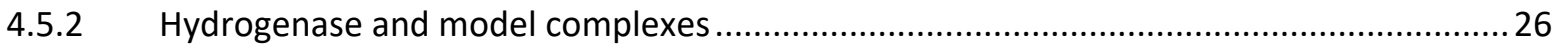

4.5.3 Phosphine carbonyl hydride complexes .....................................................................26

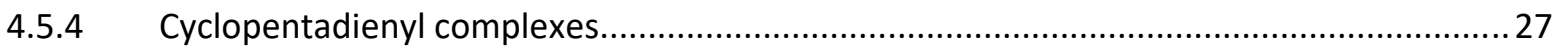

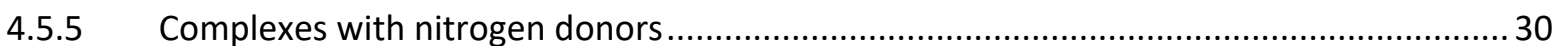

4.5.6 Complexes with several phosphorus donors ................................................................... 31

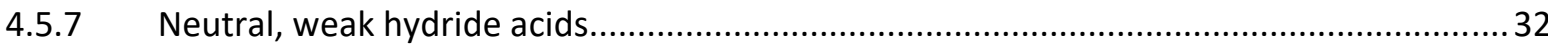

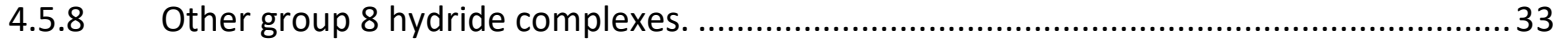

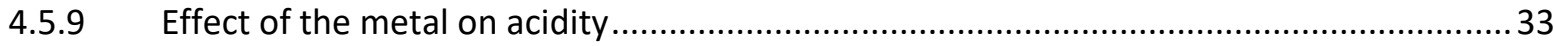

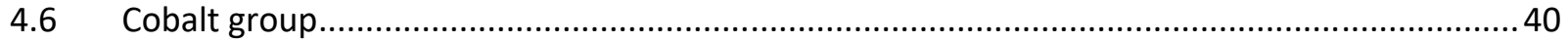

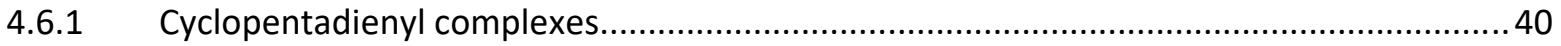

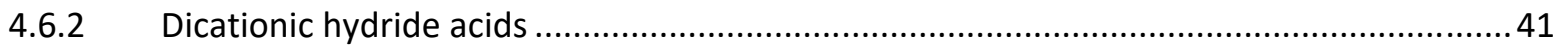

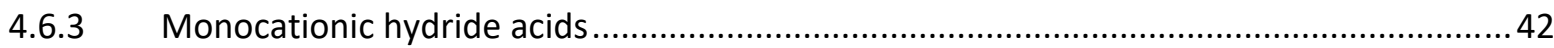

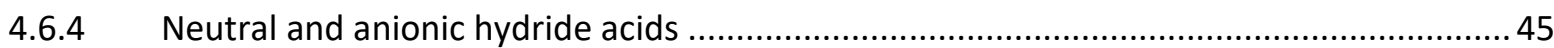

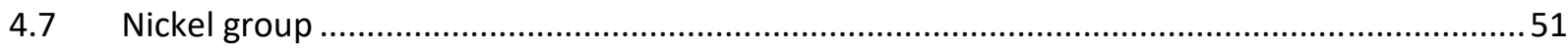

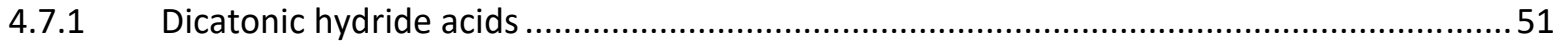

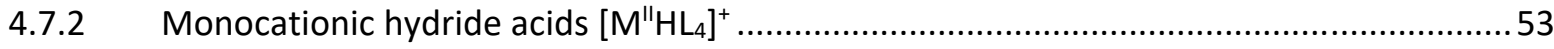

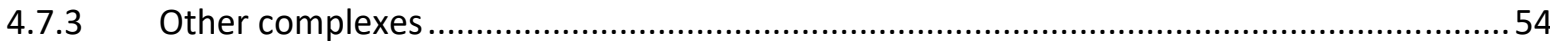

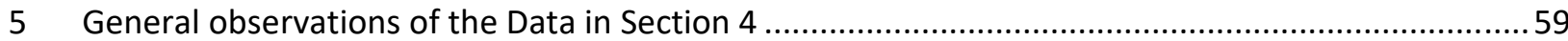

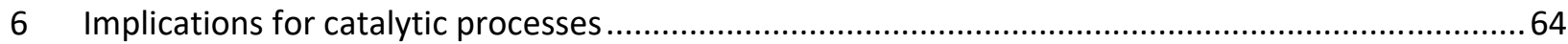

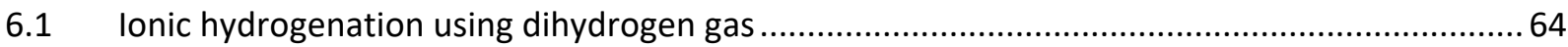

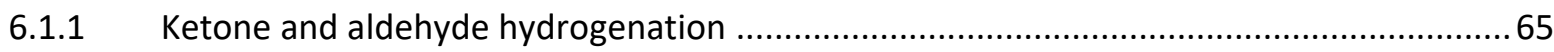

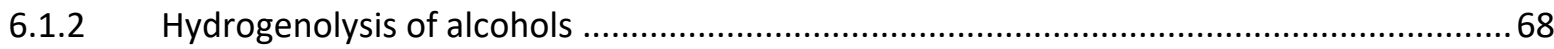

6.1.3 Water and aldehyde shift to hydrogen and carboxylic acid ..........................................68

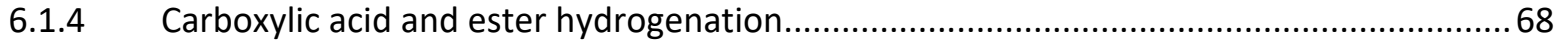

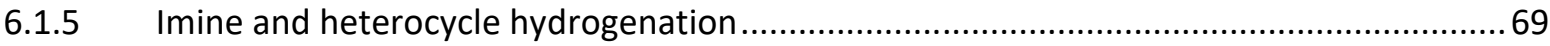

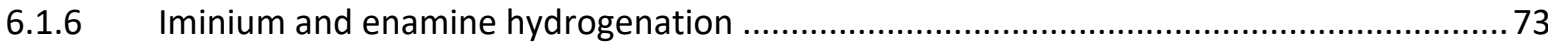

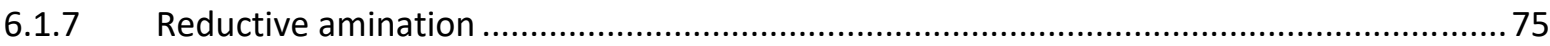

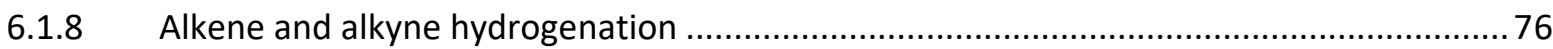

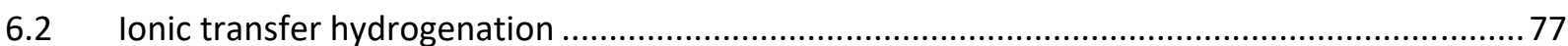

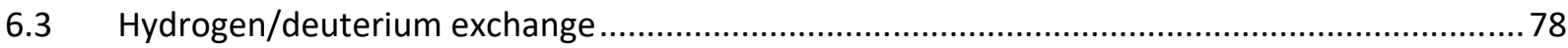

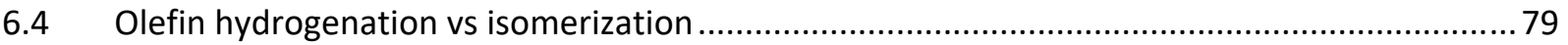




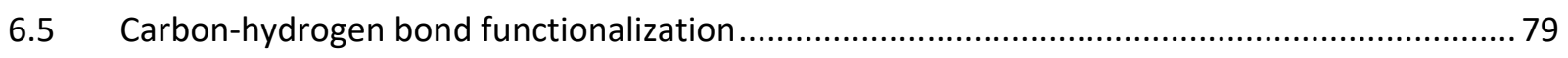

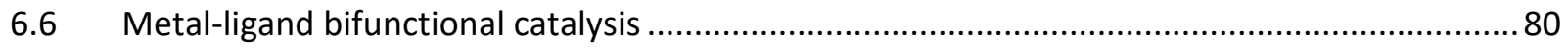

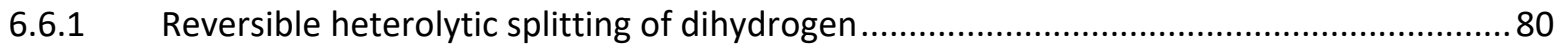

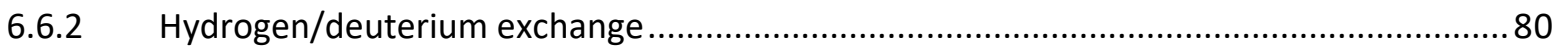

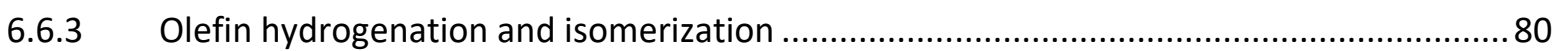

6.6.4 Aldehyde, ketone and imine hydrogenation and amine dehydrogenation....................... 82

6.7 Carbon dioxide hydrogenation and formic acid dehydrogenation .......................................... 83

$6.8 \quad H y d r o g e n$ oxidation and evolution electrocatalysts ........................................................... 85

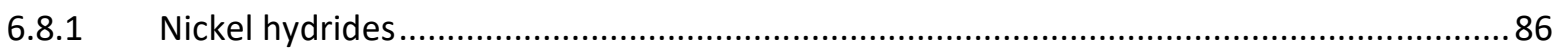

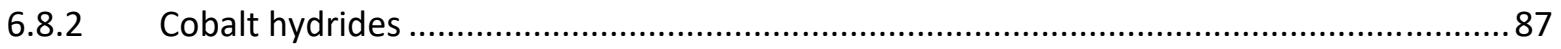

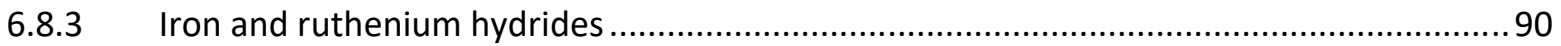

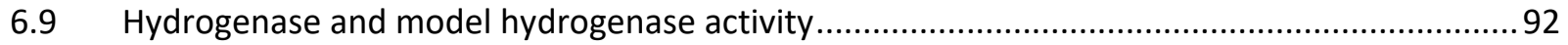

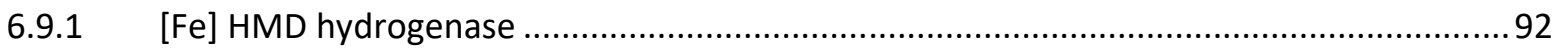

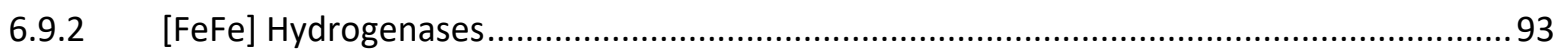

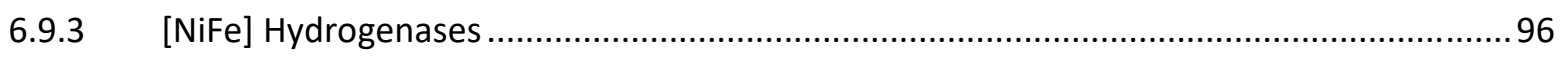

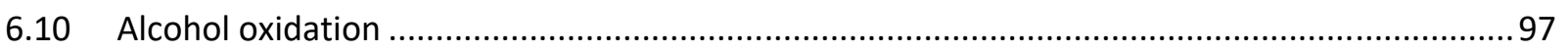

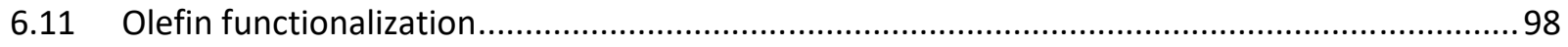

6.11.1 Heck coupling reaction (palladium and nickel) .............................................................98

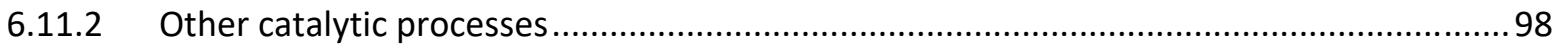

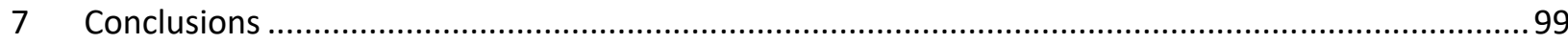

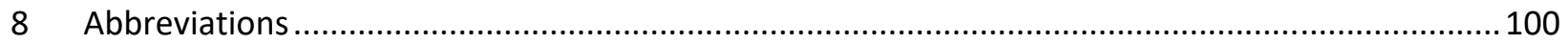

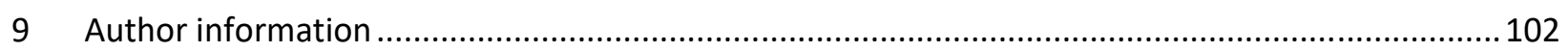

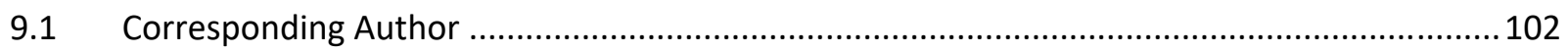

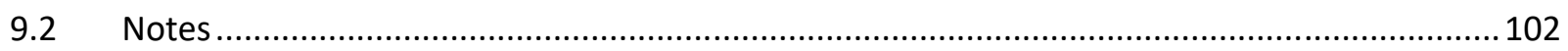

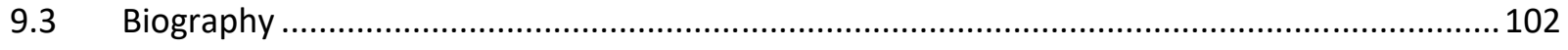

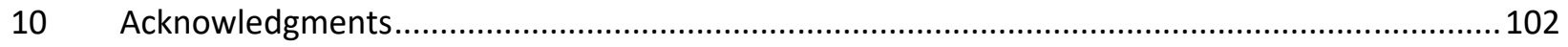

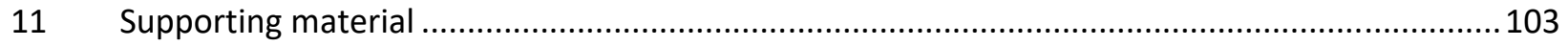

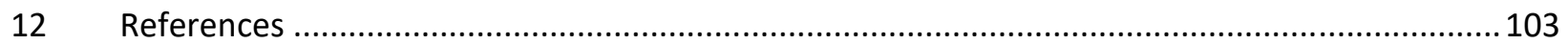

\section{INTRODUCTION}

Transition metal hydride complexes are usually amphoteric, not only acting as hydride donors, but also as Brønsted-Lowry acids. This review is a survey of reactions of transition metal complexes with acids and bases that help establish the relative Brønsted-Lowry acid strengths of transition metal hydride and dihydrogen complexes. It concentrates on thermodynamic properties; the kinetics of the 
reactions have been examined elsewhere..$^{1-2}$ It organizes the literature that mainly follows a comprehensive review of the subject in 1992. ${ }^{1}$ There have been several other useful reviews and summary articles regarding the acid and base strength of transition metal hydride and dihydrogen complexes..$^{3-9}$ There was much interest in the protonation behavior of metal hydrides after it was established in $1985^{10-11}$ that dihydrogen complexes could be prepared by such reactions and this provides a particularly rich literature for the acid-base reactions reviewed here. ${ }^{4-5}$

Chemists frequently refer to the $\mathrm{p} K_{\mathrm{a}}$ values of compounds to plan out syntheses or explain reaction pathways. Estimates of the $\mathrm{p} K_{\mathrm{a}}$ values of $\mathrm{C}-\mathrm{H}, \mathrm{O}-\mathrm{H}$ and $\mathrm{N}-\mathrm{H}$ containing compounds are of great use in predicting reactivity as long as the appropriate $\mathrm{p} K_{\mathrm{a}}$ value for the solvent of interest is used (often this is not the case). The $\mathrm{p} K_{\mathrm{a}}$ of $\mathrm{M}-\mathrm{H}$ bonds should find similar utility if used carefully as illustrated in this article. The physical organic chemistry community has provided extensive compilations of $\mathrm{p} K_{\mathrm{a}}$ data for organic compounds in several solvents. ${ }^{12-16}$ Methods have been developed to quantitate acid strength in low dielectric solvents. ${ }^{7,13,17-18}$ This article attempts to provide the start of a similar compilation for hydride and dihydrogen-containing coordination compounds.

This review orders the approximate equilibrium strengths of hydride acids based on literature reports of reactions observed. Acid strengths from superacidic to very weakly acidic hydrides (with very strong conjugate bases) are reported. The protonation/deprotonation of hydrides often have a low kinetic barrier so that there is often a meaningful equilibrium set up at room temperature. However it should be remembered that there are reports of sterically hindered reaction partners taking several days to attain a proton transfer equilibrium at room temperature. ${ }^{7,19}$ Our report ${ }^{8}$ of a simple method for estimating the $\mathrm{p} K_{\mathrm{a}}$ of metal hydride and dihydrogen complexes by the addition of ligand acidity constants, hereafter referred to as the LAC method, greatly assists in structuring the literature of transition metal hydride complexes. Since these are estimated values, they will be denoted $\mathrm{p} K_{\mathrm{a}}{ }^{\mathrm{LAC}}$. We have shown that these reproduce the reported $\mathrm{p} K_{\mathrm{a}}{ }^{\mathrm{THF}}$ (also referred to as $\mathrm{pK}_{\alpha}{ }^{\mathrm{THF}}$, the ion pair-corrected values) or $\mathrm{p} K_{\mathrm{a}}^{\mathrm{DCM}}$ values for many hydrides reported to within $3 \mathrm{p} K_{\mathrm{a}}$ units. Equations are available to convert $\mathrm{p} K_{\mathrm{a}}{ }^{\mathrm{LAC}}$ or $\mathrm{p} K_{\mathrm{a}}{ }^{\mathrm{THF}}$ for approximate use in other solvents. ${ }^{7,16}$ The LAC method provides the opportunity to bring together and systematize diverse reports of over 450 reactions of acids with metal complexes and bases with metal hydrides and dihydrogen complexes, including catalytic cycles where these reactions are proposed or observed.

Transition metal hydride and dihydrogen complexes are intermediates in many homogeneous catalytic processes. Hydrogenation is the most obvious one and here the heterolytic splitting of dihydrogen is often a key step, directly reflecting the acidity of the metal complex. Information in this article helps to understand the thermodynamics of this type of reaction as well many other catalytic reactions of academic and industrial importance. The heterolytic splitting of dihydrogen can also occur on main group elements ( $\mathrm{B}, \mathrm{Al}, \mathrm{P})$ by the frustrated Lewis pair (FLP) mechanism but this will not be discussed here. ${ }^{20-24}$ Main group elements on metals can also be sites of the FLP enabled heterolytic splitting of dihydrogen. ${ }^{24-25}$

\section{Experimental and theoretical methods for determining acid strengths of transition metal hydrides}

This review will concentrate on the determination of acid dissociation constants $K_{a}$ (Equation 1 ). Typically this involves finding equilibria (Equation 2) with protonated bases of known $\mathrm{K}_{\mathrm{a}}$ (Equation 3 ). The results are reported as $p K_{\mathrm{a}}$ values (Equation 4). As in the classic studies of acid strength of organic compounds, ${ }^{12,16,26-27}$ early experimental equilibria involving hydride acids were measured using solvents of high to medium dielectric constant including water, methanol, or acetonitrile and were measured 
against standard compounds using UV-visible detection and, for metal carbonyls, IR and NMR detection. ${ }^{1,3}$ Enthalpies of protonation can also be employed indirectly to obtain these equilibrium constants; this is done by obtaining a correlation equation between $\mathrm{pK}_{\mathrm{a}}^{\text {solvent }} \mathrm{vs}$ the enthalpy of protonation for compounds where both quantities have been measured. ${ }^{7,28-29}$ Equilibria for other metal hydride and dihydrogen complexes have been measured in MeCN, THF, and DCM using NMR as well. ${ }^{7-}$

${ }^{8,28,30}$ Advances in density functional theory (DFT) computation and especially the treatment of solvation have led to applications in the calculations of relative $\mathrm{p} K_{\mathrm{a}}$ of transition metal hydrides (see Section 4). ${ }^{31-}$ 35

Equation 1

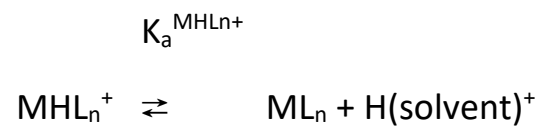

Equation 2

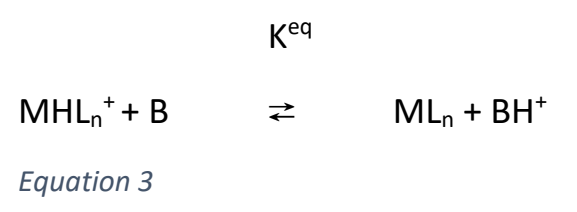

Equation 3

$\mathrm{BH}^{+} \stackrel{\mathrm{Ka}^{\mathrm{BH}+}}{\rightleftarrows} \quad \mathrm{B}+\mathrm{H}(\text { solvent })^{+}(3)$

Equation 4

$\mathrm{pK}_{\mathrm{a}}^{\mathrm{MHLn+}}=\mathrm{p} K_{\mathrm{a}}^{\mathrm{BH}+}-\mathrm{pK}^{\mathrm{eq}}$

The measurement of $K_{\mathrm{a}}$ can be complicated by a variety of factors including ion pairing, the forming of aggregates of ion pairs at high concentrations, selective interactions such as hydrogenbonding of the reactants or products with the solvent or with themselves to form homoconjugates or heteroconjugates. ${ }^{26}$ These problems can be usually avoided by studying dilute solutions $(<0.01 \mathrm{M})$ in solvents of high or medium dielectric constant and employing reactants and products that have similar solvent-ion and ion-ion interactions. Examples of this will be provided in the discussion that follows.

\subsection{Measurement of $\mathrm{pK} \mathrm{K}_{\mathrm{a}}$ for acids in solvents with medium to high dielectric constants \\ 2.1.1 Acetonitrile}

The use of $\mathrm{MeCN}$ is strongly recommended whenever possible for $\mathrm{p} K_{\mathrm{a}}$ determinations of hydride complexes. ${ }^{1}$ This solvent has a sufficiently large dielectric constant (36.0) to minimize problems associated with ion pairing that can influence the equilibria of interest. There is a large collection of $\mathrm{p} K_{\mathrm{a}}{ }^{\mathrm{MeCN}}$ of reference organic acids to use (see Table 1 and Table 2 for representative acids that appear in this review) $\cdot{ }^{15} \mathrm{~A}$ wide range of acid strengths can be resolved in acetonitrile because of its small autoprotolysis constant of approx. $10^{-39}$ (see Equation 5). Values ranging from $10^{-33}$ to $10^{-39}$ have been reported. ${ }^{15,36}$ The $10^{-39}$ value appears to be correct because the largest $\mathrm{p} K_{\mathrm{a}}{ }^{\mathrm{MeCN}}$ that could be resolved with phosphazenes of increasing basicity was 38.6 ; above this value acetonitrile was found to polymerize and decompose. The measurements involving the strongest phosphazene bases had to be done in THF or DMSO so that the reported $\mathrm{p} K_{\mathrm{a}}{ }^{\mathrm{MeCN}}$ values above 39 are estimates obtained by extrapolation. ${ }^{37}$ 
$2 \mathrm{CH}_{3} \mathrm{CN} \rightleftarrows \mathrm{CH}_{3} \mathrm{CNH}^{+}+\mathrm{CH}_{2} \mathrm{CN}^{-} \quad K_{\text {auto }}=\left[\mathrm{CH}_{3} \mathrm{CNH}^{+}\right]\left[\mathrm{CH}_{2} \mathrm{CN}^{-}\right]=10^{-39}$

Acids with $\mathrm{p} K_{\mathrm{a}}$ less than zero are leveled to the acid strength of $\left[\mathrm{HNCCH}_{3}\right]^{+}$while those greater than approx. 38 have conjugate base forms that are leveled to the base strength of $\left[\mathrm{CH}_{2} \mathrm{CN}\right]^{-}$. There are particularly accurate $\mathrm{p} K_{\mathrm{a}}{ }^{\mathrm{MeCN}}$ scales for cationic acids from 2 to $32^{16}$ and neutral acids from 3 to $17^{38}$ and there are several links between the two groups that are self-consistent. ${ }^{16}$

Certain acids in acetonitrile have more complicated behavior because of the formation of homoconjugates. ${ }^{26,36}$ Neutral acids $\mathrm{AH}$ with acidic functional groups $\mathrm{NH}, \mathrm{OH}$ or $\mathrm{XH}$ where $\mathrm{X}$ is a halogen can produce anions $A^{-}$that are destabilized by poor solvation by acetonitrile but are greatly stabilized when they act as a hydrogen bond acceptor from one (e.g. AHA', Equation 6) or more (e.g. $A(H A)_{n}{ }^{-}$) equivalents of acid HA. ${ }^{38-39}$ These HA appear considerably more acidic than cationic nitrogen acids of similar aqueous $\mathrm{p} K_{a}$ (see Section 5) since the formation of a strong hydrogen bond with the loss of some entropy of reactants to form a homoconjugate $\mathrm{AHA}^{-}$in acetonitrile can push a protonation reaction forward with the release of up to $7 \mathrm{kcal} / \mathrm{mol}$ ( $5 \mathrm{p} K_{a}$ units). The formation constants of homoconjugates been determined for several carboxylic acids and acidic alcohols and phenols in a variety of solvents ${ }^{15}$ and these can be used to correct acid-base equilibria for these association processes. ${ }^{39}$ Similarly acids $\mathrm{BH}^{+}$such as anilinium ions associate in acetonitrile (Equation 7). ${ }^{40}$ This must also be taken into account when determining acid dissociation constants. ${ }^{1,41}$ Fortunately metal hydride complexes are weak hydrogen bond donors ${ }^{41}$ and are sterically hindered from forming homoconjugates. However certain

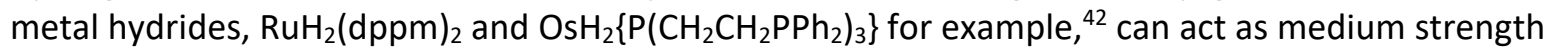
hydrogen bond acceptors.

Equation 6

$2 \mathrm{HA}+\mathrm{B} \rightleftarrows[\mathrm{HB}][\mathrm{AHA}]$

Equation 7

$2 \mathrm{HB}^{+}+\mathrm{B}^{\prime} \rightleftarrows \mathrm{HB}^{\prime+}+[\mathrm{BHB}]^{+}$

Acetonitrile with electrolyte added is an excellent medium for electrochemistry. Several $\mathrm{pK}_{\mathrm{a}}$ values listed in this review were obtained indirectly by use of thermodynamic cycles. ${ }^{43-45}$ Thermodynamic cycles that make use of $\mathrm{p} K_{\mathrm{a}}{ }^{\mathrm{MeCN}}$ values of metal hydride complexes and redox potentials of their conjugate base form can provide estimates of metal-hydrogen bond dissociation energies. ${ }^{46}$ 
Table 1 Selected cationic acid $p K_{a}$ in solvents of decreasing dielectric constant. Bracketed values are estimates.

\begin{tabular}{|c|c|c|c|c|c|}
\hline Acid/base & $\mathrm{p} K_{\mathrm{a}}^{\mathrm{aq}}$ & $\begin{array}{l}\mathrm{p} K_{\mathrm{a}}^{\mathrm{DMSO}} \\
\text { or } \mathrm{p} K_{\mathrm{a}}^{\mathrm{DMF}}\end{array}$ & $\mathrm{p} K_{\mathrm{a}}^{\mathrm{MeCN}}$ & $\begin{array}{l}\mathrm{p} K_{\mathrm{a}}{ }^{\mathrm{THF}} \text { or } \\
\mathrm{p} K_{\mathrm{a}}^{\mathrm{DCM}} \text { or } \\
\mathrm{p} K_{\mathrm{a}}^{\mathrm{LAC}}\end{array}$ & Ref. \\
\hline $\mathrm{HN}^{\mathrm{t}} \mathrm{BuP}\left(\mathrm{NMe}_{2}\right)_{2} \mathrm{NP}\left(\mathrm{NMe}_{2}\right)_{3}{ }^{+} /$ & & 21.5 & 33.5 & (28) & 37 \\
\hline \multicolumn{6}{|l|}{$\mathrm{N}^{\mathrm{t} B u P}\left(\mathrm{NMe}_{2}\right)_{2} \mathrm{NP}\left(\mathrm{NMe}_{2}\right)_{3}$} \\
\hline $\mathrm{HP}\left(\mathrm{N}^{\prime} \mathrm{PrCH}_{2} \mathrm{CH}_{2}\right)_{3} \mathrm{~N}^{+} /$ & & & 33.6 & (28) & 47 \\
\hline \multicolumn{6}{|l|}{$\mathrm{P}\left(\mathrm{N}^{\mathrm{i} P r C H}{ }_{2} \mathrm{CH}_{2}\right)_{3} \mathrm{~N}$} \\
\hline $\mathrm{HN}^{t} \mathrm{BuP}\left(\mathrm{NMe}_{2}\right)_{3}{ }^{+} /$ & & & 26.9 & 21.7 & 17,48 \\
\hline \multicolumn{6}{|l|}{$\mathrm{N}^{t} \mathrm{BuP}\left(\mathrm{NMe}_{2}\right)_{3}$} \\
\hline $\mathrm{DBU}-\mathrm{H}^{+} / \mathrm{DBU}$ & & & 24.3 & 20 & 15,17 \\
\hline $\mathrm{TMG}^{+} \mathrm{H}^{+} / \mathrm{TMG}$ & 13.6 & 13.2 & 23.3 & 17.8 & $49-50$ \\
\hline DMAP-H ${ }^{+} / \mathrm{DMAP}$ & 9.6 & & 18.2 & 14.1 & 15,50 \\
\hline $\mathrm{HNEt}_{3}{ }^{+} / \mathrm{NEt}_{3}$ & 10.7 & 9 & 18.5 & 13.7 & $15,49-50$ \\
\hline Morpholinium ${ }^{+}$/ & & & 16.6 & (10) & 51 \\
\hline \multicolumn{6}{|l|}{$\mathrm{HN}\left(\mathrm{CH}_{2} \mathrm{CH}_{2}\right)_{2} \mathrm{O}$} \\
\hline $\begin{array}{l}\text { 2,4,6-Mез } \text { py-H }^{+} / 2,4,6- \\
\mathrm{Me}_{3} \text { py }\end{array}$ & 7.3 & & 14.98 & 10.4 & 38,50 \\
\hline $\mathrm{HPCy}_{3}{ }^{+} / \mathrm{PC}_{3}$ & & & & 9.7 & 7 \\
\hline py- $\mathrm{H}^{+} /$py & 5.2 & 3.4 & 12.3 & 8.3 & 49 \\
\hline $\mathrm{PhNH}_{3}{ }^{+} / \mathrm{PhNH}_{2}$ & 4.6 & 3.6 & 10.6 & 8.0 & 49 \\
\hline $2,4-\mathrm{Cl}_{2} \mathrm{C}_{6} \mathrm{H}_{3} \mathrm{NH}_{3}^{+} / 2,4-$ & 1.5 & & & 4.5 & 50 \\
\hline \multicolumn{6}{|l|}{$\mathrm{Cl}_{2} \mathrm{C}_{6} \mathrm{H}_{3} \mathrm{NH}_{2}$} \\
\hline $\mathrm{HPPh}_{3}{ }^{+} / \mathrm{PPh}_{3}$ & 2.7 & & 8 & 3 & 7 \\
\hline [H(DMF)]OTf & 0 & & 6.1 & (1) & 15 \\
\hline$\left[\mathrm{H}_{3} \mathrm{O}\right]^{+} / \mathrm{H}_{2} \mathrm{O}$ & 0 & & 2 & (0) & 26 \\
\hline$\left[\mathrm{H}\left(\mathrm{OEt}_{2}\right)_{2}\right] \mathrm{BF}_{4} / \mathrm{OEt}_{2}$ & & & 0.2 & -5 & 28,52 \\
\hline $\mathrm{HO}=\mathrm{CMe}_{2}{ }^{+} /$acetone & $(-7)$ & & -0.1 & $(-6)$ & 26,53 \\
\hline
\end{tabular}


Table 2. Neutral acid references in solvents of decreasing dielectric constant. Bracketed values are estimates.

\begin{tabular}{|c|c|c|c|c|c|}
\hline Acid/base & $\mathrm{p} K_{\mathrm{a}}^{\mathrm{aq}}$ & $\begin{array}{l}\mathrm{p} K_{\mathrm{a}}^{\mathrm{DMSO}} \\
\text { or } \mathrm{p} K_{\mathrm{a}}^{\mathrm{DMF}}\end{array}$ & $\mathrm{p} K_{\mathrm{a}}^{\mathrm{MeCN}}$ & $\begin{array}{l}\mathrm{p} K_{\mathrm{a}}{ }^{\mathrm{THF}} \text { or } \\
\mathrm{p} K_{\mathrm{a}}^{\mathrm{DCM}} \text { or } \\
\mathrm{p} K_{\mathrm{a}}{ }^{\mathrm{LAC}}\end{array}$ & Ref. \\
\hline$\overline{\mathrm{H}_{2} / \mathrm{H}^{-}}$ & 25 & & 50 & $>49^{a}$ & 7,54 \\
\hline $\mathrm{DMSO} / \mathrm{CH}_{2} \mathrm{SOMe}^{-}$ & & 35 & & & 12,55 \\
\hline $\mathrm{CH}_{2} \mathrm{Ph}_{2} / \mathrm{CHPh}_{2}^{-}$ & & 32.3 & (46) & $48^{b}$ & $7,18,37$ \\
\hline $\mathrm{HO}^{t} \mathrm{Bu} / \mathrm{KO}^{t} \mathrm{Bu}$ & & 32 & & & 7,56 \\
\hline $\mathrm{HOH} / \mathrm{OH}^{-}$ & 15.7 & 31 & $(38-41)$ & & $12,56-57$ \\
\hline $\mathrm{CH}_{3} \mathrm{CN} / \mathrm{CH}_{2} \mathrm{CN}^{-}$ & & 31.3 & $33-39$ & & $15,26,36-37$ \\
\hline $\mathrm{HOMe} / \mathrm{OMe}^{-}$ & 15.5 & 29.0 & (39) & & $12,56-57$ \\
\hline $\mathrm{HNPh}_{2} / \mathrm{NPh}_{2}^{-}$ & & 25 & & 41 & 7,26 \\
\hline $\mathrm{CF}_{3} \mathrm{CH}_{2} \mathrm{OH} / \mathrm{CF}_{3} \mathrm{CH}_{2} \mathrm{O}^{-}$ & 12.5 & 23.5 & & & $58-59$ \\
\hline $\begin{array}{l}\mathrm{HNPhPO}(\mathrm{OEt})_{2} / \\
\mathrm{NPhPO}(\mathrm{OEt})_{2}^{-}\end{array}$ & & 18.3 & & 32 & 7,12 \\
\hline $\mathrm{HOPh} / \mathrm{OPh}^{-}$ & 9.95 & 18 & 27.2 & & 12,60 \\
\hline $\begin{array}{l}\left(\mathrm{CF}_{3}\right)_{2} \mathrm{CHOH} / \\
\left(\mathrm{CF}_{3}\right)_{2} \mathrm{CHO}^{-}\end{array}$ & 9.3 & 17.9 & & & 59,61 \\
\hline $\mathrm{MeCO}_{2} \mathrm{H} / \mathrm{OAc}^{-}$ & 4.8 & 12.3 & 22.3 & & $12,60,62$ \\
\hline $\mathrm{CH}_{2}(\mathrm{CN})_{2} / \mathrm{CH}(\mathrm{CN})_{2}^{-}$ & & 11.0 & & 24 & 7,12 \\
\hline $\mathrm{PhCO}_{2} \mathrm{H} / \mathrm{PhCO}_{2}^{-}$ & 4.3 & 11.1 & 20.7 & & $12,60,62$ \\
\hline $\mathrm{CF}_{3} \mathrm{COOH} / \mathrm{CF}_{3} \mathrm{CO}_{2}^{-}$ & & 3.4 & 12.65 & & 12,63 \\
\hline $\begin{array}{l}2,4,6- \\
\mathrm{C}_{6} \mathrm{H}_{2}\left(\mathrm{NO}_{2}\right)_{3} \mathrm{OH} / \mathrm{pic}^{-}\end{array}$ & 0 & -1 & 11 & 11 & $7,12,38,64$ \\
\hline$\left(\mathrm{CF}_{3}\right)_{3} \mathrm{COH} /\left(\mathrm{CF}_{3}\right)_{3} \mathrm{CO}^{-}$ & & 10.7 & & & 65 \\
\hline $\mathrm{HCl} / \mathrm{Cl}^{-}$ & -8 & 1.8 & 10.4 & 10 & $12,15,66$ \\
\hline HOTs/OTs' & & & 8.3 & 8.6 & 38,62 \\
\hline HOTf/OTf- & -14 & 0.3 & 2.6 & & 12,62 \\
\hline
\end{tabular}

${ }^{a}$ With $\mathrm{K}\left(18\right.$-crown-6) ${ }^{+}, \mathrm{p} K_{\mathrm{a}}$ approx. $49 .{ }^{7 b}$ Streitweiser et al. ${ }^{67}$ plus 9-phenylfluorene reference correction $^{7}$

Thermochemical cycles have also been reported to link $\mathrm{p} K_{\mathrm{a}}{ }^{\mathrm{MeCN}}$ values with electrochemical potentials, bond dissociation energies, and hydride donor thermodynamics of transition metal hydrides. ${ }^{33,45,57,68}$

\subsubsection{Water and methanol}

The strong interest in catalysis and electrocatalysis in aqueous medium has pushed ahead the study of metal hydrides in water. ${ }^{54,69-83}$ The close thermodynamic links between redox potentials and hydrogen ion concentration should provide a particularly strong framework for understanding the chemistry of transition metal hydrides in buffered solutions. A wide range of acid-base indicators can be used in titrations. A set of self-consistent constants with convenient standard states has been reported to allow a better understanding and prediction of the chemistry of transition metal hydrides in water. ${ }^{54}$ Included is a value of 25.2 for the $\mathrm{p} K_{\mathrm{a}}\left(\mathrm{H}_{2} / \mathrm{H}^{-}\right)$of dihydrogen in water. This value was derived with the unproven assumption that the hydration energies of fluoride and hydride are similar due to their similar size.$^{84}$ There have been several reports of $\mathrm{p} K_{\mathrm{a}}{ }^{\text {aq }}$ determinations of metal hydride complexes in water. 
Most have been catalogued in older reviews. ${ }^{1,3,78}$ Selected ones are included in the tables below (22 entries of the 400). Water has a dielectric constant of 80.4 so that there are minimal contributions to equilibrium constant measurements from ion pairing.

The use of water has limitations as a solvent for transition metal hydride acid-base chemistry. The common ligand sets that stabilize metal hydrides usually make the complexes hydrophobic. Water allows only a limited range of acid strengths due to its autoprotolysis constant of $1.0 \times 10^{-14}$. Only half of all of the acids listed below have estimated $\mathrm{p} K_{\mathrm{a}}^{\mathrm{aq}}$ values in the range of 0 to 14 ; however most are not soluble or would react by ligand substitution or redox reaction (e.g. hydrogen evolution). The other half would be leveled in acid strength to $\mathrm{H}_{3} \mathrm{O}^{+}$or $\mathrm{OH}^{-}$, even if they were soluble in water and did not react by substitution or redox reactions. Methanol, with an autoprotolysis constant of $10^{-16.6}$ has similar limitations. ${ }^{55}$ For very acidic hydrides, acidic solvents such as $\mathrm{CF}_{3} \mathrm{COOH}^{85} \mathrm{H}_{2} \mathrm{SO}_{4}{ }^{86}$ and $\mathrm{HF} / \mathrm{SbF}_{6}{ }^{87}$ have been employed in rare cases.

\subsubsection{Dimethylsulfoxide}

Dimethylsulfoxide is an excellent solvent for the determination of the acidity of neutral organic compounds and a wide range of reference acids of known $\mathrm{p} K_{\mathrm{a}}{ }^{\mathrm{DMSO}}$ are available. ${ }^{12}$ The autoprotolysis constant for DMSO is approximately $10^{-35}$. This provides a much wider range of resolution of acid strengths than water. Table 1 and Table 2 lists the $p K_{\mathrm{a}}{ }^{\mathrm{DMSO}}$ of selected acids that appear as reactants in this review. DMSO has a large dielectric constant of 46.7 so that ions are completed dissociated. DMSO is an excellent hydrogen bond acceptor and strongly solvates nitrogen- and oxygen-based BrønstedLowry acids. Cationic acids with $\mathrm{p} K_{\mathrm{a}}^{\mathrm{MeCN}}$ less than 2 are leveled in strength to $\left[\mathrm{HOSMe}_{2}\right]^{+}$. However this solvent is rarely used for metal hydride complexes because they might reduce this solvent to the sulfide or undergo unwanted ligand substitution since both sulfur-bonded and oxygen-bonded sulfoxides are good ligands. ${ }^{88}$ In addition, hydrides with conjugate bases with $\mathrm{p} K_{\mathrm{a}}$ greater than 35 cannot be studied in this solvent since the base will be leveled in strength to that of $\mathrm{CH}_{2} \mathrm{SOMe}^{-}$.

\subsection{Low dielectric constant solvents}

As mentioned, transition metal dihydrogen and polyhydride complexes often undergo loss of dihydrogen when dissolved in the coordinating solvents mentioned thus far. It has been found that THF or DCM (or DCE) were suitable solvents for their $\mathrm{p} K_{\mathrm{a}}$ measurements. ${ }^{5-8,28,89-93}$ THF is best used for hydrides with strong conjugate bases while DCM is useful for hydride and dihydrogen complexes that are very acidic.

The measurement of $\mathrm{pK}_{\mathrm{a}}$ in low dielectric constant solvents is often made challenging because of ion pairing and homoconjugation. Methods have been described to determine the free ion $\mathrm{pK}_{\mathrm{fi}}{ }^{\mathrm{THF}}$ values for hydrocarbon acids. ${ }^{14}$ Ion-pair dissociation constants are determined using conductivity measurements or can estimated theoretically when the concentrations are low enough $(<0.01 \mathrm{M})$ to avoid aggregation of ion pairs. ${ }^{15,94}$ Typical dissociation constants range from $10^{-4}$ to $10^{-8} \mathrm{M}$ for $1: 1$ ion pairs in THF. Thus without correction this might result in errors as large as $5 \mathrm{p} K_{\mathrm{a}}$ units. ${ }^{7}$ The values increase with decreasing inter-ion separation. In order to minimize this problem, large, weakly interacting counteranions such as tetraarylborates or $\mathrm{PF}_{6}{ }^{-}$and countercations such as $[\mathrm{K}(2,2,2-\mathrm{crypt})]^{+}$ (abbreviated $Q$ below) are employed. When solubility is a problem, the use of $\left[\mathrm{BAr}_{4}\right]^{-}$where $\mathrm{Ar}=3,5-$ $\left(\mathrm{CF}_{3}\right)_{2} \mathrm{C}_{6} \mathrm{H}_{3}$ is recommended. ${ }^{7}$

Homoconjugation is particularly important when the conjugate base form A of an acid HA forms a strong interaction, usually a hydrogen bond, with one or more equiv. of the acid (Equation 6). This is typically observed for oxygen-based acids such as alcohols and phenols (see Section 5) or hydrogen halides. 


\subsubsection{Tetrahydrofuran}

A wide range of compounds are soluble and stable in THF (dielectric constant 7.6) including labile dihydrogen complexes and very basic and reactive organic anions and transition metal hydrides. For example the $\mathrm{p} K_{\mathrm{a}}{ }^{\mathrm{THF}} 39$ has been determined for the very reactive $\mathrm{RuH}_{6}\left(\mathrm{P}^{\mathrm{i}} \mathrm{Pr}_{3}\right)_{2} /\left[\mathrm{RuH}_{5}\left(\mathrm{P}^{\mathrm{i}} \mathrm{Pr}_{3}\right)_{2}\right]^{-}$acidbase pair. Acetonitrile could not be used for this determination. The anionic conjugate base complex reacts and loses hydrogen immediately when dissolved in MeCN as expected on the basis of the MeCN autoprotolysis constant as discussed above.

THF- $d_{8}$ is readily available so that NMR can be used for equilibrium constant determinations. Potentially, $\mathrm{p} K_{\mathrm{a}}{ }^{\mathrm{THF}}$ values can range from approximately 0 for $\mathrm{H}(\mathrm{THF})_{x}{ }^{+}$to greater than 50 for the deprotonation of THF. The actual autoprotolysis constant for THF is not known. The solvent must be carefully dried and made oxygen-free for these measurements. The protonated solvent is not stable and strong acids are known to cause the ring-opening polymerization of THF.

The $\mathrm{p} K_{\mathrm{a}}$ values in the tables below may or may not be corrected for ion pairing and so there is the potential for errors up to \pm 5 units. Nevertheless, they provide a starting point to relate the acid strength of one compound with another. Some equilibria are less perturbed by ion pairing than others. For example the reaction of a cationic acid/large counterion $X^{-}$salt with a base results in little change in ion-pairing energies (Equation 8) as does the reaction of a neutral acid with an anionic base with a large countercation $\mathrm{Q}^{+}$(Equation 9).

Equation 8

$\left[H B^{1}\right] X+B^{2} \rightleftarrows B^{1}+\left[H B^{2}\right] X$

Equation 9

$\mathrm{HB}^{1}+[\mathrm{Q}] \mathrm{B}^{2} \rightleftarrows[\mathrm{Q}] \mathrm{B}^{1}+\mathrm{HB}^{2}$

In these cases the equilibrium constant should reflect the $\mathrm{K}_{\mathrm{a}}$ difference in acid strengths. Nevertheless concentrations of ions greater than $0.01 \mathrm{M}$ can lead to aggregation of ion pairs which further complicates the interpretation of the results. It is important to leave sufficient time to establish the equilibrium. The equilibria between complexes with several large ligands and high $\mathrm{p} K_{\mathrm{a}}$ values (e.g. $\left[\operatorname{Re}(\mathrm{H})_{4} \mathrm{~L}_{4}\right]^{+},\left[\mathrm{Os}(\mathrm{H})_{3} \mathrm{~L}_{4}\right]^{+}$, and $\left[\mathrm{Ru}\left(\mathrm{C}_{5} \mathrm{Me}_{5}\right)(\mathrm{H})_{2}(\mathrm{PMePh})_{2}\right]^{+}$) were very slow $(12 \mathrm{~h}$ to $3 \mathrm{~d}) .{ }^{7}$

In reactions where ion pairs are produced or consumed (Equation 10, Equation 11), applying a correction for ion pairing is essential.

Equation 10

$\left[H B^{1}\right] X+[Q] B^{2} \rightleftarrows B^{1}+H B^{2}+[Q] X$

Equation 11

$H B^{1}+B^{2} \rightleftarrows\left[H B^{2}\right] B^{1}$

For Equation 11 the inter-ion separation between $\left[\mathrm{HB}^{2}\right]^{+}$and $\left[\mathrm{B}^{1}\right]^{-}$is needed as well as any hydrogenbonding energy contributions to calculate the dissociation constant for the ion pair. The equilibrium will be temperature dependent, with a shift to the left as the temperature is raised. A further complication is the formation of homoconjugates which enhance the acidity of $\mathrm{HB}^{1}$ beyond what might be expected from the published $\mathrm{p} K_{\mathrm{a}}{ }^{\mathrm{MeCN}}$ or $\mathrm{p} K_{\mathrm{a}}{ }^{\mathrm{DMSO}}$ value (e.g. Equation 12).

Equation 12

$2 \mathrm{HB}^{1}+\mathrm{B}^{2} \rightleftarrows\left[\mathrm{HB}^{2}\right]\left[\mathrm{B}^{1} \mathrm{HB}^{1}\right]$ 
As will be noted further in Section 5, reactions in THF of neutral metal complexes with the alcohols and carboxylic acids of Table 2 are challenging to understand. ${ }^{95}$ For this reason the $\mathrm{p} K_{\mathrm{a}}{ }^{\mathrm{THF}}$ values for cationic acids (Table 1) and neutral references acids (Table 2) have been placed in separate tables. There are different correlation equations that relate $\mathrm{p} K_{\mathrm{a}}{ }^{\mathrm{MeCN}}$ or $\mathrm{p} K_{\mathrm{a}}{ }^{\mathrm{DMSO}}$ values to $\mathrm{p} K_{\mathrm{a}}{ }^{\mathrm{THF}}$ values for these two types of acids.

\subsubsection{Dichloromethane}

Many reactions involving strongly acidic hydride and dihydrogen complexes have been conducted in this solvent. It has good solvating properties although ions are paired because of the low dielectric constant (8.9). Large anions such as $\mathrm{BAr}_{4}{ }_{4}^{-}$are recommended but for very acidic compounds $\left(\mathrm{p} K_{\mathrm{a}}{ }^{\mathrm{DCM}}<5\right)$ tetraphenylborate is converted to $\mathrm{BPh}_{3}$ and benzene. ${ }^{28}$ In addition hydride acids with $\mathrm{p} K_{\mathrm{a}}{ }^{\mathrm{DCM}}$ $>15$ have conjugate base forms that react with the solvent. ${ }^{7}$ The solvent 1,2-dichloroethane (DCE) with dielectric constant 10.4 has similar characteristics. The acidity and the bond dissociation energies of about 50 cationic hydrides have been measured by protonating neutral metal complexes in DCE with triflic acid $\left(\mathrm{HOSO}_{2} \mathrm{CF}_{3}\right)$ and measuring the enthalpy of the reaction. ${ }^{29}$ These fall in the range of 10-40 $\mathrm{kcal} / \mathrm{mol}$ (or approximately $5<\mathrm{p} K_{\mathrm{a}}{ }^{\mathrm{DCM}}<13$; see Section 4.3). The use of neutral carboxylic acids, acidic alcohols and phenols should be avoided as reactants when determining $\mathrm{p} K_{\mathrm{a}}$ since they form extremely stable homoconjugates in this solvent. ${ }^{42,58-59,96}$ An excellent ladder of overlapping acid-base equilibria in DCE has been constructed of strong acids with $\mathrm{p} K_{\mathrm{a}}{ }^{\mathrm{DCE}}$ values ranging from 0 for picric acid to -18 for super acids. ${ }^{97}$ On this scale triflic acid (HOTf) has a $\mathrm{p} K_{\mathrm{a}}{ }^{\mathrm{DCE}}-11$.

\subsection{3 $\mathrm{p} K_{\mathrm{a}}$ of dihydrogen.}

The value of $\mathrm{p} K_{\mathrm{a}}{ }^{\mathrm{THF}}\left\{\mathrm{H}_{2} /\left(\mathrm{H}^{+}+\mathrm{H}^{-}\right)\right\}$is approximately $50 .^{7}$ However an incorrect value of 35 is commonly cited in the literature. This comes from the first determination of $p K_{a}{ }^{T H F} 35-37$ for dihydrogen ${ }^{98}$ obtained by studying the reaction of [K(18-crown-6)] $\mathrm{H}$ with $\mathrm{CH}_{2}\left(\mathrm{C}_{6} \mathrm{H}_{2}-2,4-\mathrm{Me}_{2}\right)_{2}$ in THF to produce $\mathrm{H}_{2}$ and $[\mathrm{K}(18-\mathrm{crown}-6)]\left[\mathrm{CH}\left(\mathrm{C}_{6} \mathrm{H}_{2}-2,4-\mathrm{Me}_{2}\right)_{2}\right]$. The $\mathrm{p} K_{\mathrm{a}}{ }^{\mathrm{THF}}$ of the diarylmethane acid was assumed to be 36.3 , based on the report of $\mathrm{p} K_{\mathrm{a}} 36.3$ per hydrogen for this acid in cyclohexylamine solvent containing cesium cyclohexamide $\mathrm{e}^{99}$ and it was assumed that this amine scale and the THF scale will could provide similar $\mathrm{p} K_{\mathrm{a}}$ values. ${ }^{27}$ However the choice of the anchor for the amine scale and the THF scale was 9-phenylfluorene (9PF) with an assigned $\mathrm{p} K_{\mathrm{a}}{ }^{\mathrm{THF}}\left(9 \mathrm{PF} /\right.$ free ion 9PF) of $18.5 .{ }^{27}$ Note that the $\mathrm{p} K_{\mathrm{a}}{ }^{\mathrm{THF}}$ of $\mathrm{CH}_{2} \mathrm{Ph}_{2}$ is about 48 (Table 2). This makes $\mathrm{p} K_{\mathrm{a}}{ }^{\mathrm{THF}}\left(\mathrm{H}_{2} / \mathrm{H}^{-}\right)$approx. 49 with a large error due to the difficulty in accounting for ion pairing. ${ }^{7}$ The highest $\mathrm{p} K_{\mathrm{a}}{ }^{\mathrm{THF}}$ for a hydride acid that we have determined is 43 for $\mathrm{IrH}_{5}\left(\mathrm{PiPr}_{3}\right)_{2}$ and the conjugate base form $\left[\mathrm{IrH}_{4}\left(\mathrm{P}^{\mathrm{i}} \mathrm{Pr}_{3}\right)_{2}\right]^{-}$does not deprotonate dissolved dihydrogen. ${ }^{100}$ However the more basic compound IrHLi(Cp*) $\left(\mathrm{PMe}_{3}\right)$ reacts with $\mathrm{H}_{2}$ in $\mathrm{THF}$ to give $\operatorname{IrH}_{2} \mathrm{Cp}^{*}\left(\mathrm{PMe}_{3}\right)$ and, presumably, $\mathrm{LiH}^{101}{ }^{101} \mathrm{The} \mathrm{p} K_{\mathrm{a}}{ }^{\mathrm{THF}}$ of this iridium dihydride was reported to be less than that of toluene but greater than that of DMSO ( $\mathrm{p} K_{\mathrm{a}}{ }^{\mathrm{DMSO}}$ approx. 35 , Table 2, $\mathrm{p} K_{\mathrm{a}}{ }^{\mathrm{THF}}>45$ ). These reactions would be consistent with a $\mathrm{p} K_{\mathrm{a}}{ }^{\mathrm{THF}}$ of approx. 50 for the dihydride and dissolved dihydrogen.

The $\mathrm{p} K_{\mathrm{a}}{ }^{\mathrm{MeCN}}$ can be calculated by use of a thermodynamic cycle using the redox potential of ferrocenium/ferrocene, the bond dissociation energy of dihydrogen and an equation that relates these quantities to the $\mathrm{p} K_{\mathrm{a}}$ of $\mathrm{H}_{2}$. In this case a $\mathrm{p} K_{\mathrm{a}}{ }^{\mathrm{MeCN}}$ value of 50 was estimated (Table 2). ${ }^{7}$

\subsection{Comparing $p K_{a}$ values of acids in different solvents}

In order to better understand the relative acid strength of hydrides it is useful to compare reactions done in different solvents. Since MeCN, THF, and DCM are the solvents most commonly used, understanding the conversion of acid strengths between these systems is essential. The change of $\mathrm{p} K_{\mathrm{a}}$ on moving an acid from MeCN to THF is well established for cationic nitrogen-based acids (Equation 13) and this equation applies to the acids shown in Table $1 .{ }^{16}$

Equation 13

$\mathrm{p} K_{\mathrm{a}}{ }^{\mathrm{MeCN}}\left(\mathrm{HB}^{+} / \mathrm{B}\right)=1.071 \mathrm{pK}_{\alpha}{ }^{\mathrm{THF}}\left(\mathrm{HB}^{+} / \mathrm{B}\right)+5.78$ 
A somewhat different correlation (Equation 14) was used for the analysis of transition metal hydride complexes and for consistency this correlation using $\mathrm{p} K_{a}{ }^{\mathrm{LAC}}$ in place of $\mathrm{pK}_{\alpha}{ }^{\mathrm{THF}}$ in Equation 14 will be used in this review. ${ }^{7-8}$ However the use of Equation 14 leads to the calculation of $\mathrm{p} K_{\mathrm{a}}{ }^{\mathrm{MeCN}}$ values that match those of Equation 13 within the range of the error ( \pm 2 units).

Equation 14

$\mathrm{p} K_{\mathrm{a}}{ }^{\mathrm{MeCN}}\left(\mathrm{HB}^{+} / \mathrm{B}\right)=1.13 \mathrm{pK}_{\alpha}{ }^{\mathrm{THF}}\left(\mathrm{HB}^{+} / \mathrm{B}\right)+3.2$

A comparison of $\mathrm{p} K_{\mathrm{a}}$ values for cationic nitrogen-based acids in several other solvents is available. ${ }^{50}$

For neutral acids the correlation is different as mentioned above (Equation 15). ${ }^{7-8}$

Equation 15

$\mathrm{p} K_{\mathrm{a}}{ }^{\mathrm{MeCN}}\left(\mathrm{HA} / \mathrm{A}^{-}\right)=0.81 \mathrm{pK}_{\alpha}{ }^{\mathrm{THF}}\left(\mathrm{HA} / \mathrm{A}^{-}\right)+1$

However the number of reliable data points to make a correlation is small and in general, the values in THF and MeCN appear to be the same within error for the neutral acids. Therefore no correction between $\mathrm{p} K_{\mathrm{a}}{ }^{\mathrm{LAC}}$ and $\mathrm{p} K_{\mathrm{a}}{ }^{\mathrm{MeCN}}$ for neutral acids will be made in this review.

The $\mathrm{p} K_{\mathrm{a}}{ }^{\mathrm{DCM}}$ values are the same as the $\mathrm{p} K_{\mathrm{a}}{ }^{\text {THF }}$ values because of a referencing convention. ${ }^{28}$ However strong acids can be distinguished even though their $\mathrm{p} K_{\mathrm{a}}{ }^{\mathrm{DCM}}$ values are negative and this suggests that the $\mathrm{p} K_{\mathrm{a}}{ }^{\mathrm{DCM}}$ values will need to be shifted by at least 8 units more positive once the leveling of very strong acids to the strength of $\left[\mathrm{CH}_{2} \mathrm{Cl}_{2} \mathrm{H}\right]^{+}$has been established.

Equations that relate $\mathrm{p} K_{\mathrm{a}}{ }^{\mathrm{DMSO}}$ and $\mathrm{p} K_{\mathrm{a}}{ }^{\mathrm{MeCN}}$ are available ${ }^{7-8,50}$ : but in general the MeCN values tend to be $9-12$ units higher than those in $\mathrm{DMSO}^{49,57}$ for both cationic and neutral acids as can be seen by inspection of Table 1 and Table 2 . Similarly equations that relate $p K_{a}^{a q}$ and $p K_{a}{ }^{\text {MeCN }}$ for cationic and neutral acids have been proposed but in general the $\mathrm{p} K_{\mathrm{a}}^{\mathrm{MeCN}}$ are 7-10 units higher for the cationic acids and 10-16 for the neutral acids. The $\mathrm{p} K_{\mathrm{a}}{ }^{\mathrm{aq}}$ and $\mathrm{p} K_{\mathrm{a}}{ }^{\mathrm{THF}}$ values appear to be approximately the same for cationic acids but obviously there are big differences in the solvation properties of these solvents.

\section{ADDITIVE LIGAND ACIDITY CONSTANT (LAC) METHOD USED FOR ORDERING ACID STRENGTHS}

We have proposed a simple method to predict $\mathrm{p} K_{\mathrm{a}}{ }^{\mathrm{THF}}$ (or $\mathrm{p} K_{\mathrm{a}}{ }^{\mathrm{DCM}}$ ) values of diamagnetic hydride and dihydrogen complexes of metals ranging from group 6 to group 10 to within approximately 3 p $K_{\mathrm{a}}$ units. We will refer to these predicted values as $\mathrm{p} K_{\mathrm{a}}{ }^{\mathrm{LAC}}$.

This method refers to the reaction of Equation 16:

Equation 16

$K_{\mathrm{a}}^{\mathrm{LAC}}$
$\left[\mathrm{MHL}_{n}\right]^{(\mathrm{x}+1)} \rightleftharpoons[\mathrm{ML}]^{\mathrm{x}}+\mathrm{H}^{+}$

They are calculated according to Equation 17:

Equation 17 of the LAC method.

$\mathrm{p} K_{\mathrm{a}}^{\mathrm{LAC}}=\Sigma \mathrm{A}_{\mathrm{L}}+\mathrm{C}_{\text {charge }}+\mathrm{C}_{\mathrm{nd}}+\mathrm{C}_{\mathrm{d} 6}$ 
1. $A_{L}$ values (Table 3 ) for each of the four to eight ligands around the metal in the conjugate base complex are added. When the ligand binds to the metal at more than one coordination site (i.e. it is bior polydentate), the $A_{L}$ value represents the contribution to each coordination site.

Table 3. Ligand acidity constants ${ }^{a}$

\begin{tabular}{|c|c|c|c|}
\hline Type of ligand & $A_{L}$ & Type of ligand & $A_{L}$ \\
\hline $\mathrm{SiCl}_{3}^{-}$ & -12 & $\begin{array}{l}\eta^{6} \text {-arene (cymene, } \\
\mathrm{C}_{6} \mathrm{Me}_{6} \text { ) }\end{array}$ & $0.7(\times 3)^{b}$ \\
\hline $\mathrm{CN}^{-}$ & -11 & $\mathrm{PX}_{3}\left(\mathrm{P}(\mathrm{OR})_{3}\right)$ & 1.6 \\
\hline Chloride, $\mathrm{Cl}^{-}$ & -6 & $\begin{array}{l}\mathrm{PAr}_{3} \text { (dppv; } \\
\text { phosphorus part of } \\
\mathrm{PPh}_{2}-\mathrm{NH}-\mathrm{NH}-\mathrm{PPh}_{2}{ }^{\mathrm{C}} \text { ) }\end{array}$ & 2.7 \\
\hline Carbonyl, CO (also $\mathrm{PF}_{3}$ ) & -4 & $\begin{array}{l}\mathrm{PAr}_{2} \mathrm{R}\left(\mathrm{PPh}_{2} \mathrm{Me}\right. \\
\mathrm{dppe}, \mathrm{dppm} ; \mathrm{dppp})\end{array}$ & 3.0 \\
\hline $\mathrm{NO}^{+}$ & -3 & $\begin{array}{l}\mathrm{PArR}_{2}\left(\mathrm{PPhMe}_{2}\right. \\
\text { EtXantphos) }\end{array}$ & 4.0 \\
\hline Olefin $\left(\mathrm{C}_{2} \mathrm{H}_{4}, \mathrm{COD}\right)$ & $-2(x 1$ or $x 2)$ & $\begin{array}{l}\text { Nitrogen donors } \\
\text { (MeCN; py; oxazolyl; } \\
\text { dach) }\end{array}$ & 4 \\
\hline $\begin{array}{l}\text { Hydridotris(pyrazolyl)borate, } \\
\mathrm{Tp}^{-}\end{array}$ & 0 & $\mathrm{NHC}$ & 4 \\
\hline Hydride, $\mathrm{H}^{-}$ & 0.2 & $\begin{array}{l}\mathrm{PR}_{3}\left(\mathrm{PCy}_{3} ; \mathrm{P}^{\prime} \mathrm{Pr}_{3} ;\right. \\
\mathrm{PMe}_{3} ; \\
\text { cyclo-( } \mathrm{PRCH}_{2} \mathrm{NR}^{\prime}- \\
\left.\left.\mathrm{CH}_{2} \mathrm{PRCH}_{2} \mathrm{NR}^{\prime}-\right)\right)\end{array}$ & 4.9 \\
\hline $\begin{array}{l}\eta^{5} \text {-Cyclopentadienide, } \mathrm{Cp}^{-} \\
\mathrm{MeC}_{5} \mathrm{H}_{4}^{-}(\mathrm{MeCp})\end{array}$ & $0.6(\times 3)^{b}$ & $\mathrm{H}_{2} \mathrm{O}$ & 6 \\
\hline \multicolumn{4}{|l|}{$\begin{array}{l}\text { Pentamethylcyclopentadienide, } \\
\text { Cp*- }\end{array}$} \\
\hline $\begin{array}{l}\text { Abbreviations: } \mathrm{COD}=1,5 \mathrm{cyclooc} \\
\mathrm{Ph}_{2} \mathrm{CH}=\mathrm{CHPPh} \\
\text { tXantphos }=9, \mathrm{dppe}=\mathrm{PPh}_{2} \mathrm{CH}_{2} \mathrm{C} \\
\text { diaminocyclohexane, } \mathrm{NHC}=\mathrm{N} \text {-het } \\
\text { Assumed to occupy } 3 \text { coordinatic }\end{array}$ & $\begin{array}{l}\text { tadiene; dtpe }= \\
\mathrm{H}_{2} \mathrm{PPh}_{2} ; \mathrm{dppm} \\
\text { iphenylphosph } \\
\text { erocyclic carbe } \\
\text { n sites: } 3 \mathrm{~A}_{L}(\mathrm{Tp})\end{array}$ & $\begin{array}{l}\left.\mathrm{H}_{4}\right)_{2} \mathrm{PCH}_{2} \mathrm{CH}_{2} \mathrm{P}\left(4-\mathrm{CF}_{3} \mathrm{C}_{6}\right. \\
\mathrm{l}_{2} \mathrm{PPh}_{2} ; \mathrm{dppp}=\mathrm{PPh}_{2} \mathrm{CH} \\
\text { hene; py = pyridine; } \mathrm{d} d \\
(\mathrm{Cp})=1.8,3 \mathrm{~A}_{\mathrm{L}}\left(\mathrm{Cp}^{*}\right)=2\end{array}$ & $\begin{array}{l}\text { 4); } 2 \text { dppv }=Z \\
\mathrm{H}_{2} \mathrm{CH}_{2} \mathrm{PPh}_{2} ; \\
h=\text { trans- }\end{array}$ \\
\hline
\end{tabular}

2. $C_{\text {charge }}$ depends on the charge $x$ of the conjugate base, $\left[M L_{n}\right]^{x}$, of Equation 17 (Table 4).

Table 4 The constant $C_{\text {charge }}$ of Equation 17.

\begin{tabular}{cc}
$\mathbf{x}$ & $\mathbf{C}_{\text {charge }}$ \\
\hline+1 & -15 \\
0 & 0 \\
-1 & 30 \\
\hline
\end{tabular}


3. $C_{n d}=0$ for $3 d$ and $4 d$ metals or $C_{n d}=2$ for $5 d$ metals. This recognizes the stronger $M-H$ bonds of the $5 d$ metals. In actual fact as we will see this difference is subject to considerable variation for metal hydride complexes depending on the group (c.f. Section 4.5.9, 4.7.2).

4. $C_{d 6}=6$ when the metal ion of the acidic hydride complex loses the $d^{6}$ octahedral configuration on going to the lower coordinate conjugate base form. For example this constant is added when calculating the $\mathrm{p} K_{\mathrm{a}}$ for the hydride $\mathrm{Fe}\left(\mathrm{Cp}^{*}\right)(\mathrm{H})(\mathrm{CO})_{2}$ which is considered to have a $\mathrm{d}^{6}$ octahedral ferrous ion while the conjugate base, $\left[\mathrm{Fe}(\mathrm{Cp} *)(\mathrm{CO})_{2}\right]^{-}$is considered to have a $\mathrm{d}^{8} 5$ coordinate iron( 0 ) atom.

$C_{d 6}=0$ for all other cases, including dihydrogen complexes with $d^{6}$ octahedral metal centers which remain six coordinate with a $d^{6}$ configuration in their conjugate base form.

The $\mathrm{p} K_{\mathrm{a}}{ }^{\mathrm{LAC}}$ match known $\mathrm{p} K_{\mathrm{a}}{ }^{\text {THF }}$ or $\mathrm{p} K_{\mathrm{a}}{ }^{\mathrm{DCM}}$ values for hydrides, usually within $3 \mathrm{p} K_{\mathrm{a}}$ units. The LAC method is still a crude method of prediction since there are many ligand substituent effects and specific solvation effects that are not accounted for. Nevertheless we find that useful trends in the literature emerge when the reactions of transition metal hydrides are analyzed in the light of these predicted values.

\section{SPECIFIC OBSERVATIONS ACCORDING TO THE GROUP.}

The reactions of acids with metal complexes to give hydrides or dihydrogen complexes are organized here by group and then by increasing reported $\mathrm{p} K_{\mathrm{a}}$ or calculated $\mathrm{p} K_{\mathrm{a}}{ }^{\mathrm{LAC}}$ value. Also included are reverse reactions, reaction of bases. There is enough data to construct tables that order the hydrides from most acidic to least acidic for the groups from chromium to nickel. As mentioned $\mathrm{p} K_{\mathrm{a}}{ }^{\mathrm{LAC}}$ values are estimates of $\mathrm{p} K_{\mathrm{a}}{ }^{\mathrm{THF}}, \mathrm{p} K_{\mathrm{a}}{ }^{\mathrm{MeCN}}, \mathrm{p} K_{\mathrm{a}}{ }^{\mathrm{aq}}$, and $\mathrm{p} K_{\mathrm{a}}^{\mathrm{MeCN}}$ (neutral acids only) with predicted $\mathrm{p} K_{\mathrm{a}}^{\mathrm{MeCN}}$ for cationic acids in parentheses. The tables will be discussed moving from the most acidic to least acidic compounds, but groups of compounds related by the same charge and type of ligands will be discussed together even though they may not follow each other in the table.

\subsection{Titanium group}

There is little information on the acidity of the hydrides of the titanium group. Cationic titanium and zirconium complexes are known to heterolytically split dihydrogen to produce hydride complexes. 102-103

\subsection{Vanadium group}

There is limited acid-base information on hydrides of this group. The carbonyl complex $\mathrm{VH}(\mathrm{CO})_{6}$ is a strong acid in water while $\mathrm{VH}(\mathrm{CO})_{5}\left(\mathrm{PPh}_{3}\right)$ has a $\mathrm{p} K_{\mathrm{a}}{ }^{\text {aq }}$ of $6.8 .^{1,104}$ The protonation of a variety of derivatives of trimethylsilylcyclopentadienyl complexes $\mathrm{NbH}(\mathrm{L})\left(\mathrm{C}_{5} \mathrm{H}_{4} \mathrm{SiMe}_{3}\right)_{2}, \mathrm{~L}=\mathrm{CNR}, \mathrm{SbPh}_{3}, \mathrm{PHPh}_{2}$, $\mathrm{PMePh}_{2}$ with $\mathrm{CF}_{3} \mathrm{COOH}$ ( $\mathrm{p} K_{a}^{\mathrm{MeCN}} 13$ ) in acetone- $\mathrm{d}_{6}$ at $228 \mathrm{~K}$ produces the dihydrogen complexes $\left[\mathrm{Nb}\left(\mathrm{H}_{2}\right)(\mathrm{L})\left(\mathrm{C}_{5} \mathrm{H}_{4} \mathrm{SiMe}_{3}\right)_{2}\right]^{+}\left(\mathrm{p} K_{a}{ }^{\mathrm{LAC}}\right.$ approximately 7$) .{ }^{105}$ This reaction may be driven by the low temperature conditions and the formation of the homoconjugated ion $\left[\mathrm{CF}_{3} \mathrm{COOH}^{\circ} \mathrm{OOCCF}_{3}\right]^{-}$. The protonation of $\mathrm{NbH}_{3}(\mathrm{Cp})_{2}$ with acids has been studied in toluene and methylcyclohexane. ${ }^{106}$ The use of trifluoroacetic acid leads, at low temperature, to the formation of $\left[\mathrm{Nb}_{(}\left(\mathrm{H}_{2}\right)_{2}(\mathrm{Cp})_{2}\right]\left[\mathrm{CF}_{3} \mathrm{COO}^{\circ} \mathrm{H}{ }^{\circ} \mathrm{OOCCF}_{3}\right]$.

\subsection{Chromium group}

Table 5 lists the reactions of hydrides of this group starting from the most acidic. The dihydrides $\left[\mathrm{WH}_{2}(\mathrm{CO})_{3}(\mathrm{Cp})\right]^{+}$and $\left[\mathrm{WH}_{2}(\mathrm{CO})_{3}\left(\mathrm{Cp}^{*}\right)\right]^{+}$(entries 1 and 2 of Table 5$)$ are the most acidic compounds. The conjugate base monohydride forms are only partially converted to these dihydrides when treated with excess $\mathrm{CF}_{3} \mathrm{SO}_{3} \mathrm{H}$ in $\mathrm{CD}_{2} \mathrm{Cl}_{2} \cdot{ }^{107}$ The high acidity results from the three pi-acid carbonyl ligands. Four 
ditungsten cationic carbonyl hydrides $\left[\mathrm{W}_{2} \mathrm{H}(\mathrm{CO})_{6} \mathrm{Cp}_{2}\right]^{+},\left[\mathrm{W}_{2} \mathrm{H}(\mathrm{CO})_{6} \text { (fulvalene) }\right]^{+}$, $\left[\mathrm{W}_{2} \mathrm{H}(\mathrm{CO})_{6}\left\{\left(\mathrm{C}_{5} \mathrm{H}_{3}\right)_{2}\left(\mathrm{SiMe}_{2}\right)_{2}\right\}\right]^{+}$and $\left[\mathrm{W}_{2} \mathrm{H}(\mathrm{CO})_{2} \mathrm{Cp}_{2}\left(\mathrm{PPh}_{2}\right)_{2}\right]^{+}$have been generated by the reaction of tungsten-tungsten bonded compounds with strong acid (entries 3 to 6 , Figure 1). The first three hexacarbonyls have decreasing acid strength as listed since the first is not formed by protonation with $\mathrm{HBF}_{4} \mathrm{Et}_{2} \mathrm{O}$ in $\mathrm{CH}_{2} \mathrm{Cl}_{2}$ while the second is not formed with $\mathrm{HBF}_{4} \cdot \mathrm{THF}$ and the third is deprotonated by DMSO in $\mathrm{CD}_{2} \mathrm{Cl}_{2}{ }^{108}$ The last complex $\left[\mathrm{W}_{2} \mathrm{H}(\mathrm{CO})_{2} \mathrm{Cp}_{2}\left(\mathrm{PPh}_{2}\right)_{2}\right]^{+}$(entry 43 ) with bridging diphenylphosphido groups has a $\mathrm{p} K_{\mathrm{a}}{ }^{\mathrm{THF}}<20$, the $\mathrm{p} K_{\mathrm{a}}{ }^{\mathrm{THF}}$ of $\mathrm{DBU}$, the base used to deprotonate the bridging hydride. ${ }^{109}$

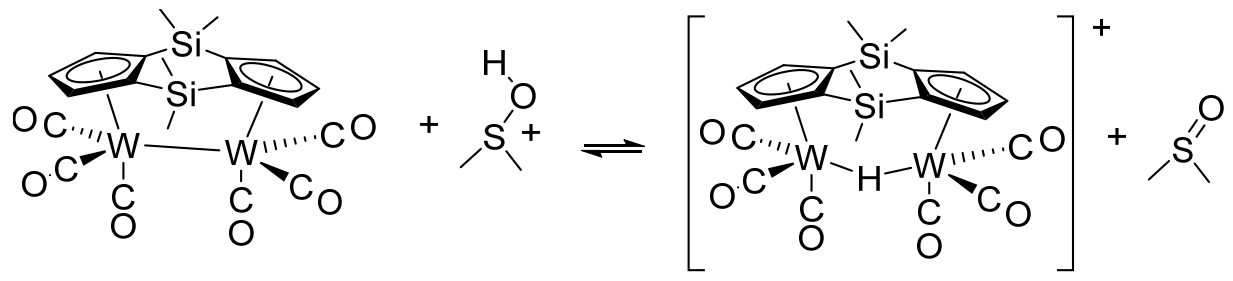

Figure 1. Reversible protonation of a tungsten-tungsten bond ${ }^{108}$

The molybdenum dihydride $\left[\mathrm{MoH}_{2}\left(\mathrm{C}_{6} \mathrm{H}_{6}\right)(\text { triphos) }]^{+2}\right.$ (entry 7 with $\left.\mathrm{p} K_{\mathrm{a}}{ }^{\mathrm{LAC}}-3\right)$ is only stable in neat $\mathrm{CF}_{3} \mathrm{COOH} .{ }^{85}$

Highly acidic dihydride or dihydrogen complexes are potential catalysts for ionic hydrogenation reactions (see Section 6.1). The molybdenum dihydride (entry 8) and the tungsten dihydrides (entries 14 and 15 ) have sufficient acidity to protonate electron rich ketones such as diethylketone and thus to function as catalysts for their ionic hydrogenation. The complex $\left[\mathrm{WH}_{2}(\mathrm{CO})_{2} \mathrm{Cp}\left(\mathrm{PPh}_{3}\right)\right]^{+}$is sufficiently acidic to protonate triphenylphosphine $\left(\mathrm{HPPh}_{3}{ }^{+} \mathrm{pK}_{\mathrm{a}}{ }^{\mathrm{THF}} 3\right)$ and $\mathrm{HPPh}_{3}{ }^{+}$is indeed detected in the mixture during ketone hydrogenation. ${ }^{110}$ For comparison, the $\mathrm{NHC}$ complex $\left[\mathrm{WH}_{2}(\mathrm{CO})_{2} \mathrm{Cp}(\mathrm{IMes})\right]^{+}$has a $\mathrm{p} K_{\mathrm{a}}{ }^{\mathrm{MeCN}} 6.3 .{ }^{111}$

Wang and Angelici ${ }^{29,112}$ systematically varied the structures of molybdenum and tungsten carbonyl phosphines (entries 9, 11-13, 16, 17, 19, 20, 23, 24, 37) and one chromium complex (entry 18) and then measured their enthalpies of protonation in 1,2-dichloroethane (DCE) using $\mathrm{CF}_{3} \mathrm{SO}_{3} \mathrm{H}$. The enthalpies were shown to be linearly correlated with $\mathrm{pK}_{\mathrm{a}}^{\mathrm{THF}}$ values in $\mathrm{THF}^{7}$ and in $\mathrm{DCM}^{28}$ with the assumption that entropy and ion pairing effects are similar for these $\mathrm{M}+\mathrm{HY} \rightarrow[\mathrm{MH}] \mathrm{Y}$ reactions. The

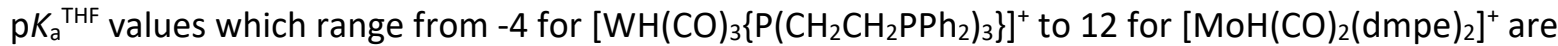
provided in Table 5 along with the values from the LAC method which agree within the $3 \mathrm{p} K_{\mathrm{a}}$ unit error. As expected the tricarbonyls are more acidic than the dicarbonyls. The acidity decreases from $\mathrm{p} K_{\mathrm{a}}{ }^{\mathrm{THF}} 5$ to 7 to 8 going down the triad of metals (entries 18-20) of the complexes $\left[\mathrm{MH}(\mathrm{CO})_{2}(\mathrm{dppm})_{2}\right]^{+}$.

Protonation of the ansa-molybdenocene dihydride provides a dihydrogen hydride complex (entry 22) which is stable below $260 \mathrm{~K}$ when the counterion is $\left[\mathrm{B}\left(3,5-\left(\mathrm{CF}_{3}\right)_{2} \mathrm{C}_{6} \mathrm{H}_{3}\right)_{4}\right]^{-113}{ }^{113}$ This cationic complex is expected to be quite acidic $\left(p K_{a}{ }^{L A C} 4\right)$ on the basis of using $6 A_{L}(C p)=3.6$ value to account for the contribution for the linked cyclopentadienyl ligands in the LAC scheme. The $p K_{a}{ }^{L A C}$ of related bispentamethylcyclopentadienyl complex (entry 26) is expected to be greater, and is estimated as $6 A_{L}\left(C p^{*}\right)=5.4$.

The reaction of several $\mathrm{Cp}^{-}$or $\mathrm{Cp}^{*-}$ containing complexes (entries 21 and 31-36) with acidic compounds $\mathrm{HY}$ at low temperature have been studied by UV-vis and/or NMR spectroscopy. The fluxional dihydride $\left[\mathrm{MoH}_{2}(\mathrm{CO})_{2}(\mathrm{Cp})(\mathrm{dppe})\right]^{+}$(entry 21 ) with a predicted $\mathrm{p} K_{\mathrm{a}}{ }^{\mathrm{LAC}}$ of 4 is produced by protonating the monohydride conjugate base in $\mathrm{CD}_{2} \mathrm{Cl}_{2}$ at $190 \mathrm{~K}$ with $\mathrm{CF}_{3} \mathrm{SO}_{3} \mathrm{H}^{.114}$ The monohydride is not protonated in neat acetic acid, consistent with the predicted high acidity of the acid form. The fluorinated alcohol $\mathrm{CF}_{3} \mathrm{CH}_{2} \mathrm{OH}$ ( $\mathrm{p} \mathrm{K}_{\mathrm{a}}{ }^{\mathrm{DMSO}} 23.5$, Table 2 ) is sufficiently acidic at temperatures below $250 \mathrm{~K}$ to set up equilibria between the trihydrides $\mathrm{MH}_{3}\left(\mathrm{Cp}^{*}\right)$ (dppe) and tetrahydride cations 
$\left[\mathrm{MH}_{4}\left(\mathrm{Cp}^{*}\right)(\mathrm{dppe})\right]\left[\mathrm{CF}_{3} \mathrm{CH}_{2} \mathrm{O}\right], \mathrm{M}=\mathrm{Mo}\left(\mathrm{p} K_{\mathrm{a}}^{\mathrm{LAC}} 9\right), \mathrm{W}\left(\mathrm{p} K_{\mathrm{a}}^{\mathrm{LAC}} 11\right)$ in $\mathrm{CH}_{2} \mathrm{Cl}_{2}$ (entries 32 and 34). The tungsten trihydride complex was noted as being more basic than the molybdenum one. The large discrepancy between the $\mathrm{p} K_{\mathrm{a}}{ }^{\mathrm{DMSO}}$ value of the alcohol and the $\mathrm{p} K_{\mathrm{a}}{ }^{\mathrm{LAC}}$ of the cationic hydrides might be explained by (1) the destabilization of the alkoxide anion in DMSO; (2) its stabilization by hydrogen-bonding with excess alcohol in $\mathrm{CH}_{2} \mathrm{Cl}_{2} ;(3)$ the thermodynamics of the $\mathrm{MH}+\mathrm{HY} \rightleftharpoons\left[\mathrm{MH}_{2}\right] \mathrm{Y}$ equilibrium where $\Delta \mathrm{S}$ is negative (approximately -13 eu ${ }^{115}$ ); (4) the favoring of ion pairing in low dielectric constant solvents like $\mathrm{CH}_{2} \mathrm{Cl}_{2}$. Smaller discrepancies are observed for the equilibria of these compounds in the low dielectric constant solvent toluene at low temperature where the molybdenum tetrahydride is in equilibrium with $\mathrm{CF}_{3} \mathrm{COOH}\left(\mathrm{p} K_{\mathrm{a}}{ }^{\mathrm{DMSO}} 3.45^{59}\right.$ ) below $250 \mathrm{~K}$ and the tungsten complex, with $\left(\mathrm{CF}_{3}\right)_{2} \mathrm{CHOH}, \mathrm{p} K_{\mathrm{a}}{ }^{\mathrm{DMSO}} 17.9^{59}$ (entries 33 and 35). All of these cationic molybdenum hydrides are unstable with respect to loss of $\mathrm{H}_{2}$ at ambient temperature. This includes $\left[\mathrm{MoH}_{2}(\mathrm{CO}) \mathrm{Cp}^{*}\left(\mathrm{PMe}_{3}\right)_{2}\right]^{+}$(entry 36$) \cdot{ }^{116}$ By contrast the more sterically hindered, less acidic complex $\left[\mathrm{MoH}_{4}\left(1,2,4-{ }^{\mathrm{t}} \mathrm{Bu}_{3} \mathrm{C}_{5} \mathrm{H}_{2}\right)\left(\mathrm{PMe}_{3}\right)_{2}\right]^{+}$(entry 39$)$ and the electron rich systems $\left[\mathrm{Mo}(\mathrm{H})_{2}(\mathrm{Cp})\left(\mathrm{PMe}_{3}\right)_{3}\right]^{+}$and $\left[\mathrm{Mo}(\mathrm{H})_{2}\left(\mathrm{Cp}^{*}\right)\left(\mathrm{PMe}_{3}\right)_{3}\right]^{+}$(entries 41 and 42$)$ are stable at room temperature. $\left[\mathrm{WH}_{4}\left(\mathrm{Cp}^{*}\right)(\mathrm{dppe})\right] \mathrm{PF}_{6}$ (entries 34,35$)$ has been characterized by X-ray crystallography. ${ }^{117}$

The catalytic activity of the complexes $\mathrm{MoH}(\mathrm{CO})_{x}\left(\mathrm{PMe}_{3}\right)_{3-x}\left(\mathrm{Cp}\right.$ or $\left.\mathrm{Cp}^{*}\right)$ were tested for the decomposition of formic acid. Under the conditions of catalysis $\left(0.3 \mathrm{M} \mathrm{HCOOH}\right.$ in $\mathrm{C}_{6} \mathrm{H}_{6}$ at $\left.373 \mathrm{~K}\right)$ the complexes with $\mathrm{x}=1$ were found to be the most active. ${ }^{118}$ This was attributed to their protonation by formic acid to give the dihydrides $\left[\mathrm{MoH}_{2}(\mathrm{CO})\left(\mathrm{PMe}_{3}\right)_{2}\left(\mathrm{Cp}\right.\right.$ or $\left.\left.\mathrm{Cp}{ }^{*}\right)\right][\mathrm{HCOO}]$ that evolved $\mathrm{H}_{2}$ and then $\mathrm{CO}_{2}$, regenerating the monohydride. These dihydrides have $\mathrm{p} K_{\mathrm{a}}{ }^{\mathrm{LAC}}$ estimated on the basis of the LAC method to be approx. 9 at $298 \mathrm{~K}$ (entry 36). The complexes with $\mathrm{x}=2$ and $\mathrm{x}=3$ had much lower turnover frequencies, consistent with the much lower $p K_{\mathrm{a}}{ }^{\mathrm{LAC}}$ of their dihydrides estimated to be -1 and -10 , respectively.

The nitrosyl ligand with $\mathrm{A}_{L}(\mathrm{NO})$ of approx. -3 , the carbonyl ligand and the positive charge in the dihydrogen or dihydride complexes $\left[\mathrm{MH}_{2}(\mathrm{NO})(\mathrm{CO})\left(\mathrm{PiPr}_{2} \mathrm{CH}_{2} \mathrm{CH}_{2} \mathrm{PPhCH}_{2} \mathrm{CH}_{2} \mathrm{P}^{\mathrm{i}} \mathrm{Pr}_{2}\right)\right]^{+}(\mathrm{M}=\mathrm{Mo}$, entry 25 and $\mathrm{M}=\mathrm{W}$, entry 28) contribute to the expected high acidity of these compounds. ${ }^{119}$ These complexes with $\mathrm{p} K_{\mathrm{a}}{ }^{\mathrm{THF}}<10$ are postulated to form from the THF complexes under $25-60$ bar of $\mathrm{H}_{2}$ at $373 \mathrm{~K}$ and to catalyze the ionic hydrogenation of imines by the outersphere proton before hydride transfer mechanism (see below).

The dihydrogen complex $\mathrm{W}\left(\mathrm{H}_{2}\right)(\mathrm{CO})_{5}$ (entry 27) can be prepared in $\mathrm{CD}_{2} \mathrm{Cl}_{2}$ at $200 \mathrm{~K}$ and is deprotonated by $\mathrm{NEt}_{3}\left(\mathrm{p} K_{\mathrm{a}}{ }^{\text {THF }} 14\right.$ for acid) and also water $\left(\mathrm{p} K_{\mathrm{a}}{ }^{\mathrm{THF}} \mathrm{O}\right.$ for $\left.\mathrm{H}_{3} \mathrm{O}^{+}\right) .{ }^{120}$ Although this dihydrogen complex is neutral, it is very acidic because of the presence of the five carbonyl ligands. The corresponding chromium and molybdenum pentacarbonyl complexes are unstable and their acid base properties have not been reported. ${ }^{120}$

The protonation of zero valent complexes yield hydrides by oxidative addition. The molybdenum(0) alkyne tetraphos complex (entry 38 ) is protonated by $\mathrm{HCl}$ in $\mathrm{THF}$ ( $\mathrm{p} K_{\mathrm{a}}{ }^{\mathrm{LAC}}$ approx. 10 ) or $\mathrm{HBF}_{4} \cdot$ ether and so the cationic hydride form has a $\mathrm{p} K_{\mathrm{a}}{ }^{\mathrm{THF}}>10$. The protonation of molybdenum( 0$)$ dinitrogen complexes has been studied for many years. The effect of a pendant amine base in the phosphine ligand on protonation has been investigated (entry 40). ${ }^{121}$ Both the molybdenum and the dinitrogen have similar basicity so that a mixture of the monohydride $\left[\mathrm{MoH}\left(\mathrm{N}_{2}\right)_{2} \mathrm{~L}_{2}\right]^{+}$and the hydrazido complex $\left[\mathrm{Mo}\left(\mathrm{NNH}_{2}\right) \mathrm{L}_{2}\left(\mathrm{O}_{3} \mathrm{SCF}_{3}\right)\right]^{+}$are obtained upon reaction with $\mathrm{CF}_{3} \mathrm{SO}_{3} \mathrm{H}$ in THF. By contrast, protonation at chromium is observed when $\mathrm{Cr}\left(\mathrm{N}_{2}\right)\left(\mathrm{P}_{3} \mathrm{Ph}_{3} \mathrm{Nn}_{3}\right)(\mathrm{dmpe})$ reacts with $\left[\mathrm{H}\left(\mathrm{OEt}_{2}\right)_{2}\right]\left[\mathrm{B}\left(\mathrm{C}_{6} \mathrm{~F}_{5}\right)_{4}\right]$ in $\mathrm{THF}$ at $223 \mathrm{~K}$ (Figure 2, entry 44). DFT calculations provided a $\mathrm{p} K_{\mathrm{a}}^{\mathrm{THF}}$ of $23 \mathrm{in}$ good agreement with the value of 20 from the $L A C$ method $\left(A_{L}\left(N_{2}\right)+2 \times A_{L}\left(P R_{3}\right)+3 \times A_{L}\left(P P h R_{2}\right)=-2+2 \times 4.9+3 \times 4=20\right)$. 


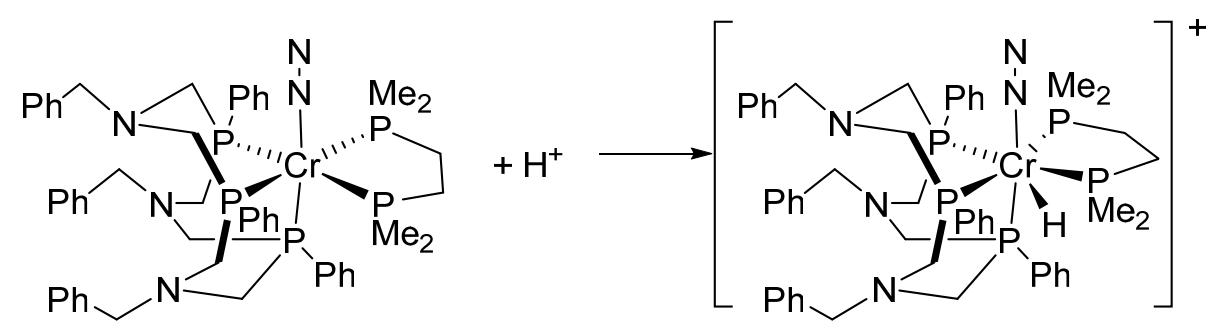

Figure 2. Protonation of a chromium dinitrogen complex in THF

Norton's group has studied the effects of ligands and metals on the $\mathrm{p} K_{\mathrm{a}}{ }^{\mathrm{MeCN}}$ of the series of hydrides $\mathrm{MH}(\mathrm{CO})_{\times}\left(\mathrm{Cp}\right.$ or $\left.\mathrm{Cp}^{*}\right)\left(\mathrm{PR}_{3}\right)_{\mathrm{y}}, \mathrm{M}=\mathrm{Cr}$, Mo and $\mathrm{W}$ (entries 43, 44, 46, 48, 50 and others discussed elsewhere $\left.{ }^{1}\right)$. For the tricarbonyls the $\mathrm{Cr}$ and Mo hydrides have similar acidity, being partially deprotonated by pyridine in MeCN while the tungsten complex is about 2.5 units less acidic, where reaction with morpholine is required. $\mathrm{MoH}(\mathrm{CO})_{3}(\mathrm{Cp})$ reacts with $\mathrm{OsH}_{2}\left(\mathrm{PMePh}_{2}\right)_{4}$ in $\mathrm{THF}-\mathrm{d}_{8}$ and reaches an equilibrium with the $1: 1$ ion pair $\left[\mathrm{OsH}_{2}\left(\mathrm{PMePh}_{2}\right)_{4}\right]\left[\mathrm{Mo}(\mathrm{CO})_{3}(\mathrm{Cp})\right]$ (entry 47). From the equilibrium constant and the estimated ion pair dissociation constant of $10^{-5} \mathrm{M}$, we determined the $\mathrm{p} K_{\mathrm{a}}^{\text {THF }}$ to be 17 , slightly higher than $\mathrm{p} K_{\mathrm{a}}{ }^{\mathrm{MeCN}}$ of 13.9. The temperature (190-293 K) and solvent dependence (hexane, THF, $\mathrm{DCM}, \mathrm{MeCN}$ ) of the reaction of $\mathrm{MH}(\mathrm{CO})_{3} \mathrm{Cp}, \mathrm{M}=\mathrm{Mo}, \mathrm{W}$, with a variety of neutral bases (hexamethylphosphoramide, pyridine and $\mathrm{NEt}_{3}$ ) have been studied in detail. ${ }^{41}$ The deprotonation of these $\mathrm{MH}(\mathrm{CO}){ }_{3} \mathrm{Cp}$ complexes by neutral bases is favored as the temperature is lowered ( $\Delta \mathrm{S}$ approx. -25 $\mathrm{eu}$ ) so that $\mathrm{NEt}_{3}$ in $\mathrm{MeCN}$ completely deprotonates these compounds at $230 \mathrm{~K}$ and 10 equiv. of py leads to an equilibrium mixture, although precipitation of $[\mathrm{Hpy}]\left[\mathrm{MoCp}(\mathrm{CO})_{3}\right]$ occurs over a $30 \mathrm{~min}$ period. Proton transfer is fast for Mo, even at low temperature and so the reactions are under thermodynamic control. Oddly, proton transfer is favored in non-polar hexane and polar MeCN but not in the low dielectric solvents THF and DCM. Specific hydrogen bonding interactions, ion pair energies, and energies of homoconjugates (e.g. [py-H-py] $]^{+}$) all contribute to the thermodynamic position of the equilibrium. The bimetallic analogue $\left\{\mathrm{W}(\mathrm{CO})_{3} \mathrm{H}\right\}_{2} \mathrm{Fv}$ with linked cyclopentadienyl groups (fulvalene, $\mathrm{Fv}$ ) has $\mathrm{p} K_{\mathrm{a}}{ }^{\mathrm{MecN}}$ 14.0 for the first deprotonation and $\mathrm{p} K_{\mathrm{a}}{ }^{\mathrm{MeCN}} 16.6$ for the second to produce $\left.\left[\mathrm{W}(\mathrm{CO})_{3}\right\}_{2} \mathrm{Fv}\right]^{2-122}$ The second deprotonation takes place at a higher $\mathrm{p} K_{\mathrm{a}}^{\mathrm{MeCN}}$ than that of $\mathrm{WH}(\mathrm{CO})_{3} \mathrm{Cp}\left(\mathrm{p} K_{\mathrm{a}}^{\mathrm{MeCN}} 16.1\right)$ because of the negative charge on the neighboring tungsten. The water soluble tungsten complex $\mathrm{WH}(\mathrm{CO})_{3}\left(\mathrm{C}_{5} \mathrm{H}_{4} \mathrm{COO}^{-}\right)$with a carboxyl group on the $\mathrm{Cp}$ ligand is found to have $\mathrm{p} K_{\mathrm{a}}$ of 5.8 in water (entry 49). This value is significantly different than the expected $p K_{a}{ }^{\text {MeCN }}$ value of about 16 or $p K_{a}{ }^{\text {THF }}$ of 21 (entry 48). As expected, replacing $\mathrm{Cp}$ with $\mathrm{Cp} *$ (entries 50,51) or replacing a carbonyl group with a phosphine (entries 52 and 53) or $\mathrm{N}$-heterocyclic carbene (entries 54, 55), results in an increase in the $\mathrm{p} K_{\mathrm{a}}$ value. Strong bases such as Schwesinger's phosphorane bases or potassium phenoxide need to be utilized to find these equilibria.

The complex $\left.\mathrm{Cr}\left\{\mathrm{PMe}_{2} \mathrm{CH}_{2}\right)_{3} \mathrm{CMe}\right\}_{2}$ is a rare, neutral, highly basic $\mathrm{d}^{6}$ octahedral complex of a group 6 metal (entry 56) thanks to the effect of six strongly donating phosphorus $\mathrm{PR}_{3}$ moeities. ${ }^{123}$ As expected from the $\mathrm{p} K_{a}^{\mathrm{LAC}} 30$ of the protonated, diamagnetic form $\left[\mathrm{Cr}{ }^{\prime \prime} \mathrm{H}\left\{\left(\mathrm{PMe}_{2} \mathrm{CH}_{2}\right)_{3} \mathrm{CMe}\right\}_{2}\right]^{+}$, a strong base such as BuLi in THF is required to deprotonate it despite the fact that the hydride is a moncation.

The least acidic group 6 metal hydride determined so far is $\mathrm{WH}_{6}\left(\mathrm{PPhMe}_{2}\right)_{3}$ with $\mathrm{p} K_{\mathrm{a}}^{\mathrm{THF}} 42$ (entry 57). This compound reacts and forms an equilibrium in THF- $d_{8}$ with the strong base $\left[\operatorname{ReH}_{6}\left(P C y_{3}\right)_{2}\right]$. The rhenium complex had already been placed on a continuous ladder of $\mathrm{p} K_{\mathrm{a}}{ }^{\mathrm{THF}}$ of hydride acids, in this case $\mathrm{ReH}_{7}\left(\mathrm{PCY}_{3}\right)_{2}\left(\mathrm{pK}_{\mathrm{a}}^{\mathrm{THF}} 42\right)$, and their conjugate bases. ${ }^{7}$ 
Table 5 Acid and base reactions involving transition metal hydrides of the group 6 metals in order of approximately increasing $p \mathrm{~K}_{a}$.

\begin{tabular}{|c|c|c|c|c|c|c|c|c|c|}
\hline Entry & Acid form & Base form $^{a}$ & Reactant & Reaction & Solvent & Temp. & $\mathrm{p} K_{\mathrm{a}}^{\text {exp }}$ & $\mathrm{p} K_{\mathrm{a}}^{\mathrm{LAC}}$ & Ref. \\
\hline 1 & {$\left[\mathrm{WH}_{2}(\mathrm{CO})_{3}(\mathrm{Cp})\right]^{+}$} & $\mathrm{MH}$ & $\mathrm{CF}_{3} \mathrm{SO}_{3} \mathrm{H}$ & $\mathrm{MH}+\mathrm{HY} \rightleftharpoons\left[\mathrm{MH}_{2}\right] \mathrm{Y}$ & $\mathrm{CD}_{2} \mathrm{Cl}_{2}$ & 298 & & -8 & 107 \\
\hline 2 & {$\left[\mathrm{WH}_{2}(\mathrm{CO})_{3}\left(\mathrm{Cp}^{*}\right)\right]^{+}$} & MH & $\mathrm{CF}_{3} \mathrm{SO}_{3} \mathrm{H}$ & $\mathrm{MH}+\mathrm{HY} \rightleftharpoons\left[\mathrm{MH}_{2}\right] \mathrm{Y}$ & $\mathrm{CD}_{2} \mathrm{Cl}_{2}$ & 298 & & -7 & 107 \\
\hline 3 & {$\left[\mathrm{~W}_{2} \mathrm{H}(\mathrm{CO})_{6} \mathrm{Cp}_{2}\right]^{+}$} & MM & {$\left[\mathrm{H}\left(\mathrm{OEt}_{2}\right)_{2}\right] \mathrm{BF}_{4}$} & $\mathrm{MM}+[\mathrm{HB}] \mathrm{Y} \rightarrow$ no reaction & $\mathrm{CH}_{2} \mathrm{Cl}_{2}$ & 298 & & $<-5$ & 122 \\
\hline 4 & {$\left[\mathrm{~W}_{2} \mathrm{H}(\mathrm{CO})_{6}(\text { fulvalene })\right]^{+}$} & MM & {$\left[\mathrm{H}\left(\mathrm{OEt}_{2}\right)_{2}\right] \mathrm{BF}_{4}$} & $\mathrm{MM}+[\mathrm{HB}] \mathrm{Y} \rightleftharpoons[\mathrm{MHM}] \mathrm{Y}+\mathrm{B}$ & $\mathrm{CH}_{2} \mathrm{Cl}_{2}$ & 298 & & -5 & 122 \\
\hline 5 & $\left.\left[\mathrm{~W}_{2} \mathrm{H}(\mathrm{CO})_{6}\left\{\mathrm{C}_{5} \mathrm{H}_{3}\right)_{2}\left(\mathrm{SiMe}_{2}\right)_{2}\right\}\right]^{+}$ & $\mathrm{MM}$ & DMSO & {$[\mathrm{MHM}] \mathrm{Y}+\mathrm{B} \rightleftharpoons \mathrm{MM}+[\mathrm{HB}] \mathrm{Y}$} & $\mathrm{CH}_{2} \mathrm{Cl}_{2}$ & 298 & -2 & & 108 \\
\hline 6 & {$\left[\mathrm{~W}_{2} \mathrm{H}(\mathrm{CO})_{2} \mathrm{Cp}_{2}\left(\mathrm{PPh}_{2}\right)_{2}\right]^{+}$} & MM & {$\left[\mathrm{H}\left(\mathrm{OEt}_{2}\right)_{2}\right] \mathrm{BF}_{4}$} & $\mathrm{MM}+[\mathrm{HB}] \mathrm{Y} \rightarrow[\mathrm{MHM}] \mathrm{Y}+\mathrm{B}$ & $\mathrm{CH}_{2} \mathrm{Cl}_{2}$ & 243 & & $>-5$ & 109 \\
\hline 7 & {$\left[\mathrm{MoH}_{2}\left(\mathrm{C}_{6} \mathrm{H}_{6}\right)(\text { triphos })\right]^{+2}$} & {$[\mathrm{MH}] \mathrm{Y}$} & $\mathrm{CF}_{3} \mathrm{COOH}$ & {$[\mathrm{MH}] \mathrm{Y}+\mathrm{HY} \rightleftharpoons\left[\mathrm{MH}_{2}\right] \mathrm{Y}_{2}$} & $\mathrm{CF}_{3} \mathrm{COOH}$ & 298 & & -3 & 85 \\
\hline 8 & {$\left[\mathrm{MoH}_{2}(\mathrm{CO})_{2}\left(\mathrm{Cp}-\mathrm{PCy}_{2}\right)\right]^{+}$} & MH & $\mathrm{O}=\mathrm{CEt}_{2}$ & {$\left[\mathrm{MH}_{2}\right] \mathrm{Y}+\mathrm{B} \rightarrow \mathrm{MH}+[\mathrm{HB}] \mathrm{Y}$} & $\mathrm{O}=\mathrm{CEt}_{2}$ & 323 & & -1 & 124 \\
\hline 9 & {$\left[\mathrm{WH}(\mathrm{CO})_{3}\left(\mathrm{PEtPh}_{2}\right)_{3}\right]^{+}$} & M & $\mathrm{CF}_{3} \mathrm{SO}_{3} \mathrm{H}$ & $\mathrm{M}+\mathrm{HY} \rightarrow[\mathrm{MH}] \mathrm{Y}$ & DCE & 298 & -0.3 & -1 & 8,112 \\
\hline 10 & {$\left[\mathrm{WH}(\mathrm{CO})_{3}\left(\mathrm{PMePh}_{2}\right)_{3}\right]^{+}$} & M & $\mathrm{CF}_{3} \mathrm{SO}_{3} \mathrm{H}$ & $\mathrm{M}+\mathrm{HY} \rightarrow[\mathrm{MH}] \mathrm{Y}$ & DCE & 298 & -1.3 & -1 & 8,112 \\
\hline 11 & {$\left[\mathrm{WH}(\mathrm{CO})_{3}(\text { triphos })\right]^{+}$} & $\mathrm{M}$ & $\mathrm{CF}_{3} \mathrm{SO}_{3} \mathrm{H}$ & $\mathrm{M}+\mathrm{HY} \rightarrow[\mathrm{MH}] \mathrm{Y}$ & DCE & 298 & -0.4 & -1 & 8,112 \\
\hline 12 & {$\left[\mathrm{WH}(\mathrm{CO})_{3}(\text { tripod })\right]^{+}$} & M & $\mathrm{CF}_{3} \mathrm{SO}_{3} \mathrm{H}$ & $\mathrm{M}+\mathrm{HY} \rightarrow[\mathrm{MH}] \mathrm{Y}$ & DCE & 298 & -3.9 & -1 & 8,112 \\
\hline 13 & {$\left[\mathrm{WH}(\mathrm{CO})_{3}(\mathrm{bpy})\left(\mathrm{PPh}_{2} \mathrm{Me}\right)\right]^{+}$} & M & $\mathrm{CF}_{3} \mathrm{SO}_{3} \mathrm{H}$ & $\mathrm{M}+\mathrm{HY} \rightarrow[\mathrm{MH}] \mathrm{Y}$ & DCE & 298 & 1 & 1 & 8,112 \\
\hline 14 & {$\left[\mathrm{WH}_{2}(\mathrm{CO})_{2} \mathrm{Cp}\left(\mathrm{PMe}_{3}\right)\right]^{+}$} & $\mathrm{MH}$ & {$[\mathrm{DCA}] \mathrm{BF}_{4}$} & $\mathrm{MH}+[\mathrm{HB}] \mathrm{Y} \rightleftharpoons\left[\mathrm{MH}_{2}\right] \mathrm{Y}+\mathrm{B}$ & $\mathrm{CH}_{3} \mathrm{CN}$ & 298 & 5.6 & $1\left(4^{c}\right)$ & 40 \\
\hline 15 & {$\left[\mathrm{WH}_{2}(\mathrm{CO})_{2} \mathrm{Cp}\left(\mathrm{PPh}_{3}\right)\right]^{+}$} & MH & $\mathrm{PPh}_{3}$ & {$\left[\mathrm{MH}_{2}\right] \mathrm{Y}+\mathrm{B} \rightarrow \mathrm{MH}+[\mathrm{HB}] \mathrm{Y}$} & $\mathrm{O}=\mathrm{CEt}_{2}$ & 298 & $<3$ & 1 & 110 \\
\hline 16 & {$\left[\mathrm{WH}(\mathrm{CO})_{3}\left(\mathrm{PPhEt}_{2}\right)_{3}\right]^{+}$} & M & $\mathrm{CF}_{3} \mathrm{SO}_{3} \mathrm{H}$ & $\mathrm{M}+\mathrm{HY} \rightarrow[\mathrm{MH}] \mathrm{Y}$ & DCE & 298 & 0.5 & 2 & 8,112 \\
\hline 17 & {$\left[\mathrm{WH}(\mathrm{CO})_{3}\left(\mathrm{PPhMe}_{2}\right)_{3}\right]^{+}$} & M & $\mathrm{CF}_{3} \mathrm{SO}_{3} \mathrm{H}$ & $\mathrm{M}+\mathrm{HY} \rightarrow[\mathrm{MH}] \mathrm{Y}$ & DCE & 298 & 0 & 2 & 8,112 \\
\hline 18 & {$\left[\mathrm{CrH}(\mathrm{CO})_{2}(\mathrm{dppm})_{2}\right]^{+}$} & M & $\mathrm{CF}_{3} \mathrm{SO}_{3} \mathrm{H}$ & $\mathrm{M}+\mathrm{HY} \rightarrow[\mathrm{MH}] \mathrm{Y}$ & DCE & 298 & 4.5 & 4 & 8,112 \\
\hline 19 & {$\left[\mathrm{MoH}(\mathrm{CO})_{2}(\mathrm{dppm})_{2}\right]^{+}$} & M & $\mathrm{CF}_{3} \mathrm{SO}_{3} \mathrm{H}$ & $\mathrm{M}+\mathrm{HY} \rightarrow[\mathrm{MH}] \mathrm{Y}$ & $\mathrm{CH}_{2} \mathrm{Cl}_{2}$ & 298 & 6.8 & 4 & 8,29 \\
\hline 20 & {$\left[\mathrm{WH}(\mathrm{CO})_{2}(\mathrm{dppm})_{2}\right]^{+}$} & M & $\mathrm{CF}_{3} \mathrm{SO}_{3} \mathrm{H}$ & $\mathrm{M}+\mathrm{HY} \rightarrow[\mathrm{MH}] \mathrm{Y}$ & DCE & 298 & 7.8 & 6 & 8,112 \\
\hline 21 & {$\left[\mathrm{MoH}_{2}(\mathrm{CO}) \mathrm{Cp}(\mathrm{dppe})\right]^{+}$} & $\mathrm{MH}$ & $\mathrm{CF}_{3} \mathrm{SO}_{3} \mathrm{H}$ & $\mathrm{MH}+\mathrm{HY} \rightleftharpoons\left[\mathrm{MH}_{2}\right] \mathrm{Y}$ & $\mathrm{CD}_{2} \mathrm{Cl}_{2}$ & 190 & $>1$ & 4 & 114 \\
\hline 22 & {$\left[\mathrm{Mo}\left(\mathrm{H}_{2}\right) \mathrm{H}\left(\mathrm{C}_{5} \mathrm{H}_{4} \mathrm{CMe}_{2} \mathrm{C}_{5} \mathrm{H}_{4}\right)\right]^{+}$} & $\mathrm{MH}_{2}$ & {$\left[\mathrm{H}(\mathrm{OEt})_{2}\right] \mathrm{BAr}_{4}$} & $\mathrm{MH}_{2}+[\mathrm{HB}] \mathrm{Y} \rightarrow\left[\mathrm{MH}_{3}\right] \mathrm{Y}+\mathrm{B}$ & $\mathrm{CD}_{2} \mathrm{Cl}_{2}$ & $<260$ & $>-5$ & 4 & 113 \\
\hline 23 & {$\left[\mathrm{WH}(\mathrm{CO})_{3}\left(\mathrm{PEt}_{3}\right)_{3}\right]^{+}$} & M & $\mathrm{CF}_{3} \mathrm{SO}_{3} \mathrm{H}$ & $\mathrm{M}+\mathrm{HY} \rightarrow[\mathrm{MH}] \mathrm{Y}$ & DCE & 298 & 4.2 & 5 & 8,112 \\
\hline 24 & {$\left[\mathrm{WH}(\mathrm{CO})_{3}\left(\mathrm{PMe}_{3}\right)_{3}\right]^{+}$} & M & $\mathrm{CF}_{3} \mathrm{SO}_{3} \mathrm{H}$ & $\mathrm{M}+\mathrm{HY} \rightarrow[\mathrm{MH}] \mathrm{Y}$ & DCE & 298 & 1.1 & 5 & 8,112 \\
\hline 25 & {$\left[\mathrm{MoH}_{2}(\mathrm{NO})(\mathrm{CO})\left({ }^{\mathrm{i}} \text { Prtriphos }\right)\right]^{+}$} & MH & {$\left[\mathrm{H}\left(\mathrm{OEt}_{2}\right)_{2}\right]\left[\mathrm{B}\left(\mathrm{C}_{6} \mathrm{~F}_{5}\right)_{4}\right]$} & $\mathrm{MH}+[\mathrm{HB}] \mathrm{Y} \rightarrow\left[\mathrm{MH}_{2}\right] \mathrm{Y}+\mathrm{B}$ & THF & 298 & $>-5$ & 8 & 119 \\
\hline 26 & {$\left[\mathrm{Mo}\left(\mathrm{H}_{2}\right) \mathrm{H}\left(\mathrm{Cp}^{*}\right)_{2}\right]^{+}$} & $\mathrm{MH}_{2}$ & $\begin{array}{l}{\left[\mathrm{Mo}\left(\mathrm{H}_{2}\right) \mathrm{H}_{\left(\mathrm{C}_{5} \mathrm{H}_{4} \mathrm{CMe}_{2}^{-}\right.}^{-}\right.} \\
\left.\left.\mathrm{C}_{5} \mathrm{H}_{4}\right)\right] \mathrm{BAr}_{4}^{\prime}\end{array}$ & $\mathrm{MH}_{2}+[\mathrm{HB}] \mathrm{Y} \rightarrow\left[\mathrm{MH}_{3}\right] \mathrm{Y}+\mathrm{B}$ & $\mathrm{CD}_{2} \mathrm{Cl}_{2}$ & 243 & & 6 & 113 \\
\hline 27 & $\mathrm{~W}\left(\mathrm{H}_{2}\right)(\mathrm{CO})_{5}$ & {$[\mathrm{MH}]^{-}$} & $\mathrm{NEt}_{3}$ & $\mathrm{MH}_{2}+\mathrm{B} \rightarrow[\mathrm{HB}][\mathrm{MH}]$ & $\mathrm{CD}_{2} \mathrm{Cl}_{2}$ & 200 & $<13$ & 12 & 120 \\
\hline 28 & {$\left[\mathrm{WH}_{2}(\mathrm{NO})(\mathrm{CO})\left({ }^{\mathrm{i}} \text { Prtriphos }\right)\right]^{+}$} & MH & {$\left[\mathrm{H}\left(\mathrm{OEt}_{2}\right)_{2}\right]\left[\mathrm{B}\left(\mathrm{C}_{6} \mathrm{~F}_{5}\right)_{4}\right]$} & $\mathrm{MH}+[\mathrm{HB}] \mathrm{Y} \rightarrow\left[\mathrm{MH}_{2}\right] \mathrm{Y}+\mathrm{B}$ & THF & 298 & $>-5$ & 10 & 119 \\
\hline
\end{tabular}




\begin{tabular}{|c|c|c|c|c|c|c|c|c|c|}
\hline 29 & {$\left[\mathrm{MoH}(\mathrm{CO})_{2}(\mathrm{dppe})_{2}\right]^{+}$} & M & $\mathrm{CF}_{3} \mathrm{SO}_{3} \mathrm{H}$ & $\mathrm{M}+\mathrm{HY} \rightarrow[\mathrm{MH}] \mathrm{Y}$ & $\mathrm{CH}_{2} \mathrm{Cl}_{2}$ & 298 & 5.5 & 4 & 8,29 \\
\hline 30 & {$\left[\mathrm{WH}(\mathrm{CO})_{2}(\mathrm{dppe})_{2}\right]^{+}$} & M & $\mathrm{CF}_{3} \mathrm{SO}_{3} \mathrm{H}$ & $\mathrm{M}+\mathrm{HY} \rightarrow[\mathrm{MH}] \mathrm{Y}$ & DCE & 298 & 4.2 & 6 & 8,112 \\
\hline 31 & {$\left[\mathrm{MoH}(\mathrm{CO})_{2}(\mathrm{dppp})_{2}\right]^{+}$} & M & $\mathrm{CF}_{3} \mathrm{SO}_{3} \mathrm{H}$ & $\mathrm{M}+\mathrm{HY} \rightarrow[\mathrm{MH}] \mathrm{Y}$ & $\mathrm{CH}_{2} \mathrm{Cl}_{2}$ & 298 & 0.8 & 4 & 8,29 \\
\hline 32 & {$\left[\mathrm{MoH}_{4} \mathrm{Cp} *(\mathrm{dppe})\right]^{+}$} & $\mathrm{MH}_{3}$ & $\mathrm{CF}_{3} \mathrm{CH}_{2} \mathrm{OH}$ & $\mathrm{MH}_{3}+\mathrm{HY} \rightleftharpoons\left[\mathrm{MH}_{4}\right] \mathrm{Y}$ & $\mathrm{CH}_{2} \mathrm{Cl}_{2}$ & $<250$ & $24^{d}$ & 9 & 115 \\
\hline 33 & {$\left[\mathrm{MoH}_{4} \mathrm{Cp} *(\mathrm{dppe})\right]^{+}$} & $\mathrm{MH}_{3}$ & $\mathrm{CF}_{3} \mathrm{COOH}$ & $\mathrm{MH}_{3}+2 \mathrm{HY} \rightleftharpoons\left[\mathrm{MH}_{4}\right][\mathrm{YHY}]$ & Toluene & $<250$ & $3^{d}$ & 9 & 95 \\
\hline 34 & {$\left[\mathrm{WH}_{4}(\mathrm{Cp} *)(\mathrm{dppe})\right]^{+}$} & $\mathrm{MH}_{3}$ & $\mathrm{CF}_{3} \mathrm{CH}_{2} \mathrm{OH}$ & $\mathrm{MH}_{3}+\mathrm{HY} \rightleftharpoons\left[\mathrm{M}^{\prime} \mathrm{H}_{4}\right] \mathrm{Y}$ & $\mathrm{CH}_{2} \mathrm{Cl}_{2}$ & $<290$ & $24^{d}$ & 11 & 117 \\
\hline 35 & {$\left[\mathrm{WH}_{4}(\mathrm{Cp} *)(\mathrm{dppe})\right]^{+}$} & $\mathrm{MH}_{3}$ & $\left(\mathrm{CF}_{3}\right)_{2} \mathrm{CHOH}$ & $\mathrm{MH}_{3}+\mathrm{HY} \rightleftharpoons\left[\mathrm{MH}_{4}\right] \mathrm{Y}$ & toluene & $<290$ & $18^{d}$ & 11 & 117 \\
\hline 36 & {$\left[\mathrm{MoH}_{2}(\mathrm{CO}) \mathrm{Cp} *\left(\mathrm{PMe}_{3}\right)_{2}\right]^{+}$} & MH & {$\left[\mathrm{H}\left(\mathrm{OEt}_{2}\right)_{2}\right] \mathrm{BF}_{4}$} & $\mathrm{MH}+[\mathrm{HB}] \mathrm{Y} \rightarrow\left[\mathrm{MH}_{2}\right] \mathrm{Y}+\mathrm{B}$ & THF & $<230$ & & 9 & 125 \\
\hline 37 & {$\left[\mathrm{MoH}(\mathrm{CO})_{2}(\mathrm{dmpe})_{2}\right]^{+}$} & M & $\mathrm{CF}_{3} \mathrm{SO}_{3} \mathrm{H}$ & $\mathrm{M}+\mathrm{HY} \rightarrow[\mathrm{MH}] \mathrm{Y}$ & $\mathrm{CH}_{2} \mathrm{Cl}_{2}$ & 298 & 12 & 12 & 8,29 \\
\hline 38 & {$\left[\mathrm{MoH}(\mathrm{MeCCCOOMe})\left(\text { tetraphos' }^{\prime}\right]^{+}\right.$} & M & $\mathrm{HCl}$ & $\mathrm{M}+\mathrm{HY} \rightarrow[\mathrm{MH}] \mathrm{Y}$ & THF & 298 & & $>10$ & 126 \\
\hline 39 & {$\left[\mathrm{MoH}_{4}\left(\mathrm{C}_{5} \mathrm{H}_{2}{ }^{\mathrm{t}} \mathrm{Bu}_{3}\right)\left(\mathrm{PMe}_{3}\right)_{2}\right]^{+}$} & $\mathrm{MH}_{3}$ & {$\left[\mathrm{H}\left(\mathrm{OEt}_{2}\right)_{2}\right] \mathrm{BF}_{4}$} & $\mathrm{MH}_{3}+[\mathrm{HB}] \mathrm{Y} \rightarrow\left[\mathrm{MH}_{4}\right] \mathrm{Y}+\mathrm{B}$ & THF & & & 13 & 127 \\
\hline 40 & {$\left[\mathrm{MoH}\left(\mathrm{N}_{2}\right)_{2}\left\{\mathrm{PhN}\left(\mathrm{CH}_{2} \mathrm{PEt}_{2}\right)_{2}\right\}_{2}\right]^{+}$} & M & $\mathrm{CF}_{3} \mathrm{SO}_{3} \mathrm{H}$ & $\mathrm{M}+\mathrm{HY} \rightarrow[\mathrm{MH}] \mathrm{Y}$ & THF & 233 & & 16 & 121 \\
\hline 41 & {$\left[\mathrm{Mo}(\mathrm{H})_{2} \mathrm{Cp}\left(\mathrm{PMe}_{3}\right)_{3}\right]^{+}$} & MH & {$\left[\mathrm{H}\left(\mathrm{OEt}_{2}\right)_{2}\right] \mathrm{BF}_{4}$} & $\mathrm{MH}+[\mathrm{HB}] \mathrm{Y} \rightarrow\left[\mathrm{MH}_{2}\right] \mathrm{Y}+\mathrm{B}$ & $\mathrm{CH}_{3} \mathrm{CN}$ & 298 & & $\begin{array}{r}17 \\
\left(24^{c}\right)\end{array}$ & 128 \\
\hline 42 & {$\left[\mathrm{Mo}(\mathrm{H})_{2} \mathrm{Cp} *\left(\mathrm{PMe}_{3}\right)_{3}\right]^{+}$} & MH & {$\left[\mathrm{H}\left(\mathrm{OEt}_{2}\right)_{2}\right] \mathrm{BF}_{4}$} & $\mathrm{MH}+[\mathrm{HB}] \mathrm{Y} \rightarrow\left[\mathrm{MH}_{2}\right] \mathrm{Y}+\mathrm{B}$ & THF & 298 & & 18 & 129 \\
\hline 43 & {$\left[\mathrm{~W}_{2} \mathrm{H}(\mathrm{CO})_{2} \mathrm{Cp}_{2}\left(\mathrm{PPh}_{2}\right)_{2}\right]^{+}$} & MM & DBU & {$[\mathrm{MHM}] \mathrm{Y}+\mathrm{B} \rightarrow \mathrm{MM}+[\mathrm{HB}] \mathrm{Y}$} & $\mathrm{CH}_{2} \mathrm{Cl}_{2}$ & 243 & & $<20$ & 109 \\
\hline 44 & {$\left[\mathrm{CrH}\left(\mathrm{N}_{2}\right)\left(\mathrm{P}^{\mathrm{Ph}_{3} \mathrm{~N}^{\mathrm{Bn}}}\right)(\mathrm{dmpe})\right]^{+}$} & M & {$\left[\mathrm{H}\left(\mathrm{OEt}_{2}\right)_{2}\right]\left[\mathrm{B}\left(\mathrm{C}_{6} \mathrm{~F}_{5}\right)_{4}\right]$} & $\mathrm{M}+[\mathrm{HB}] \mathrm{Y} \rightarrow[\mathrm{MH}] \mathrm{Y}+\mathrm{B}$ & THF & 223 & 23 & 22 & 130 \\
\hline 45 & $\mathrm{CrH}(\mathrm{CO})_{3} \mathrm{Cp}$ & {$[\mathrm{M}]^{-}$} & pyridine & $\mathrm{MH}+\mathrm{B} \rightleftharpoons[\mathrm{HB}][\mathrm{M}]$ & $\mathrm{CH}_{3} \mathrm{CN}$ & 298 & 13.3 & 17 & 131 \\
\hline 46 & $\mathrm{MoH}(\mathrm{CO})_{3} \mathrm{Cp}$ & {$\left[\mathrm{M}^{-}\right.$} & pyridine & $\mathrm{MH}+\mathrm{B} \rightleftharpoons[\mathrm{HB}][\mathrm{M}]$ & $\mathrm{CH}_{3} \mathrm{CN}$ & 298 & 13.9 & 17 & 131 \\
\hline 47 & $\mathrm{MoH}(\mathrm{CO})_{3} \mathrm{Cp}$ & {$[\mathrm{M}]^{-}$} & $\mathrm{OsH}_{2}\left(\mathrm{PMePh}_{2}\right)_{4}$ & $\mathrm{MH}+\mathrm{M}^{\prime} \mathrm{H}_{2} \rightleftharpoons[\mathrm{M}]\left[\mathrm{M}^{\prime} \mathrm{H}_{3}\right]$ & THF & 298 & 17 & 17 & 7 \\
\hline 48 & $\mathrm{WH}(\mathrm{CO})_{3} \mathrm{Cp}$ & {$[\mathrm{M}]^{-}$} & morpholine & $\mathrm{MH}+\mathrm{B} \rightleftharpoons[\mathrm{HB}][\mathrm{M}]$ & $\mathrm{CH}_{3} \mathrm{CN}$ & 298 & 16.1 & 18 & 131 \\
\hline 49 & $\mathrm{WH}(\mathrm{CO})_{3}\left(\mathrm{C}_{5} \mathrm{H}_{4} \mathrm{COO}^{-}\right)$ & {$[\mathrm{M}]^{-}$} & $\mathrm{H}_{2} \mathrm{O}$ & $\mathrm{MH}+\mathrm{H}_{2} \mathrm{O} \rightleftharpoons \mathrm{M}+\mathrm{H}_{3} \mathrm{O}^{+}$ & $\mathrm{H}_{2} \mathrm{O}$ & 298 & 5.8 & 18 & 132 \\
\hline 50 & $\mathrm{CrH}(\mathrm{CO})_{3} \mathrm{Cp}^{*}$ & {$[\mathrm{M}]^{-}$} & $\mathrm{NH}_{2} \mathrm{CH}_{2} \mathrm{Ph}$ & $\mathrm{MH}+\mathrm{B} \rightleftharpoons[\mathrm{HB}][\mathrm{M}]$ & $\mathrm{CH}_{3} \mathrm{CN}$ & 298 & 17.1 & 20 & 133 \\
\hline 51 & $\mathrm{MoH}(\mathrm{CO})_{3} \mathrm{Cp}^{*}$ & {$[\mathrm{M}]^{-}$} & morpholine & $\mathrm{MH}+\mathrm{B} \rightleftharpoons[\mathrm{HB}][\mathrm{M}]$ & $\mathrm{CH}_{3} \mathrm{CN}$ & 298 & 17.1 & 20 & 51 \\
\hline 52 & $\mathrm{CrH}(\mathrm{CO})_{2} \mathrm{Cp}\left(\mathrm{PCy}_{3}\right)$ & {$\left[\mathrm{M}^{-}\right.$} & ${ }^{t} \mathrm{BuP}_{1}(\mathrm{dma})$ & $\mathrm{MH}+\mathrm{B} \rightleftharpoons[\mathrm{HB}][\mathrm{M}]$ & $\mathrm{CH}_{3} \mathrm{CN}$ & 298 & 26.1 & 28 & 134 \\
\hline 53 & $\mathrm{WH}(\mathrm{CO})_{2} \mathrm{Cp}\left(\mathrm{PMe}_{3}\right)$ & {$[\mathrm{M}]^{-}$} & $\mathrm{KOPh}$ & $\mathrm{MH}+\mathrm{KY} \rightleftharpoons \mathrm{K}[\mathrm{M}]+\mathrm{HY}$ & $\mathrm{CH}_{3} \mathrm{CN}$ & 298 & 26.6 & 30 & 51 \\
\hline 54 & $\mathrm{CrH}(\mathrm{CO})_{2} \mathrm{Cp}(\mathrm{IMes})$ & {$[\mathrm{M}]^{-}$} & {$\left[\mathrm{H}^{t} \mathrm{BuP}_{1}(\mathrm{pyrr})\right] \mathrm{BF}_{4}$} & $\mathrm{Z}[\mathrm{M}]+[\mathrm{HB}] \mathrm{Y} \rightleftharpoons \mathrm{MH}+\mathrm{B}+\mathrm{ZY}$ & $\mathrm{CH}_{3} \mathrm{CN}$ & 298 & 27.2 & 28 & 134 \\
\hline 55 & $\mathrm{WH}(\mathrm{CO})_{2} \mathrm{Cp}(\mathrm{IMes})$ & {$[\mathrm{M}]^{-}$} & $\mathrm{P}\left(\mathrm{NMeCH}_{2} \mathrm{CH}_{2}\right)_{3} \mathrm{~N}$ & $\mathrm{MH}+\mathrm{B} \rightleftharpoons[\mathrm{HB}][\mathrm{M}]$ & $\mathrm{CH}_{3} \mathrm{CN}$ & 298 & 31.9 & 31 & 111 \\
\hline 56 & {$\left[\mathrm{CrH}\left\{\left(\mathrm{PMe}_{2} \mathrm{CH}_{2}\right)_{3} \mathrm{CMe}\right\}_{2}\right]^{+}$} & {$[\mathrm{M}]$} & $\mathrm{BuLi}$ & {$[\mathrm{MH}] \mathrm{Y}+\mathrm{LiB} \rightleftharpoons \mathrm{M}+\mathrm{BH}+\mathrm{LiY}$} & THF & 298 & & 30 & 123 \\
\hline 57 & $\mathrm{WH}_{6}\left(\mathrm{PPhMe}_{2}\right)_{3}$ & {$\left[\mathrm{MH}_{5}\right]^{-}$} & $\mathrm{Z}\left[\mathrm{ReH}_{6}\left(\mathrm{PCy}_{3}\right)_{2}\right]$ & $\begin{array}{l}\mathrm{MH}_{6}+\mathrm{Z}\left[\mathrm{M}^{\prime} \mathrm{H}_{6}\right] \rightleftharpoons \mathrm{Z}\left[\mathrm{MH}_{5}\right]+ \\
\mathrm{M}^{\prime} \mathrm{H}_{7}\end{array}$ & THF & 298 & 42 & 45 & 93 \\
\hline
\end{tabular}




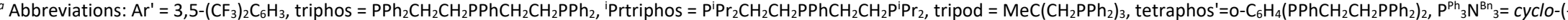

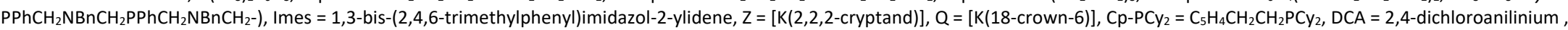

${ }^{\mathrm{t} B u P_{1} \mathrm{dma}}=\left(\right.$ tertbutylimino)tris(dimethylamino)phosphorane),$\left[\mathrm{H}^{\mathrm{t}} \mathrm{BuP} \mathrm{P}_{1}(\mathrm{pyrr}]^{+}=\right.$(tertbutylimino)tris (pyrrolidino) phosphorinium.

${ }^{b}$ The ligands are the same as in the acid form apart from the loss of a proton (and counteranion for cationic complexes).

${ }^{c} \mathrm{p} K_{\mathrm{a}}$ corrected to the MeCN scale for cationic acids using Equation 14

${ }^{d} \mathrm{pK}_{\mathrm{a}}{ }^{\mathrm{DMSO}}$ but reaction done in lower dielectric constant solvent 


\subsection{Manganese group}

Table 6 starts with a series of dihydrogen or dihydride carbonyl phosphine rhenium complexes (entries $1,2,6,10,11,15,29$ ) ranging in $\mathrm{p} K_{\mathrm{a}}^{\mathrm{LAC}}$ from -18 to 27 . The dihydrogen complex

$\left[\operatorname{Re}\left(\mathrm{H}_{2}\right)(\mathrm{CO})_{5}\right]\left[\mathrm{B}\left(\mathrm{C}_{6} \mathrm{~F}_{5}\right)_{4}\right]$ is one of the most acidic compounds reported in this review. It is only formed by protonation of the monohydride when an excess $\mathrm{CF}_{3} \mathrm{SO}_{3} \mathrm{H}$ in fluorobenzene is used (Table 6, entry 1). ${ }^{120}$ The LAC methods gives a $\mathrm{p} K_{\mathrm{a}}{ }^{\mathrm{LAC}}$ of -18 . Errors might result from the additive method breaking down when five pi acids are at the metal, from the different dielectric properties of fluorobenzene and THF, and from a strong $\mathrm{H}-\mathrm{H}$ bond in the dihydrogen ligand because of little backdonation from the metal $\mathrm{d}$ electrons into the $\sigma^{*}$ orbital of the $\mathrm{H}_{2}$. The tetracarbonyl dihydrogen complex $\left[\operatorname{Re}\left(\mathrm{H}_{2}\right)(\mathrm{CO})_{4}\left(\mathrm{Pi}^{\mathrm{i}} \mathrm{Pr}_{3}\right)\right]^{+}$(entry $2)$ is assumed to form when $\left[\operatorname{Re}\left(\mathrm{ClCH}_{2} \mathrm{Cl}\right)(\mathrm{CO})_{4}\left(\mathrm{PiPr}_{3}\right)\right]\left[\mathrm{B}\left(3,5-\left(\mathrm{CF}_{3}\right)_{2} \mathrm{C}_{6} \mathrm{H}_{3}\right)_{4}\right]$ reacts with dihydrogen in $\mathrm{CD}_{2} \mathrm{Cl}_{2}{ }^{135}$ However it is highly acidic, immediately protonating ${ }^{\mathrm{P}} \mathrm{Pr}_{2} \mathrm{O}$, and forming a Re-H-Re bridged dimer. This establishes its $\mathrm{p} K_{\mathrm{a}}$ to be less than zero. The nitrosyl and carbonyl ligands make $\left[\operatorname{Re}\left(\mathrm{H}_{2}\right)(\mathrm{H})(\mathrm{NO})(\mathrm{CO})\left(\mathrm{PiPr}_{3}\right)\right]^{+}$very acidic, with a $\mathrm{p} K_{\mathrm{a}}{ }^{\mathrm{DCM}}$ approx. $-1 .{ }^{136}$ The tricarbonyl dihydrogen complex $\left[\operatorname{Re}\left(\mathrm{H}_{2}\right)(\mathrm{CO})_{3}\left(\mathrm{PCy}_{3}\right)_{2}\right]^{+}$(entry 6$)$ in $\mathrm{CD}_{2} \mathrm{Cl}_{2}$ is deprotonated by proton sponge but not by $\mathrm{NPh}^{1} \mathrm{Pr}_{2}{ }^{137}$ therefore its $\mathrm{p} K_{\mathrm{a}}$ appears to be between approx. 5 and 12 if no kinetic barriers are preventing reaction. The LAC method predicts a value of 0 , not in good agreement. The dicarbonyl dihydrogen complex $\left[\mathrm{Re}\left(\mathrm{H}_{2}\right)(\mathrm{CO})_{2}\left(\mathrm{Me}\left(\mathrm{CH}_{2} \mathrm{PPh}_{2}\right)_{3}\right)\right]^{+}$(entries 10,11$)$ is deprotonated by $\mathrm{NEt}_{3}{ }^{138}$ (thus $\mathrm{p} K_{\mathrm{a}}<13$ ) and is in equilibrium with the acidic alcohol $\left(\mathrm{CF}_{3}\right)_{3} \mathrm{COH}$ ( $\mathrm{p} K_{\mathrm{a}}{ }^{\mathrm{DMSO}}$ 10.7) in $\mathrm{CH}_{2} \mathrm{Cl}_{2}$ at less than $260 \mathrm{~K} .{ }^{65}$ The dihydride/dihydrogen mixture $\left[\mathrm{ReH}_{2}(\mathrm{CO})_{2}\left(\mathrm{PMe}_{3}\right)_{3}\right]^{+}$(entry 15$)$ catalyzes the ionic hydrogenation of aldimines in chlorobenzene at $303-373 \mathrm{~K}, 100$ bar H$_{2} .{ }^{139}$ For the catalytic cycle it is proposed that the dihydride is sufficiently acidic to protonate the imine to give an electrophilic iminium which is then attacked by $\mathrm{ReH}(\mathrm{CO})_{2}\left(\mathrm{PMe}_{3}\right)_{3}$ to give the amine product. The predicted $\mathrm{p} K_{\mathrm{a}}^{\mathrm{LAC}}$ of 9 supports this mechanism. With no carbonyl ligands the complex $\left[\mathrm{Re}(\mathrm{H})_{2}\left(\mathrm{PMe}_{3}\right)_{5}\right]^{+}$(entry 29$)$ is an extremely weak acid with a measured $\mathrm{p} K_{\mathrm{a}}{ }^{\mathrm{THF}}$ of $24.2 .{ }^{7}$ An equilibrium was detected between this dihydride cation in THF under $\mathrm{Ar}$ and the tetrahydride cation $\left[\mathrm{ReH}_{4}\left(\mathrm{PMe}_{3}\right)_{4}\right]^{+}$which has a $\mathrm{p} K_{\mathrm{a}}^{\mathrm{THF}}$ of 22.1 (entry 27).

The series of cationic manganese carbonyl hydrides (entries 15 and 17) is less extensive than that of rhenium discussed above. $\left[\mathrm{Mn}\left(\mathrm{H}_{2}\right)(\mathrm{CO})\left(\mathrm{P}(\mathrm{OEt})_{3}\right)_{4}\right]^{+}$in $\mathrm{CD}_{2} \mathrm{Cl}_{2}$ is deprotonated by $\mathrm{NEt}_{3},{ }^{140}$ providing an upper limit of the $\mathrm{p} K_{\mathrm{a}}$ of $13\left(\mathrm{p} K_{\mathrm{a}}{ }^{\mathrm{LAC}}\right.$ predicted to be 7). The hydride complex

$\left[\mathrm{MnH}(\mathrm{CO})\left(\mathrm{PAr}_{2}{ }_{2} \mathrm{CH}_{2} \mathrm{PAr}_{2}{ }_{2}\right)\right.$ (cyclo- $\left.\left.\mathrm{PPhCH}_{2} \mathrm{NBnCH}_{2} \mathrm{PPhCH}_{2} \mathrm{NHBnCH}_{2}-\right)\right] \mathrm{BAr}_{4}{ }_{4}, \mathrm{Ar}^{\prime}=3,5-\left(\mathrm{CF}_{3}\right)_{2} \mathrm{C}_{6} \mathrm{H}_{3}$, has a protonated amine in the ligand. It undergoes extremely fast elimination and re-uptake of dihydrogen in $\mathrm{CH}_{2} \mathrm{Cl}_{2}$ solution in one of the most rapid heterolytic splitting reactions recorded $\left(>10^{7} \mathrm{~s}^{-1}\right.$ at $25^{\circ} \mathrm{C}$, Figure 3). ${ }^{141}$ Thus the postulated intermediate dihydrogen complex $\left[\mathrm{Mn}\left(\mathrm{H}_{2}\right)\right]^{+}$(entry 17 ) must have a $\mathrm{p} K_{\mathrm{a}}$ near to that of the amine (12). The LAC method predicts a $\mathrm{p} K_{\mathrm{a}}$ of 10.

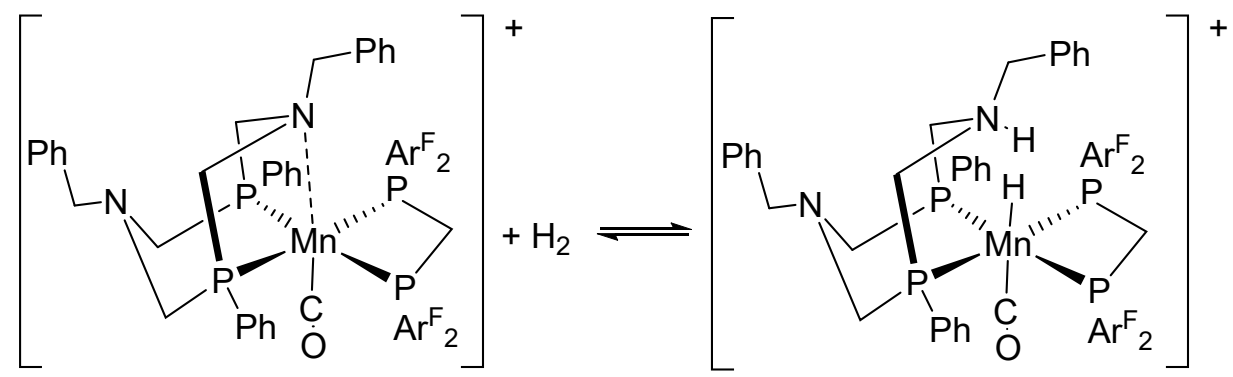

Figure 3. The heterolytic splitting of dihydrogen at a $\mathrm{Mn}(\mathrm{I})$ complex

A series of cationic hydrido rhenium(III) complexes containing bipyridine and carbonyl or phosphite ligands were synthesized and treated with $\mathrm{HBF}_{4} \cdot \mathrm{Et}_{2} \mathrm{O}$ at low temperature to see if dihydrogen complexes could be generated. ${ }^{142}$ The tricarbonyl $\left[\mathrm{ReH}_{2}(\mathrm{CO})_{3}(\mathrm{bpy})\right]\left[\mathrm{BPh}_{4}\right]$ did not react with an excess of this acid, consistent with predicted $\mathrm{p} K_{\mathrm{a}}^{\mathrm{LAC}}$ of -17 for the postulated dicationic trihydride 
$\left[\mathrm{ReH}_{3}(\mathrm{CO})_{3}(\mathrm{bpy})\right]^{2+}$ (not listed in the Table). However the tris(phosphinite) complexes $\left[\mathrm{ReH}(\mathrm{Cl})\left(\mathrm{PPh}(\mathrm{OEt})_{2}\right)_{3}(\mathrm{bpy})\right] \mathrm{BPh}_{4}$ and $\left[\mathrm{ReH}_{2}\left(\mathrm{PPh}(\mathrm{OEt})_{2}\right)_{3}(\mathrm{bpy})\right] \mathrm{BPh}_{4}$ in $\mathrm{CD}_{2} \mathrm{Cl}_{2}$ could be protonated at about $190 \mathrm{~K}$, to give very acidic dicationic hydride complexes (entries 3 and 7). The former reaction had to be conducted with a large excess of acid, consistent with the predicted $\mathrm{p} K_{\mathrm{a}}^{\mathrm{LAC}}$ of -5 .

The nitrosyl and carbonyl ligands in $\left[\operatorname{ReH}(\mathrm{NO})(\mathrm{CO})_{2}\left(\mathrm{PPh}_{3}\right)_{2}\right]^{+}$and $\left[\operatorname{Re}\left(\mathrm{H}_{2}\right)(\mathrm{NO})(\mathrm{CO}) \mathrm{Cp}^{*}\right]^{+}$(entries 4 and 5) make these highly acidic. The latter was reported to have a $\mathrm{p} K_{\mathrm{a}}$ on the pseudo aqueous scale of -2 since it was deprotonated by diethyl ether in $\mathrm{CH}_{2} \mathrm{Cl}_{2}$ to produce a hydride bridged $\mathrm{Re}-\mathrm{H}-\mathrm{Re}$ dimer. ${ }^{143}$

The enthalpies of protonation of two $\operatorname{Re}(\mathrm{CO})_{2}\left(\mathrm{Cp}^{*}\right)\left(\mathrm{PR}_{3}\right)$ complexes by $\mathrm{CF}_{3} \mathrm{SO}_{3} \mathrm{H}$ were measured ${ }^{112}$ and related to $p K_{\mathrm{a}}^{\text {THF }}$ values of approx. 2 for the hydrides $\left[\operatorname{ReH}(\mathrm{CO})_{2}\left(\mathrm{Cp}^{*}\right)\left(\mathrm{PR}_{3}\right)\right]^{+}($entries 8 and 9). One of the earliest reported $p K_{a}$ determinations of a hydride is 8.5 for $\left[\operatorname{ReH}_{2}(C p)_{2}\right]^{+}$in a $60 \%$ dioxane solution (entry 12 ).

The acidic properties of at least two hydride-bridged dirhenium complexes have been reported (entries $13,14,34)$. The compound $\operatorname{Re}_{2} \mathrm{H}_{2}(\mathrm{CO})_{9}$, thought to have one bridging hydride and one terminal hydride, is deprotonated by $\mathrm{PMe}_{2} \mathrm{Ph}$ in $\mathrm{THF}\left(\mathrm{p} K_{\mathrm{a}}{ }^{\mathrm{THF}}\left(\mathrm{HPMe}_{2} \mathrm{Ph}^{+}\right) 8\right)$. Thus this neutral rhenium complex has a $\mathrm{p} K_{\mathrm{a}}<7$. Clearly the conjugate base form is stabilized by the large number of carbonyl ligands present. The hydride-bridged conjugate base $\left[\mathrm{NEt}_{4}\right]\left[\mathrm{Re}_{2} \mathrm{H}(\mathrm{CO})_{9}\right]$ in $\mathrm{CD}_{2} \mathrm{Cl}_{2}$ is partially protonated by the alcohol $\left(\mathrm{CF}_{3}\right)_{2} \mathrm{CHOH}\left(\mathrm{p} K_{\mathrm{a}}\right.$ aq $9.3 ; \mathrm{p} K_{\mathrm{a}}{ }^{\mathrm{DMSO}}$ 17.9). The reason provided for why this alcohol protonates this weakly basic anion is the favorable formation of the strongly hydrogen bonded homoconjugate anion $\left[\left(\mathrm{CF}_{3}\right)_{2} \mathrm{CHOH} \cdots \mathrm{OCH}\left(\mathrm{CF}_{3}\right)_{2}\right]^{-}$that is solvated by excess alcohol. ${ }^{61}$ The other dirhenium complex is the very weakly acidic complex $\mathrm{Re}_{2} \mathrm{H}_{8}\left(\mathrm{PMePh}_{2}\right)_{4}$ that has four bridging hydrides. In THF it is partially deprotonated by the base $\left[\mathrm{PO}(\mathrm{OEt})_{2} \mathrm{NPh}\right]^{-}$to give a triply hydride bridged dirhenate complex, indicating that its $p K_{\mathrm{a}}{ }^{\mathrm{THF}}$ is 33 (Figure 4). ${ }^{144}$ Thus the two dirhenium complexes in Table 6 illustrate the dramatic change in acidity on going from carbonyl to phosphine ligation.
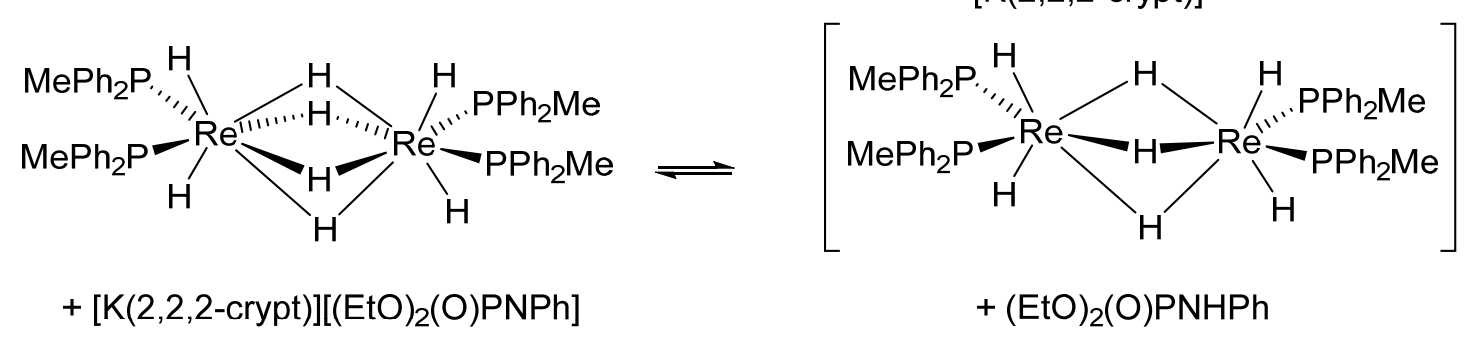

$+[\mathrm{K}(2,2,2-\mathrm{crypt})]\left[(\mathrm{EtO})_{2}(\mathrm{O}) \mathrm{PNPh}\right]$

Figure 4. The deprotonation of a hydrido-bridged rhenium dimer

The properties of several cationic polyhydride rhenium complexes have been reported (entries $18,22,24-27)$. The hexahydride $\left[\mathrm{ReH}_{6}\left(\mathrm{PPh}_{3}\right)_{2}\left(\mathrm{PTA}^{\mathrm{P}}-\mathrm{HBF}_{4}\right)\right]^{+}$is predicted to have a $\mathrm{p} K_{\mathrm{a}}{ }^{\mathrm{LAC}}$ of approx. 10; a nitrogen on one of the PTA ligands is protonated as well as the rhenium. A series of tetrahydride cations were linked via successive equilibria to determine the $\mathrm{p} K_{\mathrm{a}}{ }^{\text {THF }}$ ranging from 14.7 (entry 22) to 22.1 (entry 27). ${ }^{7}$ The compound $\left[\mathrm{ReH}_{4}\left(\mathrm{PhMe}_{2}\right)_{4}\right]^{+}$forms useful equilibria with protonated DBU in MeCN (entry 26) thus providing a link to the $\mathrm{p} K_{\mathrm{a}}^{\mathrm{MeCN}}$ scale and with $\mathrm{CH}_{2}(\mathrm{CN})_{2}$ in THF (entry 25 ).

Neutral hydride acids with several $\pi$-acid ligands are as acidic as the cationic acids just discussed. The aqueous $\mathrm{p} K_{\mathrm{a}}{ }^{\text {aq }}$ of $\mathrm{MnH}(\mathrm{CO})_{5}$ was reported as 7.1 (entry 19) and that of $\operatorname{ReH}(\mathrm{CO})_{5}$ as a very weak acid. $^{3}$ The $\mathrm{p} K_{\mathrm{a}}{ }^{\mathrm{MeCN}}$ determined by reaction with morpholine and $\mathrm{NEt}_{3}$, respectively, are 15.1 and $21.1 .{ }^{51}$ This change of $6 p K_{\mathrm{a}}$ units on going from the $3 \mathrm{~d}$ to $5 \mathrm{~d}$ metal is much larger than the average value of 2 used in the LAC method. In the gas phase the difference in enthalpy of protonation of the corresponding anions differ by about $13 \mathrm{kcal} / \mathrm{mol}$ (318 for $\mathrm{Mn}$, approx. $331 \mathrm{for} \mathrm{Re}$ ) and this difference was attributed to the stronger metal-hydride bond for rhenium. ${ }^{145-146}$ The gas phase acidities of the $\mathrm{PF}_{3}$ substituted 
complexes $\mathrm{MnH}(\mathrm{CO})_{3}\left(\mathrm{PF}_{3}\right)_{2}$ and $\mathrm{MnH}(\mathrm{CO})_{2}\left(\mathrm{PF}_{3}\right)_{3}$ were found to be greater than that of the pentacarbonyl complex and similar to $\mathrm{CF}_{3} \mathrm{SO}_{3} \mathrm{H}^{146}$ This suggests that $\mathrm{PF}_{3}$ has a more negative $A_{L}$ than $\mathrm{CO}$ in the $\mathrm{LAC}$ scheme. The $\mathrm{p} K_{\mathrm{a}}{ }^{\mathrm{LAC}}$ values calculated by the $\mathrm{LAC}$ method for the $\mathrm{d}^{6}$ octahedral hydrides $\mathrm{MHL}_{5} /\left[\mathrm{ML}_{5}\right]^{-}$such as those of entries 19-21, and 30 are obtained by adding the $A_{L}$ of the five ligands of the conjugate base form, then adding 6 to account for the large ligand field stabilization of the $\mathrm{MHL}_{5}$ hydrides, adding 30 because of the negative charge on the conjugate base and finally 2 for the rhenium complexes.

Kristjánsdóttir and Norton ${ }^{1}$ reported that the substitution of one carbonyl in $\mathrm{MnH}(\mathrm{CO})_{5}$ with $\mathrm{PPh}_{3}$ made the hydride $\mathrm{MnH}(\mathrm{CO})_{4}\left(\mathrm{PPh}_{3}\right)$ (entry 23) less acidic by 2.6 units in MeCN, resulting in a $K_{\mathrm{a}}{ }^{\mathrm{MeCN}}$ of 20.4. Substitution of three carbonyls with an $\eta^{6}-\mathrm{C}_{6} \mathrm{H}_{6}$ ligand caused a decrease in acidity of 6.4 units, making 26.8. This suggests that the $3 \mathrm{~A}_{\mathrm{L}}\left(\eta^{6}-\mathrm{C}_{6} \mathrm{H}_{6}\right)=3$ (entry 30). They also reported the $\mathrm{p} K_{\mathrm{a}}{ }^{\mathrm{MeCN}}$ of $\operatorname{ReH}_{2}(\mathrm{Cp})(\mathrm{CO})_{2}$ to be 23.0 .

The strong base $\mathrm{Na}\left[\mathrm{N}\left(\mathrm{SiMe}_{3}\right)_{2}\right]$ was used to remove an $\mathrm{HBr}$ equivalent from $\operatorname{Re}\left(\mathrm{H}_{2}\right)(\mathrm{Br})_{2}(\mathrm{NO})\left(\mathrm{P}^{\mathrm{i} P r_{3}}\right)_{2}$ in benzene to make $\operatorname{ReH}(\mathrm{Br})(\mathrm{NO})\left(\mathrm{P}^{\mathrm{i}} \mathrm{Pr}_{3}\right)_{2} \cdot{ }^{147}$ The need for a strong base is consistent with the large value of the $\mathrm{p} K_{\mathrm{a}}{ }^{\mathrm{LAC}}$ of 27 (entry 31 ).

The equilibrium between the acid/base pairs $\mathrm{ReH}_{7}\left(\mathrm{Ph}_{2} \mathrm{PC}_{6} \mathrm{H}_{4} \mathrm{~F}\right)_{2} /\left[\mathrm{ReH}_{6}\left(\mathrm{Ph}_{2} \mathrm{PC}_{6} \mathrm{H}_{4} \mathrm{~F}\right)_{2}\right]^{-}$(entry 32) and $\left[\mathrm{ReH}_{2}\left(\mathrm{PMe}_{3}\right)_{5}\right]^{+} / \mathrm{ReH}\left(\mathrm{PMe}_{3}\right)_{5}$ provided a useful link between a $\mathrm{p} K_{\mathrm{a}}^{\mathrm{THF}}$ ladder of cationic hydrides and a ladder of neutral hydrides including the remaining heptahydrides and a pentahydride listed in Table 6, entries 33,35 and $36 .^{7}$ To make this link the ion pair dissociation constants had to be estimated by use of the Fuoss equation with approximate ionic radii. The approximations made here mean that the $\mathrm{p} K_{\mathrm{a}}^{\text {THF }}$ values above 30 for neutral hydrides listed have potential errors up to $\pm 3 p K_{a}$ units. A remarkable feature of the $\mathrm{ReH}_{7} \mathrm{~L}_{2}$ complexes is the large change in acidity with small changes in the structure of $\mathrm{L}$. For example $\mathrm{ReH}_{7}\left(\mathrm{PPh}_{3}\right)_{2}$ (entry 33, $\mathrm{p} K_{\mathrm{a}}{ }^{\mathrm{THF}} 30$ ) is 12 units more acidic than $\mathrm{ReH}_{7}\left(\mathrm{PCy}_{3}\right)_{2}$ (entry $36, \mathrm{p} K_{\mathrm{a}}{ }^{\mathrm{THF}}$ 42). This large change is not accounted for in the LAC method that predicts an average change of only 4 units. 


\begin{tabular}{|c|c|c|c|c|c|c|c|c|c|}
\hline Entry & Acid form & Base form ${ }^{b}$ & Reactant & Reaction & Solvent & Temp. & $\mathbf{p K}_{\mathrm{a}}{ }^{\exp }$ & $\mathrm{pK}_{\mathrm{a}}^{\mathrm{LAC}}$ & Ref. \\
\hline 1 & {$\left[\operatorname{Re}\left(\mathrm{H}_{2}\right)(\mathrm{CO})_{5}\right]^{+}$} & MH & $\mathrm{Et}_{2} \mathrm{O}$ & {$\left[\mathrm{MH}_{2}\right] \mathrm{Y}+\mathrm{B} \rightarrow \mathrm{MH}+[\mathrm{HB}] \mathrm{Y}$} & $\mathrm{C}_{6} \mathrm{H}_{5} \mathrm{~F}$ & 298 & & -18 & 120 \\
\hline 2 & {$\left[\operatorname{Re}\left(\mathrm{H}_{2}\right)(\mathrm{CO})_{4}\left(\mathrm{P}^{\mathrm{i}} \mathrm{Pr}_{3}\right)\right]^{+}$} & {$[\mathrm{MHM}]^{+}$} & ${ }^{i} \mathrm{Pr}_{2} \mathrm{O}$ & $2\left[\mathrm{MH}_{2}\right] \mathrm{Y}+\mathrm{B} \rightarrow[\mathrm{MHM}] \mathrm{Y}+[\mathrm{HB}] \mathrm{Y}$ & $\mathrm{CD}_{2} \mathrm{Cl}_{2}$ & 298 & $<0$ & -9 & 135 \\
\hline 3 & {$\left[\mathrm{ReH}_{2} \mathrm{Cl}\left(\mathrm{PPh}(\mathrm{OEt})_{2}\right)_{3}(\mathrm{bpy})\right]^{+2}$} & {$[\mathrm{MH}]^{+}$} & {$\left[\mathrm{H}\left(\mathrm{OEt}_{2}\right)_{2}\right] \mathrm{BF}_{4}$} & {$[\mathrm{MH}] \mathrm{Y}+[\mathrm{HB}] \mathrm{Y} \rightarrow\left[\mathrm{MH}_{2}\right] \mathrm{Y}_{2}+\mathrm{B}$} & $\mathrm{CD}_{2} \mathrm{Cl}_{2}$ & 193 & & -6 & 142 \\
\hline 4 & {$\left[\mathrm{ReH}(\mathrm{NO})(\mathrm{CO})_{2}\left(\mathrm{PPh}_{3}\right)_{2}\right]^{+}$} & M & $\mathrm{CF}_{3} \mathrm{SO}_{3} \mathrm{H}$ & $\mathrm{M}+\mathrm{HY} \rightarrow[\mathrm{MH}] \mathrm{Y}$ & $\mathrm{Et}_{2} \mathrm{O}$ & 298 & & -4 & 148 \\
\hline 5 & {$\left[\operatorname{Re}\left(\mathrm{H}_{2}\right)(\mathrm{NO})(\mathrm{CO}) \mathrm{Cp}^{*}\right]^{+}$} & MH & $\mathrm{Et}_{2} \mathrm{O}$ & {$\left[\mathrm{MH}_{2}\right] \mathrm{Y}+\mathrm{B} \rightarrow \mathrm{MH}+[\mathrm{HB}] \mathrm{Y}$} & $\mathrm{CH}_{2} \mathrm{Cl}_{2}$ & 190 & -2 & -2 & 143 \\
\hline 6 & {$\left[\operatorname{Re}\left(\mathrm{H}_{2}\right)(\mathrm{CO})_{3}\left(\mathrm{PCy}_{3}\right)_{2}\right]^{+}$} & MH & proton sponge & {$\left[\mathrm{MH}_{2}\right] \mathrm{Y}+\mathrm{B} \rightarrow \mathrm{MH}+[\mathrm{HB}] \mathrm{Y}$} & $\mathrm{CD}_{2} \mathrm{Cl}_{2}$ & 298 & $<12$ & 0 & 137 \\
\hline 7 & {$\left[\mathrm{ReH}_{3}\left(\mathrm{PPh}(\mathrm{OEt})_{2}\right)_{3}(\mathrm{bpy})\right]^{+2}$} & {$\left[\mathrm{MH}_{2}\right]^{+}$} & {$\left[\mathrm{H}\left(\mathrm{OEt}_{2}\right)_{2}\right] \mathrm{BF}_{4}$} & {$\left[\mathrm{MH}_{2}\right] \mathrm{Y}+[\mathrm{HB}] \mathrm{Y} \rightarrow\left[\mathrm{MH}_{3}\right] \mathrm{Y}_{2}+\mathrm{B}$} & $\mathrm{CD}_{2} \mathrm{Cl}_{2}$ & 193 & & 0 & 142 \\
\hline 8 & {$\left[\mathrm{ReH}\left(\mathrm{Cp}^{*}\right)(\mathrm{CO})_{2}\left(\mathrm{PMe}_{2} \mathrm{Ph}\right)\right]^{+}$} & M & $\mathrm{CF}_{3} \mathrm{SO}_{3} \mathrm{H}$ & $\mathrm{M}+\mathrm{HY} \rightarrow[\mathrm{MH}] \mathrm{Y}$ & DCE & 298 & 0.5 & 1 & 8,112 \\
\hline 9 & {$\left[\mathrm{ReH}\left(\mathrm{Cp}^{*}\right)(\mathrm{CO})_{2}\left(\mathrm{PMe}_{3}\right)\right]^{+}$} & M & $\mathrm{CF}_{3} \mathrm{SO}_{3} \mathrm{H}$ & $\mathrm{M}+\mathrm{HY} \rightarrow[\mathrm{MH}] \mathrm{Y}$ & DCE & 298 & 1.5 & 2 & 8,112 \\
\hline 10 & {$\left[\operatorname{Re}\left(\mathrm{H}_{2}\right)(\mathrm{CO})_{2}\left(\mathrm{Me}\left(\mathrm{CH}_{2} \mathrm{PPh}_{2}\right)_{3}\right)\right]^{+}$} & MH & $\mathrm{NEt}_{3}$ & {$\left[\mathrm{MH}_{2}\right] \mathrm{Y}+\mathrm{B} \rightarrow \mathrm{MH}+[\mathrm{HB}] \mathrm{Y}$} & $\mathrm{CH}_{2} \mathrm{Cl}_{2}$ & 298 & $<13$ & 3 & 138 \\
\hline 11 & {$\left[\mathrm{Re}\left(\mathrm{H}_{2}\right)(\mathrm{CO})_{2}\left(\mathrm{Me}\left(\mathrm{CH}_{2} \mathrm{PPh}_{2}\right)_{3}\right)\right]^{+}$} & MH & $\left(\mathrm{CF}_{3}\right)_{3} \mathrm{COH}$ & $\mathrm{MH}+\mathrm{HY} \rightleftharpoons\left[\mathrm{MH}_{2}\right] \mathrm{Y}$ & $\mathrm{CH}_{2} \mathrm{Cl}_{2}$ & $<260$ & $11^{c}$ & 3 & 65 \\
\hline 12 & {$\left[\mathrm{ReH}_{2}(\mathrm{Cp})_{2}\right]^{+}$} & MH & $\mathrm{H}_{2} \mathrm{O}$ & $\mathrm{MH}_{2}+\mathrm{H}_{2} \mathrm{O} \rightleftharpoons \mathrm{MH}+\mathrm{H}_{3} \mathrm{O}^{+}$ & $\mathrm{H}_{2} \mathrm{O} /$ dioxane & & 8.5 & 6 & 149 \\
\hline $\begin{array}{l}13 \\
14\end{array}$ & $\begin{array}{l}\operatorname{Re}_{2} \mathrm{H}_{2}(\mathrm{CO})_{9} \\
\operatorname{Re}_{2} \mathrm{H}_{2}(\mathrm{CO})_{9}\end{array}$ & $\begin{array}{l}\mathrm{M}_{2} \mathrm{H}_{2} \\
{[\mathrm{MHM}]^{-}}\end{array}$ & $\begin{array}{l}\mathrm{PMe}_{2} \mathrm{Ph} \\
\left(\mathrm{CF}_{3}\right)_{2} \mathrm{CHOH}\end{array}$ & $\begin{array}{l}\mathrm{M}_{2} \mathrm{H}_{2}+\mathrm{B} \rightarrow[\mathrm{HB}]\left[\mathrm{M}_{2} \mathrm{H}\right] \\
\mathrm{Z}[\mathrm{MHM}]+2 \mathrm{HY} \rightleftharpoons\left[\mathrm{M}_{2} \mathrm{H}_{2}\right]+ \\
\mathrm{Z}[\mathrm{YHY}]\end{array}$ & $\begin{array}{l}\mathrm{THF} \\
\mathrm{CD}_{2} \mathrm{Cl}_{2}\end{array}$ & $<240$ & $\begin{array}{l}<7 \\
18^{c}\end{array}$ & & $\begin{array}{l}61 \\
61\end{array}$ \\
\hline 15 & {$\left[\mathrm{Mn}\left(\mathrm{H}_{2}\right)(\mathrm{CO})\left(\mathrm{P}(\mathrm{OEt})_{3}\right)_{4}\right]^{+}$} & $\mathrm{MH}$ & $\mathrm{NEt}_{3}$ & {$\left[\mathrm{MH}_{2}\right] \mathrm{Y}+\mathrm{B} \rightleftharpoons \mathrm{MH}+[\mathrm{HB}] \mathrm{Y}$} & $\mathrm{CD}_{2} \mathrm{Cl}_{2}$ & 298 & $<13$ & 2 & 140 \\
\hline $\begin{array}{l}16 \\
17\end{array}$ & $\begin{array}{l}{\left[\mathrm{ReH}_{2}(\mathrm{CO})_{2}\left(\mathrm{PMe}_{3}\right)_{3}\right]^{+}} \\
{\left[\mathrm{MnH}(\mathrm{CO})\left(\mathrm{PAr}_{2} \mathrm{CH}_{2} \mathrm{PAr}\right.\right.} \\
2)(\mathrm{PPh}- \\
\mathrm{NBn}-\mathrm{PPh}-\mathrm{NBn}-]^{+}\end{array}$ & $\begin{array}{l}\mathrm{MH} \\
\mathrm{MH}\end{array}$ & $\begin{array}{l}\mathrm{PhCH}=\mathrm{NCH}_{2} \mathrm{Ph} \\
\mathrm{N}\left(\mathrm{CH}_{2} \mathrm{Ph}\right)\left(\mathrm{CH}_{2} \mathrm{PPhR}\right)_{2}\end{array}$ & $\begin{array}{l}{\left[\mathrm{MH}_{2}\right] \mathrm{Y}+\mathrm{B} \rightarrow \mathrm{MH}+[\mathrm{HB}] \mathrm{Y}} \\
{\left[\mathrm{MH}_{2}\right] \mathrm{Y}+\mathrm{B} \rightleftharpoons \mathrm{MH}+[\mathrm{HB}] \mathrm{Y}}\end{array}$ & $\begin{array}{l}\mathrm{C}_{6} \mathrm{D}_{5} \mathrm{Cl} \\
\mathrm{CH}_{2} \mathrm{Cl}_{2}\end{array}$ & $\begin{array}{l}298 \\
298\end{array}$ & & $\begin{array}{r}9 \\
10\end{array}$ & $\begin{array}{l}139 \\
141\end{array}$ \\
\hline 18 & {$\left[\mathrm{ReH}_{6}\left(\mathrm{PPh}_{3}\right)_{2}\left(\mathrm{PTA}-\mathrm{HBF}_{4}\right)\right]^{+}$} & $\mathrm{MH}_{5}$ & {$\left[\mathrm{H}\left(\mathrm{OEt}_{2}\right)_{2}\right] \mathrm{BF}_{4}$} & $\mathrm{MH}_{5}+[\mathrm{HB}] \mathrm{Y} \rightarrow\left[\mathrm{MH}_{6}\right] \mathrm{Y}+\mathrm{B}$ & $\mathrm{CD}_{2} \mathrm{Cl}_{2}$ & $<270$ & & 11 & 150 \\
\hline 19 & $\mathrm{MnH}(\mathrm{CO})_{5}$ & {$[\mathrm{M}]^{-}$} & $\mathrm{H}_{2} \mathrm{O}$ & $\mathrm{MH}+\mathrm{H}_{2} \mathrm{O} \rightleftharpoons[\mathrm{M}]^{-}+\mathrm{H}_{3} \mathrm{O}^{+}$ & $\mathrm{H}_{2} \mathrm{O}$ & 298 & 7.1 & 15 & 3 \\
\hline 20 & $\mathrm{MnH}(\mathrm{CO})_{5}$ & $\{\mathrm{M}]^{-}$ & morpholine & $\mathrm{MH}+\mathrm{B} \rightleftharpoons[\mathrm{HB}][\mathrm{M}]$ & $\mathrm{CH}_{3} \mathrm{CN}$ & 298 & 15.1 & 15 & 51 \\
\hline 21 & $\operatorname{ReH}(\mathrm{CO})_{5}$ & {$[\mathrm{M}]^{-}$} & $\mathrm{NEt}_{3}$ & $\mathrm{MH}+\mathrm{B} \rightleftharpoons[\mathrm{HB}][\mathrm{M}]$ & $\mathrm{CH}_{3} \mathrm{CN}$ & 298 & 21.1 & 17 & 51 \\
\hline 22 & {$\left[\mathrm{ReH}_{4}\left(\mathrm{PMePh}_{2}\right)_{4}\right]^{+}$} & $\mathrm{MH}_{3}$ & {$\left[\mathrm{OsH}_{3}\left(\mathrm{PMe}_{2} \mathrm{Ph}\right)_{4}\right] \mathrm{BPh}_{4}$} & $\mathrm{MH}_{3}+\left[\mathrm{M}^{\prime} \mathrm{H}_{3}\right] \mathrm{Y} \rightleftharpoons\left[\mathrm{MH}_{4}\right] \mathrm{Y}+\mathrm{M}^{\prime} \mathrm{H}_{2}$ & THF & 298 & 14.7 & 15 & 7 \\
\hline 23 & $\mathrm{MnH}(\mathrm{CO})_{4}\left(\mathrm{PPh}_{3}\right)$ & {$[\mathrm{M}]^{-}$} & $\mathrm{NEt}_{3}$ & $\mathrm{MH}+\mathrm{B} \rightleftharpoons[\mathrm{HB}][\mathrm{M}]$ & $\mathrm{CH}_{3} \mathrm{CN}$ & 298 & 20.4 & 22 & 1 \\
\hline 24 & {$\left[\mathrm{ReH}_{4}\left(\mathrm{PMe}_{2} \mathrm{Ph}\right)_{4}\right]^{+}$} & $\mathrm{MH}_{3}$ & {$\left[\mathrm{OsH}_{3}\left(\mathrm{PEt}_{3}\right)_{4}\right] \mathrm{BPh}_{4}$} & $\mathrm{MH}_{3}+\left[\mathrm{M}^{\prime} \mathrm{H}_{3}\right] \mathrm{Y} \rightleftharpoons\left[\mathrm{MH}_{4}\right] \mathrm{Y}+\mathrm{M}^{\prime} \mathrm{H}_{2}$ & THF & 298 & 20.0 & 19 & 7 \\
\hline 25 & {$\left[\mathrm{ReH}_{4}\left(\mathrm{PMe}_{2} \mathrm{Ph}\right)_{4}\right]^{+}$} & $\mathrm{MH}_{3}$ & {$[\mathrm{Q}][\mathrm{NCCHCN}]$} & {$\left[\mathrm{MH}_{4}\right] \mathrm{Y}+\mathrm{ZY} \rightleftharpoons \mathrm{MH}_{3}+\mathrm{HY}+\mathrm{ZY}$} & THF & 298 & 20.0 & 19 & 7 \\
\hline 26 & {$\left[\mathrm{ReH}_{4}\left(\mathrm{PMe}_{2} \mathrm{Ph}\right)_{4}\right]^{+}$} & $\mathrm{MH}_{3}$ & DBU & {$\left[\mathrm{MH}_{4}\right] \mathrm{Y}+\mathrm{B} \rightleftharpoons \mathrm{MH}_{3}+[\mathrm{HB}] \mathrm{Y}$} & $\mathrm{CH}_{3} \mathrm{CN}$ & 298 & 25.3 & $19\left(25^{d}\right)$ & 151 \\
\hline 27 & {$\left[\mathrm{ReH}_{4}\left(\mathrm{PMe}_{3}\right)_{4}\right]^{+}$} & $\mathrm{MH}_{3}$ & {$\left[\mathrm{ReH}_{4}\left(\mathrm{PMe}_{2} \mathrm{Ph}\right)_{4}\right] \mathrm{BPh}_{4}$} & $\mathrm{MH}_{3}+\left[\mathrm{M}^{\prime} \mathrm{H}_{4}\right] \mathrm{Y} \rightleftharpoons\left[\mathrm{MH}_{4}\right] \mathrm{Y}+\mathrm{M}^{\prime} \mathrm{H}_{3}$ & THF & 298 & 22.1 & 22 & 7 \\
\hline 28 & $\mathrm{ReH}_{2}(\mathrm{Cp})(\mathrm{CO})_{2}$ & MH & TMG & $\mathrm{MH}_{2}+\mathrm{B} \rightleftharpoons[\mathrm{HB}][\mathrm{MH}]$ & $\mathrm{CH}_{3} \mathrm{CN}$ & 298 & 23.0 & 26 & 151 \\
\hline
\end{tabular}




\begin{tabular}{|c|c|c|c|c|c|c|c|c|c|}
\hline 29 & {$\left[\mathrm{ReH}_{2}\left(\mathrm{PMe}_{3}\right)_{5}\right]^{+}$} & $\mathrm{MH}$ & $\mathrm{ReH}_{3}\left(\mathrm{PMe}_{3}\right)_{4}$ & {$\left[\mathrm{MH}_{2}\right] \mathrm{Y}+\mathrm{M}^{\prime} \mathrm{H}_{3} \rightleftharpoons \mathrm{MH}+\left[\mathrm{M}^{\prime} \mathrm{H}_{4}\right] \mathrm{Y}$} & THF & 298 & 24.2 & 27 & 7 \\
\hline 30 & $\mathrm{MnH}(\mathrm{CO})_{2}\left(\mathrm{C}_{6} \mathrm{H}_{6}\right)$ & {$[\mathrm{M}]^{-}$} & $\mathrm{KOPh}$ & $\mathrm{MH}+\mathrm{KY} \rightleftharpoons \mathrm{K}[\mathrm{M}]+\mathrm{HY}$ & $\mathrm{CH}_{3} \mathrm{CN}$ & 298 & 26.8 & 31 & 1 \\
\hline 31 & $\operatorname{Re}\left(\mathrm{H}_{2}\right)(\mathrm{Br})_{2}(\mathrm{NO})\left(\mathrm{PiPr}_{3}\right)_{2}$ & MH & $\mathrm{Na}\left[\mathrm{N}\left(\mathrm{SiMe}_{3}\right)_{2}\right]$ & $\mathrm{MH}_{2} \mathrm{Br}+\mathrm{NaY} \rightarrow \mathrm{MH}+\mathrm{NaBr}+\mathrm{HY}$ & $\mathrm{C}_{6} \mathrm{H}_{6}$ & 298 & & 29 & 147 \\
\hline 32 & $\mathrm{ReH}_{7}\left(\mathrm{Ph}_{2} \mathrm{PC}_{6} \mathrm{H}_{4} \mathrm{~F}\right)_{2}$ & {$\left[\mathrm{MH}_{6}\right]^{-}$} & $\mathrm{ReH}\left(\mathrm{PMe}_{3}\right)_{5}$ & $\mathrm{MH}_{7}+\mathrm{M}^{\prime} \mathrm{H} \rightleftharpoons\left[\mathrm{M}^{\prime} \mathrm{H}_{2}\right]\left[\mathrm{MH}_{6}\right]$ & THF & 298 & 28 & 39 & 7 \\
\hline 33 & $\mathrm{ReH}_{7}\left(\mathrm{PPh}_{3}\right)_{2}$ & {$\left[\mathrm{MH}_{6}\right]^{-}$} & $\mathrm{FeH}(\mathrm{Cp})(\mathrm{CO})_{2}$ & $\mathrm{Z}\left[\mathrm{MH}_{6}\right]+\mathrm{M}^{\prime} \mathrm{H} \rightleftharpoons \mathrm{MH}_{7}+\mathrm{Z}\left[\mathrm{M}^{\prime}\right]$ & THF & 298 & 30 & 39 & 7 \\
\hline 34 & $\mathrm{Re}_{2} \mathrm{H}_{8}\left(\mathrm{PMePh}_{2}\right)_{4}$ & {$\left[\mathrm{M}_{2} \mathrm{H}_{7}\right]^{-}$} & $\mathrm{Z}\left[\mathrm{PO}(\mathrm{OEt})_{2} \mathrm{NPh}\right]$ & $\mathrm{M}_{2} \mathrm{H}_{8}+\mathrm{ZY} \rightleftharpoons \mathrm{Z}\left[\mathrm{M}_{2} \mathrm{H}_{7}\right]+\mathrm{HY}$ & THF & 298 & 33 & & 144 \\
\hline 35 & $\mathrm{ReH}_{4}(\mathrm{NO})\left(\mathrm{P}^{\mathrm{i}} \mathrm{Pr}_{3}\right)_{2}$ & {$\left[\mathrm{MH}_{3}\right]^{-}$} & $\mathrm{OsH}_{4}(\mathrm{CO})\left(\mathrm{PiPr}_{2}\right)_{2}$ & $\mathrm{Z}\left[\mathrm{MH}_{3}\right]+\mathrm{M}^{\prime} \mathrm{H}_{4} \rightleftharpoons \mathrm{MH}_{4}+\mathrm{Z}\left[\mathrm{M}^{\prime} \mathrm{H}_{3}\right]$ & THF & 298 & 38 & 37 & 7 \\
\hline 36 & $\mathrm{ReH}_{5}\left(\mathrm{PMePh}_{2}\right)_{3}$ & {$\left[\mathrm{MH}_{4}\right]^{-}$} & $\mathrm{Z}\left[\mathrm{NPh}_{2}\right]$ & $\mathrm{MH}_{5}+\mathrm{ZY} \leftarrow \mathrm{Z}\left[\mathrm{MH}_{4}\right]+\mathrm{HY}$ & THF & 298 & 40 & 42 & 7 \\
\hline 37 & $\mathrm{ReH}_{7}\left(\mathrm{PCy}_{3}\right)_{2}$ & {$\left[\mathrm{MH}_{6}\right]^{-}$} & $\mathrm{Z}\left[\mathrm{PO}(\mathrm{OEt})_{2} \mathrm{NPh}\right.$ & $\mathrm{MH}_{7}+\mathrm{ZY} \rightleftharpoons \mathrm{Z}\left[\mathrm{MH}_{6}\right]+\mathrm{HY}$ & THF & 298 & 42 & 43 & 7 \\
\hline
\end{tabular}

${ }^{a}$ Abbreviations: PPh-NBn-PPh-NBn $=$ cyclo- $\mathrm{PPhCH}_{2} \mathrm{NBnCH}_{2} \mathrm{PPhCH}_{2} \mathrm{NBnCH}_{2}-$

${ }^{b}$ The ligands are the same as in the acid form apart from the loss of a proton (and counteranion for cationic complexes).

${ }^{c} \mathrm{pK}_{\mathrm{a}}^{\mathrm{DMSO}}$ but reaction done in lower dielectric constant solvent.

${ }^{d} \mathrm{pK}_{\mathrm{a}}$ corrected to the MeCN scale for cationic acids using Equation 14 


\subsection{Iron group}

\subsubsection{Very acidic dihydrogen complexes}

The acidity of a variety of Fe(II), Ru(II) and Os(II) dihydrogen complexes of the type trans$\left[\mathrm{M}\left(\mathrm{H}_{2}\right)(\pi \text {-acid-L)(diphosphine })_{2}\right]^{2+}$ have been examined (Table 8 entries $\left.1,5-9\right)$. The dipositive charge on the complex combined with the presence of a carbonyl or isonitrile $\pi$-acid ligand makes these complexes some of the most acidic iron group complexes studied ( $\mathrm{p} K_{\mathrm{a}}^{\mathrm{THF}}-7$ to -3$)$. In order to observe [Fe $\left.\left(\mathrm{H}_{2}\right)(\mathrm{CO})(\mathrm{dppe})_{2}\right]^{2+}$ (entry 1 ) in $\mathrm{CD}_{2} \mathrm{Cl}_{2}, 10$ equiv. of $\mathrm{CF}_{3} \mathrm{SO}_{3} \mathrm{H}$ needed to be added to the monohydride conjugate base form. ${ }^{152}$ Twelve equiv. of $\mathrm{CF}_{3} \mathrm{SO}_{3} \mathrm{H}$ needed to be added to $\left[\mathrm{OsH}(\mathrm{CO})(\mathrm{dppp})_{2}\right]^{+}$in $\mathrm{CD}_{2} \mathrm{Cl}_{2}$ to form a similar dihydrogen complex. ${ }^{153}$ The acid $\mathrm{HBF}_{4} \mathrm{Et}_{2} \mathrm{O}$ in $\mathrm{CD}_{2} \mathrm{Cl}_{2}$ was not strong enough to generate either of these complexes indicating that the $\mathrm{p} K_{\mathrm{a}}{ }^{\mathrm{DCM}}$ is $<-4.7 .^{28}$ The $\mathrm{p} K_{\mathrm{a}}{ }^{\mathrm{THF}} 2$ of HOTf (Table 2) at first sight does not seem consistent with these observations. However as we will see in several instances, a small neutral acid such as HOTf reacting with a neutral base to produce a strongly ion-paired anion and cation in a solvent of low dielectric constant is more favorable than the reaction with a cationic acid such as $\left[\mathrm{H}\left(\mathrm{OEt}_{2}\right)_{2}\right]^{+}$. These two examples are stable with respect to loss of $\mathrm{H}_{2}$ at room temperature, unlike the equally acidic ruthenium complex $\left[\mathrm{Ru}\left(\mathrm{H}_{2}\right)(\mathrm{CO})(\mathrm{dppp})_{2}\right]^{2+}$ which decomposes above $240 \mathrm{~K} .{ }^{153}$ Very acidic hydrogen isocyanide analogues of these complexes can also be prepared by protonating cyanide complexes of the type trans- $\mathrm{MH}(\mathrm{CN})$ (diphosphine) ${ }_{2}$ with excess $\mathrm{CF}_{3} \mathrm{SO}_{3} \mathrm{H}$ (entries 6-9). ${ }^{154}$ When the diphosphine is donating, as in $\left[\mathrm{Fe}\left(\mathrm{H}_{2}\right)(\mathrm{CNH})(\text { depe })_{2}\right]^{2+}$ the $p K_{\mathrm{a}}{ }^{\mathrm{THF}}$ increases to 3 (entry 36). The complex $\left[\mathrm{Fe}\left(\mathrm{H}_{2}\right)(\mathrm{MeCN})\left(\mathrm{PMe}_{2} \mathrm{CH}_{2} \mathrm{PMe}_{2}\right)\left(\mathrm{PEt}_{2} \mathrm{CH}_{2} \mathrm{NMeHCH}_{2} \mathrm{PEt}_{2}\right)\right]^{3+}$ with an ammonium group in the backbone of the ligand has a $\mathrm{p} K_{\mathrm{a}}{ }^{\mathrm{MeCN}}$ approx. $5 .{ }^{155}$

\subsubsection{Hydrogenase and model complexes}

The FeFe hydrogenases have a dithiolate that bridges the irons at the active site (see Section 6.9.2). A wide range of acidity ( $\mathrm{p} K_{\mathrm{a}}^{\mathrm{THF}}<-5$ to 21 ) has been found for several complexes designed to model aspects of these hydrogenases (entries $3,54,59,98,115,135,152$ ).

The presence of cyanide and dihydrogen at the active site of hydrogenases is modelled by the dihydrogen complex $\left[\mathrm{Fe}\left(\mathrm{H}_{2}\right)(\text { depe })_{2}(\mathrm{CN})\right]^{+}$(entry 97$) .{ }^{154}$ This complex has a $\mathrm{p} K_{\mathrm{a}}{ }^{\mathrm{DCM}}$ of 9 due to the acidifying effect of the cyanide ligand. The combination of carbonyl and cyanide ligands in $\mathrm{FeH}(\mathrm{CN})(\mathrm{CO})_{4}$ (entries 53,54 ) makes this complex sufficiently acidic to be deprotonated by aniline ( $\mathrm{p} K_{\mathrm{a}}{ }^{\mathrm{MeCN}}$ of 10.5 for anilinium) in $\mathrm{MeCN}$. The anionic hydride $\left[\mathrm{FeH}(\mathrm{CN})_{2}(\mathrm{CO})_{3}\right]^{-}$has a $\mathrm{p}_{\mathrm{a}}{ }^{\mathrm{MeCN}}$ that is greater than 17 since the dianionic conjugate form deprotonates ammonium (entry 151). Such an anionic Fe(II) complex is not sufficiently acidic to release protons under biological conditions.

Single iron hydrogenases are also known with the active site summarized as $\mathrm{Fe}\left(\mathrm{H}_{2}\right)(\mathrm{CO})_{2}($ acylpy)(Scysteine) (entry 83). These are discussed in Section 6.9.1

\subsubsection{Phosphine carbonyl hydride complexes}

The acidity of a range of $\left[\mathrm{MH}(\mathrm{CO})_{x} L_{5-x}\right]^{+}$complexes $\mathrm{x}=1$ to 4 have been studied (for example entries $4,13,19-21,23-28,30,31,43-47,154)$. For this class of complexes the hydride form has extra stability due to the high ligand field stabilization energy of the $d^{6}$ octahedral configuration, contributing an additional 6 units (less acidic) than the $p K_{a}$ value obtained by adding the $A_{L}$ values of the ligands in the conjugate base form. ${ }^{8}$ The tetracarbonyl complex cis- $\left[\mathrm{RuH}(\mathrm{CO})_{4}\left(\mathrm{PCY}_{3}\right)\right]^{+}$of entry 4 with a $K_{\mathrm{a}} \mathrm{LAC}^{\mathrm{LAC}}$ estimated to be -5 is observed in sulfuric acid solution. $\mathrm{A} \mathrm{p} K_{\mathrm{a}}^{\mathrm{DCM}}$ ladder of tricarbonyl iron hydrides $\left[\mathrm{FeH}(\mathrm{CO})_{3} \mathrm{~L}_{2}\right]^{+}(13,19-21,23,28,30,31,45-47)$ was constructed that spans the range from $\mathrm{p} K_{\mathrm{a}}{ }^{\mathrm{DCM}}$ of $-3(\mathrm{~L}$ $=\mathrm{P}\left(\mathrm{C}_{6} \mathrm{H}_{4}-4-\mathrm{F}\right)_{3}$, entry 13$)$ to $4\left(\mathrm{~L}=\mathrm{PCy}_{3}\right.$, entries 45-46) with the expected decreases in acidity as aryl groups are replaced with alkyl groups on the phosphorus donors. ${ }^{28}$ This allowed the $\mathrm{p} K_{\mathrm{a}}{ }^{\mathrm{DCM}}$ of fifteen other hydride and dihydrogen compounds whose acid-base reactions have been reported to be placed on this scale as well as the $\mathrm{pK}_{\mathrm{a}}{ }^{\mathrm{DCM}}$ of $\left[\mathrm{HOEt}_{2}\right] \mathrm{BF}_{4} / \mathrm{Et}_{2} \mathrm{O}$ of -4.7 . This latter value underlines the fact that the $\mathrm{pK}_{\mathrm{a}}{ }^{\mathrm{DCM}}$ scale is not referenced correctly since protonated $\mathrm{CH}_{2} \mathrm{Cl}_{2}$ should be 0 on this scale. Wang and 
Angelici measured the enthalpy of protonation of complexes that produced monohydride complexes $\left[\mathrm{MH}(\mathrm{CO})_{3} \mathrm{~L}_{2}\right]^{+}$with a chelating $\mathrm{L}_{2}$ (entries $24-26,43,44$ ); the derived $\mathrm{p} K_{\mathrm{a}}{ }^{\mathrm{LAC}}$ values show the same trends and mesh well with the monodentate series. Also included is a separate report of the formation of reactive $\left[\mathrm{RuH}(\mathrm{CO})_{3}(\mathrm{dppe})\right]^{+}$formed by protonation of $\mathrm{Ru}(\mathrm{CO})_{3}$ (dppe) by $\mathrm{CF}_{3} \mathrm{SO}_{3} \mathrm{H}$ in $\mathrm{C}_{6} \mathrm{D}_{6}$ (entry 27). ${ }^{156}$ This complex is thought to be an off-cycle product in a Ru-catalyzed water gas shift reaction. A very early example of the deprotonation of a dicarbonyl hydride was the reaction of $\left[\mathrm{RuH}(\mathrm{CO})_{2}\left(\mathrm{PPh}_{3}\right)_{3}\right]^{+}\left(\mathrm{p} K_{\mathrm{a}}{ }^{\mathrm{LAC}}\right.$ approx. 7) with sodium methoxide in an unspecified solvent to give $\mathrm{Ru}(\mathrm{CO})_{2}\left(\mathrm{PPh}_{3}\right)_{3} .{ }^{157} \mathrm{An}$ example of a

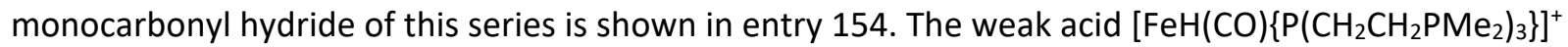
was deprotonated by $\mathrm{KO}^{\mathrm{t}} \mathrm{Bu}$ in $\mathrm{THF}$ to give the iron(0) carbonyl complex. ${ }^{158} \mathrm{~A}$ related deprotonation of an $\mathrm{Fe}(\mathrm{II})$ dinitrogen hydride complex (entry 155 ) and protonations of $\mathrm{Fe}(0)$ and $\mathrm{Ru}(0)$ dinitrogen complexes (entries 153 and 156) are also included in Table 8. Structural aspects of the protonation of triosmium carbonyl phosphine cluster compounds have been studied. ${ }^{159}$

As a side note, the Lewis acid $\mathrm{GaCl}_{3}$ behaves like a large proton in reactions with iron group carbonyl phosphine complexes $\mathrm{M}(\mathrm{CO})_{n}\left(\mathrm{PMe}_{3}\right)_{5-n}$ complexes $(n=5,4)$ to give adducts $\mathrm{M}\left(\mathrm{GaCl}_{3}\right)(\mathrm{CO})_{\mathrm{n}}\left(\mathrm{PMe}_{3}\right)_{5-\mathrm{n} .}{ }^{160}$ The order of stability mirrors the $\mathrm{p} K_{\mathrm{a}}{ }^{\mathrm{LAC}}$ values of the corresponding hydrides although the ruthenium complexes are more stable than the iron complexes, possibly for steric reasons.

\subsubsection{Cyclopentadienyl complexes}

An extensive range of "half sandwich complexes" containing cyclopentadienyl (Cp) and substituted cyclopentadienyl, especially pentamethyl cyclopentadienyl (Cp*), have been studied with $\mathrm{p} K_{\mathrm{a}}{ }^{\mathrm{LAC}}$ ranging from -5 to 33 . The most acidic of these are the cationic dicarbonyl dihydrogen complexes $\left[\mathrm{M}\left(\mathrm{H}_{2}\right)(\mathrm{CO})_{2}\left(\mathrm{Cp}^{*}\right)\right]\left[\mathrm{CF}_{3} \mathrm{SO}_{3}\right] \mathrm{M}=\mathrm{Ru}$ (entry 5$)^{161-162}$ and Os (entry 12$)^{107}$ which are only partially protonated by 1 equiv. $\mathrm{CF}_{3} \mathrm{SO}_{3} \mathrm{H}$ in $\mathrm{CD}_{2} \mathrm{Cl}_{2}$. The osmium complex is actually a mixture of a trans-dihydride (87\%) and dihydrogen complex (13\%), with the lower concentration dihydrogen complex being more acidic. The ruthenium complex is only stable at low temperature. Nevertheless it has been implicated in the catalytic cycle for the deoxygenation of 1,2-propanediol to 1-propanol. ${ }^{107,161-162}$ Substitution of a carbonyl for phosphite and $\mathrm{Cp}^{*}$ for $\mathrm{Cp}$ gives the acidic dihydrogen complex $\left[\mathrm{Ru}\left(\mathrm{H}_{2}\right)(\mathrm{CO})(\mathrm{Cp})\left(\mathrm{P}(\mathrm{OPh})_{3}\right)\right]^{+}$ (entry 22) which has a larger equilibrium constant than $\left[\mathrm{Ru}\left(\mathrm{H}_{2}\right)(\mathrm{CO})_{2}\left(\mathrm{Cp}^{*}\right)\right]^{+}$for the reaction: $\mathrm{CF}_{3} \mathrm{SO}_{3} \mathrm{H}+$ $\mathrm{RuH}=\left[\mathrm{Ru}\left(\mathrm{H}_{2}\right)\right]\left[\mathrm{CF}_{3} \mathrm{SO}_{3}\right] .{ }^{161}$ The dfepe ligand $\mathrm{P}\left(\mathrm{C}_{2} \mathrm{~F}_{5}\right)_{2} \mathrm{CH}_{2} \mathrm{CH}_{2} \mathrm{P}\left(\mathrm{C}_{2} \mathrm{~F}_{5}\right)_{2}$ has electron-withdrawing characteristics similar to that of two carbonyl ligands. The complex $\left[\mathrm{RuH}_{2}(\mathrm{Cp})(\mathrm{dfepe})\right]^{+}$is prepared by protonation of the monohydride with HOTf and is deprotonated by ether in DCM. ${ }^{163}$ The complexes $\left[\mathrm{Ru}\left(\mathrm{H}_{2}\right)(\mathrm{CO})(\mathrm{Cp})\left(\mathrm{PR}_{3}\right)\right]^{+}$(entries 34 and 35$)$ are expected to have higher $\mathrm{p} K_{\mathrm{a}}^{\mathrm{THF}}$ than the phosphite complex but their reported reactions do not allow a precise value to be determined. It is interesting that an unstable $\mathrm{PCy}_{3}$ derivative is formed at low temperature by the reaction of excess $\left(\mathrm{CF}_{3}\right)_{3} \mathrm{COH}$ in $\mathrm{CD}_{2} \mathrm{Cl}_{2}$ (entry 35 ). This reaction would not be expected on the basis of the $\mathrm{p} K_{\mathrm{a}}^{\text {THF }}$ of this alcohol (approx. 21, Table 2) however strong ion pair formation plus a strongly hydrogen-bonded homoconjugate ion and the low temperature all contribute to the enhanced acidity. In keeping with this observation, $\left[\mathrm{Ru}\left(\mathrm{H}_{2}\right) \mathrm{H}_{2}\left(\mathrm{Cp}^{*}\right)\left(\mathrm{PCy}_{3}\right)\right]\left[\left(\mathrm{CF}_{3}\right)_{2} \mathrm{CHOH} \cdots \mathrm{OCH}\left(\mathrm{CF}_{3}\right)_{2}\right]$ forms in toluene- $\mathrm{d}_{8}$ at $200 \mathrm{~K}$ by reversible protonation of the corresponding trihydride complex with $\left(\mathrm{CF}_{3}\right)_{2} \mathrm{CHOH} .{ }^{164}$

The complex denoted $\left[(\mathrm{CO})_{2} \mathrm{Ru}(\mu-\mathrm{H})(\mu-\mathrm{Cp}-\mathrm{Cp}) \mathrm{Ru}(\mathrm{CO})_{2}\right]^{+}$(entry 76$)$ was found to have a $\mathrm{p} K_{\mathrm{a}}{ }^{\mathrm{MeCN}}$ of $6.4^{165}$ which can be converted to an approx. $\mathrm{p} K_{\mathrm{a}}^{\text {THF }}$ of 1 . Despite the presence of the four carbonyl ligands, the stability of this hydride benefits from the pseudo six-coordinate, $d^{6}$ configuration of the metals (Figure 5). This complex was found not to catalyze the deoxygenation of 1,2-propanediol unlike similar monomer ruthenium complexes. ${ }^{161}$ 


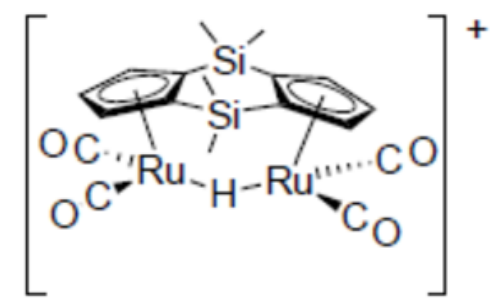

Figure 5. Hydrido-bridged ruthenium complex.

The osmium(IV) complex $\left[\mathrm{OsH}(\mathrm{Cl})(\mathrm{Cp})\left(\mathrm{PPh}_{3}\right)_{2}\right]^{+}$(entry 39$)$ is estimated to have a $\mathrm{p}_{\mathrm{a}}{ }^{\mathrm{THF}}$ of 1 based on Angelici's work. ${ }^{7,112}$ The acidifying effect of the chloride lowers the $\mathrm{p} K_{\mathrm{a}}$ relative to the $\mathrm{p} K_{\mathrm{a}}{ }^{\mathrm{DCM}}$ of 13 for the dihydride analogue $\left[\mathrm{OsH}_{2}(\mathrm{Cp})\left(\mathrm{PPh}_{3}\right)_{2}\right]^{+}$(entries 79, 80).-8,29,166

The appearance of a neutral hydride $\mathrm{FeH}(\mathrm{CO})\left(\mathrm{SiCl}_{3}\right)_{2}(\mathrm{Cp})$ (entry 41 ) among these very acidic cyclopentadienyl complexes is remarkable. It is so acidic that it is reported to partially protonate the acetonitrile solvent. ${ }^{167}$ Clearly the $\mathrm{SiCl}_{3}$ groups strongly stabilize the anionic conjugate base and so we assign an $A_{L}$ value for this group of -12 . This value is consistent with the fact that $\mathrm{FeH}_{2}\left(\eta^{6}\right.$-toluene) $\left(\mathrm{SiCl}_{3}\right)_{2}$ with a $\mathrm{p} K_{\mathrm{a}}{ }^{\mathrm{LAC}}$ of 6 is deprotonated by pyridine ( $\mathrm{p} K_{\mathrm{a}}{ }^{\mathrm{MeCN}} 12.3, \mathrm{p} K_{\mathrm{a}}{ }^{\mathrm{THF}} 8.3$ ) in $\mathrm{CH}_{3} \mathrm{CN}$ solvent (entry 67). An order of acidity was established for three $\mathrm{SiCl}_{3}$-containing complexes in $\mathrm{CH}_{2} \mathrm{Cl}_{2}$ : $\mathrm{FeH}(\mathrm{CO})(\mathrm{SiCl})_{2}(\mathrm{Cp})>$ $\mathrm{FeH}(\mathrm{CO})_{4}\left(\mathrm{SiCl}_{3}\right)>\mathrm{MnH}(\mathrm{CO})_{2}\left(\mathrm{SiCl}_{3}\right)(\mathrm{Cp})^{167}$ which nicely agrees with the $\mathrm{p} K_{a}{ }^{\mathrm{LAC}}$ order for the three acids $0<$ $8<12$, respectively.

A wide variety of cationic complexes $\left[\mathrm{M}\left(\mathrm{Cp} \text { or } \mathrm{Cp}^{*}\right) \mathrm{H}_{2} \mathrm{~L}_{2}\right]^{+} \mathrm{M}=\mathrm{Fe}, \mathrm{Ru}, \mathrm{Os}, \mathrm{L}=$ phosphorus donor have been prepared and studied (entries 52, 72-80, 84-93, 95, 96, 99-113, 116, 120, 121, 127, 129-131). $6,30,89-90$ Depending on $L$ the complexes can have a dihydrogen ligand or two hydride ligands or an equilibrium mixture of the two. Bidentate ligands forming four- or five-membered rings with the metal allow both the trans-dihydride and dihydrogen tautomers to coexist. ${ }^{90}$ In the isosteric series of complexes $\left[\mathrm{CpRuH}_{2} \mathrm{~L}\right]^{+}$, where $\mathrm{L}$ is a para-substituted tertiary diphosphine ligand (e.g. entries 52,90 ), decreasing the electron density on the metal favors the formation of the $\eta^{2}$-dihydrogen tautomer over that of the dihydride. ${ }^{89}$ The most thermodynamically stable products for the electron-rich $\mathrm{Cp}^{*}$ complexes are the trans-dihydrides in a square-based piano-stool geometry with monodentate phosphines or a bidentate phosphine with a large enough bite angle (i.e. dppp, entry 84 ) to span trans sites without much strain. Their acidities range widely from a $K_{\mathrm{a}}{ }^{\mathrm{DCM}}$ of 4 for $\left[\mathrm{RuH}_{2}\left(\mathrm{Cp}^{*}\right)(\mathrm{dtfpe})\right]^{+}$(entry 52 with a less donating dtfpe ligand $\left.\mathrm{PAr}_{2} \mathrm{CH}_{2} \mathrm{CH}_{2} \mathrm{PAr}_{2}, \mathrm{Ar}=4-\mathrm{CF}_{3} \mathrm{C}_{6} \mathrm{H}_{4}\right)$ to a $\mathrm{p} K_{\mathrm{a}}{ }^{\mathrm{THF}}$ of 14.6 for $\left[\mathrm{Ru}(\mathrm{H})_{2}\left(\mathrm{Cp}^{*}\right)(\mathrm{dmpe})\right]^{+}$(entry 130). The acidic dtfpe complex was used to protonate dinitrogen coordinated to tungsten. ${ }^{168}$ The thermodynamic acidity of dihydrogen and dihydride tautomers are similar and just depend on relative amounts of the two forms when they are in dynamic exchange. When the dihydride form is more abundant, as in the complexes $\left[\mathrm{CpRuH}_{2}\left(\mathrm{~L}_{2}\right)\right]^{+}, \mathrm{L}_{2}=\mathrm{dppm}$ (entry 85$)$, dppe (entry 90), and dape $\left(\mathrm{Ar}=4-\mathrm{MeC}_{6} \mathrm{H}_{4}\right)$, the dihydrogen form is more acidic. However, for the more electron rich complexes $[\mathrm{CpRuH}(\mathrm{dmpe})]^{+}$and $\left[\mathrm{Cp}^{*} \mathrm{RuH}_{2}(\mathrm{dppm})\right]^{+}$, the dihydride form has a greater thermodynamic acidity. ${ }^{89}$ Since the conjugate base form of the two tautomers is the same monohydride complex, the LAC method assigns the same $\mathrm{p} K_{\mathrm{a}}{ }^{\mathrm{LAC}}$ to them both. The osmium analogues are consistently 3-5 $\mathrm{p} K_{\mathrm{a}}$ units less acidic than the ruthenium ones (entries 78 vs 79-80; $85-86$ vs $87,88-90$ vs 91 ) Certain $\left[\mathrm{RuH}_{2}(\mathrm{Cp}) \text { (diphosphine) }\right]^{+}$have been used as catalysts for the hydrogenation of imines and iminium compounds; these compounds are sufficiently acidic to protonate an imine and thus make it susceptible to hydride attack (see below). ${ }^{169}$ The introduction of a cobaltacenium backbone in the diphosphine (entries 105-106) does not have a significant impact on the $\mathrm{p} K_{\mathrm{a}}$ when compared to the $\mathrm{p} K_{\mathrm{a}}$ of other neutral diphosphine ligands such as dppe (entries 103-104, 107109). Introduction of amines in the backbone of the ligand allows the iron complex of entry 113 (Figure 6, A) to act as a dihydrogen oxidation electrocatalyst ${ }^{170}$ and of entry 127 to act as a hydrogen evolution electrocatalyst (see below). ${ }^{171}$ Note that a $\mathrm{p} K_{\mathrm{a}}{ }^{\mathrm{MeCN}}$ of 22 is given for entry 113 even though the acidity of 
the dihydrogen complex was bracketed between $\mathrm{DBU}-\mathrm{H}^{+}$and $\mathrm{NEt}_{3} \mathrm{H}^{+}$in $\mathrm{PhF} .{ }^{170}$ The dihydrogen complex of Figure $6 \mathrm{~B}$ has the same acidity as the protonated amine ( $\mathrm{p} K_{\mathrm{a}}{ }^{\mathrm{MeCN}}$ of 18.9 corresponding to $\mathrm{p} K_{\mathrm{a}}{ }^{\text {THF }}$ of 13 ). Similarly the amine dangling from the cyclopentadienyl ligand of the osmium complex of entry 131 (Figure $6 \mathrm{C}$ ) has a similar basicity to that of the osmium so that a dihydride or a protonated amine complex can be observed. ${ }^{172}$ In contrast the amine is more basic $\left(p K_{\mathrm{a}} 13\right)$ than the ruthenium in the complexes [RuH(Cp$\left.\left.\mathrm{NHMe}_{2}\right)(\mathrm{dppm})\right]^{+}$so that two equiv. of $\mathrm{HBF}_{4}$ are required to produce the dihydrogen complex [Ru(Cp$\left.\left.\mathrm{NHMe}_{2}\right)\left(\mathrm{H}_{2}\right)(\mathrm{dppm})\right]^{+2}$ (entry 93). This last complex is a poorly active catalyst for $\mathrm{CO}_{2}$ hydrogenation. ${ }^{173}$

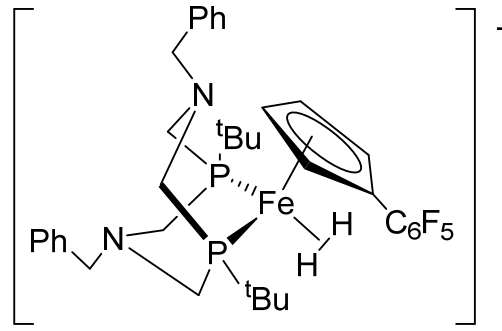

A
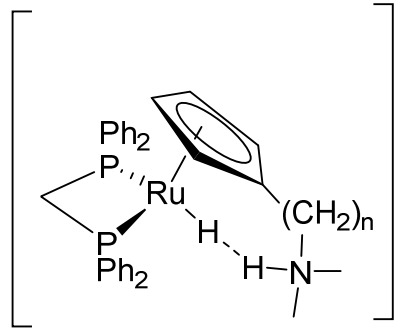

B, $\mathrm{n}=2,3$

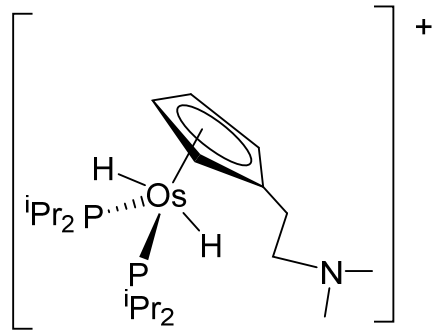

C

Figure 6. Iron group cyclopentadienyl complexes with ligands with tethered bases.

As expected the chloro complex $\left[\mathrm{RuHCl}(\mathrm{Cp})\left(\mathrm{PMe}_{3}\right)_{2}\right]^{+}$(entry 65, $\left.\mathrm{p} K_{\mathrm{a}}{ }^{\mathrm{DCE}}=\mathrm{p} K_{\mathrm{a}}{ }^{\mathrm{DCM}} 2\right)$ is more acidic than the dihydride complex $\left[\mathrm{Ru}\left(\mathrm{H}_{2}\right)(\mathrm{Cp})\left(\mathrm{PMe}_{3}\right)_{2}\right]^{+}$(entry $\left.120, \mathrm{p} K_{\mathrm{a}}{ }^{\mathrm{DCM}}=13.9\right)$ by $12 \mathrm{p} K_{\mathrm{a}}$ units. The $\mathrm{Cp}^{*}$ analogues (entries 72 and 129) show a similar difference (10 $\mathrm{p} K_{\mathrm{a}}$ units). It is interesting to note that the water soluble complex $\mathrm{Ru}(\mathrm{H})(\mathrm{Cp})(\mathrm{PTA})_{2}$ undergoes $\mathrm{H} / \mathrm{D}$ exchange in $\mathrm{D}_{2} \mathrm{O}$ which provides evidence that $\left[\mathrm{RuH}_{2}(\mathrm{Cp})(\mathrm{PTA})_{2}\right]^{+}$is a strong acid in water, unstable with respect to protonation of a nitrogen on the PTA ligand while its $\mathrm{p} K_{\mathrm{a}}{ }^{\mathrm{LAC}}$ is approx. 7 (entries 73-74). ${ }^{174}$

Cationic complexes containing just cyclopentadienyl ligands and hydrides are quite acidic. The protonated metallocenes $\left[\mathrm{MH}\left(\mathrm{Cp}^{*}\right)_{2}\right]^{+}$with $\mathrm{M}=\mathrm{Ru}$ is determined to be more acidic $\left(\mathrm{p} K_{\mathrm{a}}{ }^{\mathrm{THF}}=\mathrm{p} K_{\mathrm{a}}{ }^{\mathrm{DCM}}=1\right.$, entry 56) compared to the hydride with $\mathrm{M}=\mathrm{Os}$ with $\mathrm{p} K_{\mathrm{a}}{ }^{\mathrm{MeCN}} 9.9$ (entry 57 ). This last entry can be converted into a $\mathrm{p} K_{\mathrm{a}}{ }^{\mathrm{THF}}$ of 4 . The trimetallic complexes with six bridging hydrides $\left[\mathrm{M}_{3} \mathrm{H}_{6}\left(\mathrm{Cp}^{*}\right)_{3}\right]^{+}$(Figure 7) are less acidic with $p K_{\mathrm{a}}^{\text {THF }}$ of 11 for $\mathrm{M}=\mathrm{Ru}$ and $>13$ for $\mathrm{M}=0$ s. Interestingly the ruthenium complex has similar acid strength to ammonium ( $p K_{\mathrm{a}}{ }^{\mathrm{MeCN}}$ of 16.5 , thus $\mathrm{p} K_{\mathrm{a}}{ }^{\mathrm{THF}}$ of 11 ) (entry 117 ) and benzoic acid (entry 118) in THF. ${ }^{175-176}$ Entry 118 suggests that this ruthenium complex likely has a benzoate counterion that is hydrogen-bonded to additional benzoic acid in THF. Thus benzoic acid is effectively a stronger acid than its $\mathrm{p} K_{\mathrm{a}}{ }^{\mathrm{MeCN}} 21$ (or $\mathrm{p} K_{\mathrm{a}}{ }^{\mathrm{THF}} 20$ ) would indicate because of these homoconjugate effects. For the simple molecule ferrocene is not clear whether protonation occurs at the metal or at a cyclopentadienyl ring (as an agostic $\eta^{2}-\mathrm{CH}$ ). ${ }^{177}$
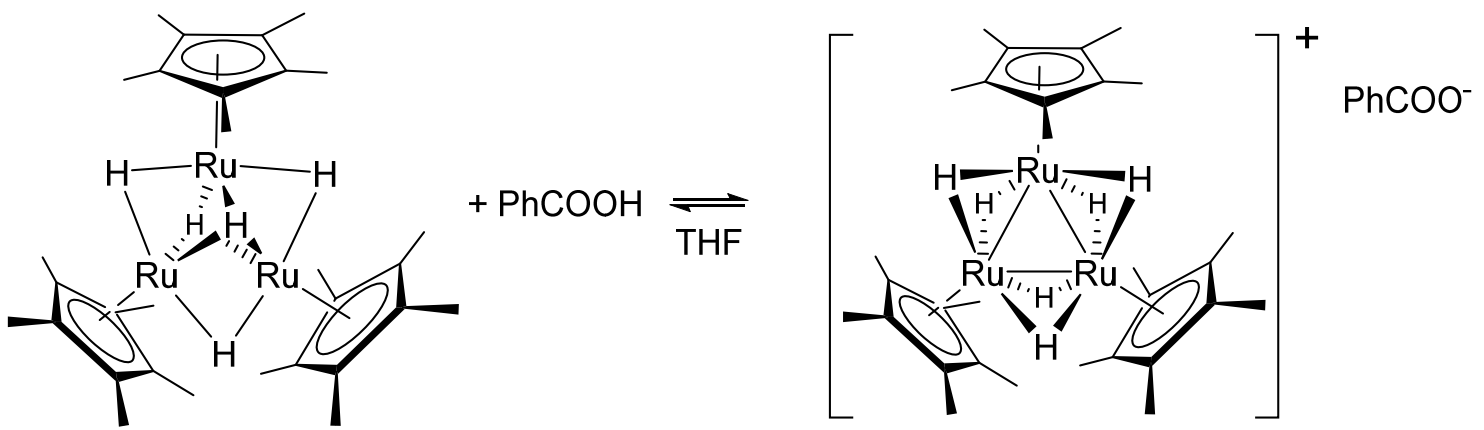

Figure 7. Equilibrium reaction involving $\left.\left[\mathrm{Ru}_{3} \mathrm{H}_{6}(\mathrm{Cp})^{*}\right]_{3}\right]^{+}$

The neutral complexes $\mathrm{MH}\left(\mathrm{Cp}\right.$ or $\left.\mathrm{Cp}^{*}\right)(\mathrm{CO})_{2}$ (entries 159-162, 164) have $\mathrm{pK}_{\mathrm{a}}^{\mathrm{MeCN}}$ in the range 27$33\left(p K_{\mathrm{a}}^{\mathrm{LAC}}=30-32\right)$. They are weakly acidic because of the unfavorable solvation of the anionic conjugate 
base form and the loss of ligand field stabilization of the pseudo-octahedral $d^{6}$ metal hydride complex. $\mathrm{FeH}(\mathrm{CO})_{2} \mathrm{Cp}$ * reacts with $[\mathrm{K}(18-\mathrm{crown}-6)]\left[\mathrm{ReH}_{6}\left(\mathrm{PPh}_{3}\right)_{2}\right]$ to give an equilibrium with [K(18-crown6)] $\left[\mathrm{Fe}(\mathrm{CO})_{2} \mathrm{Cp}^{*}\right]$ and $\mathrm{ReH}_{7}\left(\mathrm{PPh}_{3}\right)_{2}$ (entry 164) and another unidentified low concentration species. Assuming that ion-pair dissociation constants are comparable, the $\mathrm{p} K_{\mathrm{a}}^{\text {THF }}$ of the iron complex was determined to be approximately $31 .^{7}$ Its $\mathrm{p} K_{\mathrm{a}}{ }^{\mathrm{MeCN}} 29.7$ has been determined using phenolate base. ${ }^{39}$ The complex $\mathrm{OsH}_{5} \mathrm{Cp}^{*}\left(\mathrm{p}_{a}^{\mathrm{LAC}} \quad 35\right)$ can be deprotonated by ${ }^{\mathrm{t}} \mathrm{BuLi} / \mathrm{pmdeta}$ (pmdeta = pentamethyldiethylenetriamine) in pentane to produce the monoanion [Li(pmdeta)][OSH $\left.{ }_{4} \mathrm{Cp}^{*}\right] .{ }^{178}$

\subsubsection{Complexes with nitrogen donors}

A series of tris-pyrazolylborate ( $\mathrm{HBPz}_{3}^{-}$, also abbreviated $\mathrm{Tp}$ ) and 1,4,7- triazacyclononane (tacn, also abbreviated tacn with hydrogens on the amines) half sandwich complexes with structures that parallel those of the cyclopentadienyl complexes just described have been prepared and studied (e.g. entries $10,17,32,40,63,64,66,71){ }^{6,179-181}\left[\mathrm{Ru}\left(\mathrm{H}_{2}\right)(\mathrm{CO})\left(\mathrm{PPh}_{3}\right)\left(\mathrm{HBPz}_{3}\right)\right]^{+}$has a $\mathrm{p} K_{\mathrm{a}}{ }^{\mathrm{DCM}}$ of -2 (entry 17$)$, similar to that of the $\mathrm{Cp}$ relative $\left[\mathrm{Ru}\left(\mathrm{H}_{2}\right)(\mathrm{CO})\left(\mathrm{P}(\mathrm{OPh})_{3}\right) \mathrm{Cp}\right]^{+}$(entry 22$)$. The Os analogue $\left[\mathrm{Os}\left(\mathrm{H}_{2}\right)(\mathrm{CO})\left(\mathrm{PPh}_{3}\right)\left(\mathrm{HBPz}_{3}\right)\right]^{+}$is less acidic with a reported $\mathrm{p} K_{\mathrm{a}}{ }^{\mathrm{DCM}}$ of 9 for a reaction at $213 \mathrm{~K}$ (entry 40$)$. The tacn ruthenium complexes with similar co-ligands were found to be more acidic (e.g. entry 10$){ }^{6}$ The complexes with two phosphorus donors have $\mathrm{p} K_{\mathrm{a}}{ }^{\mathrm{DCM}}$ in the range 8-9 for the $\mathrm{HBPz}_{3}$ complexes $\left[\mathrm{M}\left(\mathrm{H}_{2}\right) \mathrm{L}_{2}\left(\mathrm{HBPz}_{3}\right)\right]^{+}$(entries 63, 64 and 66), and 3 for the tacn complex $\left[\mathrm{Ru}\left(\mathrm{H}_{2}\right)\left(\mathrm{PPh}_{3}\right)_{2}(\operatorname{tacn})\right]^{+2}$. While both the $\mathrm{HBPz}_{3}{ }^{-}$and tacn ligands provide three nitrogen donors fac on the metal, the use of the neutral tacn ligand results in a more acidic complex. Similarly the complex $\left[\mathrm{Ru}\left(\mathrm{H}_{2}\right)\left(\mathrm{PPh}_{3}\right)_{2}(\mathrm{tpm})\right]^{2+}$, where tpm is tris(pyrazolyl)methane, has a $\mathrm{p} K_{\mathrm{a}}{ }^{\mathrm{DCM}} 2.8{ }^{182}$

Several bipyridine complexes have been studied (entries $11,14,15,33,81,136,157)$ with $p K_{\mathrm{a}}^{\mathrm{LAC}}$ ranging from -4 to 26 . The bipyridine ligand contributes $8 \mathrm{p} K_{\mathrm{a}}$ units to a metal hydride complex according to the LAC system. The usual trend of replacement of carbonyl ligands by phosphine or phosphite ligands resulting in expected increases of $\mathrm{p} K_{\mathrm{a}}$ is observed. The dramatic effect of five nitrogen donors is noted for the complex [RuH(tpy)(bpy)] ${ }^{+}$which was deprotonated by the strong Verkade base $\mathrm{P}\left(\mathrm{NMeCH}_{2} \mathrm{CH}_{2}\right)_{3} \mathrm{~N}$ (entry 157); ${ }^{183}$ this complex has a $\mathrm{p} K_{\mathrm{a}}{ }^{\mathrm{LAC}}$ of 26 . By contrast the paramagnetic dicationic iron(III) hydride with a $\mathrm{Py}_{2}$ Tstacn containing two pyridinyl donors, two amine donors and one tosylamine donor in a pentadentate ligand is predicted by DFT to have a $\mathrm{p} K_{\mathrm{a}}{ }^{\text {aq }}$ of 1.8 (Figure 8). ${ }^{184} \mathrm{An}$ acidic dihydrogen intermediate $\left[\mathrm{Ru}\left(\mathrm{H}_{2}\right) \mathrm{H}(\mathrm{N}-\mathrm{N})\left(\mathrm{PPh}_{3}\right)_{2}\right]$ reversibly heterolytically splits dihydrogen to the diazafluorenide part of the ligand in the complex of Figure $9\left(\mathrm{p} K_{\mathrm{a}}{ }^{\mathrm{THF}}\right.$ fluorene is approx. 35). ${ }^{185} \mathrm{The} \mathrm{p} K_{\mathrm{a}}^{\mathrm{LAC}}$ of the dihydrogen complex is estimated to be between 14 (assuming a cationic ruthenium with nitrogen donors like bipyridine) and 44 (assuming a neutral ruthenium). It must be near the $p K_{\mathrm{a}}{ }^{\mathrm{THF}} 35$ of fluorene. ${ }^{7}$

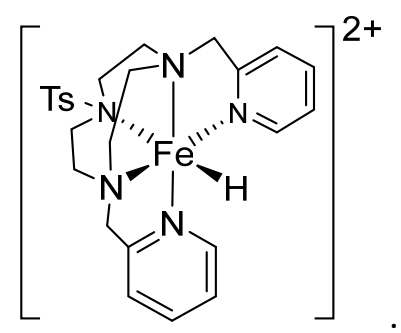

Figure 8. Iron(III) hydride complex with a pentadentate ligand. 


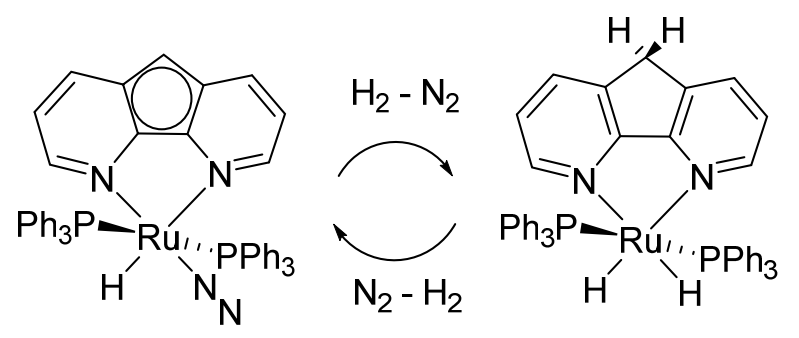

Figure 9. The heterolytic splitting of dihydrogen at a ruthenium(II) diazafluorenide complex.

The octaethylporphyrin complex $\mathrm{Os}\left(\mathrm{H}_{2}\right)(\mathrm{oep})(\mathrm{THF})$ was weakly acidic, requiring lithium diisopropylamide in THF to convert it to the mono anion (entry 158). ${ }^{186}$

The water soluble complexes $\left[\mathrm{RuH}_{2}\left(\mathrm{C}_{6} \mathrm{Me}_{6}\right)(\mathrm{bpy})\right]^{+2}$ with $\mathrm{p} K_{\mathrm{a}}^{\mathrm{aq}}<6$ (entry 81 ) and $\left[\mathrm{RuH}\left(\mathrm{C}_{6} \mathrm{Me}_{6}\right)(\mathrm{bpy})\right]^{+}$with $\mathrm{p} K_{\mathrm{a}}{ }^{\mathrm{MeCN}}$ of 23 and $\mathrm{p} K_{\mathrm{a}}{ }^{\mathrm{LAC}}$ of 16 (entry 136$)^{183}$ are of interest because of their catalytic activity in the reduction of $\mathrm{CO}_{2}$ using borohydride. ${ }^{187}$ The dicationic complex was postulated to form at $\mathrm{pH}$ 3-6 but this seems unlikely on the basis of the $\mathrm{p} K_{\mathrm{a}}^{\mathrm{LAC}}$ of approx. -5 . The monohydride complex was found to be a good hydride donor. ${ }^{183}$ The monocationic arene complex $\left[\mathrm{Ru}\left(\mathrm{H}_{2}\right)(\text { cymene)(Tsdpen) }]^{+}\right.$ has a $\mathrm{p} K_{\mathrm{a}}^{\mathrm{MeCN}}$ of 16.1 (entry 144).

The complex $\left[\mathrm{Os}\left(\mathrm{H}_{2}\right)\left(\mathrm{NH}_{3}\right)_{5}\right]^{2+}\left(\mathrm{pK}_{\mathrm{a}}^{\mathrm{MeOH}}>16\right)$ cannot be deprotonated by one equiv of methoxide in methanol. ${ }^{188}$ The LAC method is in poor agreement giving $\mathrm{p} K_{\mathrm{a}}{ }^{\mathrm{LAC}}$ of 7 when using $\mathrm{A}_{\mathrm{L}}$ (N donor) 4 . The amine ligand may have an $A_{L}$ of 6 due to solvation (hydrogen-bonding) effects to explain this. The oxidized, $\mathrm{d}^{5}$ complex $\left[\mathrm{OsH}_{2}\left(\mathrm{NH}_{3}\right)_{5}\right]^{3+}$ is only stable at very low $\mathrm{pH}$ in water as expected on the basis of increase in positive charge by one unit (at least $15 \mathrm{p} K_{\mathrm{a}}$ units). ${ }^{188}$

Complexes with mixed nitrogen and phosphorus donors are also placed in position in Table 8 (entries $38,48,49,82,94$ ) and the reactions reported agree with the $\mathrm{p} K_{\mathrm{a}}{ }^{\mathrm{LAC}}$ values.

\subsubsection{Complexes with several phosphorus donors}

The complexes trans- $\left[\mathrm{M}\left(\mathrm{H}_{2}\right) \mathrm{H}\left(\mathrm{PAr}_{2} \mathrm{CH}_{2} \mathrm{CH}_{2} \mathrm{PAr}_{2}\right)_{2}\right]^{+}$are a family of dihydrogen complexes where the electronic properties can be systematically varied without changing the steric factors. ${ }^{91}$ When $\mathrm{Ar}=4$ $\mathrm{CF}_{3} \mathrm{C}_{6} \mathrm{H}_{4}$ (dtfpe) the $\mathrm{pK}_{\mathrm{a}}^{\mathrm{THF}}$ increases from Fe (6.7) to Ru (8) to Os (8.4) (entries 60-62). Interestingly the ruthenium complex (entry 123 ) is least acidic (14) when $\mathrm{Ar}=\mathrm{Ph}$ with the iron and osmium complexes at $\mathrm{p} K_{\mathrm{a}}{ }^{\mathrm{THF}} 12$. This unusual order was attributed to the strong short bond in the $\mathrm{H}_{2}$ ligand of the ruthenium complex. When $\mathrm{Ar}=4-\mathrm{MeOC}_{6} \mathrm{H}_{4}$ the $\mathrm{p} K_{\mathrm{a}}^{\mathrm{THF}}$ for Ru increases to 17 (entry 134). As expected replacing the hydride trans to dihydrogen with electronegative chloride greatly decreases the $\mathrm{p} K_{\mathrm{a}}$ for $\mathrm{Ru}$ when $\mathrm{Ar}=\mathrm{Ph}$ to 4.7 (entry 70) and Os to 7.4. ${ }^{189}$ The corresponding dppp complexes (entries 68,69 vs 125,126 ) show similar trends although in this case the osmium chloro complex is much less acidic $\left(\mathrm{p} K_{\mathrm{a}}{ }^{\mathrm{DCM}}=12.3\right)$ than the ruthenium complex $\left(\mathrm{p} K_{\mathrm{a}}{ }^{\mathrm{DCM}}=5.6\right) .{ }^{153}$ The complexes $\mathrm{FeH}_{2}\left(\mathrm{PR}_{2} \mathrm{CH}_{2} \mathrm{CH}_{2} \mathrm{PR}_{2}\right)_{2}, \mathrm{R}=\mathrm{Me}$, Et, $\mathrm{Pr}$ with four very electron donating phosphorus groups are in equilibrium at $267 \mathrm{~K}$ with the dihydrogen complexes $\left[\mathrm{Fe}\left(\mathrm{H}_{2}\right) \mathrm{H}\left(\mathrm{PR}_{2} \mathrm{CH}_{2} \mathrm{CH}_{2} \mathrm{PR}_{2}\right)_{2}\right]^{+}\left(\mathrm{p} K_{\mathrm{a}}{ }^{\mathrm{LAC}} 20\right)$ in neat ethanol $\left(\mathrm{p} K_{\mathrm{a}} 16\right) .{ }^{190}$ Similarly the related tetraphos complex $\mathrm{FeH}_{2}\left\{\mathrm{P}\left(\mathrm{CH}_{2} \mathrm{CH}_{2} \mathrm{PMe}\right)_{3}\right\}$ is protonated by ethanol to give $\left[\mathrm{Fe}\left(\mathrm{H}_{2}\right) \mathrm{H}\left\{\mathrm{P}\left(\mathrm{CH}_{2} \mathrm{CH}_{2} \mathrm{PMe}_{2}\right)_{3}\right\}\right]^{+}$; when the ethanol is removed, the dihydride is regenerated. ${ }^{191}$ The ruthenium complex $\mathrm{RuH}_{2}(\mathrm{dmpe})_{2}$ is also in equilibrium with the $\left[\mathrm{Ru}\left(\mathrm{H}_{2}\right) \mathrm{H}(\mathrm{dmpe})_{2}\right]^{+}$in neat ethanol. ${ }^{192}$ Water soluble complexes of the type $\left[\mathrm{M}\left(\mathrm{H}_{2}\right)(\mathrm{H})(\mathrm{dmprpe})_{2}\right]^{+}\left(\mathrm{M}=\mathrm{Fe}\right.$. $\mathrm{Ru}$, Os), dmprpe $=\mathrm{P}\left(\left(\mathrm{CH}_{2}\right)_{3} \mathrm{OMe}\right)_{2} \mathrm{CH}_{2} \mathrm{CH}_{2} \mathrm{P}\left(\left(\mathrm{CH}_{2}\right)_{3} \mathrm{OMe}\right)_{2}$, are stable in buffered aqueous solutions at $\mathrm{pH} 7 .^{78}$

The osmium trihydride cations [ $\left.\mathrm{OsH}_{3} \mathrm{~L}_{4}\right]^{+} \mathrm{L}=\mathrm{PPh}_{2} \mathrm{Me}, \mathrm{PMe}_{2} \mathrm{Ph}, \mathrm{PMe}_{3}$ and $\mathrm{PEt}_{3}$ (entries 132, 133, $137,138,147,149)$ are useful acids to establish the $p K_{a}{ }^{\text {THF }}$ scale from 12 to 19 . They also provide a link to Angelici's enthalpy of protonation scale in dichloroethane solvent (DCE). ${ }^{7}$ The complexes 
$\left[\mathrm{M}\left(\mathrm{H}_{2}\right) \mathrm{H}\left(\mathrm{P}(\mathrm{OEt})_{3}\right)_{4}\right]^{+}, \mathrm{M}=\mathrm{Fe}$, Os are readily deprotonated by $\mathrm{NEt}_{3}$ as expected based on their $\mathrm{pK}_{\mathrm{a}}{ }^{\mathrm{LAC}}$ of 810. ${ }^{193-194}$ In the series $\left[\mathrm{MH}_{4}\left(\mathrm{PMe}_{3}\right)_{4}\right]^{+}$the $\mathrm{p} K_{\mathrm{a}}{ }^{\mathrm{THF}}$ increases from $\mathrm{M}=\mathrm{Fe}(16)$ to $\mathrm{M}=\mathrm{Ru}$ and Os (17). ${ }^{7}$ The iron complex is a mixture of dihydrogen hydride and trihydride tautomers while the ruthenium complex is in the (cis) dihydrogen hydride form. ${ }^{195}$ The conjugate base dihydrides react with methanol to form equilibrium mixtures from which $\mathrm{p} K_{\mathrm{a}}{ }^{\mathrm{MeOH}}$ can be determined to show the regular trend: $\mathrm{Fe}(10.3)<\mathrm{Ru}$ $(10.9)<$ Os (11.2). ${ }^{195}$ The complexes with $\mathrm{PEt}_{3}$ ligands (entries 148 and 149) are less acidic than the $\mathrm{PMe}_{3}$ analogues, as expected. The five coordinate dihydrogen complex $\left[\mathrm{Fe}\left(\mathrm{H}_{2}\right)\left\{\mathrm{Si}\left(\mathrm{C}_{6} \mathrm{H}_{4} \mathrm{P}^{\mathrm{P}} \mathrm{Pr}_{2}\right)_{3}\right\}\right]^{+}$was determined to have a $\mathrm{p} K_{\mathrm{a}}{ }^{\text {THF }}=10.8$ (entry 150). This was also reported as the converted value, $\mathrm{p} K_{\mathrm{a}}{ }^{\mathrm{MeCN}}$ 15.9. ${ }^{196}$ The $\mathrm{Fe}(0)$ complex Fe $\left\{{ }^{\mathrm{t}} \mathrm{BuSi}\left(\mathrm{CH}_{2} \mathrm{PMe}_{2}\right)_{3}\right\}$ (dmpe) with five basic phosphorus donors partially deprotonates the methyl group of ethylacetate in benzene solution to give the Fe(II) hydride of entry 163. ${ }^{197}$ This reaction is consistent with the high $\mathrm{p} K_{\mathrm{a}}{ }^{\mathrm{LAC}}$ of 30 calculated for this hydride. The complex $\mathrm{FeH}_{2}\left(\mathrm{PMe}_{3}\right)_{4}\left(\mathrm{p} K_{\mathrm{a}}{ }^{\mathrm{LAC}} 56\right)$ could not be deprotonated by neat $\mathrm{CH}_{2} \mathrm{PMe}_{3} .{ }^{198}$

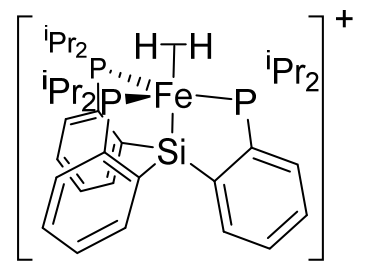

Figure 10. $\left[\mathrm{Fe}\left(\mathrm{H}_{2}\right)\left(\mathrm{Si}_{(}\left(\mathrm{C}_{6} \mathrm{H}_{4} \mathrm{P}^{i} \mathrm{Pr}_{2}\right)_{3}\right]^{+}\right.$

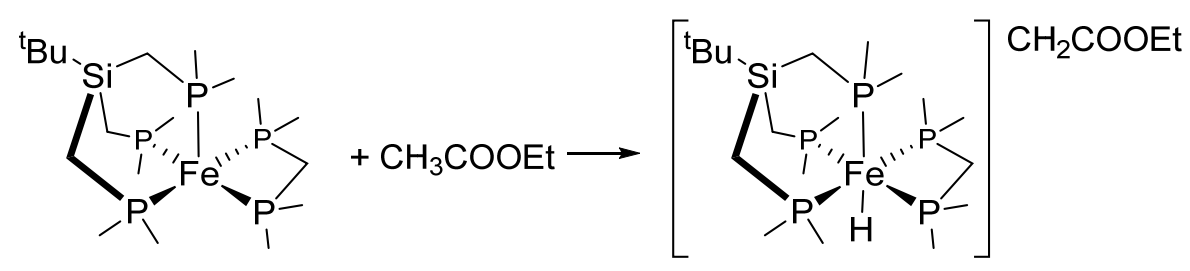

Figure 11. Protonation of Fe $\left\{{ }^{t} \mathrm{BuSi}\left(\mathrm{CH}_{2} \mathrm{PMe}_{2}\right)_{3}\right\}(\mathrm{dmpe})$.

\subsubsection{Neutral, weak hydride acids}

Entries 139-143 are neutral carbonyl hydride complexes with $\mathrm{p} K_{\mathrm{a}}{ }^{\mathrm{MeCN}}$ in the range 11-21. The first is an Fe(II) complex with a cyclometallated triphenylphosphite ligand. In the $\mathrm{M}(\mathrm{H})_{2}(\mathrm{CO})_{4}$ series (entries 140-142) the iron complex with $\mathrm{p} K_{\mathrm{a}}^{\mathrm{MeCN}}=11.4$ is a significantly stronger acid than the ruthenium (20) and osmium (21) analogues. ${ }^{51}$ The Fe complex has a $\mathrm{p} K_{\mathrm{a}}{ }^{\mathrm{aq}}$ of 4.0 and a $\mathrm{p} K_{\mathrm{a}}{ }^{\mathrm{MeOH}}$ 6.9. ${ }^{1}$ These values are quite different than the $\mathrm{p} K_{\mathrm{a}}{ }^{\mathrm{LAC}}$ of 20 . The small conjugate base $\left[\mathrm{FeH}(\mathrm{CO})_{4}\right]^{-}$will have quite different solvation in hydrogen bonding solvents than in THF or MeCN. The ion pairing effects caused by this small anion will be quite significant in THF. A second $\mathrm{p} K_{\mathrm{a}}{ }^{\mathrm{aq}}$ for $\left.\left[\mathrm{FeH}(\mathrm{CO})_{4}\right]^{-/} / \mathrm{Fe}(\mathrm{CO})_{4}\right]^{2-}$ has been reported to be 12.7. ${ }^{1}$ The cluster complex $\mathrm{Ru}_{4} \mathrm{H}_{4}(\mathrm{CO})_{10}\left(\mathrm{P}(\mathrm{OMe})_{3}\right)_{2}$ is in equilibrium with pyridinium in $\mathrm{MeCN}$ and its $\mathrm{p} K_{\mathrm{a}}{ }^{\mathrm{MeCN}}$ is $15.4{ }^{1}$ As mentioned earlier, the many carbonyls make the cluster complex more acidic than expected for a neutral hydride complex such as $\mathrm{RuH}_{2}(\mathrm{CO})_{4}$.

The neutral hydrides in Table 8 with two or more phosphine ligands are very weak bases (entries 165-171). The weakest measured is the bis-dihydrogen complex $\mathrm{Ru}\left(\mathrm{H}_{2}\right)_{2} \mathrm{H}_{2}\left(\mathrm{P}^{\mathrm{i}} \mathrm{Pr}_{3}\right)_{2}\left(\mathrm{p} K_{\mathrm{a}}{ }^{\mathrm{THF}}=39\right)$ which gives the pentagonal bipyramidal pentahydride anion $\left[\mathrm{RuH}_{5}\left(\mathrm{P}^{\mathrm{i}} \mathrm{Pr}_{3}\right)_{2}\right]^{-}$when it is deprotonated. ${ }^{199}$ The corresponding osmium hexahydride is more acidic $\left(\mathrm{p} K_{\mathrm{a}}^{\mathrm{THF}}=36\right)$. Again strong $\mathrm{H}-\mathrm{H}$ bonding in the ruthenium acid may make this complex less acidic than expected.

The hydride $\mathrm{FeH}(\mathrm{CO})_{2}$ (tris(NHC)BPh) is formed by the reversible protonation of $[\mathrm{K}(\mathrm{cryptand})]\left[\mathrm{Fe}(\mathrm{CO})_{2}(\right.$ tris $\left.(\mathrm{NHC}) \mathrm{BPh})\right]$ by toluene in $\mathrm{THF}^{200}{ }^{20}$ The $\mathrm{p} K_{\mathrm{a}}{ }^{\mathrm{THF}}$ of this hydride was determined to 
be 44 on the basis of $\mathrm{p} K_{\mathrm{a}}^{\text {THF }}$ of 44 for toluene estimated by Breslow in 1980 . However since $\mathrm{CH}_{2} \mathrm{Ph}_{2}$ has a $\mathrm{p} K_{\mathrm{a}}{ }^{\text {THF }}$ of approx. 48 on our scale, the $\mathrm{p} K_{\mathrm{a}}{ }^{\text {THF }}$ of toluene would be about 50 . Thus anionic tridentate NHC ligand has an $A_{L}$ of $8 / 3$ to make a $p K_{a}{ }^{L A C}=2 \times-4+3 \times 8 / 3+6+30=50$ for this $d^{6}$ octahedral hydride.
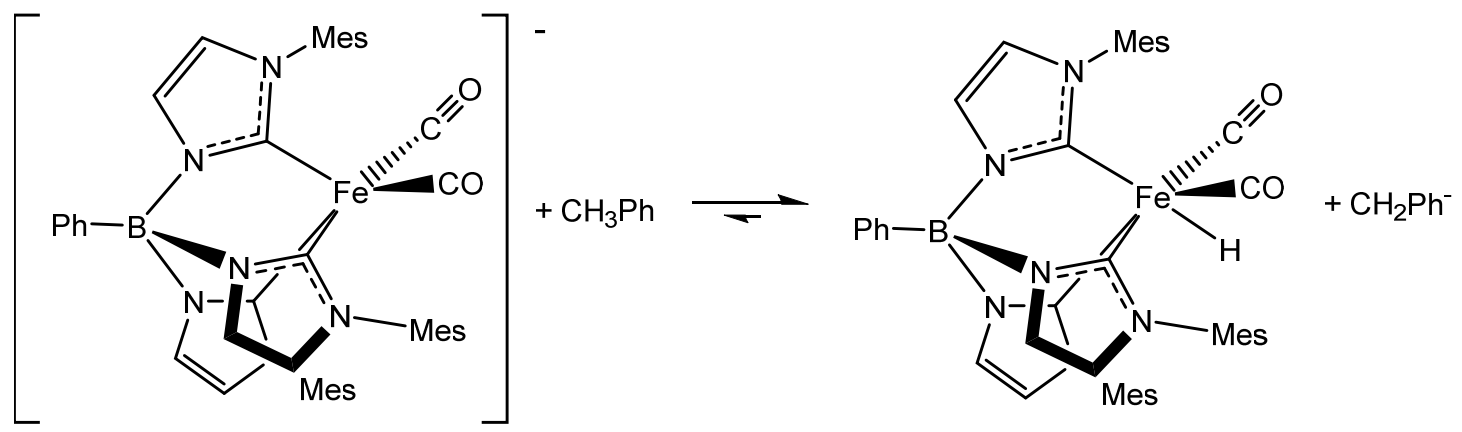

Figure 12. The deprotonation of toluene by $[\mathrm{K}(\mathrm{cryptand})]\left[\mathrm{Fe}(\mathrm{CO})_{2}(\operatorname{tris}(\mathrm{NHC}) \mathrm{BPh})\right]$ in $\mathrm{THF}(\mathrm{Mes}=$ mesityl).

\subsubsection{Other group 8 hydride complexes.}

Entry 37 is a bis-dihydrogen complex of osmium(II) with a cyclometallated aryl N-heterocyclic carbene ligand. Its $\mathrm{p} K_{\mathrm{a}}{ }^{\text {acetone }}$ is 3 . The ruthenium(II) dihydride complex of entry 42 has a $\mathrm{p} K_{\mathrm{a}}{ }^{\mathrm{LAC}}$ of 4 yet is in equilibrium with $\mathrm{CF}_{3} \mathrm{SO}_{3} \mathrm{H}$ at low temperature. ${ }^{201}$ The pentaaqua dihydrogen complex $\left[\mathrm{Ru}\left(\mathrm{H}_{2}\right)\left(\mathrm{OH}_{2}\right)_{5}\right]^{2+}$ deprotonates somewhere in the region between $\mathrm{pH} 3$ and 14 (entry 51). ${ }^{74}$ The iron(IV) dihydride with a cyclometallated phosphite ligand is deprotonated by a bulky amine base (entry 114).

\subsubsection{Effect of the metal on acidity}

Table 7 lists complexes with the same ligand set but different iron group metal ions. There is no obvious trend in the difference in $p K_{a}$ between the complexes of the $3 d, 4 d$ and $5 d$ metals. Ruthenium complexes are about 1 unit less acidic than the iron congeners apart from the tetracarbonyl example which may have special ion pairing effects. The $\mathrm{p} K_{\mathrm{a}}$ gap between the $4 \mathrm{~d}$ and $5 \mathrm{~d}$ complexes is on average 2.6. Thus the LAC method underestimates the gap between the metals in this triad by approx. $2 \mathrm{p} K_{\mathrm{a}}$ units (within the error of the method). Further refinement of the method may be required.

Table 7. Effect of the metal on the $p K_{a}^{\exp a}$

\begin{tabular}{lllll} 
& Fe & Ru & Os & Entry \\
\hline$\left[\mathrm{MH}(\mathrm{Cp} *)_{2}\right]^{+}$ & & 0.8 & 5 & 56,58 \\
{$\left[\mathrm{M}\left(\mathrm{H}_{2}\right) \mathrm{H}(\mathrm{dtfpe})_{2}\right]^{+}$} & 6.7 & 8 & 8.4 & $60-62$ \\
{$\left[\mathrm{M}\left(\mathrm{H}_{2}\right)(\mathrm{HBPz})_{3}\left(\mathrm{PPh}_{3}\right)_{2}\right]^{+}$} & & 7.6 & 8.4 & 63,64 \\
{$\left[\mathrm{M}\left(\mathrm{H}_{2}\right) \mathrm{Cl}(\mathrm{dppp})_{2}\right]^{+}$} & & 5.6 & 12.5 & 68,69 \\
{$\left[\mathrm{M}(\mathrm{H})_{2}(\mathrm{Cp})\left(\mathrm{PPh}_{3}\right)_{2}\right]^{+}$} & & 7.6 & 13.4 & 77,80 \\
{$\left[\mathrm{M}(\mathrm{H})_{2}(\mathrm{Cp})\left(\mathrm{PPh}_{3}\right)_{2}\right]^{+}$} & & 6.8 & 11.0 & 78,79 \\
{$\left[\mathrm{M}\left(\mathrm{H}_{2}\right) \mathrm{H}(\mathrm{dppe})_{2}\right]^{+}$} & 12 & 14 & 12 & $122-124$ \\
$\mathrm{MH}_{2}(\mathrm{CO})_{4}$ & 11.4 & 20 & 21 & $140-142$ \\
{$\left[\mathrm{MH}_{3}(\mathrm{PMe})_{4}\right]^{+b}$} & 16 & 17 & 17 & $145-147$ \\
$\mathrm{MH}(\mathrm{CO})_{2}(\mathrm{Cp})$ & 27 & 28 & 33 & $160-162$ \\
\hline
\end{tabular}

${ }^{a} \mathrm{p} K_{\mathrm{a}}{ }^{\exp }=$ literature value in the solvent specified in Table 8.

${ }^{b}$ dihydrogen/dihydride and trihydride isomers 


\begin{tabular}{|c|c|c|c|c|c|c|c|c|c|}
\hline Entry & Acid form & Base form ${ }^{b}$ & Reactant & Reaction & Solvent & Temp. & $\mathbf{p K}_{\mathrm{a}}^{\mathrm{exp}}$ & $\mathbf{p K}_{\mathbf{a}}^{\mathrm{LAC}}$ & Ref. \\
\hline 1 & {$\left[\mathrm{Fe}\left(\mathrm{H}_{2}\right)(\mathrm{CO})(\mathrm{dppe})_{2}\right]^{+2}$} & {$[\mathrm{MH}]^{+}$} & $\mathrm{CF}_{3} \mathrm{SO}_{3} \mathrm{H}$ & {$[\mathrm{MH}] \mathrm{Y}+\mathrm{HY} \rightleftharpoons\left[\mathrm{MH}_{2}\right] \mathrm{Y}_{2}$} & $\mathrm{CH}_{2} \mathrm{Cl}_{2}$ & 298 & -5 & -7 & 152,202 \\
\hline $\begin{array}{l}2 \\
3\end{array}$ & $\begin{array}{l}{\left[\mathrm{Os}\left(\mathrm{H}_{2}\right)(\mathrm{CO})(\mathrm{dppp})_{2}\right]^{+2}} \\
{\left[(\mathrm{CO})_{3} \mathrm{Fe}(\mu-\mathrm{H})(\mu-\right.} \\
\left.\left.\mathrm{SCH}_{2} \mathrm{CH}_{2} \mathrm{CH}_{2} \mathrm{~S}\right) \mathrm{Fe}(\mathrm{CO})_{3}\right]^{+}\end{array}$ & $\begin{array}{l}{[\mathrm{MH}]^{+}} \\
\mathrm{MM}\end{array}$ & $\begin{array}{l}\mathrm{CF}_{3} \mathrm{SO}_{3} \mathrm{H} \\
{\left[\mathrm{SiEt}_{3}\right]\left[\mathrm{B}\left(\mathrm{C}_{6} \mathrm{~F}_{5}\right)_{4}\right]+\mathrm{HCl}}\end{array}$ & $\begin{array}{l}{[\mathrm{MH}] \mathrm{Y}+\mathrm{HY} \rightleftharpoons\left[\mathrm{MH}_{2}\right] \mathrm{Y}_{2}} \\
\mathrm{MM}+\mathrm{HY} \rightleftharpoons[\mathrm{MHM}] \mathrm{Y}\end{array}$ & $\begin{array}{l}\mathrm{CD}_{2} \mathrm{Cl}_{2} \\
\mathrm{C}_{6} \mathrm{H}_{5} \mathrm{~F}\end{array}$ & $\begin{array}{l}298 \\
298\end{array}$ & $\begin{array}{r}-6 \\
<-5\end{array}$ & -5 & $\begin{array}{l}153 \\
203\end{array}$ \\
\hline 4 & {$\left[\mathrm{RuH}(\mathrm{CO})_{4}\left(\mathrm{PCy}_{3}\right)\right]^{+}(\mathrm{cis})$} & M & $\mathrm{H}_{2} \mathrm{SO}_{4}$ & $\mathrm{M}+\mathrm{HY} \rightarrow[\mathrm{MH}] \mathrm{Y}$ & $\mathrm{H}_{2} \mathrm{SO}_{4}$ & 298 & & -5 & 86 \\
\hline 5 & {$\left[\mathrm{Ru}\left(\mathrm{H}_{2}\right)(\mathrm{CO})_{2}\left(\mathrm{Cp}^{*}\right)\right]^{+}$} & MH & $\mathrm{CF}_{3} \mathrm{SO}_{3} \mathrm{H}$ & $\mathrm{MH}+\mathrm{HY} \rightleftharpoons\left[\mathrm{MH}_{2}\right] \mathrm{Y}$ & $\mathrm{CD}_{2} \mathrm{Cl}_{2}$ & 193 & & -5 & $161-162$ \\
\hline 6 & {$\left[\mathrm{Fe}\left(\mathrm{H}_{2}\right)(\mathrm{CNH})(\mathrm{dppe})_{2}\right]^{+2}$} & {$[\mathrm{MH}]^{+}$} & $\mathrm{CF}_{3} \mathrm{SO}_{3} \mathrm{H}$ & {$[\mathrm{MH}] \mathrm{Y}+\mathrm{HY} \rightleftharpoons\left[\mathrm{MH}_{2}\right] \mathrm{Y}_{2}$} & $\mathrm{CD}_{2} \mathrm{Cl}_{2}$ & 298 & $<0$ & -5 & 154,202 \\
\hline 7 & {$\left[\mathrm{Ru}\left(\mathrm{H}_{2}\right)(\mathrm{CNH})(\mathrm{dppe})_{2}\right]^{+2}$} & {$[\mathrm{MH}]^{+}$} & $\mathrm{CF}_{3} \mathrm{SO}_{3} \mathrm{H}$ & {$[\mathrm{MH}] \mathrm{Y}+\mathrm{HY} \rightleftharpoons\left[\mathrm{MH}_{2}\right] \mathrm{Y}_{2}$} & $\mathrm{CD}_{2} \mathrm{Cl}_{2}$ & 298 & -5 & -5 & 154 \\
\hline 8 & {$\left[\mathrm{Os}\left(\mathrm{H}_{2}\right)(\mathrm{CNH})(\mathrm{dppe})_{2}\right]^{+2}$} & {$[\mathrm{MH}]^{+}$} & $\mathrm{CF}_{3} \mathrm{SO}_{3} \mathrm{H}$ & {$[\mathrm{MH}] \mathrm{Y}+\mathrm{HY} \rightleftharpoons\left[\mathrm{MH}_{2}\right] \mathrm{Y}_{2}$} & $\mathrm{CD}_{2} \mathrm{Cl}_{2}$ & 298 & $<0$ & -3 & 154 \\
\hline 9 & {$\left[\mathrm{Ru}\left(\mathrm{H}_{2}\right)(\mathrm{CNH})(\mathrm{dppp})_{2}\right]^{+2}$} & {$[\mathrm{MH}]^{+}$} & $\mathrm{CF}_{3} \mathrm{SO}_{3} \mathrm{H}$ & {$[\mathrm{MH}] \mathrm{Y}+\mathrm{HY} \rightleftharpoons\left[\mathrm{MH}_{2}\right] \mathrm{Y}_{2}$} & $\mathrm{CD}_{2} \mathrm{Cl}_{2}$ & 298 & $<0$ & -5 & 154 \\
\hline 10 & {$\left[\mathrm{Ru}\left(\mathrm{H}_{2}\right)(\mathrm{CO})\left(\mathrm{PPh}_{3}\right)(\operatorname{tacn})\right]^{+2}$} & {$[\mathrm{MH}]^{+}$} & $\mathrm{Et}_{2} \mathrm{O}$ & {$\left[\mathrm{MH}_{2}\right] \mathrm{Y}+\mathrm{B} \rightleftharpoons \mathrm{MH}+[\mathrm{HB}] \mathrm{Y}$} & $\mathrm{CH}_{2} \mathrm{Cl}_{2}$ & 298 & -2 & -4 & 28,180 \\
\hline 11 & {$\left[\mathrm{Os}\left(\mathrm{H}_{2}\right)(\mathrm{CO})\left(\mathrm{PPh}_{3}\right)_{2}(\mathrm{bpy})\right]^{+2}$} & {$[\mathrm{MH}]^{+}$} & $\mathrm{CF}_{3} \mathrm{SO}_{3} \mathrm{H}$ & {$[\mathrm{MH}] \mathrm{Y}+\mathrm{HY} \rightleftharpoons\left[\mathrm{MH}_{2}\right] \mathrm{Y}_{2}$} & $\mathrm{CD}_{2} \mathrm{Cl}_{2}$ & 298 & -5 & -4 & 204 \\
\hline 12 & {$\left[\mathrm{OsH}_{2}(\mathrm{CO})_{2}\left(\mathrm{Cp}^{*}\right)\right]^{+}$} & MH & $\mathrm{CF}_{3} \mathrm{SO}_{3} \mathrm{H}$ & $\mathrm{MH}+\mathrm{HY} \rightleftharpoons\left[\mathrm{MH}_{2}\right] \mathrm{Y}$ & $\mathrm{CD}_{2} \mathrm{Cl}_{2}$ & 298 & & -3 & 107 \\
\hline 13 & {$\left[\mathrm{FeH}(\mathrm{CO})_{3}\left(\mathrm{P}\left(\mathrm{C}_{6} \mathrm{H}_{4} \mathrm{~F}\right)_{3}\right)_{2}\right]^{+}$} & M & $\mathrm{Fe}(\mathrm{CO})_{3}\left(\mathrm{PPh}_{3}\right)_{2}$ & {$[\mathrm{MH}] \mathrm{Y}+\mathrm{B} \rightleftharpoons[\mathrm{M}]+[\mathrm{HB}] \mathrm{Y}$} & $\mathrm{CH}_{2} \mathrm{Cl}_{2}$ & 298 & -3 & -3 & 28 \\
\hline 14 & {$\left[\mathrm{FeH}_{2}\left(\mathrm{P}(\mathrm{OEt})_{3}\right)_{3}(\mathrm{bpy})\right]^{+2}$} & {$[\mathrm{MH}]^{+}$} & $\mathrm{CF}_{3} \mathrm{SO}_{3} \mathrm{H}$ & {$[\mathrm{MH}] \mathrm{Y}+\mathrm{HY} \rightarrow\left[\mathrm{MH}_{2}\right] \mathrm{Y}_{2}$} & $\mathrm{CH}_{2} \mathrm{Cl}_{2}$ & 193 & & -2 & 205 \\
\hline 15 & {$\left[\mathrm{Ru}\left(\mathrm{H}_{2}\right)\left(\mathrm{P}(\mathrm{OEt})_{3}\right)_{3}(\mathrm{bpy})\right]^{+2}$} & {$[\mathrm{MH}]^{+}$} & $\mathrm{CF}_{3} \mathrm{SO}_{3} \mathrm{H}$ & {$[\mathrm{MH}] \mathrm{Y}+\mathrm{HY} \rightleftharpoons\left[\mathrm{MH}_{2}\right] \mathrm{Y}_{2}$} & $\mathrm{CH}_{2} \mathrm{Cl}_{2}$ & 298 & & -2 & 206 \\
\hline 16 & {$\left[\mathrm{Os}\left(\mathrm{H}_{2}\right)(\mathrm{CO})(\mathrm{pyS})\left(\mathrm{PPh}_{3}\right)_{2}\right]^{+}$} & MH & $\mathrm{H}_{2} \mathrm{O}$ & {$\left[\mathrm{MH}_{2}\right] \mathrm{Y}+\mathrm{B} \rightleftharpoons \mathrm{MH}+[\mathrm{HB}] \mathrm{Y}$} & $\mathrm{CDCl}_{3}$ & 298 & -2 & & 207 \\
\hline 17 & {$\left[\mathrm{Ru}\left(\mathrm{H}_{2}\right)(\mathrm{CO})\left(\mathrm{PPh}_{3}\right)\left(\mathrm{HBPz}_{3}\right)\right]^{+}$} & MH & {$\left[\mathrm{RuH}(\mathrm{CO})\left(\mathrm{PPh}_{3}\right)(\operatorname{tacn})\right]^{+}$} & {$\left[\mathrm{MH}_{2}\right] \mathrm{Y}+\mathrm{M}^{\prime} \mathrm{H} \rightarrow \mathrm{MH}+\left[\mathrm{M}^{\prime} \mathrm{H}_{2}\right] \mathrm{Y}$} & $\mathrm{CH}_{2} \mathrm{Cl}_{2}$ & 298 & -2 & -1 & 28,180 \\
\hline 18 & $\mathrm{Os}_{9} \mathrm{H}_{2}(\mathrm{CO})_{24}$ & {$\left[\mathrm{M}_{9} \mathrm{H}\right]-$} & {$\left[\mathrm{H}\left(\mathrm{OEt}_{2}\right)\right] \mathrm{BF}_{4}$} & $\mathrm{Z}\left[\mathrm{M}_{9} \mathrm{H}\right]+[\mathrm{HB}] \mathrm{Y} \rightleftharpoons \mathrm{M}_{9} \mathrm{H}_{2}+\mathrm{ZY}+\mathrm{B}$ & $\mathrm{CH}_{2} \mathrm{Cl}_{2}$ & 298 & $<0$ & & 208 \\
\hline 19 & {$\left[\mathrm{FeH}(\mathrm{CO})_{3}\left(\mathrm{Ptol}_{3}\right)_{2}\right]^{+}$} & M & $\mathrm{Fe}(\mathrm{CO})_{3}\left(\mathrm{PCyPh}_{2}\right)_{2}$ & {$[\mathrm{MH}] \mathrm{Y}+\mathrm{B} \rightleftharpoons[\mathrm{M}]+[\mathrm{HB}] \mathrm{Y}$} & $\mathrm{CH}_{2} \mathrm{Cl}_{2}$ & 298 & 0.1 & -1 & 28 \\
\hline 20 & {$\left[\mathrm{FeH}(\mathrm{CO})_{3}\left(\mathrm{PPh}_{3}\right)_{2}\right]^{+}$} & M & $\mathrm{Fe}(\mathrm{CO})_{3}\left(\mathrm{Ptol}_{3}\right)_{2}$ & {$[\mathrm{MH}] \mathrm{Y}+\mathrm{B} \rightleftharpoons[\mathrm{M}]+[\mathrm{HB}] \mathrm{Y}$} & $\mathrm{CH}_{2} \mathrm{Cl}_{2}$ & 298 & -1.1 & -1 & 28 \\
\hline 21 & {$\left[\mathrm{FeH}(\mathrm{CO})_{3}\left(\mathrm{PPh}_{3}\right)_{2}\right]^{+}$} & M & $\mathrm{CF}_{3} \mathrm{SO}_{3} \mathrm{H}$ & $\mathrm{M}+\mathrm{HY} \rightarrow[\mathrm{MH}] \mathrm{Y}$ & DCE & 298 & -0.6 & -1 & 8,112 \\
\hline 22 & {$\left[\mathrm{Ru}\left(\mathrm{H}_{2}\right)(\mathrm{CO}) \mathrm{Cp}\left(\mathrm{P}(\mathrm{OPh})_{3}\right)\right]^{+}$} & MH & $\mathrm{CF}_{3} \mathrm{SO}_{3} \mathrm{H}$ & $\mathrm{MH}+\mathrm{HY} \rightleftharpoons\left[\mathrm{MH}_{2}\right] \mathrm{Y}$ & $\mathrm{CD}_{2} \mathrm{Cl}_{2}$ & 193 & & 0 & 161 \\
\hline 23 & {$\left[\mathrm{FeH}(\mathrm{CO})_{3}\left(\mathrm{PPh}_{2} \mathrm{Cy}\right)_{2}\right]^{+}$} & M & {$\left[\mathrm{HPPh}_{3}\right] \mathrm{BF}_{4}$} & $\mathrm{M}+[\mathrm{HB}] \mathrm{Y} \rightleftharpoons[\mathrm{MH}] \mathrm{Y}+\mathrm{B}$ & $\mathrm{CH}_{2} \mathrm{Cl}_{2}$ & 298 & 1.3 & 0 & 28 \\
\hline 24 & {$\left[\mathrm{FeH}(\mathrm{CO})_{3}(\mathrm{dppp})\right]^{+}$} & M & $\mathrm{CF}_{3} \mathrm{SO}_{3} \mathrm{H}$ & $\mathrm{M}+\mathrm{HY} \rightarrow[\mathrm{MH}] \mathrm{Y}$ & DCE & 298 & 2.0 & 0 & 8,112 \\
\hline 25 & {$\left[\mathrm{FeH}(\mathrm{CO})_{3}(\mathrm{dppm})\right]^{+}$} & M & $\mathrm{CF}_{3} \mathrm{SO}_{3} \mathrm{H}$ & $\mathrm{M}+\mathrm{HY} \rightarrow[\mathrm{MH}] \mathrm{Y}$ & DCE & 298 & 3.6 & 0 & 8,112 \\
\hline 26 & {$\left[\mathrm{FeH}(\mathrm{CO})_{3}(\mathrm{dppe})\right]^{+}$} & M & $\mathrm{CF}_{3} \mathrm{SO}_{3} \mathrm{H}$ & $\mathrm{M}+\mathrm{HY} \rightarrow[\mathrm{MH}] \mathrm{Y}$ & DCE & 298 & 3.2 & 0 & 8,29 \\
\hline 27 & {$\left[\mathrm{RuH}(\mathrm{CO})_{3}(\mathrm{dppe})\right]^{+}$} & M & $\mathrm{CF}_{3} \mathrm{SO}_{3} \mathrm{H}$ & $\mathrm{M}+\mathrm{HY} \rightarrow[\mathrm{MH}] \mathrm{Y}$ & $\mathrm{C}_{6} \mathrm{D}_{6}$ & 298 & & 0 & 156 \\
\hline 28 & {$\left[\mathrm{FeH}(\mathrm{CO})_{3}\left(\mathrm{PPh}_{2} \mathrm{Me}\right)_{2}\right]^{+}$} & M & $\mathrm{CF}_{3} \mathrm{SO}_{3} \mathrm{H}$ & $\mathrm{M}+\mathrm{HY} \rightarrow[\mathrm{MH}] \mathrm{Y}$ & DCE & 298 & 0.1 & 0 & 8,112 \\
\hline
\end{tabular}




\begin{tabular}{|c|c|c|c|c|c|c|c|c|c|}
\hline 29 & {$\left[\mathrm{Fe}\left(\mathrm{H}_{2}\right)(\mathrm{CO})(\text { depe })_{2}\right]^{+2}$} & {$[\mathrm{MH}]^{+}$} & $\mathrm{CF}_{3} \mathrm{SO}_{3} \mathrm{H}$ & {$[\mathrm{MH}] \mathrm{Y}+\mathrm{HY} \rightarrow\left[\mathrm{MH}_{2}\right] \mathrm{Y}_{2}$} & $\mathrm{CH}_{2} \mathrm{Cl}_{2}$ & 298 & 0 & 1 & 154 \\
\hline 30 & {$\left[\mathrm{FeH}(\mathrm{CO})_{3}\left(\mathrm{PPhCy}_{2}\right)_{2}\right]^{+}$} & M & $\mathrm{PPh}_{3}$ & {$[\mathrm{MH}] \mathrm{Y}+\mathrm{B} \rightleftharpoons[\mathrm{M}]+[\mathrm{HB}] \mathrm{Y}$} & $\mathrm{CH}_{2} \mathrm{Cl}_{2}$ & 298 & 3.1 & 2 & 28 \\
\hline 31 & {$\left[\mathrm{FeH}(\mathrm{CO})_{3}\left(\mathrm{PPhMe}_{2}\right)_{2}\right]^{+}$} & M & $\mathrm{CF}_{3} \mathrm{SO}_{3} \mathrm{H}$ & $\mathrm{M}+\mathrm{HY} \rightarrow[\mathrm{MH}] \mathrm{Y}$ & DCE & 298 & 2.1 & 2 & 8,112 \\
\hline 32 & {$\left[\mathrm{Ru}\left(\mathrm{H}_{2}\right)\left(\mathrm{PPh}_{3}\right)_{2}(\operatorname{tacn})\right]^{+2}$} & {$[\mathrm{MH}]^{+}$} & $\mathrm{RuHCl}(\mathrm{dppe})_{2}$ & {$\left[\mathrm{MH}_{2}\right] \mathrm{Y}+\mathrm{M}^{\prime} \mathrm{H} \rightleftharpoons \mathrm{MH}+\left[\mathrm{M}^{\prime} \mathrm{H}_{2}\right] \mathrm{Y}$} & $\mathrm{CH}_{2} \mathrm{Cl}_{2}$ & 298 & 3.2 & 3 & 28,180 \\
\hline 33 & {$\left[\mathrm{Ru}\left(\mathrm{H}_{2}\right)\left(\mathrm{P}(\mathrm{OEt})_{3}\right)(\mathrm{bpy})_{2}\right]^{+2}$} & {$[\mathrm{MH}]^{+}$} & $\mathrm{CF}_{3} \mathrm{SO}_{3} \mathrm{H}$ & {$[\mathrm{MH}] \mathrm{Y}+\mathrm{HY} \rightleftharpoons\left[\mathrm{MH}_{2}\right] \mathrm{Y}_{2}$} & $\mathrm{CH}_{2} \mathrm{Cl}_{2}$ & 298 & & 3 & 206 \\
\hline 34 & {$\left[\mathrm{Ru}\left(\mathrm{H}_{2}\right)(\mathrm{CO})(\mathrm{Cp})\left(\mathrm{P}^{\mathrm{i}} \mathrm{Pr}_{3}\right)\right]^{+}$} & $\mathrm{MH}$ & $\mathrm{NEt}_{3}$ & {$\left[\mathrm{MH}_{2}\right] \mathrm{Y}+\mathrm{B} \rightarrow \mathrm{MH}+[\mathrm{HB}] \mathrm{Y}$} & $\mathrm{CH}_{2} \mathrm{Cl}_{2}$ & 298 & $<13$ & 3 & 209 \\
\hline 35 & {$\left[\mathrm{Ru}\left(\mathrm{H}_{2}\right)(\mathrm{CO})(\mathrm{Cp})\left(\mathrm{PCy}_{3}\right)\right]^{+}$} & $\mathrm{MH}$ & $\left(\mathrm{CF}_{3}\right)_{3} \mathrm{COH}$ & $\mathrm{MH}+2 \mathrm{HY} \rightarrow\left[\mathrm{MH}_{2}\right](\mathrm{YHY})$ & $\mathrm{CH}_{2} \mathrm{Cl}_{2}$ & 200 & $11^{c}$ & 3 & 210 \\
\hline 36 & {$\left[\mathrm{Fe}\left(\mathrm{H}_{2}\right)(\mathrm{CNH})(\mathrm{depe})_{2}\right]^{+2}$} & {$[\mathrm{MH}]^{+}$} & $\mathrm{CF}_{3} \mathrm{SO}_{3} \mathrm{H}$ & {$[\mathrm{MH}] \mathrm{Y}+\mathrm{HY} \rightarrow\left[\mathrm{MH}_{2}\right] \mathrm{Y}_{2}$} & $\mathrm{CH}_{2} \mathrm{Cl}_{2}$ & 298 & 3 & 3 & 8,154 \\
\hline 37 & {$\left[\mathrm{Os}\left(\mathrm{H}_{2}\right)_{2}\left(\mathrm{NHC}-\mathrm{C}_{6} \mathrm{H}_{4}\right)\left(\mathrm{P}^{\mathrm{i}} \mathrm{Pr}_{3}\right)_{2}\right]^{+}$} & $\mathrm{MH}_{3}$ & acetone & {$\left[\mathrm{MH}_{4}\right] \mathrm{Y}+\mathrm{B} \rightleftharpoons \mathrm{MH}_{3}+[\mathrm{HB}] \mathrm{Y}$} & acetone & 298 & 3.0 & & 211 \\
\hline 38 & {$\left[\mathrm{Os}\left(\mathrm{H}_{2}\right)\left(\mathrm{CH}_{3} \mathrm{CN}\right)(\mathrm{dppe})_{2}\right]^{+2}$} & {$[\mathrm{MH}]^{+}$} & $\mathrm{Et}_{2} \mathrm{O}$ & {$\left[\mathrm{MH}_{2}\right] \mathrm{Y}_{2}+\mathrm{B} \rightleftharpoons[\mathrm{MH}] \mathrm{Y}+[\mathrm{HB}] \mathrm{Y}$} & $\mathrm{CH}_{2} \mathrm{Cl}_{2}$ & 298 & -4 & 3 & 28 \\
\hline 39 & {$\left[\mathrm{OsH}(\mathrm{Cl})(\mathrm{Cp})\left(\mathrm{PPh}_{3}\right)_{2}\right]^{+}$} & M & $\mathrm{CF}_{3} \mathrm{SO}_{3} \mathrm{H}$ & $\mathrm{M}+\mathrm{HY} \rightarrow[\mathrm{MH}] \mathrm{Y}$ & DCE & 298 & 1.2 & 3 & 7,112 \\
\hline 40 & {$\left[\mathrm{Os}\left(\mathrm{H}_{2}\right)(\mathrm{CO})\left(\mathrm{P}^{\mathrm{i}} \mathrm{Pr}_{3}\right)\left(\mathrm{HBPz}_{3}\right)\right]^{+}$} & MH & $\mathrm{PPh}_{3}$ & {$\left[\mathrm{MH}_{2}\right] \mathrm{Y}+\mathrm{B} \rightleftharpoons \mathrm{MH}+[\mathrm{HB}] \mathrm{Y}$} & $\mathrm{CD}_{2} \mathrm{Cl}_{2}$ & 213 & 9.0 & 3 & 181 \\
\hline 41 & $\mathrm{FeH}(\mathrm{CO})\left(\mathrm{SiCl}_{3}\right)_{2}(\mathrm{Cp})$ & {$[\mathrm{M}]-$} & $\mathrm{CH}_{3} \mathrm{CN}$ & $\mathrm{MH}+\mathrm{B} \rightleftharpoons[\mathrm{M}]-+[\mathrm{HB}]^{+}$ & $\mathrm{CH}_{3} \mathrm{CN}$ & 298 & 2.6 & 4 & 167 \\
\hline 42 & {$\left[\mathrm{RuH}_{2}(\mathrm{Cl})(\mathrm{CO})\left(\mathrm{PPh}_{2}-\mathrm{NBn}-\mathrm{PPh}_{2}\right)\right]^{+}$} & MH & $\mathrm{CF}_{3} \mathrm{SO}_{3} \mathrm{H}$ & $\mathrm{MH}+\mathrm{HY} \rightleftharpoons\left[\mathrm{MH}_{2}\right] \mathrm{Y}$ & $\mathrm{CD}_{2} \mathrm{Cl}_{2}$ & 198 & & 4 & 201 \\
\hline 43 & {$\left[\mathrm{FeH}(\mathrm{CO})_{3}(\mathrm{dmpm})\right]^{+}$} & M & $\mathrm{CF}_{3} \mathrm{SO}_{3} \mathrm{H}$ & $\mathrm{M}+\mathrm{HY} \rightarrow[\mathrm{MH}] \mathrm{Y}$ & DCE & 298 & 7.1 & 4 & 8,29 \\
\hline 44 & {$\left[\mathrm{FeH}(\mathrm{CO})_{3}(\mathrm{dcpe})\right]^{+}$} & M & $\mathrm{CF}_{3} \mathrm{SO}_{3} \mathrm{H}$ & $\mathrm{M}+\mathrm{HY} \rightarrow[\mathrm{MH}] \mathrm{Y}$ & DCE & 298 & 6.1 & 4 & 8,29 \\
\hline 45 & {$\left[\mathrm{FeH}(\mathrm{CO})_{3}\left(\mathrm{PCy}_{3}\right)_{2}\right]^{+}$} & M & $\mathrm{CF}_{3} \mathrm{SO}_{3} \mathrm{H}$ & $\mathrm{M}+\mathrm{HY} \rightarrow[\mathrm{MH}] \mathrm{Y}$ & DCE & 298 & 4.4 & 4 & 92 \\
\hline 46 & {$\left[\mathrm{FeH}(\mathrm{CO})_{3}\left(\mathrm{PCy}_{3}\right)_{2}\right]^{+}$} & $\mathrm{M}$ & $\mathrm{PPh}_{3}$ & {$[\mathrm{MH}] \mathrm{Y}+\mathrm{B} \rightleftharpoons[\mathrm{M}]+[\mathrm{HB}] \mathrm{Y}$} & $\mathrm{CH}_{2} \mathrm{Cl}_{2}$ & 298 & 4.4 & 4 & 28 \\
\hline 47 & {$\left[\mathrm{FeH}(\mathrm{CO})_{3}\left(\mathrm{PMe}_{3}\right)_{2}\right]^{+}$} & M & $\mathrm{CF}_{3} \mathrm{SO}_{3} \mathrm{H}$ & $\mathrm{M}+\mathrm{HY} \rightarrow[\mathrm{MH}] \mathrm{Y}$ & DCE & 298 & 3.2 & 4 & 8,112 \\
\hline 48 & {$\left[\mathrm{Ru}\left(\mathrm{H}_{2}\right) \mathrm{Cl}\left(\mathrm{PPh}_{3}\right)(\mathrm{P}-\mathrm{py}-\mathrm{P})\right]^{+}$} & MH & {$\left[\mathrm{HPTol}_{3}\right] \mathrm{BF}_{4}$} & $\mathrm{MH}+[\mathrm{HB}] \mathrm{Y} \rightleftharpoons\left[\mathrm{MH}_{2}\right] \mathrm{Y}+\mathrm{B}$ & $\mathrm{CH}_{2} \mathrm{Cl}_{2}$ & 298 & 4.0 & 4 & 28,212 \\
\hline 49 & {$\left[\mathrm{Os}\left(\mathrm{H}_{2}\right) \mathrm{Cl}\left(\mathrm{PPh}_{3}\right)(\mathrm{P}-\mathrm{py}-\mathrm{P})\right]^{+}$} & MH & $\mathrm{RuH}(\mathrm{Cp})\left(\mathrm{PPh}_{3}\right)_{2}$ & {$\left[\mathrm{MH}_{2}\right] \mathrm{Y}+\mathrm{M}^{\prime} \mathrm{H} \rightleftharpoons \mathrm{MH}+\left[\mathrm{M}^{\prime} \mathrm{H}_{2}\right] \mathrm{Y}$} & $\mathrm{CH}_{2} \mathrm{Cl}_{2}$ & 298 & 7.2 & 6 & 6 \\
\hline 50 & {$\left[\mathrm{FeH}\left(\mathrm{Py}_{2} \text { Tstacn }\right)\right]^{+2}$} & {$[\mathrm{M}]^{+}$} & $\mathrm{H}_{2} \mathrm{O}$ & {$[\mathrm{MH}]^{+2}+\mathrm{H}_{2} \mathrm{O} \rightleftharpoons[\mathrm{M}]^{+}+\mathrm{H}_{3} \mathrm{O}^{+}$} & $\mathrm{H}_{2} \mathrm{O} / \mathrm{CH}_{3} \mathrm{CN}$ & 298 & 1.8 & 5 & 184 \\
\hline 51 & {$\left[\mathrm{Ru}\left(\mathrm{H}_{2}\right)\left(\mathrm{H}_{2} \mathrm{O}\right)_{5}\right]^{+2}$} & {$[\mathrm{MH}]^{+}$} & $\mathrm{OH}-$ & {$\left[\mathrm{MH}_{2}\right] \mathrm{Y}_{2}+\mathrm{B} \rightleftharpoons[\mathrm{MH}] \mathrm{Y}+[\mathrm{HB}] \mathrm{Y}$} & $\mathrm{H}_{2} \mathrm{O}$ & 298 & $\mathrm{~d}$ & 5 & 74 \\
\hline 52 & {$\left[\mathrm{RuH}_{2}(\mathrm{Cp})(\mathrm{dtfpe})\right]^{+}$} & MH & {$\left[\mathrm{HPTol}_{3}\right] \mathrm{BF} 4$} & $\mathrm{MH}+[\mathrm{HB}] \mathrm{Y} \rightleftharpoons\left[\mathrm{MH}_{2}\right] \mathrm{Y}+\mathrm{B}$ & $\mathrm{CH}_{2} \mathrm{Cl}_{2}$ & 298 & 4.0 & 5 & 168 \\
\hline 53 & $\mathrm{FeH}(\mathrm{CN})(\mathrm{CO})_{4}$ & {$[\mathrm{M}]-$} & $\mathrm{HCl}$ & $\mathrm{K}[\mathrm{M}]+\mathrm{HCl} \rightarrow \mathrm{MH}+\mathrm{KCl}$ & $\mathrm{CH}_{3} \mathrm{CN}$ & 298 & & 9 & 213 \\
\hline 54 & $\mathrm{FeH}(\mathrm{CN})(\mathrm{CO})_{4}$ & {$[\mathrm{M}]-$} & $\mathrm{NH}_{2} \mathrm{Ph}$ & $\mathrm{MH}+\mathrm{B} \rightarrow[\mathrm{HB}][\mathrm{M}]$ & $\mathrm{CH}_{3} \mathrm{CN}$ & 298 & & 9 & 213 \\
\hline 55 & $\begin{array}{l}(\mathrm{CO})_{3} \mathrm{Fe}\left(\mu-\mathrm{SCH}_{2} \mathrm{CH}_{2} \mathrm{CH}_{2} \mathrm{~S}-\right)(\mu- \\
\left.\mathrm{H}) \mathrm{Fe}(\mathrm{CO})\left(\mathrm{PPh}_{2} \mathrm{CH}_{2} \mathrm{NPrCH}_{2} \mathrm{PPh}_{2}\right)\right]^{+}\end{array}$ & [M]- & $\mathrm{NH}_{2} \mathrm{Ph}$ & {$[\mathrm{MHM}] \mathrm{Y}+\mathrm{B} \rightarrow \mathrm{MM}+[\mathrm{HB}] \mathrm{Y}$} & $\mathrm{CH}_{2} \mathrm{Cl}_{2}$ & 298 & $<8$ & & 214 \\
\hline 56 & {$\left[\mathrm{RuH}\left(\mathrm{Cp}^{*}\right)_{2}\right]^{+}$} & $\mathrm{M}$ & $\mathrm{CF}_{3} \mathrm{SO}_{3} \mathrm{H}$ & $\mathrm{M}+\mathrm{HY} \rightarrow[\mathrm{MH}] \mathrm{Y}$ & DCE & 298 & 0.8 & 5 & 8,29 \\
\hline 57 & {$\left[\mathrm{OsH}\left(\mathrm{Cp}^{*}\right)_{2}\right]^{+}$} & $\mathrm{M}$ & {$\left[\mathrm{NH}_{3} \mathrm{Ph}\right] \mathrm{BF}_{4}$} & $\mathrm{M}+[\mathrm{HB}] \mathrm{Y} \rightleftharpoons[\mathrm{MH}] \mathrm{Y}+\mathrm{B}$ & $\mathrm{CH}_{3} \mathrm{CN}$ & 298 & 9.9 & $7\left(12^{e}\right)$ & $7,112,215$ \\
\hline 58 & {$\left[\mathrm{OsH}\left(\mathrm{Cp}^{*}\right)_{2}\right]^{+}$} & M & $\mathrm{CF}_{3} \mathrm{SO}_{3} \mathrm{H}$ & $\mathrm{M}+\mathrm{HY} \rightarrow[\mathrm{MH}] \mathrm{Y}$ & DCE & 298 & 5.1 & 7 & 7,112 \\
\hline
\end{tabular}




\begin{tabular}{|c|c|c|c|c|c|c|c|c|c|}
\hline 59 & $\begin{array}{l}{\left[(\mathrm{CO})_{3} \mathrm{Fe}(\mu-\mathrm{H})\left(\mu-\mathrm{SCH}_{2} \mathrm{CH}_{2} \mathrm{CH}_{2}\right) \mathrm{Ni}-\right.} \\
(\mathrm{dppe})]^{+}\end{array}$ & MM & $\mathrm{NH}_{2} \mathrm{Ph}$ & {$[\mathrm{MHM}] \mathrm{Y}+\mathrm{B} \rightleftharpoons \mathrm{MM}+[\mathrm{HB}] \mathrm{Y}$} & $\mathrm{PhCN}$ & 298 & 10.7 & & 63 \\
\hline 60 & {$\left[\mathrm{Fe}\left(\mathrm{H}_{2}\right) \mathrm{H}(\mathrm{dtfpe})_{2}\right]^{+}$(trans) } & $\mathrm{MH}_{2}$ & $\mathrm{OsH}_{2}(\mathrm{dtfpe})_{2}$ & {$\left[\mathrm{MH}_{3}\right] \mathrm{Y}+\mathrm{M}^{\prime} \mathrm{H}_{2} \rightleftharpoons \mathrm{MH}_{2}+\left[\mathrm{M}^{\prime} \mathrm{H}_{3}\right] \mathrm{Y}$} & THF & 298 & 6.7 & 7 & 7 \\
\hline 61 & {$\left[\mathrm{Ru}\left(\mathrm{H}_{2}\right) \mathrm{H}(\mathrm{dtfpe})_{2}\right]^{+}$(trans) } & $\mathrm{MH}_{2}$ & {$\left[\mathrm{Ru}(\mathrm{H})_{2}\left(\mathrm{Cp}^{*}\right)\left(\mathrm{PMePh}_{2}\right)_{2}\right]^{+}$} & $\mathrm{MH}_{2}+\left[\mathrm{M}^{\prime} \mathrm{H}_{2}\right] \mathrm{Y} \rightleftharpoons\left[\mathrm{M}\left(\mathrm{H}_{2}\right) \mathrm{H}\right] \mathrm{Y}+\mathrm{M}^{\prime} \mathrm{H}$ & THF & 298 & 8 & 7 & 7 \\
\hline 62 & {$\left[\mathrm{Os}\left(\mathrm{H}_{2}\right) \mathrm{H}(\mathrm{dtfpe})_{2}\right]^{+}$(trans) } & $\mathrm{MH}_{2}$ & $\mathrm{RuH}(\mathrm{Cp})\left(\mathrm{PPh}_{3}\right)_{2}$ & {$\left[\mathrm{MH}_{3}\right] \mathrm{Y}+\mathrm{M}^{\prime} \mathrm{H} \rightleftharpoons \mathrm{MH}_{2}+\left[\mathrm{M}^{\prime} \mathrm{H}_{2}\right] \mathrm{Y}$} & THF & 298 & 8.4 & 9 & 7,91 \\
\hline 63 & {$\left[\mathrm{Ru}\left(\mathrm{H}_{2}\right)\left(\mathrm{HBPz}_{3}\right)\left(\mathrm{PPh}_{3}\right)_{2}\right]^{+}$} & MH & $\operatorname{RuH}(\mathrm{Cp})(\mathrm{dppm})$ & {$\left[\mathrm{MH}_{2}\right] \mathrm{Y}+\mathrm{M}^{\prime} \mathrm{H} \rightleftharpoons \mathrm{MH}+\left[\mathrm{M}^{\prime} \mathrm{H}_{2}\right] \mathrm{Y}$} & $\mathrm{CH}_{2} \mathrm{Cl}_{2}$ & 298 & 7.6 & 6 & 180 \\
\hline 64 & {$\left[\mathrm{Os}(\mathrm{H})_{2}\left(\mathrm{HBPz}_{3}\right)\left(\mathrm{PPh}_{3}\right)_{2}\right]^{+}$} & $\mathrm{MH}$ & $\mathrm{RuH}(\mathrm{Cp})\left(\mathrm{PPh}_{3}\right)_{2}$ & {$\left[\mathrm{MH}_{2}\right] \mathrm{Y}+\mathrm{M}^{\prime} \mathrm{H} \rightleftharpoons \mathrm{MH}+\left[\mathrm{M}^{\prime} \mathrm{H}_{2}\right] \mathrm{Y}$} & $\mathrm{CH}_{2} \mathrm{Cl}_{2}$ & 298 & 8.8 & 8 & 166 \\
\hline 65 & {$\left[\mathrm{RuHCl}(\mathrm{Cp})\left(\mathrm{PMe}_{3}\right)_{2}\right]^{+}$} & M & $\mathrm{CF}_{3} \mathrm{SO}_{3} \mathrm{H}$ & $\mathrm{M}+\mathrm{HY} \rightarrow[\mathrm{MH}] \mathrm{Y}$ & DCE & 298 & 2.1 & 6 & 8,29 \\
\hline 66 & {$\left[\mathrm{Ru}\left(\mathrm{H}_{2}\right)\left(\mathrm{HBPz}_{3}\right)(\mathrm{dppe})\right]^{+}$} & MH & $\operatorname{RuH}(\mathrm{Cp})(\mathrm{dppm})$ & {$\left[\mathrm{MH}_{2}\right] \mathrm{Y}+\mathrm{M}^{\prime} \mathrm{H} \rightleftharpoons \mathrm{MH}+\left[\mathrm{M}^{\prime} \mathrm{H}_{2}\right] \mathrm{Y}$} & $\mathrm{CH}_{2} \mathrm{Cl}_{2}$ & 298 & 7.9 & 6 & 180 \\
\hline 67 & $\mathrm{FeH}_{2}$ (toluene) $\left(\mathrm{SiCl}_{3}\right)_{2}$ & {$[\mathrm{MH}]-$} & py & $\mathrm{MH}_{2}+\mathrm{B} \rightarrow[\mathrm{MH}]-+[\mathrm{HB}]^{+}$ & $\mathrm{CH}_{3} \mathrm{CN}$ & 298 & $<12$ & 6 & 216 \\
\hline 68 & {$\left[\mathrm{Ru}\left(\mathrm{H}_{2}\right) \mathrm{Cl}(\mathrm{dppp})_{2}\right]^{+}$} & MH & $\mathrm{PPh}_{3}$ & {$\left[\left[\mathrm{MH}_{2}\right] \mathrm{Y}+\mathrm{B} \rightleftharpoons \mathrm{MH}+[\mathrm{HB}] \mathrm{Y}\right.$} & $\mathrm{CH}_{2} \mathrm{Cl}_{2}$ & 298 & 5.6 & 6 & 153,217 \\
\hline 69 & {$\left[\mathrm{Os}\left(\mathrm{H}_{2}\right) \mathrm{Cl}(\mathrm{dppp})_{2}\right]^{+}$} & MH & $\mathrm{NEt}_{3}$ & {$\left[\mathrm{MH}_{3}\right] \mathrm{Y}+\mathrm{B} \rightleftharpoons \mathrm{MH}_{2}+[\mathrm{HB}] \mathrm{Y}$} & $\mathrm{CH}_{2} \mathrm{Cl}_{2}$ & 298 & 12.5 & 8 & 153 \\
\hline 70 & {$\left[\mathrm{Ru}\left(\mathrm{H}_{2}\right) \mathrm{Cl}(\mathrm{dppe})_{2}\right]^{+}$} & $\mathrm{MH}$ & $\mathrm{PPhEt}_{2}$ & {$\left[\left[\mathrm{MH}_{2}\right] \mathrm{Y}+\mathrm{B} \rightleftharpoons \mathrm{MH}+[\mathrm{HB}] \mathrm{Y}\right.$} & $\mathrm{CH}_{2} \mathrm{Cl}_{2}$ & 298 & 4.7 & 6 & 28,218 \\
\hline 71 & {$\left[\mathrm{Ru}\left(\mathrm{H}_{2}\right)\left(\mathrm{PPh}_{3}\right)\left(\mathrm{CH}_{3} \mathrm{CN}\right)\left(\mathrm{HBPz}_{3}\right)\right]^{+}$} & $\mathrm{MH}$ & $\mathrm{RuH}(\mathrm{Cp})\left(\mathrm{PPh}_{3}\right)_{2}$ & {$\left[\mathrm{MH}_{2}\right] \mathrm{Y}+\mathrm{M}^{\prime} \mathrm{H} \rightleftharpoons \mathrm{MH}+\left[\mathrm{M}^{\prime} \mathrm{H}_{2}\right] \mathrm{Y}$} & $\mathrm{CH}_{2} \mathrm{Cl}_{2}$ & 298 & 8.9 & 7 & 180 \\
\hline 72 & {$\left[\mathrm{RuH}(\mathrm{Cl})(\mathrm{Cp} *)\left(\mathrm{PMe}_{3}\right)_{2}\right]^{+}$} & M & $\mathrm{CF}_{3} \mathrm{SO}_{3} \mathrm{H}$ & $\mathrm{M}+\mathrm{HY} \rightarrow[\mathrm{MH}] \mathrm{Y}$ & DCE & 298 & 7.1 & 7 & 8,29 \\
\hline 73 & {$\left[\mathrm{Ru}(\mathrm{HD})(\mathrm{Cp})(\mathrm{PTA})_{2}\right]^{+}$} & MH & $\mathrm{D}_{2} \mathrm{O}$ & $\mathrm{MH}+\mathrm{D}_{2} \mathrm{O} \rightleftharpoons[\mathrm{MHD}]^{+}+\mathrm{OD}^{-}$ & $\mathrm{D}_{2} \mathrm{O}$ & 298 & & 7 & 72 \\
\hline 74 & {$\left[\mathrm{Ru}\left(\mathrm{H}_{2}\right)(\mathrm{Cp})(\mathrm{PTA})_{2}\right]^{+}$} & MH & $\mathrm{H}_{3} \mathrm{O}^{+}$ & $\mathrm{MH}+\mathrm{H}^{+} \rightleftharpoons\left[\mathrm{MH}_{2}\right]^{+}$ & $\mathrm{H}_{2} \mathrm{O}$ & 298 & -1.0 & 7 & 174 \\
\hline 75 & {$\left[\mathrm{Ru}(\mathrm{H})_{2}(\mathrm{Cp})\left(\mathrm{PPh}_{2} \mathrm{C}_{6} \mathrm{H}_{4} \mathrm{PPh}_{2}\right]^{+}\right.$} & MH & {$\left[\mathrm{Ru}\left(\mathrm{H}_{2}\right)(\mathrm{Cp})(\mathrm{dppm})\right] \mathrm{BF}_{4}$} & $\mathrm{MH}+\left[\mathrm{M}^{\prime} \mathrm{H}_{2}\right] \mathrm{Y} \rightleftharpoons\left[\mathrm{MH}_{2}\right] \mathrm{Y}+\mathrm{M}^{\prime} \mathrm{H}$ & THF & 298 & 6.0 & 7 & 169 \\
\hline 76 & {$\left[(\mathrm{CO})_{2} \mathrm{Ru}(\mu-\mathrm{H})(\mu-\mathrm{Cp}-\mathrm{Cp}) \mathrm{Ru}(\mathrm{CO})_{2}\right]^{+}$} & $\mathrm{M}_{2}$ & {$\left[\mathrm{HPPh}_{3}\right] \mathrm{BF}_{4}$} & $\mathrm{M}_{2}+[\mathrm{HB}] \mathrm{Y} \rightleftharpoons[\mathrm{MHM}] \mathrm{Y}+\mathrm{B}$ & $\mathrm{CH}_{3} \mathrm{CN}$ & 298 & 6.4 & & 165 \\
\hline 77 & {$\left[\mathrm{Ru}(\mathrm{H})_{2}(\mathrm{Cp})\left(\mathrm{PPh}_{3}\right)_{2}\right]^{+}$} & MH & {$\left[\mathrm{HPCy}_{3}\right] \mathrm{BF}_{4}$} & $\mathrm{MH}+[\mathrm{HB}] \mathrm{Y} \rightleftharpoons\left[\mathrm{MH}_{2}\right] \mathrm{Y}+\mathrm{B}$ & THF & 298 & 7.6 & 7 & 7 \\
\hline 78 & {$\left[\mathrm{Ru}(\mathrm{H})_{2}(\mathrm{Cp})\left(\mathrm{PPh}_{3}\right)_{2}\right]^{+}$} & MH & $\mathrm{CF}_{3} \mathrm{SO}_{3} \mathrm{H}$ & $\mathrm{MH}+\mathrm{HY} \rightarrow\left[\mathrm{MH}_{2}\right] \mathrm{Y}$ & DCE & 298 & 6.8 & 7 & 8,29 \\
\hline 79 & {$\left[\mathrm{Os}(\mathrm{H})_{2}(\mathrm{Cp})\left(\mathrm{PPh}_{3}\right)_{2}\right]^{+}(\operatorname{trans})$} & MH & $\mathrm{CF}_{3} \mathrm{SO}_{3} \mathrm{H}$ & $\mathrm{MH}+\mathrm{HY} \rightarrow\left[\mathrm{MH}_{2}\right] \mathrm{Y}$ & DCE & 298 & 11.0 & 9 & 8,29 \\
\hline 80 & {$\left[\mathrm{Os}(\mathrm{H})_{2}(\mathrm{Cp})\left(\mathrm{PPh}_{3}\right)_{2}\right]^{+}$(trans) } & $\mathrm{MH}$ & $\mathrm{OsH}(\mathrm{Cp})(\mathrm{dppp})$ & {$\left[\mathrm{MH}_{2}\right] \mathrm{Y}+\mathrm{M}^{\prime} \mathrm{H} \rightleftharpoons \mathrm{MH}+\left[\mathrm{M}^{\prime} \mathrm{H}_{2}\right] \mathrm{Y}$} & $\mathrm{CH}_{2} \mathrm{Cl}_{2}$ & 298 & 13.4 & 9 & 7,166 \\
\hline 81 & {$\left[\mathrm{RuH}_{2}\left(\mathrm{C}_{6} \mathrm{Me}_{6}\right)(\mathrm{bpy})\right]^{+2}$} & {$[\mathrm{MH}]^{+}$} & $\mathrm{H}_{3} \mathrm{O}^{+}(\mathrm{pH} 6)$ & {$[\mathrm{MH}]^{+}+\mathrm{H}+\rightleftharpoons \mathrm{M}+\left[\mathrm{MH}_{2}\right]^{+2}$} & $\mathrm{H}_{2} \mathrm{O}$ & 298 & $<6$ & -5 & 187 \\
\hline 82 & {$\left[\mathrm{Ru}\left(\mathrm{H}_{2}\right) \mathrm{Cl}\left(\mathrm{tmeP}_{2} \mathrm{NH}_{2}\right)\right]^{+}$} & MH & {$\left[\mathrm{HPPhCy}_{2}\right] \mathrm{BF}_{4}$} & $\mathrm{MH}+[\mathrm{HB}] \mathrm{Y} \rightleftharpoons\left[\mathrm{MH}_{2}\right] \mathrm{Y}+\mathrm{B}$ & $\mathrm{CH}_{2} \mathrm{Cl}_{2}$ & 298 & 6.9 & 8 & 92 \\
\hline 83 & $\mathrm{Fe}\left(\mathrm{H}_{2}\right)(\mathrm{CO})_{2}($ acyl-py)(Scysteine) & $\mathrm{MH}$ & internal FeSR & $\mathrm{MH}_{2}(\mathrm{SR}) \rightleftharpoons \mathrm{MH}(\mathrm{HSR})$ & Enzyme & 298 & 9 & & 219 \\
\hline 84 & {$\left[\mathrm{Ru}(\mathrm{H})_{2}(\mathrm{Cp})(\mathrm{dppp})\right]^{+}$} & $\mathrm{MH}$ & {$\left[\mathrm{RuH}_{2}(\mathrm{Cp})\left(\mathrm{PPh}_{3}\right)_{2}\right] \mathrm{BF}_{4}$} & $\mathrm{MH}+\left[\mathrm{M}^{\prime} \mathrm{H}_{2}\right] \mathrm{Y} \rightleftharpoons\left[\mathrm{MH}_{2}\right] \mathrm{Y}+\mathrm{M}^{\prime} \mathrm{H}$ & THF & 298 & 8.7 & 8 & 7 \\
\hline 85 & {$\left[\mathrm{Ru}\left(\mathrm{H}_{2}\right)(\mathrm{Cp})(\mathrm{dppm})\right]^{+}$} & MH & {$\left[\mathrm{RuH}_{2}(\mathrm{Cp})\left(\mathrm{PPh}_{3}\right)_{2}\right] \mathrm{BF}_{4}$} & $\mathrm{MH}+\left[\mathrm{M}^{\prime} \mathrm{H}_{2}\right] \mathrm{Y} \rightleftharpoons\left[\mathrm{MH}_{2}\right] \mathrm{Y}+\mathrm{M}^{\prime} \mathrm{H}$ & THF & 298 & 7.2 & 8 & 7,169 \\
\hline 86 & {$\left[\mathrm{Ru}\left(\mathrm{H}_{2}\right)(\mathrm{Cp})(\mathrm{dppm})\right]^{+}$} & MH & $\mathrm{CF}_{3} \mathrm{SO}_{3} \mathrm{H}$ & $\mathrm{MH}+\mathrm{HY} \rightarrow\left[\mathrm{MH}_{2}\right] \mathrm{Y}$ & DCE & 298 & 6.3 & 8 & 8,29 \\
\hline 87 & {$\left[\mathrm{Os}(\mathrm{H})_{2}(\mathrm{Cp})(\mathrm{dppm})\right]^{+}(\operatorname{trans})$} & MH & $\mathrm{RuH}(\mathrm{Cp})\left(\mathrm{PPh}_{3}\right)_{2}$ & {$\left[\mathrm{MH}_{2}\right] \mathrm{Y}+\mathrm{M}^{\prime} \mathrm{H} \rightleftharpoons \mathrm{MH}+\left[\mathrm{M}^{\prime} \mathrm{H}_{2}\right] \mathrm{Y}$} & $\mathrm{CH}_{2} \mathrm{Cl}_{2}$ & 298 & 10.0 & 10 & 166 \\
\hline 88 & {$\left[\mathrm{Ru}(\mathrm{H})_{2}(\mathrm{Cp})(\mathrm{dppe})\right]^{+}$} & MH & $\mathrm{CF}_{3} \mathrm{SO}_{3} \mathrm{H}$ & $\mathrm{MH}+\mathrm{HY} \rightarrow\left[\mathrm{MH}_{2}\right] \mathrm{Y}$ & DCE & 298 & 6.4 & 8 & 8,29 \\
\hline
\end{tabular}




\begin{tabular}{|c|c|c|c|c|c|c|c|c|c|}
\hline 89 & {$\left[\mathrm{Ru}(\mathrm{H})_{2}(\mathrm{Cp})(\mathrm{dppe})\right]^{+}$} & MH & $\left(\mathrm{CF}_{3}\right)_{2} \mathrm{CHOH}$ & $\mathrm{MH}+2 \mathrm{HY} \rightleftharpoons\left[\mathrm{MH}_{2}\right][\mathrm{YHY}]$ & $\mathrm{CD}_{2} \mathrm{Cl}_{2}$ & 200 & & 8 & 96 \\
\hline 90 & {$\left[\mathrm{Ru}(\mathrm{H})_{2}(\mathrm{Cp})(\mathrm{dppe})\right]^{+}$} & $\mathrm{MH}$ & {$\left[\mathrm{RuH}_{2}(\mathrm{Cp})\left(\mathrm{PPh}_{3}\right)_{2}\right] \mathrm{BF}_{4}$} & $\mathrm{MH}+\left[\mathrm{M}^{\prime} \mathrm{H}_{2}\right] \mathrm{Y} \rightleftharpoons\left[\mathrm{MH}_{2}\right] \mathrm{Y}+\mathrm{M}^{\prime} \mathrm{H}$ & THF & 298 & 7.2 & 8 & 7 \\
\hline 91 & {$\left[\mathrm{Os}(\mathrm{H})_{2}(\mathrm{Cp})(\mathrm{dppe})\right]^{+}(\operatorname{trans})$} & MH & $\mathrm{RuH}(\mathrm{Cp})\left(\mathrm{PPh}_{3}\right)_{2}$ & {$\left[\mathrm{MH}_{2}\right] \mathrm{Y}+\mathrm{M}^{\prime} \mathrm{H} \rightleftharpoons \mathrm{MH}+\left[\mathrm{M}^{\prime} \mathrm{H}_{2}\right] \mathrm{Y}$} & $\mathrm{CH}_{2} \mathrm{Cl}_{2}$ & 298 & 11.8 & 10 & 166 \\
\hline 92 & {$\left[\mathrm{Os}(\mathrm{H})_{2}(\mathrm{Cp})\left(\mathrm{PPh}_{2} \mathrm{Me}\right)_{2}\right]^{+}$} & MH & $\mathrm{CF}_{3} \mathrm{SO}_{3} \mathrm{H}$ & $\mathrm{MH}+\mathrm{HY} \rightarrow\left[\mathrm{MH}_{2}\right] \mathrm{Y}$ & DCE & 298 & 12.1 & 10 & 8,29 \\
\hline 93 & {$\left[\mathrm{Ru}\left(\mathrm{Cp}-\mathrm{NHMe}_{2}\right)\left(\mathrm{H}_{2}\right)(\mathrm{dppm})\right]^{+2}$} & MH & $\mathrm{NMe}_{2} \mathrm{R}$ & {$\left[\mathrm{MH}_{2}\right] \mathrm{Y}+\mathrm{B} \rightleftharpoons \mathrm{MH}+[\mathrm{HB}] \mathrm{Y}$} & THF & 298 & 7.1 & 8 & 173 \\
\hline 94 & {$\left[\mathrm{Ru}\left(\mathrm{H}_{2}\right)(\mathrm{Cl})(\mathrm{dach})\left(\mathrm{PPh}_{3}\right)_{2}\right]^{+}$} & MH & {$\left[\mathrm{HPBu}_{3}\right] \mathrm{BF}_{4}$} & $\mathrm{MH}+[\mathrm{HB}] \mathrm{Y} \rightleftharpoons\left[\mathrm{MH}_{2}\right] \mathrm{Y}+\mathrm{B}$ & $\mathrm{CH}_{2} \mathrm{Cl}_{2}$ & 298 & 8.6 & 8 & 92 \\
\hline 95 & {$\left[\mathrm{Ru}(\mathrm{H})_{2}\left(\mathrm{Cp}^{*}\right)\left(\mathrm{PPh}_{3}\right)_{2}\right]^{+}$} & MH & {$\left[\mathrm{HP}\left({ }^{\mathrm{t}} \mathrm{Bu}\right)_{3}\right] \mathrm{BF}_{4}$} & $\mathrm{MH}+[\mathrm{HB}] \mathrm{Y} \rightleftharpoons\left[\mathrm{MH}_{2}\right] \mathrm{Y}+\mathrm{B}$ & THF & 298 & 11 & 8 & 7,89 \\
\hline 96 & {$\left[\mathrm{Ru}(\mathrm{H})_{2}\left(\mathrm{Cp}^{*}\right)\left(\mathrm{PPh}_{3}\right)_{2}\right]^{+}$} & $\mathrm{MH}$ & $\mathrm{CF}_{3} \mathrm{SO}_{3} \mathrm{H}$ & $\mathrm{MH}+\mathrm{HY} \rightarrow\left[\mathrm{MH}_{2}\right] \mathrm{Y}$ & DCE & 298 & 9.8 & 8 & 8,29 \\
\hline $\begin{array}{l}97 \\
98\end{array}$ & $\begin{array}{l}{\left[\mathrm{Fe}\left(\mathrm{H}_{2}\right)(\mathrm{CN})(\text { depe })_{2}\right]^{+}} \\
(\mathrm{CO})_{2}\left(\mathrm{PMe}_{3}\right) \mathrm{Fe}(\mu-\mathrm{H})\left(\mu-\mathrm{SCH}_{2} \mathrm{CH}_{2} \mathrm{CH}_{2} \mathrm{~S}\right) \\
\mathrm{Fe}(\mathrm{CO})_{2}(\mathrm{CN})\end{array}$ & $\begin{array}{l}\mathrm{MH} \\
{[\mathrm{MM}]^{-}}\end{array}$ & $\begin{array}{l}{\left[\mathrm{HPCy}_{3}\right] \mathrm{BF}_{4}} \\
\mathrm{HCl}\end{array}$ & $\begin{array}{l}{\left[\mathrm{MH}+[\mathrm{HB}] \mathrm{Y} \rightleftharpoons\left[\mathrm{MH}_{2}\right] \mathrm{Y}+\mathrm{B}\right.} \\
\mathrm{Z}[\mathrm{MM}]+\mathrm{HCl} \rightarrow \mathrm{MHM}+\mathrm{ZCl}\end{array}$ & $\begin{array}{l}\mathrm{CH}_{2} \mathrm{Cl}_{2} \\
\mathrm{CH}_{3} \mathrm{CN}\end{array}$ & $\begin{array}{l}298 \\
298\end{array}$ & $\begin{array}{r}9 \\
11\end{array}$ & 8 & $\begin{array}{l}8,154 \\
66\end{array}$ \\
\hline 99 & {$\left[\mathrm{Ru}(\mathrm{H})_{2}\left(\mathrm{Cp}^{*}\right)\left(\mathrm{PMePh}_{2}\right)_{2}\right]^{+}$} & MH & {$\left[\mathrm{HP}\left({ }^{\mathrm{t}} \mathrm{Bu}\right)_{3}\right] \mathrm{BF}_{4}$} & $\mathrm{MH}+[\mathrm{HB}] \mathrm{Y} \rightleftharpoons\left[\mathrm{MH}_{2}\right] \mathrm{Y}+\mathrm{B}$ & THF & 298 & 12 & 9 & 7,90 \\
\hline 100 & {$\left[\mathrm{Ru}\left(\mathrm{H}_{2}\right)\left(\mathrm{Cp}^{*}\right)(\mathrm{dppm})\right]^{+}$} & MH & {$\left[\mathrm{HPCy}_{3}\right] \mathrm{BF}_{4}$} & $\mathrm{MH}+[\mathrm{HB}] \mathrm{Y} \rightleftharpoons\left[\mathrm{MH}_{2}\right] \mathrm{Y}+\mathrm{B}$ & THF & 298 & 9.2 & 9 & 7,90 \\
\hline 101 & {$\left[\mathrm{Ru}(\mathrm{H})_{2}\left(\mathrm{Cp}^{*}\right)(\mathrm{dppm})\right]^{+}$} & MH & {$\left[\mathrm{HPCy}_{3}\right] \mathrm{BF}_{4}$} & $\mathrm{MH}+[\mathrm{HB}] \mathrm{Y} \rightleftharpoons\left[\mathrm{MH}_{2}\right] \mathrm{Y}+\mathrm{B}$ & THF & 298 & 8.9 & 9 & 7,90 \\
\hline 102 & {$\left[\mathrm{Fe}\left(\mathrm{H}_{2}\right)\left(\mathrm{Cp}^{*}\right)(\mathrm{dppe})\right]^{+}$} & MH & $4-\mathrm{NO}_{2} \mathrm{C}_{6} \mathrm{H}_{4} \mathrm{OH}$ & $\mathrm{MH}+2 \mathrm{HY} \rightleftharpoons\left[\mathrm{MH}_{2}\right][\mathrm{YHY}]$ & $\mathrm{CD}_{2} \mathrm{Cl}_{2}$ & 200 & $11^{c}$ & 9 & 220 \\
\hline 103 & {$\left[\mathrm{Ru}\left(\mathrm{H}_{2}\right)(\mathrm{Cp} *)(\mathrm{dppe})\right]^{+}$} & MH & $4-\mathrm{NO}_{2} \mathrm{C}_{6} \mathrm{H}_{4} \mathrm{OH}$ & $\mathrm{MH}+2 \mathrm{HY} \rightarrow\left[\mathrm{MH}_{2}\right][\mathrm{YHY}]$ & $\mathrm{CD}_{2} \mathrm{Cl}_{2}$ & $<230$ & $11^{c}$ & 9 & 221 \\
\hline 104 & {$\left[\mathrm{Ru}\left(\mathrm{H}_{2}\right)\left(\mathrm{Cp}^{*}\right)(\mathrm{dppe}]^{+}\right.$} & MH & $\left(\mathrm{CF}_{3}\right)_{2} \mathrm{CHOH}$ & $\mathrm{MH}+2 \mathrm{HY} \rightleftharpoons\left[\mathrm{MH}_{2}\right][\mathrm{YHY}]$ & $\mathrm{CD}_{2} \mathrm{Cl}_{2}$ & $<230$ & $18^{c}$ & 9 & 221 \\
\hline 105 & {$\left[\mathrm{Ru}\left(\mathrm{H}_{2}\right) \mathrm{Cp} *\left\{\left(\mathrm{PPh}_{2} \mathrm{C}_{5} \mathrm{H}_{4}\right) \mathrm{Co}\left(\mathrm{C}_{5} \mathrm{H}_{4} \mathrm{PPh}_{2}\right)\right\}\right]^{+2}$} & MH & 2,5-lutidine & {$\left[\mathrm{MH}_{2}\right] \mathrm{Y}+\mathrm{B} \rightarrow \mathrm{MH}+[\mathrm{HB}] \mathrm{Y}$} & $\mathrm{CD}_{2} \mathrm{Cl}_{2}$ & 298 & $<9$ & 9 & 222 \\
\hline 106 & {$\left[\mathrm{Ru}(\mathrm{H})_{2} \mathrm{Cp} *\left\{\left(\mathrm{PPh}_{2} \mathrm{C}_{5} \mathrm{H}_{4}\right) \mathrm{Co}\left(\mathrm{C}_{5} \mathrm{H}_{4} \mathrm{PPh}_{2}\right)\right\}\right]^{+2}$} & MH & $\mathrm{NEt}_{3}$ & {$\left[\mathrm{MH}_{2}\right] \mathrm{Y}+\mathrm{B} \rightleftharpoons \mathrm{MH}+[\mathrm{HB}] \mathrm{Y}$} & $\mathrm{CD}_{2} \mathrm{Cl}_{2}$ & 298 & 13 & 9 & 222 \\
\hline 107 & {$\left[\mathrm{Ru}(\mathrm{H})_{2}(\mathrm{Cp} *)(\mathrm{dppe})\right]^{+}$} & MH & $\left.\left[\mathrm{PhMeC}=\mathrm{NC}_{4} \mathrm{H}_{8}\right)\right] \mathrm{BF}_{4}$ & $\mathrm{MH}+[\mathrm{HB}] \mathrm{Y} \rightleftharpoons\left[\mathrm{MH}_{2}\right] \mathrm{Y}+\mathrm{B}$ & $\mathrm{CD}_{2} \mathrm{Cl}_{2}$ & 298 & 11.0 & 9 & 169 \\
\hline 108 & {$\left[\mathrm{Ru}(\mathrm{H})_{2}\left(\mathrm{Cp}^{*}\right)(\mathrm{dppe})\right]^{+}$} & MH & $\mathrm{CF}_{3} \mathrm{COOH}$ & $\mathrm{MH}+\mathrm{HY} \rightarrow\left[\mathrm{MH}_{2}\right] \mathrm{Y}$ & $\mathrm{CD}_{2} \mathrm{Cl}_{2}$ & 193 & & 9 & 221 \\
\hline 109 & {$\left[\mathrm{Ru}(\mathrm{H})_{2}(\mathrm{Cp} *)(\mathrm{dppe})\right]^{+}$} & MH & {$\left[\mathrm{Ru}\left(\mathrm{H}_{2}\right)(\mathrm{Cp})(\mathrm{dppm})\right] \mathrm{BF}_{4}$} & $\mathrm{MH}+\left[\mathrm{M}^{\prime} \mathrm{H}_{2}\right] \mathrm{Y} \rightleftharpoons\left[\mathrm{MH}_{2}\right] \mathrm{Y}+\mathrm{M}^{\prime} \mathrm{H}$ & THF & 298 & 11.0 & 9 & 169 \\
\hline 110 & {$\left[\mathrm{Os}(\mathrm{H})_{2}\left(\mathrm{Cp}^{*}\right)(\mathrm{dppe})\right]^{+}$} & MH & $\mathrm{CF}_{3} \mathrm{CH}_{2} \mathrm{OH}$ & $\mathrm{MH}+2 \mathrm{HY} \rightleftharpoons\left[\mathrm{MH}_{2}\right][\mathrm{YHY}]$ & $\mathrm{CD}_{2} \mathrm{Cl}_{2}$ & 230 & $24^{c}$ & 11 & 223 \\
\hline 111 & {$\left[\mathrm{Ru}\left(\mathrm{H}_{2}\right)(\mathrm{Cp})\left(\mathrm{P}^{\mathrm{i}} \mathrm{Pr}_{2} \mathrm{NHC}_{6} \mathrm{H}_{10} \mathrm{NHP}^{\mathrm{i}} \mathrm{Pr}_{2}\right)\right]^{+}$} & MH & $\mathrm{PhCOOH}$ & $\mathrm{MH}+\mathrm{HY} \rightleftharpoons\left[\mathrm{MH}_{2}\right] \mathrm{Y}$ & toluene & 298 & $11^{c}$ & 10 & 224 \\
\hline 112 & {$\left[\mathrm{Ru}\left(\mathrm{H}_{2}\right)(\mathrm{Cp})\left(\mathrm{P}^{\mathrm{i}} \mathrm{Pr}_{2} \mathrm{NHC}_{6} \mathrm{H}_{10} \mathrm{NHP}^{\mathrm{i}} \mathrm{Pr}_{2}\right)\right]^{+}$} & MH & $\left(\mathrm{CF}_{3}\right)_{2} \mathrm{CHOH}$ & $\mathrm{MH}+\mathrm{HY} \rightleftharpoons\left[\mathrm{MH}_{2}\right] \mathrm{Y}$ & $\mathrm{CD}_{2} \mathrm{Cl}_{2}$ & 298 & $18^{c}$ & 10 & 224 \\
\hline 113 & {$\left[\mathrm{Fe}\left(\mathrm{H}_{2}\right)(\mathrm{Cp})(\mathrm{PPh}-\mathrm{NPh}-\mathrm{PPh}-\mathrm{NPh})\right]^{+}$} & $\mathrm{MH}$ & DBU & {$\left[\mathrm{MH}_{2}\right] \mathrm{Y}+\mathrm{B} \rightarrow \mathrm{MH}+[\mathrm{HB}] \mathrm{Y}$} & $\mathrm{PhF}$ & 298 & 22.0 & 10 & 170 \\
\hline 114 & & MH & $\mathrm{N}^{\mathrm{i}} \mathrm{Pr}_{2} \mathrm{Et}$ & {$\left[\mathrm{MH}_{2}\right] \mathrm{Y}+\mathrm{B} \rightarrow \mathrm{MH}+[\mathrm{HB}] \mathrm{Y}$} & $\mathrm{CD}_{2} \mathrm{Cl}_{2}$ & 298 & & $<12$ & 225 \\
\hline 115 & $\begin{array}{l}{\left[(\mathrm{CO})_{2}\left(\mathrm{PMe}_{3}\right) \mathrm{Fe}(\mu-\mathrm{H})\left(\mu-\mathrm{SCH}_{2} \mathrm{NBnCH}_{2} \mathrm{~S}\right)\right.} \\
\left.\mathrm{Fe}(\mathrm{CO})_{2}\left(\mathrm{PMe}_{3}\right)\right]^{+}\end{array}$ & $\mathrm{MM}$ & $\mathrm{HCl}$ & $\mathrm{MM}+\mathrm{HCl} \rightarrow[\mathrm{MHM}] \mathrm{Cl}$ & $\mathrm{CH}_{3} \mathrm{CN}$ & 298 & 15 & & 226 \\
\hline 116 & {$\left[\mathrm{Ru}(\mathrm{H})_{2}\left(\mathrm{Cp}^{*}\right)\left(\mathrm{PMe}_{2} \mathrm{Ph}\right)_{2}\right]^{+}$} & MH & {$\left[\mathrm{RuH}\left(\mathrm{Cp}^{*}\right)\left(\mathrm{PMePh}_{2}\right)_{2}\right] \mathrm{BF}_{4}$} & $\mathrm{MH}+\left[\mathrm{M}^{\prime} \mathrm{H}_{2}\right] \mathrm{Y} \rightleftharpoons\left[\mathrm{MH}_{2}\right] \mathrm{Y}+\mathrm{M}^{\prime} \mathrm{H}$ & THF & 298 & 14 & 11 & 7,90 \\
\hline 117 & {$\left[\mathrm{Ru}_{3}(\mathrm{H})_{6}\left(\mathrm{Cp}^{*}\right)_{3}\right]^{+}$} & $\mathrm{M}_{3} \mathrm{H}_{5}$ & $\mathrm{NH}_{3}$ & {$\left[\mathrm{M}_{3} \mathrm{H}_{6}\right] \mathrm{Y}+\mathrm{B} \rightleftharpoons \mathrm{M}_{3} \mathrm{H}_{5}+[\mathrm{HB}] \mathrm{Y}$} & THF & 298 & 11 & & 176 \\
\hline 118 & {$\left[\mathrm{Ru}_{3}(\mathrm{H})_{6}\left(\mathrm{Cp}^{*}\right)_{3}\right]^{+}$} & $\mathrm{M}_{3} \mathrm{H}_{5}$ & $\mathrm{PhCOOH}$ & $\mathrm{M}_{3} \mathrm{H}_{5}+\mathrm{HY} \rightleftharpoons\left[\mathrm{M}_{3} \mathrm{H}_{6}\right] \mathrm{Y}$ & THF & 298 & 21 & & 175 \\
\hline
\end{tabular}




\begin{tabular}{|c|c|}
\hline 119 & {$\left[\mathrm{Os}_{3}(\mathrm{H})_{6}\left(\mathrm{Cp}^{*}\right)_{3}\right]^{+}$} \\
\hline 120 & {$\left[\mathrm{Ru}(\mathrm{H})_{2}(\mathrm{Cp})\left(\mathrm{PMe}_{3}\right)_{2}\right]^{+}$} \\
\hline 121 & {$\left[\mathrm{Ru}(\mathrm{H})_{2}(\mathrm{Cp})(\mathrm{dmpe})\right]^{+}$} \\
\hline 122 & {$\left[\mathrm{Fe}\left(\mathrm{H}_{2}\right) \mathrm{H}(\mathrm{dppe})_{2}\right]^{+}$(trans) } \\
\hline 123 & {$\left[\mathrm{Ru}\left(\mathrm{H}_{2}\right) \mathrm{H}(\mathrm{dppe})_{2}\right]^{+}$(trans) } \\
\hline 124 & {$\left[\mathrm{Os}\left(\mathrm{H}_{2}\right) \mathrm{H}\left(\mathrm{dppe}_{2}\right]^{+}\right.$(trans) } \\
\hline 125 & {$\left[\mathrm{Ru}\left(\mathrm{H}_{2}\right) \mathrm{H}(\mathrm{dppp})_{2}\right]^{+}($trans $)$} \\
\hline $\begin{array}{l}126 \\
127\end{array}$ & $\begin{array}{l}{\left[\mathrm{Os}(\mathrm{H})_{3}(\mathrm{dppp})_{2}\right]^{+}} \\
{\left[\mathrm{Fe}\left(\mathrm{H}_{2}\right)(\mathrm{CpMe})\left(\mathrm{P}^{t} \mathrm{Bu}-\mathrm{N}-\mathrm{P}^{t} \mathrm{Bu}-\mathrm{N}-\right)\right]^{+}}\end{array}$ \\
\hline 128 & {$\left[\mathrm{Ru}\left(\mathrm{H}_{2}\right)\left(\mathrm{PCy}_{3}\right)\left({ }^{\prime} \mathrm{S}_{4}{ }^{\prime}\right)\right]$} \\
\hline 129 & {$\left[\mathrm{Ru}(\mathrm{H})_{2}\left(\mathrm{Cp}^{*}\right)\left(\mathrm{PMe}_{3}\right)_{2}\right]^{+}$} \\
\hline 130 & {$\left[\mathrm{Ru}(\mathrm{H})_{2}(\mathrm{Cp} *)(\mathrm{dmpe})\right]^{+}$} \\
\hline 131 & {$\left[\mathrm{OsH}_{2}\left(\mathrm{Cp}-\mathrm{NMe}_{2}\right)\left(\mathrm{P}^{\mathrm{i}} \mathrm{Pr}_{3}\right)_{2}\right]^{+}$} \\
\hline 132 & {$\left[\mathrm{OsH}_{3}\left(\mathrm{PPh}_{2} \mathrm{Me}\right)_{4}\right]^{+}$} \\
\hline 133 & {$\left[\mathrm{OsH}_{3}\left(\mathrm{PPh}_{2} \mathrm{Me}\right)_{4}\right]^{+}$} \\
\hline 134 & {$\left[\mathrm{Ru}\left(\mathrm{H}_{2}\right) \mathrm{H}(\text { dape })_{2}\right]^{+}$} \\
\hline 135 & $\begin{array}{l}{[(\mathrm{dppv})(\mathrm{H}) \mathrm{Fe}(\mu-\mathrm{CO})(\mu-} \\
\left.\left.\mathrm{SCH}_{2} \mathrm{NHCH}_{2} \mathrm{~S}\right) \mathrm{Fe}(\mathrm{CO})(\mathrm{dppv})\right]^{+}\end{array}$ \\
\hline 136 & {$\left[\mathrm{RuH}\left(\mathrm{C}_{6} \mathrm{Me}_{6}\right)(\mathrm{bpy})\right]^{+}$} \\
\hline 137 & {$\left[\mathrm{OsH}_{3}\left(\mathrm{PMe}_{2} \mathrm{Ph}\right)_{4}\right]^{+}$} \\
\hline 138 & {$\left[\mathrm{OsH}_{3}\left(\mathrm{PMe}_{2} \mathrm{Ph}\right)_{4}\right]^{+}$} \\
\hline 139 & $\mathrm{FeH}(\mathrm{CO})_{2}\left\{\mathrm{C}_{6} \mathrm{H}_{4} \mathrm{OP}(\mathrm{OPh})_{2}\right\}\left(\mathrm{P}(\mathrm{OPh})_{3}\right)$ \\
\hline 140 & $\mathrm{FeH}_{2}(\mathrm{CO})_{4}$ \\
\hline 141 & $\mathrm{RuH}_{2}(\mathrm{CO})_{4}$ \\
\hline 142 & $\mathrm{OsH}_{2}(\mathrm{CO})_{4}$ \\
\hline $\begin{array}{l}143 \\
144\end{array}$ & $\begin{array}{l}\mathrm{Ru}_{4} \mathrm{H}_{4}(\mathrm{CO})_{10}\left(\mathrm{P}(\mathrm{OMe})_{3}\right)_{2} \\
{\left[\mathrm{Ru}\left(\mathrm{H}_{2}\right)(\text { cymene })(\text { Tsdpen })\right]^{+}}\end{array}$ \\
\hline 145 & {$\left[\mathrm{FeH}_{3}\left(\mathrm{PMe}_{3}\right)_{4}\right]^{+}$} \\
\hline 146 & {$\left[\mathrm{Ru}\left(\mathrm{H}_{2}\right) \mathrm{H}\left(\mathrm{PMe}_{3}\right)_{4}\right]^{+}$(cis) } \\
\hline 147 & {$\left[\mathrm{OsH}_{3}\left(\mathrm{PMe}_{3}\right)_{4}\right]^{+}$} \\
\hline 148 & {$\left[\mathrm{RuH}_{3}\left(\mathrm{PEt}_{3}\right)_{4}\right]^{+}$} \\
\hline
\end{tabular}

\begin{tabular}{|c|c|c|c|c|c|c|c|}
\hline $\mathrm{M}_{3} \mathrm{H}_{5}$ & {$\left[\mathrm{HNEt}_{3}\right] \mathrm{BF}_{4}$} & $\mathrm{M}_{3} \mathrm{H}_{5}+[\mathrm{HB}] \mathrm{Y} \rightarrow\left[\mathrm{M}_{3} \mathrm{H}_{6}\right] \mathrm{Y}+\mathrm{B}$ & THF & 298 & $>13$ & & 176 \\
\hline $\begin{array}{l}\text { MH } \\
\text { MH }\end{array}$ & $\begin{array}{l}\text { proton sponge } \\
\mathrm{NEt}_{3}\end{array}$ & $\begin{array}{l}{\left[\mathrm{MH}_{2}\right] \mathrm{Y}+\mathrm{B} \rightleftharpoons \mathrm{MH}+[\mathrm{HB}] \mathrm{Y}} \\
{\left[\mathrm{MH}_{2}\right] \mathrm{Y}+\mathrm{B} \rightleftharpoons \mathrm{MH}+[\mathrm{HB}] \mathrm{Y}}\end{array}$ & $\begin{array}{l}\mathrm{CD}_{2} \mathrm{Cl}_{2} \\
\mathrm{CH}_{3} \mathrm{CN}\end{array}$ & $\begin{array}{l}298 \\
298\end{array}$ & $\begin{array}{l}13.9 \\
17.6\end{array}$ & $\begin{array}{r}12 \\
12 \\
\left(17^{e}\right)\end{array}$ & $\begin{array}{l}227 \\
30\end{array}$ \\
\hline $\mathrm{MH}_{2}$ & $\mathrm{NEt}_{3}$ & {$\left[\mathrm{MH}_{3}\right] \mathrm{Y}+\mathrm{B} \rightleftharpoons \mathrm{MH}_{2}+[\mathrm{HB}] \mathrm{Y}$} & THF & 298 & 12 & 12 & $7-8$ \\
\hline $\mathrm{MH}_{2}$ & {$\left[\mathrm{Ru}(\mathrm{H})_{2}\left(\mathrm{Cp}^{*}\right)\left(\mathrm{PMe}_{2} \mathrm{Ph}\right)_{2}\right]^{+}$} & {$\left[\mathrm{MH}_{3}\right] \mathrm{Y}+\mathrm{M}^{\prime} \mathrm{H} \rightleftharpoons \mathrm{MH}_{2}+\left[\mathrm{M}^{\prime} \mathrm{H}_{2}\right] \mathrm{Y}$} & THF & 298 & 14 & 12 & 7 \\
\hline $\mathrm{MH}_{2}$ & {$\left[\mathrm{RuH}_{2}\left(\mathrm{Cp}^{*}\right)\left(\mathrm{PMePh}_{2}\right)_{2}\right] \mathrm{BPh}_{4}$} & $\mathrm{MH}_{2}+\left[\mathrm{M}^{\prime} \mathrm{H}_{2}\right] \mathrm{Y} \rightleftharpoons\left[\mathrm{MH}_{3}\right] \mathrm{Y}+\mathrm{M}^{\prime} \mathrm{H}$ & THF & 298 & 12 & 14 & 7 \\
\hline $\mathrm{MH}_{2}$ & $\mathrm{NEt}_{3}$ & {$\left[\mathrm{MH}_{3}\right] \mathrm{Y}+\mathrm{B} \rightleftharpoons \mathrm{MH}_{2}+[\mathrm{HB}] \mathrm{Y}$} & $\mathrm{CH}_{2} \mathrm{Cl}_{2}$ & 298 & 10.2 & 12 & 153 \\
\hline $\begin{array}{l}\mathrm{MH}_{2} \\
\mathrm{MH}\end{array}$ & $\begin{array}{l}\mathrm{NEt}_{3} \\
\mathrm{NEt}_{3}\end{array}$ & $\begin{array}{l}{\left[\mathrm{MH}_{3}\right] \mathrm{Y}+\mathrm{B} \rightleftharpoons \mathrm{MH}_{2}+[\mathrm{HB}] \mathrm{Y}} \\
{\left[\mathrm{MH}_{2}\right] \mathrm{Y}+\mathrm{B} \rightleftharpoons \mathrm{MH}+[\mathrm{HB}] \mathrm{Y}}\end{array}$ & $\begin{array}{l}\mathrm{CH}_{2} \mathrm{Cl}_{2} \\
\mathrm{CH}_{3} \mathrm{CN}\end{array}$ & $\begin{array}{l}298 \\
298\end{array}$ & $\begin{array}{l}10.3 \\
18.9\end{array}$ & $\begin{array}{r}14 \\
12 \\
\left(17^{e}\right)\end{array}$ & $\begin{array}{l}153 \\
171\end{array}$ \\
\hline MH & $\mathrm{CD}_{3} \mathrm{OD}$ & $\mathrm{Z}[\mathrm{MH}]+\mathrm{HY} \rightleftharpoons \mathrm{M}\left(\mathrm{H}_{2}\right)+\mathrm{ZY}$ & THF & 223 & 16 & & 228 \\
\hline MH & {$\left[\mathrm{Ru}(\mathrm{H})_{2}\left(\mathrm{Cp}^{*}\right)\left(\mathrm{PMe}_{2} \mathrm{Ph}\right)_{2}\right] \mathrm{BPh}_{4}$} & $\mathrm{MH}+\left[\mathrm{M}^{\prime} \mathrm{H}_{2}\right] \mathrm{Y} \rightleftharpoons\left[\mathrm{MH}_{2}\right] \mathrm{Y}+\mathrm{M}^{\prime} \mathrm{H}$ & THF & 298 & 17 & 13 & 7 \\
\hline MH & {$\left[\mathrm{Ru}(\mathrm{H})_{2}\left(\mathrm{Cp}^{*}\right)\left(\mathrm{PMe}_{2} \mathrm{Ph}\right)_{2}\right] \mathrm{BPh}_{4}$} & $\mathrm{MH}+\left[\mathrm{M}^{\prime} \mathrm{H}_{2}\right] \mathrm{Y} \rightleftharpoons\left[\mathrm{MH}_{2}\right] \mathrm{Y}+\mathrm{M}^{\prime} \mathrm{H}$ & THF & 298 & 14.6 & 13 & 169 \\
\hline MH & {$\left[\mathrm{HNEt}_{3}\right] \mathrm{BPh}_{4}$} & $\mathrm{MH}+[\mathrm{HB}] \mathrm{Y} \rightarrow\left[\mathrm{MH}_{2}\right] \mathrm{Y}+\mathrm{B}$ & $\mathrm{CD}_{2} \mathrm{Cl}_{2}$ & 298 & $>13$ & 14 & 172 \\
\hline $\mathrm{MH}_{2}$ & $\mathrm{NEt}_{3}$ & {$\left[\mathrm{MH}_{3}\right] \mathrm{Y}+\mathrm{B} \rightleftharpoons \mathrm{MH}_{2}+[\mathrm{HB}] \mathrm{Y}$} & THF & 298 & 12.4 & 14 & 7 \\
\hline $\mathrm{MH}_{2}$ & $\mathrm{CF}_{3} \mathrm{SO}_{3} \mathrm{H}$ & $\mathrm{MH}_{2}+\mathrm{HY} \rightarrow\left[\mathrm{MH}_{3}\right] \mathrm{Y}$ & DCE & 298 & 11.8 & 14 & 8,29 \\
\hline $\begin{array}{l}\mathrm{MH}_{2} \\
\mathrm{MM}\end{array}$ & {$\left[\mathrm{Ru}\left(\mathrm{Cp}^{*}\right)(\mathrm{H})_{2}(\mathrm{PMe})_{2}\right]^{+}$} & $\mathrm{MH}_{2}+\left[\mathrm{M}^{\prime} \mathrm{H}_{2}\right] \mathrm{Y} \rightleftharpoons\left[\mathrm{M}\left(\mathrm{H}_{2}\right) \mathrm{H}\right] \mathrm{Y}+\mathrm{M}^{\prime} \mathrm{H}$ & $\begin{array}{l}\mathrm{THF} \\
\mathrm{CH}_{2} \mathrm{Cl}_{2}\end{array}$ & $\begin{array}{l}298 \\
298\end{array}$ & $\begin{array}{r}17 \\
15.5\end{array}$ & 16 & $\begin{array}{l}7,91 \\
34\end{array}$ \\
\hline MH & TMG & {$[\mathrm{MH}] \mathrm{Y}+\mathrm{B} \rightleftharpoons \mathrm{M}+[\mathrm{HB}] \mathrm{Y}$} & $\mathrm{CH}_{3} \mathrm{CN}$ & 298 & 23 & $\begin{array}{r}16 \\
\left(22^{e}\right)\end{array}$ & 183 \\
\hline $\mathrm{MH}_{2}$ & $\mathrm{NEt}_{3}$ & {$\left[\mathrm{MH}_{3}\right] \mathrm{Y}+\mathrm{B} \rightleftharpoons \mathrm{MH}_{2}+[\mathrm{HB}] \mathrm{Y}$} & THF & 298 & 14.7 & 18 & 7 \\
\hline $\mathrm{MH}_{2}$ & $\mathrm{CF}_{3} \mathrm{SO}_{3} \mathrm{H}$ & $\mathrm{MH}_{2}+\mathrm{HY} \rightarrow\left[\mathrm{MH}_{3}\right] \mathrm{Y}$ & DCE & 298 & 14.7 & 18 & 7,229 \\
\hline$[\mathrm{M}]-$ & DBU & $\mathrm{MH}+\mathrm{B} \rightarrow[\mathrm{HB}][\mathrm{M}]$ & THF & 298 & & $<19$ & 230 \\
\hline$[\mathrm{MH}]-$ & aniline & $\mathrm{MH}_{2}+\mathrm{B} \rightleftharpoons[\mathrm{HB}][\mathrm{MH}]$ & $\mathrm{CH}_{3} \mathrm{CN}$ & 253 & 11.4 & 20 & 51 \\
\hline$[\mathrm{MH}]-$ & morpholine & $\mathrm{MH}_{2}+\mathrm{B} \rightleftharpoons[\mathrm{HB}][\mathrm{MH}]$ & $\mathrm{CH}_{3} \mathrm{CN}$ & 253 & 20 & 20 & 51 \\
\hline$[\mathrm{MH}]-$ & $\mathrm{NEt}_{3}$ & $\mathrm{MH}_{2}+\mathrm{B} \rightleftharpoons[\mathrm{HB}][\mathrm{MH}]$ & $\mathrm{CH}_{3} \mathrm{CN}$ & 298 & 21 & 22 & 51231 \\
\hline $\begin{array}{l}{\left[\mathrm{M}_{4} \mathrm{H}_{3}\right]-} \\
\mathrm{MH}\end{array}$ & $\begin{array}{l}\text { pyridine } \\
{\left[\mathrm{NH}_{4}\right] \mathrm{BF}_{4}}\end{array}$ & $\begin{array}{l}\mathrm{M}_{4} \mathrm{H}_{4}+\mathrm{B} \rightleftharpoons[\mathrm{HB}]\left[\mathrm{M}_{4} \mathrm{H}_{3}\right] \\
\mathrm{MH}+[\mathrm{HB}] \mathrm{Y} \rightleftharpoons\left[\mathrm{MH}_{2}\right] \mathrm{Y}+\mathrm{B}\end{array}$ & $\begin{array}{l}\mathrm{CH}_{3} \mathrm{CN} \\
\mathrm{CH}_{3} \mathrm{CN}\end{array}$ & $\begin{array}{l}298 \\
298\end{array}$ & $\begin{array}{l}15.4 \\
16.1\end{array}$ & $\begin{array}{r}8.5 \\
\left(13^{e}\right)\end{array}$ & $\begin{array}{l}1 \\
232\end{array}$ \\
\hline $\mathrm{MH}_{2}$ & {$\left[\mathrm{OsH}_{3}\left(\mathrm{PMe}_{3}\right)_{4}\right] \mathrm{BPh}_{4}$} & $\mathrm{MH}_{2}+\left[\mathrm{M}^{\prime} \mathrm{H}_{3}\right] \mathrm{Y} \rightleftharpoons\left[\mathrm{MH}_{3}\right] \mathrm{Y}+\mathrm{M}^{\prime} \mathrm{H}_{2}$ & THF & 298 & 16 & 20 & 7,195 \\
\hline $\mathrm{MH}_{2}$ & {$\left[\mathrm{OsH}_{3}\left(\mathrm{PMe}_{3}\right)_{4}\right] \mathrm{BPh}_{4}$} & $\mathrm{MH}_{2}+\left[\mathrm{M}^{\prime} \mathrm{H}_{3}\right] \mathrm{Y} \rightleftharpoons\left[\mathrm{M}\left(\mathrm{H}_{2}\right) \mathrm{H}\right] \mathrm{Y}+\mathrm{M}^{\prime} \mathrm{H}_{2}$ & THF & 298 & 17 & 20 & 7 \\
\hline $\mathrm{MH}_{2}$ & {$\left[\mathrm{OsH}_{2}\left(\mathrm{PMe}_{2} \mathrm{Ph}\right)_{4}\right.$} & {$\left[\mathrm{MH}_{3}\right] \mathrm{Y}+\mathrm{M}^{\prime} \mathrm{H}_{2} \rightleftharpoons \mathrm{MH}_{2}+\left[\mathrm{M}^{\prime} \mathrm{H}_{3}\right] \mathrm{Y}$} & THF & 298 & 17 & 22 & 7 \\
\hline $\mathrm{MH}_{2}$ & {$\left[\mathrm{OsH}_{3}\left(\mathrm{PMe}_{3}\right)_{4}\right] \mathrm{BPh}_{4}$} & $\mathrm{MH}_{2}+\left[\mathrm{M}^{\prime} \mathrm{H}_{3}\right] \mathrm{Y} \rightleftharpoons\left[\mathrm{MH}_{3}\right] \mathrm{Y}+\mathrm{M}^{\prime} \mathrm{H}_{2}$ & THF & 298 & 17 & 20 & 7,195 \\
\hline
\end{tabular}




\begin{tabular}{|c|c|c|c|c|c|c|c|c|c|}
\hline 149 & {$\left[\mathrm{OsH}_{3}\left(\mathrm{PEt}_{3}\right)_{4}\right]^{+}$} & $\mathrm{MH}_{2}$ & {$\left[\mathrm{OsH}_{3}\left(\mathrm{PMe}_{3}\right)_{4}\right] \mathrm{BPh}_{4}$} & $\mathrm{MH}_{2}+\left[\mathrm{M}^{\prime} \mathrm{H}_{3}\right] \mathrm{Y} \rightleftharpoons\left[\mathrm{MH}_{3}\right] \mathrm{Y}+\mathrm{M}^{\prime} \mathrm{H}_{2}$ & THF & 298 & 19 & 22 & 7 \\
\hline 150 & {$\left[\mathrm{Fe}\left(\mathrm{H}_{2}\right)\left\{\mathrm{Si}\left(\mathrm{C}_{6} \mathrm{H}_{4} \mathrm{P}^{\mathrm{i}} \mathrm{Pr}_{2}\right)_{3}\right\}\right]^{+}$} & MH & proton sponge & {$\left[\mathrm{MH}_{2}\right] \mathrm{Y}+\mathrm{B} \rightleftharpoons \mathrm{MH}+[\mathrm{HB}] \mathrm{Y}$} & THF & 298 & 16 & 16 & 196 \\
\hline 151 & {$\left[\mathrm{FeH}(\mathrm{CN})_{2}(\mathrm{CO})_{3}\right]-$} & {$[\mathrm{M}]-$} & $\mathrm{NH}_{4} \mathrm{PF}_{6}$ & $\mathrm{Z}_{2}[\mathrm{M}]+[\mathrm{HB}] \mathrm{Y} \rightarrow \mathrm{Z}[\mathrm{MH}]+\mathrm{B}+\mathrm{ZY}$ & $\mathrm{CH}_{3} \mathrm{CN}$ & 298 & $>17$ & & 213,233 \\
\hline 152 & {$\left[(\mathrm{CO})_{3} \mathrm{Fe}(\mathrm{H})(\mathrm{CO})\left(\mathrm{SC}_{6} \mathrm{H}_{4} \mathrm{~S}\right) \mathrm{Fe}(\mathrm{CO})_{2}\right]^{2-}$} & $\mathrm{MM}$ & & Electrochemical cycle & $\mathrm{CH}_{3} \mathrm{CN}$ & 298 & 21 & & 234 \\
\hline 153 & {$\left[\mathrm{FeH}\left(\mathrm{N}_{2}\right)\left\{\mathrm{P}\left(\mathrm{CH}_{2} \mathrm{CH}_{2} \mathrm{P}^{\mathrm{i}} \mathrm{Pr}_{2}\right)_{3}\right\}\right]^{+}$} & M & {$\left[2,6-\mathrm{Me}_{2} \mathrm{C}_{6} \mathrm{H}_{3} \mathrm{NH}\right] \mathrm{BF}_{4}$} & $\mathrm{M}+[\mathrm{HB}] \mathrm{Y} \rightarrow[\mathrm{MH}] \mathrm{Y}+\mathrm{B}$ & THF & 298 & & 24 & 235 \\
\hline 154 & {$\left[\mathrm{FeH}(\mathrm{CO})\left\{\mathrm{P}\left(\mathrm{CH}_{2} \mathrm{CH}_{2} \mathrm{PMe}_{2}\right)_{3}\right\}\right]^{+}$} & M & $\mathrm{KO}^{\mathrm{t}} \mathrm{Bu}$ & {$[\mathrm{MH}] \mathrm{Y}+\mathrm{KY} \rightarrow \mathrm{M}+\mathrm{KY}+\mathrm{HY}$} & THF & 298 & & 24 & 158 \\
\hline 155 & {$\left[\mathrm{FeH}\left(\mathrm{N}_{2}\right)(\mathrm{dmprpe})_{2}\right]^{+}$} & M & $\mathrm{KO}^{\mathrm{t}} \mathrm{Bu}$ & {$[\mathrm{MH}] \mathrm{Y}+\mathrm{KY} \rightarrow \mathrm{M}+\mathrm{KY}+\mathrm{HY}$} & THF & 298 & & 24 & 236 \\
\hline 156 & {$\left[\mathrm{RuH}\left(\mathrm{N}_{2}\right)\left\{\mathrm{P}\left(\mathrm{CH}_{2} \mathrm{CH}_{2} \mathrm{P}^{\mathrm{i}} \mathrm{Pr}_{2}\right)_{3}\right\}\right]^{+}$} & M & {$\left[2,6-\mathrm{Me}_{2} \mathrm{C}_{6} \mathrm{H}_{3} \mathrm{NH}\right] \mathrm{BF}_{4}$} & $\mathrm{M}+[\mathrm{HB}] \mathrm{Y} \rightarrow[\mathrm{MH}] \mathrm{Y}+\mathrm{B}$ & THF & 298 & & 24 & 235 \\
\hline 157 & {$[\mathrm{RuH}(\mathrm{tpy})(\mathrm{bpy})]^{+}$} & $\mathrm{M}$ & $\begin{array}{l}\mathrm{P}\left(\mathrm{NMeCH}_{2} \mathrm{CH}_{2}\right)_{3} \mathrm{~N} \\
\text { proazaphosphatrane }\end{array}$ & {$[\mathrm{MH}] \mathrm{Y}+\mathrm{B} \rightarrow \mathrm{M}+[\mathrm{HB}] \mathrm{Y}$} & $\mathrm{CH}_{3} \mathrm{CN}$ & 298 & $<33$ & 26 & 183 \\
\hline 158 & Os( $\left.\mathrm{H}_{2}\right)($ octaethylporphyrin)(THF) & {$[\mathrm{MH}]-$} & $\mathrm{LiN}^{\mathrm{i}} \mathrm{Pr}_{2}$ & $\mathrm{MH}_{2}+\mathrm{ZY} \rightarrow \mathrm{Z}[\mathrm{MH}]+\mathrm{HY}$ & THF & 298 & $f$ & & 186 \\
\hline 159 & $\mathrm{FeH}(\mathrm{CO})_{2}(\mathrm{Cp})$ & {$[\mathrm{M}]-$} & & electrochemistry simulation & $\mathrm{CH}_{3} \mathrm{CN}$ & 298 & 27.5 & 30 & 57 \\
\hline 160 & $\mathrm{FeH}(\mathrm{CO})_{2} \mathrm{Cp}$ & {$[\mathrm{M}]-$} & $\begin{array}{l}\text { 1,5,7 triazabicyclo[4.4.0]dec- } \\
\text { 5-ene (TBD) }\end{array}$ & $\mathrm{MH}+\mathrm{B} \rightleftharpoons[\mathrm{HB}][\mathrm{M}]$ & $\mathrm{CH}_{3} \mathrm{CN}$ & 298 & 27 & 30 & 39 \\
\hline 161 & $\mathrm{RuH}(\mathrm{CO})_{2} \mathrm{Cp}$ & {$[\mathrm{M}]-$} & $\begin{array}{l}1,5,7 \text { triazabicyclo[4.4.0]dec- } \\
5 \text {-ene }\end{array}$ & $\mathrm{MH}+\mathrm{B} \rightleftharpoons[\mathrm{HB}] \mathrm{M}$ & $\mathrm{CH}_{3} \mathrm{CN}$ & 298 & 28 & 30 & 39 \\
\hline 162 & $\mathrm{OsH}(\mathrm{CO})_{2} \mathrm{Cp}$ & {$[\mathrm{M}]-$} & $\begin{array}{l}\mathrm{P}\left(\mathrm{N}^{i} \mathrm{BuCH}_{2} \mathrm{CH}_{2}\right)_{3} \mathrm{~N} \text { Verkade's } \\
\text { superbase }\end{array}$ & $\mathrm{MH}+\mathrm{B} \rightleftharpoons[\mathrm{HB}][\mathrm{M}]$ & $\mathrm{CH}_{3} \mathrm{CN}$ & 298 & 33 & 32 & 237 \\
\hline 163 & {$\left[\mathrm{Fe}(\mathrm{H})\left({ }^{\mathrm{t}} \mathrm{BuSi}\left(\mathrm{CH}_{2} \mathrm{PMe}_{2}\right)_{3}\right)(\mathrm{dmpe})\right]^{+}$} & M & $\mathrm{CH}_{3} \mathrm{COOEt}$ & $\mathrm{M}+\mathrm{HY} \rightleftharpoons[\mathrm{MH}] \mathrm{Y}$ & $\mathrm{C}_{6} \mathrm{D}_{6}$ & 298 & & 30 & 197 \\
\hline 164 & $\mathrm{FeH}(\mathrm{CO})_{2} \mathrm{Cp}^{*}$ & {$[\mathrm{M}]-$} & {$\left[\mathrm{ReH}_{6}\left(\mathrm{PPh}_{3}\right)_{2}\right]-$} & $\mathrm{Z}\left[\mathrm{MH}_{6}\right]+\mathrm{M}^{\prime} \mathrm{H} \rightleftharpoons \mathrm{MH}_{7}+\mathrm{Z}\left[\mathrm{M}^{\prime}\right]$ & THF & 298 & 31 & 31 & $7-8$ \\
\hline 165 & $\mathrm{RuH}_{2}\left(\mathrm{H}_{2}\right)(\mathrm{CO})\left(\mathrm{PiPr}_{3}\right)_{2}$ & {$\left[\mathrm{MH}_{3}\right]-$} & $\mathrm{ReH}_{7}\left(\mathrm{PCy}_{3}\right)_{2}$ & $\mathrm{Z}\left[\mathrm{MH}_{3}\right]+\mathrm{M}^{\prime} \mathrm{H}_{7} \rightleftharpoons \mathrm{MH}_{4}+\mathrm{Z}\left[\mathrm{M}^{\prime} \mathrm{H}_{6}\right]$ & THF & 298 & 38 & 36 & 7 \\
\hline 166 & $\mathrm{Os}\left(\mathrm{H}_{2}\right)(\mathrm{H})_{2}(\mathrm{CO})\left(\mathrm{P}^{\mathrm{i}} \mathrm{Pr}_{3}\right)_{2}$ & {$\left[\mathrm{MH}_{3}\right]-$} & $\mathrm{OsH}_{6}\left(\mathrm{PiPr}_{3}\right)_{2}$ & $\mathrm{Z}\left[\mathrm{MH}_{3}\right]+\mathrm{M}^{\prime} \mathrm{H}_{6} \rightleftharpoons \mathrm{MH}_{4}+\mathrm{Z}\left[\mathrm{M}^{\prime} \mathrm{H}_{5}\right]$ & THF & 298 & 36 & 38 & 7 \\
\hline 167 & $\mathrm{FeH}_{2}(\mathrm{CO})_{2}\left(\mathrm{PBu}_{3}\right)_{2}$ & {$[\mathrm{MH}]-$} & $\mathrm{KH}$ & $\mathrm{MH}+\mathrm{KH} \rightarrow \mathrm{K}\{\mathrm{M}]+\mathrm{H}_{2}$ & THF & 298 & & 38 & 238 \\
\hline 168 & $\mathrm{RuH}_{2}\left(\mathrm{H}_{2}\right)\left(\mathrm{PPh}_{3}\right)_{3}$ & {$\left[\mathrm{MH}_{3}\right]-$} & $\mathrm{OsH}_{6}\left(\mathrm{P}^{\mathrm{i}} \mathrm{Pr}_{3}\right)_{2}$ & $\mathrm{Z}\left[\mathrm{MH}_{3}\right]+\mathrm{M}^{\prime} \mathrm{H}_{6} \rightleftharpoons \mathrm{MH}_{4}+\mathrm{Z}\left[\mathrm{M}^{\prime} \mathrm{H}_{5}\right]$ & THF & 298 & 36 & 39 & 7 \\
\hline 169 & $\mathrm{RuH}_{2}\left(\mathrm{H}_{2}\right)_{2}\left(\mathrm{P}^{\mathrm{i}} \mathrm{Pr}_{3}\right)_{2}$ & {$\left[\mathrm{MH}_{3}\right]-$} & $\mathrm{OsH}_{4}(\mathrm{CO})\left(\mathrm{P}^{\mathrm{i}} \mathrm{Pr}_{3}\right)_{2}$ & $\mathrm{Z}\left[\mathrm{MH}_{5}\right]+\mathrm{M}^{\prime} \mathrm{H}_{4} \rightleftharpoons \mathrm{MH}_{6}+\mathrm{Z}\left[\mathrm{M}^{\prime} \mathrm{H}_{3}\right]$ & THF & 298 & 39 & 41 & 7 \\
\hline 170 & $\mathrm{OsH}_{6}\left(\mathrm{P}^{\mathrm{i}} \mathrm{Pr}_{3}\right)_{2}$ & {$\left[\mathrm{MH}_{5}\right]-$} & $\begin{array}{l}{[\mathrm{K}(2,2,2-} \\
\text { crown })]\left[\mathrm{ReH}_{6}\left(\mathrm{PPh}_{3}\right)_{2}\right]\end{array}$ & $\mathrm{MH}_{6}+\mathrm{Z}\left[\mathrm{M}^{\prime} \mathrm{H}_{6}\right] \rightleftharpoons \mathrm{Z}\left[\mathrm{MH}_{5}\right]+\mathrm{M}^{\prime} \mathrm{H}_{7}$ & THF & 298 & 36 & 43 & 7 \\
\hline 171 & $\mathrm{OsH}_{6}\left(\mathrm{P}^{\mathrm{i}} \mathrm{Pr}_{3}\right)_{2}$ & {$\left[\mathrm{MH}_{5}\right]-$} & $\mathrm{HPPh}_{2}$ & $\mathrm{MH}_{6}+\mathrm{Z}\left[\mathrm{M}^{\prime} \mathrm{H}_{6}\right] \rightleftharpoons \mathrm{Z}\left[\mathrm{MH}_{5}\right]+\mathrm{M}^{\prime} \mathrm{H}_{7}$ & THF & 298 & 36 & 43 & 7 \\
\hline
\end{tabular}

${ }^{a}$ Abbreviations: $\mathrm{pK}_{\mathrm{a}}{ }^{\mathrm{exp}}=$ literature value; $\mathrm{pK}_{\mathrm{a}}{ }^{\mathrm{LAC}}=$ from additivity acidity method; dppm $=\mathrm{PPh}_{2} \mathrm{CH}_{2} \mathrm{PPh}_{2}, \mathrm{dppe}=\mathrm{PPh}_{2} \mathrm{CH}_{2} \mathrm{CH}_{2} \mathrm{PPh}_{2}, \mathrm{dppp}^{\mathrm{P}} \mathrm{PPh}_{2} \mathrm{CH}_{2} \mathrm{CH}_{2} \mathrm{CH}_{2} \mathrm{PPh}_{2}$, tacn $=1,4,7-\mathrm{triazacyclononane}_{2} \mathrm{PPh}-\mathrm{NBn}_{2}$ $\mathrm{PPh}_{2}=\mathrm{PPh}_{2} \mathrm{CH}_{2} \mathrm{CH}_{2} \mathrm{NBnCH}_{2} \mathrm{CH}_{2} \mathrm{PPh}_{2}$, dmpm $=\mathrm{PMe}_{2} \mathrm{CH}_{2} \mathrm{PMe}_{2}$, dcpe $=\mathrm{PCy}_{2} \mathrm{CH}_{2} \mathrm{CH}_{2} \mathrm{PCy}$, $\mathrm{Py} \mathrm{Tstacn}_{2}=\mathrm{TsN}_{2} \mathrm{CH}_{2} \mathrm{CH}_{2} \mathrm{~N}\left(\mathrm{CH}_{2} \mathrm{py}_{4} \mathrm{CH}_{2}-\right\}_{2}, \mathrm{dtfpe}=\left(\left(4-\mathrm{CF}_{3} \mathrm{C}_{6} \mathrm{H}_{4}\right)_{2} \mathrm{PCH}_{2} \mathrm{CH}_{2} \mathrm{P}\left(\mathrm{C}_{6} \mathrm{H}_{4} \mathrm{CF}_{3}\right)_{2}, \mathrm{HBPZ}_{3}=\right.$

hydrotris(pyrazolyl)borate, $\mathrm{PTA}=\mathrm{P}\left(\mathrm{CH}_{2} \mathrm{NCH}_{2}\right)_{3}, \mathrm{Cp}-\mathrm{Cp}=\mathrm{C}_{5} \mathrm{H}_{3}\left(\mathrm{SiMe}_{2}\right)_{2} \mathrm{C}_{5} \mathrm{H}_{3}, \mathrm{Cp}-\mathrm{NMe}_{2}=\mathrm{C}_{5} \mathrm{H}_{4} \mathrm{CH}_{2} \mathrm{CH}_{2} \mathrm{NMe}_{2},\left\{\mathrm{Cp}-\mathrm{NHMe}_{2}\right\}^{+}=\left\{\mathrm{C}_{5} \mathrm{H}_{4} \mathrm{CH}_{2} \mathrm{CH}_{2} \mathrm{NHMe}_{2}\right\}^{+}$, dach $=1,2-$ transdiaminocyclohexane, $\mathrm{P}-\mathrm{py}-\mathrm{P}=$

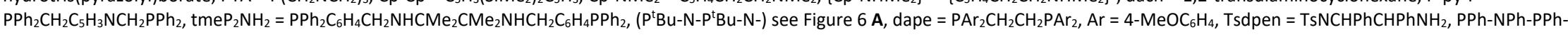
$\mathrm{NPh}=$ cyclo- $\left\{-\mathrm{PPhCH}_{2} \mathrm{NPhCH}_{2} \mathrm{PPhCH} \mathrm{NPhCH}_{2}\right\}$, dmprpe $=\mathrm{P}\left(\left(\mathrm{CH}_{2}\right)_{3} \mathrm{OMe}\right)_{2} \mathrm{CH}_{2} \mathrm{CH}_{2} \mathrm{P}\left(\left(\mathrm{CH}_{2}\right)_{3} \mathrm{OMe}\right)_{2}$.

${ }^{b}$ The ligands are the same as in the acid form apart from the loss of a proton (and counteranion for cationic complexes).

${ }^{c} \mathrm{pK}_{\mathrm{a}}{ }^{\mathrm{DMSO}}$ but reaction done in lower dielectric constant solvent.

${ }^{d} 3<\mathrm{pK}_{\mathrm{a}}<14$

${ }^{e} \mathrm{pK}_{\mathrm{a}}$ corrected to the MeCN scale for cationic acids using Equation 14

${ }^{f} 12<\mathrm{pK}_{\mathrm{a}}<50$ 


\subsection{Cobalt group}

\subsubsection{Cyclopentadienyl complexes}

Half sandwich hydride complexes of iridium with $\mathrm{Cp}$ or $\mathrm{Cp}$ * ligands represent the most acidic (entries 1-2) and least acidic (entries 83-84) of the cobalt group (Table 9). Dihydride complexes of iridium of this type have been studied for factors that influence trans vs cis dihydride or dihydrogen structures and for applications in catalysis. The very water sensitive dicationic complex $\left[\mathrm{IrH}_{2}\left(\mathrm{Cp}^{*}\right)(\mathrm{dppm})\right]\left[\mathrm{B}\left(\mathrm{C}_{6} \mathrm{~F}_{5}\right)_{4}\right]_{2}$ (entry 1 of Table 9 ) is prepared by reaction with starting chloride complex $\left[\mathrm{IrCl}\left(\mathrm{Cp}^{*}\right)(\mathrm{dppm})\right]\left[\mathrm{B}\left(\mathrm{C}_{6} \mathrm{~F}_{5}\right)_{4}\right]$ with $\left[\mathrm{SiEt}_{3}\right]\left[\mathrm{B}\left(\mathrm{C}_{6} \mathrm{~F}_{5}\right)_{4}\right]$ under dihydrogen in $\mathrm{CD}_{2} \mathrm{Cl}_{2}$. It exists as a mixture of a compressed cis-dihydride structure with an $\mathrm{H}$... $\mathrm{H}$ distance of $1.5 \AA$ and a trans-dihydride structure. Traces of water convert it to a monohydride making the dihydride $\mathrm{p} K_{\mathrm{a}}$ less than zero, consistent with its $\mathrm{pK}_{\mathrm{a}}{ }^{\mathrm{LAC}}$ of -4 . The corresponding $\mathrm{PMe}_{2} \mathrm{CH}_{2} \mathrm{PMe}_{2}(\mathrm{dmpm})$ complex (entry 2) was prepared in a similar fashion and is also extremely acidic. The $\mathrm{p} K_{\mathrm{a}}{ }^{\mathrm{DCM}}$ must be less than -4 since the monohydride $\left[\mathrm{IrH}\left(\mathrm{Cp}^{*}\right)(\mathrm{dppm})\right]\left[\mathrm{B}\left(\mathrm{C}_{6} \mathrm{~F}_{5}\right)_{4}\right]$ does not react with $\mathrm{CF}_{3} \mathrm{SO}_{3} \mathrm{H}$ in $\mathrm{CD}_{2} \mathrm{Cl}_{2} \cdot{ }^{239}$ In this case the $\mathrm{pK}_{\mathrm{a}}{ }^{\mathrm{LAC}}$ of 0 is an overestimation. A related dihydrogen complex with a chelating dicarbene ligand $\left[\operatorname{Ir}\left(\mathrm{H}_{2}\right)(\mathrm{Cp} *)(\mathrm{NHC}-\right.$ $\mathrm{NHC}$ ) $]^{2+}$ (entry 4, 5, Figure 13 ) is also strongly acidic but less so than the dmpm derivative since it is deprotonated by $\mathrm{Et}_{2} \mathrm{O}$ and $\mathrm{H}_{2} \mathrm{O}$ but full formed by the addition of one equivalent of $\mathrm{CF}_{3} \mathrm{SO}_{3} \mathrm{H}^{240}$

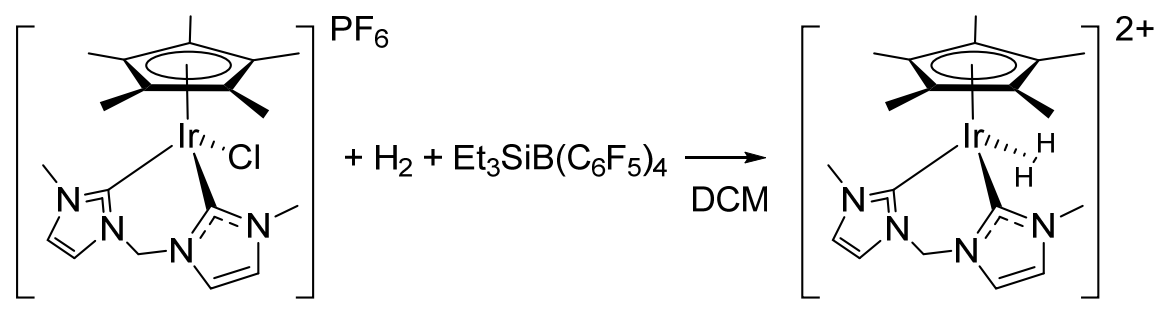

Figure 13. Formation of a very acidic iridium dihydrogen complex

The reaction of $\left[\operatorname{Ir}\left(\mathrm{Cp}^{*}\right)\left(\mathrm{H}_{2} \mathrm{O}\right)(\mathrm{bpy})\right]^{2+}$ with hydrogen in water results in the formation of $\left[\mathrm{IrH}\left(\mathrm{Cp} \mathbf{p}^{*}\right)(\mathrm{bpy})\right]^{+}$and hydronium ion. ${ }^{241}$ This heterolytic splitting step, which is expected based on the $\mathrm{p} K_{\mathrm{a}}{ }^{\mathrm{LAC}}$ of -2 for the intermediate dihydrogen complex $\left[\operatorname{Ir}\left(\mathrm{Cp}^{*}\right)\left(\mathrm{H}_{2}\right)(\mathrm{bpy})\right]^{2+}$ (not listed in the Table) is important in the mechanism for the hydrogenation of carbon dioxide into formic acid catalyzed by the monohydride complex in water at pH 3 (see Section 6.7).

The enthalpy of protonation of a wide range of $\operatorname{Ir}\left(\mathrm{Cp}^{*}\right)$ and $\operatorname{Ir}(\mathrm{Cp})$ complexes were determined by Wang and Angelici (entries 10, 12, 13, 17, 30, 32, 33, 35, 37, 38, 47-49). ${ }^{29,112}$ The hydrides generated in situ include $\left[\mathrm{IrH}\left(\mathrm{Cp}^{*}\right)(\mathrm{CO})_{2}\right] \mathrm{CF}_{3} \mathrm{SO}_{3}$ (entry 10, $\mathrm{pK}_{\mathrm{a}}^{\mathrm{LAC}} 3$ ), $\left[\mathrm{IrH}_{3}(\mathrm{Cp})\left(\mathrm{P}(\mathrm{OPh})_{3}\right)\right] \mathrm{CF}_{3} \mathrm{SO}_{3}$ (entry 12, $\mathrm{pK}_{\mathrm{a}}^{\mathrm{LAC}} 7$ ) and $\left[\mathrm{IrH}_{3}(\mathrm{Cp})\left(\mathrm{PPh}_{3}\right)\right] \mathrm{CF}_{3} \mathrm{SO}_{3}$ (entry $13, \mathrm{pK}_{\mathrm{a}}^{\mathrm{LAC}} 7$ ). The two trihydrides display interesting patterns in the hydride region of their ${ }^{1} \mathrm{H}$ NMR spectra due to a quantum mechanical exchange coupling phenomenon. ${ }^{242}$ Related acidic dihydrogen complexes of cobalt(III) $\left[\mathrm{Co}\left(\mathrm{H}_{2}\right)(\mathrm{Cp} *) \mathrm{H}\left(\mathrm{P}(\mathrm{OMe})_{3}\right]^{+}\right.$were prepared and deprotonated by $\mathrm{NEt}_{3} .{ }^{243}$ The iridium(III) complex of entry 50, $\left[\mathrm{IrH}_{2}(\mathrm{CO})\left(\mathrm{PPh}_{3}\right)_{3}\right] \mathrm{CF}_{3} \mathrm{SO}_{3}$, although not containing a cyclopentadienyl ligand, has a $\mathrm{p} K_{\mathrm{a}}{ }^{\mathrm{DCM}} 11$.

The oxidation of dihydrogen in DCM by an iridium $\mathrm{Cp}^{*}$ complex containing an amidophenolate ligand was postulated to proceed via oxidation and then deprotonation of two acidic species by 2,6ditertiarybutylpyridine ( $\mathrm{p} K_{\mathrm{a}}{ }^{\mathrm{MeCN}} 11.5, \mathrm{p} K_{\mathrm{a}}{ }^{\mathrm{DCM}}$ approx. 7) as shown in Figure 14. Their $\mathrm{p} K_{\mathrm{a}}^{\mathrm{DCM}}$ values are listed as $<6$ in entries 15-16 in Table 9. 

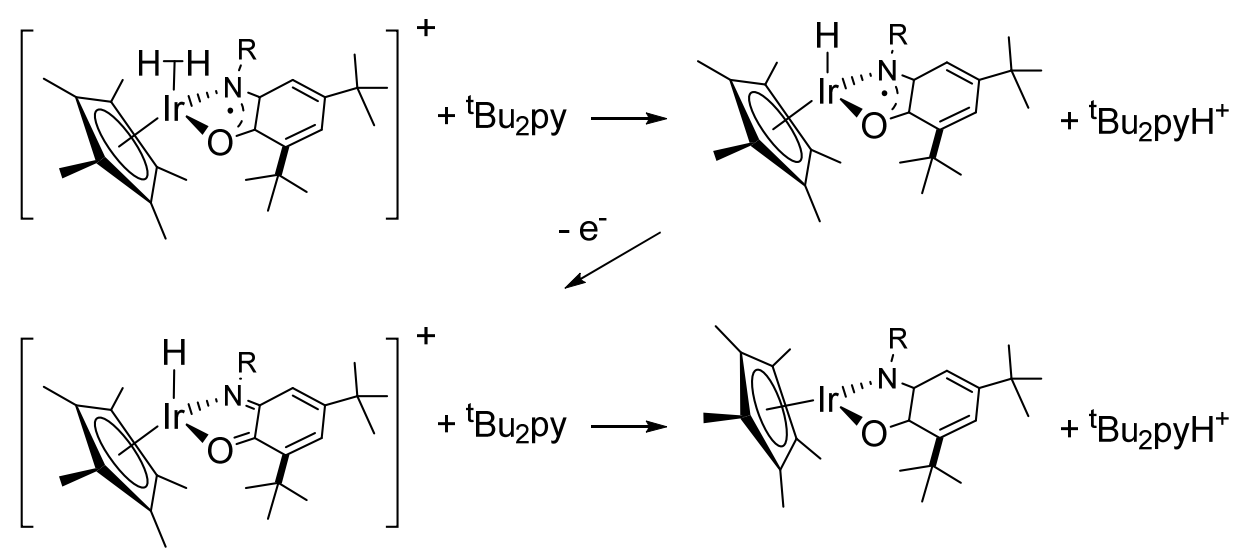

Figure 14. Successive deprotonations of an iridium hydride complexes starting with a radical-based ligand

The $I \mathrm{r}^{\mathrm{III}}$ hydride $\left[\mathrm{IrH}\left(\mathrm{Cp}{ }^{*}\right)(\mathrm{bpy})\right]^{+}$with a bipyridine ligand has $\mathrm{p} K_{\mathrm{a}}{ }^{\mathrm{MeCN}} 23$ as determined by its equilibrium with DBU-H $\mathrm{H}^{+}$(entry 63). ${ }^{244}$ The conjugate base $\mathrm{Ir}^{\prime}$ form is very basic, dissolving in water to the $\mathrm{Ir}^{\mathrm{III}}$ hydride cation and hydroxide ion (entry 64). ${ }^{245}$ This basic nature is consistent with the $\mathrm{p} K_{\mathrm{a}}{ }^{\mathrm{LAC}} 19$ which converts to $\mathrm{pK}_{\mathrm{a}}{ }^{\mathrm{MeCN}} 24$. The photolysis at $430 \mathrm{~nm}$ of $\left[\mathrm{IrH}\left(\mathrm{Cp}^{*}\right)(\mathrm{bpy})\right]^{+}$in $\mathrm{MeOH}$ results in the elimination of a proton to form the conjugate base $\operatorname{Ir}\left(\mathrm{Cp}{ }^{*}\right)(\mathrm{bpy})$ complex which is reprotonated rapidly. ${ }^{246} \mathrm{The}$ excitation of the $\operatorname{Ir}(\mathrm{III})$ to bpy charge transfer band effectively oxidizes the iridium, making it much more acidic by losing the $d^{6}$ electron configuration (worth $-6 \mathrm{p} K_{\mathrm{a}}$ units) and increasing the charge by one (worth -15 $\mathrm{p} K_{\mathrm{a}}$ units) making an effective $\mathrm{p} K_{\mathrm{a}}{ }^{\mathrm{LAC}}$ of 19-21 $=-2$ for the excited complex.

Entries 66 and 69 are cationic $\mathrm{Ir}^{\vee}$ dihydrides with $\mathrm{Cp}^{*}$ and chlelating monoanionic ligands. Their $\mathrm{p} K_{\mathrm{a}}{ }^{\mathrm{MeCN}}$ are determined to be 13.9 (equilibrium with lutidinium) and 17.4 (equilibrium with $\mathrm{HNEt}_{3}{ }^{+}$), respectively. ${ }^{232}$

The neutral hydride $\mathrm{Rh}^{\mathrm{I}} \mathrm{H}\left(\mathrm{Cp}{ }^{*}\right)\left(\mathrm{NC}_{5} \mathrm{H}_{4} \mathrm{C}_{6} \mathrm{H}_{4}\right)$ (entry 71 ) has a monoanionic cyclometallated phenylpyridine ligand. It is a very weak acid ( $\left.\mathrm{p} K_{\mathrm{a}}{ }^{\mathrm{MeCN}} 30.3\right)$ requiring reaction with strong phosphazene base to observe an equilibrium in $\mathrm{MeCN}$. The neutral dihydride $\operatorname{Ir}^{\prime \prime \prime} \mathrm{H}_{2}\left(\mathrm{Cp}^{*}\right)\left(\mathrm{PMe}_{3}\right)$ (entries 83 and 84 ) can be deprotonated by BuLi in THF and the conjugate base form is so basic than it reacts with hydrogen gas, presumably to make $\mathrm{LiH}$, and it reacts with dimethylsulfoxide (DMSO) to give the anion $\mathrm{CH}_{2} \mathrm{SOMe}^{-101}$ The $\mathrm{p} K_{\mathrm{a}}{ }^{\mathrm{LAC}}$ of 46 may be too low, considering that the $\mathrm{p} K_{\mathrm{a}}{ }^{\mathrm{MeCN}}\left(\mathrm{H}_{2} / \mathrm{H}^{-}\right)$is approx. 50 . However the correct accounting of ion pairing could result in significant increases to the numbers for this complex.

Hydrides of this group with $\mathrm{Cp}$ or $\mathrm{Cp}$ * ligands are important in a variety of catalytic applications as discussed further below.

\subsubsection{Dicationic hydride acids}

As expected on the basis of the LAC equation, dicationic acids normally have low $\mathrm{p} K_{\mathrm{a}}$ values. In addition to the very acidic dicationic cyclopentadienyl complexes just discussed (entries 1,2, 4, 5 of Table 9) there are several other dicationic complexes in Table 9 with $\mathrm{p} K_{\mathrm{a}}$ values ranging from less than zero in water (entry 7) for the rhodium(III) complex $\left[\mathrm{RhH}(\mathrm{CNR})_{4}\left(\mathrm{OH}_{2}\right)\right]^{2+}$ with $4 \pi$-acid isonitrile ligands ${ }^{73,247}$ to 18.9 in $\mathrm{MeCN}$ (entry 39$)$ for $\left[\mathrm{RhH}(\mathrm{dmpe})_{2}(\mathrm{MeCN})\right]^{2+}$ with strongly donating phosphine ligands. In between is $\left[\mathrm{RhH}(\mathrm{dppe})(\mathrm{MeOH})_{3}\right]^{2+}$ (entry 8 ) which is in equilibrium with protonated methanol. ${ }^{248}$ The complex $\left[\operatorname{Ir}^{\prime \prime \prime} \mathrm{H}\left(\mathrm{CN}^{t} \mathrm{Bu}\right)_{5}\right]^{2+}$ is formed presumably from the protonation of $\left[\operatorname{Ir}^{\prime}\left(\mathrm{CN}^{t} \mathrm{Bu}\right)_{5}\right]^{+}$with $\mathrm{NH}_{4} \mathrm{PF}_{6}$ in $\mathrm{MeOH}\left(\mathrm{p} \mathrm{K}_{\mathrm{a}}{ }^{\mathrm{MeOH}}\right.$ approx. 9). ${ }^{249}$ Titration of the water soluble complex $\left[\operatorname{Ir}(\mathrm{COD})\left(\mathrm{PMe}_{3}\right)_{3}\right]^{+}$with $\mathrm{HCl}$ provides the $\mathrm{p} K_{\mathrm{a}}{ }^{\mathrm{aq}} 4.2$ for $\left[\mathrm{IrH}(\mathrm{COD})\left(\mathrm{PMe}_{3}\right)_{3}\right]^{2+}\left(\mathrm{p} K_{\mathrm{a}}{ }^{\mathrm{LAC}}=2 \times-2+3 \times 4.9+2-15+6=4\right) .{ }^{250}$ Complexes $\left[\mathrm{MH} \text { (diphosphine) }{ }_{2}(\mathrm{MeCN})\right]^{2+}(\mathrm{M}=\mathrm{Co} \text {, entry } 22 ; \mathrm{M}=\mathrm{Rh} \text {, entries } 25-27,39-43)^{251}$ have $\mathrm{p} K_{\mathrm{a}}{ }^{\mathrm{MeCN}}$ ranging 
from 5.8 to 18.9 and the cobalt(III) complex $\left[\mathrm{CoH}\left(\mathrm{P}_{4}\right)(\mathrm{MeCN})\right]^{2+}$ (entry 45$)^{252}$ with phosphine and nitrile donors has a $\mathrm{p} K_{\mathrm{a}}{ }^{\mathrm{MeCN}}$ of 16 (Figure 15). The effect of the metal on $\mathrm{p} K_{\mathrm{a}}{ }^{\mathrm{MeCN}}$ is illustrated by the compounds $\left[\mathrm{M}^{\prime \prime \prime} \mathrm{H}(\mathrm{dppe})_{2}(\mathrm{MeCN})\right]^{2+}$ where $\mathrm{Rh}^{\text {III }}(9.0$, entry 26$)<\mathrm{Co}^{\prime \prime \prime}(11.3$, entry 22$)$ (a similar ordering of the $4 \mathrm{~d}$ vs $3 \mathrm{~d}$ metal is seen for $\mathrm{Pd}^{\prime \prime}<\mathrm{Ni}^{\prime \prime}$ (see below). Complexes with predominantly nitrogen donors have $\mathrm{pK}_{\mathrm{a}}{ }^{\mathrm{aq}}$ in the range 9-14: $\left[\mathrm{RhH}\left(\mathrm{NH}_{3}\right)_{4}\left(\mathrm{H}_{2} \mathrm{O}\right]^{2+}\right.$ (entry 23), ${ }^{73}\left[\mathrm{RhH}(\text { bpy })_{2}\left(\mathrm{H}_{2} \mathrm{O}\right]^{2+}\right.$ (entry 24), ${ }^{73}[\mathrm{CoH}(\mathrm{rac}-$ macrocycle) $\left.\left(\mathrm{H}_{2} \mathrm{O}\right)\right]^{2+}$ (entry 44 , Figure 16$)^{253}$ and $\left[\mathrm{CoH}\left(\mathrm{N}\left(\mathrm{CH}_{2} \mathrm{CH}_{2} \text { py }\right)_{2} \mathrm{CH}_{2} \text { bpy) }\right]^{2+}\right.$ (entry 46 , Figure 16). ${ }^{83}$

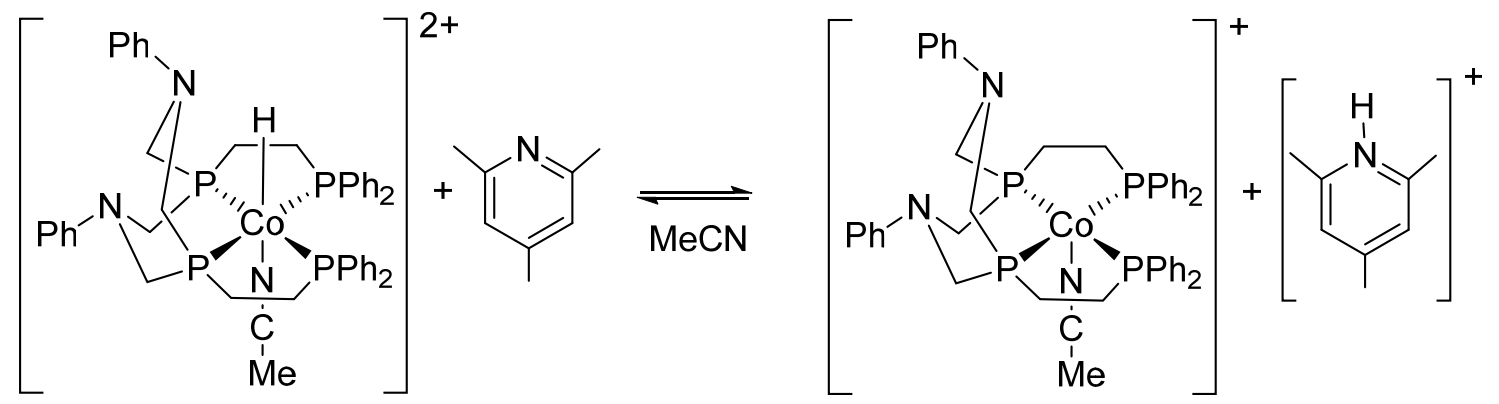

Figure 15. Equilibrium of a Cobalt(III) complex of a tetraphosphine $\left(P_{4}\right)$ ligand with protonated collidine.

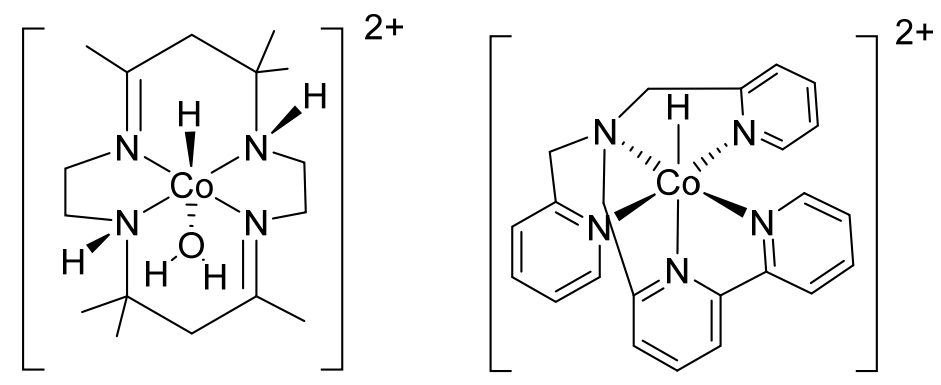

Figure 16. Cobalt(III) hydride complexes

\subsubsection{Monocationic hydride acids}

There is a wide range of $\mathrm{p} K_{\mathrm{a}}$ values for these positively charged complexes ranging from $\mathrm{pK}^{\mathrm{DCM}}-4$ for the iridium(III) cis-dihydride of entry 3 to $\mathrm{p} K_{\mathrm{a}}{ }^{\mathrm{MeCN}} 32.4$ for the paramagnetic cobalt(II) hydride complex $\left[\mathrm{CoH}\left(\mathrm{P}_{4}\right)\right]^{+}$(entry 78). ${ }^{252}$ The iridium(I) monohydride $\mathrm{IrH}(\mathrm{dpfepe})_{2}$ containing electronegative chelating ligands $\left(\mathrm{C}_{2} \mathrm{~F}_{5}\right)_{2} \mathrm{PCH}_{2} \mathrm{CH}_{2} \mathrm{P}\left(\mathrm{C}_{2} \mathrm{~F}_{5}\right)_{2}$ is not protonated by $\mathrm{HBF}_{4} \mathrm{Et}_{2} \mathrm{O}$ in $\mathrm{CH}_{2} \mathrm{Cl}_{2}$ and requires two equiv. of triflic acid in $\mathrm{CH}_{2} \mathrm{Cl}_{2}$ to give the iridium(III) cis-dihydride of entry $3 .{ }^{254}$ The complex $\left[\operatorname{Ir}\left(\mathrm{H}_{2}\right) \mathrm{H}(\mathrm{SCHS})\left(\mathrm{PCy}_{3}\right)_{2}\right]^{+}$(entry 6$)^{255}$ is so acidic that it is deprotonated by water in $\mathrm{CH}_{2} \mathrm{Cl}_{2}$ (Figure 17). Similarly the complex [ $\mathrm{IrH}_{2}$ (PPhtrop $\left.)_{2}\right]^{+}$where trop is an appended olefin is in equilibrium with $\mathrm{IrH}$ (PPhtrop) $)_{2}$ and $\mathrm{H}_{3} \mathrm{O}^{+}$in THF/DCM/ $\mathrm{H}_{2} \mathrm{O}$ mixtures and is estimated to have a $\mathrm{p} \mathrm{a}_{\mathrm{a}}{ }^{\text {aq }} 2 .{ }^{256}$

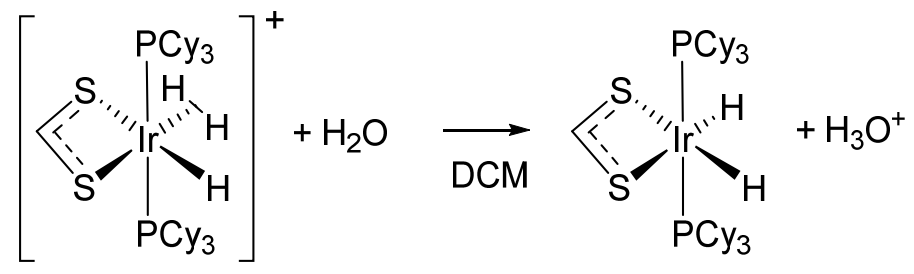

Figure 17. Deprotonation of an iridium dihydrogen complex by water in DCM

The complex $\left[\mathrm{RhH}(\mathrm{Cl})(\mathrm{CO})\left(\mathrm{PPh}_{3}\right)_{2}\right]^{+}$is prepared by protonating $\mathrm{RhCl}(\mathrm{CO})\left(\mathrm{PPh}_{3}\right)_{2}$. It has a $\mathrm{p}_{\mathrm{a}}{ }^{\mathrm{LAC}} 1$ and indeed has a $\mathrm{p} K_{\mathrm{a}}^{\mathrm{MeOH}}$ of 1.8 (entry 9). ${ }^{257}$ The iridium analogue $\left[\mathrm{IrH}(\mathrm{Cl})(\mathrm{CO})\left(\mathrm{PPh}_{3}\right)_{2}\right]^{+}$(entry 11) is slightly less acidic, as expected, with a $\mathrm{pK}_{\mathrm{a}}{ }^{\mathrm{MeOH}}$ of 2.1. Replacing the $\mathrm{PPh}_{3}$ with $\mathrm{PMe}_{2} \mathrm{Ph}$ reduces the 
acidity further (entry 18) although not as much in $\mathrm{MeOH}\left(\mathrm{p} K_{\mathrm{a}}{ }^{\mathrm{MeOH}} 2.8\right)$ as predicted for THF ( $\left.\mathrm{p} K_{\mathrm{a}}{ }^{\mathrm{LAC}} 6\right)$. The complex $[\mathrm{IrH}(\mathrm{I})(\mathrm{COD})(J o s i p h o s)] \mathrm{BF}_{4}$ (Figure 18) with a $\mathrm{p} K_{\mathrm{a}}{ }^{\mathrm{LAC}} 5$ is partially dehydrohalogenated by imine that models the substrate of the Metolachlor process, a large scale industrial asymmetric hydrogenation process (see Section 6.1.5); ${ }^{258}$ its iminium form is expected to have a $\mathrm{p} K_{\mathrm{a}}{ }^{\mathrm{DCM}}$ near to this value.
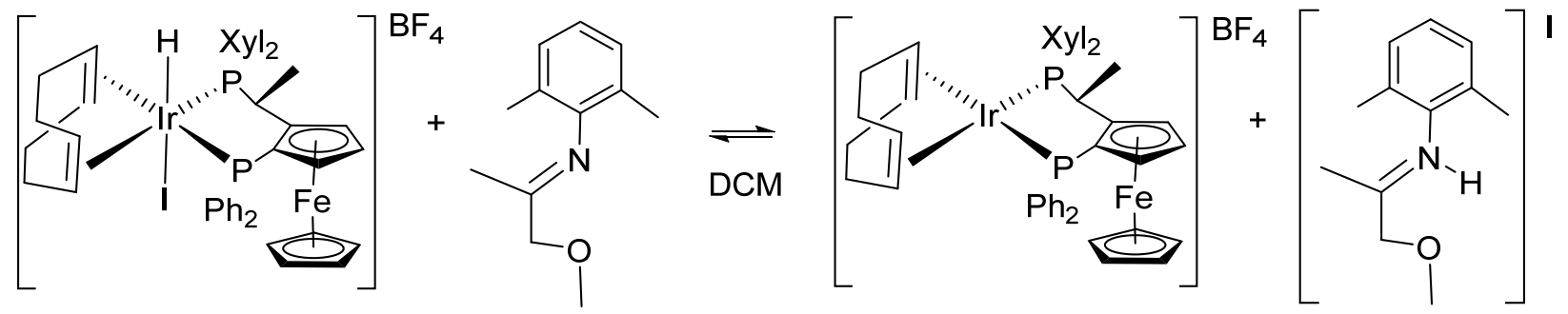

Figure 18. Deprotonation of an iridium(III) complex by an imine.

The entries 19-21 represent the delicate balance of protonation state of the complexes $\left[\operatorname{Ir}\left(\mathrm{H}_{2}\right) \mathrm{H}\left(\mathrm{bq}-\mathrm{NH}_{2}\right)(\mathrm{L})_{2}\right] \mathrm{A} /\left[\mathrm{Ir}(\mathrm{H})_{2}\left(\mathrm{bq}-\mathrm{NH}_{3}\right)(\mathrm{L})_{2}\right] \mathrm{A}$ that depends on $\mathrm{L}$ and the counterion $\mathrm{A}$ (Figure 19). ${ }^{259}$ When the counterion is kept fixed as $A=B_{4}$, then the small basic $L=P P h_{2} M e$, causes protonation of the iridium to produce a dihydrogen hydride structure with the anion participating as a hydrogen bond acceptor from the dihydrogen ligand. When $\mathrm{L}$ is large, either $\mathrm{PPh}_{3}$ or $\mathrm{PCy}_{3}$, the protonation occurs at the aniline-like amino group with the anion participating as a hydrogen bond acceptor. Since the $\mathrm{p} K_{\mathrm{a}}{ }^{\mathrm{DCM}}$ of anilinium is 8 , these complexes are thought to have values near to 8 as well. While not listed in the table, the dihydrogen complexes $\left[R h\left(\mathrm{H}_{2}\right)_{2} \mathrm{H}_{2}\left(\mathrm{PR}_{3}\right)_{2}\right]^{+}, \mathrm{R}=\mathrm{Cy}$, $\mathrm{Pr}$ are acidic and decompose by elimination of protonated phosphine. ${ }^{260}$

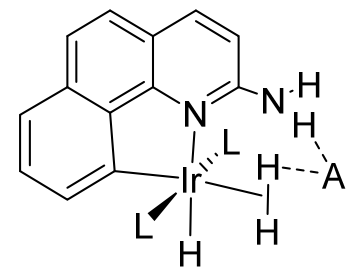<smiles></smiles>

$$
\mathrm{L}=\mathrm{PMe}_{2} \mathrm{Ph} \text { (small) } \quad \mathrm{L}=\mathrm{PCy}_{3} \text { or } \mathrm{PPh}_{3} \text { (big) }
$$

Figure 19. The structure of an iridium(III) complex depends on the nature of the ligand $L$ and the anion $A\left(B F_{4}^{-}\right)$

Similarly entries 28 and 29 (Figure 20) demonstrate the powerful influence hydrogen bonding can have on the effective $\mathrm{p} K_{\mathrm{a}}$ of acids in low dielectric constant solvents. ${ }^{261}$ The methyl piperidinium group attached to the iridium(III) dihydride complex should have a $\mathrm{p} K_{\mathrm{a}}{ }^{\mathrm{DCM}}$ of approx. 13 while the iridium trihydride cation is expected to have a $\mathrm{p} K_{\mathrm{a}}{ }_{\mathrm{C}}^{\mathrm{LAC}}$ of approx. 7. In the presence of hydrogen bond acceptors, either THF or $\mathrm{OPPh}_{3}$ the piperidinium form is favored (entry 28) while in neat $\mathrm{DCM}$, the trihydride form is favoured (entry 29). The cobalt(III)/(I) electrocatalyst $\left[\mathrm{CoH}\left(\mathrm{C}_{5} \mathrm{H}_{4} \mathrm{C}_{5} \mathrm{~F}_{4} \mathrm{~N}\right)\left(\mathrm{P}^{\mathrm{tBu}} \mathrm{N}^{\mathrm{Ph} 2}\right)\right]^{+}$with an electronwithdrawing fluoropyridyl substituent on the $\mathrm{Cp}$ ring was determined to have a $\mathrm{p} K_{\mathrm{a}}{ }^{\mathrm{MeCN}} 15.6$; ${ }^{262}$ the $\mathrm{p} K_{\mathrm{a}}{ }^{\mathrm{LAC}}$ is 18 for the $\mathrm{d}^{6}$ octahedral complex with a Cp ligand. 


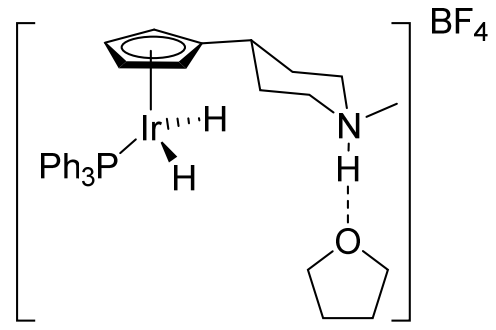

in THF

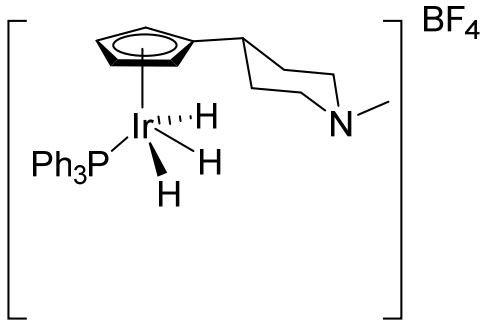

in DCM

Figure 20. The position of protonation depends on the additives present.

Burgess and coworkers have established the acidic nature of the iridium(V) complexes of entries 31 and 34 by estimating $\mathrm{p} K_{\mathrm{a}}{ }^{\mathrm{MeCN}}$ values of 11.5 and 17.4 respectively by use of DFT calculations. ${ }^{263}$ The complex with a chelating ligand consisting of a triarylphosphine donor and an oxazoline donor is calculated to be about 6 units more acidic than one with a chelating $\mathrm{N}$-heterocyclic carbene donor and an oxazoline donor (Figure 21). The values are similar to those predicted by the LAC method scale, $\mathrm{p} K_{\mathrm{a}}{ }^{\mathrm{MeCN}} 12$ and 15 , respectively, using the $\mathrm{A}_{\mathrm{L}}$ values of 2 for the $\mathrm{PAr}_{3}$ donor, 5 for the $\mathrm{NHC}$ donor and 4 for the oxazoline donor and the conversion from the THF to MeCN scale. The related iridium(V) NHC complex of entry 51 has a $\mathrm{p} K_{\mathrm{a}}{ }^{\mathrm{LAC}} 13$ and this explains why it can be deprotonated by DBU to give the trihydride iridium(III) complex (with DBU- $\mathrm{H}^{+} \mathrm{p} K_{\mathrm{a}}^{\text {THF }}$ 20) but not by quinoline (with quin- $\mathrm{H}^{+} \mathrm{p} K_{\mathrm{a}}^{\text {THF }}$ approx. 8, like $\left.\mathrm{py}-\mathrm{H}^{+}\right)$.

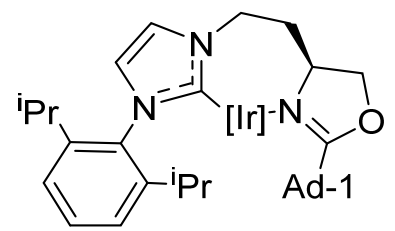

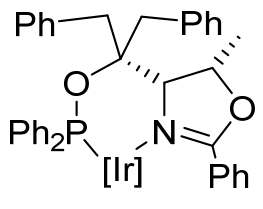

Figure 21. CN and PN ligands on iridium

The iridium(III) hydride complex with a tetradentate $k^{3}-\mathrm{P}, \mathrm{k}^{1}-\mathrm{N}$ ligand $\operatorname{Ir} \mathrm{H}_{3}\left\{\mathrm{~N}\left(\mathrm{CH}_{2} \mathrm{CH}_{2} \mathrm{PPh}_{2}\right)_{3}\right\}$ is protonated with a strong acid in DCM to produce an unstable complex $\left[\operatorname{IrH}_{4}\left\{\mathrm{~N}_{(}\left(\mathrm{CH}_{2} \mathrm{CH}_{2} \mathrm{PPh}_{2}\right)_{3}\right\}\right]^{+}$(entry 54). ${ }^{58}$ The $\mathrm{p} K_{\mathrm{a}}{ }^{\mathrm{LAC}}$ for the product protonated at the metal $\left[\operatorname{Ir}^{\mathrm{V}} \mathrm{H}_{4} \mathrm{~L}\right]^{+}$or at the hydride $\left[\mathrm{Ir}^{11 !} \mathrm{H}_{2}\left(\mathrm{H}_{2}\right) \mathrm{L}\right]^{+}$is approx. 15 so that the reaction would be very favorable. In actual fact it is reported that the complex is a seven coordinate tetrahydride with a $\mathrm{k}^{3}$-P ligand i.e. the nitrogen donor has detached. By contrast the

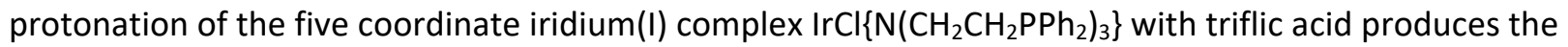
six coordinate $\mathrm{d}^{6}$ iridium(III) complex [ $\mathrm{IrHClL} \mathrm{CF}_{3} \mathrm{SO}_{3}$ as expected for a $\mathrm{p} K_{\mathrm{a}}{ }^{\mathrm{LAC}}$ of 15 (entry 55).

Entries 56, 57 and 58 present two basic iridium complexes that are protonated by excess methanol or water in toluene or dioxane. The first is $\mathrm{Cp}^{*} \mid \mathrm{Ir}^{\prime \prime}(\mu-\mathrm{H})_{2} \mathrm{Ir}^{\prime \prime} \mathrm{Cp} \mathrm{p}^{*}$ which protonates at the bridging position to produce two formally $\mathrm{Ir}^{\mathrm{II \prime}}$ centers in $\left[\mathrm{Cp}^{*}\left|\mathrm{Ir}^{\prime \prime \prime}(\mu-\mathrm{H})_{3}\right| \mathrm{Ir}^{\prime \prime \prime} \mathrm{Cp} \mathrm{p}^{*}\right]^{+}$with a homoconjugated $[\mathrm{MeOH} . . \mathrm{OMe}]^{-}$methoxide ion. ${ }^{264}$ The protonated form is favored as the temperature is lowered below $298 \mathrm{~K}$ as is normally observed when neutral acids and bases produce ionic species in a low dielectric constant solvent. The $\mathrm{p} K_{\mathrm{a}}^{\mathrm{LAC}}$ is estimated to be around 25 based on a $\mathrm{p} K_{\mathrm{a}}^{\mathrm{THF}}$ approx. 43 for $\mathrm{MeOH}$ and the fact that the acid ( $\mathrm{MeOH}$ ) behaves much stronger (by approx. $20 \mathrm{p} K_{\mathrm{a}}$ units) in such reactions than would be indicated by the $\mathrm{p} K_{\mathrm{a}}$ value. The second is the complex $\operatorname{Ir}^{\prime} \mathrm{Cl}\left(\mathrm{PMe}_{3}\right)_{3}$ which produces the hydride $\operatorname{IrH}(\mathrm{Cl})(\mathrm{OMe})\left(\mathrm{PMe}_{3}\right)_{3}$ or $\mathrm{IrH}(\mathrm{Cl})(\mathrm{OH})\left(\mathrm{PMe}_{3}\right)_{3}$ upon treatment with $\mathrm{MeOH}$ or water (entries 57 and 58$){ }^{265}$ The $\mathrm{pK}_{\mathrm{a}}^{\mathrm{LAC}} 17$ is based on the $\mathrm{IrCl}\left(\mathrm{PMe}_{3}\right)_{3}$ formula and the $\mathrm{d}^{6}$ octahedral structure of the acid form. This reaction is thought to proceed via protonation to first form a five coordinate $\mathrm{Ir}^{\mathrm{III}}$ complex $\left[\mathrm{IrHCl}\left(\mathrm{PMe}_{3}\right)_{3}\right]^{+}$ 
with homoconjugated anions. The dimeric complex $\left[\{\mathrm{IrH}(\mathrm{CO})(\mathrm{Cp} *)\}_{2}(\mu-\mathrm{H})\right]^{+}$is deprotonated by $\mathrm{NEt}_{3}$ in $\mathrm{DCM}$ while $\left[\left\{\mathrm{IrH}\left(\mathrm{P}(\mathrm{OPh})_{3}\right)(\mathrm{Cp} *)\right\}_{2}(\mu-\mathrm{H})\right]^{+}$requires the stronger base, lithium diethylamide. ${ }^{266}$

Entries 59 and 70 are cobalt(III) complexes with two dppe ligands. The first, $\left[\mathrm{CoH}_{2}(\mathrm{dppe})_{2}\right]^{+}$has a $\mathrm{p} K_{\mathrm{a}}{ }^{\mathrm{MeCN}}$ measured as 22.8 (in equilibrium with TMG- $\mathrm{H}^{+}$); ${ }^{44}$ the $\mathrm{p} K_{\mathrm{a}}{ }^{\mathrm{LAC}} 18$ is in agreement when converted to $\mathrm{p} K_{\mathrm{a}}{ }^{\mathrm{MeCN}} 24$. Entry 70 is the paramagnetic complex [Co" $\left.\mathrm{H}(\mathrm{dppe})_{2}(\mathrm{MeCN})\right]^{+}$which is weakly acidic $\left(\mathrm{p} K_{\mathrm{a}}^{\mathrm{MeCN}} 23.6, \mathrm{p} K_{\mathrm{a}}{ }^{\mathrm{LAC}} 22\right)^{44}$ because of its good donor ligands. The $\mathrm{p} K_{\mathrm{a}}{ }^{\mathrm{MeCN}}$ in this case was determined indirectly by use of electrochemical measurements and a thermodynamic cycle (Figure 22).

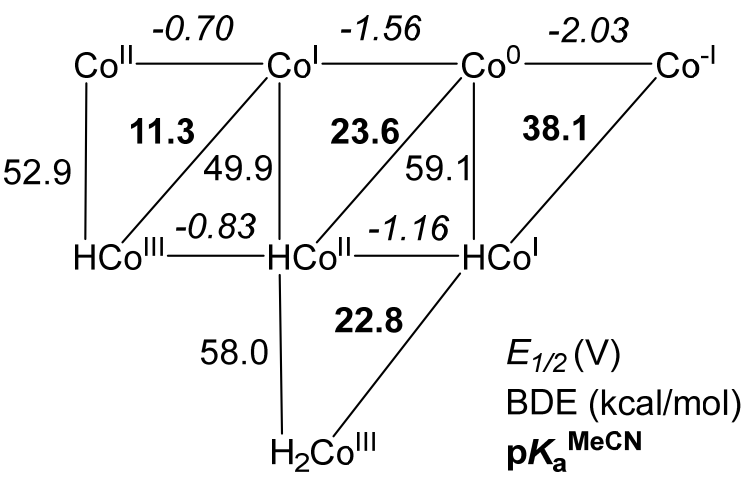

Figure 22. Thermodynamic cycles for the [Co(dppe) 2 ] system relating $\mathrm{pK}_{a}($ bold), $\mathrm{Co}-\mathrm{H}$ bond dissociation energy (plain text) and reduction potentials (italic).

Similar cycles were used to estimate the $\mathrm{p} K_{\mathrm{a}}{ }^{\mathrm{MeCN}} 31.7$ for trans-[Co $\left.{ }^{11 \prime} \mathrm{H}_{2}\left(\mathrm{P}_{4}\right)\right]^{+}$(entry 72 , Figure 15 ) and 32.4 for $\left[\mathrm{Co} " \mathrm{H}\left(\mathrm{P}_{4}\right)\right]^{+}$(entry 78$) .{ }^{252}$ The related tetraphos complexes $\left[\mathrm{MH}_{2}\left\{\mathrm{P}\left(\mathrm{CH}_{2} \mathrm{CH}_{2} \mathrm{PPh}_{2}\right)_{3}\right\}\right]^{+}, \mathrm{M}=\mathrm{Co},{ }^{267}$ $\mathrm{Rh}^{268}\left(\mathrm{p} K_{\mathrm{a}}{ }^{\mathrm{LAC}} 20\right)$ can be prepared by protonation of the basic monohydrides $\mathrm{MH}\left\{\mathrm{P}\left(\mathrm{CH}_{2} \mathrm{CH}_{2} \mathrm{PPh}_{2}\right)_{3}\right\}$ with $\mathrm{CF}_{3} \mathrm{COOH}\left(\mathrm{p} K_{\mathrm{a}}{ }^{\mathrm{MeCN}} 13\right)$ in THF. In order to reverse the protonation to prepare the monohydride of rhodium(I), a strong base like MeLi or KO ${ }^{\mathrm{t}} \mathrm{Bu}$ was required. ${ }^{267}$

The least acidic cationic hydride complexes in Table 9 are the rhodium(III) and iridium(III) octahedral complexes containing four very basic phosphorus donors (entries 73-77) and are estimated to have $\mathrm{p} K_{\mathrm{a}}{ }^{\mathrm{LAC}}$ in the range of 26-28 (pK $\left.K_{\mathrm{a}}^{\mathrm{MeCN}} 31-33\right)$. This agrees well with the determination of $\mathrm{p} K_{\mathrm{a}}{ }^{\mathrm{MeCN}}$ 30.6 for $\left[\mathrm{RhH}_{2}(\mathrm{depx})_{2}\right]^{+}$, depx $=1,3-\left(\mathrm{PEt}_{2} \mathrm{CH}_{2}\right)_{2} \mathrm{C}_{6} \mathrm{H}_{4}$ (Figure 23), by use of a phosphazene base. ${ }^{68}$ The complexes $\left[\mathrm{RhH}_{2}(\mathrm{dmpe})_{2}\right]^{+}$and $\left[\mathrm{RhH}_{2}(\text { depe })_{2}\right]^{+}$have similar acidity to ${ }^{\mathrm{t}} \mathrm{BuOH}$ in THF (entry 74,75$)$. The iridium(I) complex IrMe $\left(\mathrm{PMe}_{3}\right)_{4}$ is very basic, deprotonating the weak hydrides $\mathrm{FeH}(\mathrm{CO})_{2} \mathrm{Cp}\left(\mathrm{p} K_{\mathrm{a}}{ }^{\mathrm{LAC}} 30\right)$ and $\mathrm{MnH}(\mathrm{CO})_{5}\left(\mathrm{p} K_{\mathrm{a}}^{\mathrm{LAC}} 16\right)$ in pentane, to give the cationic hydride $\left[\mathrm{IrH}(\mathrm{Me})\left(\mathrm{PMe}_{3}\right)_{4}\right]^{+}\left(\mathrm{p} K_{\mathrm{a}}{ }^{\mathrm{LAC}}\right.$ approx. 28) strongly ion paired with the conjugate base form of these carbonyls (entries 76, 77). ${ }^{269}$<smiles>CCPc1ccccc1CC</smiles>

depx

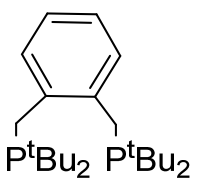

dtpx

Figure 23. The chelating diphosphines ortho-bis(diethylphosphino)xylene (depx) and ortho-bis(ditertiarybutylphosphino)xylene (dtpx)

\subsubsection{Neutral and anionic hydride acids}

The neutral dimeric rhodium complex of entry 36 is unusually acidic, eliminating $\mathrm{HCl}$ reversibly (Figure 24, $\mathrm{L}=1$-adamantylisocyanide, $\mathrm{P}-\mathrm{N}-\mathrm{P}=$ bis(trifluoroethoxy) phosphino)methylamine. ${ }^{270}$ The electronegative groups on the bridging phosphine-amine ligands, the chloride ligands and the $\pi$-acidic 
isocyanide ligand all contribute to the acidity. The $\mathrm{p} K_{\mathrm{a}}{ }^{\mathrm{LAC}}$ of $\mathrm{HCl}$ is 10 suggesting that this complex has a similar $\mathrm{p} K_{\mathrm{a}}^{\mathrm{LAC}}$.

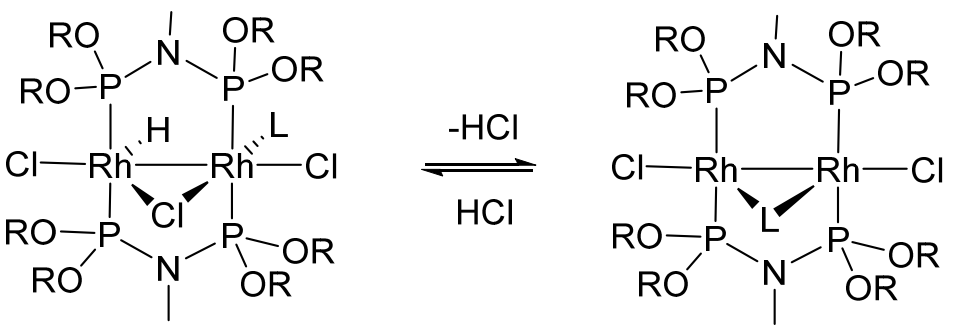

Figure 24. Reversible addition of $\mathrm{HCl}$ to a dimeric rhodium complex

The $\pi$-acidic carbonyl ligands of $\mathrm{CoH}(\mathrm{CO})_{4}$ cause this complex $\left(\mathrm{p} K_{\mathrm{a}}{ }^{\mathrm{MeCN}} 8.3\right)$ to have a similar acidity to $\mathrm{HCl}$ (entry 52$)^{40}$ and para-trifluoromethylanilinium (entry 53). ${ }^{51}$ Substitution of a carbonyl with $\left(\mathrm{P}(\mathrm{OPh})_{3}\right)_{3}$ (entry 65) or $\mathrm{PPh}_{3}$ (entry 67) cause the expected decreases in $\mathrm{p} K_{\mathrm{a}}{ }^{\mathrm{MeCN}}$ values. Completely replacing the carbonyls with phosphorus donors in $\mathrm{CoH}(\mathrm{dppe})_{2}$ (entry 79) results in a $\mathrm{p} K_{\mathrm{a}}{ }^{\mathrm{MeCN}}$ of 38 on the basis of a thermochemical cycle. The conjugate base form of this last complex [Co(dppe $\left.)_{2}\right]^{-}$when dissolved in $\mathrm{MeCN}$ (pK(autoionization) approx. 38) would probably deprotonate MeCN to give this

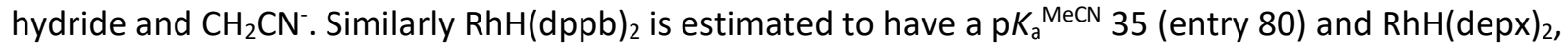
51 (entry 85). $\mathrm{p} K_{\mathrm{a}}{ }^{\mathrm{MeCN}}$ ranging from $39.4(\mathrm{R}=\mathrm{Ph})$ to $49.9\left(\mathrm{R}=\mathrm{Cy}\right.$ ) have been reported for $\mathrm{RhH}\left(\mathrm{P}^{\mathrm{R} 2} \mathrm{~N}^{\mathrm{Ar} 2}\right)_{2}$ complexes. ${ }^{271}$

Table 9 also classifies reactions of anionic rhodium and iridium hydrides in water (entries 60-62 and 68). Rhodium(III) dihydrides $\left[\mathrm{RhH}_{2} \mathrm{ClL}_{3}\right]^{\mathrm{n}-}$ with sulfonated phosphine ligands are protonated at $\mathrm{pH}$ 8.0-8.5 to produce dihydrogen complexes $\left[\mathrm{Rh}_{(}\left(\mathrm{H}_{2}\right) \mathrm{HCl}_{3}\right]^{\mathrm{n}-1}$ (entries $60-61$ ). The negative charge on the ligands appears to reduce the acidity of the complex relative to analogous $\mathrm{PPh}_{3}$ complexes $\left[\mathrm{Rh}\left(\mathrm{H}_{2}\right) \mathrm{HClL}_{3}\right]^{+}$which have $\mathrm{p} K_{\mathrm{a}}^{\mathrm{LAC}} 3$. The rhodium(III) hydride with a tetra p-sulfonatophenyl porphyrin ligand is a weak acid with $\mathrm{p} K_{\mathrm{a}}{ }^{\text {aq }} 7.0$ (entry 62 ) ${ }^{272}$ while the iridium analogue has $\mathrm{p} K_{\mathrm{a}}{ }^{\text {aq }} 11.7$ (entry 68). ${ }^{80}$ The replacement of eight $\mathrm{H}$ by $\mathrm{F}$ at the pyrrole positions to give the rhodium porphyrin $\left[\mathrm{RhD} \text { (porphyrinF } \mathrm{F}_{8}-\mathrm{Ar}_{4}\right]^{3-}$ where $\mathrm{Ar}$ is $\mathrm{C}_{6} \mathrm{H}_{2} \mathrm{~F}_{2} \mathrm{SO}_{3}{ }^{-}$) reduces the $\mathrm{p} K_{\mathrm{a}}{ }^{\text {aq }}$ to 2.2. ${ }^{273}$

The iridium(V) pentahydrides $\mathrm{Ir}_{5} \mathrm{~L}_{2}$ with tricyclohexylphosphine (entry 81) and triisopropylphosphine (entry 82 ) are very weak acids with $\mathrm{p} K_{\mathrm{a}}^{\text {THF }} 42$ and 43 , respectively. The first complex was determined by NMR measurements to react with [K(18-crown-6)] $\left[\mathrm{WH}_{5}\left(\mathrm{PMe}_{2} \mathrm{Ph}\right)_{3}\right]$ to create an equilibrium with $\mathrm{WH}_{6}\left(\mathrm{PMe}_{2} \mathrm{Ph}\right)_{3}\left(\mathrm{p} K_{\mathrm{a}}{ }^{\mathrm{THF}} 42\right.$, entry 55 of Table 5). ${ }^{100}$ The second iridium complex reacted with [K(18-crown-6)][ $\left[\mathrm{IH}_{4}\left(\mathrm{P}^{\mathrm{i}} \mathrm{Pr}_{3}\right)_{2}\right]$ to create an equilibrium with $\mathrm{IrH}_{5}\left(\mathrm{P}^{\mathrm{i}} \mathrm{Pr}_{3}\right)_{2}$. The complex $\mathrm{CoH}\left(\mathrm{PMe}_{3}\right)_{4}\left(\mathrm{p} K_{\mathrm{a}}{ }^{\mathrm{LAC}} 50\right)$ could not be deprotonated by neat $\mathrm{CH}_{2} \mathrm{PMe}_{3}{ }^{198}$

Other less quantifiable reactions that involve the acid-base chemistry of cobalt group hydride and dihydrogen complexes can be found elsewhere. ${ }^{274-279}$ 


\begin{tabular}{|c|c|c|c|c|c|c|c|c|c|}
\hline Entry & Acid & Base $^{b}$ & Reactant & Reaction & Solvent & Temp. & $\mathrm{pK}_{\mathrm{a}}^{\text {exp }}$ & $\mathbf{p K}_{\mathbf{a}}^{\mathrm{LAC}}$ & Reference \\
\hline 1 & {$\left[\mathrm{IrH}_{2}(\mathrm{Cp} *)(\mathrm{dppm})\right]^{+2}$} & {$[\mathrm{MH}] \mathrm{Y}$} & $\mathrm{H}_{2} \mathrm{O}$ & {$\left[\mathrm{MH}_{2}\right] \mathrm{Y}_{2}+\mathrm{B} \leftarrow[\mathrm{MH}] \mathrm{Y}+[\mathrm{HB}] \mathrm{Y}$} & $\mathrm{CD}_{2} \mathrm{Cl}_{2}$ & 298 & $<0$ & -4 & 239 \\
\hline 2 & {$\left[\operatorname{IrH}_{2}\left(\mathrm{Cp}^{*}\right)(\mathrm{dmpm})\right]^{+2}$} & {$[\mathrm{MH}] \mathrm{Y}$} & $\mathrm{CF}_{3} \mathrm{SO}_{3} \mathrm{H}$ & {$[\mathrm{MH}] \mathrm{Y}+\mathrm{HY} \leftarrow\left[\mathrm{MH}_{2}\right] \mathrm{Y}_{2}$} & $\mathrm{CD}_{2} \mathrm{Cl}_{2}$ & 298 & $<-4$ & 0 & 239 \\
\hline 3 & {$\left[\mathrm{IrH}_{2}(\text { dpfepe })_{2}\right]^{+}$} & MH & $\mathrm{CF}_{3} \mathrm{SO}_{3} \mathrm{H}$ & $\mathrm{MH}+\mathrm{HY} \rightleftharpoons\left[\mathrm{MH}_{2}\right] \mathrm{Y}$ & $\mathrm{CH}_{2} \mathrm{Cl}_{2}$ & 298 & -4 & & 254 \\
\hline 4 & {$\left[\operatorname{Ir}\left(\mathrm{H}_{2}\right)\left(\mathrm{Cp}^{*}\right)(\mathrm{NHC}-\mathrm{NHC})\right]^{+2}$} & {$[\mathrm{MH}] \mathrm{Y}$} & $\mathrm{Et}_{2} \mathrm{O}$ & {$\left[\mathrm{MH}_{2}\right] \mathrm{Y}_{2}+\mathrm{B} \rightarrow[\mathrm{MH}] \mathrm{Y}+[\mathrm{HB}] \mathrm{Y}$} & $\mathrm{CD}_{2} \mathrm{Cl}_{2}$ & 298 & $<0$ & 0 & 240 \\
\hline 5 & {$\left[\operatorname{Ir}\left(\mathrm{H}_{2}\right)\left(\mathrm{Cp}^{*}\right)(\mathrm{NHC}-\mathrm{NHC})\right]^{+2}$} & {$[\mathrm{MH}] \mathrm{Y}$} & $\mathrm{CF}_{3} \mathrm{SO}_{3} \mathrm{H}$ & {$[\mathrm{MH}] \mathrm{Y}+\mathrm{HY} \rightarrow\left[\mathrm{MH}_{2}\right] \mathrm{Y}_{2}$} & $\mathrm{CD}_{2} \mathrm{Cl}_{2}$ & 298 & $>-4$ & 0 & 240 \\
\hline 6 & {$\left[\operatorname{Ir}\left(\mathrm{H}_{2}\right) \mathrm{H}(\mathrm{SCHS})\left(\mathrm{PCy}_{3}\right)_{2}\right]^{+}$} & $\mathrm{MH}_{2}$ & $\mathrm{H}_{2} \mathrm{O}$ & {$\left[\mathrm{MH}_{3}\right] \mathrm{Y}+\mathrm{B} \rightleftharpoons \mathrm{MH}_{2}+[\mathrm{HB}] \mathrm{Y}$} & $\mathrm{CD}_{2} \mathrm{Cl}_{2}$ & 298 & -1.0 & & 255 \\
\hline 7 & {$\left[\mathrm{RhH}(\mathrm{CNR})_{4}\right]^{+2}$} & {$[\mathrm{MH}] \mathrm{Y}$} & & {$[\mathrm{M}]^{+}+\mathrm{H}^{+} \rightleftharpoons[\mathrm{MH}]^{+2}$} & $\mathrm{H}_{2} \mathrm{O}$ & 298 & $<0$ & & 73 \\
\hline 8 & {$\left[\mathrm{RhH}(\mathrm{dppe})(\mathrm{MeOH})_{3}\right]^{+2}$} & {$[\mathrm{M}]^{+}$} & $\mathrm{HBF}_{4}$ & {$[\mathrm{M}]^{+}+\mathrm{H}^{+} \rightleftharpoons[\mathrm{MH}]^{+2}$} & $\mathrm{MeOH}$ & 298 & 1.0 & & 248 \\
\hline 9 & {$\left[\mathrm{RhH}(\mathrm{Cl})(\mathrm{CO})\left(\mathrm{PPh}_{3}\right)_{2}(\mathrm{MeOH})\right]^{+}$} & M & & $\mathrm{M}+\mathrm{H}^{+} \rightleftharpoons \mathrm{MH}^{+}$ & $\mathrm{MeOH}$ & 298 & 1.8 & 1 & 3,257 \\
\hline 10 & {$\left[\operatorname{IrH}\left(\mathrm{Cp}^{*}\right)(\mathrm{CO})_{2}\right]^{+}$} & M & $\mathrm{CF}_{3} \mathrm{SO}_{3} \mathrm{H}$ & $\mathrm{MH}+\mathrm{HY} \rightarrow\left[\mathrm{MH}_{2}\right] \mathrm{Y}$ & DCE & 298 & 2.2 & 3 & 8,112 \\
\hline 11 & {$\left[\mathrm{IrH}(\mathrm{CO}) \mathrm{Cl}\left(\mathrm{PPh}_{3}\right)_{2}\right]^{+}$} & M & $\mathrm{CF}_{3} \mathrm{SO}_{3} \mathrm{H}$ & $\mathrm{M}+\mathrm{H}^{+} \rightleftharpoons[\mathrm{MH}]^{+}$ & $\mathrm{MeOH}$ & 298 & 2.1 & 3 & 3,257 \\
\hline 12 & {$\left[\mathrm{IrH}_{3}(\mathrm{Cp})\left(\mathrm{P}(\mathrm{OPh})_{3}\right)\right]^{+}$} & $\mathrm{MH}_{2}$ & $\mathrm{CF}_{3} \mathrm{SO}_{3} \mathrm{H}$ & $\mathrm{MH}+\mathrm{HY} \rightarrow\left[\mathrm{MH}_{2}\right] \mathrm{Y}$ & DCE & 298 & -3.1 & 6 & 8,29 \\
\hline 13 & {$\left[\mathrm{IrH}_{3}(\mathrm{Cp})\left(\left(\mathrm{PPh}_{3}\right)\right]^{+}\right.$} & $\mathrm{MH}_{2}$ & $\mathrm{CF}_{3} \mathrm{SO}_{3} \mathrm{H}$ & $\mathrm{MH}_{2}+\mathrm{HY} \rightarrow\left[\mathrm{MH}_{3}\right] \mathrm{Y}$ & DCE & 298 & 1.2 & 7 & 8,29 \\
\hline 14 & {$[\operatorname{IrH}(\mathrm{I})(\mathrm{COD})\{\text { Josiphos }\}]^{+}$} & M & $\operatorname{Imine}^{a}$ & {$[\mathrm{MH}] \mathrm{Y}+\mathrm{B} \rightleftharpoons \mathrm{M}+[\mathrm{HB}] \mathrm{Y}$} & $\mathrm{CH}_{2} \mathrm{Cl}_{2}$ & 298 & & 5 & 258 \\
\hline 15 & {$\left[\operatorname{Ir}\left(\mathrm{H}_{2}\right)\left\{{ }^{\mathrm{t}} \mathrm{BuNC}{ }_{6} \mathrm{H}_{3}\left({ }^{\mathrm{t}} \mathrm{Bu}\right)_{2} \mathrm{O}\right\} \mathrm{Cp}^{*}\right]^{+}$} & MH & $2,6-\mathrm{Bu}_{2} \mathrm{C}_{5} \mathrm{H}_{3} \mathrm{~N}$ & {$\left[\mathrm{MH}_{2}\right] \mathrm{Y}+\mathrm{B} \rightarrow \mathrm{MH}+[\mathrm{HB}] \mathrm{Y}$} & $\mathrm{CH}_{2} \mathrm{Cl}_{2}$ & 295 & $<6$ & & 280 \\
\hline 16 & {$\left[\operatorname{Ir}(\mathrm{H})\left\{{ }^{t} \mathrm{BuNC}_{6} \mathrm{H}_{3}\left({ }^{+} \mathrm{Bu}\right)_{2} \mathrm{O}\right\} \mathrm{Cp}^{*}\right]^{+}$} & M & 2,6- ${ }^{\mathrm{t}} \mathrm{Bu}_{2} \mathrm{C}_{5} \mathrm{H}_{3} \mathrm{~N}$ & {$[\mathrm{MH}] \mathrm{Y}+\mathrm{B} \rightarrow \mathrm{M}+[\mathrm{HB}] \mathrm{Y}$} & $\mathrm{CH}_{2} \mathrm{Cl}_{2}$ & 295 & $<6$ & & 280 \\
\hline 17 & {$[\operatorname{IrH}(\mathrm{Cp})(\mathrm{COD})]^{+}$} & M & $\mathrm{CF}_{3} \mathrm{SO}_{3} \mathrm{H}$ & $\mathrm{MH}+\mathrm{HY} \rightarrow\left[\mathrm{MH}_{2}\right] \mathrm{Y}$ & DCE & 298 & 3.0 & 6 & 8,112 \\
\hline 18 & {$\left[\mathrm{IrH}(\mathrm{CO}) \mathrm{Cl}\left(\mathrm{PPhMe}_{2}\right)_{2}\right]^{+}$} & M & $\mathrm{CF}_{3} \mathrm{SO}_{3} \mathrm{H}$ & $\mathrm{M}+\mathrm{H}^{+} \rightleftharpoons[\mathrm{MH}]^{+}$ & $\mathrm{MeOH}$ & 298 & 2.8 & 6 & 3,257 \\
\hline 19 & {$\left[\operatorname{Ir}\left(\mathrm{H}_{2}\right) \mathrm{H}\left(\mathrm{bq}-\mathrm{NH}_{2}\right)\left(\mathrm{PPh}_{2} \mathrm{Me}\right)_{2}\right]^{+}$} & $\mathrm{MH}_{2}$ & $\mathrm{bqNH} \mathrm{H}_{2} / \mathrm{BF}_{4}^{-}$ & {$\left[\mathrm{MH}_{3}\right] \mathrm{Y}+\mathrm{B} \leftarrow \mathrm{MH}_{2}+[\mathrm{HB}] \mathrm{Y}$} & $\mathrm{CD}_{2} \mathrm{Cl}_{2}$ & 298 & $\sim 6$ & & 259 \\
\hline 20 & {$\left[\mathrm{Ir}\left(\mathrm{H}_{2}\right) \mathrm{H}\left(\mathrm{bq}-\mathrm{NH}_{2}\right)\left(\mathrm{PCy}_{3}\right)_{2}\right]^{+}$} & $\mathrm{MH}_{2}$ & $\mathrm{bqNH}_{2} / \mathrm{BF}_{4}^{-}$ & {$\left[\mathrm{MH}_{3}\right] \mathrm{Y}+\mathrm{B} \rightarrow \mathrm{MH}_{2}+[\mathrm{HB}] \mathrm{Y}$} & $\mathrm{CD}_{2} \mathrm{Cl}_{2}$ & 298 & $\sim 8$ & & 259 \\
\hline 21 & {$\left[\operatorname{Ir}\left(\mathrm{H}_{2}\right) \mathrm{H}\left(\mathrm{bq}-\mathrm{NH}_{2}\right)\left(\left(\mathrm{PPh}_{3}\right)_{2}\right]^{+}\right.$} & $\mathrm{MH}_{2}$ & $\mathrm{bqNH}_{2} / \mathrm{BF}_{4}^{-}$ & {$\left[\mathrm{MH}_{3}\right] \mathrm{Y}+\mathrm{B} \rightarrow \mathrm{MH}_{2}+[\mathrm{HB}] \mathrm{Y}$} & $\mathrm{CD}_{2} \mathrm{Cl}_{2}$ & 298 & $\sim 8$ & 7 & 259 \\
\hline 22 & {$\left[\mathrm{CoH}\left(\mathrm{CH}_{3} \mathrm{CN}\right)(\mathrm{dppe})_{2}\right]^{+2}$} & {$[\mathrm{M}]^{+}$} & $\mathrm{CH}_{3} \mathrm{OC}_{6} \mathrm{H}_{4} \mathrm{NH}_{2}$ & {$[\mathrm{MH}] \mathrm{Y}_{2}+\mathrm{B} \rightleftharpoons[\mathrm{MH}] \mathrm{Y}+[\mathrm{HB}] \mathrm{Y}$} & $\mathrm{CH}_{3} \mathrm{CN}$ & 298 & 11.3 & $\left(13^{c}\right)$ & 44 \\
\hline 23 & {$\left[\mathrm{RhH}\left(\mathrm{NH}_{3}\right)_{4}\left(\mathrm{H}_{2} \mathrm{O}\right)\right]^{+2}$} & {$[\mathrm{M}]^{+}$} & & {$[\mathrm{M}]^{+}+\mathrm{H}^{+} \rightleftharpoons[\mathrm{MH}]^{+2}$} & $\mathrm{H}_{2} \mathrm{O}$ & 298 & $>14$ & 7 & 73 \\
\hline 24 & {$\left[\mathrm{RhH}(\mathrm{bpy})_{2}\left(\mathrm{H}_{2} \mathrm{O}\right)\right]^{+2}$} & {$[\mathrm{M}]^{+}$} & & {$[\mathrm{M}]^{+}+\mathrm{H}^{+} \rightleftharpoons[\mathrm{MH}]^{+2}$} & $\mathrm{H}_{2} \mathrm{O}$ & 298 & 9.5 & 7 & 73 \\
\hline 25 & {$\left[\mathrm{RhH}\left(\mathrm{CH}_{3} \mathrm{CN}\right)(\mathrm{dppb})_{2}\right]^{+2}$} & {$[\mathrm{M}]^{+}$} & $4-\mathrm{BrC}_{6} \mathrm{H}_{4} \mathrm{NH}_{2}$ & {$[\mathrm{MH}] \mathrm{Y}_{2}+\mathrm{B} \rightleftharpoons[\mathrm{M}] \mathrm{Y}+[\mathrm{HB}] \mathrm{Y}$} & $\mathrm{CH}_{3} \mathrm{CN}$ & 298 & 9.4 & $\begin{array}{r}7 \\
\left(13^{c}\right)\end{array}$ & 251 \\
\hline 26 & {$\left[\mathrm{RhH}\left(\mathrm{CH}_{3} \mathrm{CN}\right)(\mathrm{dppe})_{2}\right]^{+2}$} & {$[\mathrm{M}]^{+}$} & $4-\mathrm{BrC}_{6} \mathrm{H}_{4} \mathrm{NH}_{2}$ & {$[\mathrm{MH}] \mathrm{Y}_{2}+\mathrm{B} \rightleftharpoons[\mathrm{M}] \mathrm{Y}+[\mathrm{HB}] \mathrm{Y}$} & $\mathrm{CH}_{3} \mathrm{CN}$ & 298 & 9.0 & $\begin{array}{r}7 \\
\left(13^{c}\right)\end{array}$ & 251 \\
\hline 27 & {$\left[\mathrm{RhH}\left(\mathrm{CH}_{3} \mathrm{CN}\right)(\mathrm{dppp})_{2}\right]^{+2}$} & {$[\mathrm{M}]^{+}$} & {$[\mathrm{DMF}-\mathrm{H}] \mathrm{CF}_{3} \mathrm{SO}_{3}$} & {$[\mathrm{M}] \mathrm{Y}+[\mathrm{HB}] \mathrm{Y} \rightleftharpoons[\mathrm{MH}] \mathrm{Y}_{2}+\mathrm{B}$} & $\mathrm{CH}_{3} \mathrm{CN}$ & 298 & 5.8 & $\begin{array}{r}7 \\
\left(13^{c}\right)\end{array}$ & 251 \\
\hline
\end{tabular}




\begin{tabular}{|c|c|}
\hline 28 & {$\left[\mathrm{IrH}_{3}\left\{\mathrm{C}_{5} \mathrm{H}_{4} \mathrm{CH}\left(\mathrm{CH}_{2} \mathrm{CH}_{2}\right)_{2} \mathrm{NMe}\right\}\left(\left(\mathrm{PPh}_{3}\right)\right]^{+}\right.$} \\
\hline 29 & {$\left[\mathrm{IrH}_{3}\left\{\mathrm{C}_{5} \mathrm{H}_{4} \mathrm{CH}\left(\mathrm{CH}_{2} \mathrm{CH}_{2}\right)_{2} \mathrm{NMe}\right\}\left(\left(\mathrm{PPh}_{3}\right)\right]^{+}\right.$} \\
\hline $\begin{array}{l}30 \\
31\end{array}$ & $\begin{array}{l}{\left[\mathrm{IrH}\left(\mathrm{Cp}^{*}\right)(\mathrm{COD})\right]^{+}} \\
{\left[\mathrm{IrH}_{4}\left(\mathrm{C}_{2} \mathrm{H}_{4}\right)\left(\mathrm{PPh}_{2} \mathrm{C}_{6} \mathrm{H}_{4} \text {-oxazoline }\right)\right]^{+}}\end{array}$ \\
\hline 32 & {$\left[\operatorname{IrH}(\mathrm{Cp})\left(\left(\mathrm{PPh}_{3}\right)(\mathrm{CO})\right]^{+}\right.$} \\
\hline $\begin{array}{l}33 \\
34\end{array}$ & $\begin{array}{l}{\left[\mathrm{IrH}(\mathrm{Cp})\left(\mathrm{PPh}_{2} \mathrm{Me}\right)(\mathrm{CO})\right]^{+}} \\
{\left[\mathrm{IrH}_{4}\left(\mathrm{C}_{2} \mathrm{H}_{4}\right)(\mathrm{NHC} \text {-oxazoline })\right]^{+}}\end{array}$ \\
\hline 35 & {$\left[\operatorname{IrH}\left(\mathrm{Cp}^{*}\right)\left(\left(\mathrm{PPh}_{3}\right)(\mathrm{CO})\right]^{+}\right.$} \\
\hline 36 & $\mathrm{Cl}(\mathrm{H}) \mathrm{Rh}(\mu-\mathrm{P}-\mathrm{P})_{2}(\mu \mathrm{Cl}) \mathrm{RhCl}(\mathrm{THF})$ \\
\hline 37 & {$\left[\mathrm{IrH}\left(\mathrm{Cp}^{*}\right)\left(\mathrm{PMePh}_{2}\right)(\mathrm{CO})\right]^{+}$} \\
\hline $\begin{array}{l}38 \\
39\end{array}$ & $\begin{array}{l}{\left[\mathrm{IrH}(\mathrm{Cp})\left(\mathrm{PPhMe}_{2}\right)(\mathrm{CO})\right]^{+}} \\
{\left[\mathrm{Rh}(\mathrm{H})(\mathrm{dmpe})_{2}\left(\mathrm{CH}_{3} \mathrm{CN}\right)\right]^{+2}}\end{array}$ \\
\hline 40 & {$\left[\mathrm{RhH}\left(\mathrm{CH}_{3} \mathrm{CN}\right)(\text { depe })_{2}\right]^{+2}$} \\
\hline 41 & {$\left[\mathrm{RhH}\left(\mathrm{CH}_{3} \mathrm{CN}\right)(\mathrm{depp})_{2}\right]^{+2}$} \\
\hline 42 & {$\left[\mathrm{RhH}\left(\mathrm{CH}_{3} \mathrm{CN}\right)(\mathrm{depx})_{2}\right]^{+2}$} \\
\hline 43 & {$\left[\mathrm{RhH}\left(\mathrm{CH}_{3} \mathrm{CN}\right)\left(\mathrm{PCy}_{2} \mathrm{CH}_{2} \mathrm{CH}_{2} \mathrm{PCy}_{2}\right)_{2}\right]^{+2}$} \\
\hline $\begin{array}{l}44 \\
45\end{array}$ & $\begin{array}{l}{\left[\mathrm{CoH}(\text { rac-macrocycle })\left(\mathrm{H}_{2} \mathrm{O}\right)\right]^{+2}} \\
{\left[\mathrm{CoH}\left(\mathrm{P}_{4}\right)\left(\mathrm{CH}_{3} \mathrm{CN}\right)\right]^{+2} \text { (trans) }}\end{array}$ \\
\hline 46 & {$\left[\mathrm{CoH}\left\{\mathrm{N}\left(\mathrm{CH}_{2} \mathrm{CH}_{2} \mathrm{py}\right)_{2} \mathrm{CH}_{2} \mathrm{bpy}\right\}\right]^{+2}$} \\
\hline 47 & {$\left[\mathrm{IrH}(\mathrm{CO})\left(\mathrm{Cp}^{*}\right)\left(\mathrm{PPhMe}_{2}\right]^{+}\right.$} \\
\hline 48 & {$\left[\mathrm{IrH}(\mathrm{CO})(\mathrm{Cp})\left(\mathrm{PMe}_{3}\right)\right]^{+}$} \\
\hline 49 & {$\left[\mathrm{IrH}(\mathrm{CO})(\mathrm{Cp})\left(\mathrm{PEt}_{3}\right)\right]^{+}$} \\
\hline 50 & {$\left[\mathrm{IrH}_{2}(\mathrm{CO})\left(\left(\mathrm{PPh}_{3}\right)_{3}\right]^{+}\right.$} \\
\hline 51 & {$\left[\mathrm{IrH}_{4}\left(\left(\mathrm{PPh}_{3}\right)_{2}(\mathrm{Benz}-\mathrm{NHC})\right]^{+}\right.$} \\
\hline 52 & $\mathrm{CoH}(\mathrm{CO})_{4}$ \\
\hline 53 & $\mathrm{CoH}(\mathrm{CO})_{4}$ \\
\hline 54 & 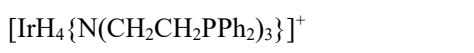 \\
\hline 55 & {$\left[\mathrm{IrH}(\mathrm{Cl})\left\{\mathrm{N}\left(\mathrm{CH}_{2} \mathrm{CH}_{2} \mathrm{PPh}_{2}\right)_{3}\right\}\right]^{+}$} \\
\hline
\end{tabular}

\begin{tabular}{|c|c|c|}
\hline $\mathrm{MH}_{2}$ & $\mathrm{CD}_{2} \mathrm{Cl}_{2}$ & $\mathrm{MH}_{2}+[\mathrm{HB}] \mathrm{Y} \leftarrow\left[\mathrm{MH}_{3}\right] \mathrm{Y}$ \\
\hline $\mathrm{MH}_{2}$ & THF & {$\left[\mathrm{MH}_{3}\right] \mathrm{Y}+\mathrm{B} \rightarrow \mathrm{MH}_{2}[\mathrm{YHB}]$} \\
\hline $\begin{array}{l}\mathrm{M} \\
\mathrm{MH}_{3}\end{array}$ & $\mathrm{CF}_{3} \mathrm{SO}_{3} \mathrm{H}$ & $\begin{array}{l}\mathrm{MH}+\mathrm{HY} \rightarrow\left[\mathrm{MH}_{2}\right] \mathrm{Y} \\
\text { DFT calculation }\end{array}$ \\
\hline M & $\mathrm{CF}_{3} \mathrm{SO}_{3} \mathrm{H}$ & $\mathrm{MH}+\mathrm{HY} \rightarrow\left[\mathrm{MH}_{2}\right] \mathrm{Y}$ \\
\hline $\begin{array}{l}\mathrm{M} \\
\mathrm{MH}_{3}\end{array}$ & $\mathrm{CF}_{3} \mathrm{SO}_{3} \mathrm{H}$ & $\begin{array}{l}\mathrm{MH}+\mathrm{HY} \rightarrow\left[\mathrm{MH}_{2}\right] \mathrm{Y} \\
\text { DFT calculation }\end{array}$ \\
\hline M & $\mathrm{CF}_{3} \mathrm{SO}_{3} \mathrm{H}$ & $\mathrm{MH}+\mathrm{HY} \rightarrow\left[\mathrm{MH}_{2}\right] \mathrm{Y}$ \\
\hline $\mathrm{MM}$ & $\mathrm{HCl}$ & $\mathrm{MM}+\mathrm{HCl} \rightleftharpoons \mathrm{HM}(\mu-\mathrm{Cl}) \mathrm{M}$ \\
\hline $\mathrm{MH}$ & $\mathrm{CF}_{3} \mathrm{SO}_{3} \mathrm{H}$ & $\mathrm{MH}+\mathrm{HY} \rightarrow\left[\mathrm{MH}_{2}\right] \mathrm{Y}$ \\
\hline $\begin{array}{l}\mathrm{M} \\
{[\mathrm{M}]^{+}}\end{array}$ & $\begin{array}{l}\mathrm{CF}_{3} \mathrm{SO}_{3} \mathrm{H} \\
\text { [proton sponge- } \\
\mathrm{H}_{\mathrm{C}} \mathrm{CF}_{3} \mathrm{SO}_{3}\end{array}$ & $\begin{array}{l}\mathrm{MH}+\mathrm{HY} \rightarrow\left[\mathrm{MH}_{2}\right] \mathrm{Y} \\
{[\mathrm{M}] \mathrm{Y}+[\mathrm{HB}] \mathrm{Y} \rightleftharpoons[\mathrm{MH}] \mathrm{Y}_{2}+\mathrm{B}}\end{array}$ \\
\hline$[\mathrm{M}]^{+}$ & & {$[\mathrm{M}] \mathrm{Y}+[\mathrm{HB}] \mathrm{Y} \rightleftharpoons[\mathrm{MH}] \mathrm{Y}_{2}+\mathrm{B}$} \\
\hline$[\mathrm{M}]^{+}$ & $\begin{array}{l}{[4-} \\
\left.\mathrm{CH}_{3} \mathrm{OC}_{6} \mathrm{H}_{4} \mathrm{NH}_{3}\right] \\
\mathrm{CF}_{3} \mathrm{SO}_{3}\end{array}$ & {$[\mathrm{M}] \mathrm{Y}+[\mathrm{HB}] \mathrm{Y} \rightleftharpoons[\mathrm{MH}] \mathrm{Y}_{2}+\mathrm{B}$} \\
\hline$[\mathrm{M}]^{+}$ & $\mathrm{CH}_{3} \mathrm{OC}_{6} \mathrm{H}_{4} \mathrm{NH}_{2}$ & {$[\mathrm{MH}] \mathrm{Y}_{2}+\mathrm{B} \rightleftharpoons[\mathrm{M}] \mathrm{Y}+[\mathrm{HB}] \mathrm{Y}$} \\
\hline$[\mathrm{M}]^{+}$ & {$[\mathrm{DMF}-\mathrm{H}] \mathrm{CF}_{3} \mathrm{SO}_{3}$} & {$[\mathrm{M}] \mathrm{Y}+[\mathrm{HB}] \mathrm{Y} \rightleftharpoons[\mathrm{MH}] \mathrm{Y}_{2}+\mathrm{B}$} \\
\hline $\begin{array}{l}{[\mathrm{M}]^{+}} \\
{[\mathrm{M}]^{+}}\end{array}$ & $\begin{array}{l}\text { 2,4,6- } \mathrm{Me}_{3} \mathrm{C}_{5} \mathrm{H}_{2} \mathrm{~N} \\
\text { collidine }\end{array}$ & $\begin{array}{l}\text { From pH } \\
{[\mathrm{MH}] \mathrm{Y}_{2}+\mathrm{B} \rightleftharpoons[\mathrm{M}] \mathrm{Y}+[\mathrm{HB}] \mathrm{Y}}\end{array}$ \\
\hline$[\mathrm{M}]^{+}$ & $\mathrm{H}_{2} \mathrm{O}$ & {$[\mathrm{MH}] \mathrm{Y}_{2}+\mathrm{H}_{2} \mathrm{O} \rightarrow[\mathrm{M}] \mathrm{Y}+\mathrm{H}_{3} \mathrm{O}+$} \\
\hline M & $\mathrm{CF}_{3} \mathrm{SO}_{3} \mathrm{H}$ & $\mathrm{MH}+\mathrm{HY} \rightarrow\left[\mathrm{MH}_{2}\right] \mathrm{Y}$ \\
\hline M & $\mathrm{CF}_{3} \mathrm{SO}_{3} \mathrm{H}$ & $\mathrm{MH}+\mathrm{HY} \rightarrow\left[\mathrm{MH}_{2}\right] \mathrm{Y}$ \\
\hline M & $\mathrm{CF}_{3} \mathrm{SO}_{3} \mathrm{H}$ & $\mathrm{MH}+\mathrm{HY} \rightarrow\left[\mathrm{MH}_{2}\right] \mathrm{Y}$ \\
\hline MH & $\mathrm{CF}_{3} \mathrm{SO}_{3} \mathrm{H}$ & $\mathrm{MH}+\mathrm{HY} \rightarrow\left[\mathrm{MH}_{2}\right] \mathrm{Y}$ \\
\hline $\mathrm{MH}_{3}$ & DBU & {$\left[\mathrm{MH}_{4}\right] \mathrm{Y}+\mathrm{B} \rightarrow \mathrm{MH}_{3}+[\mathrm{HB}] \mathrm{Y}$} \\
\hline$[\mathrm{M}]^{-}$ & $\mathrm{HCl}$ & $\mathrm{Z}[\mathrm{M}]+2 \mathrm{HCl} \rightleftharpoons \mathrm{MH}+\mathrm{Z}[\mathrm{ClHCl}]$ \\
\hline$[\mathrm{M}]$ & $4-\mathrm{CF}_{3} \mathrm{C}_{6} \mathrm{H}_{4} \mathrm{NH}_{2}$ & $\mathrm{MH}+\mathrm{B} \rightleftharpoons[\mathrm{HB}][\mathrm{M}]$ \\
\hline $\mathrm{MH}_{3}$ & {$\left[\mathrm{H}\left(\mathrm{OEt}_{2}\right)_{2}\right] \mathrm{BF}_{4}$} & $\mathrm{MH}_{3}+[\mathrm{HB}] \mathrm{Y} \rightarrow\left[\mathrm{MH}_{4}\right] \mathrm{Y}$ \\
\hline M & $\mathrm{CF}_{3} \mathrm{SO}_{3} \mathrm{H}$ & $\mathrm{M}+\mathrm{HY} \rightarrow[\mathrm{MH}] \mathrm{Y}$ \\
\hline
\end{tabular}

\begin{tabular}{|c|c|c|c|c|}
\hline $\mathrm{CD}_{2} \mathrm{Cl}_{2}$ & 298 & & 7 & 261 \\
\hline THF & 298 & $<13$ & & 261 \\
\hline $\begin{array}{l}\mathrm{DCE} \\
\mathrm{CH}_{3} \mathrm{CN}\end{array}$ & $\begin{array}{l}298 \\
298\end{array}$ & $\begin{array}{r}6.1 \\
11.5\end{array}$ & $\begin{array}{r}7 \\
7 \\
\left(12^{c}\right)\end{array}$ & $\begin{array}{r}8,112 \\
263\end{array}$ \\
\hline DCE & 298 & 7.0 & 9 & 8,112 \\
\hline $\begin{array}{l}\mathrm{DCE} \\
\mathrm{CH}_{3} \mathrm{CN}\end{array}$ & $\begin{array}{l}298 \\
298\end{array}$ & $\begin{array}{r}7.8 \\
17.4\end{array}$ & $\begin{array}{r}9 \\
10 \\
\left(15^{c}\right)\end{array}$ & $\begin{array}{r}8,112 \\
263\end{array}$ \\
\hline DCE & 298 & 10.9 & 10 & 8,112 \\
\hline THF/diox. & 298 & & 10 & 270 \\
\hline DCE & 298 & 10.9 & 10 & 8,112 \\
\hline DCE & 298 & 8.3 & 10 & 8,112 \\
\hline $\mathrm{CH}_{3} \mathrm{CN}$ & 298 & 18.9 & $\begin{array}{r}11 \\
\left(16^{c}\right)\end{array}$ & 281 \\
\hline $\mathrm{CH}_{3} \mathrm{CN}$ & 298 & 16.6 & $\begin{array}{r}11 \\
\left(16^{c}\right)\end{array}$ & 251 \\
\hline $\mathrm{CH}_{3} \mathrm{CN}$ & 298 & 14.4 & $\begin{array}{r}11 \\
\left(16^{c}\right)\end{array}$ & 251 \\
\hline $\mathrm{CH}_{3} \mathrm{CN}$ & 298 & 11.5 & $\begin{array}{r}11 \\
\left(16^{c}\right)\end{array}$ & 68 \\
\hline $\mathrm{CH}_{3} \mathrm{CN}$ & 298 & 6.0 & $\begin{array}{r}11 \\
\left(16^{c}\right)\end{array}$ & 251 \\
\hline $\mathrm{H}_{2} \mathrm{O}$ & 298 & 11.7 & 11 & 253 \\
\hline $\mathrm{CH}_{3} \mathrm{CN}$ & 298 & 16.0 & $\begin{array}{r}11 \\
\left(16^{c}\right)\end{array}$ & 252 \\
\hline $\mathrm{H}_{2} \mathrm{O}$ & 298 & 15 & 11 & 83 \\
\hline DCE & 298 & 11.4 & 11 & 29 \\
\hline DCE & 298 & 8.7 & 11 & 8,112 \\
\hline DCE & 298 & 8.6 & 11 & 8,112 \\
\hline DCE & 298 & 11.8 & 12 & 8,112 \\
\hline toluene & 298 & $<19$ & 13 & 282 \\
\hline $\mathrm{CH}_{3} \mathrm{CN}$ & 253 & 8.3 & 14 & 40 \\
\hline $\mathrm{CH}_{3} \mathrm{CN}$ & 253 & 8.3 & 14 & 51 \\
\hline $\mathrm{CD}_{2} \mathrm{Cl}_{2}$ & $<240$ & & 16 & 58 \\
\hline THF & 298 & & 15 & 58 \\
\hline
\end{tabular}




\begin{tabular}{|c|c|}
\hline 56 & {$\left[\mathrm{Cp} * \operatorname{Ir}(\mu \mathrm{H})_{3} \operatorname{IrCp} *\right](\mathrm{OMe})$} \\
\hline 57 & $\operatorname{IrH}(\mathrm{Cl})\left(\mathrm{PMe}_{3}\right)_{3}(\mathrm{OMe})$ \\
\hline $\begin{array}{l}58 \\
59\end{array}$ & $\begin{array}{l}\operatorname{IrH}(\mathrm{Cl})\left(\mathrm{PMe}_{3}\right)_{3}(\mathrm{OH}) \\
{\left[\mathrm{CoH}_{2}(\mathrm{dppe})_{2}\right]^{+}}\end{array}$ \\
\hline 60 & {$\left[\mathrm{Rh}\left(\mathrm{H}_{2}\right) \mathrm{H}(\mathrm{Cl})\left\{\mathrm{PPh}_{2}\left(\mathrm{C}_{6} \mathrm{H}_{4} \mathrm{SO}_{3}\right)\right\}_{3}\right]^{2-}$} \\
\hline 61 & {$\left[\mathrm{Rh}\left(\mathrm{H}_{2}\right) \mathrm{H}(\mathrm{Cl})\left\{\mathrm{P}\left(\mathrm{C}_{6} \mathrm{H}_{4} \mathrm{SO}_{3}\right)_{3}\right\}_{3}\right]^{8-}$} \\
\hline $\begin{array}{l}62 \\
63\end{array}$ & $\begin{array}{l}{\left[\mathrm{RhD}(\mathrm{tspp})\left(\mathrm{D}_{2} \mathrm{O}\right)\right]^{4-}} \\
{\left[\mathrm{IrH}\left(\mathrm{Cp}^{*}\right)(\mathrm{bpy})\right]^{+}}\end{array}$ \\
\hline $\begin{array}{l}64 \\
65\end{array}$ & $\begin{array}{l}{[\mathrm{IrH}(\mathrm{Cp} *)(\mathrm{bpy})]^{+}} \\
\mathrm{CoH}(\mathrm{CO})_{3}\left(\mathrm{P}(\mathrm{OPh})_{3}\right)\end{array}$ \\
\hline 66 & {$\left[\mathrm{IrH}_{2}\left(\mathrm{Cp}^{*}\right)\left(\mathrm{TsNCHPhCHPhNH}_{2}\right)\right]^{+}$} \\
\hline 67 & $\mathrm{CoH}(\mathrm{CO})_{3}\left(\left(\mathrm{PPh}_{3}\right)\right.$ \\
\hline 68 & {$\left[\operatorname{IrD}(\operatorname{tspp})\left(\mathrm{D}_{2} \mathrm{O}\right)\right]^{4-}$} \\
\hline 69 & {$\left[\mathrm{IrH}_{2}\left(\mathrm{Cp}^{*}\right)\left(\mathrm{NH}_{2} \mathrm{CPh}_{2} \mathrm{C}_{6} \mathrm{H}_{4}\right)\right]^{+}$} \\
\hline 70 & {$\left[\mathrm{CoH}(\mathrm{dppe})_{2}\left(\mathrm{CH}_{3} \mathrm{CN}\right)\right]^{+}$} \\
\hline $\begin{array}{l}71 \\
72\end{array}$ & $\begin{array}{l}\mathrm{RhH}\left(\mathrm{Cp}^{*}\right)\left(\mathrm{NC}_{5} \mathrm{H}_{4}-\mathrm{C}_{6} \mathrm{H}_{4}\right) \\
{\left[\mathrm{CoH}_{2}\left(\mathrm{P}_{4}\right)\right]^{+}(\operatorname{trans})}\end{array}$ \\
\hline 73 & {$\left[\mathrm{Rh}(\mathrm{H})_{2}(\mathrm{depx})_{2}\right]^{+}$} \\
\hline 74 & {$\left[\mathrm{Rh}(\mathrm{H})_{2}(\mathrm{dmpe})_{2}\right]^{+}$} \\
\hline 75 & {$\left[\mathrm{Rh}(\mathrm{H})_{2}(\mathrm{depe})_{2}\right]^{+}$} \\
\hline 76 & {$\left[\mathrm{IrH}(\mathrm{Me})\left(\mathrm{PMe}_{3}\right)_{4}\right]^{+}$} \\
\hline 77 & {$\left[\mathrm{IrH}(\mathrm{Me})\left(\mathrm{PMe}_{3}\right)_{4}\right]^{+}$} \\
\hline 78 & {$\left[\mathrm{CoH}\left(\mathrm{P}_{4}\right)\right]^{+}$} \\
\hline 79 & $\mathrm{CoH}(\mathrm{dppe})_{2}$ \\
\hline 80 & $\mathrm{RhH}(\mathrm{dppb})_{2}$ \\
\hline 81 & $\operatorname{IrH}_{5}\left(\mathrm{P}^{\mathrm{i}} \mathrm{Pr}_{3}\right)_{2}$ \\
\hline 82 & $\operatorname{IrH}_{5}\left(\mathrm{PCy}_{3}\right)_{2}$ \\
\hline 83 & $\operatorname{Ir}(\mathrm{H})_{2}\left(\mathrm{Cp}^{*}\right)\left(\mathrm{PMe}_{3}\right)$ \\
\hline 84 & $\operatorname{Ir}(\mathrm{H})_{2}\left(\mathrm{Cp}^{*}\right)\left(\mathrm{PMe}_{3}\right)$ \\
\hline
\end{tabular}

\begin{tabular}{|c|c|c|}
\hline $\mathrm{MH}_{2} \mathrm{M}$ & $\mathrm{MeOH}$ & $\mathrm{MH}_{2} \mathrm{M}+2 \mathrm{HY} \rightleftharpoons\left[\mathrm{MH}_{3} \mathrm{M}\right][\mathrm{YHY}]$ \\
\hline M & $\mathrm{MeOH}$ (excess) & $\mathrm{M}+\mathrm{nHY} \rightarrow[\mathrm{MH}][\mathrm{YHY}+(\mathrm{n}-2) \mathrm{HY}]$ \\
\hline $\begin{array}{l}\text { M } \\
\text { MH }\end{array}$ & $\begin{array}{l}\mathrm{H}_{2} \mathrm{O} \text { (excess) } \\
\text { TMG }\end{array}$ & $\begin{array}{l}\mathrm{M}+\mathrm{nHY} \rightarrow[\mathrm{MH}][\mathrm{YHY}+(\mathrm{n}-2) \mathrm{HY}] \\
{\left[\mathrm{MH}_{2}\right] \mathrm{Y}+\mathrm{B} \rightleftharpoons \mathrm{MH}+[\mathrm{HB}] \mathrm{Y}}\end{array}$ \\
\hline $\mathrm{MH}_{2}$ & & {$\left[\mathrm{MH}_{3}\right]^{+} \rightleftharpoons \mathrm{MH}_{2}+\mathrm{H}^{+}$} \\
\hline $\mathrm{MH}_{2}$ & & {$\left[\mathrm{MH}_{3}\right]^{+} \rightleftharpoons \mathrm{MH}_{2}+\mathrm{H}^{+}$} \\
\hline $\begin{array}{l}{[\mathrm{M}]^{-}} \\
\mathrm{M}\end{array}$ & DBU & $\begin{array}{l}{[\mathrm{M}]^{-}+\mathrm{H}^{+} \rightleftharpoons \mathrm{MH}} \\
\mathrm{MH}+\mathrm{B} \rightleftharpoons[\mathrm{HB}][\mathrm{M}]\end{array}$ \\
\hline M & $\mathrm{H}_{2} \mathrm{O}$ & $\mathrm{M}+\mathrm{H}^{+} \rightarrow \mathrm{MH}^{+}$ \\
\hline M & $\mathrm{CH}_{3} \mathrm{OC}_{6} \mathrm{H}_{4} \mathrm{NH}_{2}$ & $\mathrm{MH}+\mathrm{B} \rightleftharpoons[\mathrm{HB}][\mathrm{M}]$ \\
\hline MH & $\begin{array}{l}{[2,6-} \\
\text { lutidinium }] \mathrm{BF}_{4}\end{array}$ & $\mathrm{MH}+[\mathrm{HB}] \mathrm{Y} \rightleftharpoons\left[\mathrm{MH}_{2}\right] \mathrm{Y}+\mathrm{B}$ \\
\hline$\left[\mathrm{M}^{-}\right.$ & morpholine & $\mathrm{MH}+\mathrm{B} \rightleftharpoons[\mathrm{HB}][\mathrm{M}]$ \\
\hline$[\mathrm{M}]^{-}$ & & {$[\mathrm{M}]^{-}+\mathrm{H}^{+} \rightleftharpoons \mathrm{MH}$} \\
\hline MH & {$\left[\mathrm{HNEt}_{3}\right] \mathrm{BF}_{4}$} & $\mathrm{MH}+[\mathrm{HB}] \mathrm{Y} \rightleftharpoons\left[\mathrm{MH}_{2}\right] \mathrm{Y}+\mathrm{B}$ \\
\hline M & & From thermodynamic cycle \\
\hline $\begin{array}{l}\text { M } \\
\text { MH }\end{array}$ & $\left(\mathrm{C}_{4} \mathrm{H}_{8} \mathrm{~N}\right)_{3} \mathrm{P}=\mathrm{N}^{\mathrm{t} B u}$ & $\begin{array}{l}\mathrm{MH}+\mathrm{B} \rightleftharpoons[\mathrm{HB}] \mathrm{M} \\
\text { From thermodynamic cycle }\end{array}$ \\
\hline MH & $\left(\mathrm{Me}_{2} \mathrm{~N}\right)_{3} \mathrm{P}=\mathrm{NMe}$ & {$\left[\mathrm{MH}_{2}\right] \mathrm{Y}+\mathrm{B} \rightleftharpoons \mathrm{MH}+[\mathrm{HB}] \mathrm{Y}$} \\
\hline MH & $\mathrm{KO}^{t} \mathrm{Bu}$ & {$\left[\mathrm{MH}_{2}\right] \mathrm{Y}+\mathrm{KX} \rightleftharpoons \mathrm{MH}+\mathrm{KY}+\mathrm{HX}$} \\
\hline MH & $\mathrm{KO}^{t} \mathrm{Bu}$ & {$\left[\mathrm{MH}_{2}\right] \mathrm{Y}+\mathrm{KX} \rightarrow \mathrm{MH}+\mathrm{KY}+\mathrm{HX}$} \\
\hline M & $\mathrm{FeH}(\mathrm{CO})_{2} \mathrm{Cp}$ & $\mathrm{M}+\mathrm{M}^{\prime} \mathrm{H} \rightarrow[\mathrm{MH}]\left[\mathrm{M}^{\prime}\right]$ \\
\hline M & $\mathrm{MnH}(\mathrm{CO})_{5}$ & $\mathrm{M}+\mathrm{M}^{\prime} \mathrm{H} \rightarrow[\mathrm{MH}]\left[\mathrm{M}^{\prime}\right]$ \\
\hline M & & From thermodynamic cycle \\
\hline$[\mathrm{M}]^{-}$ & & From thermodynamic cycle \\
\hline$[\mathrm{M}]^{-}$ & & From thermodynamic cycle \\
\hline$\left[\mathrm{MH}_{4}\right]^{-}$ & $\mathrm{WH}_{6}\left(\mathrm{PMe}_{2} \mathrm{Ph}\right)_{3}$ & $\mathrm{Z}\left[\mathrm{MH}_{4}\right]+\mathrm{M}^{\prime} \mathrm{H}_{6} \rightleftharpoons \mathrm{MH}_{5}+\mathrm{K}\left[\mathrm{M}^{\prime} \mathrm{H}_{5}\right]$ \\
\hline$\left[\mathrm{MH}_{4}\right]^{-}$ & $\operatorname{IrH}_{5}\left(\mathrm{P}^{\mathrm{i}} \mathrm{Pr}_{3}\right)_{2}$ & $\mathrm{Z}\left[\mathrm{MH}_{4}\right]+\mathrm{M}^{\prime} \mathrm{H}_{5} \rightleftharpoons \mathrm{MH}_{5}+\mathrm{K}\left[\mathrm{M}^{\prime} \mathrm{H}_{4}\right]$ \\
\hline$[\mathrm{MH}]^{-}$ & $\mathrm{H}_{2}$ & $\mathrm{Z}[\mathrm{MH}]+\mathrm{H}_{2} \rightarrow \mathrm{MH}_{2}+\mathrm{ZH}$ \\
\hline$[\mathrm{MH}]^{-}$ & DMSO & $\mathrm{Z}[\mathrm{MH}]+\mathrm{HY} \rightarrow \mathrm{MH}_{2}+\mathrm{ZY}$ \\
\hline
\end{tabular}

\begin{tabular}{|c|c|c|c|c|}
\hline toluene & 298 & & 25 & 264 \\
\hline toluene & 243 & & 17 & 265 \\
\hline $\begin{array}{l}\text { dioxane } \\
\mathrm{CH}_{3} \mathrm{CN}\end{array}$ & $\begin{array}{l}298 \\
298\end{array}$ & 22.8 & $\begin{array}{r}17 \\
18 \\
\left(24^{c}\right)\end{array}$ & $\begin{array}{r}265 \\
44\end{array}$ \\
\hline $\mathrm{H}_{2} \mathrm{O}$ & 298 & 8.5 & & 75 \\
\hline $\mathrm{H}_{2} \mathrm{O}$ & 298 & 8.0 & & 75 \\
\hline $\begin{array}{l}\mathrm{H}_{2} \mathrm{O} \\
\mathrm{CH}_{3} \mathrm{CN}\end{array}$ & $\begin{array}{l}298 \\
298\end{array}$ & $\begin{array}{r}7.0 \\
23.0\end{array}$ & $\begin{array}{r}19 \\
\left(26^{c}\right)\end{array}$ & $\begin{array}{l}272 \\
244\end{array}$ \\
\hline $\begin{array}{l}\mathrm{H}_{2} \mathrm{O} \\
\mathrm{CH}_{3} \mathrm{CN} \\
\left(\mathrm{H}_{2} \mathrm{O}\right)\end{array}$ & $\begin{array}{l}298 \\
298\end{array}$ & 11.4 & $\begin{array}{l}19 \\
18\end{array}$ & $\begin{array}{r}245 \\
51\end{array}$ \\
\hline $\mathrm{CH}_{3} \mathrm{CN}$ & 298 & 13.9 & $\begin{array}{c}11 \\
\left(17^{c}\right)\end{array}$ & 232 \\
\hline $\begin{array}{l}\mathrm{CH}_{3} \mathrm{CN} \\
\left(\mathrm{H}_{2} \mathrm{O}\right)\end{array}$ & 298 & 15.4 & 20 & 51 \\
\hline $\mathrm{H}_{2} \mathrm{O}$ & 298 & 11.7 & & 80 \\
\hline $\mathrm{CH}_{3} \mathrm{CN}$ & 298 & 17.4 & & 232 \\
\hline $\mathrm{CH}_{3} \mathrm{CN}$ & 298 & 23.0 & 22 & 44 \\
\hline $\mathrm{CH}_{3} \mathrm{CN}$ & 298 & 30.3 & & 2 \\
\hline $\mathrm{CH}_{3} \mathrm{CN}$ & 298 & 31.7 & $\begin{array}{r}22 \\
\left(29^{c}\right) \\
26\end{array}$ & 252 \\
\hline $\mathrm{CH}_{3} \mathrm{CN}$ & 298 & 30.6 & $\left(33^{c}\right)$ & 68 \\
\hline THF & 298 & & 26 & 283 \\
\hline THF & 298 & & 26 & 283 \\
\hline pentane & 298 & $>28$ & 28 & 269 \\
\hline pentane & 298 & $>15$ & 28 & 269 \\
\hline $\mathrm{CH}_{3} \mathrm{CN}$ & 298 & 32.4 & & 252 \\
\hline $\mathrm{CH}_{3} \mathrm{CN}$ & 298 & 38.0 & 42 & 31,44 \\
\hline $\mathrm{CH}_{3} \mathrm{CN}$ & 298 & 35.0 & 42 & 251 \\
\hline THF & 298 & 42 & 43 & 100 \\
\hline THF & 298 & 43 & 43 & 100 \\
\hline THF & 298 & $>50$ & 46 & 101 \\
\hline THF & 298 & $>48$ & 46 & 101 \\
\hline
\end{tabular}


${ }^{a}$ Abbreviations: $\mathrm{pK}_{\mathrm{a}}^{\mathrm{exp}}=$ literature value; $\mathrm{pK}_{\mathrm{a}}^{\mathrm{LAC}}=$ from additivity acidity method; imine $=2,6-\mathrm{Me}_{2} \mathrm{C}_{6} \mathrm{H}_{3} \mathrm{~N}=\mathrm{C}(\mathrm{Me})\left(\mathrm{CH}_{2} \mathrm{OMe}\right)$, diox. $=$ dioxane, $\mathrm{P}_{4}=\mathrm{PPh}_{2} \mathrm{CH}_{2} \mathrm{CH}_{2} \mathrm{~N}\left(\mathrm{CH}_{2} \mathrm{NHPhCH}_{2}\right)_{2} \mathrm{NCH}_{2} \mathrm{CH}_{2} \mathrm{PPh} 2$

${ }^{b}$ The ligands are the same as in the acid form apart from the loss of a proton (and counteranion for cationic complexes).

${ }^{c} \mathrm{pK}_{\mathrm{a}}$ corrected to the MeCN scale for cationic acids Equation 14 


\subsection{Nickel group}

Hydride complexes of this group are found in many catalytic processes (see particularly Sections 6.8 and 6.11 ) and so there have been several investigations to understand their acidity and electrochemistry.

\subsubsection{Dicatonic hydride acids}

Nickel complexes with chelating phosphine ligands are of particular interest due to their application as electrocatalysts for the oxidation of dihydrogen or reduction of protons. ${ }^{284}$ These studies have resulted in the determination of acidity of a range of dicationic nickel(III) monohydride complexes $\left[\mathrm{NiHL}_{2}\right]^{2+}$ and nickel(IV) dihydride (or nickel(II) dihydrogen) complexes $\left[\mathrm{NiH}_{2} \mathrm{~L}_{2}\right]^{2+}$ as illustrated in Table 11 , entries 2-10. These dicationic complexes were not easily accessible by experimental means and so their properties were obtained indirectly via DFT calculations and thermochemical cycles as shown in Figure $25 .^{32}$ The $p K_{a}{ }^{\mathrm{MeCN}}$ for the dppe complexes are very negative with the nickel(III) complex (entry 2) more acidic than the nickel(IV) complex. The complexes become less acidic as the substituents on phosphorus are changed from aryl to alkyl, as expected. When there are basic nitrogen groups attached to the ligand as in entries 4, 9 and 10, the nitrogen is protonated in preference to the less basic metal center (or hydride ligand).

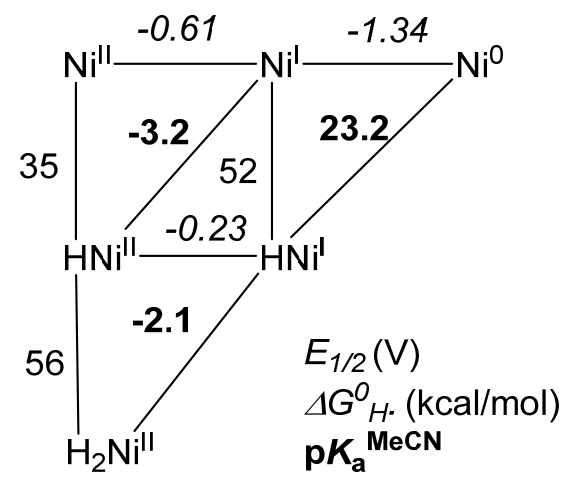

Figure 25. Thermodynamic cycles for the Ni(depp) 2 system

An interesting dicationic hydride complex is the tetraplatinum dihydride polycarbonyl complex (entry 11, Figure 26) which is in equilibrium with the monohydride and $\left[\mathrm{H}\left(\mathrm{OEt}_{2}\right)_{2}\right] \mathrm{BF}_{4}$ in $\mathrm{DCM} .{ }^{285} \mathrm{The}$ electron deficient nature of the dicationic cluster explains its high acidity.

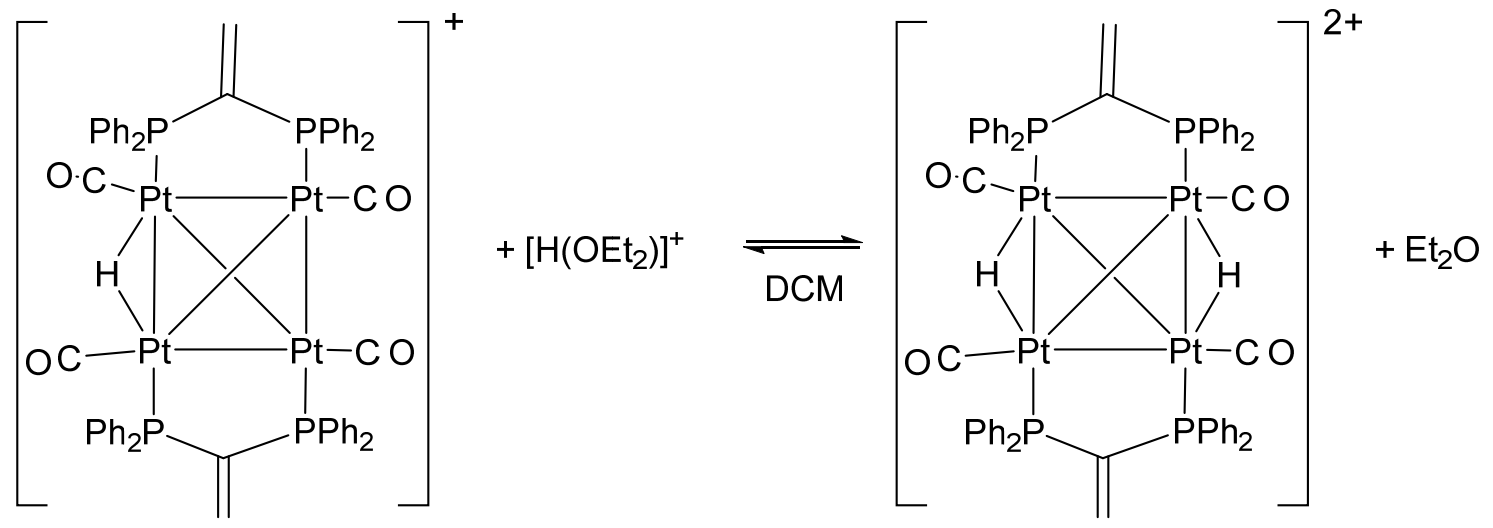

Figure 26. Protonation of a tetranuclear platinum complex 
The dicationic bisdihydrogen complex hexanuclear cluster (entry 17) is thought to form by reaction of the triflato starting cluster with dihydrogen in DCM. ${ }^{286}$ It then protonates triphenylphosphine $\left(\mathrm{p} K_{\mathrm{a}}{ }^{\mathrm{DCM}} 3\right.$ ) in DCM to give the neutral dihydride cluster as shown (Figure 27). Again the electron deficient nature of the dicationic cluster contributes to its high acidity.
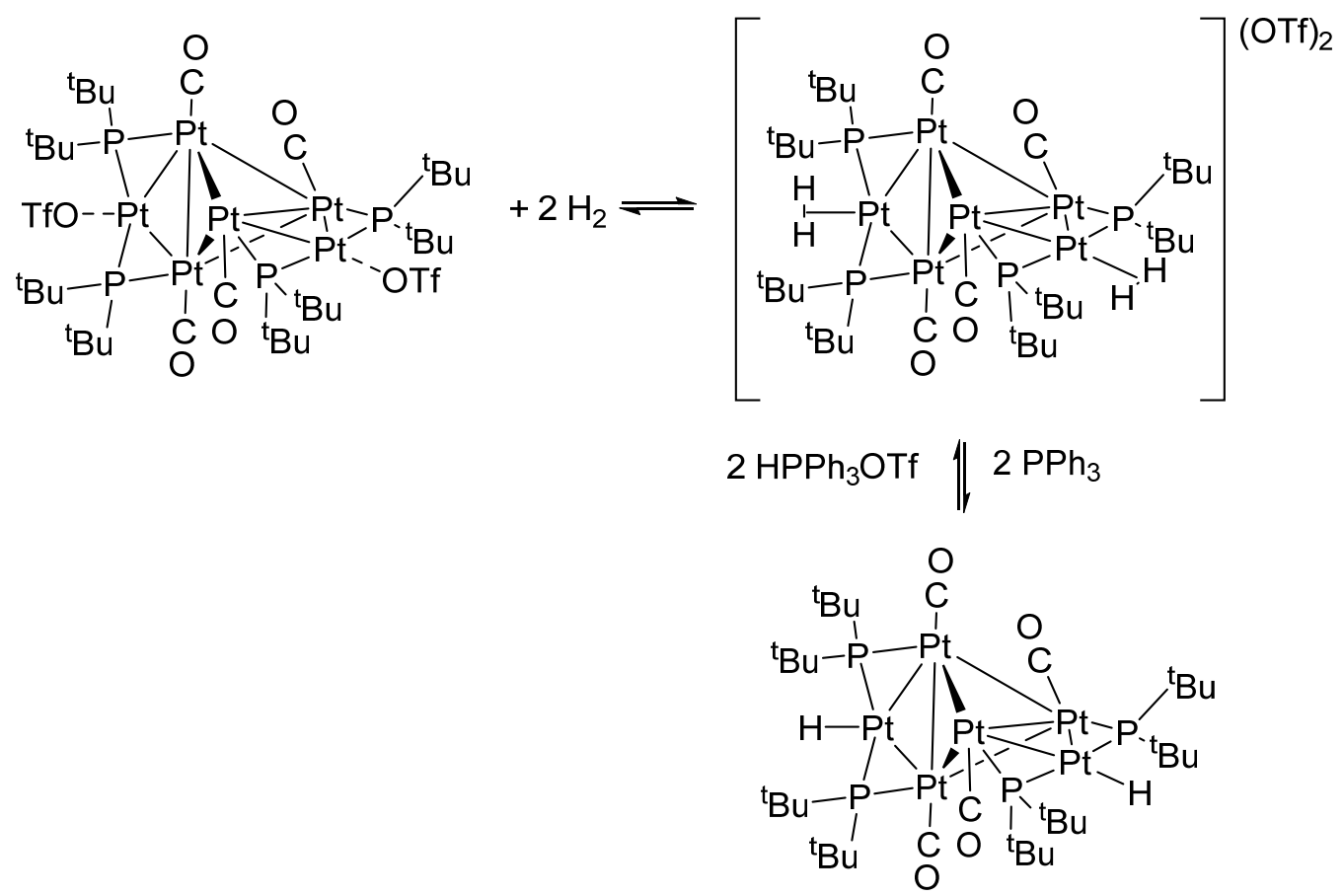

Figure 27. The heterolytic splitting of dihydrogen at a tetranuclear platinum cluster

When the complex [ $\mathrm{Ni}^{\prime \prime}(\text { triphos) }(\mathrm{SEt})]^{+}$, where triphos $=\left(\mathrm{PPh}_{2} \mathrm{CH}_{2} \mathrm{CH}_{2}\right)_{2} \mathrm{PPh}$, is protonated (entry 13), the thiol complex [Ni"(triphos)(SHEt)] ${ }^{2+}$ with $p K_{a}{ }^{M e C N} 14.6$ is produced instead of the hydride complex $\left[\mathrm{Ni}^{\mathrm{V}} \mathrm{H} \text { (triphos)(SEt) }\right]^{2+}$ which would be expected to have a $\mathrm{p} K_{\mathrm{a}}{ }^{\mathrm{LAC}}$ near 0 . The instability of $\mathrm{Ni}^{\mathrm{IV}}$ hydrides was discussed above.

With the more donating cyclam ligand, the dicationic nickel(III) hydride is formed in water (entry 14) at $\mathrm{pH}$ 1.8. It is interesting that the $\mathrm{p} K_{\mathrm{a}}^{\mathrm{LAC}}$ would be calculated as $4 \times 4-15=1$. It is not known whether the LAC method can be generally applied to paramagnetic hydride complexes.

The palladium(0) complex $\mathrm{Pd}\left(\mathrm{PPh}_{2} \mathrm{py}\right)_{2}(\mathrm{NCHC}=\mathrm{CHCN})$ in $\mathrm{DCM}$ (entry 16$)$ is protonated twice at low temperature with excess triflic acid at the pyridine substituents $\left(p K_{a}{ }^{\mathrm{LAC}} 8\right)$ but not the metal $\left(\mathrm{p}_{\mathrm{a}}{ }^{\mathrm{LAC}} 4\right.$ for monohydride cation, -11 for dihydride cation). ${ }^{287}$

The $\mathrm{p} K_{\mathrm{a}}^{\mathrm{MeCN}}$ of the dicationic platinum(IV) complex $\left[\mathrm{PtH}_{2} \text { (EtXantphos) }{ }_{2}\right]^{2+}$ (Figure 28) was found to be 6.8 by reaction with p-cyanoanilinium (entry 18 ). ${ }^{288}$ Interestingly the dicationic platinum(III) complex $\left[\mathrm{PtH}(\text { EtXantphos })_{2}\right]^{2+}$ was found to have a very similar $\mathrm{p} K_{\mathrm{a}}^{\mathrm{MeCN}} 7.1$ by means of electrochemical measurements and a thermochemical cycle (entry 19). 


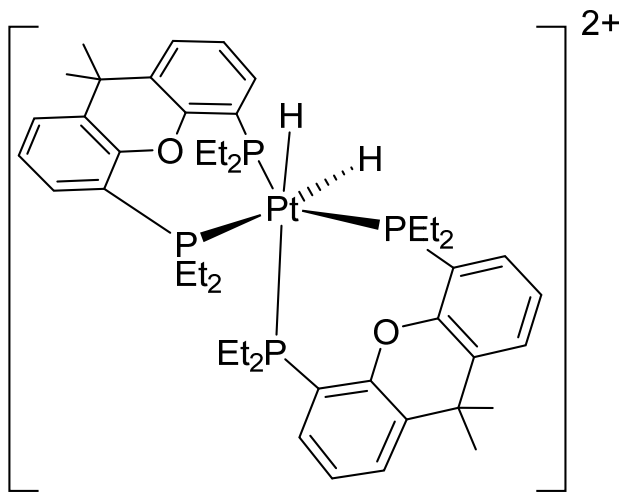

Figure 28. $\left.[\mathrm{PtH} \text { (EtXantphos) })_{2}\right]^{2+}$

\subsubsection{Monocationic hydride acids $\left[\mathrm{M}^{\prime \prime} \mathrm{HL}_{4}\right]^{+}$}

The majority of monocationic hydrides have the general formula $\left[\mathrm{M}^{\prime \prime} \mathrm{HL}_{4}\right]^{+}$that contain four phosphorus donors $L$ as monodentate or bidentate $\left(L_{2}\right)$ ligands. These span the range of acidities from exceedingly acidic $\left[\mathrm{PtH}\left(\mathrm{PF}_{3}\right)_{4}\right]^{+}$which only exists in "magic acid" (entry 1$)^{87}$ to very weakly acidic $\left[\mathrm{PtH}(\mathrm{dmpe})_{2}\right]^{+}$with $\mathrm{p} K_{\mathrm{a}}{ }^{\mathrm{MeCN}}$ 31.1.(entry 57$)^{289}$ While an LAC $\mathrm{A}_{L}$ parameter has not be established for $\mathrm{PF}_{3}$, it is likely it is similar to that of $\mathrm{CO}(-4)$, making the $\mathrm{p} K_{a}{ }^{\mathrm{LAC}}$ of $\left[\mathrm{PtH}\left(\mathrm{PF}_{3}\right)_{4}\right]^{+}$approx. -10 . By contrast the $\mathrm{A}_{\mathrm{L}}$ of dmpe is $2 * 4.9$ making the $\mathrm{p} K_{\mathrm{a}}^{\mathrm{LAC}}$ of $\left[\mathrm{PtH}(\mathrm{dmpe})_{2}\right]^{+} 22$ (which translates into a $\mathrm{p} K_{\mathrm{a}}{ }^{\mathrm{MeCN}}$ of 28 ). Note that $\left[\mathrm{PtH}(\mathrm{CO})\left(\mathrm{PPh}_{3}\right)_{2}\right]^{+}\left(\mathrm{p} K_{\mathrm{a}}{ }^{\mathrm{LAC}} 3\right)$ is formed in neat $\mathrm{CF}_{3} \mathrm{COOH}^{290}$ The reaction of $\left[\mathrm{PdH}\left(\mathrm{PPh}_{3}\right)_{3}\right]^{+}$with $\mathrm{CO}$ results in proton elimination in aqueous $\mathrm{CF}_{3} \mathrm{COOH}$ to give a lower valent $\mathrm{Pd}$ carbonyl complex. ${ }^{291-292}$ This palladium solution catalyzes the hydrocarbonylation of ethylene. ${ }^{292}$

Table 10 lists examples of $\mathrm{p} K_{\mathrm{a}}{ }^{\mathrm{MeCN}}$ of $\left[\mathrm{M}^{\prime \prime} \mathrm{HL}_{4}\right]^{+}$from Table 11 to illustrate the effect of the metal and increasing donating ligand. The order of increasing $\mathrm{p} K_{\mathrm{a}}$ is $\mathrm{Pd}<\mathrm{Ni}<\mathrm{Pt}$ with the difference between $\mathrm{Ni}$ and Pt of about 7 units, much larger than 2 observed for other $3 d / 5 d$ combinations discussed above. Thus the LAC method will underestimate the $\mathrm{p} K_{\mathrm{a}}$ values of $\mathrm{Pt}(\mathrm{II})$ complexes. Relativistic contributions to the bonding increase on going from $\mathrm{W}$ to $\mathrm{Pt}$, possibly contributing to this difference. The increase in $\mathrm{p} K_{\mathrm{a}}$ on going down the Table 10 is explained mainly by the usual inductive effect of the substituents at phosphorus although the ligands with methyl substituents (dmpp and dmpe) provide less acidic complexes than those with ethyl substituents (depp, depe). The large bite angle EtXantphos ligand seems to cause a dramatic difference of 9 in the $\mathrm{p} K_{\mathrm{a}}$ of the $\mathrm{Pd}$ and $\mathrm{Pt}$ complexes [MH(EtXantphos) $\left.{ }_{2}\right]^{+}$.

Table 10. The $\mathrm{pK}_{a}{ }^{\mathrm{MeCN}}$ of the complexes $\left[\mathrm{M}^{\prime \prime} \mathrm{HL}_{4}\right]^{+}$

\begin{tabular}{lcccc} 
Formula & $\mathrm{Ni}(\mathrm{II})$ & $\mathrm{Pd}(\mathrm{II})$ & $\mathrm{Pt}(\mathrm{II})$ & $\begin{array}{l}\text { Entries of } \\
\text { Table } 11\end{array}$ \\
\hline$\left[\mathrm{MH}\left(\mathrm{P}(\mathrm{OMe})_{3}\right)_{4}\right]^{+}$ & & & & $30,23,40$ \\
{$\left[\mathrm{MH}(\text { dppe })_{2}\right]^{+}$} & 13.4 & 10.6 & 18.5 & 31,44 \\
{$\left[\mathrm{MH}(\text { EtXantphos })_{2}\right]^{+}$} & 14.7 & & 22.2 & 39,54 \\
{$\left[\mathrm{MH}\left(\mathrm{Et}_{2} \mathrm{PCH}_{2} \mathrm{NMeCH}_{2} \mathrm{PEt}_{2}\right)_{2}\right]^{+}$} & 22.2 & 18.5 & 27.3 & 43,42 \\
{$\left[\mathrm{MH}(\text { depp })_{2}\right]^{+}$} & 23.3 & 22.1 & & 48,46 \\
{$\left[\mathrm{MH}(\text { depe })_{2}\right]^{+}$} & 23.8 & 22.9 & & $49,47,55$ \\
{$\left[\mathrm{MH}(\mathrm{dmpp})_{2}\right]^{+}$} & 24.0 & 23.2 & 29.7 & 50,56 \\
{$\left[\mathrm{MH}(\mathrm{dmpe})_{2}\right]^{+}$} & 24.3 & & 30.4 & 51,57 \\
\hline
\end{tabular}

The complex $\mathrm{Ni}$ (dppe) ${ }_{2}$ reacts with $\mathrm{HCl}$ in $\mathrm{THF}$ to quickly give an equilibrium $(\mathrm{K}=200)$ with $\left[\mathrm{NiH}(\mathrm{dppe})_{2}\right] \mathrm{Cl}$ (entry 28 ) and then slowly to produce $\mathrm{H}_{2}{ }^{293}$ If the $\mathrm{p} K_{\mathrm{a}}{ }^{\mathrm{THF}}$ of $\mathrm{HCl}$ is 10 then the $\mathrm{p} K_{\mathrm{a}}{ }^{\mathrm{THF}}\left[\mathrm{NiH}(\mathrm{dppe})_{2}\right] \mathrm{Cl}$ is 12 , 
consistent with the $\mathrm{p} K_{\mathrm{a}}{ }^{\mathrm{LAC}} 12$. The palladium analogue can be prepared by reacting $\mathrm{Pd}(\mathrm{dppe})_{2}$ with triflic acid in THF at $273 \mathrm{~K}$ (entry 26). Two palladium complexes (entries 38 and 41) with wide bite angle ligands were found to have $\mathrm{p} K_{\mathrm{a}}{ }^{\mathrm{MeCN}} 18.3$ and 19.8, similar to that of [PdH(EtXantphos) ${ }_{2}{ }^{+}$(entry 39). ${ }^{294}$ Positioning amines on the backbone of the diphosphine can favor hydrogen evolution when the protonated amine is more acidic than the nickel hydride [NiH(-PMe-NPh-PMe-NPh- $\left.)_{2}\right]^{+}\left(\mathrm{p} K_{\mathrm{a}}{ }^{\mathrm{MeCN}} 22.5\right.$, entry 45) or hydrogen oxidation when the protonated amine is basic in the nickel hydride [NiH(-PCy$\left.\left.\mathrm{N}^{t} \mathrm{Bu}-\mathrm{PCy}-\mathrm{N}^{t} \mathrm{Bu}-\right)_{2}\right]^{+}\left(p K_{\mathrm{a}}{ }^{\mathrm{MeCN}} 24.7\right.$, entry 53, Figure 29). ${ }^{295-296}$ See the catalysis Section 6.8 for more details.

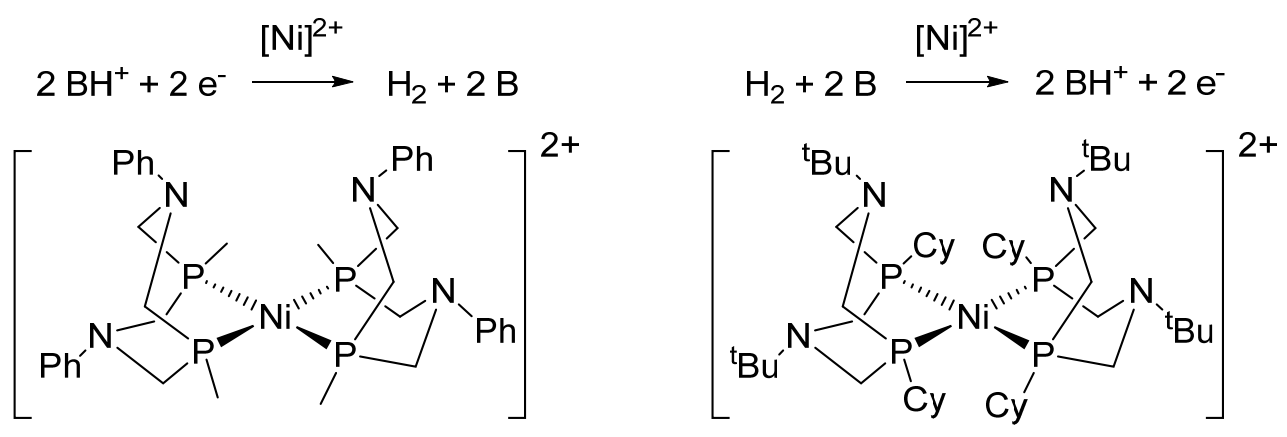

Figure 29. Nickel bis(diphosphine) complexes that catalyze the electrochemical reduction of acids and oxidation of dihydrogen.

Water soluble complexes $\left[\mathrm{PtH}(\mathrm{PTA})_{4}\right]^{+}\left(\mathrm{p} K_{\mathrm{a}}\right.$ aq 7.9 , entry 21$){ }^{297}\left[\mathrm{PtH}(\mathrm{TPPTS}-\mathrm{Na})_{4}\right]^{+}\left(\mathrm{p} K_{\mathrm{a}}{ }^{\text {aq }} 10\right.$, entry 22) and $\left[\mathrm{PtH}\left(\mathrm{P}\left(\mathrm{CH}_{2} \mathrm{OH}\right)_{3}\right)_{4}\right]^{+}\left(\mathrm{p} K_{\mathrm{a}}\right.$ aq 11 , entry 27$)$ show acid/base equilibria in basic conditions (see Figure 30 for the structures of PTA and TPPTS-Na).

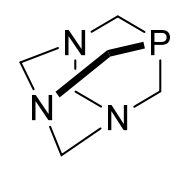

PTA<smiles>O=S(=O)(O[Na])c1cccc(P(c2cccc(S(=O)(=O)O[Na])c2)c2cccc(S(=O)(=O)O[Na])c2)c1</smiles>

TPPTS-Na

Figure 30. Phosphorus donor ligands PTA and TPPTS-Na that impart water solubility.

\subsubsection{Other complexes}

The complex $\left[\mathrm{PtH}\left\{\mathrm{PMe}\left(\mathrm{C}_{2} \mathrm{~F}_{5}\right)_{2}\right\}_{2}(\mathrm{CO})\right]^{+}$(not listed in the table) is likely to be extremely acidic because of the $\mathrm{CO}$ and fluorinated ligands. It is prepared in neat triflic acid. ${ }^{298}$

The nickel(III) hydride $\left[\mathrm{NiH}\left(\mathrm{P}^{t} \mathrm{Bu}_{2} \mathrm{CH}_{2} \mathrm{C}_{6} \mathrm{H}_{3} \mathrm{CH}_{2} \mathrm{P}^{t} \mathrm{Bu}_{2}\right)\right]^{+}$is calculated to have a p $K_{\mathrm{a}}{ }^{\mathrm{MeCN}} 1.7$ (entry 12). ${ }^{299}$. The cyclometallated aryl in this pincer complex makes the hydride less acidic than the dicationic nickel(III) hydrides discussed above.

The $\mathrm{Ni}^{\prime \prime}$ olefin complex $\left[\mathrm{NiH}\left(\mathrm{CH}_{2}=\mathrm{CHOBu}\right)(\mathrm{dppf})\right]^{+}$is a key intermediate in the nickel-catalyzed Heck coupling reaction (entry 15$).{ }^{300}$ The base $\mathrm{NCy}_{2} \mathrm{Me}\left(\mathrm{p} K_{\mathrm{a}}{ }^{\mathrm{THF}} 14\right.$ ) is needed to deprotonate this complex in dioxane to turn over the catalyst. The strength of the base is appropriate given the $\mathrm{p} K_{\mathrm{a}}{ }^{\mathrm{LAC}} 4$ of the nickel hydride intermediate.

A precatalyst for the Lucite process for the hydromethoxycarbonylation of ethylene is the hydride $\left[\mathrm{PtH}\left(\mathrm{P}^{t} \mathrm{Bu}_{2} \mathrm{CH}_{2} \mathrm{C}_{6} \mathrm{H}_{4} \mathrm{CH}_{2} \mathrm{P}^{t} \mathrm{Bu}_{2}\right)(\mathrm{CO})\right]^{+}$(see Figure 23 for the structure of the ligand dtpx). This 
complex can be prepared from the $\mathrm{Pt}^{0}$ complex by protonation with $\mathrm{HBF}_{4}$ (entry 20). ${ }^{301}$ Similarly $\mathrm{PdH}(\mathrm{Cl})\left(\mathrm{PCy}_{3}\right)_{2}$ can be prepared from $\mathrm{Pd}\left(\mathrm{PCy}_{3}\right)_{2}$ by reaction with $\left[\mathrm{HNMeCy}_{2}\right] \mathrm{Cl}\left(\mathrm{p} K_{\mathrm{a}}^{\text {THF }} 14\right)$ in dioxane while $\mathrm{PdH}(\mathrm{Cl})\left(\mathrm{P}^{\mathrm{t}} \mathrm{Bu}_{3}\right)_{2}$ reacts with $\mathrm{NMeCy_{2 }}$ to give $\mathrm{Pd}\left(\mathrm{P}^{\mathrm{t}} \mathrm{Bu}_{3}\right)_{2}$ (entries 24,25$) \cdot{ }^{302}$ These reactions may proceed via the intermediate $\left[\mathrm{PdH}\left(\mathrm{PR}_{3}\right)_{2}\right]^{+}$(see Section 6.11.1). The larger size of the $\mathrm{P}^{\mathrm{t}} \mathrm{Bu}$ ligands make the latter hydride complex more acidic and susceptible to deprotonation. These reactions are relevant to Heck coupling catalysis where $\mathrm{Pd}^{0}$ must be generated from $\mathrm{Pd}$ " by such a reaction with base.

The hydride $\left[\mathrm{Pd}^{\prime \prime} \mathrm{H}\left(\mathrm{PPh}_{3}\right)_{2}(\mathrm{DMF})\right]^{+}$with acetate or formate counterions is in equilibrium with $\mathrm{Pd}\left(\mathrm{PPh}_{3}\right)_{3}$ and acetic acid $\left(\mathrm{p} K_{\mathrm{a}}^{\mathrm{DMF}} 12.6\right)^{15}$ in DMF with an equilibrium constant of about 125 , and with formic acid $\left(\mathrm{p} K_{\mathrm{a}}^{\mathrm{DMF}} 11.6\right)^{15}$ with $\mathrm{K} 250 .{ }^{303} \mathrm{The} \mathrm{p} K_{\mathrm{a}}{ }^{\mathrm{LAC}}$ of $\left[\mathrm{PdH}\left(\mathrm{PPh}_{3}\right)_{3}\right]^{+}$is predicted to be 9 (not listed the Table). The deprotonation of $\left[\mathrm{PtH}\left(\mathrm{PPh}_{3}\right)_{3}\right]^{+}$by ethanolic $\mathrm{KOH}$ to produce $\mathrm{Pt}\left(\mathrm{PPh}_{3}\right)_{3}$ was reported in 1966. ${ }^{304}$ The palladium complexes $\mathrm{Pd}\left(\mathrm{P}^{\mathrm{i}} \mathrm{Pr}_{2} \mathrm{CH}_{2} \mathrm{CH}_{2} \mathrm{CH}_{2} \mathrm{P}^{\mathrm{i} P \mathrm{Pr}_{2}}\right)\left(\mathrm{PR}_{3}\right), \mathrm{R}=\mathrm{Cy}$, Et are very basic because of the three trialkylphosphine donors and so are protonated to equilibrium with phenol or $\mathrm{CF}_{3} \mathrm{CH}_{2} \mathrm{OH}$ in toluene- $\mathrm{d}_{8}$ to produce $\left[\mathrm{PdH}\left(\mathrm{PiPr}_{2} \mathrm{CH}_{2} \mathrm{CH}_{2} \mathrm{CH}_{2} \mathrm{P}^{\mathrm{i}} \mathrm{Pr}_{2}\right)\left(\mathrm{PR}_{3}\right)\right]^{+} .{ }^{305}$

Complexes of entries 32-37 are platinum(IV) hydrides, prepared by reacting the corresponding platinum(II) complexes with nitrogen donors and hydrocarbyl groups with acids $\mathrm{HX}$ ranging from neat $\mathrm{MeOH}\left(\mathrm{p} K_{\mathrm{a}}{ }^{\mathrm{MeOH}} 16\right)$ to $\mathrm{PhOH}\left(\mathrm{p} K_{\mathrm{a}}^{\mathrm{LAC}}\left(\mathrm{PhOH} / \mathrm{OPh}^{-}\right)\right.$approx. 30) in acetone to $\mathrm{HCl}\left(\mathrm{p} K_{\mathrm{a}}^{\mathrm{LAC}} 10\right)$ in THF or DCM. This class of reaction has been reviewed. ${ }^{306}$ All of these are calculated to have $p K_{a}{ }^{\mathrm{LAC}}$ approx. 16 assuming the hydrocarbyl ligands have an $\mathrm{A}_{\mathrm{L}}$ near 0 , but this has not been established. The $\mathrm{p} K_{\mathrm{a}}{ }^{\mathrm{LAC}}$ could be higher than 24 with a larger $A_{L}$ for the methyl group and a larger $5 \mathrm{~d}$ metal correction as discussed above for Pt complexes. A higher value would explain the protonation reaction using phenol (entry 33 ).

The heterolytic splitting of dihydrogen (3.5-7 atm) by palladium alkoxide pincer complexes in $\mathrm{C}_{6} \mathrm{D}_{6}$, as well as the reverse reaction, the reaction of palladium(II) hydrides with excess alcohols to give dihydrogen and the alkoxide complex have been studied (Figure 31). ${ }^{307} \mathrm{It}$ is reported that the equilibrium lies to the left for the acidic alcohols phenol ( $\mathrm{p} K_{\mathrm{a}}{ }^{\mathrm{aq}} 9.95, \mathrm{p} K_{\mathrm{a}}{ }^{\mathrm{LAC}} 30$ ), 2,2,2-trifluoroethanol $\left(\mathrm{p} K_{\mathrm{a}}{ }^{\mathrm{aq}} 12.5, \mathrm{p} K_{\mathrm{a}}{ }^{\mathrm{LAC}} 39\right)$ and 2,2-difluoroethanol ( $\mathrm{p} K_{\mathrm{a}}^{\text {aq }}$ 13.3) but it lies to the right for 2-fluoroethanol $\left(\mathrm{p} K_{\mathrm{a}}\right.$ aq 14.4). Different palladium triflate or hydroxide pincer complexes also reacts with dihydrogen to give hydride complexes. ${ }^{308-309}$

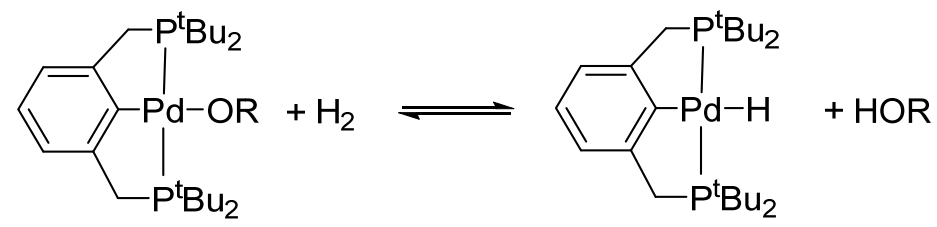

Figure 31. The heterolytic splitting of dihydrogen at palladium(II).

Other less quantifiable reactions that involve the acid-base chemistry of nickel group hydride and dihydrogen complexes can be found elsewhere. ${ }^{310-314}$ 


\begin{tabular}{|c|c|c|c|c|c|c|c|c|c|}
\hline Entry & Acid & Base $^{b}$ & Reactant & Reaction & Solvent & Temp. & $\mathbf{p K}_{\mathrm{a}}^{\exp }$ & $\mathbf{p K}_{\mathrm{a}}^{\mathrm{LAC}}$ & Reference \\
\hline 1 & {$\left[\mathrm{PtH}\left(\mathrm{PF}_{3}\right)_{4}\right]^{+}$} & M & $\mathrm{HF} / \mathrm{SbF}_{5}$ & $\mathrm{M}+\mathrm{HY} \rightleftharpoons[\mathrm{MH}] \mathrm{Y}$ & $\mathrm{HF} / \mathrm{SbF}_{5}$ & 298 & $<<0$ & & 87 \\
\hline 2 & {$\left[\mathrm{NiH}(\mathrm{dppe})_{2}\right]^{+2}$} & M & & DFT calculation & $\mathrm{MeCN}$ & 298 & -8.6 & & 32 \\
\hline 3 & {$\left[\mathrm{NiH}_{2}(\mathrm{dppe})_{2}\right]^{+2}$} & {$[\mathrm{MH}]^{+}$} & & DFT calculation & $\mathrm{MeCN}$ & 298 & -7.3 & -3 & 32 \\
\hline 4 & {$\left[\mathrm{NiH}_{2}(\mathrm{dppp})(-\mathrm{PPh}-\mathrm{NBn}-\mathrm{PPh}-\mathrm{NBn}-]^{+2}\right.$} & {$[\mathrm{MH}]^{+}$} & $\mathrm{NR}_{2} \mathrm{CH}_{2} \mathrm{Ph}$ & reversible proton transfer to nitrogen & & 203 & & -1 & 315 \\
\hline 5 & {$\left[\mathrm{NiH}(\mathrm{depp})_{2}\right]^{+2}$} & {$[\mathrm{M}]^{+}$} & & thermochemical cycle & $\mathrm{MeCN}$ & 298 & -3.2 & & 45 \\
\hline 6 & {$\left[\mathrm{NiH}_{2}(\mathrm{depp})_{2}\right]^{+2}$} & {$[\mathrm{MH}]^{+}$} & & thermochemical cycle & $\mathrm{MeCN}$ & 298 & -1.5 & 5 & 45 \\
\hline 7 & {$\left[\mathrm{NiH}(\mathrm{dmpe})_{2}\right]^{+2}$} & {$[\mathrm{M}]^{+}$} & & DFT calculation & $\mathrm{MeCN}$ & 298 & -0.8 & & 32 \\
\hline 8 & {$\left[\mathrm{NiH}_{2}(\mathrm{dmpe})_{2}\right]^{+2}$} & {$[\mathrm{MH}]^{+}$} & & DFT calculation & $\mathrm{MeCN}$ & 298 & 0.9 & 5 & 32 \\
\hline 9 & {$\left[\mathrm{NiH}(-\mathrm{PPh}-\mathrm{NPh}-\mathrm{PPh}-\mathrm{NHPh}-)_{2}\right]^{+2}$} & {$[\mathrm{M}]^{+}$} & {$[\mathrm{DMF}-\mathrm{H}] \mathrm{CF}_{3} \mathrm{SO}_{3}$} & protonation at nitrogen, not $\mathrm{Ni}$ & $\mathrm{MeCN}$ & 298 & $<6$ & & $316-318$ \\
\hline $\begin{array}{l}10 \\
11\end{array}$ & $\begin{array}{l}{\left[\mathrm{NiH}_{2}(-\mathrm{PCy}-\mathrm{NBn}-\mathrm{PCy}-\mathrm{NBn}-)_{2}\right]^{+2}} \\
{\left[\mathrm{Pt}_{4}(\mathrm{u}-\mathrm{H})_{2}(\mathrm{u}-\right.} \\
\left.\left.\mathrm{PPh}_{2} \mathrm{C}\left(=\mathrm{CH}_{2}\right) \mathrm{PPh}_{2}\right)_{2}(\mathrm{CO})_{4}\right]^{+2}\end{array}$ & $\begin{array}{l}{[\mathrm{MH}]^{+}} \\
{\left[\mathrm{M}_{4} \mathrm{H}\right]^{+}}\end{array}$ & $\begin{array}{l}\mathrm{NR}_{2}\left(\mathrm{CH}_{2} \mathrm{Ph}\right) \\
{\left[\mathrm{H}\left(\mathrm{OEt}_{2}\right)_{2}\right] \mathrm{BF}_{4}}\end{array}$ & $\begin{array}{l}\text { protonation at nitrogen, not Ni } \\
{\left[\mathrm{M}_{4} \mathrm{H}\right] \mathrm{Y}+[\mathrm{HB}] \mathrm{Y} \rightleftharpoons\left[\mathrm{M}_{4} \mathrm{H}_{2}\right] \mathrm{Y}_{2}+\mathrm{B}}\end{array}$ & $\begin{array}{l}\mathrm{MeCN} \\
\mathrm{CH}_{2} \mathrm{Cl}_{2}\end{array}$ & $\begin{array}{l}298 \\
298\end{array}$ & $<12$ & $\begin{array}{l}5 \\
0\end{array}$ & $\begin{array}{r}318-319 \\
285\end{array}$ \\
\hline 12 & {$\left[\mathrm{NiH}\left(\mathrm{P}^{\mathrm{t}} \mathrm{Bu}_{2} \mathrm{CH}_{2} \mathrm{C}_{6} \mathrm{H}_{3} \mathrm{CH}_{2} \mathrm{P}^{\mathrm{t}} \mathrm{Bu}_{2}\right)\right]^{+}$} & M & & DFT calculation & $\mathrm{MeCN}$ & 298 & 1.7 & & 299 \\
\hline 13 & {$[\mathrm{NiH}(\mathrm{SEt})(\text { triphos })]^{+2}$} & $\mathrm{M}(\mathrm{SEt})$ & HNiSEt & {$[\mathrm{HMX}]^{+2} \rightarrow[\mathrm{MXH}]^{+2}$} & $\mathrm{MeCN}$ & 298 & 14.6 & 1 & 320 \\
\hline 14 & {$[\mathrm{NiH}(\text { cyclam })]^{+2}$} & {$[\mathrm{M}]^{+}$} & & {$[\mathrm{M}]^{+}+\mathrm{H}+\rightleftharpoons[\mathrm{MH}]^{+}$} & $\mathrm{H}_{2} \mathrm{O}$ & 298 & 1.8 & 1 & 69 \\
\hline 15 & {$\left[\mathrm{NiH}\left(\mathrm{CH}_{2}=\mathrm{CHOBu}\right)(\mathrm{dppf})\right]^{+}$} & M & $\mathrm{NCy}_{2} \mathrm{Me}$ & {$[\mathrm{MH}] \mathrm{Y}+\mathrm{B} \rightleftharpoons \mathrm{M}+[\mathrm{HB}] \mathrm{Y}$} & dioxane & 298 & $<13$ & 4 & 300 \\
\hline 16 & {$\left[\mathrm{Pd}\left(\mathrm{PPh}_{2} \mathrm{C}_{5} \mathrm{H}_{4} \mathrm{NH}\right)_{2}(\mathrm{NCHC}=\mathrm{CHCN})\right]^{+2}$} & {$[\mathrm{M}]^{+}$} & $\mathrm{CF}_{3} \mathrm{SO}_{3} \mathrm{H}$ & protonation at py, not metal & $\mathrm{CD}_{2} \mathrm{Cl}_{2}$ & 203 & & 4 & 287 \\
\hline 17 & {$\left[\mathrm{Pt}_{6}\left(\mathrm{H}_{2}\right)_{2}\left(\mathrm{u}-\mathrm{P}^{\mathrm{t} B u_{2}}\right)_{4}(\mathrm{CO})_{4}\right]^{+2}$} & $\mathrm{M}_{6} \mathrm{H}_{2}$ & $\mathrm{PPh} 3$ & {$\left[\mathrm{M}_{6} \mathrm{H}_{4}\right] \mathrm{Y}_{2}+2 \mathrm{~B} \rightleftharpoons \mathrm{M}_{6} \mathrm{H}_{2}+2[\mathrm{HB}] \mathrm{Y}$} & $\mathrm{CH}_{2} \mathrm{Cl}_{2}$ & 298 & & $<5$ & 286 \\
\hline 18 & {$\left[\mathrm{PtH}_{2}(\text { EtXantphos })_{2}\right]^{+2}$} & {$[\mathrm{MH}]^{+}$} & {$\left[\mathrm{NCC}_{6} \mathrm{H}_{4} \mathrm{NH}_{3}\right\} \mathrm{BF}_{4}$} & {$[\mathrm{MH}] \mathrm{Y}+[\mathrm{HB}] \mathrm{Y} \rightarrow\left[\mathrm{MH}_{2}\right] \mathrm{Y}_{2}+\mathrm{B}$} & $\mathrm{MeCN}$ & 298 & 6.8 & $3\left(7^{c}\right)$ & 288 \\
\hline 19 & {$\left[\mathrm{PtH}(\text { EtXantphos })_{2}\right]^{+2}$} & {$[\mathrm{MH}]^{+}$} & & from thermochemical cycle & $\mathrm{MeCN}$ & 298 & 7.1 & & 288 \\
\hline 20 & {$\left[\mathrm{PtH}\left(\mathrm{P}^{\mathrm{t}} \mathrm{Bu}_{2} \mathrm{CH}_{2} \mathrm{C}_{6} \mathrm{H}_{4} \mathrm{CH}_{2} \mathrm{P}^{\mathrm{t}} \mathrm{Bu}_{2}\right)(\mathrm{CO})\right]^{+}$} & M & {$\left[\mathrm{H}\left(\mathrm{OEt}_{2}\right)_{2}\right]\left[\mathrm{B}\left(\mathrm{C}_{6} \mathrm{~F}_{5}\right)_{4}\right\}$} & $\mathrm{M}+[\mathrm{HB}] \mathrm{Y} \rightarrow[\mathrm{MH}] \mathrm{Y}+\mathrm{B}$ & $\mathrm{PhCl}$ & 298 & & 8 & 301 \\
\hline 21 & {$\left[\mathrm{PtH}(\mathrm{PTA})_{4}\right]^{+}$} & M & $3,5-\mathrm{Cl}_{2} \mathrm{C}_{6} \mathrm{H}_{3} \mathrm{OH}$ & $\mathrm{M}+\mathrm{H}+\rightleftharpoons \mathrm{MH}+$ & $\mathrm{H}_{2} \mathrm{O}$ & 298 & 7.9 & & 297 \\
\hline 22 & {$\left[\mathrm{Pt}(\mathrm{H})(\mathrm{TPPTS})_{3}\right]^{+}$} & M & & $\mathrm{M}+\mathrm{H}+\rightleftharpoons \mathrm{MH}+$ & $\mathrm{H}_{2} \mathrm{O}$ & 298 & 10 & 10.1 & 71 \\
\hline 23 & {$\left[\mathrm{PdH}\left(\mathrm{P}(\mathrm{OMe})_{3}\right)_{4}\right]^{+}$} & M & & {$[\mathrm{MH}] \mathrm{Y}+\mathrm{B} \rightleftharpoons \mathrm{M}+[\mathrm{HB}] \mathrm{Y}$} & $\mathrm{MeCN}$ & 298 & 10.6 & $6\left(11^{c}\right)$ & 1 \\
\hline 24 & $\mathrm{PdH}(\mathrm{Cl})\left(\mathrm{PCy}_{3}\right)_{2}$ & M & {$\left[\mathrm{HNMeCy}_{2}\right] \mathrm{Cl}$} & $\mathrm{M}+[\mathrm{HB}] \mathrm{Y} \rightarrow \mathrm{MHY}+\mathrm{B}$ & dioxane & 293 & & 11.8 & 302 \\
\hline 25 & $\mathrm{PdH}(\mathrm{Cl})\left(\mathrm{P}^{\mathrm{B}} \mathrm{Bu}_{3}\right)_{2}$ & M & $\mathrm{NMeCy}_{2}$ & $\mathrm{MHY}+\mathrm{B} \rightarrow \mathrm{M}+[\mathrm{HB}] \mathrm{Y}$ & dioxane & 293 & & 11.8 & 302 \\
\hline 26 & {$\left[\mathrm{PdH}(\mathrm{dppe})_{2}\right]^{+}$} & M & $\mathrm{CF}_{3} \mathrm{SO}_{3} \mathrm{H}$ & $\mathrm{M}+\mathrm{HY} \rightarrow[\mathrm{MH}] \mathrm{Y}$ & THF & 273 & $>-4$ & 12 & 321 \\
\hline 27 & {$\left[\mathrm{PtH}\left(\mathrm{P}\left(\mathrm{CH}_{2} \mathrm{OH}\right)_{3}\right)_{4}\right]^{+}$} & M & & $\mathrm{M}+\mathrm{H}+\rightleftharpoons \mathrm{MH}+$ & $\mathrm{H}_{2} \mathrm{O}$ & 298 & 11 & & 70 \\
\hline 28 & {$\left[\mathrm{NiH}(\mathrm{dppe})_{2}\right]^{+}$} & M & $\mathrm{HCl}$ & $\mathrm{M}+\mathrm{HY} \rightleftharpoons[\mathrm{MH}] \mathrm{Y}$ & THF & 298 & 12.3 & 12 & 293 \\
\hline
\end{tabular}




\begin{tabular}{|c|c|c|c|c|c|c|c|c|c|}
\hline 29 & {$\left[\mathrm{NiH}(\mathrm{dppv})_{2}\right]^{+}$} & M & $\mathrm{CH}_{3} \mathrm{OC}_{6} \mathrm{H}_{4} \mathrm{NH}_{2}$ & {$[\mathrm{MH}] \mathrm{Y}+\mathrm{B} \rightleftharpoons \mathrm{M}+[\mathrm{HB}] \mathrm{Y}$} & $\mathrm{MeCN}$ & 298 & 13.2 & $12\left(17^{c}\right)$ & 32,322 \\
\hline 30 & {$\left[\mathrm{NiH}\left(\mathrm{P}(\mathrm{OMe})_{3}\right)_{4}\right]^{+}$} & M & & {$[\mathrm{MH}] \mathrm{Y}+\mathrm{B} \rightleftharpoons \mathrm{M}+[\mathrm{HB}] \mathrm{Y}$} & $\mathrm{MeCN}$ & 298 & 13.4 & $6\left(11^{c}\right)$ & 1 \\
\hline 31 & {$\left[\mathrm{NiH}(\mathrm{dppe})_{2}\right]^{+}$} & M & py & {$[\mathrm{MH}] \mathrm{Y}+\mathrm{B} \rightleftharpoons \mathrm{M}+[\mathrm{HB}] \mathrm{Y}$} & $\mathrm{PhCN}$ & 298 & 14.7 & $12\left(17^{c}\right)$ & 323 \\
\hline 32 & {$\left[\mathrm{PtH}(\mathrm{Me})_{2}(\operatorname{tacn})\right]^{+}$} & M & $\mathrm{MeOH}$ & $\mathrm{M}+\mathrm{HY} \rightleftharpoons[\mathrm{MH}] \mathrm{Y}$ & $\mathrm{MeOH}$ & 298 & & 16 & 324 \\
\hline 33 & $\mathrm{PtH}(\mathrm{Me})_{2}\left(\mathrm{HB}(\mathrm{pz})_{3}\right)$ & KM & $\mathrm{PhOH}$ & $\mathrm{K}[\mathrm{M}]+\mathrm{HY} \rightarrow \mathrm{MH}+\mathrm{KY}$ & acetone & 298 & & 16 & 306,325 \\
\hline 34 & $\mathrm{PtH}(\mathrm{Me})_{2}\left(\mathrm{HB}\left(\mathrm{pzMe}_{2}\right)_{3}\right)$ & $\mathrm{KM}$ & $\mathrm{HCl}$ & $\mathrm{K}[\mathrm{M}]+\mathrm{HY} \rightarrow \mathrm{MH}+\mathrm{KY}$ & THF & 298 & & 16 & 306,326 \\
\hline 35 & {$\left[\mathrm{PtH}(\mathrm{Ph})_{2}(\mathrm{Ar}-\mathrm{NH}-\mathrm{NHAr})(\mathrm{MeCN})\right]^{+}$} & $\mathrm{M}$ & {$\left[\mathrm{H}\left(\mathrm{OEt}_{2}\right)_{2}\right] \mathrm{BF}_{4}$} & $\mathrm{M}+[\mathrm{HB}] \mathrm{Y} \rightarrow[\mathrm{MH}] \mathrm{Y}+\mathrm{B}$ & $\mathrm{MeCN}$ & $<240$ & & $16\left(22^{c}\right)$ & 327 \\
\hline 36 & $\mathrm{PtH}(\mathrm{Cl})\left(\mathrm{Ph}_{2}\right)_{2}\left(\mathrm{bpy}_{-}{ }^{\mathrm{t}} \mathrm{Bu}_{2}\right)$ & M & $\mathrm{HCl}$ & $\mathrm{M}+\mathrm{HX} \rightarrow \mathrm{MHX}$ & $\mathrm{CDCl}_{3}$ & 200 & & 16 & 328 \\
\hline 37 & $\mathrm{PtH}\left(\mathrm{O}_{3} \mathrm{SCF}_{3}\right)\left(\mathrm{Ph}_{2}\left(\mathrm{bpy}^{\mathrm{t}} \mathrm{Bu}_{2}\right)\right.$ & M & $\mathrm{CF}_{3} \mathrm{SO}_{3} \mathrm{H}$ & $\mathrm{M}+\mathrm{HX} \rightarrow \mathrm{MHX}$ & $\mathrm{CDCl}_{3}$ & 200 & & 16 & 328 \\
\hline 38 & {$\left[\mathrm{PdH}\left(\mathrm{Et}_{2} \mathrm{PC}_{6} \mathrm{H}_{4} \mathrm{OC}_{6} \mathrm{H}_{4} \mathrm{PEt}_{2}\right)_{2}\right]^{+}$} & M & {$\left[\mathrm{HNEt}_{3}\right] \mathrm{BF}_{4}$} & $\mathrm{M}+[\mathrm{HB}] \mathrm{Y} \rightleftharpoons[\mathrm{MH}] \mathrm{Y}+\mathrm{B}$ & $\mathrm{MeCN}$ & 298 & 18.3 & $16\left(22^{c}\right)$ & 294 \\
\hline 39 & {$\left[\mathrm{PdH}(\text { EtXantphos })_{2}\right]^{+}$} & $\mathrm{M}$ & {$\left[\mathrm{HNEt}_{3}\right] \mathrm{BF}_{4}$} & $\mathrm{M}+[\mathrm{HB}] \mathrm{Y} \rightleftharpoons[\mathrm{MH}] \mathrm{Y}+\mathrm{B}$ & $\mathrm{MeCN}$ & 298 & 18.5 & $16\left(22^{\circ}\right)$ & 294 \\
\hline 40 & {$\left[\mathrm{PtH}\left(\mathrm{P}(\mathrm{OMe})_{3}\right)_{4}\right]^{+}$} & M & & {$[\mathrm{MH}] \mathrm{Y}+\mathrm{B} \rightleftharpoons \mathrm{M}+[\mathrm{HB}] \mathrm{Y}$} & $\mathrm{MeCN}$ & 298 & 18.5 & $10\left(15^{c}\right)$ & 1 \\
\hline 41 & {$\left[\mathrm{PdH}\left(\mathrm{PEt}_{2} \mathrm{CH}_{2} \mathrm{C}_{6} \mathrm{H}_{4} \mathrm{CH}_{2} \mathrm{PEt}_{2}\right)_{2}\right]^{+}$} & M & {$\left[\mathrm{HNEt}_{3}\right] \mathrm{BF}_{4}$} & $\mathrm{M}+[\mathrm{HB}] \mathrm{Y} \rightleftharpoons[\mathrm{MH}] \mathrm{Y}+\mathrm{B}$ & $\mathrm{MeCN}$ & 298 & 19.8 & $20\left(26^{c}\right)$ & 294 \\
\hline 42 & {$\left[\mathrm{PdH}\left(\mathrm{PEt}_{2} \mathrm{CH}_{2} \mathrm{NMeCH}_{2} \mathrm{PEt}_{2}\right)_{2}\right]^{+}$} & M & {$[\mathrm{TMG}-\mathrm{H}] \mathrm{BF}_{4}$} & $\mathrm{M}+[\mathrm{HB}] \mathrm{Y} \rightleftharpoons[\mathrm{MH}] \mathrm{Y}+\mathrm{B}$ & $\mathrm{MeCN}$ & 298 & 22.1 & $20\left(26^{c}\right)$ & 329 \\
\hline 43 & {$\left[\mathrm{NiH}\left(\mathrm{Et}_{2} \mathrm{PCH}_{2} \mathrm{NMeCH}_{2} \mathrm{PEt}_{2}\right)_{2}\right]^{+}$} & M & {$\left[\mathrm{PtH}(\mathrm{dppe})_{2}\right] \mathrm{PF}_{6}$} & $\mathrm{M}+\left[\mathrm{M}^{\prime} \mathrm{H}\right] \mathrm{Y} \rightleftharpoons[\mathrm{MH}] \mathrm{Y}+\mathrm{M}^{\prime}$ & $\mathrm{PhCN}$ & 298 & 22.2 & $20\left(26^{6}\right)$ & 330 \\
\hline 44 & {$\left[\mathrm{PtH}(\mathrm{dppe})_{2}\right]^{+}$} & $\mathrm{M}$ & $\mathrm{NEt}_{3}$ & {$[\mathrm{MH}] \mathrm{Y}+\mathrm{B} \rightleftharpoons \mathrm{M}+[\mathrm{HB}] \mathrm{Y}$} & $\mathrm{MeCN}$ & 298 & 22.2 & $14\left(19^{c}\right)$ & 323 \\
\hline 45 & {$\left[\mathrm{NiH}(-\mathrm{PMe}-\mathrm{NPh}-\mathrm{PMe}-\mathrm{NPh}-)_{2}\right]^{+}$} & $\mathrm{M}$ & & thermochemical cycle & $\mathrm{MeCN}$ & 298 & 22.5 & $20\left(26^{c}\right)$ & 295 \\
\hline 46 & {$\left[\mathrm{PdH}(\mathrm{depp})_{2}\right]^{+}$} & $\mathrm{M}$ & {$[\mathrm{TMG}-\mathrm{H}] \mathrm{BF}_{4}$} & $\mathrm{M}+[\mathrm{HB}] \mathrm{Y} \rightleftharpoons[\mathrm{MH}] \mathrm{Y}+\mathrm{B}$ & $\mathrm{MeCN}$ & 298 & 22.9 & $20\left(26^{c}\right)$ & 294 \\
\hline 47 & {$\left[\mathrm{PdH}(\mathrm{depe})_{2}\right]^{+}$} & M & {$[\mathrm{TMG}-\mathrm{H}] \mathrm{BF}_{4}$} & $\mathrm{M}+[\mathrm{HB}] \mathrm{Y} \rightleftharpoons[\mathrm{MH}] \mathrm{Y}+\mathrm{B}$ & $\mathrm{MeCN}$ & 298 & 23.2 & $20\left(26^{c}\right)$ & 294 \\
\hline 48 & {$\left[\mathrm{NiH}(\mathrm{depp})_{2}\right]^{+}$} & M & TMG & {$[\mathrm{MH}] \mathrm{Y}+\mathrm{B} \rightleftharpoons \mathrm{M}+[\mathrm{HB}] \mathrm{Y}$} & $\mathrm{MeCN}$ & 298 & 23.3 & $20\left(26^{c}\right)$ & 32,289 \\
\hline 49 & {$\left[\mathrm{NiH}(\text { depe })_{2}\right]^{+}$} & $\mathrm{M}$ & $\mathrm{CH}_{3} \mathrm{OC}_{6} \mathrm{H}_{4} \mathrm{NH}_{2}$ & {$[\mathrm{MH}] \mathrm{Y}+\mathrm{B} \rightleftharpoons \mathrm{M}+[\mathrm{HB}] \mathrm{Y}$} & $\mathrm{MeCN}$ & 298 & 23.8 & $20\left(26^{\circ}\right)$ & 32,289 \\
\hline 50 & {$\left[\mathrm{NiH}(\mathrm{dmpp})_{2}\right]^{+}$} & M & 4- $\mathrm{BrC}_{6} \mathrm{H}_{4} \mathrm{NH}_{2}$ & {$[\mathrm{MH}] \mathrm{Y}+\mathrm{B} \rightleftharpoons \mathrm{M}+[\mathrm{HB}] \mathrm{Y}$} & $\mathrm{MeCN}$ & 298 & 24.0 & $20\left(26^{c}\right)$ & 32,289 \\
\hline 51 & {$\left[\mathrm{NiH}(\mathrm{dmpe})_{2}\right]^{+}$} & M & TMG & {$[\mathrm{MH}] \mathrm{Y}+\mathrm{B} \rightleftharpoons \mathrm{M}+[\mathrm{HB}] \mathrm{Y}$} & $\mathrm{MeCN}$ & 298 & 24.3 & $20\left(26^{c}\right)$ & 323 \\
\hline 52 & {$[\mathrm{NiH}(\mathrm{dmpe})(\mathrm{depe})]^{+}$} & $\mathrm{M}$ & TMG & {$[\mathrm{MH}] \mathrm{Y}+\mathrm{B} \rightleftharpoons \mathrm{M}+[\mathrm{HB}] \mathrm{Y}$} & $\mathrm{MeCN}$ & 298 & 24.3 & $20\left(26^{c}\right)$ & 323 \\
\hline 53 & {$\left[\mathrm{NiH}\left(-\mathrm{PCy}-\mathrm{N}^{+} \mathrm{Bu}-\mathrm{PCy}-\mathrm{N}^{+} \mathrm{Bu}-\right)_{2}\right]^{+}$} & M & {$[\mathrm{DBU}-\mathrm{H}] \mathrm{PF}_{6}$} & $\mathrm{M}+[\mathrm{HB}] \mathrm{Y} \rightleftharpoons[\mathrm{MH}] \mathrm{Y}+\mathrm{B}$ & $\mathrm{PhCN}$ & 298 & 24.7 & $20\left(26^{c}\right)$ & 296 \\
\hline 54 & {$\left[\mathrm{PtH}(\text { EtXantphos })_{2}\right]^{+}$} & M & $\mathrm{Ni}(\mathrm{dmpe})_{2}$ & {$[\mathrm{MH}] \mathrm{Y}_{2}+\mathrm{M}^{\prime} \rightleftharpoons[\mathrm{M}] \mathrm{Y}+\left[\mathrm{M}^{\prime} \mathrm{H}\right] \mathrm{Y}$} & $\mathrm{MeCN}$ & 298 & 27.3 & $18\left(24^{c}\right)$ & 288 \\
\hline 55 & {$\left[\mathrm{PtH}(\text { depe })_{2}\right]^{+}$} & M & KOPh & {$[\mathrm{MH}] \mathrm{Y}+\mathrm{KX} \rightleftharpoons \mathrm{M}+\mathrm{KY}+\mathrm{HX}$} & $\mathrm{MeCN}$ & 298 & 29.7 & $22\left(28^{c}\right)$ & 289 \\
\hline 56 & {$\left[\mathrm{PtH}(\mathrm{dmpp})_{2}\right]^{+}$} & M & $\mathrm{NEt}_{3}$ & {$[\mathrm{MH}] \mathrm{Y}+\mathrm{B} \rightleftharpoons \mathrm{M}+[\mathrm{HB}] \mathrm{Y}$} & $\mathrm{MeCN}$ & 298 & 30.4 & $22\left(18^{c}\right)$ & 289 \\
\hline 57 & {$\left[\mathrm{PtH}(\mathrm{dmpe})_{2}\right]^{+}$} & $\mathrm{M}$ & TMG & {$[\mathrm{MH}] \mathrm{Y}+\mathrm{B} \rightleftharpoons \mathrm{M}+[\mathrm{HB}] \mathrm{Y}$} & $\mathrm{MeCN}$ & 298 & 31.1 & $22\left(28^{c}\right)$ & 289 \\
\hline
\end{tabular}




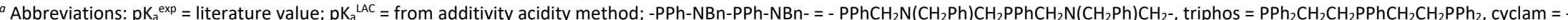
$\mathrm{NHCH}_{2} \mathrm{CH}_{2} \mathrm{NHCH}_{2} \mathrm{CH}_{2} \mathrm{NHCH}_{2} \mathrm{CH}_{2} \mathrm{NHCH}_{2} \mathrm{CH}_{2}-$, dppf $=\mathrm{PPh}_{2} \mathrm{C}_{5} \mathrm{H}_{4} \mathrm{FeC}_{5} \mathrm{H}_{4} \mathrm{PPh}_{2}$, EtXantphos =, TPPTS = P(m- $\left.\mathrm{C}_{6} \mathrm{H}_{4} \mathrm{SO}_{3} \mathrm{Na}\right)_{3},-\mathrm{PCy}-\mathrm{NBn}-\mathrm{PCy}-\mathrm{NBn}=-\mathrm{CHPCH}_{2} \mathrm{~N}\left(\mathrm{CH}_{2} \mathrm{Ph}\right) \mathrm{CH}_{2} \mathrm{PCyCH} \mathrm{CH}_{2} \mathrm{~N}\left(\mathrm{CH}_{2} \mathrm{Ph}\right) \mathrm{CH}_{2}, \mathrm{dppv}=\mathrm{Z}-$

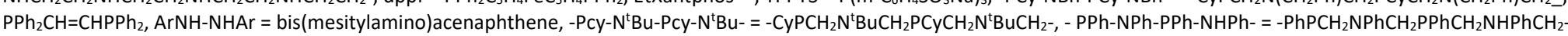

${ }^{b}$ The ligands are the same as in the acid form apart from the loss of a proton (and counteranion for cationic complexes).

$\mathrm{pK}_{\mathrm{a}}$ corrected to the MeCN scale for cationic acids using Equation 14 


\section{GENERAL OBSERVATIONS OF THE DATA IN SECTION 4}

The simple LAC equation (Equation 17) is remarkably successful in accounting for the acid-base reactions of transition metal hydride complexes. The order of ability of the ligand to increase the acidity of a diamagnetic metal hydride as expressed by the ligand acidity constant $A_{L}$ is:

$\mathrm{PR}_{3} \sim \mathrm{NHC}<\mathrm{PArR}_{2} \sim \mathrm{N}$-donors $<\mathrm{PAr}_{2} \mathrm{R}<\mathrm{PAr}_{3}<\mathrm{PX}_{3}<\mathrm{Cp} * / 3<\mathrm{Cp} / 3<$ hydride $<$ olefin $<(\mathrm{H}) \mathrm{NO}<\mathrm{CO}_{3} \sim \mathrm{PF}_{3}$ $<\mathrm{Cl}^{-}<\mathrm{CN}^{-}<\mathrm{SiCl}_{3}^{-}$

The complexes Re(H) $)_{4}(\mathrm{NO})\left(\mathrm{P}^{\mathrm{i}} \mathrm{Pr}_{3}\right)_{2}$ (entry 31, Table 5) and Os $\left(\mathrm{H}_{2}\right)(\mathrm{H})_{2}(\mathrm{CO})\left(\mathrm{P}^{\mathrm{i}} \mathrm{Pr}_{3}\right)_{2}$ (entry 166, Table 7) have similar $p K_{a}^{\text {THF }}$ values (Table 8); therefore, replacement of $\operatorname{ReH}(\mathrm{NO})$ by Os(CO) is predicted to produce compounds of similar acidity. The $A_{L}-3$ is tentatively assigned to $\mathrm{NO}^{+}$when a hydride is present. Complexes with the $\mathrm{SiCl}_{3}{ }^{-}$ligand (entries 41,67 of Table 8) are much more acidic than expected for neutral acids in THF and the tentative $A_{L}-12$ provides $p K_{a}$ that are consistent with the reactions of these iron complexes. The assumption of additive contributions is a simplification that may break down for compounds with large numbers of carbonyl ligands (e.g. $\left[\operatorname{Re}\left(\mathrm{H}_{2}\right)(\mathrm{CO})_{5}\right]^{+}, \mathrm{MH}_{2}(\mathrm{CO})_{4}$ ) where competition for $\mathrm{d}$ electrons for backdonation is quite different than for monocarbonyl complexes. Similarly it can break down for sterically demanding ligands and large bite-angle ligands. ${ }^{8}$ However in this case it is often possible to explain the deviance in terms of the stability of the higher coordinate acid versus the lower coordinate base form.

Refinements in the LAC method may be needed to correct the predicted $\mathrm{p} K_{\mathrm{a}}$ according to the group in the periodic table. Table 7 and Table 10 indicate that the gap between the $4 \mathrm{~d}$ and $5 \mathrm{~d}$ metals increases from the iron group (approx 4 units) to the nickel group (approx. 7 units) for metal hydride but only 2 units dihydrogen complexes. This may be due to an increase in $5 \mathrm{~d}$ metal-H bond strength attributed to relativistic contributions and the promotion energy from the $s$ to the $\mathrm{d}$ orbitals. ${ }^{3}$ The existing LAC scheme is parameterized to give $\mathrm{p} K_{\mathrm{a}}$ values at the midpoint of these gaps for hydride and dihydrogen complexes. However, in general the reactions listed in the tables are consistent with the $\mathrm{p} K_{\mathrm{a}}$ values predicted by the LAC method.

Trends emerge that relate reactants and classes of hydrides in solvents where conversions of values between the solvent scales are possible as shown in Figure 32 for representative examples of cationic acids. The scales in this figure are drawn to show the approximate correspondence of $\mathrm{p} K_{\mathrm{a}}$ values between THF/DCM, MeCN and DMSO. Above the scales are drawn a selection of metal hydride acids with an arrow to indicate their approx. $\mathrm{p} K_{\mathrm{a}}$ value. Below the scales are drawn a selection reference organic acids with their $\mathrm{p} K_{\mathrm{a}}$ indicated; the data for several of the compounds shown are taken from other sources. ${ }^{7,15,36}$ Of course a caveat of such diagrams is that only a few of the possible reactions in solvents have actually been done.

The polyhydride cations $\left[\mathrm{MH}_{x}\left(\mathrm{PR}_{3}\right)_{4}\right]^{+}, \mathrm{R}=$ alkyl including chelating diphosphines " $\left(\mathrm{PR}_{3}\right)_{2}$ " such as dmpe, $M=R e, x=4, M=F e, R u, O s, x=3, M=R h, I r, x=2, N i, P d, P t, x=1$ are the weakest acids in this diagram with $\mathrm{p} K_{\mathrm{a}}{ }^{\mathrm{LAC}} 20-22$ (26-28 for $\mathrm{Rh}, \mathrm{Ir}$ ), $\mathrm{p} K_{\mathrm{a}}{ }^{\mathrm{THF}} 18-26$ ( $\left.\mathrm{p} K_{\mathrm{a}}{ }^{\mathrm{MeCN}} 24-32\right)$. They are seen to be in equilibrium with organic bases such as the phosphazene $\mathrm{NMeP}\left(\mathrm{NMe}_{2}\right)_{3}, \mathrm{DBU}, \mathrm{KO} \mathrm{H}^{\mathrm{B} u}$ and TMG. As alkyl groups are replaced by aryl groups the $\mathrm{p} K_{\mathrm{a}}$ decrease. For example the complexes with formulae $\left[\mathrm{MH}_{\mathrm{x}}\left(\mathrm{PPh}_{2} \mathrm{R}\right)_{4}\right]^{+}$including diphosphines such as dppe, now have $\mathrm{p} K_{\mathrm{a}}^{\mathrm{LAC}} 12-14$ (18-20 for $\left.\mathrm{M}=\mathrm{Rh}, \mathrm{Ir}\right), \mathrm{p} K_{\mathrm{a}}{ }^{\mathrm{THF}}$ 10-16 ( $\left.p K_{a}{ }^{\mathrm{MeCN}} 16-22\right)$ and are in equilibrium with bases such as $\mathrm{NEt}_{3}$, pyrrolidine and proton sponge. Groups of $\left[\mathrm{MH}_{\mathrm{x}}\left(\mathrm{Cp}^{*}\right)\left(\mathrm{PPh}_{2} \mathrm{R}\right)_{2}\right]^{+} \mathrm{M}=\mathrm{Mo}, \mathrm{W}, \mathrm{x}=4, \mathrm{M}=\mathrm{Fe}, \mathrm{Ru}, \mathrm{Os}, \mathrm{x}=2$, with $\mathrm{p} K_{\mathrm{a}}^{\mathrm{LAC}}$ 9-11 are in 
equilibrium with bases such as $\left.\left[\mathrm{CF}_{3} \mathrm{CH}_{2} \mathrm{O}-\mathrm{HOCH}_{2} \mathrm{CF}_{3}\right)\right]^{-}, \mathrm{PCy}_{3}, \mathrm{P}^{\mathrm{t}} \mathrm{Bu}_{3}, \mathrm{NEt}_{3},\left[4-\mathrm{NO}_{2} \mathrm{C}_{6} \mathrm{H}_{4} \mathrm{O}-\mathrm{HOC}_{6} \mathrm{H}_{4} \mathrm{NO}_{2}-4\right]^{-}$, 2,6 lutidine and [PhO-HOPh)]. The corresponding iron-group $\mathrm{Cp}$ complexes have $\mathrm{p} K_{\mathrm{a}}{ }^{\mathrm{LAC}} 8-10$. The protonated metallocenes $\left[\mathrm{MH}\left(\mathrm{Cp}^{*}\right)_{2}\right]^{+}, \mathrm{M}=\mathrm{Ru}$, Os have $\mathrm{p} K_{\mathrm{a}}{ }^{\mathrm{LAC}}$ 5-7 with the osmium complex in equilibrium with anilinium. The Re relative $\left[\operatorname{ReH}(\mathrm{Cp})_{2}\right]^{+}$has $\mathrm{p} K_{\mathrm{a}}{ }^{\mathrm{aq}} 8.5$. The series $\left[\mathrm{MH}_{\mathrm{x}}(\mathrm{CO})_{3}\left(\mathrm{PR}_{3}\right)_{2}\right]^{+}$is represented by $\mathrm{x}=2, \mathrm{M}=\mathrm{Re}, \mathrm{x}=1, \mathrm{M}=\mathrm{Fe}$ with $\mathrm{p} K_{\mathrm{a}}^{\mathrm{LAC}} 0$ and 4 respectively. The iron complex is less acidic because of its $\mathrm{d}^{6}$ octahedral configuration and is in equilibrium with $\mathrm{PPh}_{3}$.

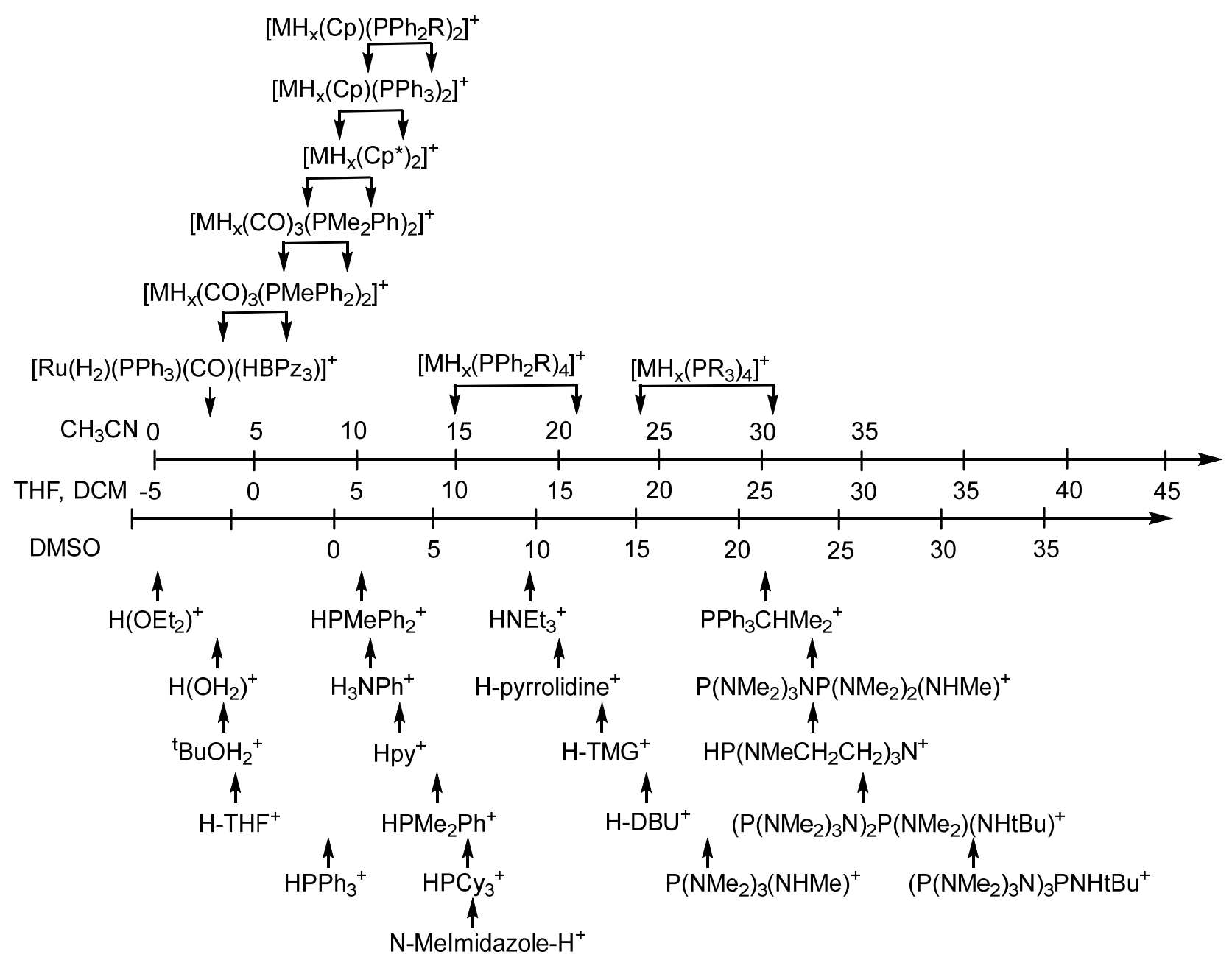

Figure 32. Matching the $\mathrm{pK}_{a}$ of classes of cationic metal hydrides and cationic reference acids

The construction of a harmonizing scale for the neutral hydride acids is more challenging because of the variation in ion-pairing, hydrogen bonding and solvation energies in the cations and anions in THF and DCM. Figure 33 shows the approximate placement of hydride acids (on top of the scales) and organic reference acids (under the scales). Several of the $\mathrm{p} K_{\mathrm{a}}{ }^{\mathrm{THF}}$ and $\mathrm{p} K_{\mathrm{a}}{ }^{\mathrm{MeCN}}$ determinations were done using reactions that conserve equal numbers of ion pairs on each side of the equation (Equation 9) and these should correspond as shown in Figure 33. Very strong bases such as $\mathrm{O}^{t} \mathrm{Bu}^{-}$and $\mathrm{NPh}_{2}{ }^{-}$will be strongly interacting with counterions and other species in solution and so a variation in $\mathrm{p} K_{\mathrm{a}}$ is noted on the diagram. 
In general as the number of carbonyl ligands increases in the coordination sphere of the metal the $\mathrm{p} K_{\mathrm{a}}$ drops when other ligands are kept similar according to the LAC scheme. Similarly, as the number of phosphine donors increases the $\mathrm{p} K_{\mathrm{a}}$ increases as expected.

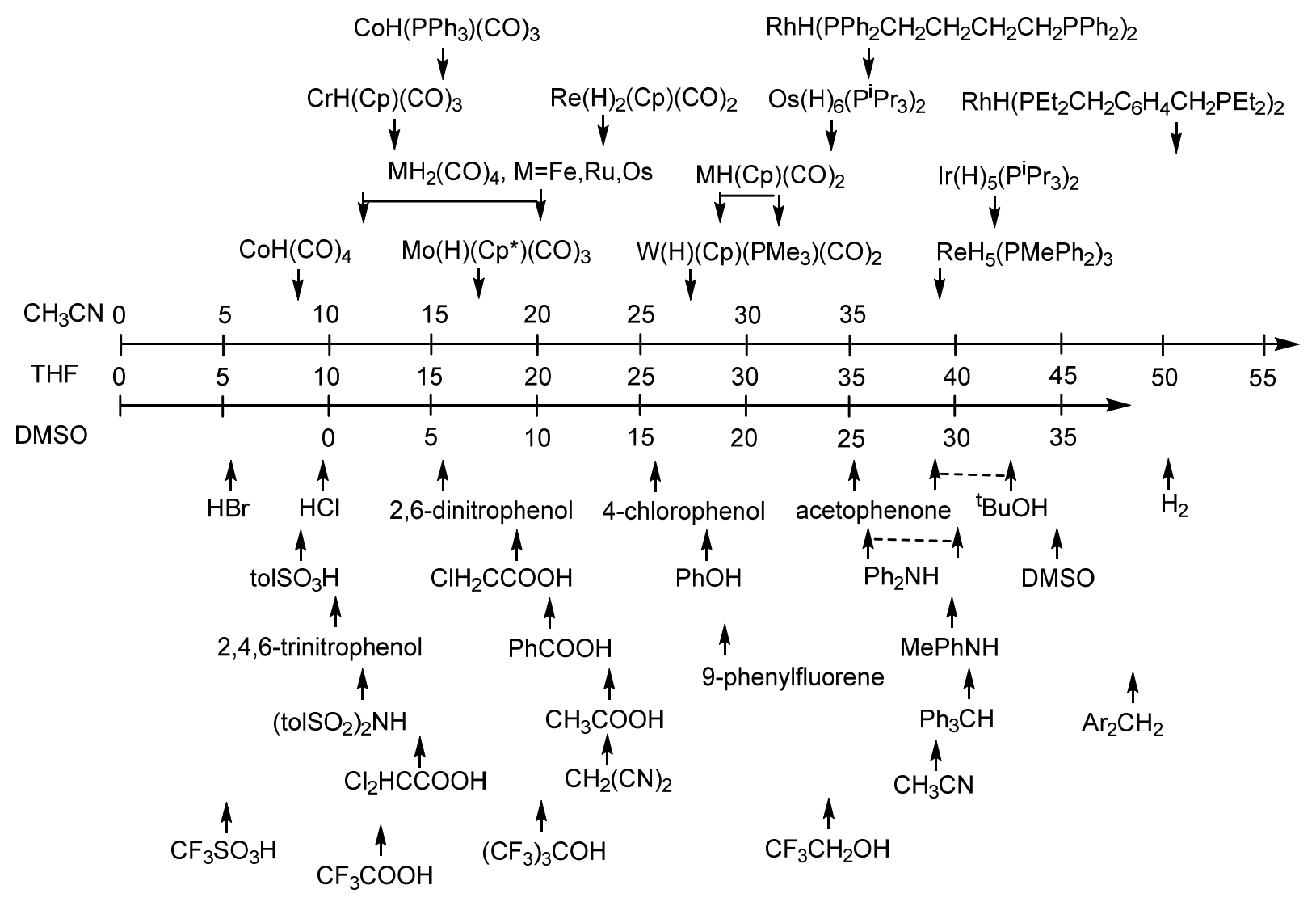

Figure 33. Matching the $\mathrm{pK}_{a}$ of neutral metal hydride acids with neutral reference acids in three solvents.

When neutral acids react with neutral bases to generate a cationic acid in a low dielectric constant solvent like THF or DCM, as in Equation $11(\mathrm{HA}+\mathrm{B}=[\mathrm{HB}][\mathrm{A}])$, the results can be quite unexpected if the $\mathrm{p} K_{\mathrm{a}}{ }^{\mathrm{DMSO}}$ or $\mathrm{p} K_{a}{ }^{a q}$ of the acids are used for comparison. Table 12 is a list of reactions of this type taken from the tables above, several observed below room temperature due to the instability of the protonated metal form. The $\Delta \mathrm{p} K_{\mathrm{a}}^{\text {THF }}$ values are calculated by adding 10 to $\mathrm{p} K_{\mathrm{a}}{ }^{\text {DMSO }}$ values of the organic acids (the correction of 10 is obtained from the data of Table 2). It should be noted that the equilibrium of Equation 11 is expected to have a negative $\Delta S$. Thus it is expected to move toward the organic acid and unprotonated metal base as the temperature increases. These trends are clearly observed in a study of the reactions of $\mathrm{MH}(\mathrm{CO}){ }_{3} \mathrm{Cp}, \mathrm{M}=\mathrm{Mo}, \mathrm{W}$ with neutral bases in hexane, THF, DCM and $\mathrm{MeCN}$ as discussed in Section 4.3. 
Table 12 Equilibria between neutral acids and bases in low dielectric constant solvents (Equation 11)

\begin{tabular}{|c|c|c|c|c|c|c|}
\hline $\begin{array}{l}\text { Table/ } \\
\text { Entry }\end{array}$ & Acid & $\begin{array}{l}\mathrm{p} K_{\mathrm{a}} \\
\text { (DMSO) }\end{array}$ & Base (M) & $\begin{array}{l}\mathrm{p} K_{\mathrm{a}}^{\mathrm{LAC}} \\
\left(\mathrm{MH}^{+}\right) \\
\end{array}$ & $\begin{array}{l}\text { Solvent/ } \\
\text { Temp. }\end{array}$ & $\begin{array}{l}\Delta \mathrm{p} K_{\mathrm{a}} \\
\text { (THF) }\end{array}$ \\
\hline Table 5/1 & HOTf & 0 & $\mathrm{WH}(\mathrm{CO}){ }_{3} \mathrm{Cp}$ & -8 & $\mathrm{DCM} / 298$ & $\sim 18$ \\
\hline Table 5/2 & HOTf & 0 & $\mathrm{WH}(\mathrm{CO})_{3} \mathrm{Cp}^{*}$ & -7 & $\mathrm{DCM} / 298$ & $\sim 17$ \\
\hline Table 8/1 & HOTf & 0 & {$\left[\mathrm{FeH}(\mathrm{CO})(\mathrm{dppe})_{2}\right]^{+}$} & -7 & $\mathrm{DCM} / 298$ & $\sim 17$ \\
\hline Table $8 / 2$ & HOTf & 0 & $\begin{array}{l}{\left[\mathrm{OsH}(\mathrm{CO})(\mathrm{dppp})_{2}\right]} \\
+\end{array}$ & -5 & $\mathrm{DCM} / 298$ & $\sim 15$ \\
\hline Table $8 / 5$ & HOTf & 0 & $\mathrm{RuH}(\mathrm{CO}){ }_{2} \mathrm{Cp} *$ & -5 & $\mathrm{DCM} / 193$ & $\sim 15$ \\
\hline Table 8/12 & HOTf & 0 & $\mathrm{OsH}(\mathrm{CO}){ }_{2} \mathrm{Cp}^{*}$ & -3 & $\mathrm{DCM} / 193$ & $\sim 13$ \\
\hline Table 5/33 & $\mathrm{CF}_{3} \mathrm{COOH}$ & 3.4 & $\mathrm{MoH}_{3} \mathrm{Cp} *(\mathrm{dppe})$ & 9 & $\begin{array}{l}\text { Toluene/ } \\
<250\end{array}$ & $\sim 4$ \\
\hline Table 6/11 & $\left(\mathrm{CF}_{3}\right)_{3} \mathrm{COH}$ & 11 & $\operatorname{ReH}(\mathrm{CO})_{2}($ tripod) & 3 & $\begin{array}{l}\text { DCM/ } \\
<260\end{array}$ & $\sim 17$ \\
\hline Table 8/35 & $\left(\mathrm{CF}_{3}\right)_{3} \mathrm{COH}$ & 11 & $\mathrm{RuH}(\mathrm{CO}) \mathrm{Cp}\left(\mathrm{PCy}_{3}\right)$ & 3 & $\mathrm{DCM} / 200$ & $\sim 18$ \\
\hline $\begin{array}{l}\text { Table } \\
8 / 102\end{array}$ & $4-\mathrm{NO}_{2} \mathrm{C}_{6} \mathrm{H}_{4} \mathrm{OH}$ & 11 & FeH(dppe)Cp* & 9 & $\mathrm{DCM} / 200$ & $\sim 12$ \\
\hline $\begin{array}{l}\text { Table } \\
8 / 103\end{array}$ & $4-\mathrm{NO}_{2} \mathrm{C}_{6} \mathrm{H}_{4} \mathrm{OH}$ & 11 & RuH(dppe)Cp* & 9 & $\mathrm{DCM} /<230$ & $\sim 12$ \\
\hline $\begin{array}{l}\text { Table } \\
8 / 111\end{array}$ & $\mathrm{PhCOOH}$ & 12 & $\mathrm{RuH}(\mathrm{P}-\mathrm{P}) \mathrm{Cp}^{a}$ & 10 & Toluene/298 & $\sim 12$ \\
\hline Table 5/35 & $\left(\mathrm{CF}_{3}\right)_{2} \mathrm{CHOH}$ & 18 & $\mathrm{WH}_{3} \mathrm{Cp} *(\mathrm{dppe})$ & 11 & $\begin{array}{l}\text { Toluene } /<29 \\
0\end{array}$ & $\sim 17$ \\
\hline $\operatorname{Ref}^{42}$ & $\left(\mathrm{CF}_{3}\right)_{2} \mathrm{CHOH}$ & 18 & $\mathrm{RuH}_{2}(\mathrm{CO})$ (triphos) & 6 & $\mathrm{DCM} / 200$ & $\sim 22$ \\
\hline $\begin{array}{l}\text { Table } \\
8 / 104\end{array}$ & $\left(\mathrm{CF}_{3}\right)_{2} \mathrm{CHOH}$ & 18 & RuH(dppe)Cp* & 9 & $\mathrm{DCM} /<230$ & $\sim 19$ \\
\hline $\begin{array}{l}\text { Table } \\
8 / 112\end{array}$ & $\left(\mathrm{CF}_{3}\right)_{2} \mathrm{CHOH}$ & 18 & $\operatorname{RuH}(\mathrm{P}-\mathrm{P}) \mathrm{Cp}^{a}$ & 10 & $\mathrm{DCM} / 298$ & $\sim 18$ \\
\hline $\operatorname{Ref} 331$ & $\mathrm{PhOH}$ & 18 & $\mathrm{RuH}_{2}(\mathrm{dppm})_{2}$ & 12 & $\mathrm{DCM} / 298$ & $\sim 16$ \\
\hline Table 5/32 & $\mathrm{CF}_{3} \mathrm{CH}_{2} \mathrm{OH}$ & 24 & $\mathrm{MoH}_{3} \mathrm{Cp} *$ (dppe) & 9 & $\mathrm{DCM} /<250$ & $\sim 25$ \\
\hline Table 5/34 & $\mathrm{CF}_{3} \mathrm{CH}_{2} \mathrm{OH}$ & 24 & $\mathrm{WH}_{3} \mathrm{Cp} *(\mathrm{dppe})$ & 11 & $\mathrm{DCM} /<290$ & $\sim 23$ \\
\hline $\begin{array}{l}\text { Table } \\
8 / 110\end{array}$ & $\mathrm{CF}_{3} \mathrm{CH}_{2} \mathrm{OH}$ & 24 & OsH(dppe)Cp* & 9 & $\mathrm{DCM} / 230$ & $\sim 25$ \\
\hline Table 5/47 & $\mathrm{MoH}(\mathrm{CO})_{3} \mathrm{Cp}$ & $14^{b}$ & $\mathrm{OsH}_{2}\left(\mathrm{PMePh}_{2}\right)_{4}$ & $14^{c}$ & THF/290 & 0 \\
\hline Table 9/77 & $\mathrm{MnH}(\mathrm{CO})_{5}$ & $15^{b}$ & $\operatorname{IrMe}\left(\mathrm{PMe}_{3}\right)_{4}$ & 28 & Pentane/298 & $-13^{d}$ \\
\hline Table 6/25 & $(\mathrm{NC})_{2} \mathrm{CH}_{2}$ & $\begin{array}{l}11 \\
\left(24^{c}\right)\end{array}$ & $\mathrm{ReH}_{3}\left(\mathrm{PMe}_{2} \mathrm{Ph}\right)_{4}$ & $20^{c}$ & THF/298 & 4 \\
\hline $\begin{array}{l}\text { Table } \\
8 / 163\end{array}$ & $\mathrm{CH}_{3} \mathrm{COOEt}$ & 24 & $\mathrm{Fe}\left(\mathrm{P}_{3}\right)(\mathrm{dmpe})^{\mathrm{e}}$ & 30 & $\mathrm{C}_{6} \mathrm{D}_{6} / 298$ & $\sim 4$ \\
\hline Table 6/32 & $\mathrm{ReH}_{7}\left(\mathrm{PPh}_{2} \mathrm{C}_{6} \mathrm{H}_{4} \mathrm{~F}\right)_{2}$ & $28^{c}$ & $\mathrm{ReH}\left(\mathrm{PMe}_{3}\right)_{5}$ & $24^{c}$ & THF/298 & 4 \\
\hline Table 9/76 & $\mathrm{FeH}(\mathrm{CO})_{2} \mathrm{Cp}$ & $27^{b}$ & $\operatorname{IrMe}\left(\mathrm{PMe}_{3}\right)_{4}$ & 28 & Pentane/298 & $-1^{d}$ \\
\hline
\end{tabular}

${ }^{a} \mathrm{P}-\mathrm{P}=\mathrm{P}^{\mathrm{i}} \mathrm{Pr}_{2} \mathrm{NHC}_{6} \mathrm{H}_{10} \mathrm{NHP}^{\mathrm{i}} \mathrm{Pr}_{2}$

${ }^{b} \mathrm{p} K_{\mathrm{a}}{ }^{\mathrm{MeCN}}$

${ }^{c}$ ion pair corrected $\mathrm{pK}_{\alpha}{ }^{\mathrm{THF}}$

${ }^{d}$ Reaction goes to completion 
${ }^{\mathrm{e}} \mathrm{P}_{3}={ }^{\mathrm{t}} \mathrm{BuSi}\left(\mathrm{CH}_{2} \mathrm{PMe}_{2}\right)_{3}$

The data from Table 12 are plotted in Figure 34. It can be seen from the Table and Figure 34 that the neutral organic acids are acting as much stronger acids than their $\mathrm{p} K_{\mathrm{a}}{ }^{\mathrm{DMSO}}$ or estimated $\mathrm{p} K_{a}{ }^{\text {THF }}$ would indicate. The $\Delta \mathrm{p} K_{\mathrm{a}}{ }^{\mathrm{THF}}$ range from 4 to 25 for the $\mathrm{OH}$-based acids, with $\mathrm{CF}_{3} \mathrm{CH}_{2} \mathrm{OH}$ providing the largest differences. This last acid has a very small, polarizing anion that will usually be strongly hydrogenbonded to more alcohol or be placed in ion pairs extremely close to the metal cation, resulting in a large ion pair attraction energy and very small ion pair dissociation constant in the low dielectric constant solvents used in the reactions. Specific hydrogen-bonding interactions in the homoconjugated base also contribute to the position of the equilibrium as well as the low temperature of the reaction in certain cases. ${ }^{41}$

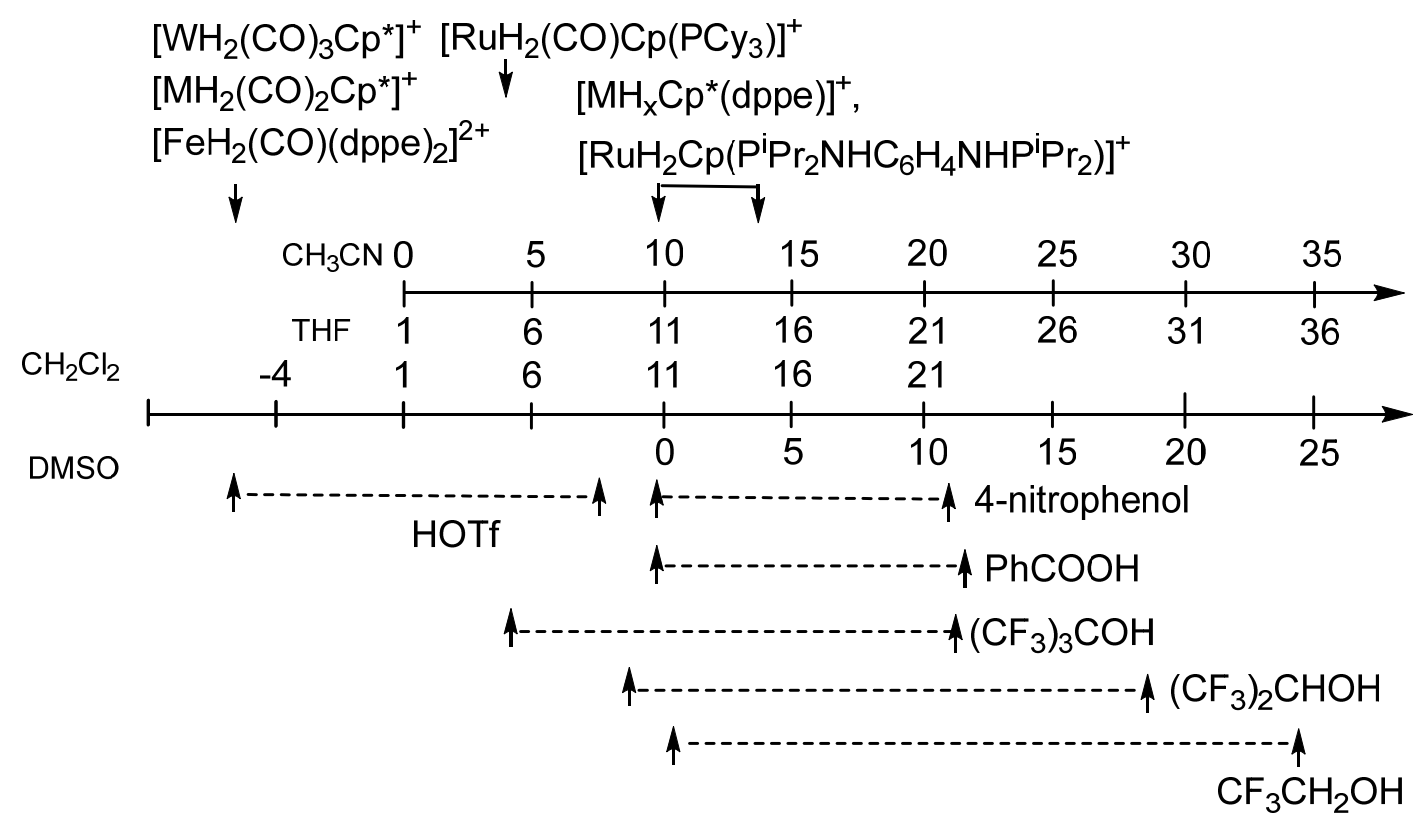

Figure 34. Equilibria observed between cationic metal hydrides and neutral organic acids ${ }^{a}$

${ }^{\text {a }}$ For $\left[\mathrm{MH}_{2}(\mathrm{CO})_{2} \mathrm{Cp}^{*}\right]^{+} \mathrm{M}=\mathrm{Fe}, \mathrm{Ru}, \mathrm{Os}$; for $\left[\mathrm{MH}_{\mathrm{x}} \mathrm{Cp} *(\mathrm{dppe})\right]^{+} \mathrm{M}=\mathrm{Mo}, \mathrm{W}, \mathrm{x}=3 ; \mathrm{M}=\mathrm{Fe}, \mathrm{Ru}, \mathrm{Os}, \mathrm{x}=2$. The arrow at the more positive position refers to the approximate $\mathrm{p} K_{\mathrm{a}}$ of the acid in THF while the arrow joined by the dotted line to less positive values refers to the effective $\mathrm{p} K_{\mathrm{a}}$ in the equilibrium (refer to Table 12). 


\section{IMPLICATIONS FOR CATALYTIC PROCESSES}

Acidic hydride and dihydrogen complexes have been implicated in the mechanism of many catalytic processes. It is instructive to consider the established or proposed acid strength of these complexes to provide a better understanding of the mechanism and possibly allow the design of new catalytic processes. Berke has proposed a generalized scheme to classify catalytic reactions involving dihydrogen with transition metal complexes into two electron and one electron processes. ${ }^{332}$ The acidity of transition metal hydride and dihydrogen complexes come into play in both classes. Within the twoelectron class, reactions proceeding via the heterolytic splitting of dihydrogen and ionic hydrogenation are important and will be discussed first. The $\mathrm{p} K_{\mathrm{a}}$ of transition metal complexes can be related via bond dissociation energies to one electron redox changes in order to characterize electrocatalysts for hydrogen evolution or hydrogen oxidation. ${ }^{32-33,318,333}$

\subsection{Ionic hydrogenation using dihydrogen gas}

In most cases, lonic hydrogenations can be further categorized by the proposed mechanism of transfer of the proton/hydride equivalent to the substrate. ${ }^{332}$ Acidic metal hydride and dihydrogen complexes are thought to be important intermediates in the catalytic hydrogenation of ketones and imines. An acidic dihydrogen or dihydride complex $\mathrm{MH}_{2} \mathrm{~L}_{n}{ }^{+}$might first transfer a proton to the substrate $\mathrm{X}=\mathrm{Y}$ (e.g. ketone, imine, electro-rich olefin) to create a more electrophilic substrate $\mathrm{X}=\mathrm{YH}^{+}$which then reacts with the moderately nucleophilic hydride complex $\mathrm{MHL}_{n}$ to produce the hydrogenated product $\mathrm{HXYH}$. The resulting metal complex $\mathrm{ML}_{n}{ }^{+}$adds dihydrogen to restart the cycle (Figure 35). ${ }^{332}$ Here the neutral unsaturated substrate is much less reactive toward nucleophiles relative to its protonated form. In this case the $\mathrm{p} K_{\mathrm{a}}{ }^{1}$ of the dihydrogen/dihydride complex is similar to the $\mathrm{p} K_{\mathrm{a}}{ }^{2}$ of the protonated substrate $\mathrm{X}=\mathrm{YH}^{+}$. The proton often transfers to the substrate in the outer coordination sphere of the metal while the product of the hydride transfer may be coordinated or not. Bullock proposed this mechanism to demonstrate that "cheap metals like molybdenum and tungsten can be used for noble tasks" usually reserved for the platinum group metals. ${ }^{334}$

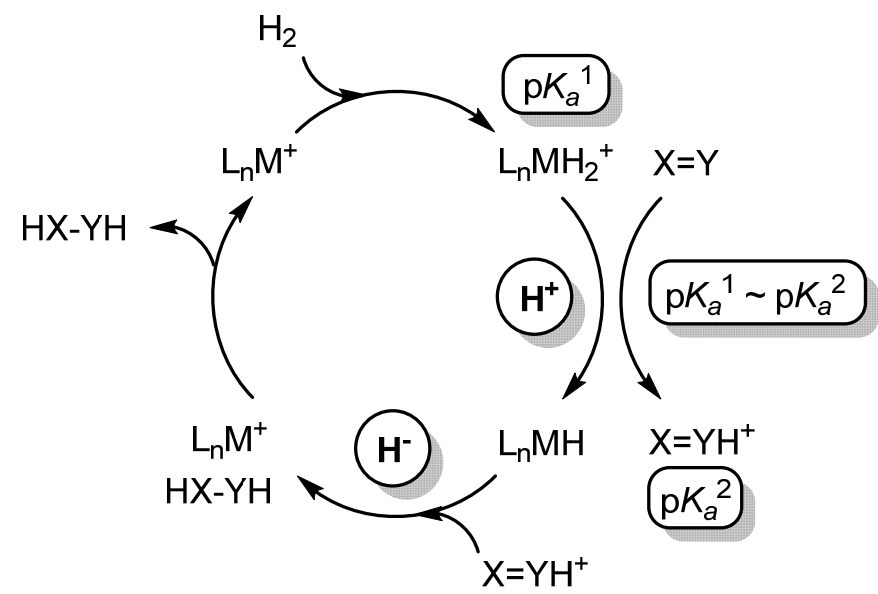

Figure 35. Proton-first ionic hydrogenation mechanism

Alternatively under less acidic conditions a base $\mathrm{B}$ might react first to abstract a proton from a hydride complex $\mathrm{MH}_{2} \mathrm{~L}_{n}{ }^{+}$to produce a more nucleophilic complex $\mathrm{MHL}_{n}$ (Figure 36). ${ }^{332}$ The first transfer 
to the substrate $X=Y$ in this case is the hydride from $M H L_{n}$ followed by the proton from the base. In this case the $\mathrm{p} K_{\mathrm{a}}{ }^{1}$ of the dihydrogen complex should be similar to the $\mathrm{p} K_{\mathrm{a}}{ }^{2}$ of the base $\mathrm{B}$. The metal complex can be a bifunctional catalyst if the base is attached to one of the ligands. Then the proton transfer step from the ligand might occur as shown, or instead it might happen in concert with the hydride transfer. Another possibility is that the substrate is attacked simultaneously by the metal hydride and the protonated base $L_{n} M H . . X=Y . . H B$ in a "frustrated Lewis pair" fashion. ${ }^{21-22,332}$

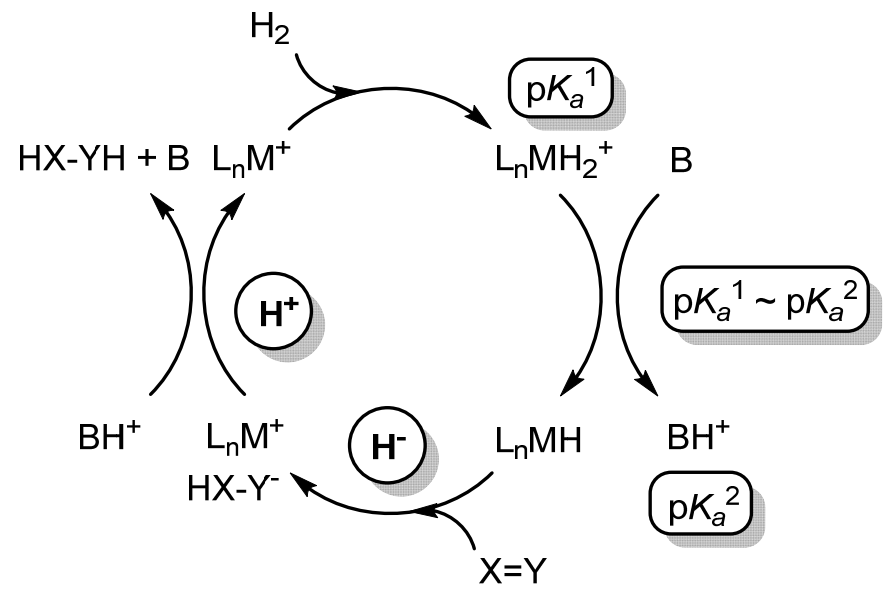

Figure 36. Hydride-first ionic hydrogenation mechanism

\subsubsection{Ketone and aldehyde hydrogenation}

A classic and pioneering example of the catalytic ionic hydrogenation of ketones was reported by Voges and Bullock. ${ }^{110,335}$ They used molybdenum and tungsten carbonyl complexes in $\mathrm{CD}_{2} \mathrm{Cl}_{2}$ or neat dialkylketone. The proposed mechanism is shown in Figure 37 annotated with $\mathrm{p} K_{a}^{\mathrm{LAC}}$ values.

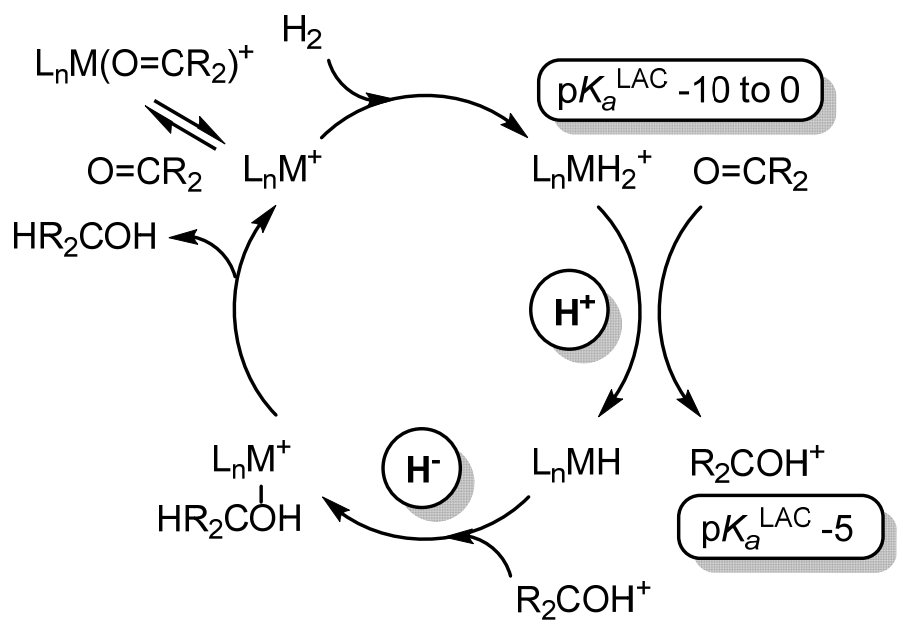

Figure 37. The proposed proton-first mechanism for the ionic hydrogenation of ketones catalyzed by group 6 metal carbonyl complexes.

Here a complex of the form $\left[M(C p)(C O)_{3-x}\left(P_{3}\right)_{x} L\right] B A r_{4}, A r=3,5$-bis(trifluoromethyl)phenyl, $M=M o, W, R$ $=\mathrm{Cy}, \mathrm{Me}, \mathrm{Ph}, \mathrm{x}=0,1, \mathrm{~L}=\mathrm{CD}_{2} \mathrm{Cl}_{2}$, ketone or alcohol, reacts with dihydrogen to produce an acidic dihydrogen complex. $\left[\mathrm{M}\left(\mathrm{H}_{2}\right)(\mathrm{Cp})(\mathrm{CO})_{3-x}\left(\mathrm{PR}_{3}\right)_{\mathrm{x}}\right]^{+}$. This complex either directly protonates the ketone or first rearranges to a dihydride and then delivers the proton to the substrate. The monohydride $\mathrm{MH}(\mathrm{Cp})(\mathrm{CO})_{3-\mathrm{x}}\left(\mathrm{PR}_{3}\right)_{x}$ that is produced then attacks the carbon of the protonated ketone in the outer 
sphere to produce the product alcohol. Dihydrogen coordinates to the unsaturated complex that is produced to close the catalytic cycle. This ionic hydrogenation mechanism does not require coordination of the ketone to the metal for the hydrogenation, thus differing from traditional mechanisms where coordination of a ketone to a metal precedes migration of a hydride to the ketone. ${ }^{110}$ However the scope of ketones that can be reduced using these catalysts is limited to a few very basic ones and the rates of reduction are very low. Formate can also be used as the hydride source in the transfer ionic hydrogenation of ketones and aldehydes catalyzed by $\mathrm{MoH}(\mathrm{CO})_{3} \mathrm{Cp}^{118}$.

In most cases, conversion of the ketone or alcohol complexes to the dihydride is the turnoverlimiting step of the catalytic cycle, with ketone and alcohol complexes being observed during the reaction. For the W-PCy $y_{3}$ system, the dihydride $\left[\mathrm{CpW}(\mathrm{CO})_{2}\left(\mathrm{PCy}_{3}\right)(\mathrm{H})_{2}\right]^{+}$is observed as the resting state of the catalytic process. Proton transfer is slow and becomes turnover-limiting in this case. The Mo catalysts are more active than the $\mathrm{W}$ ones, and the dependence on phosphine is $\mathrm{PCy}_{3}>\mathrm{PPh}_{3}>\mathrm{PMe}_{3}$. The Mo-PCy $y_{3}$ system has the fastest initial turnover rate, but it is only about $2 \mathrm{~h}^{-1}$.

Norton and coworkers reported a $\mathrm{pK}_{\mathrm{a}}^{\mathrm{MeCN}}$ of 5.6 for $\left[\mathrm{CpW}(\mathrm{CO})_{2}\left(\mathrm{PMe}_{3}\right)(\mathrm{H})_{2}\right]^{+}$which corresponds to a $\mathrm{p} K_{\mathrm{a}}{ }^{\mathrm{LAC}}$ of 1 (entry 14 of Table 5). The $\mathrm{p} K_{\mathrm{a}}{ }^{\mathrm{MeCN}}$ of protonated acetone, $\mathrm{HOCMe}_{2}{ }^{+}$is $-0.1^{53}$ corresponding to a $\mathrm{p} K_{\mathrm{a}}^{\mathrm{LAC}}$ of -6 . Thus the ketone protonation step of Figure 35 must be uphill for the tungsten complexes $\left[\mathrm{CpW}(\mathrm{CO})_{2}\left(\mathrm{PR}_{3}\right)(\mathrm{H})_{2}\right]^{+}$and this explains why this step is turnover- limiting in the hydrogenation of $\mathrm{O}=\mathrm{CEt}_{2}$ in $\mathrm{CD}_{2} \mathrm{Cl}_{2} \cdot{ }^{110}$ By comparison, the $\mathrm{p} K_{\mathrm{a}}{ }^{\mathrm{LAC}}$ of the tricarbonyl complexes $\left[\mathrm{MH}_{2}(\mathrm{CO})_{3} \mathrm{Cp}\right]^{+}$range from $-10(\mathrm{Mo})$ to $-8(\mathrm{~W})$ (entry 1 of Table 5) making the proton transfer step fast and this could explain why dihydrogen coordination becomes the slow step with these catalysts. The phosphine substituent would also serve to destabilize the adducts $\left[M(C p)(C O)_{2}\left(P R_{3}\right) L\right]^{+}, L=$ ketone or alcohol, in favor of the dihydrogen adduct in the dihydrogen coordination step of the catalytic cycle while the tricarbonyl complexes would be stronger Lewis acids and form more stable adducts. Linking the $\mathrm{Cp}$ ring to the phosphine in the complex $\mathrm{MoH}(\mathrm{CO})_{2}\left(\mathrm{C}_{5} \mathrm{H}_{4} \mathrm{CH}_{2} \mathrm{CH}_{2} \mathrm{PCy}\right)$ leads to a more robust catalyst with higher turnover numbers. ${ }^{124}$

A similar ionic hydrogenation mechanism to that shown in Figure 35 is proposed for the hydrogenation at $750 \mathrm{psi} \mathrm{H}_{2}$ of propionaldehyde to 1-propanol catalyzed by [Cp* $(\mathrm{CO}){ }_{2} \mathrm{Ru}(\mu-$ $\mathrm{H}) \mathrm{Ru}(\mathrm{CO})_{2} \mathrm{Cp}^{*}$ ]OTf in sulfolane with added HOTf at $110^{\circ} \mathrm{C} .{ }^{162}$ The aldehyde was actually being produced by the dehydration of 1,2-propanoldiol under the acidic conditions stated. The starting dimeric hydride is converted under these conditions to the very acidic dihydrogen complex $\left[\mathrm{Ru}\left(\mathrm{H}_{2}\right)(\mathrm{CO})_{2} \mathrm{Cp}^{*}\right]^{+}\left(\mathrm{p} K_{\mathrm{a}}^{\mathrm{LAC}}-5\right.$, Table 8, entry 5). First a proton is proposed to be transferred to the aldehyde to produce $\mathrm{RuH}(\mathrm{CO})_{2} \mathrm{Cp}^{*}$ which then attacks the carbonium ion to produce the alcohol product.

Complexes of the type $(R, R)$ - or $(S, S)$ - $\mathrm{RuH}$ (arene) $\left(\mathrm{NH}_{2} \mathrm{CHPhCHPhNTs}\right)$ are excellent catalysts for the asymmetric transfer hydrogenation (ATH) under argon of prochiral ketones to enantioenriched alcohols by transfer of hydrogen from the isopropanol solvent under neutral or basic conditions. ${ }^{336}$ While they were ineffective in the ATH of chromane substrates (Figure $38 . \mathrm{R}=\mathrm{H}, \mathrm{Me}, \mathrm{Cl}$ ) the following AH system did reduce these ketones. ${ }^{311}$ 


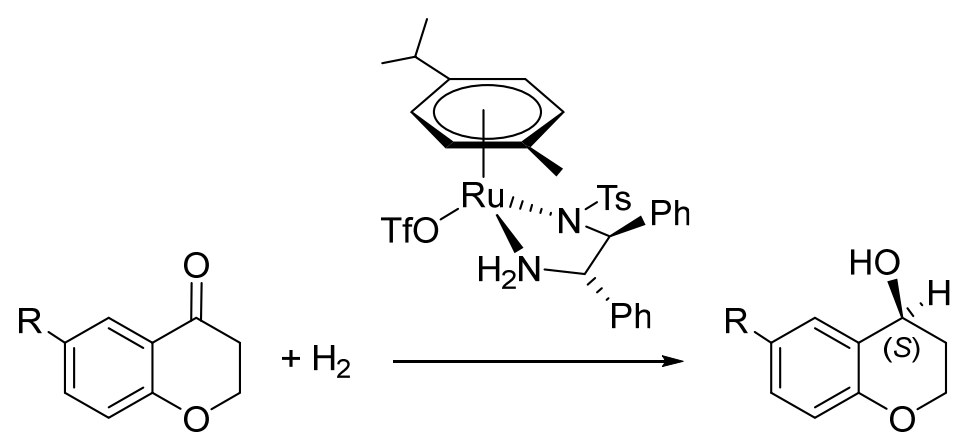

Figure 38. The asymmetric hydrogenation of chromanes catalyzed by ruthenium complexes.

Such ruthenium complexes become asymmetric hydrogenation $(\mathrm{AH})$ catalysts under slightly acidic conditions (methanol with one equiv. of HOTf per ruthenium) at $10-100$ atm $\mathrm{H}_{2}$ and $60{ }^{\circ} \mathrm{C} .{ }^{337}$ Thus when the complex $(S, S)$ - $\left[\mathrm{Ru}(\mathrm{OTf})\right.$ (cymene)( $\left.\left.\mathrm{NH}_{2} \mathrm{CHPhCHPhNTs}\right)\right]$ is used in the presence of 1 equiv. of HOTf for the hydrogenation of these chromane ketones at catalyst loading of $0.02 \%$, the alcohols are obtained in ee up to $98 \%(S)$. The dihydrogen complex $(S, S)$ - $\left[\mathrm{Ru}\left(\mathrm{H}_{2}\right)\right.$ (cymene) $\left.\left(\mathrm{NH}_{2} \mathrm{CHPhCHPhNTs}\right)\right] \mathrm{OTf}$ is proposed to form under catalytic conditions. The dihydrogen ligand is proposed to be deprotonated by the $\mathrm{MeOH}$ solvent to give the hydride $(S, S)$ - $\mathrm{RuH}$ (cymene) $\left(\mathrm{NH}_{2} \mathrm{CHPhCHPhNTs}\right)$ that is known to efficiently transfer the hydride from ruthenium and proton from the nitrogen of the primary amino group to give arylsubstituted alcohols in $>95 \%$ ee $(S)$ (see the bifunctional catalysis section below). ${ }^{338}$ Although it is tempting to propose an ionic AH mechanism as shown in Figure 36, the authors propose that methanol is more basic than the ketone under the conditions of catalysis. A DFT study of the mechanism suggests that the triflate is actually the base that deprotonates the dihydrogen under these conditions and that this $\mathrm{H}_{2}$ heterolytic splitting is the slow step in the catalytic cycle. ${ }^{339}$ Another study ${ }^{232}$ finds that $\left[\mathrm{Ru}\left(\mathrm{H}_{2}\right)(\text { cymene)(Tsdpen) }]^{+}\right.$has a $\mathrm{p} K_{\mathrm{a}}{ }^{\mathrm{MeCN}}$ of 16.1 (Table 8, entry 144). This suggests that the deprotonation of the dihydrogen complex by methanol, triflate or ketone in the cycle has a significant barrier.

The catalyst $\left[\mathrm{Ir}^{\mathrm{III}} \mathrm{Cp} *\left(\mathrm{H}_{2} \mathrm{O}\right)_{3}\right]^{2+}$ is thought to operate by a proton-first mechanism (Figure 35 ) in the hydrogenation at 1-7 atm of the $\mathrm{C}=\mathrm{O}$ bond of $n$-butyraldehyde and 2-butanone in water at an optimum $\mathrm{pH}$ of $3 .^{340}$ The complex is proposed to form the dihydrogen complex $\left[\operatorname{Ir}^{\prime \prime \prime}\left(\mathrm{H}_{2}\right) \mathrm{Cp}^{*}\left(\mathrm{OH}_{2}\right)_{2}\right]^{2+}$ (estimated $\left.\mathrm{p} K_{\mathrm{a}}{ }^{\mathrm{LAC}}-5\right)$ that heterolytically splits dihydrogen to form a carbonium ion and the monohydride $\left[\mathrm{Ir}^{\prime \prime \prime}(\mathrm{H}) \mathrm{Cp} *\left(\mathrm{OH}_{2}\right)_{2}\right]^{+}$which react to give the alcohol product according to Figure 35 . Interestingly $\mathrm{C}=\mathrm{C}$ bonds of allyl alcohol and 2-methyl-2-propen-1-ol are reduced by the same system at an even lower $\mathrm{pH}$, consistent with a carbonium ion mechanism.

Darensbourg and coworkers reported in $1986^{341}$ that complexes PPN $\left[(\mathrm{CO})_{5} \mathrm{M}(\mathrm{u}-\mathrm{H}) \mathrm{M}(\mathrm{CO})_{5}\right], \mathrm{M}=$ $\mathrm{Cr}, \mathrm{Mo}$, or $\mathrm{W}, \mathrm{PPN}=\left[\mathrm{Ph}_{3} \mathrm{PNPPh}_{3}\right]^{+}$catalyze the hydrogenation at $43 \mathrm{~atm}$ of cyclohexanone $\left(\mathrm{p} K_{\mathrm{a}}{ }^{\mathrm{LAC}}-5\right)$ and benzaldehyde in THF at $125^{\circ} \mathrm{C}$ with TON 4-18 after $24 \mathrm{~h}$. They proposed a hydride-first mechanism (Figure 39) where the hydride $\left[\mathrm{MH}(\mathrm{CO})_{5}\right]^{-}$attacks the carbonyl of the ketone to generate an alkoxide and $\mathrm{M}(\mathrm{CO})_{5}$ which then reacts with dihydrogen to produce $\mathrm{MH}_{2}(\mathrm{CO})_{5}\left(\mathrm{p} K_{\mathrm{a}}^{\mathrm{LAC}} 10-12\right.$, entry 27 Table 5) which is deprotonated by the alkoxide. The $\mathrm{p} K_{\mathrm{a}}{ }^{\mathrm{LAC}}$ of alkoxides range from 25 to 40 , depending on the substituents and the nature of the countercation. 


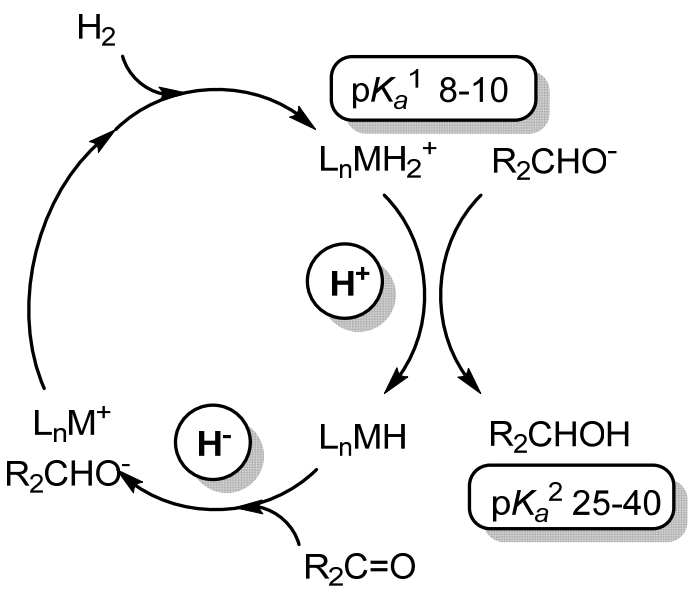

Figure 39. Hydride-first catalytic ionic hydrogenation of ketones

\subsubsection{Hydrogenolysis of alcohols}

There is much interest in using biomass-derived chemicals such as sugars as replacements for petroleum-derived chemicals for polymer and fine chemical synthesis. ${ }^{162,342}$ Model alcohols such as diols are used in catalyst development to simplify the chemistry so that principles can be uncovered. 1,2-propanediol is hydrogenolyzed predominantly to 1-propanol and water in the presence of catalysts of the type $\left[\mathrm{Ru}\left(\mathrm{H}_{2}\right)\left(\mathrm{Cp}^{\prime}\right)(\mathrm{CO})_{2}\right]^{+}$where $\mathrm{Cp}^{\prime}$ is $\mathrm{Cp}^{* 342}$ or $\mathrm{Cp}^{\prime} \mathrm{Pr}_{4}{ }^{162}$ The reaction is conducted in sulfolane solvent with added HOTf under $50 \mathrm{~atm} \mathrm{H}_{2}$ at $110^{\circ} \mathrm{C}$. These dihydrogen complexes are very acidic and the Cp* complex (Table 8, entry $5, \mathrm{pK}_{\mathrm{a}}{ }^{\mathrm{LAC}}-5$ ) was found to have the optimum activity. ${ }^{162}$ The reaction is thought to proceed through the dehydration of the diol to 1-propionaldehyde which then undergoes a proton-first hydrogenation as discussed in section 8.1.1. The dihydrogen complex $\left[\mathrm{Ru}\left(\mathrm{H}_{2}\right)\left(\mathrm{C}_{5} \mathrm{H}^{\mathrm{i} P \mathrm{Pr}_{4}}\right)(\mathrm{CO})_{2}\right] \mathrm{OTf}$ was characterized at $-80{ }^{\circ} \mathrm{C}$ in $\mathrm{CD}_{2} \mathrm{Cl}_{2}$. It was found to be in equilibrium with the monohydride and HOTf.

The aqua complexes $\left[\mathrm{Ru}(\text { arene })\left(\mathrm{OH}_{2}\right)(\text { diamine })\right]^{2+}$ form very acidic dihydrogen complexes under a pressure of hydrogen gas and also catalyze the hydrogenolysis of 1,2-diols. ${ }^{343}$ For example 1,2hexanediol is converted to mainly (60\%) to $n$-hexanol in the presence of [RuH(cymene)(bpy)] ${ }^{+}$and HOTf in sulfolane at $50 \mathrm{~atm} \mathrm{H}_{2}$ and $90{ }^{\circ} \mathrm{C}$ with a TON of approx. 60 and TOF of $3 \mathrm{~h}^{-1}$. The $\mathrm{p} K_{\mathrm{a}}^{\text {aq }}$ of $\left[\mathrm{Ru}\left(\mathrm{H}_{2}\right)(\mathrm{cymene})(\mathrm{bpy})\right]^{2+}$ was estimated to between -7 and $-2 .{ }^{343}$

\subsubsection{Water and aldehyde shift to hydrogen and carboxylic acid}

Just as carbon monoxide can act as a two electron reductant of water in the water gas shift reaction, an aldehyde can serve as a two electron reductant of water to produce hydrogen and a carboxylic acid. The complexes $\left[\mathrm{IrH}\left(\mathrm{Cp} \mathrm{p}^{*}\right)(\mathrm{bpy})\right]^{+}$and $[\mathrm{RuH}(\mathrm{cymene})(\mathrm{bpy})]^{+}$catalyze the conversion of aldehydes in water predominantly to the carboxylic acid. ${ }^{81}$ The conditions are $0.4 \mathrm{~mol} \%$ catalyst, $110{ }^{\circ} \mathrm{C}$, $24 \mathrm{~h}$. For acetaldehyde and IIII' the TON was 250 and the TOF was $5 \mathrm{~h}^{-1}$ to acetic acid and mainly ethanol. Under the same conditions the Rull catalyst was less active (TON 18, TOF $1 \mathrm{~h}^{-1}$ ) but the products in this case were acetic acid and dihydrogen. Thus the latter is a catalyst for the "water-aldehyde shift" reaction. The mechanism for dihydrogen formation is thought to be the protonation of the hydride catalyst by $\mathrm{H}_{3} \mathrm{O}^{+}$to give an unstable dihydrogen complex. For ruthenium this protonated complex is the same dihydrogen complex $\left[\mathrm{Ru}\left(\mathrm{H}_{2}\right)(\mathrm{cymene})(\mathrm{bpy})\right]^{2+}$ with $\mathrm{p} K_{\mathrm{a}}{ }^{\text {aq }}$ approx. -5 as discussed in section 8.1.2.

\subsubsection{Carboxylic acid and ester hydrogenation}

Only a few homogeneous catalysts are known to be active for the hydrogenation of neat carboxylic acids. Dicationic complexes of the type $\left[\operatorname{IrCp} *\left(\right.\right.$ bpy- $\left.\left.\mathrm{R}_{2}\right)\left(\mathrm{OH}_{2}\right)\right](\mathrm{OTf})_{2}$, where bpy- $\mathrm{R}$ is a 2,2'bipyridine with electron releasing groups $\mathrm{R}$, especially OMe (Figure 40 ), are particular active for the 
hydrogenation (at $27 \mathrm{~atm}, 120^{\circ} \mathrm{C}$ ) of glacial acetic acid to a mixture of ethanol, ethylacetate and diethyl ether. ${ }^{344}$ Propionic and butyric acid were reduced in a $\mathrm{H}_{2} \mathrm{O} / \mathrm{HBF}_{4}$ solvent under similar conditions. $\mathrm{A}$ proton-first hydrogenation mechanism similar to the ketone and aldehyde mechanism shown in Figure 41 was proposed. In this case the aqua complex coordinates dihydrogen to give the very acidic dihydrogen complex $\left[\operatorname{Ir}\left(\mathrm{H}_{2}\right) \mathrm{Cp}^{*}\left(\mathrm{bpy}-\mathrm{R}_{2}\right)\right]^{2+}\left(\mathrm{p} K_{\mathrm{a}}^{\mathrm{LAC}}-2\right)$. This complex is proposed to transfer a proton to the carboxyl group to generate a carbonium ion $\left(\mathrm{pK}_{\mathrm{a}}{ }^{\mathrm{aq}}\left(\mathrm{CH}_{3} \mathrm{C}(\mathrm{OH})_{2}{ }^{+}\right)-6.1\right)^{345}$ that is reduced to the hemiacetal (Figure 41).

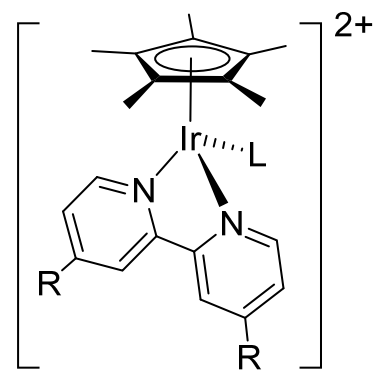

Figure 40. Precatalysts for the hydrogenation of carboxylic acids $\left(L=\mathrm{OH}_{2}, \mathrm{R}=\mathrm{OMe}\right)$

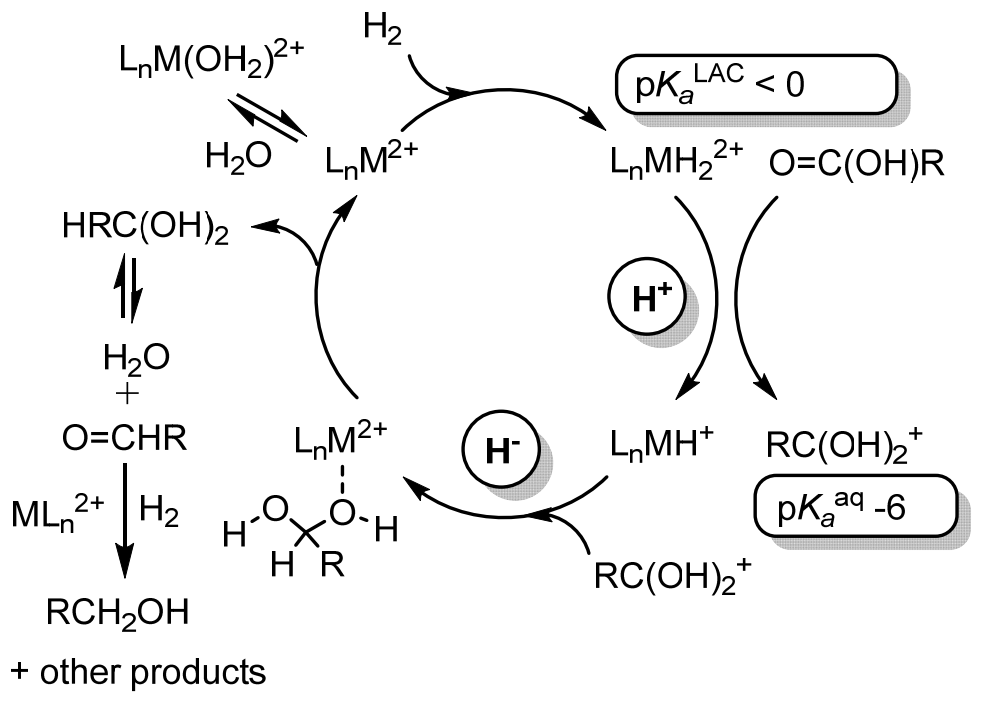

Figure 41. Proton-first mechanism for the catalytic hydrogenation of carboxylic acids

The hydride $\left[\mathrm{RuH}\left(\mathrm{P}^{n} \mathrm{Bu}_{3}\right)_{3}(\text { solvent })_{2}\right]^{+}$was detected in the catalyst solution during the production of butyrolactone from the catalytic hydrogenation of succinic anhydride. ${ }^{346}$ The catalytic activity and selectivity was greatly improved by the addition of $\mathrm{p}-\mathrm{TsOH}$. Again a proton first mechanism may be operative where an acidic dihydrogen complex is responsible for the heterolytic splitting reaction.

\subsubsection{Imine and heterocycle hydrogenation}

The proton-first ionic hydrogenation mechanism is commonly proposed for the hydrogenation of imines catalyzed by acidic dihydrogen or dihydride catalysts. For this mechanism to proceed, the $\mathrm{p} K_{\mathrm{a}}$ of the complex must be close to the $\mathrm{p} K_{\mathrm{a}}$ of the protonated imine substrate (i.e. the iminium). The iminium $\mathrm{p} K_{\mathrm{a}}$ range is not well established but likely lies between $\mathrm{p} K_{\mathrm{a}}{ }^{\mathrm{LAC}} 5$ and 10 for hydrogen, aryl and alkyl substituents on the $\mathrm{C}=\mathrm{N}$ bond; $\mathrm{p} K_{\mathrm{a}}{ }^{\mathrm{aq}}$ values from $5-12$ have been reported. ${ }^{347}$ The $\mathrm{p} K_{\mathrm{a}}$ of pyridines have been studied extensively and can be used as a guide for the solvent dependence of these values; for pyridine: $\mathrm{p} K_{\mathrm{a}}{ }^{\mathrm{aq}} 5.3 ;^{15} \mathrm{p} K_{\mathrm{a}}{ }^{\mathrm{DMSO}} 3.4 ;^{12} \mathrm{p} K_{\mathrm{a}}{ }^{\mathrm{MeCN}} 12.5 ;^{16} \mathrm{p} K_{\mathrm{a}}{ }^{\mathrm{THF}}=\mathrm{p} K_{\mathrm{a}}{ }^{\mathrm{LAC}}=6-8$ depending on counteranion 
(Table 1). ${ }^{17}$ The complex $\left[\operatorname{Re}(\mathrm{CO})_{3}\left(\mathrm{PMe}_{3}\right)_{2}(\mathrm{ClPh})\right] \mathrm{BAr}_{4}, \mathrm{Ar}=3,5-\left(\mathrm{CF}_{3}\right)_{2} \mathrm{C}_{6} \mathrm{H}_{3}$ reacts with dihydrogen in chlorobenzene $(\mathrm{PhCl})$ to produce the acidic dihydrogen complex $\left[\operatorname{Re}\left(\mathrm{H}_{2}\right)(\mathrm{CO})_{3}\left(\mathrm{PMe}_{3}\right)_{2}\right] \mathrm{BAr}_{4},\left(\mathrm{p} K_{\mathrm{a}}{ }^{\mathrm{LAC}} 0\right)^{139}$ It catalyzes the hydrogenation the aldimine $\mathrm{PhHC}=\mathrm{NCH}_{2} \mathrm{Ph}$ to the amine (Table 13, entry 1). A protonfirst mechanism (Figure 42) was proposed for the catalytic cycle that is consistent with our LAC evaluation of the relative $\mathrm{p} K_{\mathrm{a}}$ values with $\mathrm{p} K_{\mathrm{a}}\left(\mathrm{ReH}_{2}\right)<\mathrm{p} K_{\mathrm{a}}$ (imininum). Thus the much less acidic monocarbonyl complex $\left[\operatorname{Re}\left(\mathrm{H}_{2}\right)(\mathrm{CO})\left(\mathrm{PMe}_{3}\right)_{4}\right] \mathrm{BAr}{ }_{4},\left(\mathrm{p} K_{\mathrm{a}}^{\mathrm{LAC}} 18\right)$ is a very poor catalyst for this process. The dicarbonyl complex $\left[\operatorname{Re}\left(\mathrm{H}_{2}\right)(\mathrm{CO})_{2}\left(\mathrm{PMe}_{3}\right)_{3}\right] \mathrm{BAr}_{4},\left(\mathrm{p} K_{\mathrm{a}}^{\mathrm{LAC}} 9\right)$ is a catalyst for the hydrogenation of the more electron rich imine $\mathrm{Me}_{2} \mathrm{C}=\mathrm{N}^{\mathrm{P} r}$; the iminium ion in this case likely has a $\mathrm{p} K_{\mathrm{a}}$ close to 9 . To our knowledge these are the first homogeneous imine hydrogenation catalysts based on rhenium (Figure 42). ${ }^{332}$ Protonfirst mechanism for the hydrogenation of imines (NR is NAr or $\mathrm{NCH}=\mathrm{CHR}$ )

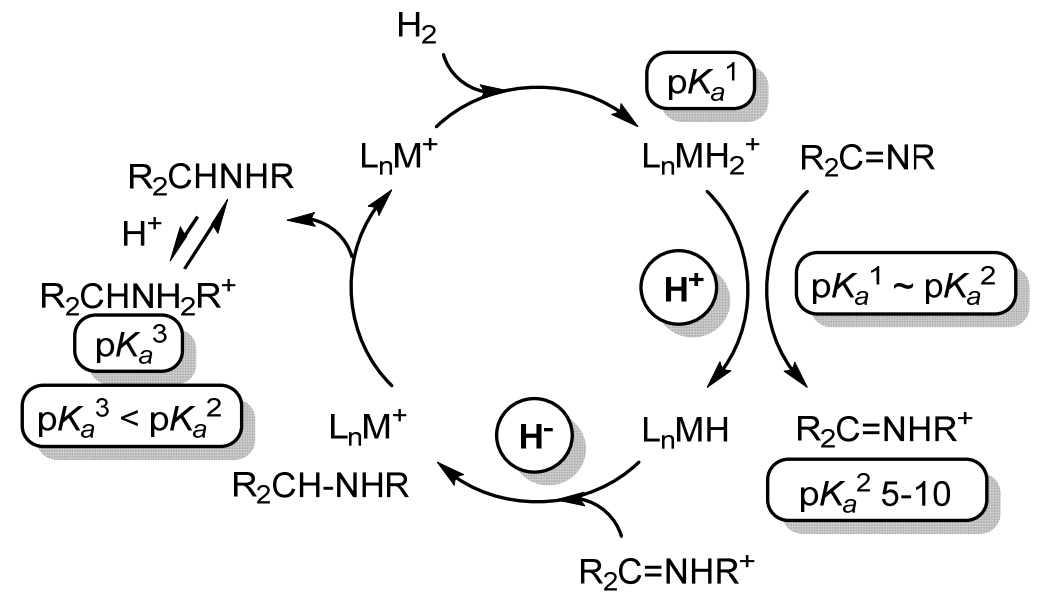

Figure 42. Proton-first mechanism for the ionic hydrogenation of imines.

As mentioned above the complexes $\left[\mathrm{MH}_{2}(\mathrm{NO})(\mathrm{CO})\left(\mathrm{P}^{\mathrm{i} P{ }_{2}} \mathrm{CH}_{2} \mathrm{CH}_{2} \mathrm{PPhCH}_{2} \mathrm{CH}_{2} \mathrm{P}^{\mathrm{i} P r}\right)_{2}\right]^{+}(\mathrm{M}=\mathrm{Mo}$, entry 25 and $\mathrm{M}=\mathrm{W}$, entry 28 of Table 5 ) with $\mathrm{p} K_{\mathrm{a}}^{\mathrm{THF}}<10$ are effective catalysts for the ionic hydrogenation of imines. ${ }^{119}$ The most efficient system $\left(\mathrm{M}=\mathrm{Mo}\right.$ with added $\left.\left[\mathrm{H}\left(\mathrm{OEt}_{2}\right)_{2}\right] \mathrm{BAr}_{4}\right)$ catalytically hydrogenated at 60 bar $\mathrm{H}_{2}$ and $140{ }^{\circ} \mathrm{C}$ the aldimine $4-\mathrm{MeOC}_{6} \mathrm{H}_{4} \mathrm{CH}=\mathrm{NPh}$ with initial TOF $1960 \mathrm{~h}^{-1}$, a significant improvement on the catalysts discussed so far. The outersphere proton before hydride transfer mechanism was proposed on the basis of several observations. The rate increases with increasing pressure and there is a kinetic isotope effect $k_{H} / k_{D} 1.34$ suggesting that dihydrogen coordination is the turnover limiting step and that proton transfer to the imine substrate is fast. The proposal for the fast step is supported by a Hammett study involving changing substituents on the arenes of the imine. For the hydrogenation of benzylidene aniline, an electron-donating group on the benzylidene side increased the overall rates significantly while the para substituent influence on the aniline side was found to be practically negligible. This suggests a non-rate-limiting proton transfer to the $\mathrm{N}$ atom of the imine. The substituent on the nitrogen should be an aryl group so that the imine substrate is more basic than the amine product. ${ }^{119}$ The $\mathrm{p} K_{\mathrm{a}}{ }^{\mathrm{THF}}\left(\mathrm{NH}_{2} \mathrm{PhR}^{+}\right)$is approx. $8^{17}$ so the $\mathrm{p} K_{\mathrm{a}}{ }^{\mathrm{THF}}\left(\mathrm{PhCH}=\mathrm{NHPh}{ }^{+}\right)$must be greater than this. It is interesting that there is no catalysis when there is an alkyl substituent on the nitrogen (e.g. $\mathrm{PhCH}_{2} \mathrm{CH}=\mathrm{NiBu}$ ). In this case the amine that is produced in the first time around the cycle is more basic than the imine and thus the amine product instead of the imine accepts the proton from the acidic hydride complex and this prevents catalysis. 
Table 13. Imine hydrogenation catalysts

\begin{tabular}{|c|c|c|c|c|c|c|c|}
\hline & Catalyst & $\begin{array}{l}\mathrm{p} K \\
\mathrm{a} \\
\mathrm{LAC}\end{array}$ & Reactant & Product & $\begin{array}{l}\text { Cond- } \\
\text { itions }\end{array}$ & $\begin{array}{l}\text { TON/ } \\
\text { TOF }\end{array}$ & $\begin{array}{l}\text { Ref } \\
\text {. }\end{array}$ \\
\hline 1 & {$\left[\operatorname{Re}\left(\mathrm{H}_{2}\right)(\mathrm{CO})_{3}\left(\mathrm{PMe}_{3}\right)_{2}\right] \mathrm{BAr}_{4}$} & 0 & $\mathrm{PhHC}=\mathrm{NCH}_{2} \mathrm{Ph}$ & $\begin{array}{l}\mathrm{PhCH}_{2-}^{-} \\
\mathrm{NHCH}_{2} \mathrm{Ph}\end{array}$ & $\begin{array}{l}100 \\
\text { atm } \\
\mathrm{H}_{2}, 90 \\
{ }^{\circ} \mathrm{C}, \\
\mathrm{PhCl}\end{array}$ & $\begin{array}{l}120 / 5.5 \\
\mathrm{~h}^{-1}\end{array}$ & 139 \\
\hline 2 & {$\left[\operatorname{Re}\left(\mathrm{H}_{2}\right)(\mathrm{CO})_{2}\left(\mathrm{PMe}_{3}\right)_{3}\right] \mathrm{BAr}_{4}$} & 9 & $\mathrm{Me}_{2} \mathrm{C}=\mathrm{NiPr}$ & $\begin{array}{l}\mathrm{Me}_{2} \mathrm{HC}- \\
\mathrm{NH}^{\mathrm{i}} \mathrm{Pr}\end{array}$ & $\begin{array}{l}55 \\
\text { atm } \\
\mathrm{H}_{2}, 90 \\
{ }^{\circ} \mathrm{C} \text {, } \\
\mathrm{THF} / \mathrm{t} \\
\text { ol }\end{array}$ & $40 / 2 h^{-1}$ & 139 \\
\hline 3 & {$\left[\operatorname{Re}\left(\mathrm{H}_{2}\right)(\mathrm{CO})\left(\mathrm{PMe}_{3}\right)_{4}\right] \mathrm{BAr}_{4}$} & 18 & $\mathrm{PhHC}=\mathrm{NCH}_{2} \mathrm{Ph}$ & $\begin{array}{l}\mathrm{PhCH}_{2-}^{-} \\
\mathrm{NHCH}_{2} \mathrm{Ph}\end{array}$ & $\begin{array}{l}2 \mathrm{~atm}, \\
, 90 \\
{ }^{\circ} \mathrm{C} \\
\mathrm{PhCl}\end{array}$ & $\begin{array}{l}10 / 0.5 \\
h^{-1}\end{array}$ & 139 \\
\hline 4 & 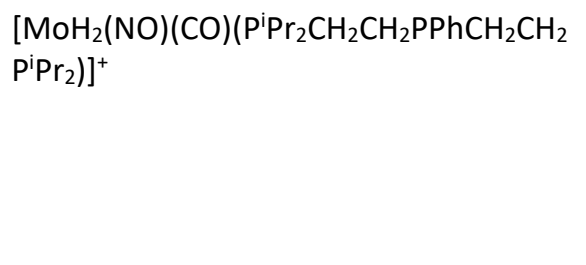 & $<8$ & $\begin{array}{l}\text { 4- } \\
\mathrm{MeOC}{ }_{6} \mathrm{H}_{4} \mathrm{CH}=\mathrm{N} \\
\mathrm{Ph}\end{array}$ & $\begin{array}{l}\text { 4- } \\
\mathrm{MeOC}_{6} \mathrm{H}_{4} \mathrm{C} \\
\mathrm{H}_{2}-\mathrm{NHPh}\end{array}$ & $\begin{array}{l}60 \\
\text { atm } \\
\mathrm{H}_{2}, \\
140 \\
{ }^{\circ} \mathrm{C}, \\
\mathrm{THF}\end{array}$ & $\begin{array}{l}500 / 19 \\
60 \mathrm{~h}^{-1}\end{array}$ & 119 \\
\hline 5 & 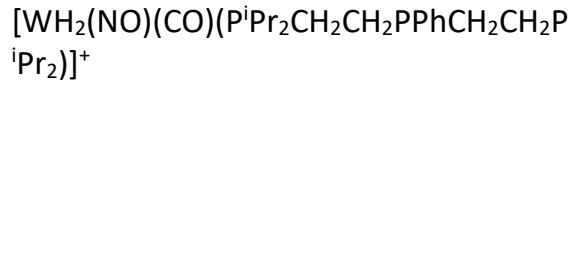 & $\begin{array}{l}<1 \\
0\end{array}$ & $\begin{array}{l}\text { 4- } \\
\mathrm{MeOC}{ }_{6} \mathrm{H}_{4} \mathrm{CH}=\mathrm{N} \\
\mathrm{Ph}\end{array}$ & $\begin{array}{l}4- \\
\mathrm{MeOC}_{6} \mathrm{H}_{4} \mathrm{C} \\
\mathrm{H}_{2}-\mathrm{NHPh}\end{array}$ & $\begin{array}{l}60 \\
\text { atm } \\
\mathrm{H}_{2} \\
140 \\
{ }^{\circ} \mathrm{C}, \\
\mathrm{THF}\end{array}$ & $\begin{array}{l}500 / 74 \\
0 h^{-1}\end{array}$ & 119 \\
\hline 6 & {$\left[\mathrm{Ru}\left(\mathrm{H}_{2}\right)(\text { cymene })(\text { Tsdpen })\right]^{+}$} & 11 & & & $\begin{array}{l}20 \\
\text { atm } \\
\mathrm{H}_{2}, 15 \\
{ }^{\circ} \mathrm{C}, \\
\mathrm{MeOH}\end{array}$ & $\begin{array}{l}500 / 83 \\
h^{-1}\end{array}$ & 348 \\
\hline 7 & {$\left[\mathrm{Ru}\left(\mathrm{H}_{2}\right)(\text { cymene })\left(\mathrm{MeSO}_{2} \mathrm{dpen}\right)\right]^{+}$} & 11 & & $\Pi$ & $\begin{array}{l}50 \\
\text { atm } \\
\mathrm{H}_{2}, 0 \\
{ }^{\circ} \mathrm{C} \text {, } \\
\text { EtOH }\end{array}$ & $92 / 4 h^{-1}$ & 348 \\
\hline 8 & {$\left[\operatorname{Ir}\left(\mathrm{H}_{2}\right) \mathrm{H}_{2}\left(\mathrm{PPh}_{3}\right)_{2}(\mathrm{NHC})\right]^{+}$} & 13 & & & $\begin{array}{l}1 \mathrm{~atm}, \\
, 35 \\
{ }^{\circ} \mathrm{C} \text {, } \\
\text { toluen } \\
\mathrm{e}\end{array}$ & $\begin{array}{l}100 />6 \\
h^{-1}\end{array}$ & 282 \\
\hline 9 & $\mathrm{RhH}_{2}\left(\mathrm{Tp}^{*}\right)\left(\mathrm{S}_{2} \mathrm{C}_{6} \mathrm{H}_{4}\right)$ & & $\mathrm{PhHC}=\mathrm{NCH}_{2} \mathrm{Ph}$ & $\begin{array}{l}\mathrm{PhCH}_{2-}^{-} \\
\mathrm{NHCH}_{2} \mathrm{Ph}\end{array}$ & $\begin{array}{l}1 \mathrm{~atm}, \\
50^{\circ} \mathrm{C}, \\
\mathrm{EtOH}\end{array}$ & & $\begin{array}{l}349 \\
- \\
350\end{array}$ \\
\hline
\end{tabular}


$1 \quad\left[\operatorname{Ir}\left(\eta^{4}-\mathrm{COD}\right)(\right.$ Josiphos$\left.)\right] \mathrm{Cl}, \mathrm{NBu}_{4} \mathrm{I}$,

$0 \quad \mathrm{MeSO}_{3} \mathrm{H}$
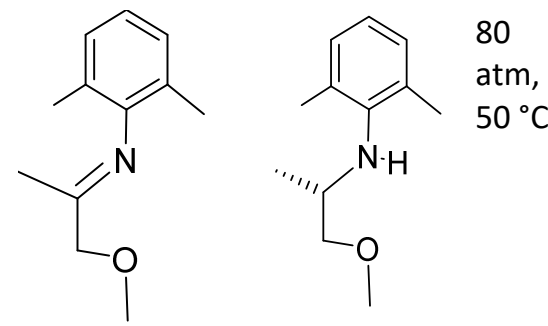

$10^{6}$

351

atm, $\quad>10^{5} \mathrm{~h}^{-1}$

${ }^{\circ} \mathrm{C}$

The dihydrogen complex $\left[\mathrm{Ru}\left(\mathrm{H}_{2}\right) \text { (cymene)(Tsdpen) }\right]^{+}$has a $\mathrm{p} K_{\mathrm{a}}{ }^{\mathrm{MeCN}}$ of 16.1, $\mathrm{p} K_{\mathrm{a}}{ }^{\mathrm{LAC}} 9$ (Table 8, entry 144). ${ }^{232}$ It has been found to catalyze the asymmetric hydrogenation of 2-alkyl substituted quinolines to high ee (96\%) under relatively mild conditions (Table 13, entry 6). ${ }^{348}$ The mechanism proposed was a proton first ionic reduction of the heterocyclic ring. Several less basic 2-aryl-quinolines were also asymmetrically hydrogenated to the amine with ee $>90 \%$ using the similar derivative $\left[\mathrm{Ru}\left(\mathrm{H}_{2}\right) \text { (cymene)(MeSO}{ }_{2} \text { dpen) }\right]^{+}$(Table 13, entry 7). ${ }^{348}$ During an investigation of the mechanism by studying stoichiometric reactions, the authors found that the hydride complex RuH(cymene)(Tsdpen) transfers its hydride to a quinoline only when the latter is protonated with HOTf.

The largest industrial asymmetric hydrogenation process is the production of the herbicide $(S)$ Metolachlor from a prochiral MEA ketimine substrate. ${ }^{351}$ The catalytic mixture is composed of the prochiral imine substrate (Figure 43), $\left[\mathrm{Ir}\left(\eta^{4}\right.\right.$-cyclooctadiene)(Josiphos) $] \mathrm{Cl}, \mathrm{NBu}_{4}, \mathrm{MeSO}_{3} \mathrm{H}$ heated to $50^{\circ} \mathrm{C}$ under $80 \mathrm{~atm} \mathrm{H}_{2}$.

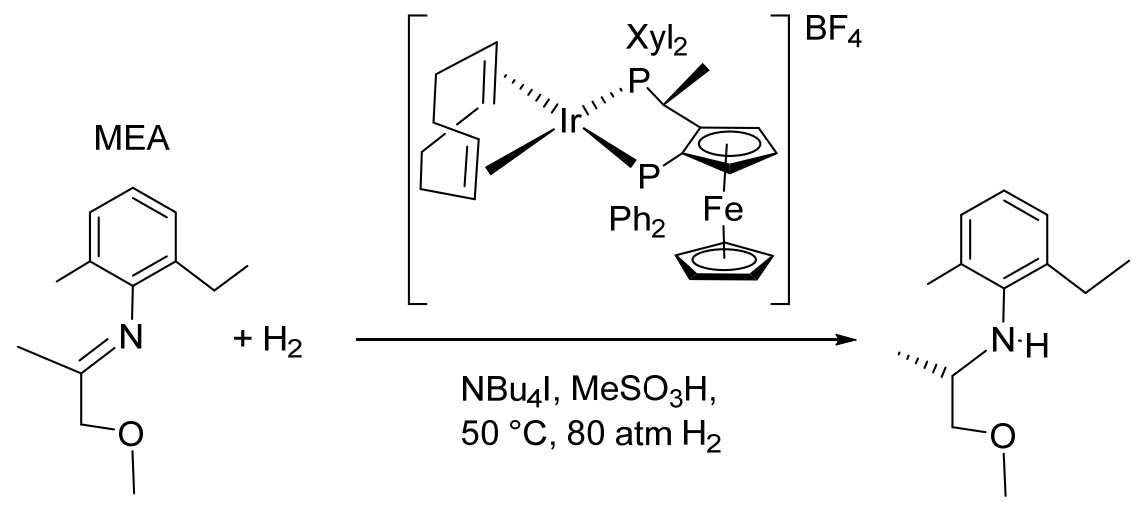

Figure 43. Iridium(I) catalyst precursor and the Metolachlor asymmetric imine hydrogenation process.

The MEA prochiral ketimine substrate has a bulky aryl group at nitrogen fulfilling the condition that the protonated imine is more basic than the amine (as just mentioned). While it has been proposed that the imine is coordinated to iridium when it is attacked by a hydride, ${ }^{258}$ it is also possible that there is a proton-first mechanism involving an acidic, cationic iridium(III) dihydrogen complex that transfers a proton to the bulky imine in the outer coordination sphere followed by hydride attack on the iminium by a neutral iridium(III) hydride in a similar fashion to that shown in Figure 42. It is interesting that an acidic medium is essential for high activity, consistent with this mechanism.

The hydrogenation of quinolines is catalyzed by an $\operatorname{Ir}(\mathrm{III})$ dihydrogen complex generated by the reaction of $\left[\mathrm{Ir}^{\prime}(\mathrm{COD})(\mathrm{NHC})\left(\mathrm{PPh}_{3}\right)\right] \mathrm{PF}_{6}$ with $1 \mathrm{~atm} \mathrm{H}_{2}$ and one equiv. of $\mathrm{PPh}_{3}$ in THF. ${ }^{282}$ The rate is slower for quinolines that are not hindered by substitution next to the nitrogen. It is proposed, based on these observations and on DFT calculations of the mechanism that quinolines are hydrogenated in a protonfirst mechanism (Figure 42). Thus the dihydrogen complex $\left[\operatorname{Ir}\left(\mathrm{H}_{2}\right) \mathrm{H}_{2}\left(\mathrm{PPh}_{3}\right)_{2}(\mathrm{NHC})\right]^{+}\left(\mathrm{p} K_{\mathrm{a}}{ }^{\mathrm{LAC}} 13\right.$; deprotonated by DBU $\mathrm{pK}_{\mathrm{a}}^{\mathrm{THF}} 20^{17}$; entry 51 of Table 9 ) is proposed to first protonate the quinoline in the 
outer coordination sphere at nitrogen ( $\mathrm{p} K_{\mathrm{a}}^{\mathrm{LAC}}$ approx. 8) in an endergonic process and then transfer a hydride to the 4-position from the resulting neutral trihydride $\mathrm{IrH}_{3}\left(\mathrm{PPh}_{3}\right)_{2}(\mathrm{NHC})$ in the turn-over limiting step (Figure 44). This 1,4-dihydroquinoline is isomerized to the 3,4-dihydroquinoline and the resulting imine is reduced by the same route to the tetrahydroquinoline.

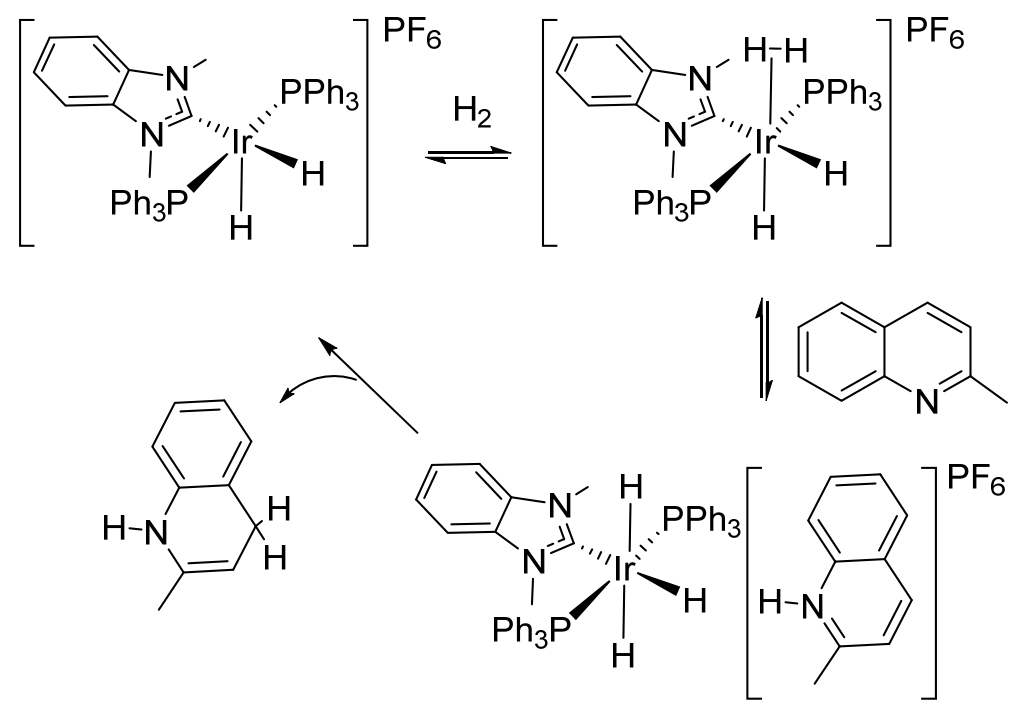

Figure 44. Proton-first reduction of a quinoline.

The complex $\mathrm{Rh}\left(\mathrm{Tp}^{*}\right)\left(\mathrm{S}_{2} \mathrm{C}_{6} \mathrm{H}_{4}\right)(\mathrm{MeCN})$ catalyzes the hydrogenation of a variety of aldimines with aryl, benzyl and allyl groups at nitrogen under very mild conditions (100:1= imine:Rh; THF, $\mathrm{H}_{2} 1 \mathrm{~atm}, 20$ $\left.{ }^{\circ} \mathrm{C}\right) .{ }^{349-350}$ The complex reacts with triethylamine $\left(\mathrm{p} K_{\mathrm{a}}{ }^{\mathrm{THF}} 13\right)$ under $1 \mathrm{~atm} \mathrm{H}_{2}$ to produce the anionic hydride $\left[\mathrm{NHEt}_{3}\right]\left[\mathrm{RhH}\left(\mathrm{Tp}^{*}\right)\left(\mathrm{S}_{2} \mathrm{C}_{6} \mathrm{H}_{4}\right)\right]$ (Figure 45$)$. On the basis of this heterolytic splitting of dihydrogen the authors proposed a proton first mechanism for this hydrogenation where the $\mathrm{NHEt}_{3}{ }^{+}$protonates the imine substrate.

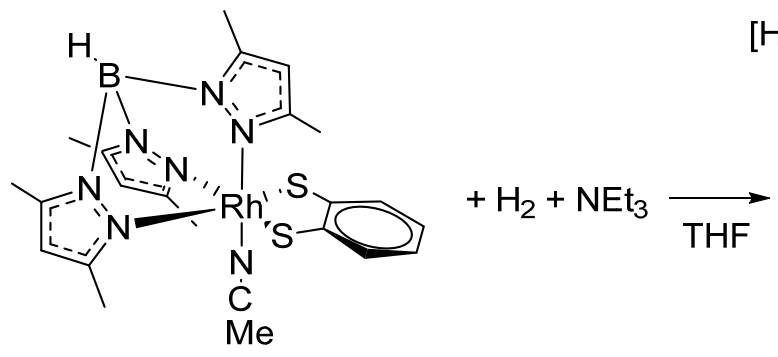

Figure 45. The heterolytic splitting of dihydrogen at $\mathrm{Rh}\left(T p^{*}\right)\left(\mathrm{S}_{2} \mathrm{C}_{6} \mathrm{H}_{4}\right)(\mathrm{MeCN})$.

The asymmetric hydrogenation of $\mathrm{N}$-aryl ketimines catalyzed by $\mathrm{Pd}(\mathrm{II})$ phosphine complexes under acidic conditions was reported by Zhou et al. ${ }^{352}$ This might also proceed by the proton-first mechanism.

\subsubsection{Iminium and enamine hydrogenation}

The availability of prochiral iminium cations opens the opportunity for an outer-sphere asymmetric hydrogenation reaction to produce valuable monochiral products. Magee and Norton reported the first asymmetric hydrogenation (at $4 \mathrm{~atm}, 25^{\circ} \mathrm{C}$ ) of prochiral iminium cations catalyzed by RuHCp*L systems, $\mathrm{L}=(S, S)-\mathrm{PPh}_{2} \mathrm{CHMeCHMePPh}_{2}$ (Chiraphos) or $(R, R)$-Norphos in DCM (Figure 46)..$^{353}$ 


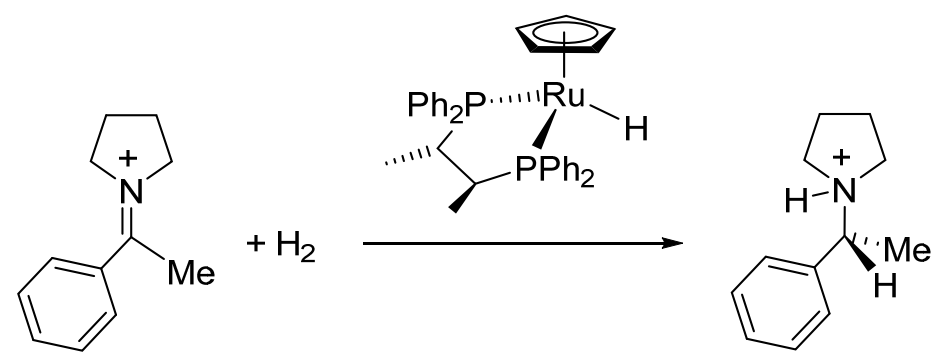

Figure 46. The hydrogenation of an iminium compound catalyzed by RuCp(H)(chiraphos).

Their proposed mechanism is an excellent example of the hydride-first mechanism shown in Figure 47. In this mechanism the neutral hydride attacks the iminium ion in the outer sphere in the turnover limiting step to produce the enantioenriched amine (e.e. up to 60\%) and the cation [RuCp* $\left.{ }^{*}\right]^{+}$which reacts with $\mathrm{H}_{2}$ to make the dihydrogen complex $\left[\mathrm{Ru}\left(\mathrm{H}_{2}\right) \mathrm{Cp}^{*} \mathrm{~L}\right]^{+}$. These dihydrogen complexes ( $\mathrm{p} K_{\mathrm{a}}^{\mathrm{THF}} 11$; e.g. dppe analogue of entry 109 , Table 8 ) were known to be deprotonated by amines to regenerate the monohydride RuHCp*L and the ammonium salt $\left(p K_{\mathrm{a}}{ }^{\mathrm{THF}} 13\right) \cdot{ }^{7}$ The dihydrogen complexes can also rearrange to dihydrides depending on the nature of $L$ which are usually less acidic. ${ }^{90}$

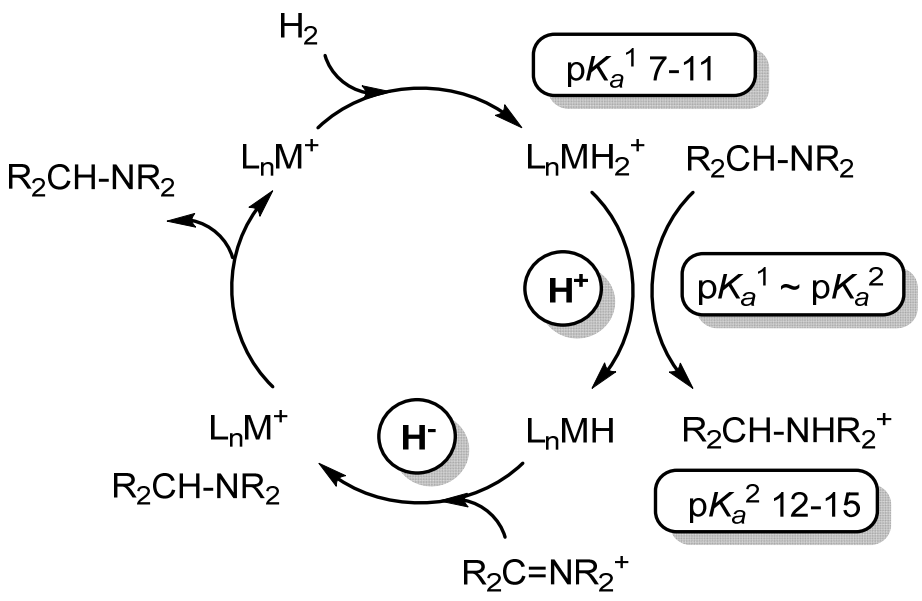

Figure 47. Hydride-first mechanism for the ionic hydrogenation of iminium compounds.

The Rh(III) hydride complex RhH(Cp*) $\left(\mathrm{py}-\mathrm{C}_{6} \mathrm{H}_{4}\right)\left(\mathrm{py}-\mathrm{C}_{6} \mathrm{H}_{4}=\right.$ cyclometallated 2-phenylpyridine) also hydrogenates iminium ions such as 1-(1-phenylethylidene)pyrrolidinium in $\mathrm{MeOH}$ very efficiently by a hydride first mechanism ( $4 \mathrm{~atm}, 22^{\circ} \mathrm{C}$, TON 100-200, TOF $\left.25-50 \mathrm{~h}^{-1}\right){ }^{2}$ The amine that is produced is basic enough to deprotonate the dihydrogen complex $\left[\mathrm{RhH}_{2}\left(\mathrm{Cp}^{*}\right)\left(\mathrm{py}-\mathrm{C}_{6} \mathrm{H}_{4}\right)\right]^{+}$that is produced in the catalytic cycle. This suggests that the $\mathrm{p} K_{\mathrm{a}}{ }^{\mathrm{LAC}}$ of this $\mathrm{Rh}(\mathrm{III})$ dihydrogen complex is less than 12 . The $\mathrm{p} K_{\mathrm{a}}{ }^{\mathrm{MeCN}}$ of the monohydride $\mathrm{RhH}\left(\mathrm{Cp}^{*}\right)\left(\mathrm{py}-\mathrm{C}_{6} \mathrm{H}_{4}\right)$ was determined to be 30.3 (Table 9, entry 71). From this the $A_{L}$ for the (2-(2-pyridyl)phenyl) ligand can be estimated to be -8. Thus the $\mathrm{p} K_{\mathrm{a}}{ }^{\mathrm{LAC}}$ of the dihydrogen complex is estimated to be -5 , easily deprotonated by the product amine or methanol.

Hydride complexes RuHCpL and RuHCp*L with more basic diphosphines $L$ such as dmpe (entries entries 121,130 , Table 8 ) deprotonate iminium salts with $p K_{\mathrm{a}}{ }^{\mathrm{LAC}}$ approx. 11 to give enamines. ${ }^{169}$ The iminium derived from pyrrolidine and acetophenone is deprotonated to the enamine but then decomposes before it is hydrogenated. However other basic enamines that are more stable do undergo ionic hydrogenations catalyzed by the acidic dihydrogen complex $\left.\left[\mathrm{Ru}\left(\mathrm{H}_{2}\right) \mathrm{Cp}(\mathrm{dppm})\right] \mathrm{BF}_{4} / \mathrm{RuHCp} \mathrm{dppm}\right)$ $\left(\mathrm{p} K_{\mathrm{a}}^{\text {THF }} 7\right.$; entry 85 of Table 8 ) in DCM, this time by a proton-first mechanism (Figure 48$) .{ }^{169}$ In this mechanism the dihydrogen complex quickly transfers a proton to the enamine converting it to an 
iminium ion which is then attacked by $\mathrm{RuHCp}(\mathrm{dppm})$ to give the amine product. This amine must be less basic than the enamine so that the cycle continues to turn over; this is usually the case for enamines. ${ }^{169}$

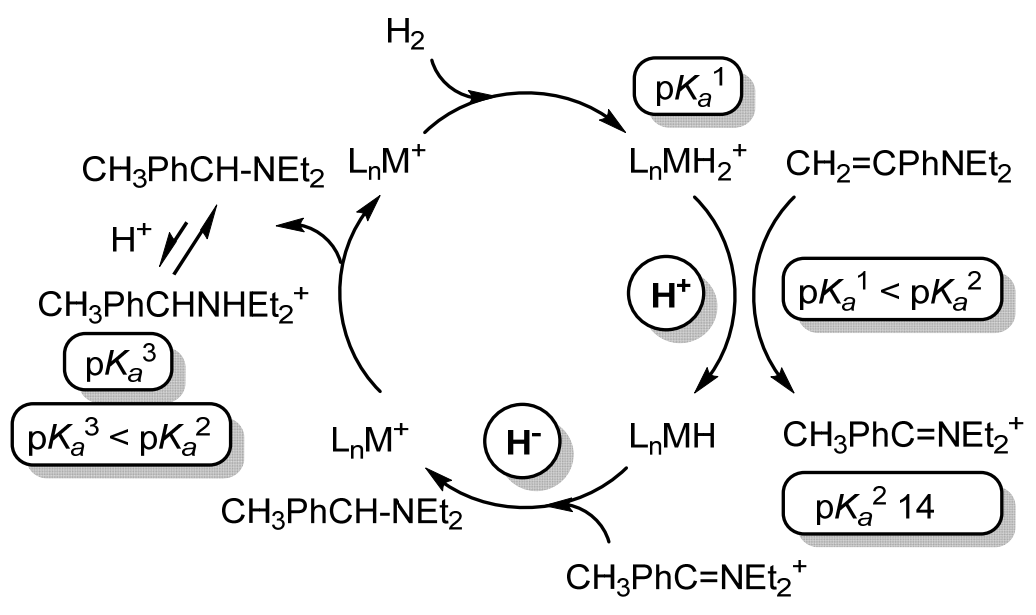

Figure 48. Proton-first mechanism for enamine hydrogenation.

The complex $\mathrm{RuH}\left(\mathrm{Cp} \mathrm{p}^{*}\right)$ (dppf) catalyzes the hydride first hydrogenation of the acyl pyridinium cation at the 4-position as shown in Figure $49\left(6 \mathrm{~atm}, 10^{\circ} \mathrm{C}\right.$, TON 43, TOF $\left.2 \mathrm{~h}^{-1}\right) \cdot{ }^{354}$ Here the N-acyl amine product of the hydride addition is not basic enough to deprotonate the dihydrogen complex $\left[\mathrm{Ru}\left(\mathrm{H}_{2}\right)(\mathrm{Cp} *)(\mathrm{dppf})\right]^{+}$of the catalytic cycle $\left(\mathrm{p} K_{\mathrm{a}}{ }^{\mathrm{LAC}} 10\right)$. Thus tetramethylpiperidine (protonated form $\mathrm{p} K_{\mathrm{a}}{ }^{\mathrm{aq}}$ $11, \mathrm{p} K_{\mathrm{a}}{ }^{\mathrm{LAC}}$ approx. 14) is added to deprotonate the dihydrogen complex. The rate of deprotonation must be greater than an irreversible isomerization of the dihydrogen complex to a trans-dihydride complex that is not sufficiently acidic to be deprotonated.

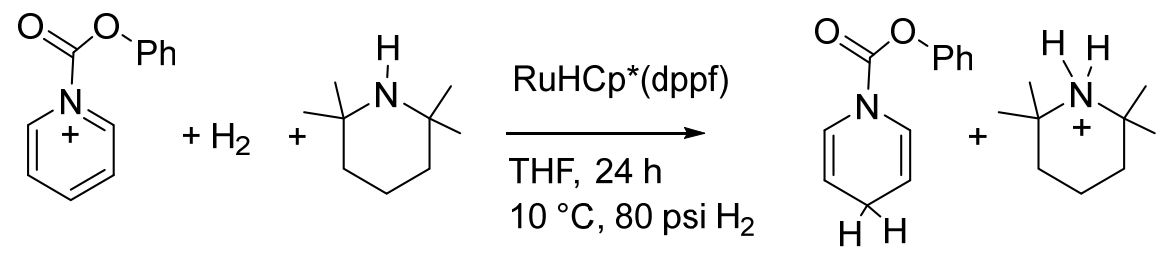

Figure 49. The hydrogenation of an acylpyridinium catalyzed by $R u H\left(C p^{*}\right)(d p p f)$ and tetramethylpiperidine.

\subsubsection{Reductive amination}

Reductive amination reactions involve a two step process where an amine and aldehyde or ketone condense to form an imine which is then reduced. An aldehyde is more easily reduced than a neutral imine while it is less easily reduced than a protonated iminium. Therefore reductive aminations are conducted under acidic conditions and may proceed by an outersphere ionic hydrogenation as discussed above. The complex $\left[\operatorname{IrCp} *(\mathrm{bpy})\left(\mathrm{OH}_{2}\right)\right]^{2+}$ is a reductive amination catalyst in water with ammonium formate as the reductant with a max. TOF at $\mathrm{pH} 5$ (Figure 50). ${ }^{355}$ The iminium reduced in this case is protonated $\alpha$-imino acids produced by the condensation of ammonia with $\alpha$-ketocarboxylic acids. The hydride complex $[\operatorname{Ir}(\mathrm{H}) \mathrm{Cp} *(\mathrm{bpy})]^{+}$transfers a hydride to the iminium to give an amino acid. At $\mathrm{pH} 5$ the hydride would not be protonated since the corresponding dication $\left[\operatorname{Ir}\left(\mathrm{H}_{2}\right) \mathrm{Cp} *(\mathrm{bpy})\right]^{2+}$ is predicted to have a $\mathrm{p} K_{\mathrm{a}}{ }^{\mathrm{LAC}}-2, \mathrm{p} K_{\mathrm{a}}{ }^{\text {aq }}<0$. It is reported that protonation does take place at $\mathrm{pH} 2$ with the irreversible formation the aqua complex $\left[\operatorname{Ir}\left(\mathrm{H}_{2} \mathrm{O}\right) \mathrm{Cp}^{*}(\mathrm{bpy})\right]^{2+}$. The same system catalyzes the reductive amination of butyraldehyde and ammonia to give butylamine. ${ }^{356}$ 


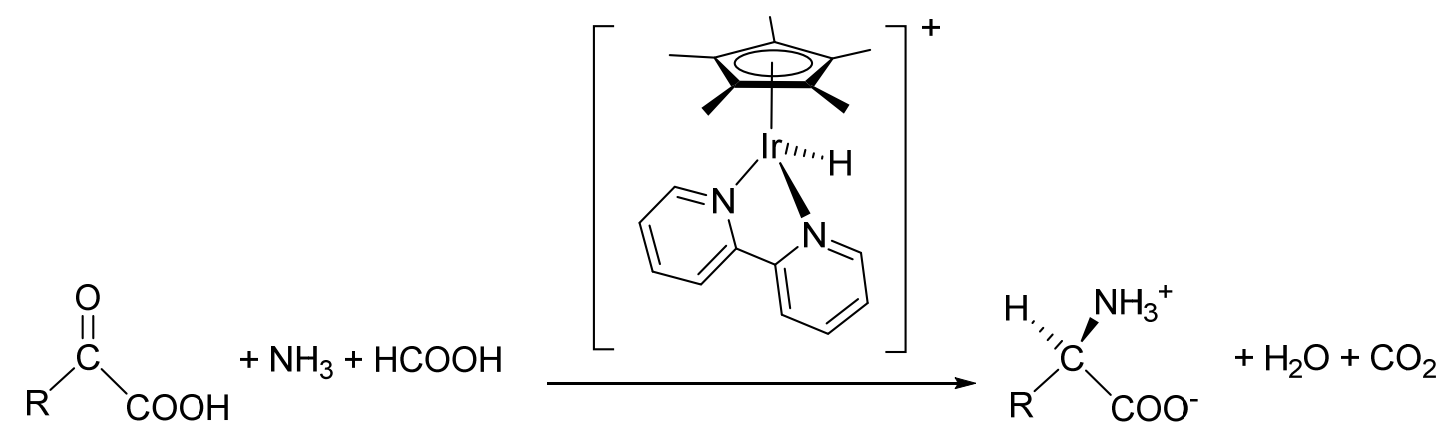

Figure 50. Reductive amination of alpha-ketoesters to alpha-amino acids catalyzed by $\operatorname{IrH}(\mathrm{Cp} *)(b p y)$

Beller and coworkers have reported the iron-catalyzed asymmetric reductive amination of ketones like acetophenone with amines such as $p$-methoxyaniline. ${ }^{357}$ Knolker's iron complex $\mathrm{FeH}(\mathrm{CO})_{2}\left(\mathrm{Cp}^{\prime}-\mathrm{OH}\right)(5 \mathrm{~mol} \%)$ is used with the chiral Bronsted acid 3,3'-bisaryl 1,1'- binaphthyl-2,2'-diyl hydrogen phosphates ( $2 \mathrm{~mol} \%$ ) in toluene at $51 \mathrm{~atm} \mathrm{H}_{2}$ and $65 \mathrm{C}$ (Figure 51 ). After a hydride transfers from the iron to an intermediate iminium ion, dihydrogen is heterolytically split at the iron to the phosphate or the amine product (a hydride first mechanism). A possible dihydrogen complex intermediate $\left[\mathrm{Fe}\left(\mathrm{H}_{2}\right)(\mathrm{CO})_{2}\left(\mathrm{Cp}^{\prime}-\mathrm{OH}\right)\right]^{+}$would be very acidic $\left(\mathrm{p} K_{\mathrm{a}}^{\mathrm{LAC}}-5\right)$.

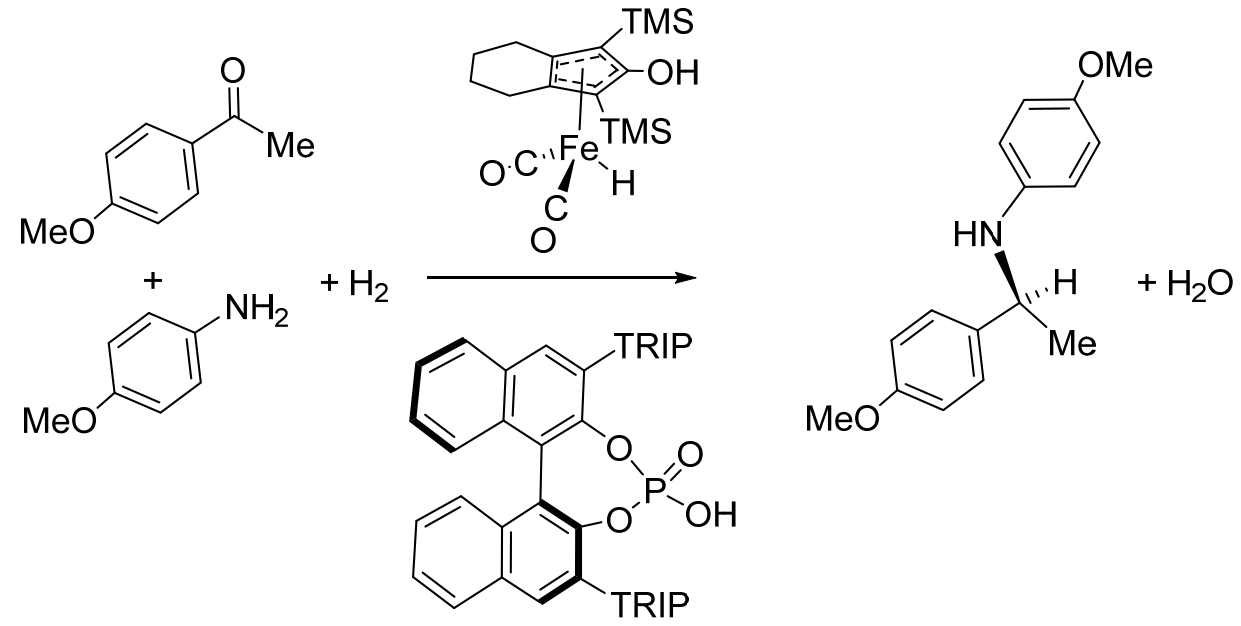

Figure 51. The reductive amination of a ketone catalyzed by Knolker's iron complex and a chiral phosphoric acid (TRIP = 2,4,6-triisopropylphenyl)

\subsubsection{Alkene and alkyne hydrogenation}

The complex $\left[\mathrm{Pd}(\mathrm{H})(\mathrm{dppe})_{2}\right](\mathrm{X}), \mathrm{X}=\mathrm{OTf}, \mathrm{BF}_{4}, \mathrm{SbF}_{6},($ Table 11, entry 26) is both hydridic and acidic and is unstable with respect to loss of $\mathrm{H}_{2}$ in MeCN. ${ }^{321,358}$ For example it transfers a hydride to the iminium $\mathrm{PhCH}_{2} \mathrm{CH}=\mathrm{NMe}_{2}{ }^{+}\left(\mathrm{pK}_{\mathrm{a}}{ }^{\text {aq }} 6\right)$ to produce the amine. ${ }^{321}$ Two equiv. of the palladium hydride in THF reduces the olefin of methyl methacrylate $\mathrm{CH}_{2}=\mathrm{CHCOOMe}$ to give $\mathrm{CH}_{3} \mathrm{CH}_{2} \mathrm{COOMe}$, one equivalent of $\left[\mathrm{Pd}^{\prime \prime}(\mathrm{dppe})_{2}\right]^{2+}$ and one equivalent of $\mathrm{Pd}(\mathrm{dppe})_{2}$. A hydride-first reduction mechanism is postulated. ${ }^{358}$ The hydride $\left[\mathrm{Pd}(\mathrm{H})(\mathrm{dppe})_{2}\right]$ OTf is a catalyst for the hydrogenation of cyclohexenone to cyclohexanone in THF at $67{ }^{\circ} \mathrm{C}, 40 \mathrm{~atm}$, with a TON of 200 and TOF of $95 \mathrm{~h}^{-1} .{ }^{358}$ The TOF increased with $\mathrm{H}_{2}$ pressure, implying that the heterolytic splitting of dihydrogen is the turn-over limiting step. The $p K_{\mathrm{a}}{ }^{\mathrm{LAC}}$ of $\left[\mathrm{Pd}\left(\mathrm{H}_{2}\right)(\mathrm{dppe})_{2}\right]^{2+}$ is predicted to be -3 , sufficiently acidic to protonate the ketone in a proton-first reduction mechanism (Figure 52). The authors proposed an alternative mechanism. ${ }^{358}$ 


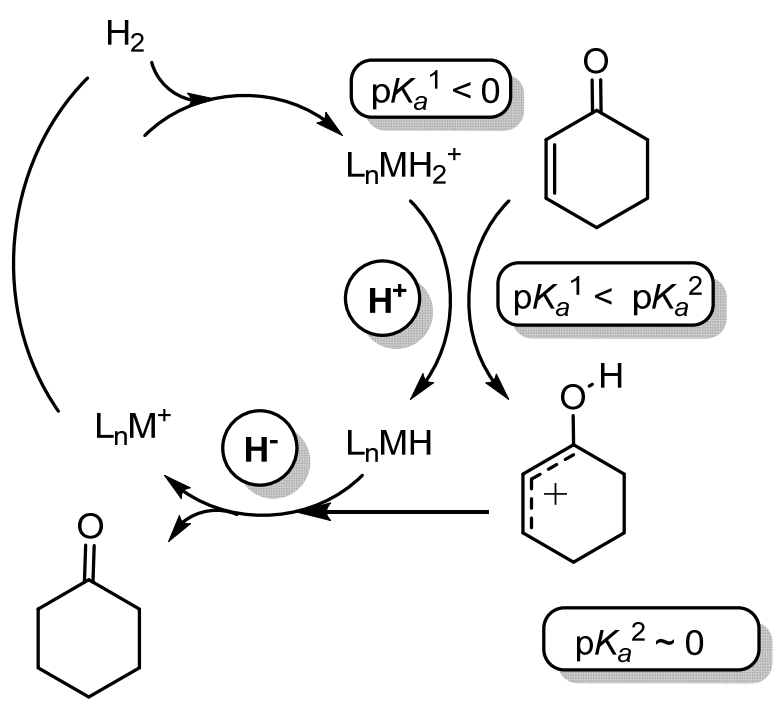

Figure 52. Proton-first reduction of an eneone complex.

Cationic gold(I) phosphine complexes catalyze the asymmetric hydrogenation of olefins related to itaconic acid in ethanol $\left(4 \mathrm{~atm} \mathrm{H}, 20^{\circ} \mathrm{C}\right.$, TON 1000, TOF approx. $6000 \mathrm{~h}^{-1}$ ) and the imine $\mathrm{PhCH}_{2} \mathrm{~N}=\mathrm{CMePh}\left(4 \mathrm{~atm} \mathrm{H}_{2}, 45^{\circ} \mathrm{C}\right.$, TON 700, TOF approx. $\left.30 \mathrm{~h}^{-1}\right) .{ }^{359}$ The ee of the alkane and amine products were up to $95 \%$ and $75 \%$, respectively when $(R, R)$-MeDuphos was used. On the basis of DFT calculations, an ionic proton-first hydrogenation mechanism for the olefin is proposed as in Figure $52 .{ }^{360}$ The heterolytic splitting of dihydrogen at $\left[\mathrm{Au}\left(\mathrm{H}_{2}\right)\left(\mathrm{PR}_{2} \mathrm{Ar}\right)\right]^{+}\left(\mathrm{p} K_{\mathrm{a}}{ }^{\mathrm{LAC}} 6\right)$ produces the hydride $\mathrm{AuH}\left(\mathrm{PR}_{2} \mathrm{Ar}\right)$ and protonated ethanol $\left(p K_{a}{ }^{\mathrm{EtOH}}=0\right)$. The $\mathrm{p} K_{\mathrm{a}}{ }^{\mathrm{LAC}}$ of this dihydrogen complex is predicted to be 6 and as expected, this heterolytic splitting step is calculated to have the highest energetic barrier in the catalytic cycle. The hydride then attacks to produce the alkane and the cation $\left[\mathrm{Au}(\mathrm{EtOH})\left(\mathrm{PR} \mathrm{Ar}_{2}\right)\right]^{+}$. The hydrogenolysis of silyl enol ethers in dichloroethane catalyzed by the acidic dihydrogen complex $\left[\mathrm{Ru}\left(\mathrm{H}_{2}\right) \mathrm{Cl}(\mathrm{dppe})_{2}\right]^{+}\left(\mathrm{p} K_{\mathrm{a}}{ }^{\mathrm{DCM}} 6\right.$, Table 8 entry 70 ) may proceed by a related proton-first mechanism. ${ }^{361} \mathrm{~A}$ variety of ruthenium dihydrogen complexes with different $\mathrm{p} K_{\mathrm{a}}$ were tested but a $\mathrm{p} K_{\mathrm{a}}$ of 6-7 was found to be optimum.

\subsection{Ionic transfer hydrogenation}

Sacrificial reductants such as alcohols and formic acid can often serve as alternatives to hydrogen gas in the transfer hydrogenation of ketones and imines. The complex $\left[\mathrm{Ru}^{\prime \prime}\left(\mathrm{C}_{6} \mathrm{Me} \mathrm{e}_{6}\right)(\mathrm{bpy})\left(\mathrm{OH}_{2}\right)\right]^{2+}$ is a water-soluble catalyst for the hydrogenation of ketones by transfer of hydrogen from aqueous formic acid a $\mathrm{pH} 3 .^{362}$ Formate is proposed to transfer a hydride to ruthenium to produce the active hydride $\left[\mathrm{Ru}^{\prime \prime} \mathrm{H}\left(\mathrm{C}_{6} \mathrm{Me}_{6}\right)(\mathrm{bpy})\right]^{+}$. The hydride is proposed to attack the ketone with simultaneous addition of a proton from $\mathrm{H}_{3} \mathrm{O}^{+}$, i.e. $\mathrm{RuH} \cdot \mathrm{R}_{2} \mathrm{CO} \cdots \mathrm{H}^{+}$to give the product alcohol. It is reasonable that this hydride can exist in $\mathrm{pH} 3$ water without being protonated to give a dihydrogen/dihydride species $\left[\mathrm{RuH}_{2}\left(\mathrm{C}_{6} \mathrm{Me}_{6}\right)(\mathrm{bpy})\right]^{2+}$; the latter has a $\mathrm{p} K_{\mathrm{a}}{ }^{\text {aq }}<6$ (Table 8, entry 81$)$ and would be expected to have a $\mathrm{p} K_{\mathrm{a}}{ }^{\text {aq }}$ of approx. -5 (see above) (see section 8.1.2). The complex $\left[\mathrm{IrH}\left(\mathrm{Cp}^{*}\right)(\mathrm{bpy})\right]^{+}$also catalyzes this transfer hydrogenation reaction. The catalyst is deactivated when the $\mathrm{pH}$ is less than 1 , consistent with the removal of the reactive hydride by protonation to produce the complex $\left[\operatorname{Ir}\left(\mathrm{H}_{2}\right)\left(\mathrm{Cp}^{*}\right)(\mathrm{bpy})\right]^{2+}$; its $\mathrm{p} K_{\mathrm{a}}{ }^{\mathrm{LAC}}$ is $2 .{ }^{363}$

An iridium(III) complex with a cyclometallated imine ligand (Figure 53) catalyzes the efficient hydrogenation of nitrogen heterocycles in aqueous buffer solutions $(\mathrm{pH} \mathrm{4.5)}$ of formic acid and sodium formate. ${ }^{364}$ Substituted quinolines were reduced at $30^{\circ} \mathrm{C}$, TON $>930$, TOF $>66 \mathrm{~h}^{-1}$. The mechanism 
proposed is very similar to the proton-first mechanism for imine hydrogenation (section 8.1.5, Figure 42) where the heterocycle is protonated and then, in a slow step, hydride is transferred from iridium to the iminium. The iridium hydride is regenerated in this case, not from dihydrogen, but from the formate. The monohydride does not appear to be protonated to $\left[\operatorname{Ir}\left(\mathrm{H}_{2}\right) \mathrm{Cp} *(\mathrm{C}-\mathrm{N})\right]^{+}$under the conditions of $\mathrm{pH} 4.5$ water.

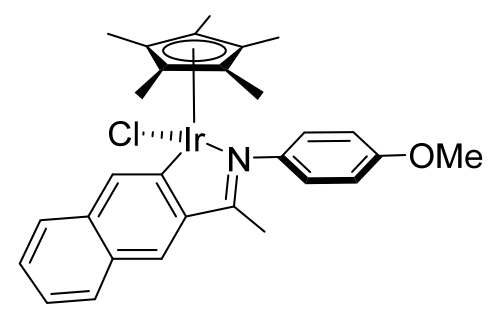

Figure 53. Cyclometallated imine on iridium for the catalytic reduction of nitrogen heterocycles.

\subsection{Hydrogen/deuterium exchange}

The reaction of metal hydride complexes with $\mathrm{D}_{2} \mathrm{O}$ can sometimes lead to $\mathrm{H} / \mathrm{D}$ exchange to form metal deuterides or vice versa. ${ }^{5,72,74,78,365}$ The water soluble complexes $\mathrm{Rh}$ (TPPTS) ${ }_{3} \mathrm{Cl}$ and $\mathrm{Rh}(\mathrm{TPPMS})_{3} \mathrm{Cl}$ (where TPPTS = tris(3-sulfonatophenyl)phosphine, trisodium salt and TPPMS = 3-

sulfonatophenyldiphenylphosphine, sodium salt) catalyze the exchange of deuterium from $D_{2}$ into water. ${ }^{75,366}$ The mechanism is thought to involve the acidic dihydrogen complexes $\left[\operatorname{Rh}^{111}\left(\mathrm{H}_{2}\right) \mathrm{HCl}\left(\mathrm{PAr}_{3}\right)_{3}\right]^{\mathrm{n}}$ (e.g. $\mathrm{n}$ is -8 for the TPPTS ligand complex or +1 if the negative charges on the sulfonated aryl groups are neglected). The rate of single exchange where one $D_{2}$ is converted into one HD and one HOD goes through a maximum at $\mathrm{pH} 8$ for the less donating TPPTS ligand with 3 electron withdrawing sulfonate groups and at $\mathrm{pH} 9$ for the more donating TPPMS ligand suggesting that these are the approximate $\mathrm{p} K_{\mathrm{a}}{ }^{\text {aq }}$ of these dihydrogen complexes. The overall negative charge of the complex reduces the acidity by about 5-6 $\mathrm{p} K_{\mathrm{a}}$ units from the value of approx. 3 for $\mathrm{p} K_{\mathrm{a}}{ }^{\mathrm{LAC}}$ predicted if a charge at the metal of $\mathrm{n}=+1$ is used. Figure 54 shows the proposed mechanism for the single exchange reaction. The oxidative addition of $D_{2}$ to $\mathrm{Rh}^{\prime} \mathrm{Cl}_{3}$ results in $\mathrm{Rh}^{\prime \prime \prime}(\mathrm{D})_{2} \mathrm{ClL}_{3}$ which is then protonated by hydronium to produce $\left[\mathrm{Rh}^{\prime \prime \prime}(\mathrm{HD}) \mathrm{DClL}_{3}\right]^{+}$. Loss of $\mathrm{DOH}_{2}{ }^{+}$produces $\mathrm{Rh}^{\mathrm{III}}(\mathrm{H})(\mathrm{D})$ which reductively eliminates $\mathrm{HD}$ to restart the cycle.

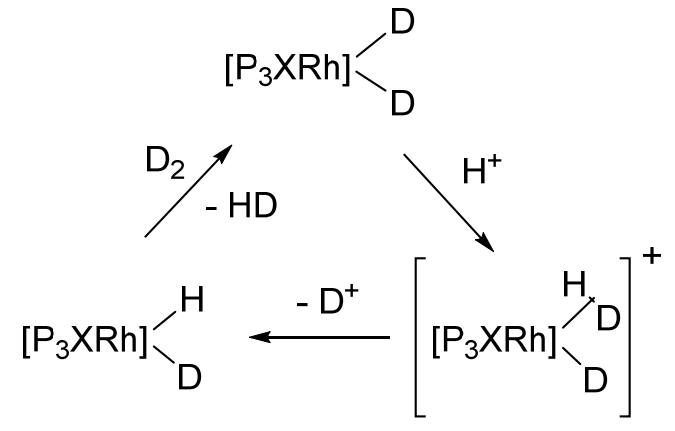

Figure 54. Proposed mechanism for the $\mathrm{D}_{2} / \mathrm{H}_{2} \mathrm{O}$ exchange catalyzed by $\mathrm{Rh}(\mathrm{TPPMS})_{3} \mathrm{Cl}$.

The complex $\left[\operatorname{Ir}\left(\mathrm{H}_{2} \mathrm{O}\right)\left(\mathrm{Cp}^{*}\right)\left(4,4^{\prime} \text {-dihydroxybpy }\right)\right]^{2+}$ in $\mathrm{D}_{2} \mathrm{O}$ catalyzes the deuteration of olefins such as itaconic acid using $\mathrm{H}_{2}$ gas or $\mathrm{HCOOH}^{79}$ For the case of $\mathrm{H}_{2}$, the acidic dihydrogen complex $\left[\operatorname{Ir}\left(\mathrm{H}_{2}\right)(\mathrm{Cp} *)\left(\mathrm{bpy}(\mathrm{OH})_{2}\right)\right]^{2+}\left(\mathrm{p} K_{\mathrm{a}}{ }^{\mathrm{LAC}}-2\right)$ will rapidly protonate $\mathrm{D}_{2} \mathrm{O}$ and exchange isotopes. The deuteride formed then reduces the olefin, possibly by a proton-first mechanism as discussed in section 8.1.8. Cationic iridium and ruthenium dihydrogen complexes are known to catalyze $\mathrm{H} / \mathrm{D}$ exchange between alcohols and deuterium gas in $\mathrm{CD}_{2} \mathrm{Cl}_{2} \cdot{ }^{367}$ 


\subsection{Olefin hydrogenation vs isomerization}

Rhodium(III) dihydrides tend to be olefin hydrogenation catalysts while Rh(I) monohydrides catalyze olefin isomerization. This was demonstrated by Schrock and Osborn where the complex $\left.\left[\mathrm{Rh}(\mathrm{H})_{2}\left(\mathrm{PPh}_{3}\right)_{2} \text { (acetone }\right)_{2}\right]^{+}\left(\mathrm{pK}_{\mathrm{a}}^{\mathrm{THF}}<13\right)$ is an active catalyst for the hydrogenation of 1-hexene to hexane

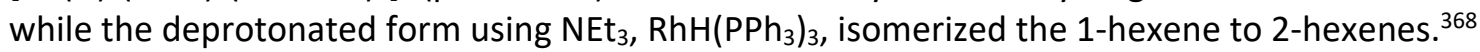

Cationic iridium complexes with enantiopure chelating ligands $(\mathrm{P}-\mathrm{N})$ with dialkylphosphinite and oxazoline donors or ligands (C-N) with NHC-oxazoline donors (Figure 21) are effective catalysts for the challenging asymmetric hydrogenation of trisubstituted and tetrasubstituted olefins in DCM. ${ }^{263,369-372}$ The proposed intermediates include tetrahydrides (or dihydrogen(dihydride) complexes $\left[\mathrm{IrH}_{4}(\mathrm{P}\right.$ $\mathrm{N})$ (olefin) $]^{+}\left(\mathrm{p} K_{\mathrm{a}}^{\mathrm{LAC}} 7\right)$ and $\left[\mathrm{IrH}_{4}(\mathrm{C}-\mathrm{N}) \text { (olefin) }\right]^{+}\left(\mathrm{p} K_{\mathrm{a}}^{\mathrm{LAC}} 9\right)$. The $\mathrm{p} K_{\mathrm{a}}{ }^{\mathrm{MeCN}}$ for these species were calculated by use of DFT to be 10 and 17, respectively, and organic acid-base indicators were used in the catalytic solutions to demonstrate the greater acidity of the $\mathrm{P}-\mathrm{N}$ donor complex. ${ }^{263}$ The acidic $\mathrm{P}-\mathrm{N}$ catalyst was reported to be less selective than the $\mathrm{C}-\mathrm{N}$ catalyst in the hydrogenation of acid sensitive enol ethers. ${ }^{369}$

Cationic palladium hydride complexes having one labile ligand are efficient olefin isomerization catalysts. For example [PdH $\left(\mathrm{PCy} 2 \mathrm{CH}_{2} \mathrm{CH}_{2} \mathrm{PCy}_{2}\right)$ (olefin) $]^{+}$complexes $\left(\mathrm{p} K_{\mathrm{a}}{ }^{\mathrm{LAC}} 8\right)$ are effective at isomerizing an alkenyl alcohol to the ketone by a chain-walking mechanism. ${ }^{373}$ One would expect this acidic catalyst to be incompatible with basic substituents on the olefin.

\subsection{Carbon-hydrogen bond functionalization}

The deprotonation of cationic rhodium dihydrides as mentioned in Section 6.4 can also be used to promote carbon-carbon bond forming reactions. ${ }^{374}$ The monohydride $\mathrm{RhH}\left(\mathrm{P}(2-\mathrm{Fur})_{3}\right)_{2}(\mathrm{~L})$ produced by deprotonation of $\left[\mathrm{RhH}_{2}\left(\mathrm{P}(2-\mathrm{Fur})_{3}\right)_{2}(\mathrm{DCM})_{2}\right]^{+}\left(\mathrm{p} K_{\mathrm{a}}{ }^{\mathrm{LAC}}\right.$ approx. 12$)$ by $\mathrm{Li}_{2} \mathrm{CO}_{3}$ in $\mathrm{DCM}$ catalyzes the addition under $1 \mathrm{~atm} \mathrm{H}_{2}$ of aldehydes to activated olefins (eneones) and enolates derived from ketones (aldol reactions). Interestingly, an acidic additive, $\mathrm{Ph}_{3} \mathrm{CCO}_{2} \mathrm{H}$ ( $\mathrm{p} K_{\mathrm{a}}{ }^{\mathrm{LAC}}$ approx. 20) is required instead for the coupling of aldehydes with alkynes catalyzed by rhodium diphosphine complexes in dichloroethane under $1 \mathrm{~atm} \mathrm{H}_{2}$. In this reaction a fast coupling of aldehydes with alkynes at $\mathrm{Rh}^{\prime}$ to give an oxarhodacyclopentene prevents dihydride formation. The role of the acid is to maintain a cation and promote the heterolytic splitting of dihydrogen at $\mathrm{Rh}$ (III) for the removal of the alcohol product.

Iridium diphosphine monohydrides presumably produced by the deprotonation of iridium dihydrides by $\mathrm{Li}_{2} \mathrm{CO}_{3}$ in DCE/EtOAc under $1 \mathrm{~atm} \mathrm{H}_{2}$ catalyze the addition of aldehydes to allenes. ${ }^{375}$ In this case the dihydrogen is proposed to hydrogenolize the iridium alkoxide bond by the heterolytic splitting of $\mathrm{H}_{2}$ to give the alcohol product although these steps are not well defined.

The formal addition of a carbon-hydrogen bond of a primary aldehyde to butadiene is catalyzed by $\mathrm{RuH}_{2}(\mathrm{CO})\left(\mathrm{PPh}_{3}\right)_{3}$ in the presence of dppf and an arylsulfonic acid. ${ }^{376}$ The role of the acid is to protonate off a hydride ligand so that the sulfonate group can coordinate and can influence the stereochemistry of the $\mathrm{C}-\mathrm{C}$ bond forming step while providing a monohydride for olefin insertion. The reaction is performed in THF at $95{ }^{\circ} \mathrm{C}$. The $\mathrm{p} K_{\mathrm{a}}^{\mathrm{LAC}}$ of the protonated intermediate, $\left[\mathrm{Ru}\left(\mathrm{H}_{2}\right) \mathrm{H}(\mathrm{CO})\left(\mathrm{PPh}_{3}\right)_{3}\right]^{+}$ is 5; sulfonic acids ( $\mathrm{p} K_{\mathrm{a}}^{\mathrm{LAC}} 8$, Table 2 ) are sufficiently acidic to cause this protonation. With enantiopure binol- or taddol-derived acids, the coupling reactions can be done enantioselectively.

Evidence for methane activation at cationic $\mathrm{Pt}$ " was provided by the protonation reaction of complex Pt"(diimine)(Me) $)_{2}$ by HOTf in $\mathrm{CF}_{3} \mathrm{CH}_{2} \mathrm{OH}_{.}{ }^{37-378}$ The complex $\left[\mathrm{Pt}^{\mathrm{IV}} \text { (diimine) }(\mathrm{H})(\mathrm{Me})_{2}\right]^{+}\left(\mathrm{p} K_{\mathrm{a}}{ }^{\mathrm{LAC}}\right.$ approx. 8) was observed at low temperature in $\mathrm{CD}_{2} \mathrm{Cl}_{2}$. 


\subsection{Metal-ligand bifunctional catalysis}

This title refers to the situation where the ligand can cooperate with the metal in the catalytic mechanism. This will usually involve the ligand "storing a proton" during catalysis. The proton is often derived from the heterolytic splitting of dihydrogen in hydrogenation reactions. More about bifunctional ligands used in electrocatalysts can be found in section 6.8 .

\subsubsection{Reversible heterolytic splitting of dihydrogen}

There many reports of the heterolytic splitting of dihydrogen to a hydride on the metal and a proton on a nitrogen, ${ }^{141,170,173,259,310,330,333,379-380}$ oxygen, ${ }^{82,381-386}$ sulfur ${ }^{207,350,387}$ or carbon ${ }^{388-390}$ basic site on a ligand in a metal complex. ${ }^{5}$ In order to observe an equilibrium between the two forms the $\mathrm{p} K_{\mathrm{a}}$ of the dihydrogen complex and that of the protonated ligand must be similar.

Equation 18

$M\left(H_{2}\right)(L-B) L_{n} \rightleftarrows M H(L-B H) L_{n} \quad$ (Equation 18)

Table 14 lists some examples where both forms have been detected directly or indirectly. The $\mathrm{p} K_{\mathrm{a}}{ }^{\mathrm{MeCN}}$ for the iron complex of entry 3 has been estimated as $18.3\left(\mathrm{p} K_{\mathrm{a}}{ }^{\mathrm{THF}}\right.$ approx 13 in agreement with the $p K_{a}{ }^{\mathrm{LAC}} 12$ ), extrapolated from PhF solvent. ${ }^{391}$ Here the proton is stored on a nitrogen of the ligand.

Table 14. Reversible heterolytic splitting of dihydrogen

\begin{tabular}{|c|c|c|c|c|}
\hline Entry & $\mathrm{M}\left(\mathrm{H}_{2}\right)(\mathrm{L}-\mathrm{B})^{a}$ & $\mathrm{p} K_{\mathrm{a}}^{\mathrm{LAC}}$ & $1 \mathrm{H}(\mathrm{L}-\mathrm{BH})$ & Ref. \\
\hline 1 & {$\left[\mathrm{Os}\left(\mathrm{H}_{2}\right)(\mathrm{CO})\left(\mathrm{PPh}_{3}\right)_{2} \text { (quinS) }\right]^{+}$} & 7 & {$\left[\mathrm{Os}(\mathrm{H})(\mathrm{CO})\left(\mathrm{PPh}_{3}\right)_{2}(\text { quinSH) }]^{+}\right.$} & 207 \\
\hline 2 & {$\left[\mathrm{Mn}\left(\mathrm{H}_{2}\right)(\mathrm{CO})\left(\mathrm{P}_{2}{ }_{2} \mathrm{~N}^{\mathrm{Bn}}{ }_{2}\right)\left(\mathrm{PAr}_{2} \mathrm{CH}_{2} \mathrm{PAr}_{2}\right)\right]^{+}$} & 10 & {$\left[\mathrm{MnH}(\mathrm{CO})\left(\mathrm{P}_{2}^{\mathrm{Ph}} \mathrm{N}^{\mathrm{Bn}}{ }_{2-}\right.\right.$} & 141 \\
\hline 3 & {$\left[\mathrm{Fe}\left(\mathrm{H}_{2}\right)\left(\mathrm{Cp}-\mathrm{C}_{5} \mathrm{~F}_{4} \mathrm{~N}\right)\left(\mathrm{P}^{\mathrm{tBu}}{ }_{2} \mathrm{~N}^{\mathrm{Bn}}{ }_{2}\right)\right]^{+}$} & 12 & $\begin{array}{l}\left.\mathrm{H}\left(\mathrm{PAr}_{2} \mathrm{CH}_{2} \mathrm{PAr}_{2}\right)\right]^{+} \\
{\left[\mathrm{Fe}(\mathrm{H})\left(\mathrm{Cp}-\mathrm{C}_{5} \mathrm{~F}_{4} \mathrm{~N}\right)\left(\mathrm{P}^{\mathrm{BBu}}{ }_{2} \mathrm{~N}^{\mathrm{Bn}}{ }_{2}-\mathrm{H}\right)\right]^{+}}\end{array}$ & 333 \\
\hline
\end{tabular}

${ }^{a} \mathrm{PPh}_{2} \mathrm{~N}^{\mathrm{Bn}}{ }_{2}=$ cyclo- $\mathrm{PPhCH}{ }_{2} \mathrm{NBnCH}_{2} \mathrm{PPhCH}_{2} \mathrm{NBnCH}_{2^{-}} ; \mathrm{Ar}=3,5-\mathrm{C}_{6} \mathrm{H}_{3}\left(\mathrm{CF}_{3}\right) ; \mathrm{P}^{\mathrm{tBu}}{ }_{2} \mathrm{~N}^{\mathrm{Bn}}{ }_{2}=$ cyclo-

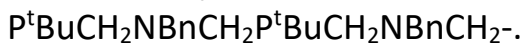

Entry 1 is an example where a thiol-substituted quinoline with $\mathrm{p} K_{\mathrm{a}}$ of approx. 7 when coordinated to osmium is in equilibrium with an osmium(II) dihydrogen complex. Entry 2 is provided by an NMR study of the rapid exchange between protons on a manganese(I) hydride ammonium complex and an indirectly detected manganese(I) dihydrogen complex of higher energy (by about $6 \mathrm{kcal} / \mathrm{mol}$ or 4 $\mathrm{p} K_{\mathrm{a}}$ units). The iron(II) dihydrogen complex of entry 3 is the more stable isomer of this equilibrating system which is active as an electrocatalyst. The basicity of the metal can determine the site of protonation; for a series of phenoxide complexes, protonation at the oxygen occurred for rhodium(I) complexes, but at the metal for more basic iridium(I). ${ }^{392}$

\subsubsection{Hydrogen/deuterium exchange}

If the reversible exchange of protons between a dihydrogen complex and a basic site on a ligand is occurring and the basic site already has a proton or deuteron, $\mathrm{HD}$ exchange can occur. ${ }^{5}$ For example iron dihydrogen complexes like that of entry 3 in Table 14 undergo H/D exchange between $\mathrm{H}_{2}$ and $\mathrm{D}_{2} \mathrm{O}$. ${ }^{171}$ Similarly the amido complex $\mathrm{RuH}\left(\mathrm{PPh}_{3}\right)_{2}\left(\mathrm{NHCMe}_{2} \mathrm{CMe}_{2} \mathrm{NH}_{2}\right)$ reacts with $\mathrm{D}_{2}$ to produce isotopomers of trans- $\mathrm{Ru}\left(\mathrm{H}^{*}\right)_{2}\left(\mathrm{PPh}_{3}\right)_{2}\left(\mathrm{~N}^{*} \mathrm{H}_{2} \mathrm{CMe}_{2} \mathrm{CMe}_{2} \mathrm{NH}_{2}{ }_{2}\right)$ where the asterisk indicates sites of deuteration. ${ }^{380}$ This $\mathrm{H} / \mathrm{D}$ exchange is caused by the reversible heterolytic splitting of $\mathrm{H}_{2} / \mathrm{HD} / \mathrm{D}_{2}$ across the ruthenium amido bond. The same reaction occurs at $\mathrm{RuH}_{2}$ (binap) $\left(\mathrm{NH}_{2} \mathrm{CMe}_{2} \mathrm{CMe}_{2} \mathrm{NH}_{2}\right) .{ }^{393}$

\subsubsection{Olefin hydrogenation and isomerization}

A bulky amine, when tethered to a cationic zirconium(IV) center enables the heterolytic splitting of dihydrogen and catalytic olefin hydrogenation (Figure 55). ${ }^{103}$ It is not know yet whether there is a side-on dihydrogen complex intermediate $\left[\mathrm{Zr}\left(\mathrm{H}_{2}\right)\left(\mathrm{Cp}^{*}\right)_{2}\left(\mathrm{OCH}_{2} \mathrm{CH}_{2} \mathrm{~N}^{i} \mathrm{Pr}_{2}\right)\right]^{+}$or whether there is an end-on 
activation between $\mathrm{Zr}$ and $\mathrm{N}$ in a similar fashion to "frustrated Lewis pair" activation of dihydrogen between $\mathrm{B}$ and $\mathrm{P}$ in $\mathrm{B}\left(\mathrm{C}_{6} \mathrm{~F}_{5}\right)_{3} / \mathrm{PR}_{3}$ systems. ${ }^{20,23}$ For catalysis to proceed in this way, the $\mathrm{p} K_{\mathrm{a}}{ }^{\mathrm{LAC}}$ of the sideon complex must be similar to that of the protonated amine, 14 , implying that the alkoxide has an $A_{\llcorner}$of less than 8 . A less basic alkoxide with an ortho-phenylene linker to a phosphine (Figure 56) enables the splitting of dihydrogen to the less basic dialkylarylphosphine (with a protonated $\left.\mathrm{p} K_{\mathrm{a}}{ }^{\mathrm{LAC}} 8\right)$ ).

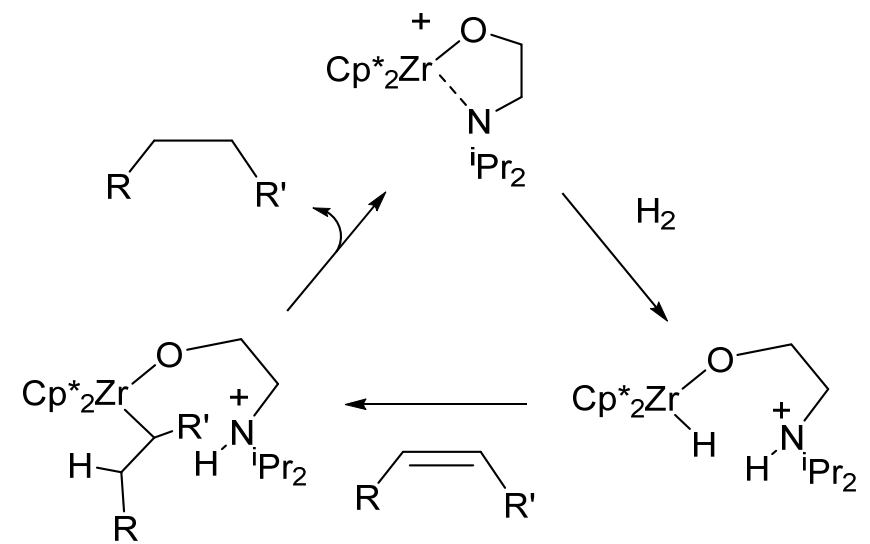

Figure 55. Mechanism proposed for the hydrogenation of olefins catalyzed by a cationic zirconium complex.

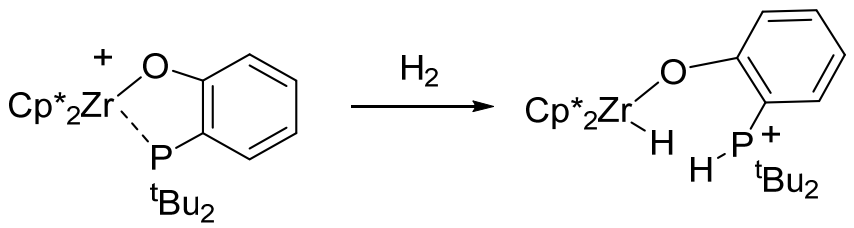

Figure 56. The heterolytic splitting of dihydrogen at a cationic zirconium complex.

A bifunctional imidazolylphosphine $\mathrm{P}^{\mathrm{P}} \mathrm{Pr}_{2}$ imid coordinated to cationic

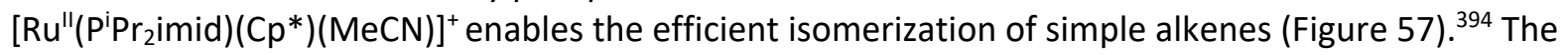
mechanism is thought to proceed via the coordination of the olefin to $\mathrm{Ru}^{\prime \prime}$, and then the transfer of a proton to the imidazole nitrogen, producing an $\eta^{3}$-allyl intermediate (Figure 58). Addition of the proton to a different carbon of the allyl group results in isomerization. While hydride intermediates were not postulated, it is noted that the $\mathrm{p} K_{\mathrm{a}}{ }^{\mathrm{LAC}}$ of $\left[\mathrm{RuH}(\mathrm{Cp})(\mathrm{allyl})\left(\mathrm{PR}_{3}\right)\right]^{+}$might be similar to that of $\left[\mathrm{RuH}_{2}(\mathrm{Cp})\left(\mathrm{PPh}_{3}\right)_{2}\right]^{+}\left(\mathrm{p} K_{\mathrm{a}}{ }^{\mathrm{THF}} 8\right.$, entry 77 of Table 8).

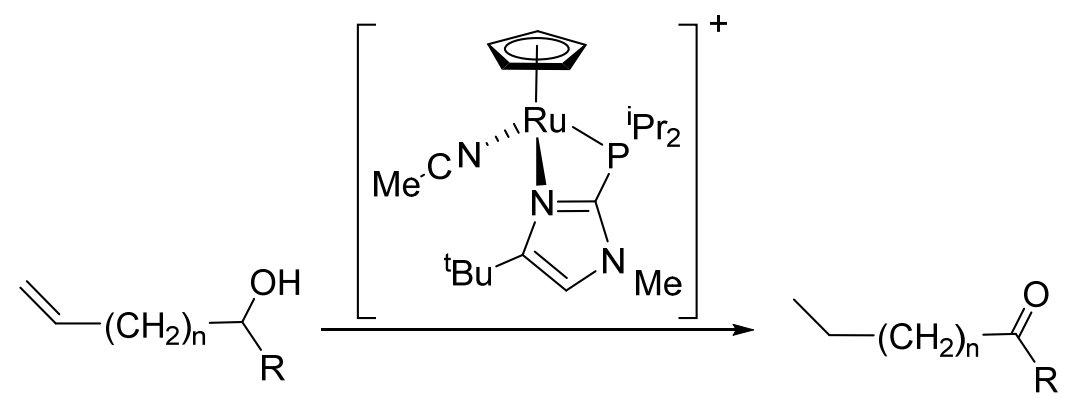

Figure 57. The isomerization of olefins catalyzed by a bifunctional ruthenium catalyst.. 


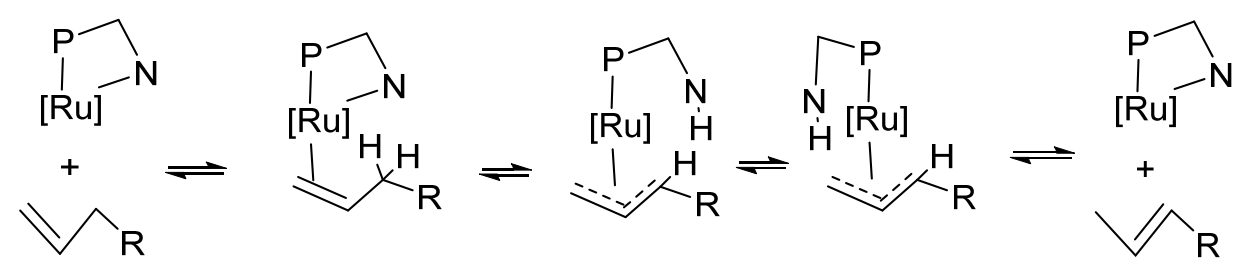

Figure 58. Proposed mechanism for the isomerization of olefins catalyzed by a bifunctional ruthenium P-N catalyst.

\subsubsection{Aldehyde, ketone and imine hydrogenation and amine dehydrogenation}

The Noyori ruthenium catalyst systems $\mathrm{RuCl}_{2}$ (binap)(diamine)/base for the efficient asymmetric hydrogenation of ketones in isopropanol proceeds through the heterolytic activation of dihydrogen at a ruthenium amido complex. The active intermediate species are neutral ruthenium complexes without $\pi$ acid ligands. The dihydrogen ligand intermediate $\mathrm{Ru}\left(\mathrm{H}_{2}\right)\left(\mathrm{NHCR} \mathrm{RCHR}^{\prime} \mathrm{RNH} \mathrm{H}_{2}\right)\left(\right.$ binap) $\left(\mathrm{R}\right.$ and/or $\mathrm{R}^{\prime}$ is $\mathrm{H}, \mathrm{Ph}$, ' $\mathrm{Pr}, \mathrm{Me}$ ) is not acidic and requires quite basic conditions for effective heterolytic splitting to form the active dihydride catalyst trans- $\mathrm{RuH}_{2}\left(\mathrm{NH}_{2} \mathrm{CR}^{\prime} \mathrm{RCR} \mathrm{RNH}_{2}\right)$ (binap). ${ }^{380,395}$ In neutral isopropanol, a more acidic cationic dihydrogen complex $\left[\mathrm{Ru}\left(\mathrm{H}_{2}\right) \mathrm{H} \text { (binap)(diamine) }\right]^{+}$was postulated to be an intermediate in the heterolytic splitting in solution. ${ }^{396}$ However this compound is not an active ketone hydrogenation catalyst until one equivalent of base, such as $\mathrm{BH}_{4}^{-}$or $\mathrm{O}^{t} \mathrm{Bu}^{-}$is added to convert it to the neutral transdihydride catalyst. ${ }^{397}$ The addition of excess base in THF causes the formation of anionic hydride species by deprotonation of the coordinated amines. ${ }^{398}$

In a similar fashion the hydrogenation of ketones at an iron catalyst with a $\mathrm{P}-\mathrm{NH}-\mathrm{N}-\mathrm{P}$ ligand $\mathrm{PPh}_{2} \mathrm{CH}_{2} \mathrm{CH}_{2} \mathrm{NHCHPhCHPhNCHCHPPh}$ is proposed to proceed via the heterolytic splitting of dihydrogen in the intermediate $\mathrm{Fe}\left(\mathrm{H}_{2}\right)(\mathrm{CO})(\mathrm{P}-\mathrm{N}-\mathrm{N}-\mathrm{P}) .{ }^{399}$ The splitting across the iron amido bond produces the hydride amine complex FeH(CO)(P-NH-N-P) which reduces the ketone. ${ }^{399-400}$ The dihydrogen intermediate is not very acidic so the heterolytic splitting step is rate-limiting.

The bifunctional Noyori ketone and imine transfer hydrogenation catalyst system $\mathrm{RuH}\left(\mathrm{NH}_{2} \mathrm{CHPhCHPhNTs}\right.$ )(arene)/Ru(NHCHPhCHPhNTs)(arene) can be converted into a pressure hydrogenation system in the presence of one equivalent of HOTf. In this case the heterolytic splitting of dihydrogen is thought to occur at the acidic cationic complex $\left[\mathrm{Ru}\left(\mathrm{H}_{2}\right)\left(\mathrm{NH}_{2} \mathrm{CHPhCHPhNTs}\right) \text { (arene) }\right]^{+}$ $\left(\mathrm{p} K_{\mathrm{a}}{ }^{\mathrm{MeCN}} 16\right.$, Table 8, entry 144 ); see Figure $59 .{ }^{337}$ The triflate ion is thought to assist in the deprotonation step. ${ }^{339}$

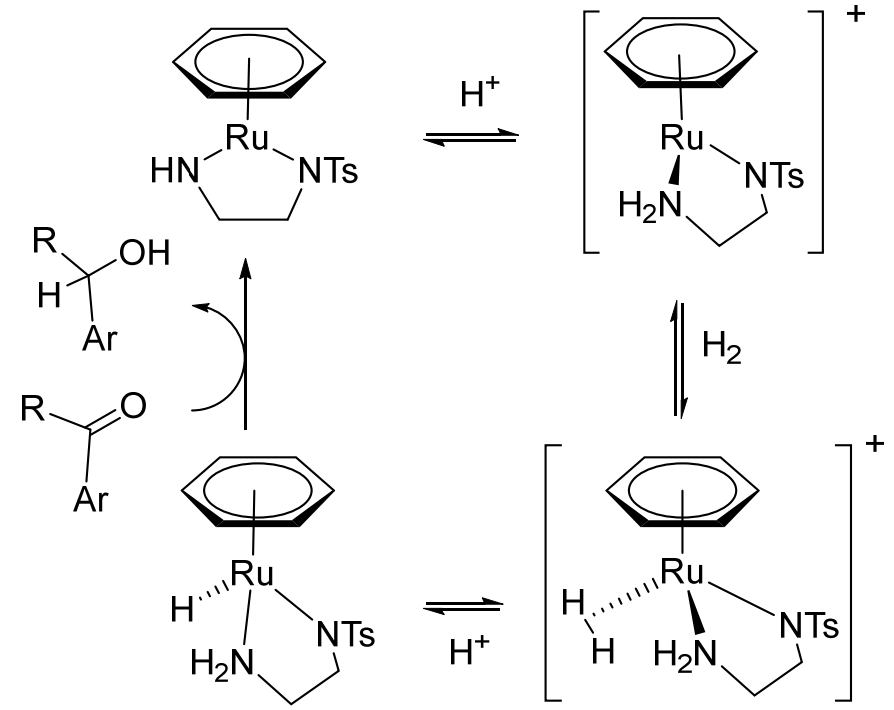

Figure 59. Ketone hydrogenation catalyzed by a ruthenium tosyldiamine complex. 
The formation of lactams from amines and water with the elimination of $\mathrm{H}_{2}$ is catalyzed by a ruthenium complex with a specially designed bifunctional P-N-P ligand that can store a hydride on its acridine backbone. The hydrogen evolution step is proposed to be the formation of dihydrogen by protonation of a hydride on ruthenium by an aqua ligand on ruthenium. ${ }^{82}$

\subsection{Carbon dioxide hydrogenation and formic acid dehydrogenation}

Finding efficient catalysts for the hydrogenation of carbon dioxide is an important goal toward a sustainable future. Formate is a useful product of such a process that stores energy. The formation of formic acid is thermodynamically uphill and so base is usually required for $\mathrm{CO}_{2}$ hydrogenation. Their catalytic decomposition into hydrogen and $\mathrm{CO}_{2}$ provides a gas for use in fuel cells, for example.

A very active catalyst for $\mathrm{CO}_{2}$ hydrogenation to formate in basic solution is the $\mathrm{Ir}^{\mathrm{III}}$ complex IrH $\mathrm{H}_{3}\left(\mathrm{PPr}_{2} \mathrm{PCH}_{2} \mathrm{C}_{5} \mathrm{H}_{3} \mathrm{~N}-\mathrm{CH}_{2} \mathrm{P}^{\mathrm{i}} \mathrm{Pr}_{2}\right)$ of Figure 60$)$

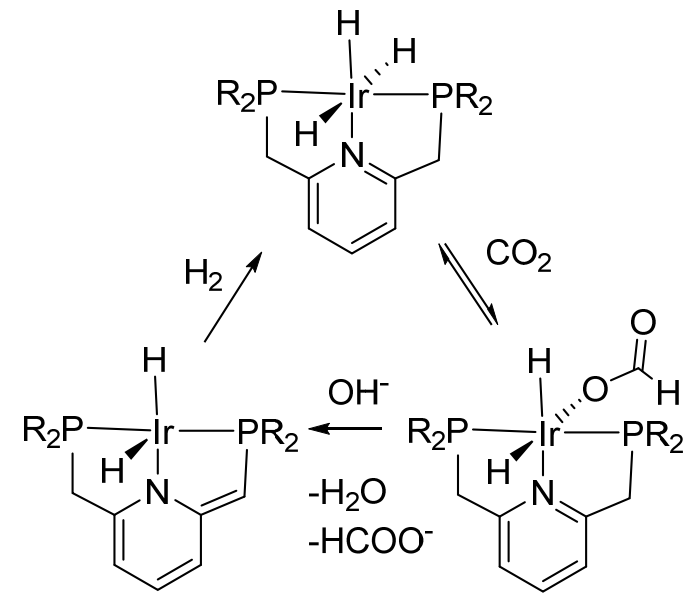

Figure 60. Proposed mechanism for the hydrogenation of carbon dioxide catalyzed by an iridium pincer complex.

The conditions are $120 \mathrm{C}, 60$ atm $\mathrm{H}_{2} / \mathrm{CO}_{2}, 1 \mathrm{M} \mathrm{KOH}, 3.5 \times 10^{6} \mathrm{TON}, 73000 \mathrm{~h}^{-1} \mathrm{TOF}$. This mechanism is proposed to involve the heterolytic splitting of dihydrogen between the iridium and a carbon of the deprotonated backbone of the ligand in the complex $\operatorname{Ir}\left(\mathrm{H}_{2}\right) \mathrm{H}_{2}\left({ }^{\mathrm{i}} \mathrm{Pr}_{2} \mathrm{PCH}_{2} \mathrm{C}_{5} \mathrm{H}_{3} \mathrm{NCHP}^{\mathrm{P}} \mathrm{Pr}_{2}\right)$. The dihydrogen ligand will be weakly acidic in this neutral complex.

The ruthenium hydride complex $\left[\mathrm{Ru}(\mathrm{H})(\mathrm{Tp})\left(\mathrm{PPh}_{3}\right)\left(\mathrm{OH}_{2}\right)\right.$ was found to catalyze the hydrogenation of $\mathrm{CO}_{2}$ to triethylammonium formate in THF/ $\mathrm{H}_{2} \mathrm{O}$ when $\mathrm{NEt}_{3}$ was added $\left(50 \mathrm{~atm} \mathrm{CO}_{2} / \mathrm{H}_{2}, 100{ }^{\circ} \mathrm{C}\right.$, TON up to 700 , TOF $\left.43 \mathrm{~h}^{-1}\right) .{ }^{401}$ The hydride and proton on the aqua ligand were proposed to transfer to $\mathrm{CO}_{2}$

(Figure 61). Then the heterolytic splitting of dihydrogen to the hydroxide ligand in $\left[\mathrm{Ru}\left(\mathrm{H}_{2}\right)(\mathrm{OH})\left(\mathrm{PPh}_{3}\right)(\mathrm{Tp})\right]$ regenerates the starting catalyst. 


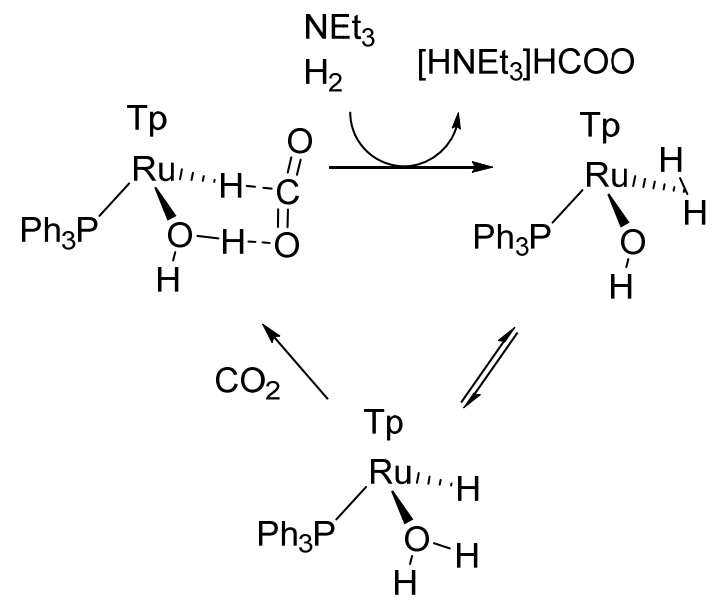

Figure 61. The heterolytic splitting of dihydrogen at a ruthenium carbon dioxide hydrogenation catalyst.

Complexes of the type $\left[\mathrm{RuH}\left(\mathrm{C}_{6} \mathrm{Me}_{6}\right)\left(\mathrm{bpy}-\mathrm{R}_{2}\right)\right]^{+}\left(\mathrm{R}=4,4^{\prime}-\mathrm{H}, \mathrm{OMe}\right)$ and $\left[\mathrm{IrH}\left(\mathrm{C}_{5} \mathrm{Me}_{5}\right)\left(\mathrm{bpy}-\mathrm{R}_{2}\right)\right]^{+}$are good catalysts for the hydrogenation of $\mathrm{CO}_{2}$ to formic acid in aqueous solution at $\mathrm{pH} 3 .{ }^{241}$ The hydrides attack $\mathrm{CO}_{2}$ and the dicationic complexes that result are proposed to coordinate dihydrogen and heterolytically split it into a hydride and proton to the aqueous medium. Certainly the dihydrogen complexes $\left[\mathrm{Ru}\left(\mathrm{H}_{2}\right)\left(\mathrm{C}_{6} \mathrm{Me}_{6}\right)\left(\mathrm{bpy}-\mathrm{R}_{2}\right)\right]^{2+}$ and $\left(\mathrm{p} K_{\mathrm{a}}{ }^{\mathrm{LAC}} \sim-4\right)$ and $\left[\operatorname{Ir}\left(\mathrm{H}_{2}\right)\left(\mathrm{C}_{5} \mathrm{Me}_{5}\right)\left(\mathrm{bpy}-\mathrm{R}_{2}\right)\right]^{2+}\left(\mathrm{p} K_{\mathrm{a}}{ }^{\mathrm{LAC} \sim}-2\right)$ are sufficiently acidic to act in this way. An interesting bifunctional iridium catalyst $\left[\operatorname{lrH}\left(\mathrm{Cp} \mathrm{p}^{*}\right)(\mathrm{dhbp})\right]^{+}, \mathrm{dhbp}=$ 4,4'-dihydroxy-2,2'-bipyridine, is even active for the hydrogenation of $\mathrm{CO}_{2}$ in water to formate (Figure 62). ${ }^{402-403}$ When $4,4^{\prime}, 6,6^{\prime}$-tetrahydroxy-2, 2'-bipyrimidine (thbpym) is used as a bridging ligand, catalysis is significantly improved $\left(60^{\circ} \mathrm{C}, 200,000 \mathrm{~h}^{-1} \mathrm{TOF}, 300,000 \mathrm{TON}\right.$. The iridium complexes transfer a hydride to $\mathrm{CO}_{2}$ and the resulting complexes coordinate and split dihydrogen heterolytically to a phenoxide-like substituent on the ligand. A water molecule is proposed to shuttle a proton in the $\mathrm{H}_{2}$ splitting step. ${ }^{383}$ The complex also catalyzes the reverse reaction, $\mathrm{H}_{2}$ evolution from formate and water. While the complex $\left[\operatorname{Ir}\left(\mathrm{H}_{2}\right)\left(\mathrm{Cp}^{*}\right)(\mathrm{bpy})\right]^{2+}$ has a $\mathrm{p} K_{\mathrm{a}}^{\mathrm{LAC}}-2$, the hydroxylated bipyridine ligands will be significantly more donating with its negative charges, making the $\mathrm{H}_{2}$ less acidic but the deprotonated hydride form, more nucleophilic toward $\mathrm{CO}_{2}$. The optimum $\mathrm{pH}$ for $\mathrm{H}_{2}$ splitting was found to be 8 for the catalyst with the thbpym ligand. ${ }^{403}$ Under these conditions the nitrogen donor ligand is completely deprotonated and there is an aqua ligand on iridium.<smiles></smiles>

Figure 62. Heterolytic splitting of dihydrogen by the bifunctional iridium catalyst $\left[\mathrm{IrH}\left(\mathrm{Cp}{ }^{*}\right)(\mathrm{dhbp})\right]^{+}$for $\mathrm{CO}_{2}$ hydrogenation.

The simple complex $\left[\operatorname{IrCl}\left(\mathrm{Cp}^{*}\right)(\mathrm{bpy})\right]^{+}$is reported to be an electrocatalyst for $\mathrm{CO}_{2}$ reduction. ${ }^{245}$ In the proposed mechanism the $\operatorname{Ir}^{\prime}$ complex $\operatorname{IrCp}(\mathrm{bpy})$ is protonated by water $\left(\mathrm{p} K_{\mathrm{a}} 15\right)$ to give the hydride $\left[\mathrm{IrH}\left(\mathrm{Cp} \mathrm{p}^{*}\right)(\mathrm{bpy})\right]^{+}\left(\mathrm{p} K_{\mathrm{a}}{ }^{\mathrm{LAC}} 19, \mathrm{p} K_{\mathrm{a}}{ }^{\mathrm{MeCN}} 23\right.$, Table 9, entries 63, 64). This cationic complex is reduced by one electron to the more nucleophilic neutral hydride which attacks the $\mathrm{CO}_{2}$ to form the formate complex.

Molybdenum and tungsten complexes with a bifunctional P-NH-P ligand were reported to be poor catalysts for $\mathrm{CO}_{2}$ hydrogenation. ${ }^{404} \mathrm{~A}$ simple $\mathrm{Cu}$ "-DBU system was also found to catalyze the hydrogenation of $\mathrm{CO}_{2}$ to $[\mathrm{DBU}-\mathrm{H}] \mathrm{HCO}_{2}$ in dioxane at $100{ }^{\circ} \mathrm{C}\left(20 \mathrm{~atm} \mathrm{H}, 20 \mathrm{~atm} \mathrm{CO}, 100 \mathrm{TON}, 5 \mathrm{~h}^{-1}\right.$ TOF). ${ }^{405}$ The likely mechanism involves the heterolytic splitting of $\mathrm{H}_{2}$ at cationic $\mathrm{Cu}$ '. Iron complexes with 
tetradentate phosphorus and silicon donor ligands are known to catalyze $\mathrm{CO}_{2}$ hydrogenation as well with TON up to $1661 .{ }^{196,406} \mathrm{An}$ intermediate in catalysis, the dihydrogen complex $\left[\mathrm{Fe}\left(\mathrm{H}_{2}\right)\left\{\mathrm{Si}\left(\mathrm{C}_{6} \mathrm{H}_{4} \mathrm{P}^{\mathrm{i}} \mathrm{Pr}_{2}\right)_{3}\right\}\right]^{+}$ (Figure 10) was determined to have a $\mathrm{p}_{\mathrm{a}}{ }_{\mathrm{T}}^{\mathrm{THF}} 11 .{ }^{196} \mathrm{For}$ a tetraphos system the proposed dihydrogen intermediate $\left[\mathrm{Fe}\left(\mathrm{H}_{2}\right)(\mathrm{H})\left(\mathrm{PP}_{3}\right)\right]^{+}$has a $\mathrm{p} K_{\mathrm{a}}^{\mathrm{LAC}}$ of 12 .

A desirable product of $\mathrm{CO}_{2}$ hydrogenation is methanol. This has been achieved with the homogeneous catalyst of the type $\left[\mathrm{Ru}(\mathrm{THF})\left(\mathrm{O}_{2} \mathrm{CH}\right)\left\{\mathrm{Me}\left(\mathrm{CH}_{2} \mathrm{PPh}_{2}\right)_{3}\right\}\right]^{+}$under conditions of $140 \mathrm{C}, 20$ atm $\mathrm{CO}_{2}, 60$ atm $\mathrm{H}_{2}, 360$ TON, 15 TOF. $^{384}$ Dihydrogen is proposed to split in the cationic Ru" complex $\left[\mathrm{Ru}\left(\mathrm{H}_{2}\right)\left(\mathrm{O}_{2} \mathrm{CH}\right)\left\{\mathrm{Me}\left(\mathrm{CH}_{2} \mathrm{PPh}_{2}\right)_{3}\right\}\right]^{+}$to $\eta^{1}$-coordinated formate in the first step. Hemiacetal and methoxide intermediates may also be involved in heterolytic splitting process.

Complexes of the type $\mathrm{MoH}(\mathrm{CO})\left(\mathrm{Cp}\right.$ or $\left.\mathrm{Cp}^{*}\right)\left(\mathrm{PMe}_{3}\right)_{2}$ are catalysts for the dehydrogenation of formic acid at $100{ }^{\circ} \mathrm{C}$ with TOF $\left.30-50 \mathrm{~h}^{-1}\right)$. ${ }^{118}$ The mechanism is proposed to be the protonation of the hydride by the acid to give $\left[\mathrm{MoH}_{2}(\mathrm{CO})\left(\mathrm{Cp}^{*}\right)\left(\mathrm{PMe}_{3}\right)_{2}\right]^{+}\left(\mathrm{p} K_{\mathrm{a}}{ }^{\mathrm{LAC}} 9\right.$, entry 36, Table 5) which loses $\mathrm{H}_{2}$ and binds $\mathrm{HCO}_{2}$. Elimination of $\mathrm{CO}_{2}$ results in the regeneration of the starting hydride. The complex $\left[\mathrm{MoH}_{2}(\mathrm{Cp})\left(\mathrm{PMe}_{3}\right)_{3}\right] \mathrm{HCO}_{2}$ (Entry 41, Table 5, $\mathrm{p} K_{\mathrm{a}}{ }^{\mathrm{LAC}} 17$ ) is quite stable and is a poor catalyst while very unstable $\left[\mathrm{MoH}_{2}\left(\mathrm{Cp}^{*}\right)(\mathrm{CO})_{2}\left(\mathrm{PMe}_{3}\right)\right]^{+}\left(\mathrm{p} K_{\mathrm{a}}^{\mathrm{LAC}} 1\right)$ is a poor catalyst, partly because the conjugate hydride form is a weak nucleophile. $\mathrm{MoH}(\mathrm{Cp})(\mathrm{CO})_{3}$ is difficult to protonate and is a very poor catalyst. The cluster compound $\mathrm{Ru}_{4} \mathrm{H}_{4}(\mathrm{CO})_{12}\left(\mathrm{pK}_{\mathrm{a}}{ }^{\mathrm{MeOH}} 11.7^{231}\right)$ was found to be a stable catalyst for formic acid decomposition at $85^{\circ} \mathrm{C}$ in DMF. 407

\subsection{Hydrogen oxidation and evolution electrocatalysts}

The experimental determination of the $\mathrm{p} K_{\mathrm{a}}$ of transition metal hydride complexes provides a valuable guide, along with electrochemical measurements, for the systematic improvement of the thermodynamics of molecular electrocatalysts for $\mathrm{H}_{2}$ oxidation and evolution. ${ }^{33,284,315,333}$ The free energy of hydride removal from a complex $\left[\mathrm{MHL}_{n}\right]^{+}\left(\Delta \mathrm{G}_{\mathrm{H}^{-}}\right)$(Equation 22) can be related its $\mathrm{p} K_{\mathrm{a}}{ }^{\mathrm{MeCN}}\left(\left[\mathrm{MHL}_{n}\right]^{+}, \mathrm{ML}_{n}\right)$ (Equation 19) with the electrochemical potential $\mathrm{E}_{1 / 2}\left(\mathrm{ML}_{n}{ }^{2+} / \mathrm{ML}_{n}\right)$ of it conjugate base form for the solvent acetonitrile (Equation 20) and the free energy for reduction of a proton in acetonitrile (Equation 21). ${ }^{45}$ Only certain metal complexes can sustain the two electron redox couple needed for this process.

Equation 19

$\left[\mathrm{HML}_{n}\right]^{+} \rightleftarrows \mathrm{H}^{+}+\mathrm{ML}_{\mathrm{n}} \quad \Delta \mathrm{G}^{0}=1.37 \mathrm{p} K_{\mathrm{a}}^{\mathrm{MeCN}}$

Equation 20

$M L_{n} \rightleftarrows 2 \mathrm{e}^{-}+\left[\mathrm{ML}_{n}\right]^{2+} \quad \Delta \mathrm{G}^{0}=46.1 \mathrm{E}_{1 / 2}\left(\left[\mathrm{ML}_{n}\right]^{2+} / \mathrm{ML}_{n}\right)$

Equation 21

$\mathrm{H}^{+}+2 \mathrm{e}^{-} \rightleftarrows \mathrm{H}^{-} \quad \Delta \mathrm{G}^{0}=79.6$

Equation 22

$\left[\mathrm{HML}_{n}\right]^{+} \rightleftarrows \mathrm{H}^{-}+\left[\mathrm{ML}_{n}\right]^{2+} \quad \Delta \mathrm{G}_{\text {hydr }}^{0}=1.37 \mathrm{p} K_{\mathrm{a}}{ }^{\mathrm{MeCN}}+46.1 \mathrm{E}_{1 / 2}\left(\left[\mathrm{ML}_{\mathrm{n}}\right]^{2+} / \mathrm{ML}_{\mathrm{n}}\right)+79.6$

The free energy of the heterolytic splitting of dihydrogen at a metal complex $\Delta G_{\text {hetero }}$ (Equation 26 ) is related to the free energy of the heterolytic splitting of dihydrogen in acetonitrile (Equation 23), the hydride affinity of the complex $\Delta \mathrm{G}_{\mathrm{H}^{-}}$(Equation 24) along with the $\mathrm{p} K_{\mathrm{a}}{ }^{\mathrm{MeCN}}$ value of the acid form of the base used to accept the proton (Equation 25). It can be seen that the greater $\Delta \mathrm{G}_{\mathrm{H}^{-}}$and the greater the $\mathrm{p} K_{\mathrm{a}}$ (the stronger the base), the more favorable will be the $\mathrm{H}_{2}$ splitting.

Equation 23 
$\mathrm{H}_{2} \rightarrow \mathrm{H}^{+}+\mathrm{H}^{-} \quad \Delta \mathrm{G}^{0}=76 \mathrm{kcal} / \mathrm{mol}$

Equation 24

$\mathrm{H}^{-}+\left[\mathrm{ML}_{\mathrm{n}}\right]^{2+} \rightarrow\left[\mathrm{MHL}_{\mathrm{n}}\right]^{+} \quad \Delta \mathrm{G}^{0}=-\Delta \mathrm{G}_{\mathrm{hydr}}^{0}$

Equation 25

$\mathrm{H}^{+}+$base $\rightarrow[\mathrm{H}-\text { base }]^{+} \quad \Delta \mathrm{G}^{0}=-1.37 \mathrm{p} K_{\mathrm{a}}\left([\mathrm{H}-\text { base }]^{+}\right)$

Equation 26

$\mathrm{H}_{2}+\left[\mathrm{ML}_{\mathrm{n}}\right]^{2+} \rightarrow\left[\mathrm{MHL}_{\mathrm{n}}\right]^{+}+[\mathrm{H}-\text { base }]^{+} \quad \Delta \mathrm{G}^{0}{ }_{\text {hetero }}=76-\Delta \mathrm{G}^{0}{ }_{\text {hydr }}-1.37 \mathrm{p} K_{\mathrm{a}}\left([\mathrm{H} \text {-base }]^{+}\right)$

For example the thermodynamic data for the electrocatalyst [Ni(depp $\left.)_{2}\right]^{2+}$ depp $=$

$\mathrm{PEt}_{2} \mathrm{CH}_{2} \mathrm{CH}_{2} \mathrm{CH}_{2} \mathrm{PEt}_{2}$ can be written in the compact form of Figure 25 . The $\Delta \mathrm{G}_{\mathrm{H}^{-}}$for [ $\left[\mathrm{NiH}(\mathrm{depp})_{2}\right]^{+}$is 67 $\mathrm{kcal} / \mathrm{mol}$ and the $\mathrm{p} K_{\mathrm{a}}{ }^{\mathrm{MeCN}}$ is 23 (entry 48 , Table $11, \mathrm{p} K_{\mathrm{a}}{ }^{\mathrm{LAC}} 20$ ) resulting in a $\Delta G_{\text {hetero }}$ of $-3 \mathrm{kcal} / \mathrm{mol}$ for using a base $\mathrm{B}$ with $\mathrm{p} K_{\mathrm{a}}{ }^{\mathrm{MeCN}}\left(\mathrm{BH}^{+}\right)$8.5.

One mechanism of dihydrogen evolution involves the protonation of a transition metal hydride to produce a labile dihydrogen ligand. Similarly the deprotonation of a metal dihydrogen or dihydride complex is often an important step in dihydrogen oxidation. For an efficient catalytic process these reactions should be near the equilibrium point (Equation 27).

Equation 27

$\mathrm{MH}+\mathrm{H}^{+} \rightleftarrows \mathrm{M}\left(\mathrm{H}_{2}\right)^{+} \rightleftarrows \mathrm{M}(\mathrm{H})_{2}^{+}(27)$

Thus a knowledge of the acidity of the dihydrogen complex is useful. In the direction of hydrogen production, a common mechanism is the protonation of a metal complex $\mathrm{M}$ to give a metal hydride $\mathrm{MH}^{+}$ that is then reduced and protonated again to give dihydrogen that is evolved. Here too a knowledge of the $\mathrm{p} K_{\mathrm{a}}$ of $\mathrm{MH}^{+}$is useful.

Apart from the LAC method described in this article, more involved DFT methods ${ }^{31-32}$ can be used to calculate the relative $\mathrm{p} K_{\mathrm{a}}$ of metal hydrides in order to develop better electrocatalysts. ${ }^{33-34,52}$

\subsubsection{Nickel hydrides}

Nickel is the most abundant and inexpensive of the group 10 metals and so its complexes have been examined the most intensively as electrocatalysts. A range of complexes with chelating diphosphine ligands have been studied that have a wide range of $p K_{\mathrm{a}}^{\mathrm{MecN}}$ values $(-7$ to +25 , Table 11$)$. For kinetic and thermodynamic reasons ${ }^{33}$ it is more efficient to have bifunctional chelating diphosphines on nickel that can store a proton on a nitrogen in the backbone (Table 11, entries 4, 9, 10, 43, 45, 53) rather than a simple diphosphine such as the depp case just discussed. A particularly efficient electrocatalyst for dihydrogen oxidation in the presence of $\mathrm{NEt}_{3}$ is $\left[\mathrm{Ni}\left\{-\mathrm{PCyCH}_{2} \mathrm{~N}^{t} \mathrm{BuCH}_{2} \mathrm{PCyCH}_{2} \mathrm{~N}^{\mathrm{t} B u C H_{2}-}\right.\right.$ \}$\left._{2}\right]^{2+}$ (Figure 64). ${ }^{296}$ The bulky basic amine ( $\mathrm{p} K_{\mathrm{a}}{ }^{\mathrm{MeCN}} 18$ for the ammonium form) in the backbone will deprotonate the putative dihydrogen complex $\left(\mathrm{p} K_{\mathrm{a}}{ }^{\mathrm{LAC}} 5\right)$ that first forms. The $\mathrm{p} K_{\mathrm{a}}{ }^{\mathrm{MeCN}}$ of the hydride that forms was determined by equilibrium with [MTBD-H]BPh4 ( $\mathrm{p} K_{\mathrm{a}}^{\mathrm{MeCN}} 25.5$ ) or DBU to be 24.6 (entry 53, Table 11). The amine in the backbone, which is reduced in basicity due to the positive charge on the complex, ${ }^{33}$ cannot deprotonate this hydride until it is oxidized at the electrode to $\mathrm{Ni}(\mathrm{III})$. This follows from the fact that when transition metal hydrides are oxidized by one unit their $\mathrm{p} K_{\mathrm{a}}$ decreases by 15 to 21 units. ${ }^{315}$ The $\mathrm{p} K_{\mathrm{a}}{ }^{\mathrm{LAC}}$ of $\left[\mathrm{Ni}^{\mathrm{III}}(\mathrm{H}) \mathrm{L}_{4}\right]^{2+}$ is approx. 5 if the method is applicable to paramagnetic compounds. 


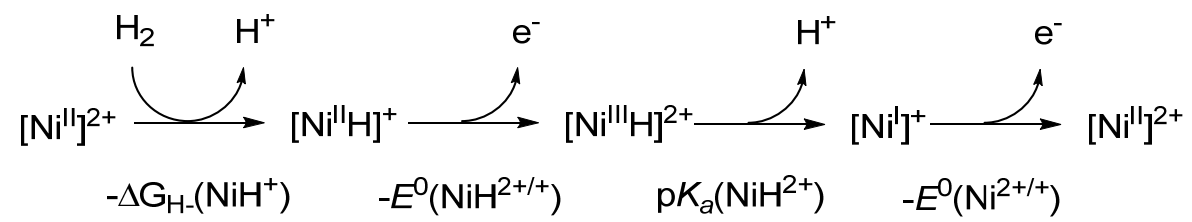

Figure 63. Thermodynamic quantities in the oxidation of dihydrogen by Ni complexes.

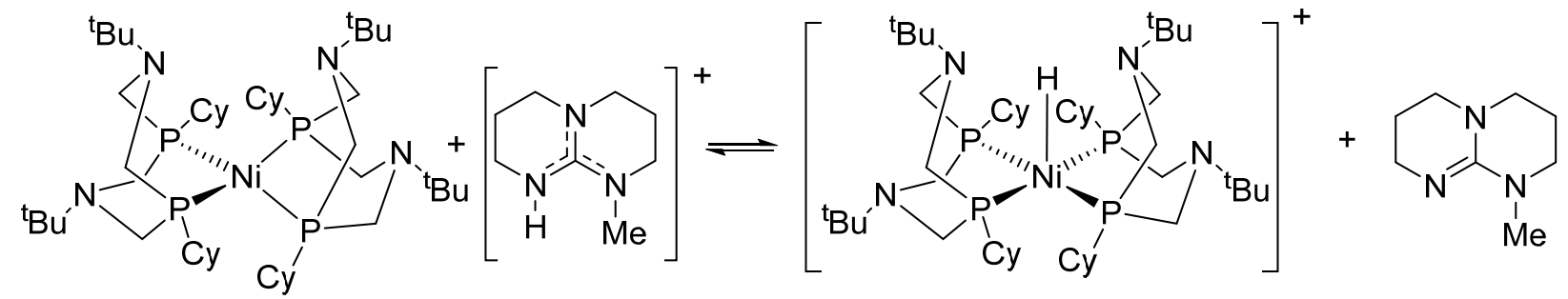

Figure 64. The protonation by MTBD- $\mathrm{H}^{+}$of a nickel electrocatalyst for the oxidation of dihydrogen

By contrast the complexes [Ni\{-PPhCH$\left.\left.{ }_{2} \mathrm{CH}_{2} \mathrm{PPhCH}_{2} \mathrm{NPhCH}_{2}-\right\}_{2}\right]^{2+284}$ and [Ni\{$\left.\left.\mathrm{PPhCH}_{2} \mathrm{NArCH}_{2} \mathrm{PPhCH}_{2} \mathrm{NArCH}_{2}-\right\}_{2}\right]^{2+316}$ (entry 9, Table 11) with a weaker amine group $\left(\mathrm{Ar}=4-\mathrm{BrC}_{6} \mathrm{H}_{4}\right.$ or $\mathrm{Ph}$ ) catalyze the very efficient electrochemical production of dihydrogen in the presence of protonated dimethylformamide. The rate determining step is thought to be the protonation of the hydride [NiHL(L$\mathrm{H})]^{2+}$ by the pendant, acidic ammonium group with $\mathrm{p} K_{\mathrm{a}}^{\mathrm{MeCN}} 5$, which is more acidic than expected due to the positive charge on the complex. The strength of the acid source determines the mechanism of the proton reduction step in $\mathrm{MeCN}$. The use of the strong acid [H-DMF] ${ }^{+}$results in the protonation of a nickel(I) intermediate $\left[\mathrm{Ni}^{\prime} \mathrm{L}_{2}\right]^{+}$to give $\left[\mathrm{Ni}^{\prime \prime \prime} \mathrm{HL}_{2}\right]^{2+}$ while the weaker acid $\left[\mathrm{PhNH}_{3}\right]^{+}$only protonates the more basic nickel $(0)$ intermediate $\mathrm{NiL}_{2}$ to give $\left[\mathrm{Ni}^{\prime \prime} \mathrm{HL}_{2}\right]^{+}$which is calculated to be $8 \mathrm{p} K_{\mathrm{a}}$ units less acidic than $\left[\mathrm{Ni}^{\mathrm{Il}} \mathrm{HL}_{2}\right]^{2+} .{ }^{408}$

The nickel(II) pincer complex $\mathrm{NiH}\left(\mathrm{P}^{\mathrm{t}} \mathrm{Bu}_{2} \mathrm{CH}_{2} \mathrm{C}_{6} \mathrm{H}_{3} \mathrm{CH}_{2} \mathrm{P}^{\mathrm{t}} \mathrm{Bu}\right.$ ) (Figure 65) is thought to be a catalytic intermediate in the electrocatalytic production of dihydrogen from $\mathrm{HBF}_{4}$ in $\mathrm{MeCN}^{299}$ This acid protonates the hydride irreversibly.

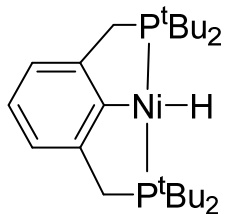

Figure 65. $\mathrm{NiH}\left(\mathrm{P}^{t} \mathrm{Bu}_{2} \mathrm{CH}_{2} \mathrm{C}_{6} \mathrm{H}_{3} \mathrm{CH}_{2} \mathrm{P}^{t} \mathrm{Bu} u_{2}\right)$.

\subsubsection{Cobalt hydrides}

Pendant amines have also been used in ligands on cobalt to improve the electrocatalytic properties of the metal complex for hydrogen generation. The tetradentate $\mathrm{P}_{4}$ ligand shown in Figure 15 can be used to produce the cobalt electrocatalyst $\left[\mathrm{Co} "(\mathrm{NCMe})\left(\mathrm{P}_{4}\right)\right]^{2+}$ for hydrogen evolution from protonated DMF ${ }^{252}$ The $\mathrm{Co}(\mathrm{III})$ hydride $\left[\mathrm{CO}^{\mathrm{III}} \mathrm{H}\left(\mathrm{P}_{4}\right)(\mathrm{MeCN})\right]^{2+}$ was also prepared; it is postulated to be in the catalytic cycle (Figure 66). ${ }^{409}$ This hydride complex has a $\mathrm{p} K_{\mathrm{a}}{ }^{\mathrm{MeCN}}\left(\left[\mathrm{Co}{ }^{11 \prime} \mathrm{H}(\mathrm{NCMe}) \mathrm{P}_{4}\right]^{2+} /\left[\mathrm{Co}^{\prime}(\mathrm{NCMe}) \mathrm{P}_{4}\right]^{+}\right)$ 16.0 (entry 45 , Table 9$)$ as it was found to be deprotonated and be in equilibrium with collidine $(2,4,6$ trimethylpyridine, $\mathrm{p} K_{\mathrm{a}}{ }^{\mathrm{MeCN}}$ (collidinium) 15.0). The protonation of the $\mathrm{Co}(\mathrm{II})$ hydride $\left[\mathrm{Co}{ }^{\prime \prime} \mathrm{H}(\mathrm{NCMe}) \mathrm{P}_{4}\right]^{+}$by an endo ammonium group [HNPhR $]_{2}^{+}$in the ligand backbone is proposed to be the hydrogen-evolving step. This acid was calculated to have a $\mathrm{p} K_{\mathrm{a}}{ }^{\mathrm{MeCN}} 2.0 .^{409}$ The LAC calculation has only been established for diamagnetic complexes but if applied to $\left[\mathrm{Co}^{\prime \prime}\left(\mathrm{H}_{2}\right)\left(\mathrm{P}_{4}\right)(\mathrm{NCMe})\right]^{2+}$ produces a $\mathrm{p} K_{\mathrm{a}}{ }^{\mathrm{LAC}} 2 \times 4+2 \times 5+4-15=7$. However this paramagnetic complex is more acidic than this estimate. The $\mathrm{P}_{4}$ ligand with a propylene spacer to the terminal $\mathrm{PPh}_{2}$ groups was also used to make similar complexes. 


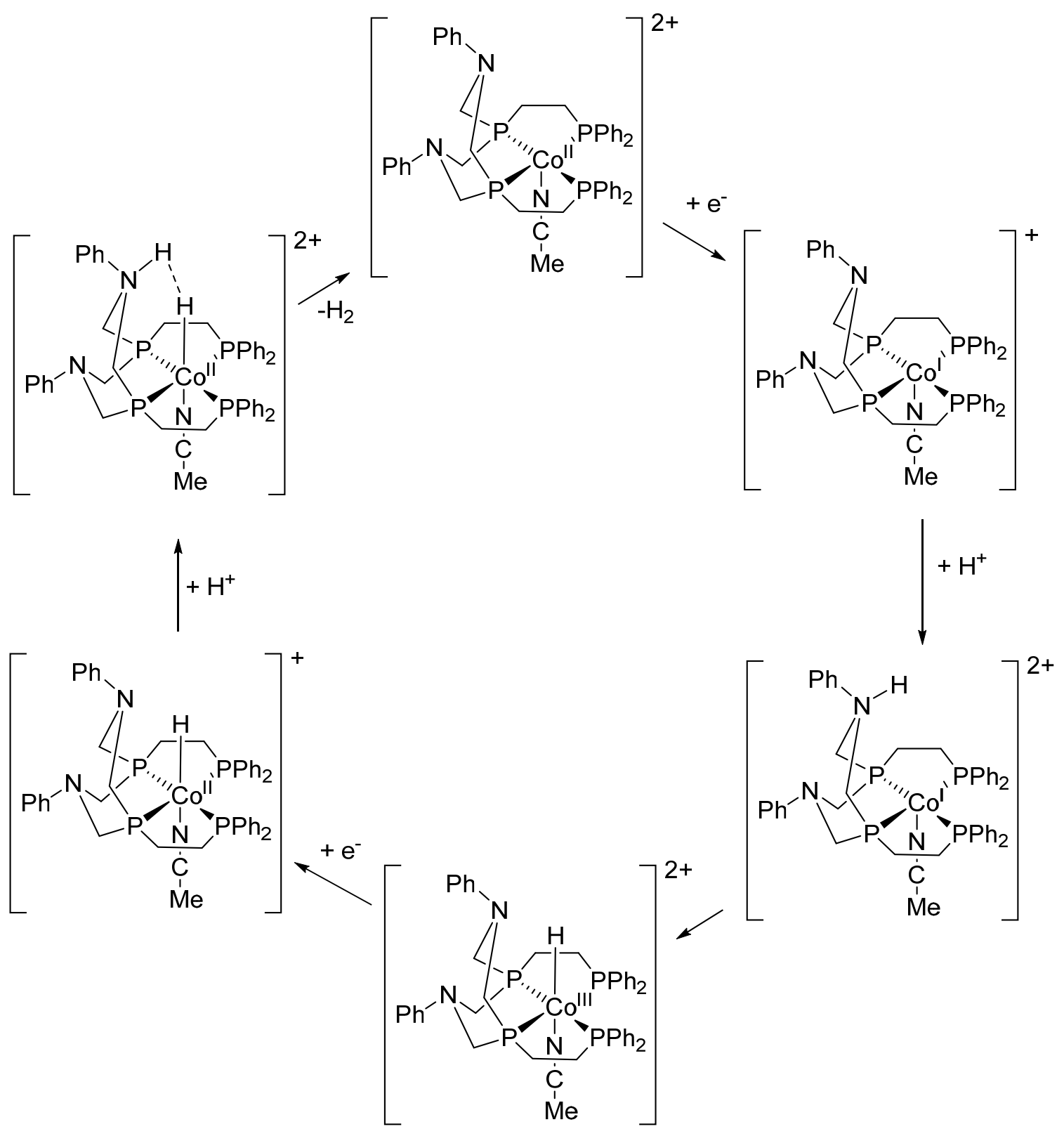

Figure 66. Proposed mechanism for the electrocatalytic production of dihydrogen catalyzed by a cobalt complex.

The $\mathrm{p} K_{\mathrm{a}}{ }^{\mathrm{MeCN}}$ of the hydrides $\left[\mathrm{Co} " \mathrm{H}\left(\mathrm{P}_{4}\right)\right]^{+}(33)$ and trans-[$\left[\mathrm{CoH}_{2}\left(\mathrm{P}_{4}\right)\right]^{+}(32)$ were also determined indirectly from thermodynamic cycles (Figure 67 ). The $\mathrm{p} K_{\mathrm{a}}^{\mathrm{LAC}}$ for the latter complex is $2 \times 3+2 \times 4.9+6=22$, which translates into a $\mathrm{p} K_{\mathrm{a}}{ }^{\mathrm{MeCN}} 29$, in approx. agreement (entry 72, Table 9) 


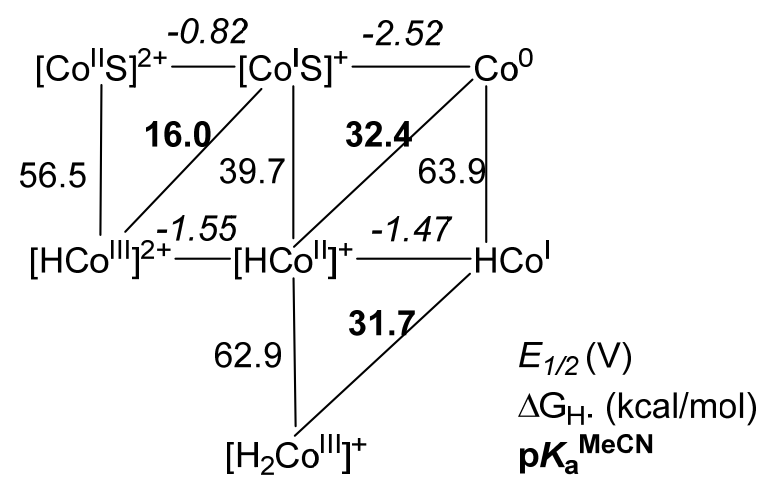

Figure 67. Thermodynamic cycles of the $\mathrm{CoP}_{4}$ system $(\mathrm{S}=\mathrm{MeCN})$

A pentadentate nitrogen donor on cobalt (Figure 68) promotes the electrocatalytic production of hydrogen from water buffered at $\mathrm{pH} 8 .{ }^{83}$ Two hydrides are postulated to be in the catalytic cycle, as in the previous case, although only $\left[\mathrm{Co}{ }^{I I \prime} \mathrm{H}(\mathrm{L})\right]^{2+}$ was observed. The authors note that this hydride has a $\mathrm{p} K_{\mathrm{a}}{ }^{\text {aq }} 13$ (from DFT) and is not likely to be protonated at $\mathrm{pH} 8$ conditions. We calculate the $\mathrm{p} K_{\mathrm{a}}{ }^{\mathrm{LAC}}$ of $5 \times 4+6-15=11$ for this hydride, and $<-4$ for the protonated form $\left[\mathrm{Co}^{11 \prime} \mathrm{H}_{2}(\mathrm{~L})\right]^{3+}$, consistent with these ideas. A related redox active pentadentate ligand on cobalt catalyzed proton reduction at low overpotentials in aqueous solution. ${ }^{410}$

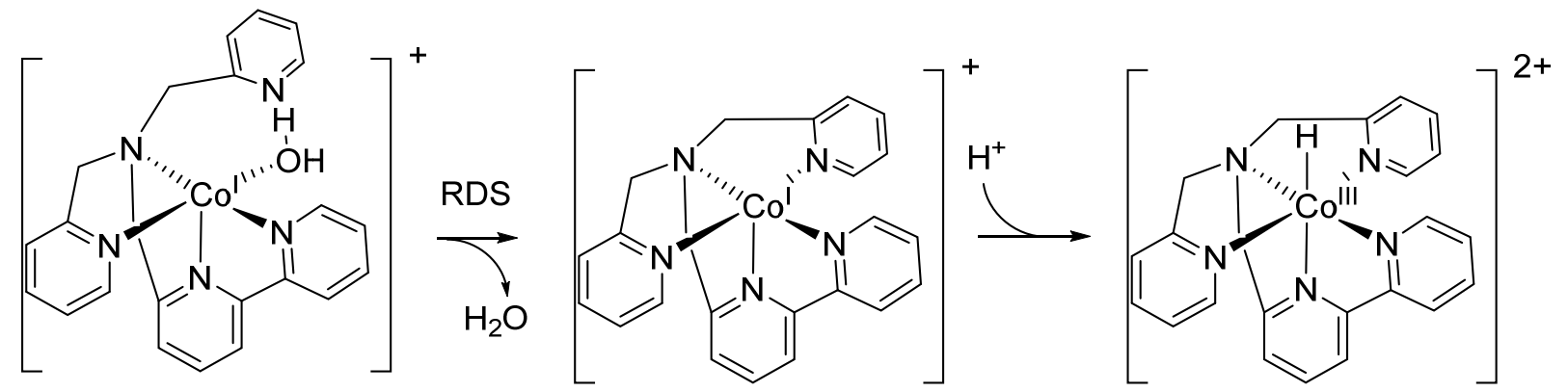

Figure 68. Steps in electrochemical hydrogen production catalyzed by a cobalt complex.

A cobalt complex [Co"l'HL $]^{+}$with a pentadentate ligand with one amido ligand, two amine donors and two pyridyl donors was calculated by DFT to have a $\mathrm{p} K_{\mathrm{a}}{ }^{\text {aq }} 7$ (Figure 69). ${ }^{184}$ This complex is a catalyst in a photochemical hydrogen evolution system from a solution of $\mathrm{NEt}_{3}$ at $\mathrm{pH} 12$ with an iridium complex as a photosensitizer. The corresponding [ $\left[\mathrm{Fe}^{\mathrm{III}} \mathrm{HL}\right]^{+}$complex $\left(\mathrm{p} \mathrm{K}_{\mathrm{a}}^{\mathrm{aq}} 2\right)$ had the incorrect redox potentials to carry out this reaction while the $\left[\mathrm{Ni}^{\prime \prime \prime} \mathrm{HL}\right]^{+}\left(\mathrm{p} K_{\mathrm{a}}^{\mathrm{aq}}-0.4\right)$ was too acidic.

The electrochemical and acid-base properties of tetradentate $\mathrm{N}_{4}$ ligands have been examined experimentally and theoretically. ${ }^{411} \mathrm{~A}$ range of $\mathrm{p} K_{\mathrm{a}}{ }^{\mathrm{MeCN}}$ values from -18 to +18 relative to a standard cobalt complex were calculated for Co(III) hydrides depending on the protonation state of the metal. 


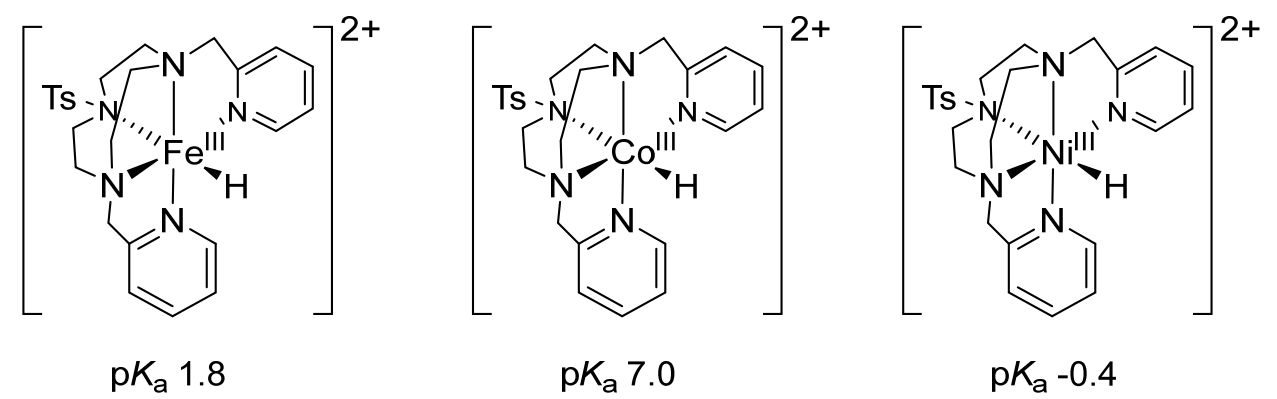

Figure 69. Iron, cobalt and nickel complexes with a pentadentate nitrogen donor ligand.

\subsubsection{Iron and ruthenium hydrides}

There is great interest in iron complexes as electrocatalysts for hydrogen oxidation and evolution because of known high activity of hydrogenase enzymes for this process in nature (see Section 6.9). Cyclopentadienyl complexes of iron have been studied extensively, culminating in the report of an efficient catalyst for hydrogen oxidation. ${ }^{171}$ The catalyst is an iron(II) hydride $\mathrm{FeH}\left(\mathrm{Cp}^{\prime}\right)\left(\mathrm{P} \mathrm{P}^{\mathrm{BBu}}{ }^{\mathrm{B}} \mathrm{N}^{\mathrm{Bn} 2}\right)$ with coordinated by a cyclopentadienyl ligand $\mathrm{C}^{\prime}$ ' with the correct electron-withdrawing characteristics (a $\mathrm{C}_{6} \mathrm{~F}_{5}$ substituent) and a basic chelating diphosphine ligand $\left(\mathrm{P}^{\mathrm{tBu} 2} \mathrm{~N}^{\mathrm{Bn} 2}\right)$ with $\mathrm{N}\left(\mathrm{CH}_{2} \mathrm{Ph}\right) \mathrm{R}_{2}$ bases in the backbone for efficient proton relaying (Figure 70). The catalyst operates in fluorobenzene (PhF), catalyzing the oxidation of dihydrogen at $1 \mathrm{~atm}$ to protons accepted by N-methylpyrrolidine or $\mathrm{NEt}_{3}$. Two acid-base processes that involve the iron are thought to be involved in the cycle. The first is the deprotonation of dihydrogen in $\left[\mathrm{Fe}\left(\mathrm{H}_{2}\right) \mathrm{Cp}^{\prime}\left(\mathrm{P}^{\mathrm{tBu} 2} \mathrm{~N}^{\mathrm{Bn} 2}\right)\right] \mathrm{BAr}{ }_{4}\left(\mathrm{Ar}^{\mathrm{F}}=3,5-\left(\mathrm{CF}_{3}\right)_{2} \mathrm{C}_{6} \mathrm{H}_{3}\right)$ by the ligands' amine base. $\mathrm{NEt}_{3}$ was found to deprotonate and be in equilibrium with this dihydrogen complex in $\mathrm{PhF}$ and so the dihydrogen complex' $\mathrm{p} K_{\mathrm{a}}{ }^{\mathrm{MeCN}}$ was estimated to be 18.9 ; the $\mathrm{p} K_{\mathrm{a}}{ }^{\mathrm{LAC}}$ is 12 which converts to $\mathrm{p} K_{\mathrm{a}}{ }^{\mathrm{MeCN}} 17$, consistent with this estimate. The product of this deprotonation is a dihydrogen-bonded Fe(II) hydride; a related complex has been crystallized and characterized by single crystal neutron diffraction. ${ }^{412}$ The second acid-base process is the deprotonation of the unobserved Fe(III) hydride $\left[\mathrm{Fe}(\mathrm{H}) \mathrm{C} p^{\prime}\left(\mathrm{P}^{\mathrm{tBu} 2} \mathrm{~N}^{\mathrm{Bn} 2}\right)\right] \mathrm{BAr}_{4}^{\mathrm{F}}$ by the internal base. 


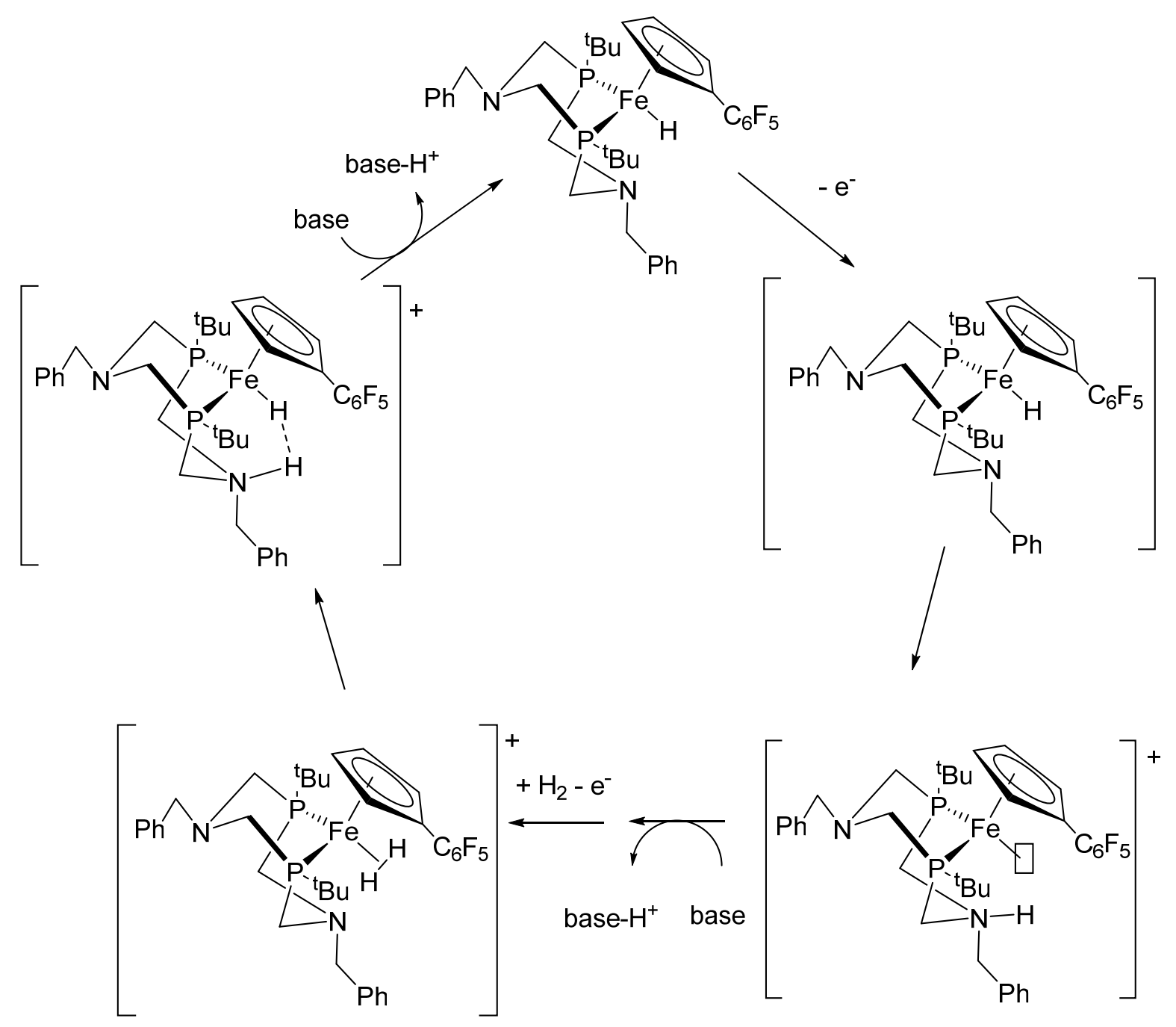

Figure 70. Proposed catalytic cycle for the oxidation of dihydrogen catalyzed by a bifunctional iron complex.

Related complexes FeH(Cp) $\left(P^{\mathrm{Ph} 2} \mathrm{~N}^{\mathrm{Ph} 2}\right)$ and $\mathrm{FeH}(\mathrm{Cp})\left(\mathrm{P}^{\mathrm{Ph} 2} \mathrm{~N}^{\mathrm{Bn} 2}\right)$ have been prepared and studied. ${ }^{170}$ They form dihydrogen complexes $\left[\mathrm{Fe}\left(\mathrm{H}_{2}\right)(\mathrm{Cp})\left(\mathrm{P}^{\mathrm{Ph} 2} \mathrm{~N}^{\mathrm{Ph} 2}\right)\right] \mathrm{BAr}{ }_{4}^{\mathrm{f}}$ with $\mathrm{p} K_{\mathrm{a}}{ }^{\mathrm{MeCN}} 20-24$ extrapolated from $\mathrm{PhF}$ solution. The $\mathrm{p} K_{\mathrm{a}}{ }^{\mathrm{LAC}}$ is approx. 8 and $\mathrm{p} K_{\mathrm{a}}{ }^{\mathrm{MeCN}} 13$, much less than the range reported. However the low dielectric constant of PhF makes acidity measurements difficult because of the ion-pairing. The related $C p^{*}$ complexes $\mathrm{FeH}(\mathrm{Cp} *)\left(\mathrm{P}^{\mathrm{Ph} 2} \mathrm{~N}^{\mathrm{Ph} 2}\right)$ and $\mathrm{FeH}(\mathrm{Cp} *)\left(\mathrm{P}^{\mathrm{Cy} 2} \mathrm{~N}^{\mathrm{Ph} 2}\right)$ have more basic hydrides react with the strong acid $\mathrm{NHTf}_{2}\left(\mathrm{p} K_{\mathrm{a}}{ }^{\mathrm{MeCN}} 1.0\right)$, resulting in hydrogen evolution catalysis in fluorobenzene. ${ }^{413}$ The high acidity of the medium results in catalyst decomposition over time.

The properties of analogous ruthenium(II) complexes $\mathrm{RuH}\left(\mathrm{CP} \mathrm{P}^{*}\right)\left(\mathrm{P}^{\mathrm{Ph} 2} \mathrm{~N}^{\mathrm{Bn} 2}\right)$ and $\mathrm{RuH}\left(\mathrm{CP}{ }^{*}\right)\left(\mathrm{P}^{\mathrm{tBu} 2} \mathrm{~N}^{\mathrm{Ph} 2}\right)$ were reported. ${ }^{414}$ While the $\mathrm{p} K_{\mathrm{a}}$ of the corresponding dihydrogen complexes were not reported, the acidity of the ruthenium complexes was stated to be less than that of the iron complexes because of the donating $\mathrm{Cp}^{*}$ ligand, despite the fact that $\mathrm{Ru}$ is more electronegative than Fe. Thus a stronger base, DBU $\left(\mathrm{p} K_{\mathrm{a}}{ }^{\mathrm{MeCN}} 24.3\right.$ for $\left.\mathrm{DBU}-\mathrm{H}^{+}\right)$, was required to accept protons created by the oxidation of $\mathrm{H}_{2}$ catalyzed by these ruthenium complexes in $\mathrm{PhCl}$.

The simple hydride $\mathrm{FeH}(\mathrm{Cp})(\mathrm{CO})_{2}\left(\mathrm{p} K_{\mathrm{a}}{ }^{\mathrm{MeCN}} 26.0\right)$ is also an electrocatalyst for hydrogen evolution from acetic acid solutions in $\mathrm{MeCN}$ or in water. ${ }^{57,62}$ The turnover limiting step was the protonation of $\left[\mathrm{Fe}(\mathrm{Cp})(\mathrm{CO})_{2}\right]^{-}$by acetic acid ( $\mathrm{p} K_{\mathrm{a}}{ }^{\mathrm{MeCN}} 22.3$ ). This study provided a correction to a previously reported 
$\mathrm{p} K_{\mathrm{a}}{ }^{\mathrm{MeCN}}$ value for this hydride and an example of the electrochemical generation of $\mathrm{H}_{2}$ from a very weak acid, 4-tert-butylphenol ( $\left.\mathrm{p} K_{\mathrm{a}}{ }^{\mathrm{MeCN}} 27.5\right)$.

\subsection{Hydrogenase and model hydrogenase activity}

These enzymes allow bacteria to metabolize or produce hydrogen gas. There is wide variability in the structures of these enzymes but they can be classed into at least three main groups as discussed here. The first [Fe] have one iron at the active site, the second [FeFe] has two and the third [NiFe] has an iron and a nickel. Other enzymes have hydrogenase function including nitrogenase.

\subsection{1 [Fe] HMD hydrogenase}

These enzymes bind dihydrogen at the open Fe(II) site of the structure shown below producing a dihydrogen complex of the type $\mathrm{Fe}\left(\mathrm{H}_{2}\right)(\mathrm{CO})_{2}(\mathrm{SR})(\mathrm{COR})(\mathrm{py})$ (Figure 71$) .{ }^{415}$ DFT modelling suggested a mechanism where the thiolate ligand deprotonates the dihydrogen (Figure 72). ${ }^{219,416}$ The $\Delta G_{\text {hetero }}$ is calculated to be $-15 \mathrm{kcal} / \mathrm{mol}$ by DFT for a simplified model. ${ }^{219}$ The hydride, once formed, transfers to a cationic methenyltetrahydromethanopterin (methenyl-H4MPT+) group to produce methylenetetrahydromethanopterin. ${ }^{417}$ The dihydrogen complex would have a $p K_{\mathrm{a}}^{\mathrm{LAC}}$ of approx. 26 if the acidity constants of the thiolate and acyl groups are 0 . Usually coordinated thiols have $p K_{\mathrm{a}}$ near $9^{207,387}$ so that the acyl and thiolates must be greatly acidifying or there are positive charges in the vicinity of the active site. For example the complex $\left.\left[\mathrm{Os}\left(\mathrm{H}_{2}\right) \text { (quinS)(CO)(PPh}\right)_{2}\right]^{+}$is in equilibrium with its thiol hydride form. ${ }^{207}$ The substrate $\mathrm{MPT}^{+}$hydride acceptor is a cation that is positioned close to the dihydrogen binding site and could provide the positive charge needed to acidify the dihydrogen ligand.

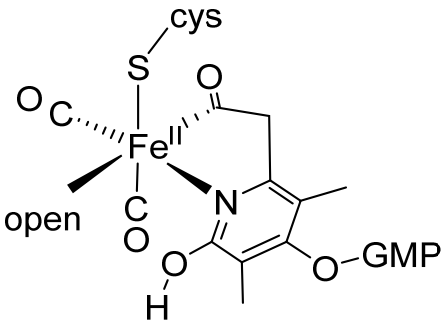

Figure 71. The active site of the [Fe] HMD hydrogenase with a guanylylpyridinol (FeGP) cofactor

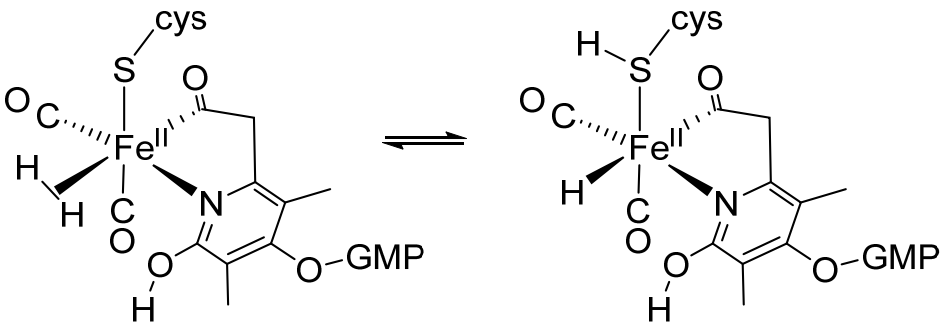

Figure 72. The heterolytic splitting of dihydrogen to the cysteine sulfur of the [Fe] hydrogenase.

A second mechanism has been proposed based on elaborate QMM calculations where the pyridinol group acts in concert with an imidazole side chain to deprotonate the dihydrogen. The base in this case is hydrogen-bonded imidazolium with a $\mathrm{p} K_{\mathrm{a}}^{\mathrm{LAC}}$ of approx. 10 . The hydride is considered to transfer to the cationic substrate as it forms in a frustrated Lewis pair activation. ${ }^{418}$ This was found to be more favorable than thiol formation.

The unstable dihydrogen complex $\mathrm{Ru}\left(\mathrm{H}_{2}\right)\left(\mathrm{PCy}_{3}\right)\left(\mathrm{S}_{4}{ }^{\prime}\right)$, where ' $\mathrm{S}_{4}$ ' is a tetradentate sulfur donor ligand, was generated by reaction of the conjugate base hydride with methanol in THF at low temperature. ${ }^{228}$ The H/D exchange reactions catalyzed by this system mimic aspects of hydrogenase reactivity. There are a variety of other reports involving the acid-base chemistry of iron hydride and dihydrogen complexes of relevance to hydrogenases. 41942042142252423424425426427428429430 


\subsection{2 [FeFe] Hydrogenases}

Hydride and dihydrogen complexes of iron likely form at the active site of FeFe and FeNi hydrogenase enzymes. ${ }^{431-433}$ These enzymes have carbonyl and cyanide ligands on the iron that participate in the catalytic splitting of $\mathrm{H}_{2}$ into protons and electrons, dihydrogen oxidation, and the reverse process, hydrogen production. Presumably these reactions take place at the $\mathrm{pH}$ level of biological media, near 7 in aqueous solution but possibly higher in the interior of the enzyme that might have a dielectric constant of 8 , as low as THF as a solvent. ${ }^{28,434}$ The [FeFe] hydrogenases reversibly catalyze the evolution and oxidation of dihydrogen at a site thought to an iron(II) or iron(I) at the bimetallic core of an iron cluster, complete with a pendant amine base, much like the model complex described in section 6.8.3 (Figure 73). For efficient catalysis the $\mathrm{p} K_{\mathrm{a}}$ of the dihydrogen ligand should be similar to that of the amine base; thus a $\mathrm{p} K_{a}{ }_{a}^{\mathrm{LAC}}$ near 10 . The carbonyl $\left(A_{L}-4\right)$ and cyanide $\left(A_{L}\right.$ approx. -11$)$ ligands are strongly acidifying to bring down the $\mathrm{p} K_{\mathrm{a}}^{\mathrm{LAC}}$ of the dihydrogen ligand in this neutral complex to approx. 10.
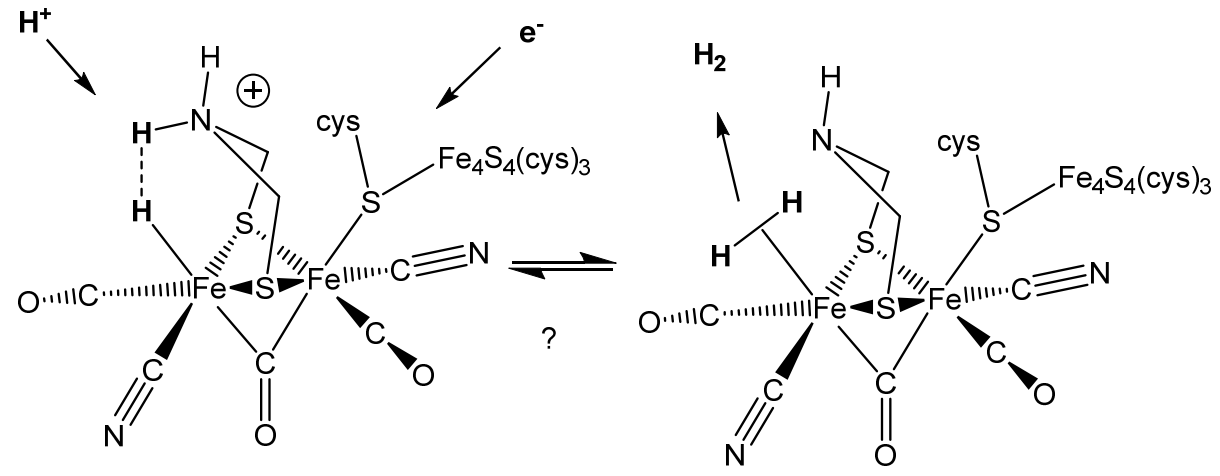

Figure 73. The active site of the [FeFe] hydrogenase.

The protonation steps to form the dihydrogen ligand are proposed to take place at more electron $\mathrm{Fe}(\mathrm{I})$ centers created by one electron reductions of Fe(II). This reduction is estimated to increase the basicity of the Fe-Fe site by $15 \pm 2 \mathrm{p} K_{\mathrm{a}}$ units in MeCN. ${ }^{435}$

There has been an intense research effort into the synthesis of functional complexes than model this hydrogenase active site. ${ }^{435-437}$ One of the closest models to date involves a trimetallic iron complex with phosphine ligands instead of cyanide ligands and a ferrocene moiety in place of the $\mathrm{Fe}_{4} \mathrm{~S}_{4}$ cluster as an electron acceptor (Figure 74). ${ }^{438}$ This complex catalyzes the oxidation of dihydrogen to protons delivered to $\mathrm{P}$ (ortho-tol) ${ }_{3}$ ( $\mathrm{p} K_{\mathrm{a}}{ }^{\mathrm{LAC}}$ approx. 5 for the phosphonium) and electrons to ferrocenium. The presence of the ferrocene unit was required for hydrogen uptake. The $\mathrm{H}_{2}$ binding site can be viewed, after electron transfer to the ferrocenium moiety, as $\left[\mathrm{Fe}^{\prime \prime}\left(\mathrm{H}_{2}\right)(\mu-\mathrm{SR})_{2}(\mu-\mathrm{CO})\left(\mathrm{PAr}_{3}\right)_{2}\right]^{+}$with a $\mathrm{pK}_{\mathrm{a}}^{\mathrm{LAC}}<$ $\mathrm{pK}_{\mathrm{a}}{ }^{\mathrm{LAC}}\left(\mathrm{HNBnR}_{2}{ }^{+}\right)$where the latter is $\leq 12$.

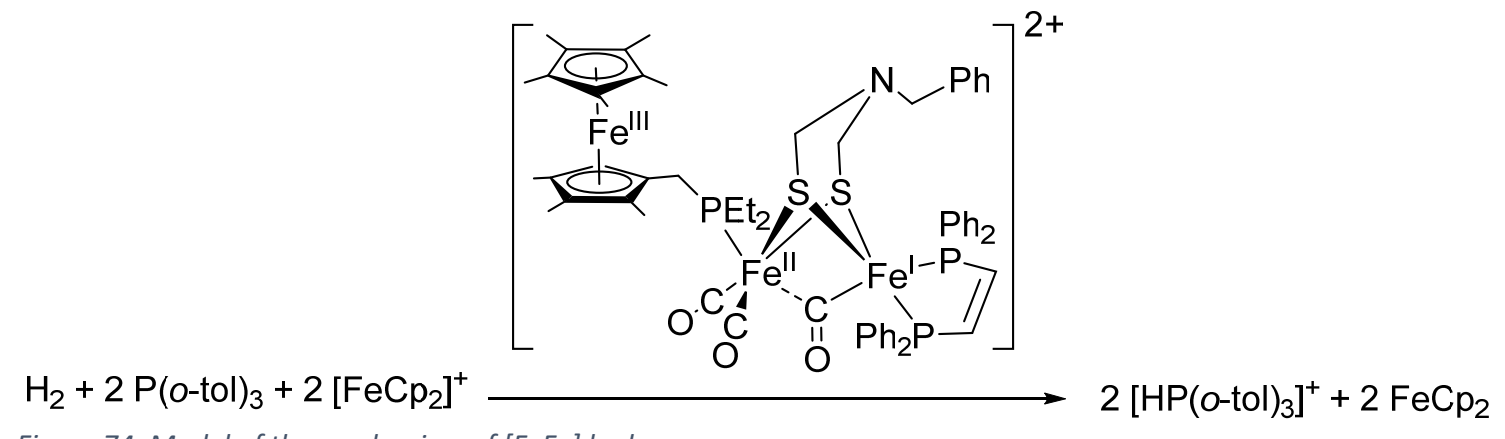

Figure 74. Model of the mechanism of [FeFe] hydrogenases. 
The acid-base properties of other [FeFe] model complexes found in the literature are tabulated in Table 15 (and Table 8 without structures). The diiron complex hydride complex $\left[\mathrm{Fe}_{2}(\mu-\mathrm{H})(\mu-\right.$ $\left.\left.\mathrm{SCH}_{2} \mathrm{CH}_{2} \mathrm{CH}_{2} \mathrm{~S}\right)(\mathrm{CO})_{6}\right]^{+}$of entry 1 of Table 15 is only formed under very strong acid conditions even though it is only monocationic. It is protonated by $\left[\mathrm{C}_{6} \mathrm{D}_{5} \mathrm{~F}-\mathrm{H}\right]^{+}$but not $\left[\mathrm{H}\left(\mathrm{OEt}_{2}\right)_{2}\right] \mathrm{BF}_{4}{ }^{203}$ Even though bridging hydrides are thought to be less acidic than terminal ones in general for such iron compounds, ${ }^{34,439}$ this complex is still highly acidic. Note however that polycarbonyl metal clusters tend to be more acidic when the hydrides are bridging because of the stabilization of the negative charge in the conjugate base form. ${ }^{1}$ For example this effect is observed for the hydride $\mathrm{Os}_{9} \mathrm{H}_{2}(\mathrm{CO})_{24}$ (entry 18, Table 8) which is in equilibrium with $\mathrm{HBF}_{4} \cdot \mathrm{Et}_{2} \mathrm{O}$ in $\mathrm{CD}_{2} \mathrm{Cl}_{2}{ }^{208}$ The acidifying effect of the six carbonyl ligands in $\left[\mathrm{Fe}_{2}(\mu-\mathrm{H})(\mu-\right.$ $\left.\left.\mathrm{SCH}_{2} \mathrm{CH}_{2} \mathrm{CH}_{2} \mathrm{~S}\right)(\mathrm{CO})_{6}\right]^{+}$is clearly not counterbalanced by the presence of thiolate ligands. When complexes like this are reduced, the $\mathrm{p} K_{\mathrm{a}}$ increases (entry 2 of Table 15). Replacing carbonyl ligands with phosphine ligands (entries 3-6) and cyanide ligands (entry 3) greatly increases the $\mathrm{p} K_{\mathrm{a}}$. This may be why cyanide ligands are found in place of some of the carbonyl ligands in nature to raise the $\mathrm{p} K_{\mathrm{a}}$ of the system closer to neutral $\mathrm{pH}$. Substituting carbonyls with a diphosphine ligand allows the synthesis of cationic hydride complexes such as $\left[(\mathrm{CO})_{3} \mathrm{Fe}(\mu-\mathrm{H})\left(\mu-\mathrm{SCH}_{2} \mathrm{CH}_{2} \mathrm{CH}_{2} \mathrm{~S}\right) \mathrm{Fe}(\mathrm{CO})(\mathrm{dppe})\right]^{+}$(entry 3, Table 15). It is in equilibrium with anilinium in benzonitrile solvent, indicating a $\mathrm{p} K_{\mathrm{a}}{ }^{\mathrm{MeCN}}$ of 10.7 and a $\mathrm{p} K_{\mathrm{a}}{ }^{\mathrm{THF}}$ of $5 .{ }^{63}$ The substitution of one carbonyl on each iron with a phosphine and a cyanide to give $(\mathrm{CO})_{2}\left(\mathrm{PMe}_{3}\right) \mathrm{Fe}(\mu-\mathrm{H})\left(\mu-\mathrm{SCH}_{2} \mathrm{CH}_{2} \mathrm{CH}_{2} \mathrm{~S}\right)$ $\mathrm{Fe}(\mathrm{CO})_{2}(\mathrm{CN})$ increases the $\mathrm{p} K_{\mathrm{a}}{ }^{\mathrm{MeCN}}$ to about 11 (entry 4). Since this is a neutral acid this corresponds to a $\mathrm{p} K_{\mathrm{a}}{ }^{\mathrm{THF}}$ of about $12 .{ }^{66}$ The presence of the very acidifying cyanide ligand $\left(A_{L} \sim-11\right)$ makes up for the loss of positive charge on the complex. Substitution with a phosphine on each iron produces complexes such as $\left[(\mathrm{CO})_{2}\left(\mathrm{PMe}_{3}\right) \mathrm{Fe}(\mu-\mathrm{H})\left(\mu-\mathrm{SCH}_{2} \mathrm{NBnCH}_{2} \mathrm{~S}\right) \mathrm{Fe}(\mathrm{CO})_{2}\left(\mathrm{PMe}_{3}\right)\right]^{+}$(entry 5$)$ with a $\mathrm{p} K_{\mathrm{a}}{ }^{\mathrm{MeCN}}$ of approx. 15 ( $\mathrm{p} K_{\mathrm{a}}{ }^{\mathrm{THF}}$ is approx. 9 for a cationic acid). Further replacement of $\mathrm{CO}$ gives complexes like that of entry 6 with $p K_{\mathrm{a}}^{\mathrm{DCM}}$ $=\mathrm{p} K_{\mathrm{a}}{ }^{\mathrm{THF}} 15.5$ where a 1,2-diphenylphosphinoethylene (dppv) ligand is chelated to each iron in $\left[(\mathrm{dppv})(\mathrm{H}) \mathrm{Fe}(\mu-\mathrm{CO})\left(\mu-\mathrm{SCH}_{2} \mathrm{NHCH}_{2} \mathrm{~S}\right) \mathrm{Fe}(\mathrm{CO})(\mathrm{dppv})\right]^{+}$and the hydride is terminal on iron, as proposed for the $[\mathrm{FeFe}]$ hydrogenase. ${ }^{34}$ If hydride of entry 6 rearranges to the bridging tautomer with a terminal carbonyl, the $\mathrm{p} K_{\mathrm{a}}{ }^{\mathrm{MeCN}}$ increases to greater than 18.6. ${ }^{440}$ Strong acids $\left(\mathrm{p} K_{\mathrm{a}}{ }^{\mathrm{MeCN}}>15.5\right)$ protonate the terminal hydride complex to form $\mathrm{H}_{2}$ via the pendant amine ${ }^{34}$ while weak acids bypass the amine when the complex is used for electrocatalysis.

Reducing the oxidation state of the irons also serves to increase the $\mathrm{p}_{\mathrm{a}}{ }^{\mathrm{MeCN}}$ as illustrated by entry 8. The complex $\left[(\mathrm{CO})_{3} \mathrm{Fe}(\mathrm{H})(\mathrm{CO})\left(\mathrm{SC}_{6} \mathrm{H}_{4} \mathrm{~S}\right) \mathrm{Fe}(\mathrm{CO})_{3}\right]^{2-}$ is estimated from electrochemical measurements to have a $\mathrm{p} K_{\mathrm{a}}{ }^{\mathrm{MeCN}}$ of $21 .{ }^{234}$

The mechanism of electrocatalysis using these model complexes can depend on the strength of the acid being reduced to protons. If acetic acid is used $\left(\mathrm{p} K_{\mathrm{a}}{ }^{\mathrm{MeCN}}=22.3\right)$ the complexes with $\mathrm{p} K_{\mathrm{a}}<16$ need to be reduced before they are protonated. 435 
Table 15. Acidity of [FeFe] hydrogenase models

\begin{tabular}{|c|c|}
\hline & Acid form \\
\hline
\end{tabular}

8)

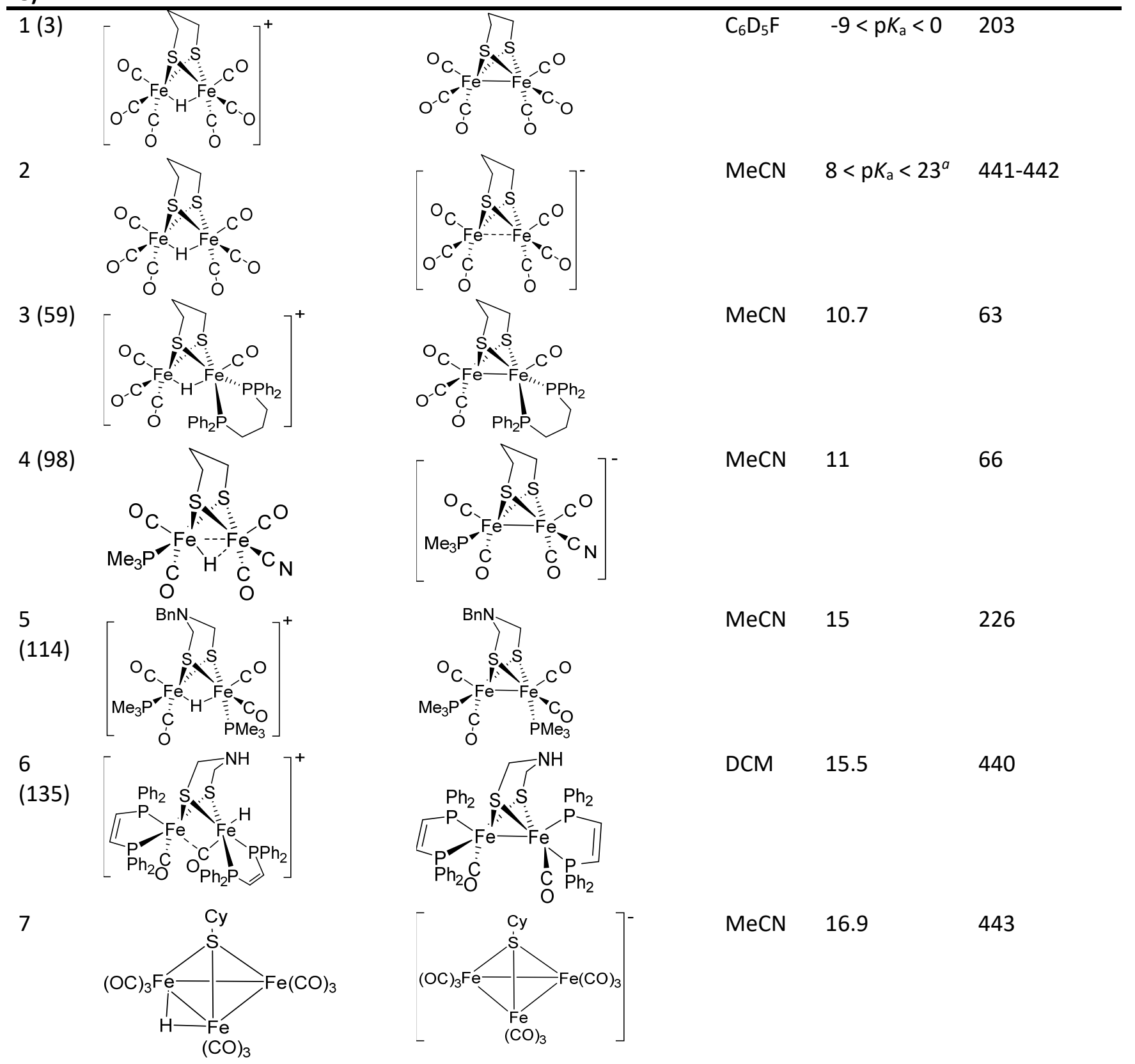


8

(152)

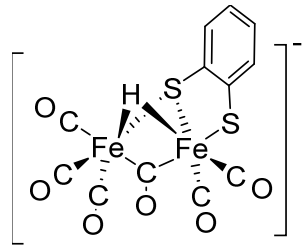

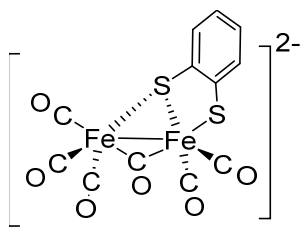

$\mathrm{MeCN}$

21

234

${ }^{a}$ HOTs $(8)<p K_{a}<$ HOAc (23)

\subsection{3 [NiFe] Hydrogenases}

A report of base dependence of the hydride-containing "NiC state" of [NiFe] hydrogenase shows the importance of the acidity of hydrides at the active site (Figure 75). ${ }^{444}$ The heterolytic splitting of dihydrogen is proposed to take place at the dimeric $\mathrm{Ni}(\mathrm{II})-\mathrm{Fe}$ (II) site of the enzyme state Ni-SI (EPR silent). As in the [FeFe] hydrogenase the role of the carbonyl and cyanide ligands on iron is to acidify the intermediate dihydrogen complex so that its $\mathrm{p} K_{\mathrm{a}}^{\mathrm{LAC}}$ is near 10 . It is interesting that the paramagnetic $\mathrm{NI}^{\text {III } \mathrm{HFe}}{ }^{\mathrm{II}} \mathrm{Ni}-\mathrm{C}$ state can reductively eliminate a proton under basic conditions to form a $\mathrm{Ni}^{\prime} \mathrm{Fe}^{\mathrm{Il}}$ form. All of the processes occur near biological $\mathrm{pH}$ values.

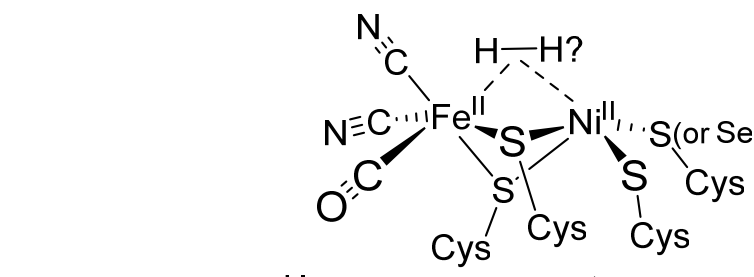

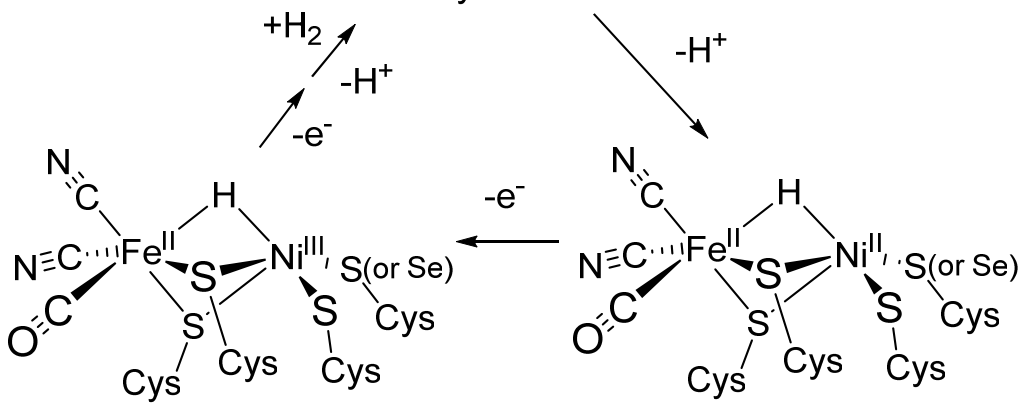

$\mathrm{Ni}-\mathrm{C}$

Figure 75. Proposed pathway for catalytic hydrogen oxidation at the [FeNi] hydrogenase.

The Ni'Fe' complexes with a bridging dithiolate ligand of Figure 76, $\mathrm{L}=\mathrm{CO}, \mathrm{PPh}_{3}$, model aspects of [NiFe] hydrogenases. ${ }^{63}$ They are electrocatalysts for hydrogen evolution by reduction of $\mathrm{CF}_{3} \mathrm{COOH}$ in DCM. The $\mathrm{p} K_{\mathrm{a}}^{\mathrm{MeCN}}$ values are 10.7 and 14.9 for $\mathrm{L}=\mathrm{CO}$ and $\mathrm{PPh}_{3}$, respectively.

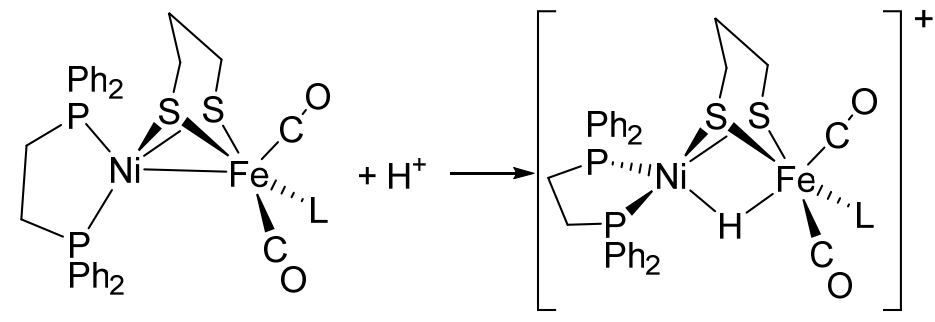

Figure 76. $\mathrm{Ni}(\mathrm{II}) \mathrm{Fe}(\mathrm{I})$ complexes with a bridging dithiolate ligand 
It has been shown by DFT that changes in the geometry about the nickel center in model complexes can result in internal redox from $\mathrm{Ni}^{\prime} \mathrm{Fe}^{l}$ to $\mathrm{Ni}^{\prime \prime} \mathrm{Fe}^{\circ}$ and an increase in basicity by $8 \mathrm{p} K_{\mathrm{a}}$ units (Figure 77). ${ }^{445}$

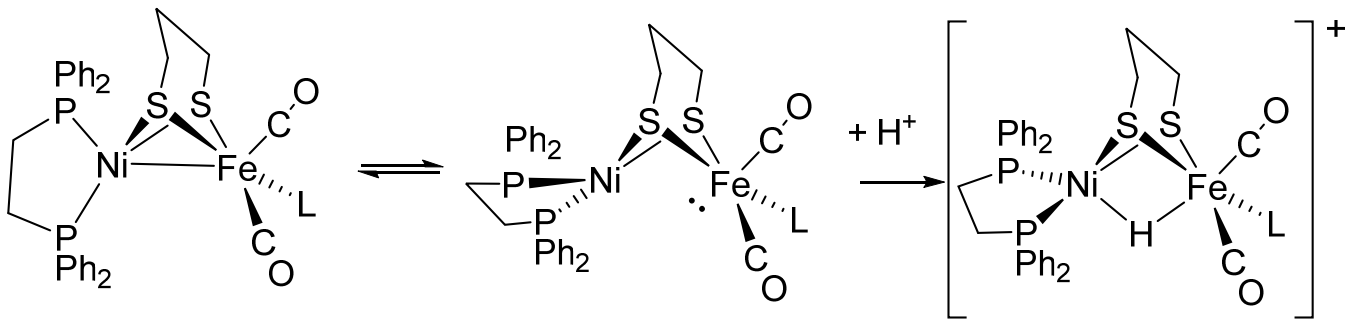

Figure 77. Proposed change in geometry of a complex modelling aspects of the active site of [NiFe] hydrogenases.

A NiRu dimeric complex splits dihydrogen heterolytically to give a bridged NiHRu complex with $\mathrm{H} / \mathrm{D}$ exchange properties similar to that of the enzyme. ${ }^{77,430}$ Similarly the nickel electrocatalysts discussed in Section 6.8.1 have some relevance to the proposed catalytic action of the enzyme. ${ }^{330}$

\subsection{Alcohol oxidation}

A nickel complex with a bifunctional diphosphine ligand catalyzes the electrochemical oxidation of alcohols to ketones (Figure 78). ${ }^{446} \mathrm{~A}$ pendant amine base in the backbone of the ligand is proposed to assist in both the deprotonation of the alcohol to form an alkoxide and the deprotonation of a $\mathrm{Ni}^{\prime \prime}$ hydride intermediate ( $\mathrm{p} K_{\mathrm{a}}{ }^{\mathrm{LAC}}$ approx. 14-18) in a similar fashion to the nickel electrocatalysts discussed in section 6.8.1. Bases with $\mathrm{p} K_{\mathrm{a}}{ }^{\mathrm{MeCN}} 18-20$ ( $\mathrm{B}=\mathrm{DABCO}, \mathrm{NEt} \mathrm{t}_{3}, \mathrm{~N}$-methylpyrrolidine) can be used to accept the protons in the reaction (Equation 28).

Equation 28

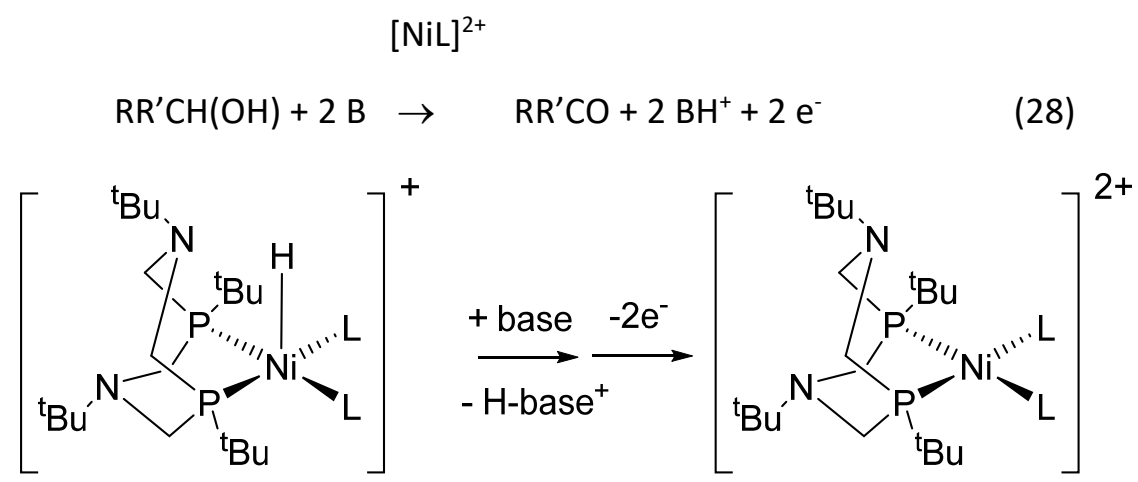

$\mathrm{L}=\mathrm{MeCN}$, base, alcohol

Figure 78. A nickel complex with a bifunctional diphosphine ligand catalyzes the electrochemical oxidation of alcohols to ketones.

Dioxygen from the air can be used as the electron acceptor and sodium carbonate, the base, in the oxidation of benzyl alcohol to the aldehyde with $[\mathrm{Cp} * \operatorname{Ir}(\mathrm{H})(\mathrm{bpym})]^{+}$or $[\mathrm{Cp} * \mathrm{Ir}(\mathrm{H})(\mathrm{bpy})]^{+}$as the catalyst (TON 5-70, Figure 79). ${ }^{447}$ These hydrides are sufficiently acidic ( $K_{\mathrm{a}}{ }^{\mathrm{MeCN}} 23.0$ for bpy complex, entry 63 , Table 8) to react with carbonate base to form the violet complexes $\mathrm{Cp}^{*} \operatorname{Ir}(\mathrm{bpym})$ or $\mathrm{Cp} * \operatorname{Ir}(\mathrm{bpy})$. These reduced complexes are thought have an electron stored on the heterocyclic ligand. ${ }^{448}$ They are very oxygen sensitive and are readily oxidized back to $\operatorname{Ir}(\mathrm{III})$. The $\operatorname{Ir}(\mathrm{III})$ complexes coordinate the alcohol as the alkoxide and beta-hydride elimination regenerates the hydride. The $\mathrm{p} K_{\mathrm{a}}{ }^{\mathrm{MeCN}}$ of the bpym complex was reported as approx. 6 but this seems too low when compared to the bpy complex. ${ }^{447}$ 


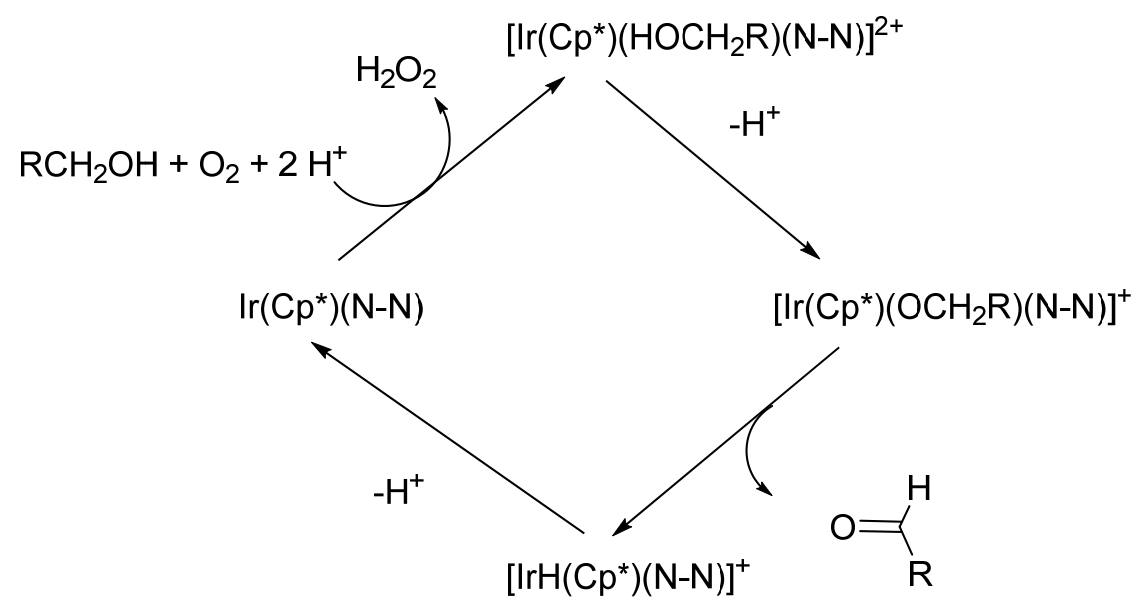

Figure 79. The oxidation of benzyl alcohol to the aldehyde with $[\mathrm{Cp} * \operatorname{Ir}(H)(\text { bpym })]^{+}$or $[\mathrm{Cp} * \operatorname{lr}(H)(b p y)]^{+}$

More efficient aerobic alcohol oxidation catalysts involve mixtures of $\mathrm{Pd}(\mathrm{OAc})_{2}$ and $\mathrm{NEt}_{3}$ in toluene in the presence of molecular sieves and catalytic HOAc. ${ }^{449} \mathrm{An}$ improved catalyst for this process is $\mathrm{Pd}(\mathrm{OAc})_{2}(\mathrm{IPr})\left(\mathrm{OH}_{2}(\mathrm{IPr})\left(\mathrm{OH}_{2}\right), \mathrm{IPr}=\right.$ 'Pr-substituted NHC ligand, that allows the use of air. ${ }^{449} \mathrm{The}$ mechanism involves formation of a Pd"(alkoxide) that undergoes beta-hydride elimination. The resulting hydride is deprotonated by $\mathrm{NEt}_{3}\left(\mathrm{pK}_{\mathrm{a}}^{\mathrm{LAC}} 13\right.$ for $\left.\mathrm{NHEt}_{3}{ }^{+}\right)$or acetate $\left(\mathrm{p} K_{\mathrm{a}}{ }^{\mathrm{LAC}} 24\right.$ for $\mathrm{HOAc}$ in THF) to give $\mathrm{Pd}(0)$ which reacts with dioxygen to go back to $\mathrm{Pd}(\mathrm{II}) .{ }^{450}$ Note that the suggested $\left[\mathrm{PdH}\left(\mathrm{NEt}_{3}\right)(\mathrm{OAc})\right]$ or $[\mathrm{PdH}(\mathrm{NHC})(\mathrm{OAC})]$ intermediate is predicted to have $\mathrm{p} K_{\mathrm{a}}{ }^{\mathrm{LAC}}$ approx. 30 . Some partial dissociation of acetate from the metal to create a positive charge would assist in the deprotonation of the hydride. ${ }^{451}$

\subsection{Olefin functionalization}

\subsubsection{Heck coupling reaction (palladium and nickel)}

The Heck coupling reaction is a particularly effective and reliable method for preparing substituted olefins from terminal olefins and functionalized hydrocarbons R-X. ${ }^{452}$ The reaction typically involves the oxidative addition of a carbon- $X$ bond to a $\mathrm{Pd}^{0} \mathrm{~L}_{2}$ complex, where $\mathrm{X}$ is, for example, halide, ${ }^{302}$ triflate ${ }^{453}$ or phosphate ${ }^{454}$ followed by insertion of an olefin into the palladium-carbon bond and then beta-hydride elimination to produce a $\mathrm{PdHX}(\mathrm{L})_{2}$ or $\mathrm{PdHXL}$ intermediate. One mol of base is required for every mol of substrate since $\mathrm{HX}$ (e.g. HOTf or $\mathrm{HBr}$ ) is eliminated. When $\mathrm{L}$ is an trialkylphosphine or $\mathrm{NHC}{ }^{455}$ the $\mathrm{p} K_{\mathrm{a}}{ }_{\mathrm{a}}^{\mathrm{LAC}}$ of the hydride intermediates is the range $30-40$ yet these hydrides reductively eliminate in the presence of a base such as $\mathrm{NCy}_{2} \mathrm{Me}\left(\mathrm{p} K_{\mathrm{a}}{ }^{\mathrm{LAC}} 13\right)$ for phosphine complexes ${ }^{302}$ and carbonate (in DMF) for NHC complexes. ${ }^{455}$ The formation of a cationic palladium hydride intermediate such as $\left[\mathrm{PdHL}_{2}\right]^{+}$before the deprotonation step could explain this discrepancy. ${ }^{451}$ In agreement with the cationic hydride idea, a palladium hydride complex $[\mathrm{PdH}(\mathrm{P}-\mathrm{O}-\mathrm{P})]^{+}\left(\mathrm{p} K_{\mathrm{a}}^{\mathrm{LAC}} 14\right)$ was shown to undergo deprotonation in DCM by DBU followed by immediate oxidative addition of a Ph-P=O bond. ${ }^{456}$ It is notable that the phosphazene base $\mathrm{P}_{2} \mathrm{Et}$ with $\mathrm{p} K_{\mathrm{a}}{ }^{\mathrm{MeCN}} 32.9$ is very useful for promoting Heck coupling reactions at room temperature. ${ }^{457}$ Theoretical work suggests that the equivalent nickel hydride intermediates in Heck-type reactions are much less acidic. ${ }^{458}$ Thus the development of nickel catalyzed Heck reactions that are thought to involve the deprotonation of cationic intermediates such as $\left[\mathrm{Ni}(\text { olefin) }(\mathrm{dppf})(\mathrm{H})]^{+}\left(\mathrm{p} K_{\mathrm{a}}{ }^{\mathrm{LAC}} 4\right)\right.$ in dioxane by $\mathrm{NC}_{2} \mathrm{Me}$ makes sense. ${ }^{300}$

\subsubsection{Other catalytic processes}

Platinum(0) diphosphine complexes can catalyze the hydrophosphination of activated olefins in the presence of water or tert-butanol. ${ }^{459}$ The role of the reagent $\mathrm{YOH}$ is to protonate the Michael adduct of a platinum phosphide and the olefin and then deprotonate the cationic hydride that is created (Figure 
80). The $\mathrm{p} K_{\mathrm{a}}^{\mathrm{LAC}}$ of $\left[\mathrm{Pt}(\mathrm{meDuphos})\left(\mathrm{PR}_{3}\right) \mathrm{H}\right]^{+}$is 16 so that alkoxide or hydroxide is strong enough to deprotonate this hydride.

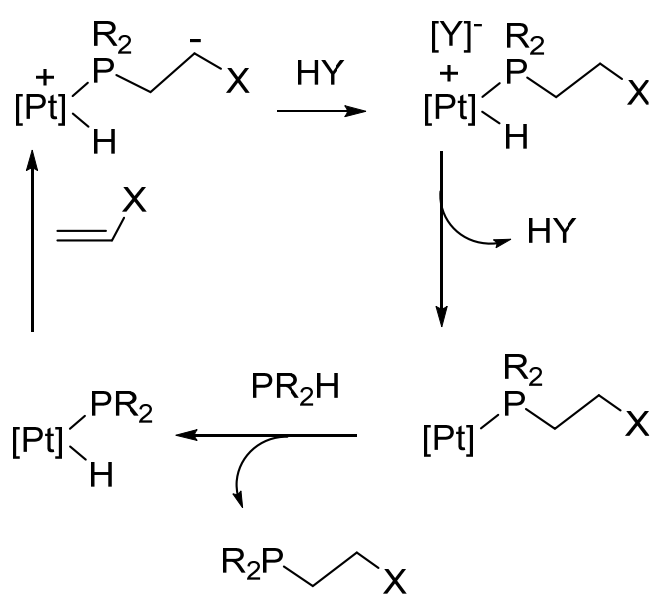

Figure 80. Proposed mechanism for the hydrophosphination of olefins ([Pt] $=\mathrm{Pt}(\mathrm{dppe}), X=\mathrm{CO}_{2} \mathrm{R}$ or $\mathrm{CN}, \mathrm{Y}=\mathrm{OH}$ or $\mathrm{O}^{t} \mathrm{Bu}, R=\mathrm{Ph}$ )

The formation of adipic acid from pentenoic acid mixtures is catalyzed by $\mathrm{Pd}(\mathrm{OAc})_{2}$ with a special chelating bis(trialkylphosphine) ligand in $\mathrm{CF}_{3} \mathrm{COOH} .{ }^{460}$ The hydride intermediates $\left[\mathrm{PdH}\left(\mathrm{PR}_{3}\right)_{2}(\mathrm{CO})\right]^{+}\left(\mathrm{pK}_{\mathrm{a}}{ }^{\mathrm{LAC}}\right.$ $6)$ and $\left[\mathrm{PdH}\left(\mathrm{PR}_{3}\right)_{2} \text { (olefin) }\right]^{+}\left(\mathrm{p} K_{\mathrm{a}}{ }^{\mathrm{LAC}} 8\right)$ are implicated in the mechanism. These are appropriate for the acidic conditions of the reaction.

\section{CONCLUSIONS}

A systematic listing of acid-base reactions of transition metal hydride and dihydrogen complexes in solvents of medium to low dielectric constant has provided an improved framework for finding patterns in the relative strengths of the acids and bases. It is possible to rationalize the acid-base behavior of hundreds of these compounds with $\mathrm{p} K_{\mathrm{a}}$ values ranging from -18 to 50 on the basis of simple considerations, predominantly the ligand additivity constant method by use of simple Equation 17 . This method is successful in accounting semiquantitatively for almost all of the acid-base reactions. Ligands that stabilize the negative charge and render the hydride acidic are olefinic, carbonyl, nitrosyl, cyanide and trichlorosilyl groups. In a diamagnetic metal hydride complex, the ligands have the dominant influence on the acidity while the metal mainly contributes a charge effect, a weakening of the acidity of complexes with a $5 \mathrm{~d}$ metal and/or with a $\mathrm{d}^{6}$-octahedral electronic configuration. For example multiple nitrogen donors or trialkylphosphine ligands make the hydride complex weakly acidic. The Fe(0) complex $\mathrm{Fe}\left\{{ }^{\mathrm{t}} \mathrm{BuSi}\left(\mathrm{CH}_{2} \mathrm{PMe}_{2}\right)_{3}\right\}(\mathrm{dmpe})$ with five basic phosphorus donors partially deprotonates the methyl group of ethylacetate in benzene solution to produce $\left[\mathrm{FeH}\left\{{ }^{\mathrm{t}} \mathrm{BuSi}\left(\mathrm{CH}_{2} \mathrm{PMe}_{2}\right)_{3}\right\}(\mathrm{dmpe})\right]\left[\mathrm{CH}_{2} \mathrm{COOEt}\right]$. In contrast five carbonyl ligands make the hydride complex $\left[\operatorname{Re}\left(\mathrm{H}_{2}\right)(\mathrm{CO})_{5}\right] \mathrm{OTf}$ a very strong acid. Accordingly $\mathrm{Re}(\mathrm{H})(\mathrm{CO})_{5}$ is an extremely weak base, only protonated by excess $\mathrm{CF}_{3} \mathrm{SO}_{3} \mathrm{H}$ in fluorobenzene.

The simple LAC method breaks down in certain circumstances. There is poor agreement between the predicted and observed $\mathrm{p} K_{\mathrm{a}}$ for the compound $\left[\mathrm{Os}\left(\mathrm{H}_{2}\right)\left(\mathrm{NH}_{3}\right)_{5}\right]^{2+}$ in methanol and polycarbonyls such as $\mathrm{MH}_{2}(\mathrm{CO})_{4}$ in $\mathrm{MeCN}$. The first compound forms multiple hydrogen bonds between the amine and the solvent, making the amine a stronger donor than calculated using the LAC equation. The small size of the tetracarbonyldihydrides likely results in strong ion-pairing energies for their conjugate base and the additive ligand approach may break down when many $\pi$-acid ligands are present. Refinements on the LAC method may be required to better account for the differences in acidity between $3 d, 4 d$ and $5 d$ elements for transition metal hydride complexes. In addition, for $\mathrm{p} K_{\mathrm{a}}$ values greater than 30 errors arise 
due to extrapolation errors, thermochemical cycle errors, solvent leveling reactions, and cumulative errors in ladders of involving overlapping equilibria with successively less acidic compounds.

Understanding how the acidity of compounds changes from solvent to solvent is very important in order to plan new reactions. This article provides simplified diagrams to make these comparisons for a variety of acids in DMSO, MeCN, THF and DCM that are useful not only for hydride acids but also for acid-base chemistry in general. Some large changes in acidity between solvents and reactions are observed for $\mathrm{OH}$-based acids, especially fluorinated alcohols where differences of up to $25 \mathrm{p} K_{\mathrm{a}}$ units are observed between expected $\mathrm{p} K_{\mathrm{a}}$ and effective $\mathrm{p} K_{\mathrm{a}}$ in THF, DCM or toluene solvents due to ion-pairing and hydrogen-bonding contributions to the equilibrium energy as well as temperature effects.

The LAC method allows the prediction of the thermodynamic site of protonation of a complex at the metal or at a ligand with a basic site such as a pendant amine or pyridyl group. Since metal-ligand bifunctional catalysis often involves the storage of protons on the ligand, this is an important consideration. The $\mathrm{p} K_{\mathrm{a}}$ of dihydrogen as a function of solvent still needs to be established more definitively. Values range from 25 in water to greater than 50 in MeCN and THF.

This framework provides a better understanding of the mechanism of a variety of catalysts including those for the hydrogenation of ketones, aldehydes, imines, carboxylic acids, alkenes, alkynes, for hydrogen/deuterium exchange, for hydrogen oxidation and evolution, for olefin functionalization

and for the hydrogenase enzymes. For example there is a class of acidic hydride complexes with $\mathrm{pK}_{\mathrm{a}}{ }^{\mathrm{LAC}}<$ 5 that catalyze the hydrogenation of ketones by a proton-first, hydride-second reduction mechanism including $\left[\mathrm{Ir}^{\mathrm{II}}\left(\mathrm{H}_{2}\right) \mathrm{Cp}^{*}\left(\mathrm{OH}_{2}\right)_{2}\right]^{2+},(\mathrm{S}, \mathrm{S})-\left[\mathrm{Ru}\left(\mathrm{H}_{2}\right)\left(\right.\right.$ cymene) $\left.\left(\mathrm{NH}_{2} \mathrm{CHPhCHPhNTs}\right)\right] \mathrm{OTf},\left[\mathrm{Ru}\left(\mathrm{H}_{2}\right)(\mathrm{CO})_{2} \mathrm{Cp}^{*}\right]^{+}$, and $\left[\mathrm{W}(\mathrm{H})_{2}(\mathrm{CO})_{2}(\mathrm{Cp})\left(\mathrm{PMe}_{3}\right)\right]^{+}$. For imines reductions, proton-first catalysts with $\mathrm{p} K_{\mathrm{a}}{ }^{\mathrm{LAC}}<12$ include $\left[\operatorname{Re}\left(\mathrm{H}_{2}\right)(\mathrm{CO})_{3}\left(\mathrm{PMe}_{3}\right)_{2}\right] \mathrm{BAr}_{4},\left[\mathrm{Au}\left(\mathrm{H}_{2}\right)\left(\mathrm{PR}_{2} \mathrm{Ar}\right)\right]^{+},\left[\operatorname{Re}\left(\mathrm{H}_{2}\right)(\mathrm{CO})_{2}\left(\mathrm{PMe}_{3}\right)_{3}\right] \mathrm{BAr}_{4}$, $\left[\mathrm{MH}_{2}(\mathrm{NO})(\mathrm{CO})\left(\mathrm{P}^{\mathrm{i} P{ }_{2}} \mathrm{CH}_{2} \mathrm{CH}_{2} \mathrm{PPhCH}_{2} \mathrm{CH}_{2} \mathrm{P}^{\mathrm{i}} \mathrm{Pr}_{2}\right)\right]^{+} \mathrm{M}=\mathrm{Mo}, \mathrm{W},\left[\mathrm{Ru}\left(\mathrm{H}_{2}\right) \text { (cymene)(Tsdpen) }\right]^{+}$and $\left[\mathrm{Ir}\left(\mathrm{H}_{2}\right) \mathrm{H}_{2}\left(\mathrm{PPh}_{3}\right)_{2}(\mathrm{NHC})\right]^{+}$. The LAC method appears to be useful in predicting classes of compounds that are active for these and other catalytic processes.

\section{ABBREVIATIONS}

$A_{L} \quad$ ligand acidity constant for use in the LAC equation (see Section 1)

$\operatorname{Ar}^{\mathrm{F}} \quad$ 3,5-bis(trifluoromethyl)aryl

BDE $\quad \mathrm{M}-\mathrm{H}$ bond dissociation energy

binap $(R, R)$ or $(S, S)$-2,2'-bis(diphenylphosphino)-1,1'-binaphthyl

bpy $2,2^{\prime}$-bipyridine

bpym bipyrimidine

$C_{5 d} \quad$ constant of the LAC equation; $C_{5 d}=2$ for $5 d$ metal hydride, 0 for $4 d$ or $3 d$ metal hydride (see

Section 1)

$\mathrm{C}_{\text {charge }}$ constant of the LAC equation to account for the charge on the conjugate base (see Section 1)

$C_{n d} \quad$ constant of the LAC equation to account for acids with the metal in the $d^{6}$ octahedral electronic configuration ( $C_{n d}=6$, otherwise $C_{n d}=0$ ) (see Section 1)

COD 2,5-cyclooctadiene

$\mathrm{Cp}^{-} \quad$ cyclopentadienide

$\mathrm{Cp}^{*-}$ pentamethylcyclopentadienide

2,2,2-crypt 2,2,2-Cryptand (4,7,13,16,21,24-hexaoxa-1,10-diazabicyclo[8.8.8] hexacosane)

cymene 1-methyl-4-(1-methylethyl)benzene

dach 1,2-transdiamino-cyclohexane

DBU 1,8-diazabicyclo-[5,4,0]-undec-7-ene

$\mathrm{DBU}-\mathrm{H}^{+}$protonated DBU 


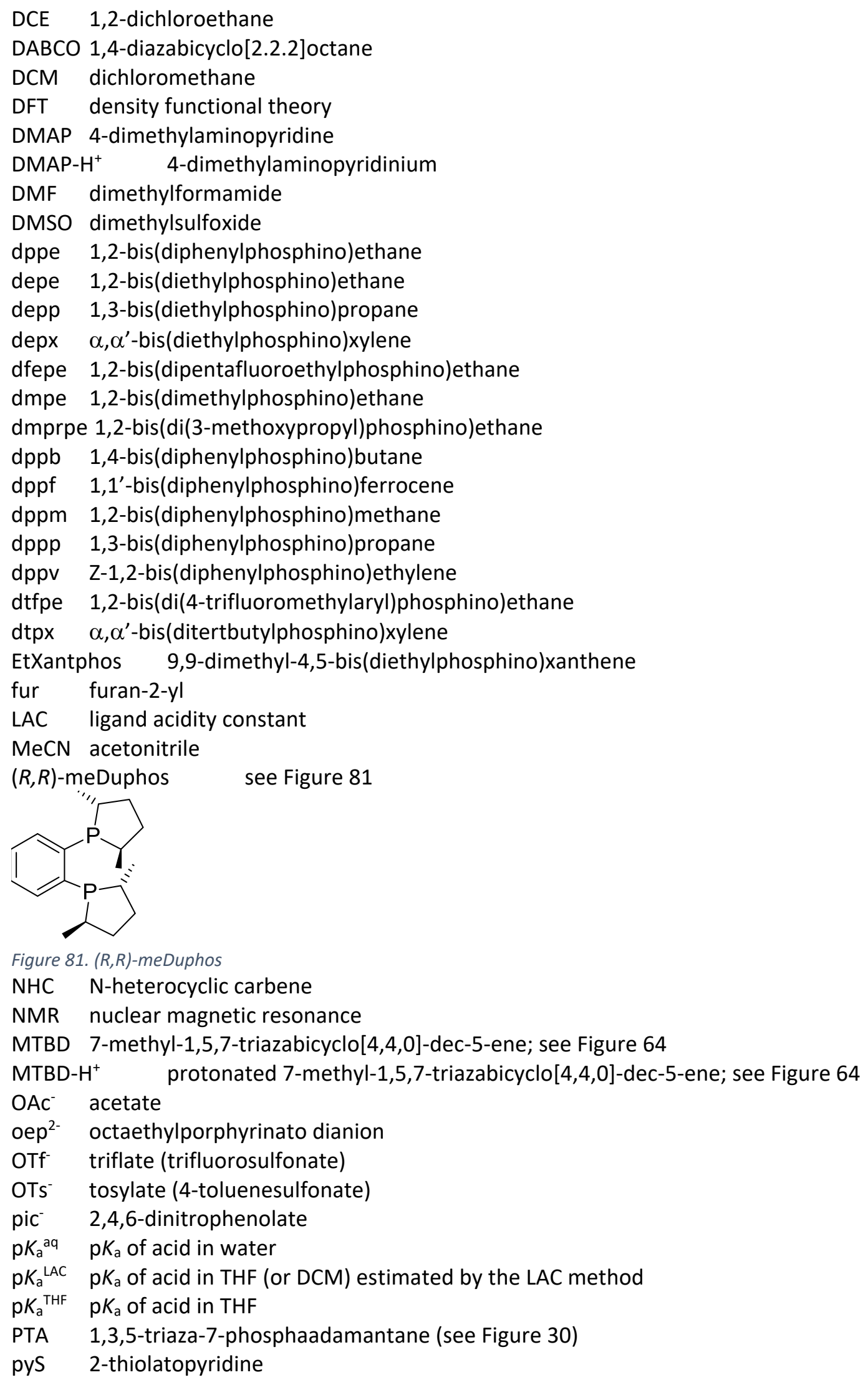


quin- $\mathrm{H}^{+}$protonated quinoline

quins 8-thiolatoquinoline

tacn 1,4,7- triazacyclononane

THF tetrahydrofuran

TMG 1,1,3,3-tetramethylguanidine

TMG-H $\mathrm{H}^{+}$1,1,3,3-tetramethylguanidinium

$\mathrm{Tp}^{-} \quad$ Hydridotris(pyrazolyl)borate

TPPMS-Na (3-sodiumsulfonatophenyl)diphenylphosphine

TPPTS-Na tris(3-sodiumsulfonatophenyl)phosphine (see Figure 30)

tpy terpyridine (2,6-bis(2-pyridyl)pyridine)

TRIP 2,4,6-tris(isopropyl)phenyl

UV ultraviolet

\section{AUTHOR INFORMATION}

\subsection{Corresponding Author}

*E-mail: rmorris@chem.utoronto.ca

\subsection{Notes}

The author declares no competing financial interest.

\subsection{Biography}

Prof. Robert H. Morris was born in Ottawa in 1952. He received his Ph.D. from the University of British Columbia in 1978 and held a NATO postdoctoral position at the AFRC Unit of Nitrogen Fixation, Sussex, U.K., and an NSERC postdoctoral position at the Pennsylvania State University before accepting a position of Assistant Professor at the University of Toronto in 1980 . He is currently Professor of Chemistry, a Fellow of the Royal Society of Canada and of the Chemical Institute of Canada. He served as Acting Chair, Interim Chair and then Chair of the Chemistry Department from 2008 to 2013. He is the recipient of the following awards and honors: the Rutherford Medal from the RSC, the Alcan Lecture Award from the CIC and the Award for Pure and Applied Inorganic Chemistry from the Canadian Society for Chemistry, Advisory Boards of Canadian Journal of Chemistry, 1996-1998; Journal of the Chemical Society, Dalton Transactions, 1997-2000; Fellow of the Royal Society of Canada, 2005; Dean's Excellence award 2009, 2010-2012, 2015; Honorary Professor, Beijing University of Chemical Technology, 2013; 2015 Killam Research Fellow (2015-2017) awarded to six scholars in Canada in any field. He has had published more than 210 journal articles and 10 book chapters. Four of his inventions are protected by national and international patents with three others pending. His research interests include organometallic chemistry and catalysis, particularly involving the iron group elements.

\section{ACKNOWLEDGMENTS}

I thank NSERC Canada for a Discovery Grant and the Canada Council for the Arts for a Killam Research Fellowship. 


\section{SUPPORTING MATERIAL}

Excel table showing calculations.

\section{REFERENCES}

(1) Kristjánsdóttir, S. S.; Norton, J. R. Acidity of Hydrido Transition Metal Complexes in Solution. In Transition Metal Hydrides. Recent Advances in Theory and Experiment; Dedieu, A., Ed.; VCH: New York, 1992, 309-359.

(2) Hu, Y.; Norton, J. R. Kinetics and Thermodynamics of $\mathrm{H}^{-} / \mathrm{H}^{\prime} / \mathrm{H}^{+}$Transfer From a Rhodium(III) Hydride. J. Am. Chem. Soc. 2014, 136, 5938-5948.

(3) Pearson, R. G. The Transition-metal-hydrogen Bond. Chem. Rev. 1985, 85, 41-49.

(4) Heinekey, D. M.; Oldham, W. J. J. Coordination Chemistry of Dihydrogen. Chem. Rev. 1993, 93, 913926.

(5) Jessop, P. G.; Morris, R. H. Reactions of Transition Metal Dihydrogen Complexes. Coord. Chem. Rev. 1992, 121, 155-284.

(6) Jia, G.; Lau, C. P. Structural, Acidity and Chemical Properties of Some Dihydrogen/hydride Complexes of Group 8 Metals with Cyclopentadienyls and Related Ligands. Coord. Chem. Rev. 1999, 190-192, 83108.

(7) Abdur-Rashid, K.; Fong, T. P.; Greaves, B.; Gusev, D. G.; Hinman, J. G.; Landau, S. E.; Lough, A. J.; Morris, R. H. An Acidity Scale in THF for Phosphorus-containing Compounds Including Metal Hydrides and Dihydrogen Complexes: Toward the Unification of Acidity Scales. J. Am. Chem. Soc. 2000, 122, 91559171.

(8) Morris, R. H. Estimating the Acidity of Transition Metal Hydride and Dihydrogen Complexes by Adding Ligand Acidity Constants. J. Am. Chem. Soc. 2014, 136, 1948-1959.

(9) Morris, R. H. Non-classical Hydrogen Bonding Along the Pathway to the Heterolytic Splitting of Dihydrogen In Recent Advances in Hydride Chemistry; Peruzzini, M., Poli, R., Eds.; Elsevier, 2001, 1-38.

(10) Morris, R. H.; Sawyer, J. F.; Shiralian, M.; Zubkowski, J. Two Molecular Hydrogen Complexes: Trans$\left[\mathrm{M}\left(\eta^{2}-\mathrm{H}_{2}\right)(\mathrm{H})\left(\mathrm{PPh}_{2} \mathrm{CH}_{2} \mathrm{CH}_{2} \mathrm{PPh}_{2}\right)_{2}\right] \mathrm{BF}_{4}(\mathrm{M}=\mathrm{Fe}, \mathrm{Ru})$. the Crystal Structure Determination of the Iron Complex. J. Am. Chem. Soc. 1985, 107, 5581-5582.

(11) Crabtree, R. H.; Lavin, M. [IrH $\left.\mathrm{Ir}_{2}\left(\mathrm{H}_{2}\right)_{2} \mathrm{~L}_{2}\right]^{+}\left\{\mathrm{L}=\mathrm{P}\left(\mathrm{C}_{6} \mathrm{H}_{11}\right)_{3}\right\}$ : a Non-classical Polyhydride Complex. J. Chem. Soc., Chem. Commun. 1985, 1661-1662.

(12) Bordwell, F. B. Equilibrium Acidities in Dimethylsulfoxide Solutions. Acc. Chem. Res. 1988, 21, 456463.

(13) Facchetti, A.; Kim, Y.-J.; Streitwieser, A. Comparisons of Ion Pair Acidities of Some Acidic Carbon Acids. J. Org. Chem. 2000, 65, 4195-4197.

(14) Streitwieser, A.; Kim, Y.-J. Ion Pair Basicity of Some Amines in THF: Implications for Ion Pair Acidity Scales. J. Am. Chem. Soc. 2000, 122, 11783-11786.

(15) Izutsu, K. Acid-base Dissociation Constants in Dipolar Aprotic Solvents; Blackwell Scientific Publications vol 35: Oxford, 1990.

(16) Kaljurand, I.; Kütt, A.; Sooväli, L.; Rodima, T.; Mäemets, V.; Leito, I.; Koppel, I. A. Extension of the Self-consistent Spectrophotometric Basicity Scale in Acetonitrile to a Full Span of 28 pKa Units:

Unification of Different Basicity Scales. J. Org. Chem. 2005, 70, 1019-1028.

(17) Garrido, G.; Koort, E.; Rafols, C.; Bosch, E.; Rodima, T.; Leito, I.; Roses, M. Acid-base Equilibria in Nonpolar Media. Absolute pKa Scale of Bases in Tetrahydrofuran. J. Org. Chem. 2006, 71, 9062-9067. (18) Antipin, I. S.; Gareyev, R. F.; Vedernikov, A. N.; Konovalov, A. I. Cryptate Acidity Scales. Solvent Polarity Effect on Ion-Pair and Free-Ion Acidity of Organic Compounds. J. Phys. Org. Chem. 1994, 7, 181191. 
(19) Hanckel, J. M.; Darensbourg, M. Y. Anion-assisted Transfer of a Sterically Constrained Proton. J. Am. Chem. Soc. 1983, 105, 6979-6980.

(20) Stephan, D. W.; Erker, G. Frustrated Lewis Pairs: Metal-free Hydrogen Activation and More. Angew. Chem., Int. Ed. 2009, 49, 46-76.

(21) Stephan, D. W.; Greenberg, S.; Graham, T. W.; Chase, P.; Hastie, J. J.; Geier, S. J.; Farrell, J. M.; Brown, C. C.; Heiden, Z. M.; Welch, G. C.; Ullrich, M. Metal-free Catalytic Hydrogenation of Polar Substrates by Frustrated Lewis Pairs. Inorg. Chem. 2011, 50, 12338-12348.

(22) Welch, G. C.; Cabrera, L.; Chase, P. A.; Hollink, E.; Masuda, J. D.; Wei, P. R.; Stephan, D. W. Tuning Lewis Acidity Using the Reactivity of "Frustrated Lewis Pairs": Facile Formation of Phosphine-boranes and Cationic Phosphonium-boranes. Dalton Trans. 2007, 3407-3414.

(23) Welch, G. C.; Juan, R. R. S.; Masuda, J. D.; Stephan, D. W. Reversible, Metal-Free Hydrogen Activation. Science 2006, 314, 1124-1126.

(24) Stephan, D. W. Frustrated Lewis Pairs: From Concept to Catalysis. Acc. Chem. Res. 2015, 48, 306316.

(25) Laurie, J. C. V.; Duncan, L.; Haltiwanger, R. C.; Weberg, R. T.; Rakowski Dubois, M. Activation of Hydrogen by Cationic Cyclopentadienyl Molybdenum Dimers with Sulfido Ligands. 1. Cationic Complexes Derived Form Protonation of 1,2-Alkenedithiolate Ligands. J. Am. Chem. Soc. 1986, 108, 6234-6241.

(26) Kolthoff, I. M. Acid-Base Equilibria in Dipolar Aprotic Solvents. Anal. Chem. 1974, 46, 1992-2003.

(27) Streitwieser, A. Carbanion Ion-pairs and Triplets. Acc. Chem. Res. 1984, 17, 353-357.

(28) Li, T.; Lough, A. J.; Morris, R. H. An Acidity Scale of Tetrafluoroborate Salts of Phosphonium and Iron Hydride Compounds in Dichloromethane-d 2 . Chem. - Eur. J. 2007, 13, 3796-3803.

(29) Angelici, R. J. Transition Metal Complex Basicities From Studies of Their Heats of Protonation: a Guide to Complex Reactivity. Acc. Chem. Res. 1995, 28, 51-60.

(30) Chinn, M. S.; Heinekey, D. M. Dihydrogen Complexes of Ruthenium. 2. Kinetic and Thermodynamic Considerations Affecting Product Distribution. J. Am. Chem. Soc. 1990, 112, 5166-5175.

(31) Qi, X.-J.; Liu, L.; Fu, Y.; Guo, Q.-X. Ab Initio Calculations of pKa Values of Transition-Metal Hydrides in Acetonitrile. Organometallics 2006, 25, 5879-5886.

(32) Chen, S.; Rousseau, R.; Raugei, S.; Dupuis, M.; DuBois, D. L.; Bullock, R. M. Comprehensive Thermodynamics of Nickel Hydride Bis(diphosphine) Complexes: a Predictive Model Through Computations. Organometallics 2011, 30, 6108-6118.

(33) Raugei, S.; DuBois, D. L.; Rousseau, R.; Chen, S. T.; Ho, M. H.; Bullock, R. M.; Dupuis, M. Toward Molecular Catalysts by Computer. Acc. Chem. Res. 2015, 48, 248-255.

(34) Huynh, M. T.; Wang, W.; Rauchfuss, T. B.; Hammes-Schiffer, S. Computational Investigation of [FeFe]-hydrogenase Models: Characterization of Singly and Doubly Protonated Intermediates and Mechanistic Insights. Inorg. Chem. 2014, 53, 10301-10311.

(35) Xu, Z.; Bytheway, I.; Jia, G.; Lin, Z. Theoretical Studies of the Acidity of the Dihydrogen Complexes Trans-[LM( $\left.\left.\mathrm{H}_{2} \mathrm{PCH}_{2} \mathrm{CH}_{2} \mathrm{PH}_{2}\right)_{2}\left(\eta^{2}-\mathrm{H}_{2}\right)\right]^{\mathrm{n}+}$. Organometallics 1999, 18, 1761-1766.

(36) Kaljurand, I.; Rodima, T.; Leito, I.; Koppel, I. A.; Schwesinger, R. Self-Consistent Spectrophotometric Basicity Scale in Acetonitrile Covering the Range Between Pyridine and DBU. J. Org. Chem. 2000, 65, 6202-6208.

(37) Schwesinger, R.; Schlemper, H.; Hasenfratz, C.; Willaredt, J.; Dambacher, T.; Breuer, T.; Ottaway, C.; Fletschinger, M.; Boele, J.; Fritz, H.; Putzas, D.; Rotter, H. W.; Bordwell, F. G.; Satish, A. V.; Ji, G. Z.; Peters, E. M.; Peters, K.; von Schnering, H. G.; Walz, L. Extremely Strong, Uncharged Auxiliary Bases; Monomeric and Polymer-supported Polyaminophosphazenes $\left(P_{2}-P_{5}\right)$. Liebigs Ann. 1996, 1055-1081. (38) Leito, I.; Kaljurand, I.; Koppel, I. A.; Yagupolskii, L. M.; Vlasov, V. M. Spectrophotometric Acidity Scale of Strong Neutral Bronsted Acids in Acetonitrile. J. Org. Chem. 1998, 63, 7868-7874.

(39) Estes, D. P.; Vannucci, A. K.; Hall, A. R.; Lichtenberger, D. L.; Norton, J. R. Thermodynamics of the Metal-Hydrogen Bonds in $\left(\eta^{5}-\mathrm{C}_{5} \mathrm{H}_{5}\right) \mathrm{M}(\mathrm{CO})_{2} \mathrm{H}(\mathrm{M}=\mathrm{Fe}, \mathrm{Ru}, \mathrm{Os})$. Organometallics 2011, 30, 3444-3447. 
(40) Papish, E. T.; Rix, F. C.; Spetseris, N.; Norton, J. R.; Williams, R. D. Protonation of CpW $(\mathrm{CO})_{2}\left(\mathrm{PMe}_{3}\right) \mathrm{H}$ : Is the Metal or the Hydride the Kinetic Site? J. Am. Chem. Soc. 2000, 122, 12235-12242.

(41) Levina, V. A.; Filippov, O. A.; Gutsul, E. I.; Belkova, N. V.; Epstein, L. M.; Lledós, A.; Shubina, E. S. Neutral Transition Metal Hydrides as Acids in Hydrogen Bonding and Proton Transfer: Media Polarity and Specific Solvation Effects. J. Am. Chem. Soc. 2010, 132, 11234-11246.

(42) Belkova, N. V.; Epstein, L. M.; Shubina, E. S. Dihydrogen Bonding, Proton Transfer and Beyond: What We Can Learn From Kinetics and Thermodynamics. Eur. J. Inorg. Chem. 2010, 3555-3565.

(43) Ryan, O. B.; Tilset, M.; Parker, V. D. Chemical and Electrochemical Oxidation of Group-6 Cyclopentadienylmetal Hydrides - 1st Estimates of 17-Electron Metal Hydride Cation Radical Thermodynamic Acidities and Their Decomposition to 17-Electron Neutral Radicals. J. Am. Chem. Soc. 1990, 112, 2618-2626.

(44) Ciancanelli, R.; Noll, B. C.; DuBois, D. L.; Rakowski-DuBois, M. Comprehensive Thermodynamic Characterization of the Metal-hydrogen Bond in a Series of Cobalt-hydride Complexes. J. Am. Chem. Soc. 2002, 124, 2984-2992.

(45) DuBois, M. R.; DuBois, D. L. The Roles of the First and Second Coordination Spheres in the Design of Molecular Catalysts for $\mathrm{H}_{2}$ Production and Oxidation. Chem. Soc. Rev. 2009, 38, 62-72.

(46) Tilset, M.; Parker, V. D. Solution Homolytic Bond Dissociation Energies of Organotransition-Metal Hydrides. J. Am. Chem. Soc. 1989, 111, 6711-6717.

(47) Kisanga, P. B.; Verkade, J. G.; Schwesinger, R. pK $K_{a}$ Measurements of $\mathrm{P}\left(\mathrm{RNCH}_{2} \mathrm{CH}_{3}\right)_{3} \mathrm{~N}$. J. Org. Chem. 2000, 65, 5431-5432.

(48) Schwesinger, R.; Hasenfratz, C.; Schlemper, H.; Walz, L.; Peters, E.-M.; Peters, K.; von Schnering, H. G. How Strong and How Hindered Can Uncharged Phosphazene Bases Be? Angew. Chem., Int. Ed. 1993, 32, 1361-1363.

(49) Kolthoff, I. M.; Chantooni, M. K.; Bhowmik, S. Dissociation Constants of Uncharged and Monovalent Cation Acids in Dimethyl Sulfoxide. J. Am. Chem. Soc. 1968, 90, 23-28.

(50) Garrido, G.; Rosés, M.; Rāfols, C.; Bosch, E. Acidity of Several Anilinium Derivatives in Pure Tetrahydrofuran. J. Solution Chem. 2008, 37, 689-700.

(51) Moore, E. J.; Sullivan, J. M.; Norton, J. R. Kinetic and Thermodynamic Acidity of Hydrido TransitionMetal Complexes. 3. Thermodynamic Acidity of Common Mononuclear Carbonyl Hydrides. J. Am. Chem. Soc. 1986, 108, 2257-2263.

(52) Lounissi, S.; Zampella, G.; Capon, J. F.; De Gioia, L.; Matoussi, F.; Mahfoudhi, S.; Petillon, F. Y.; Schollhammer, P.; Talarmin, J. Electrochemical and Theoretical Investigations of the Role of the Appended Base on the Reduction of Protons by $\left[\mathrm{Fe}_{2}(\mathrm{CO})_{4}\left(\kappa^{2}-\mathrm{PNP} \mathrm{R}^{\mathrm{R}}\right)\left(\mu-\mathrm{S}\left(\mathrm{CH}_{2}\right)_{3} \mathrm{~S}\right]\left(\mathrm{PNP} \mathrm{P}^{\mathrm{R}}=\left\{\mathrm{Ph}_{2} \mathrm{PCH}\right\}_{2} \mathrm{NR}, \mathrm{R}=\right.\right.$ $\mathrm{Me}, \mathrm{Ph})$. Chem. - Eur. J. 2012, 18, 11123-11138.

(53) Smith, K. T.; Norton, J. R.; Tilset, M. Single-step Hydride Transfer From $\mathrm{CpMo}(\mathrm{CO})_{2}\left(\mathrm{PPh}_{3}\right) \mathrm{H}$ to Protonated Ketones. Organometallics 1996, 15, 4515-4520.

(54) Connelly, S. J.; Wiedner, E. S.; Appel, A. M. Predicting the Reactivity of Hydride Donors in Water: Thermodynamic Constants for Hydrogen. Dalton Trans. 2015, 44, 5933-5938.

(55) Rondinini, S.; Longhi, P.; Mussini, P. R.; Mussini, T. Autoprotolysis Constants in Nonaqueous Solvents and Aqueous Organic Solvent Mixtures. Pure Appl. Chem. 1987, 59, 1693-1702.

(56) Olmstead, W. N.; Margolin, Z.; Bordwell, F. G. Acidities of Water and Simple Alcohols in Dimethyl Sulfoxide Solution. J. Org. Chem. 1980, 45, 3295-3299.

(57) Felton, G. A. N.; Vannucci, A. K.; Okumura, N.; Lockett, L. T.; Evans, D. H.; Glass, R. S.; Lichtenberger, D. L. Hydrogen Generation From Weak Acids: Electrochemical and Computational Studies in the [ $\left(\eta^{5}-\right.$ $\left.\left.\mathrm{C}_{5} \mathrm{H}_{5}\right) \mathrm{Fe}(\mathrm{CO})_{2}\right]_{2}$ System. Organometallics 2008, 27, 4671-4679.

(58) Rossin, A.; Gutsul, E. I.; Belkova, N. V.; Epstein, L. M.; Gonsalvi, L.; Lledós, A.; Lyssenko, K. A.; Peruzzini, M.; Shubina, E. S.; Zanobini, F. Mechanistic Studies on the Interaction of $\left[\left(\kappa^{3}-\mathrm{P}, \mathrm{P}, \mathrm{P}-\mathrm{NP}_{3}\right) \mid \mathrm{rH}_{3}\right]$ 
$\left[\mathrm{NP}_{3}=\mathrm{N}\left(\mathrm{CH}_{2} \mathrm{CH}_{2} \mathrm{PPh}_{2}\right)_{3}\right]$ with $\mathrm{HBF}_{4}$ and Fluorinated Alcohols by Combined NMR, IR, and DFT Techniques. Inorg. Chem. 2010, 49, 4343-4354.

(59) Belkova, N. V.; Collange, E.; Dub, P.; Epstein, L. M.; Lemenovskii, D. A.; Lledós, A.; Maresca, O.; Maseras, F.; Poli, R.; Revin, P. O.; Shubina, E. S.; Vorontsov, E. V. Experimental and Computational Studies of Hydrogen Bonding and Proton Transfer to Cp*Fe(dppe)H. Chem. - Eur. J. 2005, 11, 873-888.

(60) Kolthoff, I. M.; Jr, C. M. K. Protonation Constants of Very Weak Uncharged Bases in Acetonitrile. J. Am. Chem. Soc. 1973, 95, 8539-8546.

(61) Donghi, D.; Beringhelli, T.; D'Alfonso, G.; Mondini, M. NMR Investigation of the Dihydrogen-bonding and Proton-transfer Equilibria Between the Hydrido Carbonyl Anion $\left[\mathrm{HRe}_{2}(\mathrm{CO})_{9}\right]^{-}$and Fluorinated Alcohols. Chem. - Eur. J. 2006, 12, 1016-1025.

(62) Felton, G. A. N.; Glass, R. S.; Lichtenberger, D. L.; Evans, D. H. Iron-only Hydrogenase Mimics. Thermodynamic Aspects of the Use of Electrochemistry to Evaluate Catalytic Efficiency for Hydrogen Generation. Inorg. Chem. 2006, 45, 9181-9184.

(63) Barton, B. E.; Rauchfuss, T. B. Hydride-Containing Models for the Active Site of the Nickel-Iron Hydrogenases. J. Am. Chem. Soc. 2010, 132, 14877-14885.

(64) Kolthoff, I. M.; Jr., M. K. C.; Bhowmik, S. Acid-Base Properties of Mono- and Dinitrophenols in Acetonitrile. J. Am. Chem. Soc. 1966, 88, 5430-5440.

(65) Shubina, E. S.; Belkova, N. V.; Bakhmutova, E. V.; Vorontsov, E. V.; Bakhmutov, V. I.; lonidis, A. V.; Bianchini, C.; Marvelli, L.; Peruzzini, M.; Epstein, L. M. In-situ IR and NMR Study of the Interactions Between Proton Donors and the Re(I) Hydride Complex $\left[\left(\mathrm{MeC}\left(\mathrm{CH}_{2} \mathrm{PPh}_{2}\right)_{3}\right) \operatorname{Re}(\mathrm{CO})_{2} \mathrm{H}\right]$. ReH...H Bonding and Proton-transfer Pathways. Inorg. Chim. Acta 1998, 280, 302-307.

(66) Gloaguen, F.; Lawrence, J.; Rauchfuss, T.; Benard, M.; Rohmer, M.-M. Bimetallic Carbonyl Thiolates as Functional Models for Fe-Only Hydrogenases. Inorg. Chem. 2002, 41, 6573-6582.

(67) Streitwieser, A.; Ciuffarin, E.; Hammons, J. H. Acidity of Hydrocarbons. 22. Relative Equilibrium Acidities of Hydrocarbons Toward Cesium Cylcohexylamide. J. Am. Chem. Soc. 1967, 89, 63-67.

(68) Raebiger, J. W.; L., D. D. Thermodynamic Studies of $\mathrm{HRh}(\operatorname{depx})_{2}$ and $\left[(\mathrm{H})_{2} \mathrm{Rh}(\operatorname{depx})_{2}\right]\left(\mathrm{CF}_{3} \mathrm{SO}_{3}\right)$ : Relationships Between Five-Coordinate Monohydrides and Six-Coordinate Dihydrides. Organometallics 2005, 34, 110-118.

(69) Kelly, C. A.; Mulazzani, Q. G.; Venturi, M.; Blinn, E. L.; Rodgers, M. A. J. The Thermodynamics and Kinetics of $\mathrm{CO}_{2}$ and $\mathrm{H}^{+}$Binding to Ni(cyclam) ${ }^{+}$in Aqueous Solution. J. Am. Chem. Soc. 1995, 117, 49114919.

(70) Ellis, J. W.; Harrison, K. N.; Hoye, P. A. T.; Orpen, A. G.; Pringle, P. G.; Smith, M. B. Water-soluble Tris(hydroxymethyl)phosphine Complexes with Nickel, Palladium, and Platinum. Crystal Structure of $\left[\mathrm{Pd}\left\{\mathrm{P}\left(\mathrm{CH}_{2} \mathrm{OH}\right)_{3}\right\}_{4}\right] . \mathrm{CH}_{3} \mathrm{OH}$. Inorg. Chem. 1992, 31, 3026-3033.

(71) Helfer, D. S.; Atwood, J. D. Interconversion Between Platinum(II) and Platinum(0) with Change of $\mathrm{pH}$ : Aqueous Reactions of Pt(H)(TPPTS $)_{3}{ }^{+}\left(\right.$TPPTS $\left.=\mathrm{P}\left(\mathrm{m}-\mathrm{C}_{6} \mathrm{H}_{4} \mathrm{SO}_{3} \mathrm{Na}\right)_{3}\right)$. Organometallics 2002, 21, 250252.

(72) Frost, B. J.; Mebi, C. A. Aqueous Organometallic Chemistry: Synthesis, Structure, and Reactivity of the Water-Soluble Metal Hydride CpRu(PTA) $2 \mathrm{H}$. Organometallics 2004, 23, 5317-5323.

(73) Bakac, A. Aqueous Rhodium(III) Hydrides and Mononuclear Rhodium(II) Complexes. Dalton Trans. 2006, 1589-1596.

(74) Grundler, P. V.; Yazyev, O. V.; Aebischer, N.; Helm, L.; Laurenczy, G.; Merbach, A. E. Kinetic Studies on the First Dihydrogen Aquacomplex, $\mathrm{Ru}\left(\mathrm{H}_{2}\right)\left(\mathrm{H}_{2} \mathrm{O}\right)_{5}{ }^{2+}$ : Formation Under $\mathrm{H}_{2}$ Pressure and Catalytic H/D Isotope Exchange in Water. Inorg. Chim. Acta 2006, 359, 1795-1806.

(75) Carriker, J. L.; Wagenknecht, P. S.; Hosseini, M. A.; Fleming, P. E. Transition Metal Catalyzed $\mathrm{D}_{2} / \mathrm{H}_{2} \mathrm{O}$ Exchange: Distinguishing Between the Single and Double Exchange Pathways. J. Mol. Catal. A. 2007, 267, 218-223. 
(76) Lo, H. C.; Iron, M. A.; Martin, J. M. L.; Keinan, E. Proton Walk in the Aqueous Platinum Complex [TpPtMeCO] via a Sticky S-methane Ligand. Chem. - Eur. J. 2007, 13, 2812-2823.

(77) Kure, B.; Matsumoto, T.; Ichikawa, K.; Fukuzumi, S.; Higuchi, Y.; Yagi, T.; Ogo, S. pH-dependent Isotope Exchange and Hydrogenation Catalysed by Water-soluble NiRu Complexes as Functional Models for NiFe Hydrogenases. Dalton Trans. 2008, 4747-4755.

(78) Szymczak, N. K.; Tyler, D. R. Aspects of Dihydrogen Coordination Chemistry Relevant to Reactivity in Aqueous Solution. Coord. Chem. Rev. 2008, 252, 212-230.

(79) Himeda, Y.; Miyazawa, S.; Onozawa-Komatsuzaki, N.; Hirose, T.; Kasuga, K. Catalytic (transfer) Deuterogenation in $\mathrm{D}_{2} \mathrm{O}$ as Deuterium Source with $\mathrm{H}_{2}$ and $\mathrm{HCO}_{2} \mathrm{H}$ as Electron Sources. Dalton Trans. 2009, 6286-6288.

(80) Bhagan, S.; Wayland, B. B. Formation and Reactivity of a Porphyrin Iridium Hydride in Water: Acid Dissociation Constants and Equilibrium Thermodynamics Relevant to $\mathrm{Ir}-\mathrm{H}$, $\mathrm{Ir}-\mathrm{OH}$, and $\mathrm{Ir}-\mathrm{CH}_{2}-\mathrm{Bond}$ Dissociation Energetics. Inorg. Chem. 2011, 50, 11011-11020.

(81) Brewster, T. P.; Ou, W. C.; Tran, J. C.; Goldberg, K. I.; Hanson, S. K.; Cundari, T. R.; Heinekey, D. M. Iridium, Rhodium, and Ruthenium Catalysts for the "Aldehyde-Water Shift" Reaction. ACS Catal. 2014, 4, 3034-3038.

(82) Gellrich, U.; Khusnutdinova, J. R.; Leitus, G. M.; Milstein, D. Mechanistic Investigations of the Catalytic Formation of Lactams From Amines and Water with Liberation of $\mathrm{H}_{2}$. J. Am. Chem. Soc. 2015, 137, 4851-4859.

(83) Lewandowska-Andralojc, A.; Baine, T.; Zhao, X.; Muckerman, J. T.; Fujita, E.; Poyansky, D. E. Mechanistic Studies of Hydrogen Evolution in Aqueous Solution Catalyzed by a Tertpyridine-Amine Cobalt Complex. Inorg. Chem. 2015, 54, 4310-4321.

(84) Kelly, C. A.; Rosseinsky, D. R. Estimates of Hydride lon Stability in Condensed Systems: Energy of Formation and Solvation in Aqueous and Polar-organic Solvents. Phys. Chem. Chem. Phys. 2001, 3, 20862090.

(85) Hammud, H. H.; George, T. A.; Kurk, D. N.; Shoemaker, R. K. Synthesis and Characterization of Arene, Mono- and Dihydrido-arene, Monohydrido-cyclopentadienyl, and Phosphite Complexes of Molybdenum Containing the Tridentate Ligand PhP( $\left.\mathrm{CH}_{2} \mathrm{CH}_{2} \mathrm{PPh}_{2}\right)_{2}$. Inorg. Chim. Acta 1998, 281, 153-159. (86) Yarrow, P.; Ford, P. C. The Nature of Mononuclear Ruthenium Carbonyl Complexes in Strongly Acidic Solutions. J. Organometal. Chem. 1981, 214, 115-118.

(87) Drews, T.; Rusch, D.; Seidel, S.; Willemsen, S.; Seppelt, K. Systematic Reactions of Pt $\left(\mathrm{PF}_{3}\right)_{4}$. Chem. Eur. J. 2008, 14, 4280-4286.

(88) Sipos, G.; Drinkel, E. E.; Dorta, R. The Emergence of Sulfoxides as Efficient Ligands in Transition Metal Catalysis. Chem. Soc. Rev. 2015, 44, 3834-3860.

(89) Jia, G.; Morris, R. H. Wide Range of pKa Values of Coordinated Dihydrogen. Synthesis and Properties of Some $\eta^{2}$-Dihydrogen and Dihydride Complexes of Ruthenium. J. Am. Chem. Soc. 1991, 113, 875-883.

(90) Jia, G.; Lough, A. J.; Morris, R. H. Synthesis and Kinetic and Thermodynamic Acidity Properties of $\eta^{2}-$ Dihydrogen and Dihydride Complexes of the Type $\left[\mathrm{Ru}\left(\mathrm{C}_{5} \mathrm{Me}_{5}\right) \mathrm{H}_{2} \mathrm{~L}_{2}\right]^{+}$. Crystal Structure of the Complex $\left[\mathrm{Ru}\left(\mathrm{C}_{5} \mathrm{Me}_{5}\right)\left(\eta^{2}-\mathrm{H}_{2}\right)\left(\mathrm{PPh}_{2} \mathrm{CH}_{2} \mathrm{PPh}_{2}\right)\right] \mathrm{BF}_{4}$. Organometallics 1992, 11, 161-171.

(91) Cappellani, E. P.; Drouin, S. D.; Jia, G.; Maltby, P. A.; Morris, R. H.; Schweitzer, C. T. Effect of the Ligand and Metal on the pKa Values of the Dihydrogen Ligand in the Series of Complexes $\left[\mathrm{M}\left(\mathrm{H}_{2}\right) \mathrm{H}(\mathrm{L})_{2}\right]^{+}$, $\mathrm{M}=\mathrm{Fe}, \mathrm{Ru}$, Os Containing Isosteric Ditertiaryphosphine Ligands, L. J. Am. Chem. Soc. 1994, 116, 33753388.

(92) Li, T.; Lough, A. J.; Zuccaccia, C.; Macchioni, A.; Morris, R. H. An Acidity Scale of Phosphonium Tetraphenylborate Salts and Ruthenium Dihydrogen Complexes in Dichloromethane. Can. J. Chem. 2006, 84, 164-175. 
(93) Hinman, J. G.; Lough, A. J.; Morris, R. H. Properties of the Polyhydride Anions $\left[\mathrm{WH}_{5}\left(\mathrm{PMe}_{2} \mathrm{Ph}\right)_{3}\right]^{-}$and $\left[\mathrm{ReH}_{4}\left(\mathrm{PMePh}_{2}\right)_{3}\right]^{-}$and Periodic Trends in the Acidity of Polyhydride Complexes. Inorg. Chem. 2007, 46, 4392-4401.

(94) Fuoss, R. M. Ionic Association. III. the Equilibrium Between Ion Pairs and Free Ions. J. Am. Chem. Soc. 1958, 80, 5059-5061.

(95) Dub, P. A.; Baya, M.; Houghton, J.; Belkova, N. V.; Daran, J.-C.; Poli, R.; Epstein, L. M.; Shubina, E. S. Solvent Control in the Protonation of [Cp* $\left.\mathrm{Mo}(\mathrm{dppe}) \mathrm{H}_{3}\right]$ by $\mathrm{CF}_{3} \mathrm{COOH}$. Eur. J. Inorg. Chem. 2007, 28132826.

(96) Silantyev, G. A.; Filippov, O. A.; Tolstoy, P. M.; Belkova, N. V.; Epstein, L. M.; Weisz, K.; Shubina, E. S. Hydrogen Bonding and Proton Transfer to Ruthenium Hydride Complex CpRuH(dppe): Metal and Hydride Dichotomy. Inorg. Chem. 2013, 52, 1787-1797.

(97) Kütt, A.; Rodima, T.; Saame, J.; Raamat, E.; Mäemets, V.; Kaljurand, I.; Koppel, I. A.; Garlyauskayte, R. Y.; Yagupolskii, Y. L.; Yagupolskii, L. M.; Bernhardt, E.; Willner, H.; Leito, I. Equilibrium Acidities of Superacids. J. Org. Chem. 2011, 76, 391-395.

(98) Buncel, E.; Menon, B. C. Carbanion Mechanisms. 6. Metalation of Arylmethanes by Potassium Hydride/ 18-Crown-6 Ether in Tetrahydrofuran and the Acidity of Hydrogen. J. Am. Chem. Soc. 1977, 99, 4457-4461.

(99) Streitwieser, A.; Murdoch, J. R.; Haefelinger, G.; Chang, C. J. Acidity of Hydrocarbons. XLVI. Equilibrium Ion-pair Acidities of Mono-, Di-, and Triarylmethanes Toward Cesium Cyclohexylamide. J. Am. Chem. Soc. 1973, 95, 4248-4254.

(100) Landau, S. E.; Groh, K. E.; Lough, A. J.; Morris, R. H. Large Effects of Ion Pairing and ProtonicHydridic Bonding on the Stereochemistry and Basicity of Crown-, Azacrown-, and Cryptand-222potassium Salts of Anionic Tetrahydride Complexes of Iridium(III). Inorg. Chem. 2002, 41, 2995-3007. (101) Peterson, T. H.; Golden, J. T.; Bergman, R. G. Deprotonation of the Transition Metal Hydride ( $\eta^{5}$ $\left.\mathrm{CMe}_{5}\right)\left(\mathrm{PMe}_{3}\right) \mid \mathrm{rH}_{2}$. Synthesis and Chemistry of the Strongly Basic Lithium Iridate $\left(\eta^{5}-\right.$ $\left.\mathrm{C}_{5} \mathrm{Me}_{5}\right)\left(\mathrm{PMe}_{3}\right) \mathrm{Ir}(\mathrm{H})(\mathrm{Li})$. Organometallics 1999, 18, 2005-2020.

(102) Ma, K.; Piers, W. E.; Gao, Y.; Parvez, M. Isolation and Characterization of a Monomeric Cationic Titanium Hydride. J. Am. Chem. Soc. 2004, 126, 5668-5669.

(103) Xu, X.; Kehr, G.; Daniliuc, C. G.; Erker, G. Stoichiometric Reactions and Catalytic Hydrogenation with a Reactive Intramolecular $\mathrm{Zr}^{+}$/Amine Frustrated Lewis Pair. J. Am. Chem. Soc. 2015, 137, 4550-4557. (104) Hieber, W.; Winter, E.; Scubert, E. Reaktionen Des Vanadinhexacarbonyls Mit Verschiedenartigen Basen Und Die Säurefunktion Von Vanadincarbonylwasserstoff-Verbindungen, II. Chem. Ber. 1962, 95, 3070-3076.

(105) Antiñolo, A.; Pérez-Flores, J.-C.; Hervás, M. J.; García-Yuste, S.; López-Solera, M. I.; Otero, A.; Fernández-Pacheco, A. R.; Tercero-Morales, M. T. Synthesis and Reactivity of New Niobocene HydrideStibine and Hydride-Stilbene Complexes. X-ray Crystal Structure of $\left[\mathrm{Nb}\left(\eta^{5}-\mathrm{C}_{5} \mathrm{H}_{4} \mathrm{SiMe}_{3}\right)_{2}(\mathrm{H})\left(\mathrm{trans}-\eta^{2}-\mathrm{C}, \mathrm{C}-\right.\right.$ $\mathrm{PhCH}=\mathrm{CHPh}$ )]. Organometallics 2013, 32, 862-868.

(106) Bakhmutova, E. V.; Bakhmutov, V. I.; Belkova, N. V.; Besora, M.; Epstein, L. M.; Lledós, A.; Nikonov, G. I.; Shubina, E. S.; Tomas, J.; Vorontsov, E. V. First Investigation of Non-classical Dihydrogen Bonding Between an Early Transition-metal Hydride and Alcohols: IR, NMR, and DFT Approach. Chem. - Eur. J. 2004, 10, 661-671.

(107) Bullock, R. M.; Song, J. S.; Szalda, D. J. Protonation of Metal-hydrides by Strong Acids. Formation of an Equilibrium Mixture of Dihydride and Dihydrogen Complexes From Protonation of $\mathrm{Cp} * \mathrm{Os}(\mathrm{CO})_{2} \mathrm{H}$. Structural Characterization of $\left[\mathrm{CpW}(\mathrm{CO})_{2}\left(\mathrm{PMe}_{3}\right)(\mathrm{H})_{2}\right]^{+} \mathrm{OTf}$. Organometallics 1996, 15, 2504-2516. (108) McKinley, S. G.; Angelici, R. J.; Choi, M. G. Reactions of Nucleophiles with the Cationic Dicyclopentadienyl-bridged Ditungsten Complex $\left[\left\{\left(\eta^{5}-\mathrm{C}_{5} \mathrm{H}_{3}\right)_{2}\left(\mathrm{SiMe}_{2}\right)_{2}\right\} \mathrm{W}_{2}(\mathrm{CO})_{6}(\mu-\mathrm{H})\right]^{+}$. Organometallics 2002, 21, 1235-1239. 
(109) Alvarez, M. A.; Garcia, M. E.; Martinez, M. E.; Ramos, A.; Ruiz, M. A.; Saez, D.; Vaissermann, J. M-P Versus $M=M$ Bonds as Protonation Sites in the Organophosphide-bridged Complexes $\left[\mathrm{M}_{2} \mathrm{Cp}_{2}\left(\mu-\mathrm{PR}_{2}\right)(\mu-\right.$ $\left.\mathrm{PR}_{2}{ }_{2}\right)(\mathrm{CO})_{2}$ ], ( $\left.\mathrm{M}=\mathrm{Mo}, \mathrm{W} ; \mathrm{R}, \mathrm{R}^{\prime}=\mathrm{Ph}, \mathrm{Et}, \mathrm{Cy}\right)$. Inorg. Chem. 2006, 45, 6965-6978.

(110) Voges, M. H.; Bullock, R. M. Catalytic lonic Hydrogenations of Ketones Using Molybdenum and Tungsten Complexes. J. Chem. Soc., Dalton Trans. 2002, 16, 759-770.

(111) Roberts, J. A. S.; Appel, A. M.; DuBois, D. L.; Bullock, R. M. Comprehensive Thermochemistry of W$\mathrm{H}$ Bonding in the Metal Hydrides $\mathrm{CpW}(\mathrm{CO})_{2}(\mathrm{IMes}) \mathrm{H},\left[\mathrm{CpW}(\mathrm{CO})_{2}(\mathrm{IMes}) \mathrm{H}\right]^{+}$, and $\left[\mathrm{CpW}(\mathrm{CO})_{2}(\mathrm{IMes})(\mathrm{H})_{2}\right]^{+}$. Influence of an N-Heterocyclic Carbene Ligand on Metal Hydride Bond Energies. J. Am. Chem. Soc. 2011, 133, 14604-14613.

(112) Wang, D. M.; Angelici, R. J. Metal-hydrogen Bond Dissociation Enthalpies in Series of Complexes of Eight Different Transition Metals. J. Am. Chem. Soc. 1996, 118, 935-942.

(113) Pons, V.; Conway, S. L. J.; Green, M. L. H.; Green, J. C.; Herbert, B. J.; Heinekey, D. M. Structure and Dynamics of a Dihydrogen/Hydride Ansa Molybdenocene Complex. Inorg. Chem. 2004, 43, 3475-3483. (114) Cheng, T.-Y.; Szalda, D. J.; Zhang, J.; Bullock, R. M. Synthesis and Structure of CpMo(CO)(dppe)H and Its Oxidation by $\mathrm{Ph}_{3} \mathrm{C}^{+}$. Inorg. Chem. 2006, 45, 4712-4720.

(115) Belkova, N. V.; Revin, P. O.; Besora, M.; Baya, M.; Epstein, L. M.; Lledós, A.; Poli, R.; Shubina, E. S.; Vorontsov, E. V. Hydrogen Bonding and Proton Transfer to the Trihydride Complex [Cp* $\left.\mathrm{MoH}_{3}(\mathrm{dppe})\right]$ : IR, NMR, and Theoretical Investigations. Eur. J. Inorg. Chem. 2006, 2192-2209.

(116) Dub, P. A.; Filippov, O. A.; Belkova, N. V.; Daran, J.-C.; Epstein, L. M.; Poli, R.; Shubina, E. S. Hydrogen Bonding to Carbonyl Hydride Complex $\mathrm{Cp} * \mathrm{Mo}\left(\mathrm{PMe}_{3}\right)_{2}(\mathrm{CO}) \mathrm{H}$ and Its Role in Proton Transfer. Dalton Trans. 2010, 39, 2008-2015.

(117) Belkova, N. V.; Besora, M.; Baya, M.; Dub, P. A.; Epstein, L. M.; Lledós, A.; Poli, R.; Revin, P. O.; Shubina, E. S. Effect of the Nature of the Metal Atom on Hydrogen Bonding and Proton Transfer to Cp* $\mathrm{MH}_{3}$ (dppe) : Tungsten Versus Molybdenum. Chem. - Eur. J. 2008, 14, 9921-9934.

(118) Neary, M. C.; Parkin, G. Dehydrogenation, Disproportionation and Transfer Hydrogenation Reactions of Formic Acid Catalyzed by Molybdenum Hydride Compounds. Chem. Sci. 2015, 6, 1859-1865. (119) Chakraborty, S.; Blacque, O.; Fox, T.; Berke, H. Hydrogenation of Imines Catalyzed by Trisphosphine-substituted Molybdenum and Tungsten Nitrosyl Hydrides and Co-catalytic Acid. Chem. Asian J. 2014, 9, 2896-2907.

(120) Matthews, S. L.; Pons, V.; Heinekey, D. M. Dihydrogen Complexes of Electrophilic Metal Centers: Observation of $\mathrm{Cr}(\mathrm{CO})_{5}\left(\mathrm{H}_{2}\right), \mathrm{W}(\mathrm{CO})_{5}\left(\mathrm{H}_{2}\right)$ and $\left[\operatorname{Re}(\mathrm{CO})_{5}\left(\mathrm{H}_{2}\right)\right]^{+}$. J. Am. Chem. Soc. 2005, 127, 850-851. (121) Labios, L. A.; Weiss, C. J.; Egbert, J. D.; Lense, S.; Bullock, R. M.; Dougherty, W. G.; Kassel, W. S.; Mock, M. T. Synthesis and Protonation Studies of Molybdenum(0) Bis(di-nitrogen) Complexes Supported by Diphosphine Ligands -containing Pendant Amines. Z. Anorg. Allg. Chem. 2014, 641, 105-117.

(122) Tilset, M.; Vollhardt, K. P. C.; Boese, R. Chemistry of Dinuclear Fulvalene Complexes: Dihydrides, Zwitterions, and Ring-Slippage Complexes Derived From $\mathrm{FvM}_{2}(\mathrm{CO})_{6}(\mathrm{M}=\mathrm{Mo}, \mathrm{W})$. Organometallics 1994, 13, 3146-3169.

(123) Thaler, E.; Folting, K.; Huffman, J. C.; Caulton, K. G.

Bis[tris(dimethylphosphinomethyl)ethane]hydridochromium(1+) Tetraethylborate(1-): the First Synthesis of a Cationic Hydride Complex from Triethylborate(1-). Inorg. Chem. 1987, 26, 374-377. (124) Kimmich, B. F. M.; Fagan, P. J.; Hauptman, E.; Marshall, W. J.; Bullock, R. M. Molybdenum Carbonyl Complexes in the Solvent-free Catalytic Hydrogenation of Ketones. Organometallics 2005, 24, 6220-

6229.

(125) Dub, P. A.; Belkova, N. V.; Filippov, O. A.; Daran, J.-C.; Epstein, L. M.; Lledós, A.; Shubina, E. S.; Poli, R. Solvent-dependent Dihydrogen/dihydride Stability for $\left[\mathrm{Mo}(\mathrm{CO})(\mathrm{Cp} *) \mathrm{H}_{2}\left(\mathrm{PMe}_{3}\right)_{2}\right]^{+}\left[\mathrm{BF}_{4}\right]^{-}$Determined by Multiple Solvent...anion...cation Non-covalent Interactions. Chem. - Eur. J. 2010, 16, 189-201. 
(126) Niikura, F.; Seino, H.; Mizobe, Y. Preparation, Structures, and Some Reactivities of Five-Coordinate Alkyne Complexes of Mo with Tetraphosphine Or Diphosphine Coligand [Mo(RCCR')\{meso-o$\left.\left.\mathrm{C}_{6} \mathrm{H}_{4}\left(\mathrm{PPhCH}_{2} \mathrm{CH}_{2} \mathrm{PPh}_{2}\right)_{2}\right\}\right]$ and [Mo(RCCR') $\left.\left(\mathrm{Ph}_{2} \mathrm{PCH}_{2} \mathrm{CH}_{2} \mathrm{PPh}_{2}\right)_{2}\right]$. Organometallics 2009, 28, 1112-1121.

(127) Baya, M.; Houghton, J.; Daran, J. C.; Poli, R.; Male, L.; Albinati, A.; Gutman, M. Synthesis, Structure, and Electrochemical Properties of Sterically Protected Molybdenum Trihydride Redox Pairs: a Paramagnetic "stretched" Dihydrogen Complex? Chem. - Eur. J. 2007, 13, 5347-5359. (128) Fettinger, J. C.; Kraatz, H.-B.; Poli, R.; Quadrelli, E. A.; Torralba, R. C. Electrophilic Addition Vs Electron Transfer for the Interaction of $\mathrm{Ag}^{+}$with Molybdenum(II) Hydrides. 1. Reaction with $\mathrm{CpMoH}\left(\mathrm{PMe}_{3}\right)_{3}$ and the Mechanism of Decomposition of $\left[\mathrm{CpMoH}\left(\mathrm{PMe}_{3}\right)_{3}\right]^{+}$. Organometallics 1998, 17, 5767-5775.

(129) Baya, M.; Dub, P. A.; Houghton, J.; Daran, J. C.; Belkova, N. V.; Shubina, E. S.; Epstein, L. M.; Lledós, A.; Poli, R. Investigation of the $\left[\mathrm{Cp} * \mathrm{Mo}\left(\mathrm{PMe}_{3}\right)_{3} \mathrm{H}\right]^{\mathrm{n+}}(\mathrm{n}=0,1)$ Redox Pair: Dynamic Processes on Very Different Time Scales. Inorg. Chem. 2009, 48, 209-220.

(130) Mock, M. T.; Pierpont, A. W.; Egbert, J. D.; O'Hagan, M.; Chen, S.; Bullock, R. M.; Dougherty, W. G.; Kassel, W. S.; Rousseau, R. Dinitrogen Complex of Chromium Supported by a 12-Membered Phosphorus Macrocycle Containing Pendant Amines. Inorg. Chem. 2015, 54, 4827-4839.

(131) Jordan, R. F.; Norton, J. R. Kinetic and Thermodynamic Acidity of Hydrido Transition-metal Complexes. 1. Periodic Trends in Group VI Complexes and Substituent Effects in Osmium Complexes. J. Am. Chem. Soc. 1982, 104, 1255-1263.

(132) Cabelli, D. E.; Shafiq, F.; Creutz, C.; Bullock, R. M. Pulse Radiolysis Studies of Water Soluble Tungsten Hydride Complexes: One Electron Reduction of Metal Hydrides and Hydrogen Atom Transfer Reactions. Organometallics 2001, 20, 3729-3737.

(133) Choi, J.; Pulling, M. E.; Smith, D. M.; Norton, J. R. Unusually Weak Metal-hydrogen Bonds in $\mathrm{HV}(\mathrm{CO})_{4}(\mathrm{P}-\mathrm{P})$ and Their Effectiveness as H-center Dot Donors. J. Am. Chem. Soc. 2008, 130, 4250-4252. (134) van der Eide, E. F.; Helm, M. L.; Walter, E. D.; Bullock, R. M. Structural and Spectroscopic Characterization of 17- and 18- Electron Piano-Stool Complexes of Chromium. Thermochemical Analyses of Weak Cr-H Bonds. Inorg. Chem. 2013, 52, 1591-1603.

(135) Huhmann-Vincent, J.; Scott, B. L.; Kubas, G. J. Highly Electrophilic $\left[\operatorname{Re}(\mathrm{CO})_{4}\left(\mathrm{PR}_{3}\right)\right]^{+}$Center Binds $\mathrm{Et}_{2} \mathrm{O}$ and $\mathrm{CH}_{2} \mathrm{Cl}_{2}$ and Heterolytically Activates $\mathrm{H}_{2}$. J. Am. Chem. Soc. 1998, 120, 6808-6809.

(136) Feracin, S.; Buergi, T.; Bakhmutov, V. I.; Eremenko, I.; Vorontsov, E. V.; Vimenits, A. B.; Berke, H. Hydrogen/Hydrogen Exchange and Formation of Dihydrogen Derivatives of Rhenium Hydride Complexes in Acidic Solutions. Organometallics 1994, 13, 4194-4202.

(137) Heinekey, D. M.; Radzewich, C. E.; Voges, M. H.; Schomber, B. M. Cationic Hydrogen Complexes of Rhenium. 2. Synthesis, Reactivity, and Competition Studies. J. Am. Chem. Soc. 1997, 119, 4172-4181.

(138) Bianchini, C.; Marchi, A.; Marvelli, L.; Peruzzini, M.; Romerosa, A.; Rossi, R.; Vacca, A. Reactions of the Rhenium(I) Fragment $\left[\left\{\mathrm{MeC}\left(\mathrm{CH}_{2} \mathrm{PPh}_{2}\right)_{3}\right\} \operatorname{Re}(\mathrm{CO})_{2}\right]^{+}$. Synthesis and Characterization of a Stable Cationic $\eta^{2}-\mathrm{H}_{2}$ Complex of Rhenium. Organometallics 1995, 14, 3203-3215.

(139) Liu, X. Y.; Venkatesan, K.; Schmalle, H. W.; Berke, H. Solvent Stabilization and Hydrogenation Catalysis of Trimethylphosphine-substituted Carbonyl Rhenium Cations. Organometallics 2004, 23, 3153-3163.

(140) Albertin, G.; Antoniutti, S.; Bettiol, M.; Bordignon, E.; Busatto, F. Synthesis, Characterization, and Reactivity of Cationic Molecular-hydrogen Complexes of Manganese(I). Organometallics 1997, 16, 49594969.

(141) Hulley, E. B.; Welch, K. D.; Appel, A. M.; Dubois, D. L.; Bullock, R. M. Rapid, Reversible Heterolytic Cleavage of Bound $\mathrm{H}_{2}$. J. Am. Chem. Soc. 2013, 135, 11736-11739.

(142) Albertin, G.; Antoniutti, S.; Castro, J.; Garcia-Fontan, S.; Schipilliti, G. Preparation and Reactivity of Hydridorhenium Complexes with Polypyridine and Phosphonite Ligands. Eur. J. Inorg. Chem. 2007, 17131722. 
(143) Chinn, M. S.; Heinekey, D. M.; Payne, N. G.; Sofield, C. D. Highly Reactive Dihydrogen Complexes of Ruthenium and Rhenium: Facile Heterolysis of Coordinated Dihydrogen. Organometallics 1989, 8, 18241826.

(144) Hinman, J. G.; Abdur-Rashid, K.; Lough, A. J.; Morris, R. H. [\{ReH $\left.\left.2\left(\mathrm{PMePh}_{2}\right)_{2}\right\}_{2}(\mu-\mathrm{H})_{3}\right]^{-:}$: the First Member of a New Class of Anionic Polyhydride Dimers. Inorg. Chem. 2001, 40, 2480-2481.

(145) Miller, A. E. S.; Beauchamp, J. L. Gas-phase Acidities of Pentacarbonyl Manganese, Iron, and Cobalt Hydrides, $(\mathrm{CO})_{5} \mathrm{MnH},(\mathrm{CO})_{4} \mathrm{FeH}_{2}$, and (CO) ${ }_{4} \mathrm{CoH}$. J. Am. Chem. Soc. 1991, 113, 8765-8770.

(146) Miller, A. E. S.; Kawamura, A. R.; Miller, T. M. Effects of Metal and Ligand Substitutions on Gasphase Acidities of Transition-metal Hydrides. J. Am. Chem. Soc. 1990, 112, 457-458.

(147) Jiang, Y. F.; Blacque, O.; Fox, T.; Frech, C. M.; Berke, H. Development of Rhenium Catalysts for Amine Borane Dehydrocoupling and Transfer Hydrogenation of Olefins. Organometallics 2009, 28, 54935504.

(148) Southern, J. S.; Green, M. T.; Hillhouse, G. L.; Guzei, I. A.; Rheingold, A. L. Chemistry of Coordinated Nitroxyl. Reagent-Specific Protonations of Trans- $\operatorname{Re}(\mathrm{CO})_{2}(\mathrm{NO})\left(\mathrm{PR}_{3}\right)_{2}(\mathrm{R}=\mathrm{Ph}, \mathrm{Cy})$ That Give the Neutral Nitroxyl Complexes Cis, trans- $\mathrm{ReCl}(\mathrm{CO})_{2}(\mathrm{NH}=\mathrm{O})\left(\mathrm{PR}_{3}\right)_{2}$ Or the Cationic Hydride Complex [trans, trans$\left.\mathrm{ReH}(\mathrm{CO})_{2}(\mathrm{NO})\left(\mathrm{PPh}_{3}\right)_{2}{ }^{+}\right]\left[\mathrm{SO}_{3} \mathrm{CF}_{3}^{-}\right]$. Inorg. Chem. 2001, 40, 6039-6046.

(149) Green, M. L. H.; Pratt, L.; Wilkinson, G. Biscyclopentadienylrhenium Hydride. J. Chem. Soc. 1958, 3916-3922.

(150) Bolaño, S.; Gonsalvi, L.; Barbaro, P.; Peruzzini, M.; Albinati, A.; Rizzato, S.; Gutsul, E.; Belkova, N.; Epstein, L.; Shubina, E. Synthesis, Characterization, Protonation Studies and X-ray Crystal Structure of $\mathrm{ReH}_{5}\left(\mathrm{PPh}_{3}\right)_{2}$ (PTA) (PTA = 1,3,5-triaza-7-phosphaadamantane). J. Organomet. Chem. 2006, 691, 629-637. (151) Kristjánsdóttir, S. S.; Loendorf, A. J.; Norton, J. R. Kinetic and Thermodynamic Acidity of Hydrido Transition-Metal Complexes. 9. a Sterically Hindered Cationic Hydride, $\left[\mathrm{H}_{4} \mathrm{Re}\left(\mathrm{PMe}{ }_{2} \mathrm{Ph}\right)_{4}\right]^{+}$. Inorg. Chem. 1991, 30, 4470-4471.

(152) Landau, S. E.; Morris, R. H.; Lough, A. J. Acidic Dicationic Iron(II) Dihydrogen Complexes and Compounds Related by $\mathrm{H}_{2}$ Substitution. Inorg. Chem. 1999, 38, 6060-6068.

(153) Rocchini, E.; Mezzetti, A.; Rüegger, H.; Burckhardt, U.; Gramlich, V.; Del Zotto, A.; Martinuzzi, P.; Rigo, $\mathrm{P}$. Heterolytic $\mathrm{H}_{2}$ Activation by Dihydrogen Complexes. Effects of the Ligand $\mathrm{X}$ in $\left[\mathrm{M}(\mathrm{X}) \mathrm{H}_{2}\left\{\mathrm{Ph}_{2} \mathrm{P}\left(\mathrm{CH}_{2}\right)_{3} \mathrm{PPh}_{2}\right\}_{2}\right]^{\mathrm{nt}}(\mathrm{M}=\mathrm{Ru}, \mathrm{Os}, \mathrm{X}=\mathrm{CO}, \mathrm{Cl}, \mathrm{H})$. Inorg. Chem. 1997, 36, 711-720.

(154) Fong, T. P.; Forde, C. E.; Lough, A. J.; Morris, R. H.; Rigo, P.; Rocchini, E.; Stephan, T. Synthesis of the Acidic Dihydrogen Complexes Trans- $\left[\mathrm{M}\left(\mathrm{H}_{2}\right)(\mathrm{CN}) \mathrm{L}_{2}\right]^{+}$and Trans- $\left[\mathrm{M}\left(\mathrm{H}_{2}\right)(\mathrm{CNH}) \mathrm{L}_{2}\right]^{2+}$ Where $\mathrm{M}=\mathrm{Fe}, \mathrm{Ru}$, Os and $L=$ Dppm, Dppe, Dppp, Depe, and Dihydrogen Substitution by the Trifluoromethylsulfonate Anion to Give Trans-[Ru(OTf)(CN) $\left.\mathrm{L}_{2}\right]$ or Trans-[Ru(OTf)(CNH) $\left.\mathrm{L}_{2}\right] \mathrm{OTf}$. J. Chem. Soc., Dalton Trans. 1999, 4475-4486.

(155) Henry, R. M.; Shoemaker, R. K.; DuBois, D. L.; DuBois, M. R. Pendant Bases as Proton Relays in Iron Hydride and Dihydrogen Complexes. J. Am. Chem. Soc. 2006, 128, 3002-3010.

(156) Hargreaves, M. D.; Mahon, M. F.; Whittlesey, M. K. Substitution Reactions of

$\left[\mathrm{Ru}(\mathrm{dppe})(\mathrm{CO})\left(\mathrm{H}_{2} \mathrm{O}\right)_{3}\right][\mathrm{OTf}]_{2}$. Inorg. Chem. 2002, 41, 3137-3145.

(157) Cavit, B. E.; Grundy, K. R.; Roper, W. R. Ru(CO $)_{2}\left(\mathrm{PPh}_{3}\right)_{3}$ and $\mathrm{Os}(\mathrm{CO})_{2}\left(\mathrm{PPh}_{3}\right)_{3}$. an Ethylene Complex of Ruthenium and a Dioxygen Complex of Osmium. J. Chem. Soc., Chem. Commun. 1972, 60-61.

(158) Field, L. D.; Messerle, B. A.; Smernik, R. J. Synthesis and Properties of Iron(II) Hydride Complexes

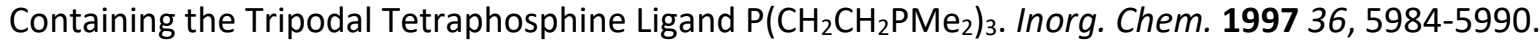

(159) Deeming, A. J.; Kabir, S. E. Protonation and Hydrogenation of Triosmium Clusters Containing the Bridging Diphosphine Ligands $\mathrm{Ph}_{2} \mathrm{P}\left(\mathrm{CH}_{2}\right)_{n} \mathrm{PPh}_{2}$ ( $\mathrm{n}=1$ to 4). J. Organometal. Chem. 1988, 340, 359-366.

(160) Braunschweig, H.; Brunecker, C.; Dewhurst, R. D.; Schneider, C.; Wennemann, B. Lewis Acid Binding and Transfer as a Versatile Experimental Gauge of the Lewis Basicity of Fe0, Ru0, and Pt0 Complexes. Chem. - Eur. J. 2015, 21, 19195-19201. 
(161) Ghosh, P.; Fagan, P. J.; Marshall, W. J.; Hauptmann, E.; Bullock, R. M. Synthesis of Ruthenium Carbonyl Complexes with Phosphine Or Substituted Cp Ligands, and Their Activity in the Catalytic Deoxygenation of 1,2-propanediol. Inorg. Chem. 2009, 48, 6490-6500.

(162) Schlaf, M.; Ghosh, P.; Fagan, P. J.; Hauptman, E.; Bullock, R. M. Catalytic Deoxygenation of 1,2Propanediol to Give N-Propanol. Adv. Syn. Catal. 2009, 351, 789-800.

(163) Ontko, A. C.; Houlis, J. F.; Schnabel, R. C.; Roddick, D. M.; Fong, T. P.; Lough, A. J.; Morris, R. H. Protonation and $\mathrm{H}_{2}$ Heterolysis Reactions of Electrophilic $\left(\eta^{5}-C_{5} R_{5}\right) R u(d f e p e)(X)(R=H, M e ; X=H, O T f)$ Complexes. Organometallics 1998, 17, 5467-5476.

(164) Gründemann, S.; Ulrich, S.; Limbach, H. H.; Golubev, N. S.; Denisov, G. S.; Epstein, L. M.; SaboEtienne, S.; Chaudret, B. Solvent Assisted Reversible Proton Transfer within an Intermolecular Dihydrogen Bond and Characterization of an Unstable Dihydrogen Complex. Inorg. Chem. 1999, 38, 2550-2551.

(165) Ovchinnikov, M. V.; Guzei, I. A.; Angelici, R. J. Amine Attack on the Carbonyl Ligands of the Protonated Dicyclopentadienyl Bridged Diruthenium Complex $\left[\left\{\left(\eta^{5}-\mathrm{C}_{5} \mathrm{H}_{3}\right)_{2}\left(\mathrm{SiMe}_{2}\right)_{2}\right\} \mathrm{Ru}_{2}(\mathrm{CO})_{4}(\mu-\mathrm{H})\right]^{+}$. Organometallics 2001, 20, 691-696.

(166) Ng, W. S.; Jia, G. C.; Hung, M. Y.; Lau, C. P.; Wong, K. Y.; Wen, L. Ligand Effect on the Structures and Acidities of $\left[\mathrm{TpOs}\left(\mathrm{H}_{2}\right)\left(\mathrm{PPh}_{3}\right)_{2}\right] \mathrm{BF}_{4}$ and $\left[\mathrm{CpOsH}_{2}\left(\mathrm{PR}_{3}\right)_{2}\right] \mathrm{BF}_{4}$. Organometallics 1998, 17, 4556-4561.

(167) Jetz, W.; Graham, W. A. G. Silicon-transition Metal Chemistry. III. Reaction Between Trichlorosilane and Cyclopentadienyldicarbonyliron Dimer. Inorg. Chem. 1971, 10, 1159-1165.

(168) Jia, G.; Morris, R. H.; Schweitzer, C. T. Acidic Dihydrogen Complex Protonating Coordinated Dinitrogen. Inorg. Chem. 1991, 30, 593-594.

(169) Guan, H.; limura, M.; Magee, M. P.; Norton, J. R.; Zhu, G. Ruthenium-Catalyzed lonic Hydrogenation of Iminium Cations. Scope and Mechanism. J. Am. Chem. Soc. 2005, 127, 7805-7814. (170) Liu, T. B.; Chen, S. T.; O'Hagan, M. J.; DuBois, M. R.; Bullock, R. M.; DuBois, D. L. Synthesis, Characterization, and Reactivity of Fe Complexes Containing Cyclic Diazadiphosphine Ligands: the Role of the Pendant Base in Heterolytic Cleavage of $\mathrm{H}_{2}$. J. Am. Chem. Soc. 2012, 134, 6257-6272.

(171) Liu, T.; Dubois, D. L.; Bullock, R. M. An Iron Complex with Pendent Amines as a Molecular Electrocatalyst for Oxidation of Hydrogen. Nature Chem. 2013, 5, 228-233.

(172) Esteruelas, M. A.; López, A. M.; Oñate, E.; Royo, E. Sequential Protonation and Methylation of a Hydride-osmium Complex Containing a Cyclopentadienyl Ligand with a Pendant Amine Group. Inorg. Chem. 2005, 44, 4094-4103.

(173) Chu, H. S.; Lau, C. P.; Wong, K. Y.; Wong, W. T. Intramolecular N-H...H-Ru Proton-hydride Interaction in Ruthenium Complexes with (2-(dimethylamino)ethyl)cyclopentadienyl and (3(dimethylamino)propyl)cyclopentadienyl Ligands. Hydrogenation of $\mathrm{CO}_{2}$ to Formic Acid via the $\mathrm{N}-\mathrm{H} . . . \mathrm{H}-$ Ru Hydrogen-bonded Complexes. Organometallics 1998, 17, 2768-2777.

(174) Kovács, G.; Rossin, A.; Gonsalvi, L.; Lledós, A.; Peruzzini, M. Comparative DFT Analysis of Ligand and Solvent Effects on the Mechanism of $\mathrm{H}_{2}$ Activation in Water Mediated by Half-Sandwich Complexes $\left[\mathrm{Cp} p^{\prime} \mathrm{Ru}(\mathrm{PTA})_{2} \mathrm{Cl}\right]\left(\mathrm{Cp}^{\prime}=\mathrm{C}_{5} \mathrm{H}_{5}, \mathrm{C}_{5} \mathrm{Me}_{5}\right.$; PTA = 1,3,5-triaza-7-phosphaadamantane). Organometallics 2010, 29, 5121-5131.

(175) Suzuki, H.; Kakigano, T.; Tada, K.; Igarashi, M.; Matsubara, K.; Inagaki, A.; Oshima, M.; Takao, T. Synthesis, Structures, and Reactions of Coordinatively Unsaturated Trinuclear Ruthenium Polyhydrido Complexes, $\left[\left\{\mathrm{Ru}\left(\mathrm{C}_{5} \mathrm{Me}_{5}\right)\right\}_{3}(\mu-\mathrm{H})_{6}\right](\mathrm{Y})\left(\mathrm{Y}=\mathrm{BF}_{4}, \mathrm{CF}_{3} \mathrm{SO}_{3}, 1 / 2\left(\mathrm{SO}_{4}\right), \mathrm{C}_{6} \mathrm{H}_{5} \mathrm{CO}_{2}, \mathrm{CH}_{3} \mathrm{CO}_{2}, \mathrm{~B}\left(\mathrm{C}_{6} \mathrm{H}_{5}\right)_{4}, \mathrm{PF}_{6}\right)$ and $\left\{\mathrm{Ru}\left(\mathrm{C}_{5} \mathrm{Me}_{5}\right)\right\}_{3}(\mu-\mathrm{H})_{3}\left(\mu_{3}-\mathrm{H}\right)_{2}$. Bull. Chem. Soc. Japan 2005, 78, 67-87.

(176) Kameo, H.; Suzuki, H. Synthesis of Trinuclear Osmium Polyhydrido Clusters $\left[\left\{\left(\mathrm{C}_{5} \mathrm{Me}_{5}\right) \mathrm{Os}\right\}_{3}(\mu-\mathrm{H})_{6}\right]^{+}$ and $\left\{\left(\mathrm{C}_{5} \mathrm{Me}_{5}\right) \mathrm{Os}\right\}_{3}(\mu-\mathrm{H})_{3}\left(\mu_{3}-\mathrm{H}\right)_{2}$ and Comparison with the Ruthenium Analogues. Organometallics 2008, 27, 4248-4253.

(177) Bühl, M.; Grigoleit, S. Molecular Dynamics of Neutral and Protonated Ferrocene. Organometallics 2005, 24, 1516-1527. 
(178) Gross, C. L.; Girolami, G. S. Synthesis and Characterization of Osmium Polyhydrides. X-ray Crystal Structures of $\left(\mathrm{C}_{5} \mathrm{Me}_{5}\right) \mathrm{OsH}_{5}$ and $\left(\mathrm{C}_{5} \mathrm{Me}_{5}\right)_{2} \mathrm{Os}_{2} \mathrm{H}_{4}$. Organometallics 2007, 26, 160-166.

(179) Chan, W.-C.; Lau, C.-P.; Chen, Y.-Z.; Fang, Y.-Q.; Ng, S.-M.; Jia, G. Syntheses and Characterization of Hydrotris(1-pyrazolyl)borate Dihydrogen Complexes of Ruthenium and Their Roles in Catalytic Hydrogenation Reactions. Organometallics 1997, 16, , 34-44.

(180) Ng, S. M.; Fang, Y. Q.; Lau, C. P.; Wong, W. T.; Jia, G. C. Synthesis, Characterization, and Acidity of Ruthenium Dihydrogen Complexes with 1, 4, 7-triazacyclononane, 1, 4, 7-trimethyl-1, 4, 7triazacyclononane, and Hydrotris(pyrazolyl)borato Ligands. Organometallics 1998, 17, 2052-2059.

(181) Bohanna, C.; Esteruelas, M. A.; Gomez, A. V.; Lopez, A. M.; Martinez, M. P. Synthesis and Spectroscopic Characterization of New Hydrido and Dihydrogen Complexes of Osmium and Ruthenium Stabilized by the Tris(pyrazolyl)borate Ligand. Organometallics 1997, 16, 4464-4468.

(182) Chu, H. S.; Xu, Z.; Ng, S. M.; Lau, C. P.; Lin, Z. Protonation of $\left[\operatorname{tpmRu}\left(\mathrm{PPh}_{3}\right)_{2} \mathrm{H}\right] \mathrm{BF}_{4}[\mathrm{tpm}=$ Tris(pyrazolyl)methane] - Formation of Unusual Hydrogen-bonded Species. Eur. J. Inorg. Chem. 2000, 993-1000.

(183) Matsubara, Y.; Fujita, E.; Doherty, M. D.; Muckerman, J. T.; Creutz, C. Thermodynamic and Kinetic Hydricity of Ruthenium(II) Hydride Complexes. J. Am. Chem. Soc. 2012, 134, 15743-15757.

(184) Call, A.; Codola, Z.; Acuna-Pares, F.; Lloret-Fillol, J. Photo- and Electrocatalytic $\mathrm{H}_{2}$ Production by New First-Row Transition-Metal Complexes Based on an Aminopyridine Pentadentate Ligand. Chem. Eur. J. 2014, 20, 6171-6183.

(185) Stepowska, E.; Jiang, H. L.; Song, D. T. Reversible $\mathrm{H}_{2}$ Splitting Between Ru(II) and a Remote Carbanion in a Zwitterionic Compound. Chem. Commun. 2010, 46, 556-558.

(186) Collman, J. P.; Wagenknecht, P. S.; Hutchison, J. E.; Lewis, N. S.; Lopez, M. A.; Guilard, R.; L'Her, M.; Bothner-By, A. A.; Mishra, P. K. Dihydrogen Complexes of Metalloporphyrins - Characterization and Catalytic Hydrogen Oxidation Activity. J. Am. Chem. Soc. 1992, 114, 5654-5664.

(187) Hayashi, H.; Ogo, S.; Abura, T.; Fukuzumi, S. Accelerating Effect of a Proton on the Reduction of $\mathrm{CO}_{2}$ Dissolved in Water Under Acidic Conditions. Isolation, Crystal Structure, and Reducing Ability of a Water-soluble Ruthenium Hydride Complex. J. Am. Chem. Soc. 2003, 125, 14266-14267.

(188) Harman, W. D.; Taube, H. Isostructural $\eta^{2}$-dihydrogen Complexes $\left[\mathrm{Os}\left(\mathrm{NH}_{3}\right)_{5}\left(\mathrm{H}_{2}\right)\right]^{\mathrm{nt}}(\mathrm{n}=2,3)$ and the Hydrogenation of Acetone. J. Am. Chem. Soc. 1990, 112, 2261.

(189) Maltby, P. A.; Schlaf, M.; Steinbeck, M.; Lough, A. J.; Morris, R. H.; Klooster, W. T.; Koetzle, T. F.; Srivastava, R. C. Dihydrogen with Frequency of Motion Near to the ${ }^{1} \mathrm{H}$ Larmor Frequency. Solid State Structures and Solution NMR Spectroscopy of Osmium Complexes Trans-[Os $\left.(\mathrm{H} \cdot \mathrm{H}) \mathrm{X}\left(\mathrm{PR}_{2} \mathrm{CH}_{2} \mathrm{CH}_{2} \mathrm{PR}_{2}\right)\right]^{+}, \mathrm{X}=$ Cl, Br. J. Am. Chem. Soc. 1996, 118, 5396-5407.

(190) Baker, M. V.; Field, L. D.; Young, D. J. Formation of Molecular Hydrogen Complexes of Iron by the Reversible Protonation of Iron Dihydrides with Alcohols. J. Chem. Soc., Chem. Commun. 1988, 546-548. (191) Field, L. D.; Li, H. L.; Messerle, B. A.; Smernik, R. J.; Turner, P. An Iron(II) Dihydrogen Hydrido Complex Containing the Tripodal Tetraphosphine Ligand $\mathrm{P}\left(\mathrm{CH}_{2} \mathrm{CH}_{2} \mathrm{PMe}_{2}\right)_{3}$. Dalton Trans. 2004, 1418 1423.

(192) Field, L. D.; Hambley, T. W.; Yau, B. C. K. Formation of Ruthenium Thiolates via Complexes of Molecular Hydrogen. Inorg. Chem. 1994, 33, 2009-2017.

(193) Amendola, P.; Antoniutti, S.; Albertin, G.; Bordignon, E. Molecular Hydrogen Complexes Preparation and Reactivity of New Ruthenium(II) and Osmium(II) Derivatives and a Comparison Along the Iron Triad. Inorg. Chem. 1990, 29, 318-324.

(194) Albertin, G.; Antoniutti, S.; Bordignon, E. New Molecular Hydrogen Iron(II) Complexes: Synthesis, Characterization, and Reactivity with Aryldiazonium Cations. J. Am. Chem. Soc. 1989, 111, 2072-2077.

(195) Gusev, D. G.; Huebener, R.; Burger, P.; Orama, O.; Berke, H. Synthesis, Structural Diversity, Dynamics, and Acidity of the $\mathrm{M}(\mathrm{II})$ and $\mathrm{M}(\mathrm{IV})$ Complexes $\left[\mathrm{MH}_{3}\left(\mathrm{PR}_{3}\right)_{4}\right]^{+}(\mathrm{M}=\mathrm{Fe}, \mathrm{Ru}, \mathrm{Os} ; \mathrm{R}=\mathrm{Me}, \mathrm{Et}) . \mathrm{J}$. $A m$. Chem. Soc. 1997, 119, 3716-3731. 


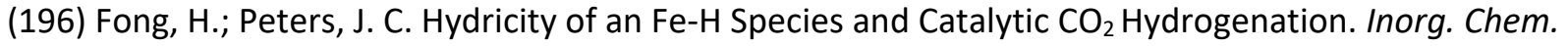
2015, 54, 5124-5135.

(197) Thoreson, K. A.; Follett, A. D.; McNeill, K. Synthesis and Characterization of Pentaphosphino ZeroValent Iron Complexes and Their Corresponding Iron(II)-Chloride and -Hydride Complexes. Inorg. Chem. 2010, 49, 3942-3949.

(198) Klein, H. F. Tetrakis(trimethylphosphane)hydridocobalt(I) and -dihydridoiron(II). Angew. Chem., Int. Ed. 1970, 9, 904.

(199) Abdur-Rashid, K.; Gusev, D.; Lough, A. J.; Morris, R. H. Synthesis and Characterization of $\mathrm{Ru}\left(\mathrm{H}_{2}\right)_{2}(\mathrm{H})_{2}\left(\mathrm{P}^{\mathrm{i}} \mathrm{Pr}_{3}\right)_{2}$. Evidence for a Bis-dihydrogen Structure and Related Chemistry. Organometallics 2000, 19, 1652-1660.

(200) Hickey, A. K.; Chen, C. H.; Pink, M.; Smith, J. M. Low-Valent Iron Carbonyl Complexes with a Tripodal Carbene Ligand. Organometallics 2015, 34, 4560-4566.

(201) Ramaraj, A.; Nethaji, M.; Jagirdar, B. R. Contrasting Reactivity Behaviour of the [RuHCl(CO)(PNP)] Complex with Electrophilic Reagents XOTf $\left(\mathrm{X}=\mathrm{H}, \mathrm{CH}_{3}, \mathrm{Me}_{3} \mathrm{Si}\right)$. Dalton Trans. 2014, 43, 14625-14635. (202) Forde, C. E.; Landau, S. E.; Morris, R. H. Dicationic Iron(II) Complexes with Dihydrogen Trans to $\pi$ acid Ligands: Trans-[Fe $\left.\left(\eta^{2}-\mathrm{H}_{2}\right)(\mathrm{L})(\mathrm{dppe})_{2}\right]^{+2}(\mathrm{~L}=\mathrm{CO}, \mathrm{CNH})$. Is There Fe- $\mathrm{H}_{2} \pi$-backbonding? J. Chem. Soc., Dalton Trans. 1997, 1663-1664.

(203) Matthews, S. L.; Heinekey, D. M. A Carbonyl-Rich Bridging Hydride Complex Relevant to the Fe-Fe Hydrogenase Active Site. Inorg. Chem. 2010, 49, 9746-9748.

(204) Luther, T. A.; Heinekey, D. M. Synthesis, Characterization, and Reactivity of Dicationic Dihydrogen Complexes of Osmium and Ruthenium. Inorg. Chem. 1998, 37, 127-132.

(205) Albertin, G.; Antoniutti, S.; Bortoluzzi, M. Preparation and Reactivity of Mixed-Ligand Iron(II) Hydride Complexes with Phosphites and Polypyridyls. Inorg. Chem. 2004, 43, 1328-1335.

(206) Albertin, G.; Antoniutti, S.; Bacchi, A.; D'Este, C.; Pelizzi, G. Preparation and Reactivity of MixedLigand Ruthenium(II) Hydride Complexes with Phosphites and Polypyridyls. Inorg. Chem. 2004, 43, 13361349.

(207) Schlaf, M.; Lough, A. J.; Morris, R. H. Dihydrogen Thiolate Vs. Hydride Thiol: Reactivity of the Series of Complexes $\mathrm{MH}(\mathrm{CO})(\mathrm{L})\left(\mathrm{PPh}_{3}\right)_{2}, \mathrm{M}=\mathrm{Ru}, \mathrm{Os}, \mathrm{L}=$ Pyridine-2-thiolate, Quinoline-8-thiolate with Acid. X-ray Structure Determination of $\left[\mathrm{Os}(\mathrm{CO})\left(\mu^{2}-\mathrm{Spy}\right)(\mathrm{pySH})\left(\mathrm{PPh}_{3}\right)\right]_{2}\left\{\mathrm{BF}_{4}\right\}_{2}$. Organometallics 1996, 15, 4423-4436.

(208) Amoroso, A. J.; Johnson, B. F. G.; Lewis, J.; Raithby, P. R.; Wong, W. T. Synthesis and Characterisation of Nona-osmium Carbonyl Clusters; Crystal and Molecular Structure of $\left[\left(\mathrm{Ph}_{3} \mathrm{P}\right)_{2} \mathrm{~N}\right]\left[\mathrm{O}{ }_{9} \mathrm{H}(\mathrm{CO})_{24}\right]$. J. Chem. Soc., Chem. Comm. 1991, 814-815.

(209) Esteruelas, M. A.; Gomez, A. V.; Lahoz, F. J.; Lopez, A. M.; Onate, E.; Oro, L. A. Five-coordinate Complex $\left[\mathrm{RuHCl}(\mathrm{CO})\left(\mathrm{P}^{\mathrm{i}} \mathrm{Pr}_{3}\right)_{2}\right]$ as a Precursor for the Preparation of New Cyclopentadienylruthenium Compounds Containing Unsaturated $\eta^{1}$-carbon Ligands. Organometallics 1996, 15, 3423-3435.

(210) Belkova, N. V.; Ionidis, A. V.; Epstein, L. M.; Shubina, E. S.; Gruendemann, S.; Golubev, N. S.; Limbach, H.-H. Proton Transfer to $\mathrm{CpRuH}(\mathrm{CO})\left(\mathrm{PC}_{3}\right)$ Studied by Low Temperature IR and NMR Spectroscopy. Eur. J. Inorg. Chem. 2001, 1753-1761.

(211) Bolaño, T.; Esteruelas, M. A.; Fernández, I.; Oñate, E.; Palacios, A.; Tsai, J. Y.; Xia, C. Osmium(II)bis(dihydrogen) Complexes Containing $\mathrm{C}_{\text {aryl, }} \mathrm{C}_{\mathrm{NHC}}$-chelate Ligands: Preparation, Bonding Situation, and Acidity. Organometallics 2015, 34, 778-789.

(212) Jia, G. C.; Lee, H. M.; Williams, I. D.; Lau, C. P.; Chen, Y. Z. Synthesis, Characterization, and Acidity Properties of $\left[\mathrm{MCl}\left(\mathrm{H}_{2}\right)(\mathrm{L})(\mathrm{PMP})\right] \mathrm{BF} 4\left(\mathrm{M}=\mathrm{Ru}, \mathrm{L}=\mathrm{PPh}_{3}, \mathrm{CO} ; \mathrm{M}=\mathrm{Os}, \mathrm{L}=\mathrm{PPh}{ }_{3} \mathrm{PMP}=2,6-\left(\mathrm{Ph}_{2} \mathrm{PCH}_{2}\right)_{2} \mathrm{C}_{5} \mathrm{H}_{3} \mathrm{~N}\right)$. Organometallics 1997, 16, 3941-3949.

(213) Kayal, A.; Rauchfuss, T. B. Protonation Studies of the New Iron Carbonyl Cyanide Trans$\left[\mathrm{Fe}(\mathrm{CO})_{3}(\mathrm{CN})_{2}\right]^{2-}$ : Implications with Respect to Hydrogenases. Inorg. Chem. 2003, 42, 5046-5048. 
(214) Wang, Y.; Wang, M.; Sun, L. C.; Ahlquist, M. S. G. Pendant Amine Bases Speed Up Proton Transfers to Metals by Splitting the Barriers. Chem. Commun. 2012, 48, 4450-4452.

(215) Pedersen, A.; Skagestad, V.; Tilset, M. Thermodynamic Acidities and Homolytic Metal-hydrogen Bond Energies of Group 8 Protonated Decamethylmetallocenes $\mathrm{Cp}^{*}{ }_{2} \mathrm{MH}^{+}(\mathrm{M}=\mathrm{Ru}$, Os). Acta Chem. Scand. 1995, 49, 632-635.

(216) Yao, Z. G.; Klabunde, K. J. The Strong Acidity and the Process for Deprotonation of ( $\eta^{6}$ toluene) $\mathrm{Fe}(\mathrm{H})_{2}\left(\mathrm{SiCl}_{3}\right)_{2}$. Inorg. Chem. 1997, 36, 2119-2123.

(217) Nishibayashi, Y.; Takemoto, S.; Iwai, S.; Hidai, M. Formation of Ammonia in the Reactions of a Tungsten Dinitrogen with Ruthenium Dihydrogen Complexes Under Mild Reaction Conditions. Inorg. Chem. 2000, 39, 5946-5957.

(218) Chin, B.; Lough, A. J.; Morris, R. H.; Schweitzer, C. T.; D'Agostino, C. Influence of Chloride Versus Hydride on $\mathrm{H}-\mathrm{H}$ Bonding and Acidity of the Trans Dihydrogen Ligand in the Complexes Trans$\left[\mathrm{Ru}\left(\mathrm{H}_{2}\right) \mathrm{X}\left(\mathrm{PR}_{2} \mathrm{CH}_{2} \mathrm{CH}_{2} \mathrm{PR}_{2}\right)_{2}\right]^{+}, \mathrm{X}=\mathrm{Cl}, \mathrm{H}, \mathrm{R}=\mathrm{Ph}$, Et. the Crystal Structure Determinations of $\left[\mathrm{RuCl}(\mathrm{dppe})_{2}\right] \mathrm{PF}_{6}$ and Trans-[Ru( $\left.\left.\mathrm{H}_{2}\right) \mathrm{Cl}(\mathrm{dppe})_{2}\right] \mathrm{PF}_{6}$. Inorg. Chem. 1994, 33, 6278-6288.

(219) Dey, A. Density Functional Theory Calculations on the Mononuclear Non-heme Iron Active Site of Hmd Hydrogenase: Role of the Internal Ligands in Tuning External Ligand Binding and Driving $\mathrm{H}_{2}$ Heterolysis. J. Am. Chem. Soc. 2010, 132, 13892-13901.

(220) Belkova, N. V.; Shubina, E. S.; Epstein, L. M. Diverse World of Unconventional Hydrogen Bonds. Acc. Chem. Res. 2005, 38, 624-631.

(221) Belkova, N. V.; Dub, P. A.; Baya, M.; Houghton, J. Kinetics and Thermodynamics of Proton Transfer to $\mathrm{Cp}{ }^{*} \mathrm{Ru}(\mathrm{dppe}) \mathrm{H}$ : via Dihydrogen Bonding and $\left(\eta^{2}-\mathrm{H}_{2}\right)$-complex to the Dihydride. Inorg. Chim. Acta 2007, 360, 149-162.

(222) Shaw, A. P.; Norton, J. R.; Buccella, D.; Sites, L. A.; Kleinbach, S. S.; Jarem, D. A.; Bocage, K. M.; Nataro, C. Synthesis, Electrochemistry, and Reactivity of Half-sandwich Ruthenium Complexes Bearing Metallocene-based Bisphosphines. Organometallics 2009, 28, 3804-3814.

(223) Dub, P. A.; Fillipov, O. A.; Silantyev, G. A.; Belkova, N. V.; Daran, J.-C.; Epstein, L. M.; Poli, R.; Shubina, E. S. Protonation of Cp*M(dppe)H Hydrides: Peculiarities of the Osmium Congener. Eur. J. Inorg. Chem. 2010, 1489-1500.

(224) Jimenez-Tenorio, M.; Palacios, M. D.; Puerta, M. C.; Valerga, P. Half-sandwich Hydride Complexes of Ruthenium with Bidentate Phosphinoamine Ligands: Proton-transfer Reactions to $\left(C_{5} R_{5}\right) R u H(L) R=H$, Me; L = Dippae, (R,R)-dippach. Inorg. Chem. 2007, 46, 1001-1012.

(225) Bhattacharya, P.; Krause, J. A.; Guan, H. R. Activation of Dihydrogen and Silanes by Cationic Iron Bis(phosphinite) Pincer Complexes. Organometallics 2014, 33, 6113-6121.

(226) Eilers, G.; Schwartz, L.; Stein, M.; Zampella, G.; De Gioia, L.; Ott, S.; Lomoth, R. Ligand Versus Metal Protonation of an Iron Hydrogenase Active Site Mimic. Chem. - Eur. J. 2007, 13, 7075-7084.

(227) Lemke, F. R.; Brammer, L. Hydride Complexes of Ruthenium and Related Metals: Preparation and Structures of $\mathrm{Cp}\left(\mathrm{PMe}_{3}\right)_{2} \mathrm{RuH}$ and [Cp( $\left.\left.\mathrm{PMe}_{3}\right)_{2} \mathrm{RuH}_{2}\right] \mathrm{BF}_{4}$. Organometallics 1995, 14, 3980-3987.

(228) Sellmann, D.; Gottschalk-Gaudig, T.; Heinemann, F. W. Transition Metal Complexes with Sulfur Ligands. 130. Synthesis, Structure, and Reactivity of the Sulfur-Rich Ruthenium Hydride Complexes $\left[\mathrm{Ru}(\mathrm{H})\left(\mathrm{PR}_{3}\right)\left({ }^{\prime} \mathrm{S}_{4}{ }^{\prime}\right)\right]^{-}$and the $\eta^{2}-\mathrm{H}_{2}$ Complex $\left[\mathrm{Ru}\left(\mathrm{H}_{2}\right)\left(\mathrm{PC} \mathrm{y}_{3}\right)\left({ }^{\prime} \mathrm{S}_{4}{ }^{\prime}\right)\right]\left(\mathrm{R}=\mathrm{Ph},{ }^{\mathrm{P}} \mathrm{Pr}, \mathrm{Cy} ;{ }^{\prime} \mathrm{S}_{4}{ }^{\prime 2-}=1,2-\mathrm{Bis}((2-\right.$ mercaptophenyl)thio)ethane(2-)). Inorg. Chem. 1998, 37, 3982-3988.

(229) Rottink, M. K.; Angelici, R. J. Ligand Effects on Heats of Protonation of Multihydrido Transition Metal Complexes of Osmium and Iridium. Inorg. Chem. 1993, 32, 3282-3286.

(230) Courtney, D.; Cromhout, N. L.; Cunningham, D.; Gallagher, J. F.; Manning, A. R.; McArdle, P.; Pratt, S. I. Main Group Derivatives of a Cyclometallated Iron Carbonyl Anion. Crystal Structures of $\mathrm{Fe}(\mathrm{CO})_{2}\left\{\mathrm{P}(\mathrm{OPh})_{3}\right\}\left\{(\mathrm{PhO})_{2} \mathrm{POC}_{6} \mathrm{H}_{4}\right\}\left(\mathrm{SnPh}_{3}\right)$ and Two Isomers of $\mathrm{Fe}(\mathrm{CO})_{2}\left\{\mathrm{P}(\mathrm{OPh})_{3}\right\}\left\{(\mathrm{PhO})_{2} \mathrm{POC}_{6} \mathrm{H}_{4}\right\}(\mathrm{I})$. Inorg. Chim. Acta 2002, 327, 98-107. 
(231) Walker, H. W.; Pearson, R. G.; Ford, P. C. Brønsted Acidities of Carbonyl Hydride Complexes of Iron, Ruthenium, and Osmium: pKa Values and Deprotonation Rates in Methanol Solution. J. Am. Chem. Soc. 1983, 105, 1179-1186.

(232) Heiden, Z. M.; Rauchfuss, T. B. Proton-Assisted Activation of Dihydrogen: Mechanistic Aspects of Proton-Catalyzed Addition of $\mathrm{H}_{2}$ to Ru and Ir Amido Complexes. J. Am. Chem. Soc. 2009, 131, 3593-3600. (233) Whaley, C. M.; Rauchfuss, T. B.; Wilson, S. R. Coordination Chemistry of $\left[\mathrm{HFe}(\mathrm{CN})_{2}(\mathrm{CO})_{3}\right]^{-}$and Its Derivatives: Toward a Model for the Iron Subsite of the [NiFe]-Hydrogenases. Inorg. Chem. 2009, 48, 4462-4469.

(234) Felton, G. A. N.; Vannucci, A. K.; Chen, J. Z.; Lockett, L. T.; Okumura, N.; Petro, B. J.; Zakai, U. I.; Evans, D. H.; Glass, R. S.; Lichtenberger, D. L. Hydrogen Generation From Weak Acids: Electrochemical and Computational Studies of a Diiron Hydrogenase Mimic. J. Am. Chem. Soc. 2007, 129, 12521-12530. (235) Field, L. D.; Guest, R. W.; Vuong, K. Q.; Dalgarno, S. J.; Jensen, P. Iron(0) and Ruthenium(0) Complexes of Dinitrogen. Inorg. Chem. 2009, 48, 2246-2253.

(236) Balesdent, C. G.; Crossland, J. L.; Regan, D. T.; Lopez, C. T.; Tyler, D. R. Characterization of an Intermediate in the Ammonia-Forming Reaction of Fe(DMeOPrPE) ${ }_{2} \mathrm{~N}_{2}$ with Acid (DMeOPrPE=1,2Bis(dimethoxypropyl)phosphino Ethane). Inorg. Chem. 2013, 52, 14178-14187.

(237) Zhang, J.; Grills, D. C.; Huang, K.-W.; Fujita, E.; Bullock, R. M. Carbon-to-Metal Hydrogen Atom Transfer: Direct Observation Using Time-Resolved Infrared Spectroscopy. J. Am. Chem. Soc. 2005, 127, 15684-15685.

(238) Brunet, J. J.; Commenges, G.; Kindela, F. B.; Neibecker, D. Ligand Substitution Processes on Carbonylmetal Derivatives. 1. Reaction of Tetracarbonylhydridoferrates with Phosphines. Organometallics 1992, 11, 1343-1350.

(239) Gelabert, R.; Moreno, M.; Lluch, J. M.; Lledós, A.; Pons, V.; Heinekey, D. M. Synthesis and Properties of Compressed Dihydride Complexes of Iridium: Theoretical and Spectroscopic Investigations. J. Am. Chem. Soc. 2004, 126, 8813-8822.

(240) Vogt, M.; Pons, V.; Heinekey, D. M. Synthesis and Characterization of a Dicationic Dihydrogen Complex of Iridium with a Bis-carbene Ligand Set. Organometallics 2005, 24, 1832-1836.

(241) Ogo, S.; Kabe, R.; Hayashi, H.; Harada, R.; Fukuzumi, S. Mechanistic Investigation of $\mathrm{CO}_{2}$ Hydrogenation by Ru(II) and Ir(III) Aqua Complexes Under Acidic Conditions: Two Catalytic Systems Differing in the Nature of the Rate Determining Step. Dalton Trans. 2006, 4657-4663.

(242) Zilm, K. W.; Heinekey, D. M.; Millar, J. M.; Payne, N. G.; Neshyba, S. P.; Duchamp, J. C.; Szczyrba, J. Quantum Mechanical Exchange of Hydrides in Solution: Proton-Proton Exchange Couplings in TransitionMetal Polyhydrides. J. Am. Chem. Soc. 1990, 112, 920-929.

(243) Doherty, M. D.; Grant, B.; White, P. S.; Brookhart, M. Reactions of $\mathrm{H}_{2}$ and $\mathrm{R}_{3} \mathrm{SiH}$ with Electrophilic Cobalt(III) Alkyl Complexes: Spectroscopic Characterization, Dynamics, and Chemistry of $\left[\mathrm{Cp} * \mathrm{Co}(\mathrm{L})(\mathrm{H})\left(\mathrm{eta}(2)-\mathrm{H}_{2}\right)\right] \mathrm{B}\left(\mathrm{Ar}^{\mathrm{F}}\right)_{4}$ and $\left[\mathrm{Cp} * \mathrm{Co}(\mathrm{L})(\mathrm{H})\left(\mathrm{eta}(2)-\mathrm{HSiR}_{3}\right)\right] \mathrm{B}\left(\mathrm{Ar}^{\mathrm{F}}\right)_{4}$. Organometallics 2007, 26, 59505960.

(244) Barrett, S. M.; Pitman, C. L.; Walden, A. G.; Miller, A. J. M. Photoswitchable Hydride Transfer From Iridium to 1-Methylnicotinamide Rationalized by Thermochemical Cycles. J. Am. Chem. Soc. 2014, 136, 14718-14721.

(245) Sypaseuth, F. D.; Matlachowski, C.; Weber, M.; Schwalbe, M.; Tzschucke, C. C. Electrocatalytic Carbon Dioxide Reduction by Using Cationic Pentamethylcyclopentadienyl-Iridium Complexes with Unsymmetrically Substituted Bipyridine Ligands. Chem. - Eur. J. 2015, 21, 6564-6571.

(246) Suenobu, T.; Guldi, D. M.; Ogo, S.; Fukuzumi, S. Excited-State Deprotonation and H/D Exchange of an Iridium Hydride Complex. Angew. Chem., Int. Ed. 2003, 42, 5492-5495.

(247) Pearson, R. G. Absolute Electronegativity, Hardness and Bond Energy In ACS Symposium Series 428: Bonding Energetics in Organometallic Compounds; Marks, T. J., Ed.; American Chemical Society: Washington DC, 1990; Vol. 428, 251-262. 
(248) Halpern, J.; Riley, D. P.; Chan, A. S. C.; Pluth, J. J. Novel Coordination Chemistry and Catalytic Properties of Cationic 1,2-bis(diphenylphosphino)ethanerhodium(I) Complexes. J. Am. Chem. Soc. 1977, 99, 8055-8057.

(249) Lacey, P.; Sykes, A. G. Isolation and X-ray Structure of $\left[\operatorname{Ir}\left(\mathrm{CNBu}^{\mathrm{t}}\right)_{5} \mathrm{H}\right]\left(\mathrm{PF}_{6}\right)_{2}$. Journal of Coordination Chemistry 2003, 56, 141-145.

(250) Merola, J. S.; Franks, M. A. The Basicity of [tris-(trimethylphosphine)(cyclooctadiene)iridium(I)]. J. Organomet. Chem. 2013, 723, 49-55.

(251) Price, A. J.; Ciancanelli, R.; Noll, B. C.; Curtis, C. J.; DuBois, D. L.; Rakowski-DuBois, M. HRh(dppb)2, a Powerful Hydride Donor. Organometallics 2002, 21, 4833-4839.

(252) Wiedner, E. S.; Appel, A. M.; Dubois, D. L.; Bullock, R. M. Thermochemical and Mechanistic Studies of Electrocatalytic Hydrogen Production by Cobalt Complexes Containing Pendant Amines. Inorg. Chem. 2013, 52, 14391-14403.

(253) Creutz, C.; Schwarz, H. A.; Wishart, J. F.; Fujita, E.; Sutin, N. Thermodynamics and Kinetics of Carbon Dioxide Binding to Two Stereoisomers of a Cobalt(I) Macrocycle in Aqueous Solution. J. Am. Chem. Soc. 1991, 113, 3361-3371.

(254) Schnabel, R. C.; Roddick, D. M. (Fluoroalkyl)phosphine Hydride Complexes of Iridium. Synthesis and Structures of (dfepe) ${ }_{2} \mathrm{IrH}$ and (dfepe) ${ }_{2} \mathrm{Ir} \mathrm{r}_{2}(\mathrm{H})(\mu-\mathrm{H})_{2}\left(\mu-\mathrm{O}_{3} \mathrm{SCF}_{3}\right)$. Organometallics 1993, 12, 704-711. (255) Nanishankar, H. V.; Dutta, S.; Nethaji, M.; Jagirdar, B. R. Dynamics of a Cis-dihydrogen/hydride Complex of Iridium. Inorg. Chem. 2005, 44, 6203-6210.

(256) Bohler, C.; Avarvari, N.; Schonberg, H.; Worle, M.; Ruegger, H.; Grutzmacher, H. Protonation and Hydrogenation Experiments with Iridium(0) and Iridium(-1) Tropp Complexes: Formation of Hydrides. Helv. Chim. Acta 2001, 84, 3127-3147.

(257) Pearson, R. G.; Kresge, C. T. Rate and Equilibrium Data for the Protonation of Vaska's Compound and Analogs. Inorg. Chem. 1981, 20, 1878-1882.

(258) Dorta, R.; Broggini, D.; Stoop, R.; Ruegger, H.; Spindler, F.; Togni, A. Chiral Iridium Xyliphos Complexes for the Catalytic Imine Hydrogenation Leading to the Metolachlor Herbicide: Isolation of Catalyst-substrate Adducts. Chem. - Eur. J. 2009, 10 IS 1, 267-278.

(259) Gruet, K.; Clot, E.; Eisenstein, O.; Lee, D. H.; Patel, B.; Macchioni, A.; Crabtree, R. H. Ion Pairing Effects in Intramolecular Heterolytic $\mathrm{H}_{2}$ Activation in an Ir(III) Complex: a Combined Theoretical/experimental Study. New. J. Chem. 2003, 27, 80-87.

(260) Ingleson, M. J.; Brayshaw, S. K.; Mahon, M. F.; Ruggiero, G. D.; Weller, A. S. Dihydrogen Complexes of Rhodium: $\left[\mathrm{RhH}_{2}\left(\mathrm{H}_{2}\right)_{x}\left(\mathrm{PR}_{3}\right)_{2}\right]^{+}(\mathrm{R}=\mathrm{Cy}$, IPr; $\mathrm{X}=1$, 2). Inorg. Chem. 2005, 44, 3162-3171.

(261) Abad, M. M.; Atheaux, I.; Maisonnat, A.; Chaudret, B. Control of Proton Transfer by Hydrogen Bonding in the Protonated Forms of the Binucleophilic Complex $\left[\left\{\eta^{5}-\mathrm{C}_{5} \mathrm{H}_{4} \mathrm{CH}\left(\mathrm{CH}_{2}\right)_{4} \mathrm{NMe}\right\} \operatorname{Ir}\left(\mathrm{PPh}_{3}\right) \mathrm{H}_{2}\right]$ Chem. Commun. 1999, 381-382.

(262) Fang, M.; Wiedner, E. S.; Dougherty, W. G.; Kassel, W. S.; Liu, T.; DuBois, D. L.; Bullock, R. M. Cobalt Complexes Containing Pendant Amines in the Second Coordination Sphere as Electrocatalysts for $\mathrm{H}_{2}$ Production. Organometallics 2014, 33, 5820-5833.

(263) Zhu, Y.; Fan, Y. B.; Burgess, K. Carbene-Metal Hydrides Can Be Much Less Acidic Than PhosphineMetal Hydrides: Significance in Hydrogenations. J. Am. Chem. Soc. 2010, 132, 6249-6253.

(264) Hou, Z. M.; Koizumi, T. A.; Fujita, A.; Yamazaki, H.; Wakatsuki, Y. The Binuclear Iridium(II) Hydride Complex $\left[\left(\mathrm{C}_{5} \mathrm{Me}_{5}\right) \operatorname{Ir}(\mu-\mathrm{H})\right]_{2}$ : a Novel Base for Reversible Deprotonation of Acidic Organic Compounds and a Unique Catalyst for C C Bond Cleavage of Aromatic 1, 2 Diols and Michael Additions. J. Am. Chem. Soc. 2001, 123, 5812-5813.

(265) Blum, O.; Milstein, D. Oxidative Addition of Water and Aliphatic Alcohols by IrCl(trialkylphosphine) $)_{3}$. J. Am. Chem. Soc. 2002, 124, 11456-11467.

(266) Heinekey, D. M.; Fine, D. A.; Harper, T. G. P.; Michel, S. T. Dinuclear Dihydride Complexes of Iridium: a Study of Structure and Dynamics. Can. J. Chem. 1995, 73, 1116-1125. 
(267) Bianchini, C.; Mealli, C.; Meli, A.; Peruzzini, M.; Zanobini, F. A Stable $\eta^{2}-\mathrm{H}_{2}$ Complex of Cobalt. Role of the $\mathrm{H}-\mathrm{H}$ Interaction in Hydrogen Transfer from Metal to Alkene. J. Am. Chem. Soc. 1988, 110, 87258726.

(268) Bianchini, C.; Mealli, C.; Peruzzini, M.; Zanobini, F. Evidence for a Molecular Hydrogen Complex of Rhodium. Some Factors Affecting cis-Dihydride <-> $\eta^{2}$-Dihydrogen Exchange. J. Am. Chem. Soc. 1987, 109, 5548-5549.

(269) Dahlenburg, L.; Hache, R. Ionic and Covalent Mixed-metal Complexes by Reaction of Transition Metal M-H Acids (M=Mo, Mn, Fe, Co) with [Ir $\left.\left(\mathrm{PMe}_{3}\right)_{4} \mathrm{CH}_{3}\right]$ Or $\left[\mathrm{Rh}\left(\mathrm{PMe}_{3}\right)_{3} \mathrm{CH}_{3}\right]$ and Structurally Related Rh-M and Ir-M Heterobimetallics ( $\mathrm{M}=\mathrm{Mn}$, Fe, Ru). Inorg. Chim. Acta 2003, 350, 77-85.

(270) Powers, D. C.; Hwang, S. J.; Zheng, S. L.; Nocera, D. G. Halide-Bridged Binuclear HX-Splitting Catalysts. Inorg. Chem. 2014, 53, 9122-9128.

(271) Lilio, A. M.; Reineke, M. H.; Moore, C. E.; Rheingold, A. L.; Takase, M. K.; Kubiak, C. P. Incorporation of Pendant Bases Into Rh(diphosphine) ${ }_{2}$ Complexes: Synthesis, Thermodynamic Studies, and Catalytic $\mathrm{CO}_{2}$ Hydrogenation Activity of $\left[\mathrm{Rh}\left(\mathrm{P}_{2} \mathrm{~N}_{2}\right)_{2}\right]^{+}$Complexes. J. Am. Chem. Soc. 2015, 137, 8251-8260.

(272) Fu, X.; Wayland, B. B. Equilibrium Thermodynamic Studies in Water: Reactions of Dihydrogen with Rhodium(III) Porphyrins Relevant to Rh-Rh, Rh-H, and Rh-OH Bond Energetics. J. Am. Chem. Soc. 2004, 126, 2623-2631.

(273) Biffinger, J. C.; Uppaluri, S.; Sun, H.; DiMagno, S. G. Ligand Fluorination to Optimize Preferential Oxidation of Carbon Monoxide by Water-Soluble Rhodium Porphyrins. ACS Catal. 2011, 1, 764-771. (274) Bakhmutov, V. I.; Bianchini, C.; Peruzzini, M.; Vizza, F.; Vorontsov, E. V. $\mathrm{H}^{1}$ and $\mathrm{H}^{2} \mathrm{~T}_{1}$ Relaxation Behavior of the Rhodium Dihydrogen Complex [(triphos)Rh $\left.\left(\eta^{2}-\mathrm{H}_{2}\right) \mathrm{H}_{2}\right]^{+}$. Inorg. Chem. 2000, 39, 16551660.

(275) Ishiwata, K.; Kuwata, S.; Ikariya, T. Hydrogen- and Oxygen-Driven Interconversion Between ImidoBridged Dirhodium(III) and Amido-Bridged Dirhodium(II) Complexes. J. Am. Chem. Soc. 2009, 131, 50015009.

(276) Elliott, P. I. P.; Haslam, C. E.; Spey, S. E.; Haynes, A. Formation and Reactivity of Ir(III) Hydroxycarbonyl Complexes. Inorg. Chem. 2006, 45, 6269-6275.

(277) Winter, A. M.; Eichele, K.; Mack, H.-G.; Kaska, W. C.; Mayer, H. A. C-H Versus Ir-X (X = H, Cl) Reactivity in a Tropylium PCP Pincer Iridium Complex. Organometallics 2005, 24, 1837-1844.

(278) Fujita, K.-i.; Nakaguma, H.; Hamada, T.; Yamaguchi, R. Intramolecular Activation of Aromatic C-H Bonds by Diphosphine and Hydrido-Bridged Dinuclear Iridium Complexes. J. Am. Chem. Soc. 2003, 125, 12368-12369.

(279) Findlater, M.; Bernskoetter, W. H.; Brookhart, M. Proton-Catalyzed Hydrogenation of a $\mathrm{d}^{8} \operatorname{Ir}(\mathrm{I})$ Complex Yields a Trans Ir(III) Dihydride. J. Am. Chem. Soc. 2010, 132, 4534-4535.

(280) Ringenberg, M. R.; Nilges, M. J.; Rauchfuss, T. B.; Wilson, S. R. Oxidation of Dihydrogen by Iridium Complexes of Redox-Active Ligands. Organometallics 2010, 29, 1956-1965.

(281) Wilson, A. D.; Miller, A. J. M.; DuBois, D. L.; Labinger, J. A.; Bercaw, J. E. Thermodynamic Studies of $\left[\mathrm{H}_{2} \mathrm{Rh} \text { (diphosphine) }{ }_{2}\right]^{+}$and $\left[\mathrm{HRh} \text { (diphosphine) }{ }_{2}\left(\mathrm{CH}_{3} \mathrm{CN}\right)\right]^{2+}$ Complexes in Acetonitrile. Inorg. Chem. 2010, 49, 3918-3926.

(282) Dobereiner, G. E.; Nova, A.; Schley, N. D.; Hazari, N.; Miller, S. J.; Eisenstein, O.; Crabtree, R. H. Iridium-catalyzed Hydrogenation of $\mathrm{N}$-heterocyclic Compounds Under Mild Conditions by an Outersphere Pathway. J. Am. Chem. Soc. 2011, 133, 7547-7562.

(283) DuBois, D. L.; Blake, D. M.; Miedaner, A.; Curtis, C. J.; DuBois, M. R.; Franz, J. A.; Linehan, J. C. Hydride Transfer From Rhodium Complexes to Triethylborane. Organometallics 2006, 25, 4414-4419. (284) Helm, M. L.; Stewart, M. P.; Bullock, R. M.; DuBois, M. R.; DuBois, D. L. A Synthetic Nickel Electrocatalyst with a Turnover Frequency Above $100,000 \mathrm{~s}^{-1}$ for $\mathrm{H}_{2}$ Production. Science 2011, 333, 863866. 
(285) Ciabatti, I.; Femoni, C.; lapalucci, M. C.; Longoni, G.; Zacchini, S. Tetrahedral $\left[\mathrm{H}_{\mathrm{n}} \mathrm{Pt}_{4}(\mathrm{CO})_{4}\left(\mathrm{P}^{\mathrm{P}} \mathrm{P}\right)_{2}\right]^{\mathrm{n+}}(\mathrm{n}$ $=1$, 2; $\left.\hat{P P}=\mathrm{CH}_{2}=\mathrm{C}\left(\mathrm{PPh}_{2}\right)_{2}\right)$ Cationic Mono- and Dihydrido Carbonyl Clusters Obtained by Protonation of the Neutral $\mathrm{Pt}_{4}(\mathrm{CO})_{4}(\mathrm{PP})_{2}$. Organometallics 2013, 32, 5180-5189.

(286) Leoni, P.; Marchetti, L.; Bonuccelli, V.; Mohapatra, S. K.; Albinati, A.; Rizzato, S. Proton-Transfer Reactions on Hexanuclear Platinum Clusters: Reversible Heterolytic Cleavage of $\mathrm{H}_{2}$ and $\mathrm{C}-\mathrm{H}$ Activation Affording a Linear, Cluster-Containing Polymer. Chem. - Eur. J. 2010, 16, 9468-9477.

(287) Scrivanti, A.; Bertoldini, M.; Beghetto, V.; Matteoli, U.; Venzo, A. Protonation of Palladium(II)-allyl and Palladium(0)-olefin Complexes Containing 2-pyridyldiphenylphosphine. J. Organomet. Chem. 2009, 694, 131-136.

(288) Miedaner, A.; Raebiger, J. W.; Curtis, C. J.; Miller, S. M.; DuBois, D. L. Thermodynamic Studies of $\left[\mathrm{HPt}(\text { EtXantphos })_{2}\right]^{+}$and $\left[(\mathrm{H})_{2} \mathrm{Pt}(\text { EtXantphos })_{2}\right]^{2+}$. Organometallics 2004, 23, 2670-2679.

(289) Curtis, C. J.; Miedaner, A.; Ellis, W. W.; DuBois, D. L. Measurement of the Hydride Donor Abilities of $\left[\mathrm{HM} \text { (diphosphine) }{ }_{2}\right]^{+}$Complexes $(\mathrm{M}=\mathrm{Ni}$, Pt) by Heterolytic Activation of Hydrogen. J. Am. Chem. Soc. 2002, 124, 1918-1925.

(290) Chinakov, V. D.; Il'inich, G. N.; Zudin, V. N.; Likholobov, V. A.; Nekipelov, V. M. Study of the Interaction of Platinum Hydride Complex $\left[\left(\mathrm{PPh}_{3}\right)_{3} \mathrm{PtH}\right]^{+}$with Carbon Monoxide and Ethylene in Trifluoroacetic Acid Solutions. J. Organomet. Chem. 1989, 366, 421-425.

(291) Zudin, V. N.; Chinakov, V. D.; Nekipelov, V. M.; Likholobov, V. A.; Ermakov, Y. I. Formation and Reactivity of Palladium Hydride Complexes, $\left[\left(\mathrm{PPh}_{3}\right)_{3} \mathrm{PdH}\right]^{+}$and $\left[\left(\mathrm{PPh}_{3}\right)_{2} \mathrm{Pd}(\mu-\mathrm{H})(\mu-\mathrm{CO}) \mathrm{Pd}\left(\mathrm{PPh}_{3}\right)_{2}\right]^{+}$, in Aqueous Trifluoroacetic Acid Solutions. J. Organomet. Chem. 1985, 289, 425-430.

(292) Zudin, V. N.; Chinakov, V. D.; Nekipelov, V. M.; Rogov, V. A.; Likholobov, V. A.; Ermakov, Y. I. Determination of Key Intermediates for Homogeneous Water-gas Shift Reaction and Hydrocarbonylation of Ethylene to Diethyl Ketone Catalyzed by the Palladium Acetate-triphenylphosphine-trifluoroacetic Acid-water System. J. Mol. Catal. 1989, 52, 27-48.

(293) Davies, S. C.; Henderson, R. A.; Hughes, D. L.; Oglieve, R. E. Reaction of $\left[\mathrm{Ni}\left(\mathrm{Ph}_{2} \mathrm{PCH}_{2} \mathrm{CH}_{2} \mathrm{PPh}_{2}\right)_{2}\right]$ with DCl: Controlling the Formation of HD and $\mathrm{D}_{2}$. J. Chem. Soc., Dalton Trans. 1998, 425-431.

(294) Raebiger, J. W.; Miedaner, A.; Curtis, C. J.; Miller, S. M.; Anderson, O. P.; DuBois, D. L. Using Ligand Bite Angles to Control the Hydricity of Palladium Diphosphine Complexes. J. Am. Chem. Soc. 2004, 126, 5502-5514.

(295) Wiese, S.; Kilgore, U. J.; Dubois, D. L.; Bullock, R. M. $\left[\mathrm{Ni}\left(\mathrm{P}^{\mathrm{Me} 2} \mathrm{~N}^{\mathrm{Ph} 2}\right)_{2}\right]\left(\mathrm{BF}_{4}\right)_{2}$ as an Electrocatalyst for $\mathrm{H}_{2}$ Production. ACS Catal. 2012, 2, 720-727.

(296) Yang, J. Y.; Smith, S. E.; Liu, T.; Dougherty, W. G.; Hoffert, W. A.; Kassel, W. S.; DuBois, M. R.; DuBois, D. L.; Bullock, R. M. Two Pathways for Electrocatalytic Oxidation of Hydrogen by a Nickel Bis(diphosphine) Complex with Pendant Amines in the Second Coordination Sphere. J. Am. Chem. Soc. 2013, 135, 9700-9712.

(297) Darensbourg, D. J.; Robertson, J. B.; Larkins, D. L.; Reibenspies, J. H. Water Soluble Organometallic Compounds. 7. Further Studies of 1, 3, 5-triaza-7-phosphaadamantane Derivatives of Group 10 Metals, Including Metal Carbonyls and Hydrides. Inorg. Chem. 1999, 38, 2473-2481.

(298) Butikofer, J. L.; Parson, T. G.; Roddick, D. M. Adduct Studies and Reactivity of Trans-

$\left[\left(\mathrm{C}_{2} \mathrm{~F}_{5}\right)_{2} \mathrm{MeP}\right]_{2} \mathrm{Pt}(\mathrm{Me}) \mathrm{X}\left(\mathrm{X}=\mathrm{O}_{2} \mathrm{CCF}_{3}\right.$, OTF, OSO $\left.{ }_{2} \mathrm{~F}\right)$. Organometallics 2006, 25, 6108-6114.

(299) Luca, O. R.; Blakemore, J. D.; Konezny, S. J.; Praetorius, J. M.; Schmeier, T. J.; Hunsinger, G. B.; Batista, V. S.; Brudvig, G. W.; Hazari, N.; Crabtree, R. H. Organometallic Ni Pincer Complexes for the Electrocatalytic Production of Hydrogen. Inorg. Chem. 2012, 51, 8704-8709.

(300) Goegsig, T. M.; Kleimark, J.; Nilsson Lill, S. O.; Korsager, S.; Lindhardt, A. T.; Norrby, P.-O.; Skrydstrup, T. Mild and Efficient Nickel-catalyzed Heck Reactions with Electron-rich Olefins. J. Am. Chem. Soc. 2012, 134, 443-452. 
(301) Forrest, S. J. K.; Pringle, P. G.; Sparkes, H. A.; Wass, D. F. Reversible CO Exchange at Platinum(0). an Example of Similar Complex Properties Produced by Ligands with Very Different Stereoelectronic Characteristics. Dalton Trans. 2014, 43, 16335-16344.

(302) Hills, I. D.; Fu, G. C. Elucidating Reactivity Differences in Palladium-Catalyzed Coupling Processes: the Chemistry of Palladium Hydrides. J. Am. Chem. Soc. 2004, 126, 13178-13179.

(303) Amatore, C.; Jutand, A.; Meyer, G.; Carelli, I.; Chiarotto, I. Reversible Formation of a Cationic Palladium(II) Hydride [HPd( $\left.\left.\mathrm{PPh}_{3}\right)_{2}\right]^{+}$in the Oxidative Addition of Acetic Or Formic Acid to Palladium(0) in DMF Eur. J. Inorg. Chem. 2000, 1855-1859.

(304) Cariati, F.; Ugo, R.; Bonati, F. Reactions of Inorganic Acids with Zerovalent Platinum, Palladium, and Nickel Compounds Having Triphenylphosphine or 1,2-Bis(diphenylphosphino)ethane as Ligands. Inorg. Chem. 1966, 5, 1128 - 1132.

(305) Perez, P. J.; Calabrese, J. C.; Bunel, E. E. Synthesis, Characterization, and Reactivity of $\left[\left(\left(^{(} \mathrm{Pr}\right)_{2} \mathrm{P}\left(\mathrm{CH}_{2}\right)_{3} \mathrm{P}\left({ }^{\mathrm{i}} \mathrm{Pr}\right)_{2}\right)\left(\mathrm{PC} \mathrm{y}_{3}\right) \mathrm{PdH}\right][\mathrm{OR}]$. Organometallics 2001, 20, 337-345.

(306) Puddephatt, R. J. Platinum(IV) Hydride Chemistry. Coord. Chem. Rev. 2001, 219, 157-185.

(307) Fulmer, G. R.; Herndon, A. N.; Kaminsky, W.; Kemp, R. A.; Goldberg, K. I. Hydrogenolysis of Palladium(II) Hydroxide, Phenoxide, and Alkoxide Complexes. J. Am. Chem. Soc. 2011, 133, 17713-17726. (308) Gregor, L. C.; Chen, C.-H.; Fafard, C. M.; Fan, L.; Guo, C.; Foxman, B. M.; Gusev, D. G.; Ozerov, O. V. Heterolytic Splitting of H-X Bonds at a Cationic (PNP)Pd Center. Dalton Trans. 2010, 39, 3195-3202.

(309) Gerber, R.; Fox, T.; Frech, C. M. PCsp ${ }^{3} P$ and PCsp ${ }^{2} P$ Palladium(II) Hydride Pincer Complexes: Small Structural Difference-Large Effect on Reactivity. Chem. - Eur. J. 2010, 16, 6771-6775.

(310) Almeida Lenero, K. Q. A.; Guari, Y.; Kamer, P. C. J.; van Leeuwen, P.; Donnadieu, B.; Sabo-Etienne, S.; Chaudret, B.; Lutz, M.; Spek, A. L. Heterolytic Activation of Dihydrogen by Platinum and Palladium Complexes. Dalton Trans. 2013, 42, 6495-6512.

(311) Tanaka, K.; Tanabe, M.; Ide, T.; Osakada, K. Cationic Hydridotriplatinum Complex with Bridging Germylene Ligands. Organometallics 2014, 33, 2608-2612.

(312) Latronico, M.; Mastrorilli, P.; Gallo, V.; Dell'Anna, M. M.; Creati, F.; Re, N.; Englert, U. Hydrido Phosphanido Bridged Polynuclear Complexes Obtained by Protonation of a Phosphinito Bridged Pt(I) Complex with $\mathrm{HBF}_{4}$ and HF. Inorg. Chem. 2011, 50, 3539-3558.

(313) Wik, B. J.; Ivanovic-Burmazovic, I.; Tilset, M.; van Eldik, R. Mechanistic Information From Lowtemperature Rapid-scan and NMR Measurements on the Protonation and Subsequent Reductive Elimination Reaction of a (diimine)platinum(II) Dimethyl Complex. Inorg. Chem. 2006, 45, 3613-3621. (314) Adams, J. J.; Arulsamy, N.; Roddick, D. M. Acceptor Pincer Coordination Chemistry of Platinum: Reactivity Properties of ( $\left.{ }^{\mathrm{CF} 3} \mathrm{PCP}\right) \mathrm{Pt}(\mathrm{L})^{+}\left(\mathrm{L}=\mathrm{NC}_{5} \mathrm{~F}_{5}, \mathrm{C}_{2} \mathrm{H}_{4}\right)$. Organometallics 2009, 28, 1148-1157. (315) DuBois, D. L.; Morris Bullock, R. Molecular Electrocatalysts for the Oxidation of Hydrogen and the Production of Hydrogen - the Role of Pendant Amines as Proton Relays. Eur. J. Inorg. Chem. 2011, 10171027.

(316) Kilgore, U. J.; Roberts, J. A. S.; Pool, D. H.; Appel, A. M.; Stewart, M. P.; DuBois, M. R.; Dougherty, W. G.; Kassel, W. S.; Bullock, R. M.; DuBois, D. L. $\left[\mathrm{Ni}\left(\mathrm{P}^{\mathrm{Ph} 2} \mathrm{~N}^{\mathrm{C} 6 \mathrm{H} 4 \times 2}\right)_{2}\right]^{2+}$ Complexes as Electrocatalysts for $\mathrm{H}_{2}$ Production: Effect of Substituents, Acids, and Water on Catalytic Rates. J. Am. Chem. Soc. 2011, 133, 5861-5872.

(317) Kilgore, U. J.; Stewart, M. P.; Helm, M. L.; Dougherty, W. G.; Kassel, W. S.; Dubois, M. R.; Dubois, D. L.; Bullock, R. M. Studies of a Series of $\left[\mathrm{Ni}\left(\mathrm{P}^{\mathrm{R} 2} \mathrm{~N}^{\mathrm{Ph} 2}\right)_{2}\left(\mathrm{CH}_{3} \mathrm{CN}\right)\right]^{2+}$ Complexes as Electrocatalysts for $\mathrm{H}_{2}$ Production: Substituent Variation at the Phosphorus Atom of the $\mathrm{P}_{2} \mathrm{~N}_{2}$ Ligand. Inorg. Chem. 2011, 50, 10908-10918.

(318) Wilson, A. D.; Shoemaker, R. K.; Miedaner, A.; Muckerman, J. T.; DuBois, D. L.; DuBois, M. R. Nature of Hydrogen Interactions with Ni(II) Complexes Containing Cyclic Phosphine Ligands with Pendant Nitrogen Bases. Proc. Natl. Acad. Sci 2007, 104, 6951-6956. 
(319) O'Hagan, M.; Shaw, W. J.; Raugei, S.; Chen, S. T.; Yang, J. Y.; Kilgore, U. J.; DuBois, D. L.; Bullock, R. M. Moving Protons with Pendant Amines: Proton Mobility in a Nickel Catalyst for Oxidation of Hydrogen. J. Am. Chem. Soc. 2011, 133, 14301-14312.

(320) Clegg, W.; Henderson, R. A. Kinetic Evidence for Intramolecular Proton Transfer Between Nickel and Coordinated Thiolate. Inorg. Chem. 2002, 41, 1128-1135.

(321) Aresta, M.; Dibenedetto, A.; Amodio, E.; Pápai, I.; Schubert, G. Synthesis, Characterization, and Reactivity of Cationic Hydride [HPd(diphosphine) $\left.{ }_{2}\right]^{+} \mathrm{CF}_{3} \mathrm{SO}_{3}{ }^{-}$, the Missing Member of the Family $\left[\mathrm{HM}(\mathrm{dppe})_{2}\right]^{+} \mathrm{X}^{-}(\mathrm{M}=\mathrm{Ni}, \mathrm{Pd}, \mathrm{Pt})$. DFT QM/MM Structural Predictions for the $\left[\mathrm{HPd}(\mathrm{dppe})_{2}\right]^{+}$Moiety. Inorg. Chem. 2002, 41, 6550-6552.

(322) Berning, D. E.; Miedaner, A.; Curtis, C. J.; Noll, B. C.; Rakowski DuBois, M. C.; DuBois, D. L. FreeEnergy Relationships Between the Proton and Hydride Donor Abilities of [HNi(diphosphine) $\left.{ }_{2}\right]^{+}$ Complexes and the Half-Wave Potentials of Their Conjugate Bases. Organometallics 2001, 20, 18321839.

(323) Berning, D. E.; Noll, B. C.; DuBois, D. L. Relative Hydride, Proton, and Hydrogen Atom Transfer Abilities of [HM(diphosphine) $\left.{ }_{2}\right] \mathrm{PF}_{6}$ Complexes ( $\mathrm{M}=\mathrm{Pt}$, Ni). J. Am. Chem. Soc. 1999, 121, 11432-11447. (324) Prokopchuk, E. M.; Jenkins, H. A.; Puddephatt, R. J. Stable Cationic Dimethyl(hydrido)platinum(IV) Complex. Organometallics 1999, 18, 2861-2866.

(325) Canty, A. J.; Fritsche, S. D.; Jin, H.; Patel, J.; Skelton, B. W.; White, A. H. Water and Protic Acids as Oxidants for Platinum(II): Diorgano(hydrido)platinum(IV) and Diorgano(hydroxo)platinum(IV) Chemistry, Including Structural Studies of Poly(pyrazol-1-yl)borate Complexes $\mathrm{Pt}(\mathrm{OH}) \mathrm{R}_{2}\left\{(\mathrm{pz})_{3} \mathrm{BH}\right\}(\mathrm{R}=$ Methyl, $\mathrm{P}$ Tolyl) and $\mathrm{Pt}(\mathrm{OH}) \mathrm{Me}_{2}\left\{(\mathrm{pz})_{4} \mathrm{~B}\right\} \cdot \mathrm{H}_{2} \mathrm{O}$. Organometallics 1997, 16, 2175-2182.

(326) O'Reilly, S. A.; White, P. S.; Templeton, J. L. Solid-state Structure of Tp'PtMe $2 \mathrm{H}$, a Dimethylhydrido Platinum(IV) Complex. J. Am. Chem. Soc. 1996, 118, 5684-5689.

(327) Parmene, J.; Krivokapic, A.; Tilset, M. Synthesis, Characterization, and Protonation Reactions of ArBIAN and Ar-BICAT Diimine Platinum Diphenyl Complexes. Eur. J. Inorg. Chem. 2010, 1381-1394.

(328) Ong, C. M.; Jennings, M. C.; Puddephatt, R. J. The Mechanism of Protonolysis of Phenylplatinum(II) Bonds in Complexes with Phenyl Trans to Nitrogen or Carbon Donors. Can. J. Chem. 2003, 81, 11961205.

(329) Curtis, C. J.; Miedaner, A.; Raebiger, J. W.; DuBois, D. L. Periodic Trends in Metal Hydride Donor Thermodynamics: Measurement and Comparison of the Hydride Donor Abilities of the Series $\mathrm{HM}(\mathrm{PNP})_{2}{ }^{+}$ $\left(\mathrm{M}=\mathrm{Ni}, \mathrm{Pd}, \mathrm{Pt} ; \mathrm{PNP}=\mathrm{Et}_{2} \mathrm{PCH}_{2} \mathrm{~N}(\mathrm{Me}) \mathrm{CH}_{2} \mathrm{PEt}_{2}\right)$. Organometallics 2004, 23, 511-516.

(330) Curtis, C. J.; Miedaner, A.; Ciancanelli, R.; Ellis, W. W.; Noll, B. C.; Rakowski-DuBois, M.; DuBois, D. L. $\left[\mathrm{Ni}\left(\mathrm{Et}_{2} \mathrm{PCH}_{2} \mathrm{NMeCH}_{2} \mathrm{PEt}_{2}\right)_{2}\right]^{2+}$ as a Functional Model for Hydrogenases. Inorg. Chem. 2003, 42, 216-227. (331) Ayllon, J. A.; Gervaux, C.; Sabo-Etienne, S.; Chaudret, B. First NMR Observation of the Intermolecular Dynamic Proton-transfer Equilibrium Between a Hydride and Coordinated Dihydrogen: $(\mathrm{dppm})_{2} \mathrm{HRuH} . . . \mathrm{H}-\mathrm{OR}=\left[(\mathrm{dppm})_{2} \mathrm{HRu}\left(\mathrm{H}_{2}\right)\right]^{+}(\mathrm{OR})^{-}$. Organometallics 1997, 16, 2000-2002.

(332) Berke, H. Conceptual Approach to the Reactivity of Dihydrogen. Chemphyschem 2010, 11, 18371849.

(333) Bullock, R. M.; Helm, M. L. Molecular Electrocatalysts for Oxidation of Hydrogen Using EarthAbundant Metals: Shoving Protons Around with Proton Relays. Acc. Chem. Res. 2015, 48, 2017-2026. (334) Bullock, R. M. Molybdenum and Tungsten Catalysts for Hydrogenation, Hydrosilylation and Hydrolysis. In Catalysis without Precious Metals; Bullock, R. M., Ed.; Wiley-VCH, 2010, Ch. 3, 51-81. (335) Bullock, R. M.; Voges, M. H. Homogeneous Catalysis with Inexpensive Metals: Ionic Hydrogenation of Ketones with Molybdenum and Tungsten Catalysts. J. Am. Chem. Soc. 2000, 122, 12594-12595. (336) Noyori, R. Asymmetric Catalysis: Science and Opportunities (Nobel Lecture). Angew. Chem., Int. Ed. 2002, 41, 2008-2022. 
(337) Ohkuma, T.; Utsumi, N.; Tsutsumi, K.; Murata, K.; Sandoval, C.; Noyori, R. The Hydrogenation/transfer Hydrogenation Network: Asymmetric Hydrogenation of Ketones with Chiral $\eta^{6}$ arene/N-tosylethylenediamine-ruthenium(II) Catalysts. J. Am. Chem. Soc. 2006, 128, 8724-8725.

(338) Haack, K. J.; Hashiguchi, S.; Fujii, A.; Ikariya, T.; Noyori, R. The Catalyst Precursor, Catalyst, and Intermediate in the Ru"-promoted Asymmetric Hydrogen-transfer Between Alcohols and Ketones. Angew. Chem., Int. Ed. 1997, 36, 285-288.

(339) Chen, Y.; Tang, Y. H.; Liu, S. B.; Lei, M.; Fang, W. H. Mechanism and Influence of Acid in Hydrogenation of Ketones by $\eta^{6}$-Arene/N-Tosylethylenediamine Ruthenium(II). Organometallics 2009, 28, 2078-2084.

(340) Makihara, N.; Ogo, S.; Watanabe, Y. pH Selective Hydrogenation of Water Soluble Carbonyl Compounds and Alkenes with $\left[\mathrm{Cp} * \mathrm{Ir}^{\prime \prime \prime}\left(\mathrm{H}_{2} \mathrm{O}\right)_{3}\right]^{2+}\left(\mathrm{Cp} *=\eta^{5}-\mathrm{C}_{5} \mathrm{Me}_{5}\right)$ as a Catalyst Precursor in Very Acidic Media. Organometallics 2001, 20, 497-500.

(341) Tooley, P. A.; Ovalles, C.; Kao, S. C.; Darensbourg, D. J.; Darensbourg, M. Y. Anionic Group 6 Hydrides and Carboxylates as Homogeneous Catalysts for Reduction of Aldehydes and Ketones. J. Am. Chem. Soc. 1986, 108, 5465-5470.

(342) Schlaf, M.; Ghosh, P.; Fagan, P. J.; Hauptman, E.; Bullock, R. M. Metal-Catalyzed Selective Deoxygenation of Diols to Alcohols. Angew. Chem., Int. Ed. 2001, 40, 3887-3890.

(343) Dykeman, R. R.; Luska, K. L.; Thibault, M. E.; Jones, M. D.; Schlaf, M.; Khanfar, M.; Taylor, N. J.; Britten, J. F.; Harrington, L. Catalytic Deoxygenation of Terminal-diols Under Acidic Aqueous Conditions by the Ruthenium Complexes $\left(\eta^{6}\right.$-arene) $\mathrm{Ru}(\mathrm{X})(\mathrm{N}-\mathrm{N})(\mathrm{OTf})_{n}, \mathrm{X}=\mathrm{H}_{2} \mathrm{O}, \mathrm{H}, \eta^{6}$-arene $=\mathrm{p}-\mathrm{Me}-{ }^{\mathrm{i} P r}-\mathrm{C}_{6} \mathrm{H}_{4}, \mathrm{C}_{6} \mathrm{Me}_{6}$, $\mathrm{N}-\mathrm{N}=$ Bipy, Phen, 6,6 '-diamino-bipy, 2,9-diamino-phen, $\mathrm{N}=1$, 2): Influence of the Ortho-amine Substituents on Catalytic Activity. J. Mol. Cat. A. Chem. 2007, 277, 233-251.

(344) Brewster, T. P.; Miller, A. J. M.; Heinekey, D. M.; Goldberg, K. I. Hydrogenation of Carboxylic Acids Catalyzed by Half-Sandwich Complexes of Iridium and Rhodium. J. Am. Chem. Soc. 2013, 135, 1602216025.

(345) Goldfarb, A. R.; Mele, A.; Gutstein, N. Basicity of the Amide Bond. J. Am. Chem. Soc. 1955, 77, 6194-6196.

(346) Ito, M.; Ikariya, T. Catalytic Hydrogenation of Polar Organic Functionalities Based on Ru-mediated Heterolytic Dihydrogen Cleavage. Chem. Commun. 2007, 5134-5142.

(347) Crugeiras, J.; Rios, A.; Riveiros, E.; Richard, J. P. Substituent Effects on the Thermodynamic Stability of Imines Formed From Glycine and Aromatic Aldehydes: Implications for the Catalytic Activity of Pyridoxal-5'-phosphate. J. Am. Chem. Soc. 2009, 131, 15815-15824.

(348) Wang, T. L.; Zhuo, L. G.; Li, Z. W.; Chen, F.; Ding, Z. Y.; He, Y. M.; Fan, Q. H.; Xiang, J. F.; Yu, Z. X.;

Chan, A. S. C. Highly Enantioselective Hydrogenation of Quinolines Using Phosphine-Free Chiral Cationic Ruthenium Catalysts: Scope, Mechanism, and Origin of Enantioselectivity. J. Am. Chem. Soc. 2011, 133, 9878-9891.

(349) Misumi, Y.; Seino, H.; Mizobe, Y. Heterolytic Cleavage of Hydrogen Molecule by Rhodium Thiolate Complexes That Catalyze Chemoselective Hydrogenation of Imines Under Ambient Conditions. J. Am. Chem. Soc. 2009, 131, 14636-14637.

(350) Seino, H.; Misumi, Y.; Hojo, Y.; Mizobe, Y. Heterolytic $\mathrm{H}_{2}$ Activation by Rhodium Thiolato Complexes Bearing the Hydrotris(pyrazolyl)borato Ligand and Application to Catalytic Hydrogenation Under Mild Conditions. Dalton Trans. 2010, 39, 3072-3082.

(351) Blaser, H. U.; Pugin, B.; Spindler, F.; Thommen, M. From a Chiral Switch to a Ligand Portfolio for Asymmetric Catalysis. Acc. Chem. Res. 2007, 40, 1240-1250.

(352) Zhou, X. Y.; Bao, M.; Zhou, Y. G. Palladium-Catalyzed Asymmetric Hydrogenation of Simple Ketimines Using a Brønsted Acid as Activator. Adv. Syn. Catal. 2011, 353, 84-88.

(353) Magee, M. P.; Norton, J. R. Stoichiometric, Catalytic, and Enantioface Selective Hydrogenation of $\mathrm{C}=\mathrm{N}$ Bonds by an Ionic Mechanism. . J. Am. Chem. Soc. 2001, 123, 1778-1779. 
(354) Shaw, A. P.; Ryland, B. L.; Franklin, M. J.; Norton, J. R.; Chen, J. Y. C.; Hall, M. L. Using a Two-Step Hydride Transfer to Achieve 1,4-Reduction in the Catalytic Hydrogenation of an Acyl Pyridinium Cation. J. Org. Chem. 2008, 73, 9668-9674.

(355) Ogo, S.; Uehara, K.; Abura, T.; Fukuzumi, S. pH-Dependent Chemoselective Synthesis of A-Amino Acids. Reductive Amination of $\alpha$-Keto Acids with Ammonia Catalyzed by Acid-Stable Iridium Hydride Complexes in Water. J. Am. Chem. Soc. 2004, 126, 3020-3021.

(356) Ogo, S.; Makihara, N.; Kaneko, Y.; Watanabe, Y. pH-Dependent Transfer Hydrogenation, Reductive Amination, and Dehalogenation of Water-Soluble Carbonyl Compounds and Alkyl Halides Promoted by Cp*Ir Complexes. Organometallics 2001, 20, 4903-4910.

(357) Zhou, S. L.; Fleischer, S.; Jiao, H. J.; Junge, K.; Beller, M. Cooperative Catalysis with Iron and a Chiral Brønsted Acid for Asymmetric Reductive Amination of Ketones. Adv. Syn. Catal. 2014, 356, 3451-3455. (358) Aresta, M.; Dibenedetto, A.; Papai, I.; Schubert, G.; Macchioni, A.; Zuccaccia, D. Behaviour of $\mathrm{PdH}$ (dppe) ${ }_{2} \mathrm{X}\left(\mathrm{X}=\mathrm{CF}_{3} \mathrm{SO}_{3}{ }^{-}, \mathrm{SbF}_{6}{ }^{-}, \mathrm{BF}_{4}{ }^{-}\right)$as Proton Or Hydride Donor: Relevance to Catalysis. Chem. - Eur. J. 2004, 10, 3708-3716.

(359) Gonzalez-Arellano, C.; Corma, A.; Iglesias, M.; Sanchez, F. Enantioselective Hydrogenation of Alkenes and Imines by a Gold Catalyst. Chem. Commun. 2005, 3451-3453.

(360) Comas-Vives, A.; Ujaque, G. Unraveling the Pathway of Gold(I)-catalyzed Olefin Hydrogenation: an Ionic Mechanism. J. Am. Chem. Soc. 2013, 135, 1295-1305.

(361) Takei, I.; Nishibayashi, Y.; Ishii, Y.; Mizobe, Y.; Uemura, S.; Hidai, M. Novel Catalytic Hydrogenolysis of Silyl Enol Ethers by the Use of Acidic Ruthenium Dihydrogen Complexes. J. Organomet. Chem. 2003, $679,32-42$.

(362) Ogo, S.; Abura, T.; Watanabe, Y. pH-Dependent Transfer Hydrogenation of Ketones with HCOONa as a Hydrogen Donor Promoted by $\left(\eta^{6}-\mathrm{C}_{6} \mathrm{Me}_{6}\right) \mathrm{Ru}$ Complexes. Organometallics 2002, 21, 2964-2969. (363) Abura, T.; Ogo, S.; Watanabe, Y.; Fukuzumi, S. Isolation and Crystal Structure of a Water-Soluble Iridium Hydride: a Robust and Highly Active Catalyst for Acid-Catalyzed Transfer Hydrogenations of Carbonyl Compounds in Acidic Media. J. Am. Chem. Soc. 2003, 125, 4149-4154.

(364) Talwar, D.; Li, H. Y.; Durham, E.; Xiao, J. L. A Simple Iridicycle Catalyst for Efficient Transfer Hydrogenation of N-Heterocycles in Water. Chem. - Eur. J. 2015, 21, 5370-5379.

(365) Lau, C. P.; Ng, S. M.; Jia, G.; Lin, Z. Some Ruthenium Hydride, Dihydrogen, and Dihydrogen-bonded Complexes in Catalytic Reactions. Coord. Chem. Rev. 2007, 251, 2223-2237.

(366) Kovács, G.; Schubert, G.; Joó, F.; Pápai, I. Theoretical Mechanistic Study of Rhodium(I) PhosphineCatalyzed H/D Exchange Processes in Aqueous Solutions. Organometallics 2005, 24, 3059-3065. (367) Albeniz, A. C.; Heinekey, D. M.; Crabtree, R. H. Dihydrogen Complexes in Catalysis: Isotope Exchange Reactions. Inorg. Chem. 1991, 30, 3632.

(368) Schrock, R. R.; Osborn, J. A. Catalytic Hydrogenation Using Cationic Rhodium Complexes. I. Evolution of the Catalytic System and the Hydrogenation of Olefins. J. Am. Chem. Soc 1976, 98, 21342143.

(369) Zhu, Y.; Burgess, K. Filling Gaps in Asymmetric Hydrogenation Methods for Acyclic Stereocontrol: Application to Chirons for Polyketide-derived Natural Products. Acc. Chem. Res. 2012, 45, 1623-1636. (370) Bell, S.; Wustenberg, B.; Kaiser, S.; Menges, F.; Netscher, T.; Pfaltz, A. Asymmetric Hydrogenation of Unfunctionalized, Purely Alkyl-Substituted Olefins. Science 2006, 311, 642-644.

(371) Gruber, S.; Pfaltz, A. Asymmetric Hydrogenation with Iridium C,N and N,P Ligand Complexes: Characterization of Dihydride Intermediates with a Coordinated Alkene. Angew. Chem., Int. Ed. 2014, 53, 1896-1900.

(372) Hedberg, C.; Kallstrom, K.; Brandt, P.; Hansen, L. K.; Andersson, P. G. Asymmetric Hydrogenation of Trisubstituted Olefins with Iridium-phosphine Thiazole Complexes: a Further Investigation of the Ligand Structure. J. Am. Chem. Soc. 2006, 128, 2995-3001. 
(373) Larionov, E.; Lin, L. Q.; Guenee, L.; Mazet, C. Scope and Mechanism in Palladium-Catalyzed Isomerizations of Highly Substituted Allylic, Homoallylic, and Alkenyl Alcohols. J. Am. Chem. Soc. 2014, 136, 16882-16894.

(374) Ngai, M. Y.; Kong, J. R.; Krische, M. J. Hydrogen-mediated C-C Bond Formation: a Broad New Concept in Catalytic C-C Coupling. J. Org. Chem. 2007, 72, 1063-1072.

(375) Bower, J. F.; Kim, I. S.; Patman, R. L.; Krische, M. J. Catalytic Carbonyl Addition Through Transfer Hydrogenation: a Departure From Preformed Organometallic Reagents. Angew. Chem., Int. Ed. 2009, 48, 34-46.

(376) Zbieg, J. R.; Yamaguchi, E.; McInturff, E. L.; Krische, M. J. Enantioselective C-H Crotylation of Primary Alcohols via Hydrohydroxyalkylation of Butadiene. Science 2012, 336, 324-327.

(377) Johansson, L.; Tilset, M. Evidence for Associative Methane Loss Following Protonation of (Diimine)Pt" $\left(\mathrm{CH}_{3}\right)_{2}$ : Three-Coordinate 14-Electron Cations $\mathrm{L}_{2} \mathrm{Pt}\left(\mathrm{CH}_{3}\right)^{+}$Are Not Necessarily Intermediates in C-H Activation at Cationic Pt Complexes. J. Am. Chem. Soc. 2001, 123, 739-740.

(378) Heyduk, A. F.; Labinger, J. A.; Bercaw, J. E. Catalytic Alcoholysis of Tetramethylsilane via PtMediated C-H Bond Activation. J. Am. Chem. Soc. 2003, 125, 6366-6367.

(379) Lough, A. J.; Park, S.; Ramachandran, R.; Morris, R. H. Switching on and Off a New Intramolecular Hydrogen-hydrogen Interaction and the Heterolytic Splitting of Dihydrogen. Crystal and Molecular Structure of $\left[\mathrm{Ir}\left\{\mathrm{H}\left(\mathrm{SC}_{5} \mathrm{H}_{4} \mathrm{NH}\right)\right\}_{2}\left(\mathrm{PCY}_{3}\right)_{2}\right]\left(\mathrm{BF}_{4}\right) \cdot 2.7 \mathrm{CH}_{2} \mathrm{Cl}_{2}$. J. Am. Chem. Soc. 1994, 116, 8356-8357.

(380) Abdur-Rashid, K.; Clapham, S. E.; Hadzovic, A.; Harvey, J. N.; Lough, A. J.; Morris, R. H. Mechanism of the Hydrogenation of Ketones Catalyzed by Trans-Dihydrido(diamine)ruthenium(II) Complexes. J. Am. Chem. Soc. 2002, 124, 15104-15118.

(381) Shvo, Y.; Czarkie, D.; Rahamim, Y.; Chodosh, D. F. A New Group of Ruthenium Complexes:

Structure and Catalysis. J. Am. Chem. Soc. 1986, 108, 7400-7402.

(382) vom Stein, T.; Meuresch, M.; Limper, D.; Schmitz, M.; Holscher, M.; Coetzee, J.; Cole-Hamilton, D. J.; Klankermayer, J.; Leitner, W. Highly Versatile Catalytic Hydrogenation of Carboxylic and Carbonic Acid Derivatives Using a Ru-Triphos Complex: Molecular Control Over Selectivity and Substrate Scope. J. Am. Chem. Soc. 2014, 136, 13217-13225.

(383) Wang, W. H.; Muckerman, J. T.; Fujita, E.; Himeda, Y. Mechanistic Insight Through Factors Controlling Effective Hydrogenation of $\mathrm{CO}_{2}$ Catalyzed by Bioinspired Proton-responsive Iridium(III) Complexes. ACS Catal. 2013, 3, 856-860.

(384) Wesselbaum, S.; Moha, V.; Meuresch, M.; Brosinski, S.; Thenert, K. M.; Kothe, J.; vom Stein, T.; Englert, U.; Holscher, M.; Klankermayer, J.; Leitner, W. Hydrogenation of Carbon Dioxide to Methanol Using a Homogeneous Ruthenium-Triphos Catalyst: From Mechanistic Investigations to Multiphase Catalysis. Chem. Sci. 2015, 6, 693-704.

(385) O, W. W. N.; Lough, A. J.; Morris, R. H. Factors Favoring Efficient Bifunctional Catalysis. a Study of a Ruthenium(II) Hydrogenation Catalyst Containing an N-Heterocyclic Carbene with a Primary Amine Donor. Organometallics 2012, 31, 2137-2151.

(386) Samouei, H.; Miloserdov, F. M.; Escudero-Adan, E. C.; Grushin, V. V. Solid-State Structure and Solution Reactivity of $\left(\mathrm{Ph}_{3} \mathrm{P}\right)_{4} \mathrm{Ru}(\mathrm{H})_{2}$ and Related $\mathrm{Ru}(\mathrm{II})$ Complexes Used in Catalysis: a Reinvestigation. Organometallics 2014, 33, 7279-7283.

(387) Jessop, P. G.; Morris, R. H. H/D Exchange Reactions of an Iridium Dithiol Complex. Inorg. Chem. 1993, 32, 2236-2237.

(388) Tanaka, R.; Yamashita, M.; Nozaki, K. Catalytic Hydrogenation of Carbon Dioxide Using Ir(III)-Pincer Complexes. J. Am. Chem. Soc. 2009, 131, 14168-14169.

(389) Annibale, V. T.; Song, D. Multidentate Actor Ligands as Versatile Platforms for Small Molecule Activation and Catalysis. RSC Advances 2013, 3, 11432-11449.

(390) Khusnutdinova, J. R.; Milstein, D. Metal-Ligand Cooperation. Angew. Chem., Int. Ed. 2015, 54, 12236-12273. 
(391) Liu, T.; Liao, Q.; O'Hagan, M.; Hulley, E. B.; DuBois, D. L.; Bullock, R. M. Iron Complexes Bearing Diphosphine Ligands with Positioned Pendant Amines as Electrocatalysts for the Oxidation of $\mathrm{H}_{2}$. Organometallics 2015, 34, 2747-2764.

(392) Dahlenburg, L.; Herbst, K. Ligand Vs. Metal Basicity: Reactions of 2-(diphenylphosphanyl)anilido and 2-(diphenylphosphanyl)phenolato Complexes of Rhodium(I) and Iridium(I) with $\mathrm{HBF}_{4}$. Z. Naturforsch., B: J. Chem. Sci. 2010, 65, 376-382.

(393) Zimmer-De luliis, M.; Morris, R. H. Kinetic Hydrogen/Deuterium Effects in the Direct Hydrogenation of Ketones Catalyzed by a Well-Defined Ruthenium Diphosphine Diamine Complex. J. Am. Chem. Soc. 2009, 131, 11263-11269.

(394) Grotjahn, D. B.; Larsen, C. R.; Gustafson, J. L.; Nair, R.; Sharma, A. Extensive Isomerization of Alkenes Using a Bifunctional Catalyst: an Alkene Zipper. J. Am. Chem. Soc. 2007, 129, 9592-9593. (395) Abdur-Rashid, K.; Faatz, M.; Lough, A. J.; Morris, R. H. Catalytic Cycle for the Asymmetric Hydrogenation of Prochiral Ketones to Chiral Alcohols: Direct Hydride and Proton Transfer From Chiral Catalysts Trans- $\mathrm{Ru}(\mathrm{H})_{2}$ (diphosphine)(diamine) to Ketones and Direct Addition of Dihydrogen to the Resulting Hydridoamido Complexes. J. Am. Chem. Soc. 2001, 123, 7473-7474.

(396) Sandoval, C. A.; Ohkuma, T.; Muniz, K.; Noyori, R. Mechanism of Asymmetric Hydrogenation of Ketones Catalyzed by BINAP/1,2-Diamine-Ruthenium(II) Complexes. J. Am. Chem. Soc. 2003, 125, 1349013503.

(397) Hamilton, R. J.; Leong, C. G.; Bigam, G.; Miskolzie, M.; Bergens, S. H. A Ruthenium-Dihydrogen Putative Intermediate in Ketone Hydrogenation. J. Am. Chem. Soc. 2005, 127, 4152-4153.

(398) John, J. M.; Takebayashi, S.; Dabral, N.; Miskolzie, M.; Bergens, S. H. Base-catalyzed Bifunctional Addition to Amides and Imides at Low Temperature. a New Pathway for Carbonyl Hydrogenation. J. Am. Chem. Soc. 2013, 135, 8578-8584.

(399) Zuo, W.; Tauer, S.; Prokopchuk, D. E.; Morris, R. H. Iron Catalysts Containing Amine(imine)diphosphine P-NH-N-P Ligands Catalyze Both the Asymmetric Hydrogenation and Asymmetric Transfer Hydrogenation of Ketones. Organometallics 2014, 33, 5791-5801. (400) Zuo, W.; Lough, A. J.; Li, Y.; Morris, R. H. Amino(imino)diphosphines Activate Iron Catalysts in the Asymmetric Transfer Hydrogenation of Ketones and Imines Science 2013, 342, 1080-1083. (401) Yin, C.; Xu, Z.; Yang, S.-Y.; Ng, S. M.; Wong, K. Y.; Lin, Z.; Lau, C. P. Promoting Effect of Water in Ruthenium-Catalyzed Hydrogenation of Carbon Dioxide to Formic Acid. Organometallics 2001, 20, 12161222.

(402) Himeda, Y. Conversion of $\mathrm{CO}_{2}$ Into Formate by Homogeneously Catalyzed Hydrogenation in Water: Tuning Catalytic Activity and Water Solubility Through the Acid-base Equilibrium of the Ligand. Eur. J. Inorg. Chem. 2007, 3927-3941.

(403) Hull, J. F.; Himeda, Y.; Wang, W. H.; Hashiguchi, B.; Periana, R.; Szalda, D. J.; Muckerman, J. T.; Fujita, E. Reversible Hydrogen Storage Using $\mathrm{CO}_{2}$ and a Proton-switchable Iridium Catalyst in Aqueous Media Under Mild Temperatures and Pressures. Nature Chem. 2012, 4, 383-388.

(404) Chakraborty, S.; Blacque, O.; Berke, H. Ligand Assisted Carbon Dioxide Activation and Hydrogenation Using Molybdenum and Tungsten Amides. Dalton Trans. 2015, 44, 6560-6570. (405) Watari, R.; Kayaki, Y.; Hirano, S.; Matsumoto, N.; Ikariya, T. Hydrogenation of Carbon Dioxide to Formate Catalyzed by a Copper/1,8-Diazabicyclo[5.4.0]undec-7-ene System. Adv. Syn. Catal. 2015, 357, 1369-1373.

(406) Ziebart, C.; Federsel, C.; Anbarasan, P.; Jackstell, R.; Baumann, W.; Spannenberg, A.; Beller, M. Well-Defined Iron Catalyst for Improved Hydrogenation of Carbon Dioxide and Bicarbonate. J. Am. Chem. Soc. 2012, 134, 20701-20704.

(407) Czaun, M.; Goeppert, A.; May, R.; Haiges, R.; Prakash, G. K. S.; Olah, G. A. Hydrogen Generation From Formic Acid Decomposition by Ruthenium Carbonyl Complexes. Tetraruthenium Dodecacarbonyl Tetrahydride as an Active Intermediate. ChemSusChem 2011, 4, 1241-1248. 
(408) Rountree, E. S.; Dempsey, J. L. Potential-Dependent Electrocatalytic Pathways: Controlling Reactivity with pKa for Mechanistic Investigation of a Nickel-Based Hydrogen Evolution Catalyst. J. Am. Chem. Soc. 2015, 137, 13371-13380.

(409) Wiedner, E. S.; Roberts, J. A. S.; Dougherty, W. G.; Kassel, W. S.; DuBois, D. L.; Bullock, R. M. Synthesis and Electrochemical Studies of Cobalt(III) Monohydride Complexes Containing Pendant Amines. Inorg. Chem. 2013, 52, 9975-9988.

(410) Nippe, M.; Khnayzer, R. S.; Panetier, J. A.; Zee, D. Z.; Olaiya, B. S.; Head-Gordon, M.; Chang, C. J.; Castellano, F. N.; Long, J. R. Catalytic Proton Reduction with Transition Metal Complexes of the Redoxactive Ligand Bpy2PYMe. Chem. Sci. 2013, 4, 3934-3945.

(411) Solis, B. H.; Yu, Y. X.; Hammes-Schiffer, S. Effects of Ligand Modification and Protonation on Metal Oxime Hydrogen Evolution Electrocatalysts. Inorg. Chem. 2013, 52, 6994-6999.

(412) Liu, T.; Wang, X.; Hoffmann, C.; Dubois, D. L.; Bullock, R. M. Heterolytic Cleavage of Hydrogen by an Iron Hydrogenase Model: an Fe-H $\cdots \mathrm{H}-\mathrm{N}$ Dihydrogen Bond Characterized by Neutron Diffraction. Angew. Chem., Int. Ed. 2014, 53, 5300-5304.

(413) Weber, K.; Weyhermueller, T.; Bill, E.; Erdem, O. F.; Lubitz, W. Design and Characterization of Phosphine Iron Hydrides: Toward Hydrogen-Producing Catalysts. Inorg. Chem. 2015, 54, 6928-6937. (414) Liu, T.; Dubois, M. R.; Dubois, D. L.; Bullock, R. M. Electrochemical Oxidation of $\mathrm{H}_{2}$ Catalyzed by Ruthenium Hydride Complexes Bearing $\mathrm{P}_{2} \mathrm{~N}_{2}$ Ligands with Pendant Amines as Proton Relays. Energy Environ. Sci. 2014, 7, 3630-3639.

(415) Dey, S.; Das, P. K.; Dey, A. Mononuclear Iron Hydrogenase. Coord. Chem. Rev. 2013, 257, 42-63. (416) Hedegard, E. D.; Kongsted, J.; Ryde, U. Multiscale Modeling of the Active Site of [Fe] Hydrogenase: the $\mathrm{H}_{2}$ Binding Site in Open and Closed Protein Conformations. Angew. Chem., Int. Ed. 2015, 54, 62466250.

(417) Kalz, K. F.; Brinkmeier, A.; Dechert, S.; Mata, R. A.; Meyer, F. Functional Model for the [Fe]Hydrogenase Inspired by the Frustrated Lewis Pair Concept. J. Am. Chem. Soc. 2014, 136, 16626-16634. (418) Finkelmann, A. R.; Senn, H. M.; Reiher, M. Hydrogen-activation Mechanism of [Fe] Hydrogenase Revealed by Multi-scale Modeling. Chem. Sci. 2014, 5, 4474-4482.

(419) Jablonskyte, A.; Wright, J. A.; Fairhurst, S. A.; Webster, L. R.; Pickett, C. J. [FeFe] Hydrogenase: Protonation of \{2Fe3S\} Systems and Formation of Super-reduced Hydride States. Angew. Chem., Int. Ed. 2014, 53, 10143-10146.

(420) Zaffaroni, R.; Rauchfuss, T. B.; Fuller, A.; De Gioia, L.; Zampella, G. Contrasting Protonation Behavior of Diphosphido Vs Dithiolato Diiron(I) Carbonyl Complexes. Organometallics 2013, 32, 232-238. (421) Almazahreh, L. R.; Imhof, W.; Talarmin, J.; Schollhammer, P.; Gorls, H.; El-khateeb, M.; Weigand, W. Ligand Effects on the Electrochemical Behavior of $\mathrm{Fe}_{2}(\mathrm{CO})_{5}(\mathrm{~L})\left\{\mu-\left(\mathrm{SCH}_{2}\right)_{2}(\mathrm{Ph}) \mathrm{P}=\mathrm{O}\right\}\left(\mathrm{L}=\mathrm{PPh}_{3}, \mathrm{P}(\mathrm{OEt})_{3}\right)$ Hydrogenase Model Complexes. Dalton Trans. 2015, 44, 7177-7189.

(422) Zaffaroni, R.; Rauchfuss, T. B.; Gray, D. L.; De Gioia, L.; Zampella, G. Terminal Vs Bridging Hydrides of Diiron Dithiolates: Protonation $\mathrm{Fe}_{2}$ (dithiolate) $(\mathrm{CO})_{2}\left(\mathrm{PMe}_{3}\right)_{4}$. J. Am. Chem. Soc. 2012, 134, 1926019269.

(423) Liu, C. P.; Peck, J. N. T.; Wright, J. A.; Pickett, C. J.; Hall, M. B. Density Functional Calculations on Protonation of the $[\mathrm{FeFe}]-H y d r o g e n a s e ~ M o d e l ~ C o m p l e x ~ \mathrm{Fe}_{2}(\mu-\mathrm{pdt})(\mathrm{CO})_{4}\left(\mathrm{PMe}_{3}\right)_{2}$ and Subsequent Isomerization Pathways. Eur. J. Inorg. Chem. 2011, 1080-1093.

(424) Galinato, M. G. I.; Whaley, C. M.; Roberts, D.; Wang, P.; Lehnert, N. Favorable Protonation of the ( $\mu$-edt) $\left[\mathrm{Fe}_{2}\left(\mathrm{PMe}_{3}\right)_{4}(\mathrm{CO})_{2}(\mathrm{H} \text {-terminal })\right]^{+}$Hydrogenase Model Complex Over Its Bridging $\mu$-H Counterpart: a Spectroscopic and DFT Study. Eur. J. Inorg. Chem. 2011, 1147-1154.

(425) Xiao, Z.; Xu, F.; Long, L.; Liu, Y.; Zampella, G.; Gioia, L. D.; Zeng, X.; Luo, Q.; Liu, X. Influence of the Basicity of Internal Bases in Diiron Model Complexes on Hydrides Formation and Their Transformation Into Protonated Diiron Hexacarbonyl Form. J. Organomet. Chem. 2010, 695, 721-729. 
(426) Gordon, J. C.; Kubas, G. J. Perspectives on How Nature Employs the Principles of Organometallic Chemistry in Dihydrogen Activation in Hydrogenases. Organometallics 2010, 29, 4682-4701.

(427) Wang, N.; Wang, M.; Zhang, T.; Li, P.; Liu, J.; Sun, L. A Proton-hydride Diiron Complex with a Basecontaining Diphosphine Ligand Relevant to the [FeFe]-hydrogenase Active Site. Chem. Commun. 2008, 5800-5802.

(428) Ezzaher, S.; Capon, J. F.; Gloaguen, F.; Petillon, F. Y.; Schollhammer, P.; Talarmin, J.; Kervarec, N. Influence of a Pendant Amine in the Second Coordination Sphere on Proton Transfer at a

Dissymmetrically Disubstituted Diiron System Related to the [2Fe] $]_{\mathrm{H}}$ Subsite of [FeFe] $\mathrm{H}_{2}$ ase. Inorg. Chem. 2009, 48, 2-4.

(429) Volkers, P.; Rauchfuss, T. B. Extending the Motif of the [FeFe] -hydrogenase Active Site Models: Protonation of $\mathrm{Fe}_{2}(\mathrm{NR})_{2}(\mathrm{CO})_{6-x} \mathrm{~L}_{x}$ Species. J. Inorg. Biochem. 2007, 101, 1748-1751.

(430) Ogo, S.; Kabe, R.; Uehara, K.; Kure, B.; Nishimura, T.; Menon, S. C.; Harada, R.; Fukuzumi, S.;

Higuchi, Y.; Ohhara, T.; Tamada, T.; Kuroki, R. A Dinuclear Ni( $\mu-\mathrm{H}) \mathrm{Ru}$ Complex Derived From $\mathrm{H}_{2}$. Science 2007, 316, 585-587.

(431) Chernev, P.; Lambertz, C.; Brünje, A.; Leidel, N.; Sigfridsson, K. G. V.; Kositzki, R.; Hsieh, C. H.; Yao, S.; Schiwon, R.; Driess, M.; Limberg, C.; Happe, T.; Haumann, M. Hydride Binding to the Active Site of [FeFe]-hydrogenase. Inorg. Chem. 2014, 53, 12164-12177.

(432) Pandelia, M. E.; Infossi, P.; Stein, M.; Giudici-Orticoni, M. T.; Lubitz, W. Spectroscopic Characterization of the Key Catalytic Intermediate $\mathrm{Ni}-\mathrm{C}$ in the $\mathrm{O}_{2}$-tolerant [NiFe] Hydrogenase I From Aquifex Aeolicus: Evidence of a Weakly Bound Hydride. Chem. Commun. 2012, 48, 823-825.

(433) Kinney, R. A.; Saouma, C. T.; Peters, J. C.; Hoffman, B. M. Modeling the Signatures of Hydrides in Metalloenzymes: ENDOR Analysis of a Di-iron Fe $(\mu-\mathrm{NH})(\mu-\mathrm{H}) \mathrm{Fe}$ Core. J. Am. Chem. Soc. 2012, 134, 12637-12647.

(434) Nielsen, J. E.; McCammon, J. A. Calculating $\mathrm{p} K_{\mathrm{a}}$ Values in Enzyme Active Sites. Protein Sci. 2003, 12, 1894-1901.

(435) Capon, J. F.; Gloaguen, F.; Petillon, F. Y.; Schollhammer, P.; Talarmin, J. Electron and Proton Transfers at Diiron Dithiolate Sites Relevant to the Catalysis of Proton Reduction by the [FeFe]hydrogenases. Coord. Chem. Rev. 2009, 253, 1476-1494.

(436) Tard, C.; Pickett, C. J. Structural and Functional Analogues of the Active Sites of the [Fe]-, [NiFe]-, and [FeFe]-Hydrogenases. Chem. Rev. 2009, 109, 2245-2274.

(437) Gloaguen, F.; Rauchfuss, T. B. Small Molecule Mimics of Hydrogenases: Hydrides and Redox. Chem. Soc. Rev. 2009, 38, 100-108.

(438) Camara, J. M.; Rauchfuss, T. B. Combining Acid-base, Redox and Substrate Binding Functionalities to Give a Complete Model for the [FeFe]-hydrogenase. Nature Chem. 2012, 4, 26-30.

(439) Zampella, G.; Greco, C.; Fantucci, P.; De Gioia, L. Proton Reduction and Dihydrogen Oxidation on Models of the $[2 \mathrm{Fe}]_{\mathrm{H}}$ Cluster of [Fe] Hydrogenases. a Density Functional Theory Investigation. Inorg. Chem. 2006, 45, 4109-4118.

(440) Carroll, M. E.; Barton, B. E.; Rauchfuss, T. B.; Carroll, P. J. Synthetic Models for the Active Site of the [FeFe]-Hydrogenase: Catalytic Proton Reduction and the Structure of the Doubly Intermediate. J. Am. Chem. Soc. 2012, 134, 18843-18852.

(441) Borg, S. J.; Behrsing, T.; Best, S. P.; Razavet, M.; Liu, X.; Pickett, C. J. Electron Transfer at a Dithiolate-Bridged Diiron Assembly: Electrocatalytic Hydrogen Evolution. J. Am. Chem. Soc. 2004, 126, 16988-16999.

(442) Chong, D. S.; Georgakaki, I. P.; Mejia-Rodriguez, R.; Samabria-Chinchilla, J.; Soriaga, M. P.; Darensbourg, M. Y. Electrocatalysis of Hydrogen Production by Active Site Analogues of the Iron Hydrogenase Enzyme: Structure/function Relationships. Dalton Trans. 2003, 14, 4158-4163. 
(443) Kristjánsdóttir, S. S.; Moody, A. E.; Weberg, R. T.; Norton, J. R. Kinetic and Thermodynamic Acidity of Hydrido Transition-Metal Complexes. 5. Sensitivity of Thermodynamic Acidity to Ligand Variation and Hydride Bonding Mode. Organometallics 1988, 7, 1983-1987.

(444) Murphy, B. J.; Hidalgo, R.; Roessler, M. M.; Evans, R. M.; Ash, P. A.; Myers, W. K.; Vincent, K. A.; Armstrong, F. A. Discovery of Dark pH-Dependent $\mathrm{H}^{+}$Migration in a [NiFe]-Hydrogenase and Its Mechanistic Relevance: Mobilizing the Hydrido Ligand of the Ni-C Intermediate. J. Am. Chem. Soc. 2015, 137, 8484-8489.

(445) Hammes-Schiffer, S. Proton-Coupled Electron Transfer: Moving Together and Charging Forward. J. Am. Chem. Soc. 2015, 137, 8860-8871.

(446) Weiss, C. J.; Wiedner, E. S.; Roberts, J. A. S.; Appel, A. M. Nickel Phosphine Catalysts with Pendant Amines for Electrocatalytic Oxidation of Alcohols. Chem. Commun. 2015, 51, 6172-6174.

(447) Gabrielsson, A.; van Leeuwen, P.; Kaim, W. Acidic Iridium Hydrides: Implications for Aerobic and Oppenauer Oxidation of Alcohols. Chem. Commun. 2006, 4926-4927.

(448) Ladwig, M.; Kaim, W. Electronic Structure of Catalytic Intermediates for Production of $\mathrm{H}_{2}$ :

$\left(\mathrm{C}_{5} \mathrm{Me}_{5}\right) \mathrm{Ir}(\mathrm{bpy})$ and Its Conjugated Acid. J. Organometal. Chem. 1992, 439, 79-90.

(449) Sigman, M. S.; Jensen, D. R. Ligand-Modulated Palladium-Catalyzed Aerobic Alcohol Oxidations.

Acc. Chem. Res. 2006, 39, 221-229.

(450) Decharin, N.; Popp, B. V.; Stahl, S. S. Reaction of $\mathrm{O}_{2}$ with [(-)-sparteine]Pd(H)Cl: Evidence for an Intramolecular [H-L] " "reductive Elimination" Pathway. J. Am. Chem. Soc. 2011, 133, 13268-13271.

(451) Popp, B. V.; Stahl, S. S. Insertion of Molecular Oxygen Into a Palladium-Hydride Bond:

Computational Evidence for Two Nearly Isoenergetic Pathways. J. Am. Chem. Soc. 2007, 129, 4410-4422.

(452) Heck, R. F. Palladium-catalyzed Reactions of Organic Halides with Olefins. Acc. Chem. Res. 1979,

$12,146-151$.

(453) Henriksen, S. T.; Norrby, P.-O.; Kaukoranta, P.; Andersson, P. G. Combined Experimental and Theoretical Study of the Mechanism and Enantioselectivity of Palladium- Catalyzed Intermolecular Heck Coupling. J. Am. Chem. Soc. 2008, 130, 10414-10421.

(454) Hansen, A. L.; Ebran, J.-P.; Ahlquist, M.; Norrby, P.-O.; Skrydstrup, T. Heck Coupling with Nonactivated Alkenyl Tosylates and Phosphates: Examples of Effective 1,2-migrations of the Alkenyl Palladium(II) Intermediates. Angew. Chem., Int. Ed. 2006, 45, 3349-3353.

(455) Guest, D.; Menezes da Silva, V. H.; de Lima Batista, A. P.; Roe, S. M.; Braga, A. A. C.; Navarro, O. (NHeterocyclic Carbene)-Palladate Complexes in Anionic Mizoroki-Heck Coupling Cycles: a Combined Experimental and Computational Study. Organometallics 2015, 34, 2463-2470.

(456) Derrah, E. J.; Martin, C.; Mallet-Ladeira, S.; Miqueu, K.; Bouhadir, G.; Bourissou, D. Chelating Assistance of P-C and P-H Bond Activation at Palladium and Nickel: Straightforward Access to Diverse Pincer Complexes From a Diphosphine-Phosphine Oxide. Organometallics 2013, 32, 1121-1128.

(457) Santanilla, A. B.; Christensen, M.; Campeau, L. C.; Davies, I. W.; Dreher, S. D. P2Et Phosphazene: a Mild, Functional Group Tolerant Base for Soluble, Room Temperature Pd-Catalyzed C-N, C-O, and C-C Cross-Coupling Reactions. Org. Lett. 2015, 17, 3370-3373.

(458) Lin, B. L.; Liu, L.; Fu, Y.; Luo, S. W.; Chen, Q.; Guo, Q. X. Comparing Nickel- and Palladium-catalyzed Heck Reactions. Organometallics 2004, 23, 2114-2123.

(459) Scriban, C.; Kovacik, I.; Glueck, D. S. A Protic Additive Suppresses Formation of Byproducts in Platinum-Catalyzed Hydrophosphination of Activated Olefins. Evidence for P-C and C-C Bond Formation by Michael Addition. Organometallics 2005, 24, 4871-4874.

(460) Low, C. H.; Nobbs, J. D.; Van Meurs, M.; Stubbs, L. P.; Drent, E.; Aitipamula, S.; Pung, M. H. L. Palladium Complexes with Bulky Diphosphine Ligands as Highly Selective Catalysts for the Synthesis of (Bio-) Adipic Acid From Pentenoic Acid Mixtures. Organometallics 2015, 34, 4281-4292. 


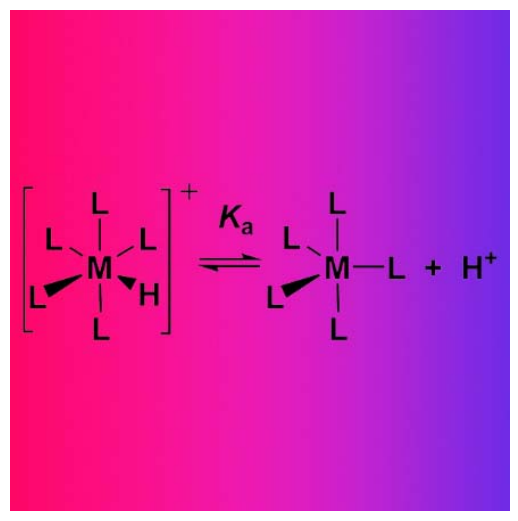

